U.S. Department of the Interior

U.S. Geological Survey

\title{
Residence Times and Nitrate Transport in Ground Water Disc harging to Streams in the Chesapeake Bay Watershed
}

by Bruce D. Lindsey, Scott W. Phillips, Colleen A. Donnelly, Gary K. Speiran,

L. Niel Plummer, John-Karl Böhlke, Michael J. Focazio, William C. Burton, and Eurybiades Busenberg

Water-Resources Investigations Report 03-4035 


\section{U.S. DEPARTMENT OF THE INTERIOR \\ GALE A. NORTON, Secretary}

\section{U.S. GEOLOGICAL SURVEY}

Charles G. Groat, Director

For additional information write to:

District Chief

U.S. Geological Survey

215 Limekiln Road

New Cumberland, Pennsylvania 17070-2424

Email: dc_pa@usgs.gov

Internet address: http://pa.water.usgs.gov
Copies of this report may be purchased from:

U.S. Geological Survey

Branch of Information Services

Box 25286

Denver Federal Center

Denver, Colorado 80225-0286

Telephone: 1-888-ASK-USGS 


\section{CONIENIS}

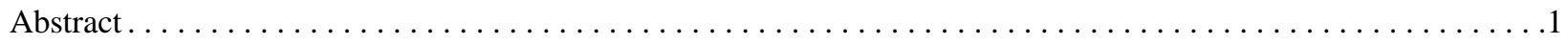

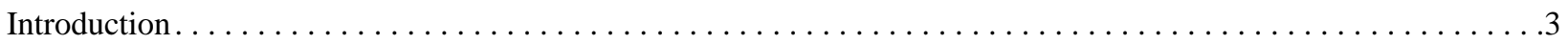

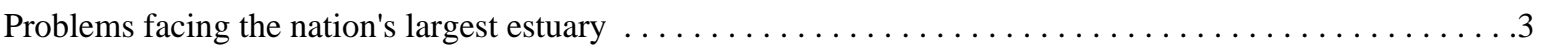

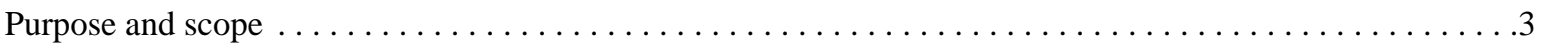

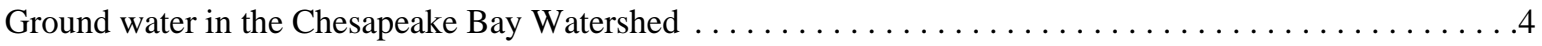

Previous USGS estimates of ground-water discharge and nitrate load to streams. . . . . . . . . 5

Previous USGS estimates of ground-water residence times and apparent ages. $\ldots \ldots \ldots \ldots \ldots \ldots 8$

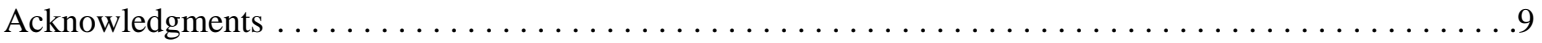

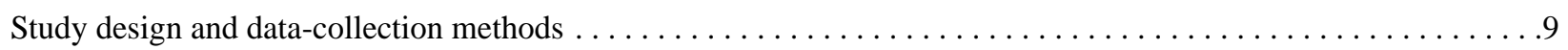

Approaches for ground-water dating, by L. Niel Plummer, John-Karl Böhlke, and Eurybiades Busenberg. . . . . .12

Recharge temperatures, excess air, and quantities of nitrogen from denitrification $\ldots \ldots \ldots \ldots \ldots \ldots 13$

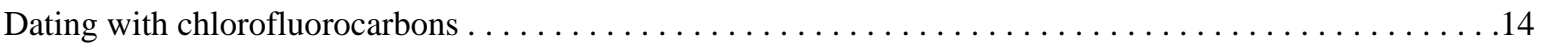

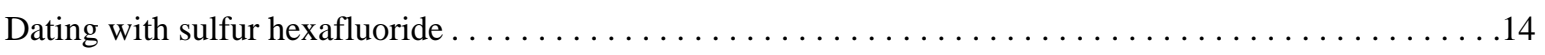

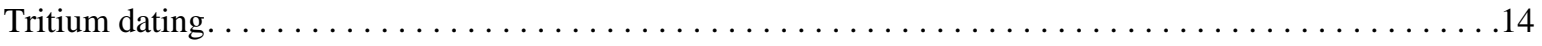

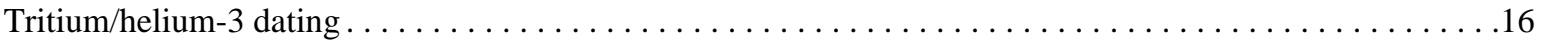

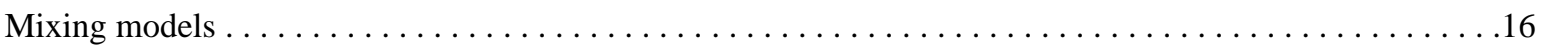

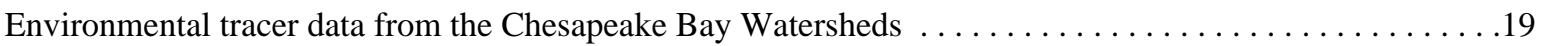

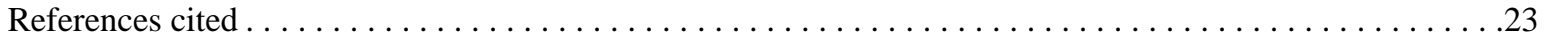

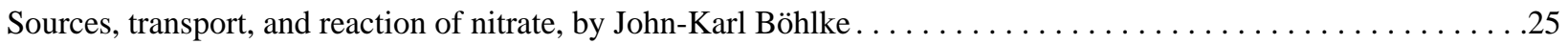

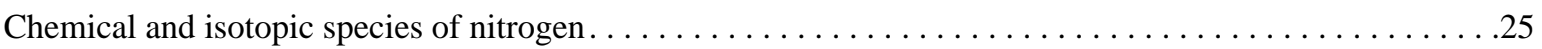

Nitrate source identification by isotope methods . . . . . . . . . . . . . . . . . . . . . 26

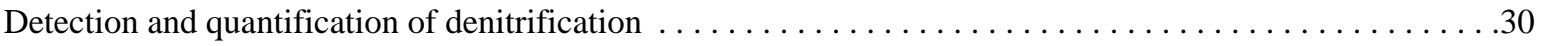

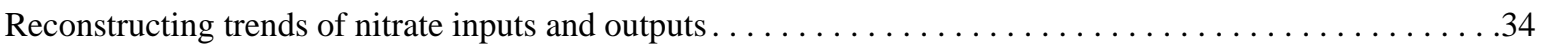

References cited . . . . . . . . . . . . . . . . . . . . . . . . . . . . . . . . . . . . . 37

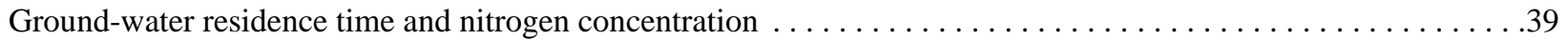

Springs in the Chesapeake Bay Watershed, by Michael J. Focazio. ...........................39

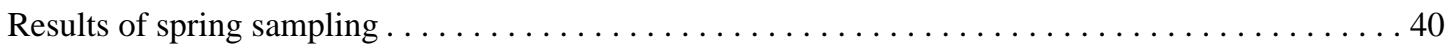

Nitrogen, field parameters, and apparent age comparisons between the wet and

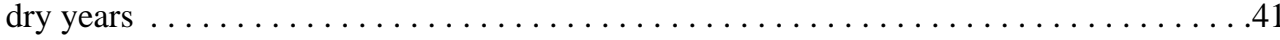

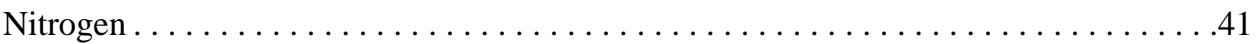

Field measurements and recharge temperatures $\ldots \ldots \ldots \ldots \ldots \ldots \ldots \ldots \ldots \ldots$

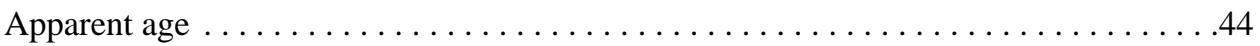

Comparison of ages determined with chlorofluorocarbon and tritium/helium . . . . . . 47

Comparison of nitrate concentrations and apparent ages of spring water..........48

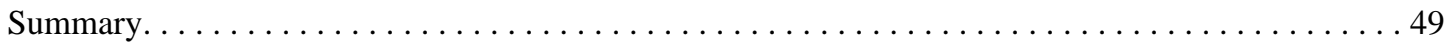

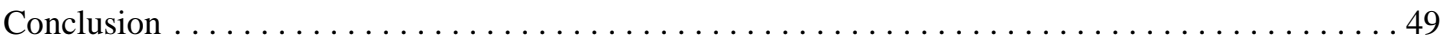

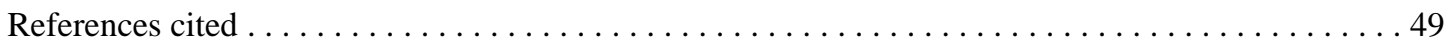




\section{CONIENIS-CONTINUED}

Ground-water residence time and nitrogen concentration-Continued

Upper Pocomoke River Watershed, by Scott W. Phillips and Colleen A. Donnelly. . . . . . . . . . . . . . 50

Description of study area and sampling network $\ldots \ldots \ldots \ldots \ldots \ldots \ldots \ldots \ldots \ldots \ldots \ldots \ldots \ldots \ldots$

Hydrogeology . . . . . . . . . . . . . . . . 51

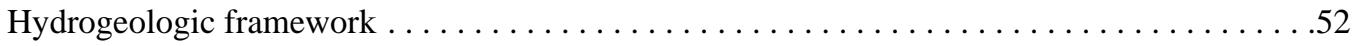

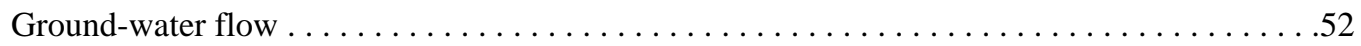

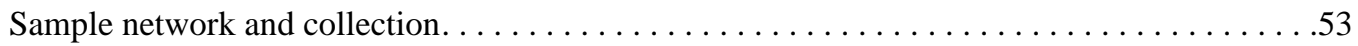

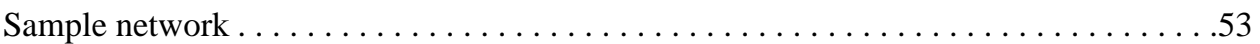

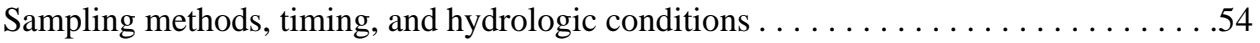

Distribution of nitrogen, dissolved oxygen, and methane in the ground-water system . . . . . . . 54

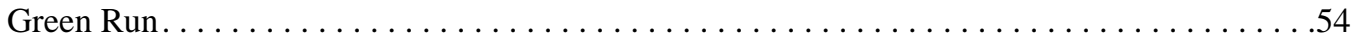

North Fork Green Run . . . . . . . . . . . . . . . . . . . . . . . . . . . . . . . . .57

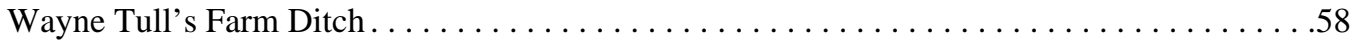

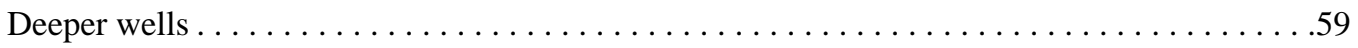

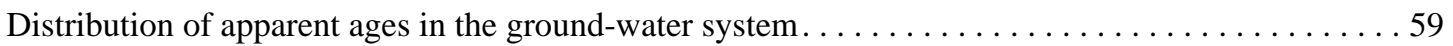

Methods used to determine apparent ages of ground water $\ldots \ldots \ldots \ldots \ldots \ldots \ldots \ldots \ldots$

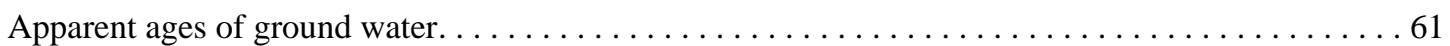

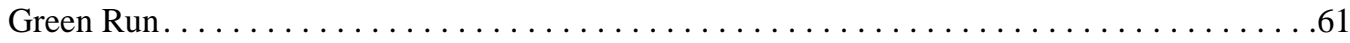

North Fork Green Run $\ldots \ldots \ldots \ldots \ldots \ldots \ldots \ldots \ldots \ldots \ldots \ldots \ldots \ldots \ldots \ldots \ldots$

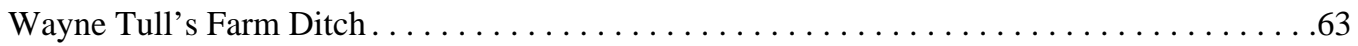

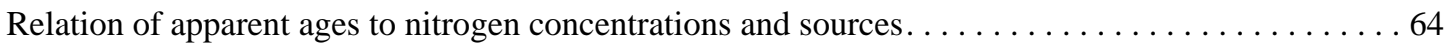

Factors affecting apparent age distribution, nitrogen occurrence, and discharge to streams . . . . . 66

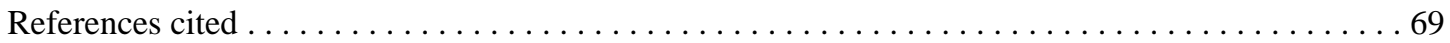

Polecat Creek Watershed, Virginia, by Gary K. Speiran . . . . . . . . . . . . . . . . . . . . . .71

Description of study area and sampling network $\ldots \ldots \ldots \ldots \ldots \ldots \ldots \ldots \ldots \ldots \ldots \ldots \ldots \ldots$

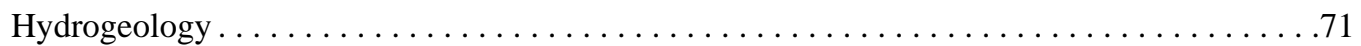

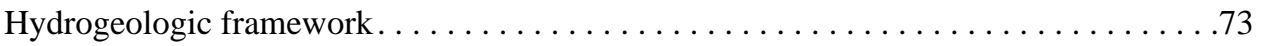

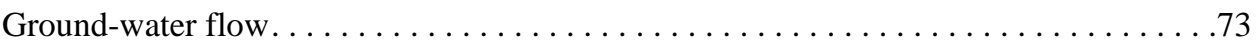

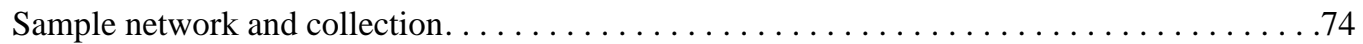

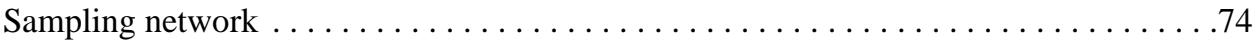

Sampling methods, timing, and hydrologic conditions $\ldots \ldots \ldots \ldots \ldots \ldots \ldots \ldots$

Distribution of nitrogen, dissolved oxygen, and methane in ground water $\ldots \ldots \ldots \ldots \ldots$

Distribution of apparent ages and residence times in ground water. $\ldots \ldots \ldots \ldots \ldots \ldots$

Methods used for determining apparent ages $\ldots \ldots \ldots \ldots \ldots \ldots \ldots \ldots \ldots \ldots \ldots \ldots$

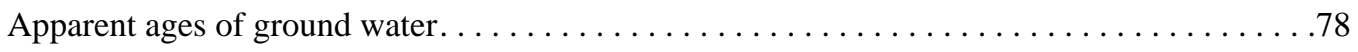

Relation of nitrogen concentrations, apparent age, and sources $\ldots \ldots \ldots \ldots \ldots \ldots 2$

Factors affecting residence-time distribution, nitrogen occurrence, and discharge to streams . . . 883

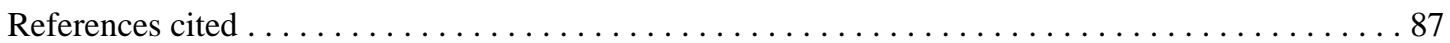




\section{CONIENIS-CONTINUED}

Ground-water residence time and nitrogen concentration-Continued

Muddy Creek Watershed, Virginia, by Gary K. Speiran $\ldots \ldots \ldots \ldots \ldots \ldots \ldots \ldots \ldots \ldots$

Description of study area and sampling network $\ldots \ldots \ldots \ldots \ldots \ldots \ldots \ldots \ldots \ldots \ldots \ldots \ldots$

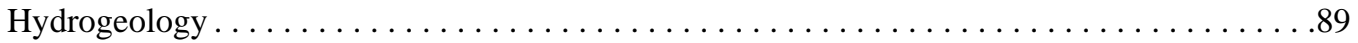

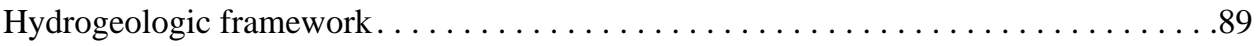

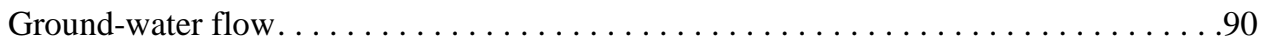

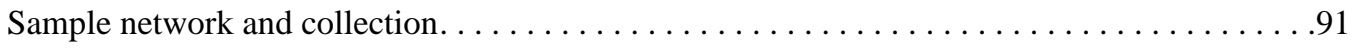

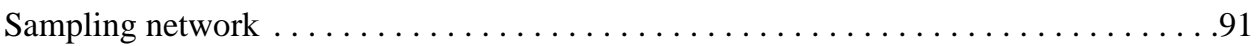

Sampling methods, timing, and hydrologic conditions $\ldots \ldots \ldots \ldots \ldots \ldots \ldots 2$

Distribution of nitrogen, dissolved oxygen, and methane in ground water $\ldots \ldots \ldots \ldots 2$

Distribution of apparent ages and residence times in ground water. $\ldots \ldots \ldots \ldots \ldots \ldots$

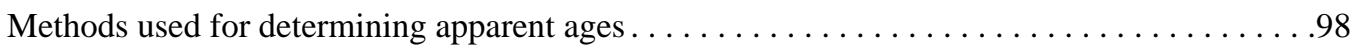

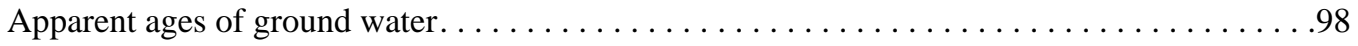

Relation of nitrogen concentrations, apparent age, and sources . . . . . . . . . . . . . 104

Factors affecting residence-time distribution, nitrogen occurrence, and discharge to streams . . . 106

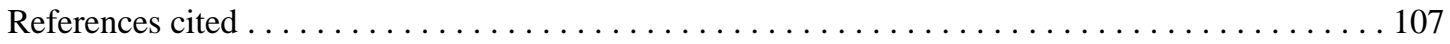

East Mahantango Creek Watershed, by Bruce D. Lindsey and William C. Burton . . . . . . . . . . . 108

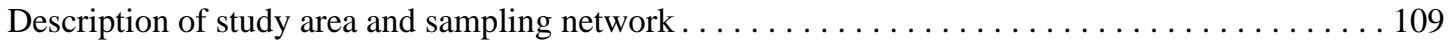

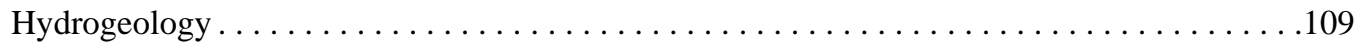

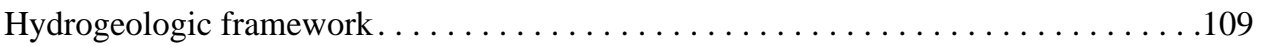

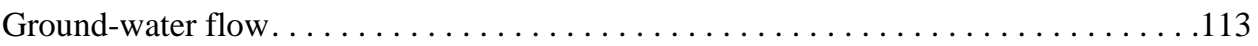

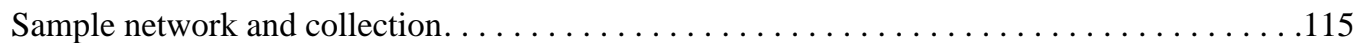

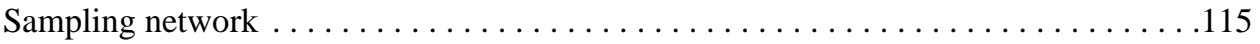

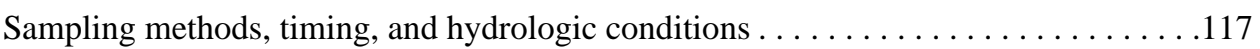

Distribution of nitrogen, dissolved oxygen, and methane in the ground-water system . . . . . . 117

Distribution of apparent ages and residence times in ground water. . . . . . . . . . . 123

Relation of nitrogen concentration, apparent age, and sources . . . . . . . . . . . . . . . 129

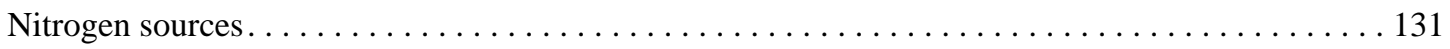

Model estimates of age distribution of ground-water discharge $\ldots \ldots \ldots \ldots \ldots \ldots \ldots \ldots \ldots$

Factors affecting residence-time distribution, nitrogen occurrence, and discharge to streams . . . . 137

References cited ........................................140

Factors affecting the residence time of, and nitrate transport in, ground water discharging to streams in the

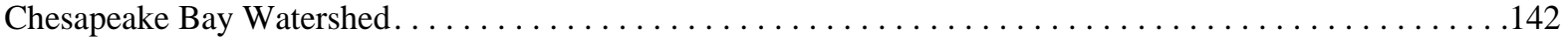

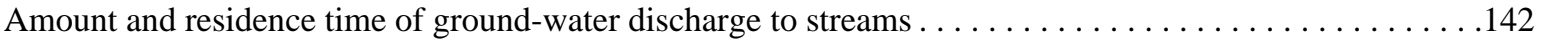

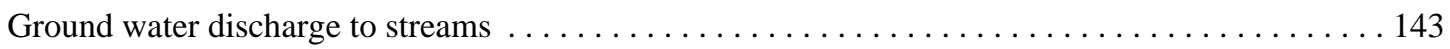

Residence time and apparent age of ground water discharge to streams . . . . . . . . . . 143

Factors affecting the discharge of ground water to streams and associated residence time. . . . . 145 


\section{CONIENIS-CONTINUED}

Factors affecting the residence time of, and nitrate transport in, ground water discharging to streams in the Chesapeake Bay Watershed-Continued

Nitrogen transport in ground water and discharge to streams $\ldots \ldots \ldots \ldots \ldots \ldots \ldots \ldots \ldots \ldots$

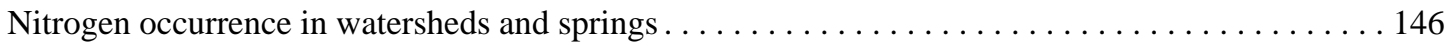

Factors affecting nitrogen transport in ground water and discharge to streams. . . . . . . . 147

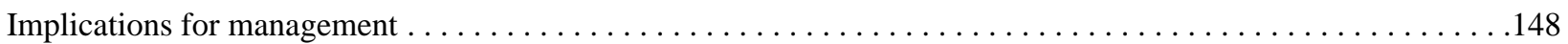

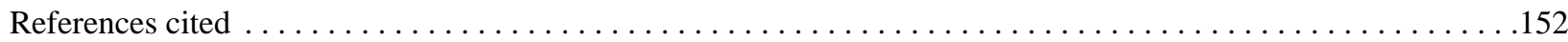

Appendix A. Site information and field measurements of stream and ground water collected in the Chesapeake Bay Watershed, June 1998 through May $2000 \ldots \ldots \ldots \ldots \ldots \ldots$

Appendix B. Nutrient and ${ }^{15} \mathrm{~N}$ concentrations in stream and ground water collected in the Chesapeake

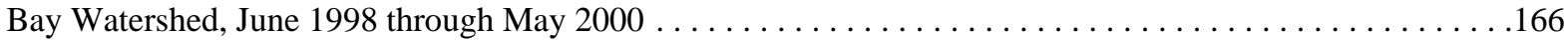

Appendix C. Apparent ages and ancillary data used for modeled recharge dates for ground water collected in the Chesapeake Bay Watershed, June 1998 through May 2000 . . . . . . . . . . . . . . . . . . . . . . 177

Appendix D. Average concentration of CFC-11, 12, and 113, $\mathrm{SF}_{6}$, tritium, and ${ }^{3} \mathrm{He}$ for ground water collected in the Chesapeake Bay Watershed, June 1998 through May 2000 . . . . . . . . . . . . . . 190

Appendix E. Tritium/helium data and apparent ages of water from wells and springs in the

Chesapeake Bay Watershed, September 1996 through May 2000

\section{IUSTRATIONS}

Figures $\quad$ 1. Map showing Chesapeake Bay Watershed and surrounding area. $\ldots \ldots \ldots \ldots$

2. Sketch showing movement of water through the hydrologic cycle $\ldots \ldots \ldots \ldots \ldots \ldots$

3. Map showing locations of stations with streamflow measurements and loads estimates, and hydrogeomorphic regions within the Chesapeake Bay Watershed . . . . . . . . 6

4. Boxplot showing distribution of ground-water flow by hydrogeomorphic region $\ldots \ldots \ldots \ldots$

5. Graph showing apparent ages (residence time) of water collected from springs in the

Chesapeake Bay Watershed in September and November 1996 . . . . . . . . . . . . . 8

6. Map showing location of springs and targeted watersheds in the Chesapeake Bay Watershed . . 10

7-13. Graphs showing:

7. Chlorofluorocarbon (CFC) and sulfur hexafluoride $\left(\mathrm{SF}_{6}\right)$ air-mixing ratios for North American Air based on National Oceanic and Atmospheric Administration data from Niwot Ridge, Colo., and tritium $\left({ }^{3} \mathrm{H}\right)$ in

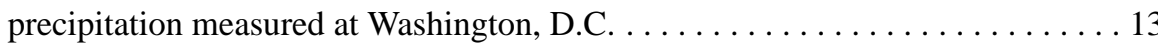

8. A smoothed record of tritium in precipitation at Washington, D.C.. . . . . . 15

9. Atmospheric ratios of chlorofluorocarbon $(\mathrm{CFC})$ and sulfur hexafluoride $\left(\mathrm{SF}_{6}\right)$ used in dating water or in dating the young fraction in mixtures of young water and old (tracer-free) water . . . . . . . . . . . . . . . . 17

10. Environmental tracers in ground waters sampled in 1999 . . . . . . . . . . . . . . 18 


\section{CONIENIS-CONTINUED}

Figures 7-13. Graphs showing-Continued:

11. Relation between concentrations of environmental tracers in waters from the Chesapeake Bay Watersheds. A. CFC-11 and CFC-12; B. CFC-113 and CFC-12; C. ${ }^{3} \mathrm{H}$ and $\mathrm{CFC}-12$; and D. ${ }^{3} \mathrm{H}$ and $\mathrm{CFC}-113$. . . . . . . . . . . . 20

12. Relation between concentrations of environmental tracers in waters from the Chesapeake Bay Watersheds. A. CFC-11 and $\mathrm{SF}_{6}$; B. CFC-12 and $\mathrm{SF}_{6}$; C. CFC-113 and $\mathrm{SF}_{6}$; and D. ${ }^{3} \mathrm{H}$ and $\mathrm{SF}_{6} \ldots \ldots \ldots \ldots \ldots \ldots \ldots \ldots \ldots \ldots \ldots \ldots \ldots \ldots \ldots$

13. Summary of nitrate concentrations and $\delta^{15} \mathrm{~N}$ values of precipitation, springs, and ground water in the Chesapeake Bay Watershed $\ldots \ldots \ldots \ldots \ldots \ldots \ldots 28$

14. Maps showing (A) nitrate concentrations and nitrogen-isotopic compositions during a synoptic survey of streams in the Mahantango WE-38 Watershed in May 1999,

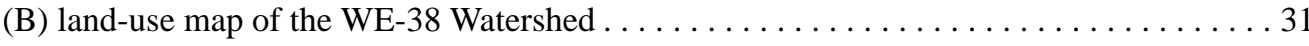

15. Schematic diagrams illustrating isotopic fractionation and gas mixing accompanying

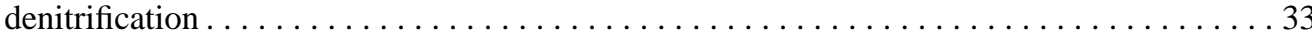

16-23. Graphs showing:

16. Ground-water record of concentrations of nitrate in recharge beneath agricultural land near Locust Grove, Md. . . . . . . . . . . . . . . . . . . . . 35

17. Simplified record of nitrate inputs to recharge and resulting hypothetical nitrate

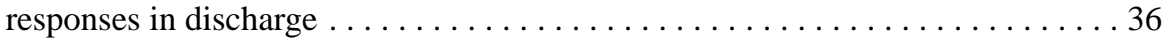

18. Measured daily streamflow at Difficult Run near Great Falls, Va., used as an indication of general hydrologic condition $\ldots \ldots \ldots \ldots \ldots \ldots \ldots \ldots . \ldots \ldots$

19. Nitrate concentrations as a function of: agricultural land use within a 1-mile radius from each spring $(\mathrm{A})$, urban land use within a 1-mile radius from each spring (B), and relation of $\delta^{15} \mathrm{~N}$ to agricultural land use (C) $\ldots \ldots 42$

20. Dry- and wet-year comparisons of nitrate concentrations (A) and $\delta^{15} \mathrm{~N}$ values (B) $\ldots 43$

21 . The relation between chlorofluorocarbon concentrations in water samples from all springs sampled during the dry and wet years $\ldots \ldots \ldots \ldots \ldots \ldots \ldots . \ldots 45$

22. The relations between apparent ages determined by chlorofluorocarbon and sulfur hexafluoride analysis during the wet and dry years (A), and chlorofluorocarbon and tritium/helium age-dating analyses (B) for all uncontaminated samples and samples older than "modern" ............. 46

23. Nitrate concentrations in spring discharge as a function of recharge year $\ldots \ldots \ldots . .48$ 24-25. Maps showing:

24. Upper Pocomoke River Watershed study area and sampling locations . . . . . . . 50

25. Unconsolidated sediments of the Atlantic Coastal Plain Physiographic Province underlying the Delmarva Peninsula ......................... 51

26. Generalized section showing subsurface materials present at local ground-water sampling areas, Upper Pocomoke River Watershed, Md. . 


\section{IUUSTRATIONS-CONIINUED}

Figures 27. Conceptual model of ground-water-flow paths discharging to streams in the Upper

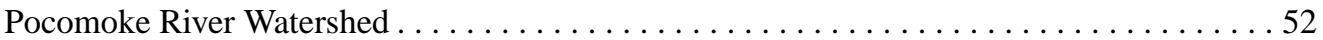

28. Diagram of 2-inch-diameter piezometer installation and portable minipiezometers in

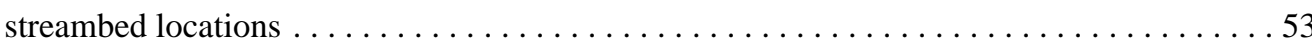

29. Graphs showing daily precipitation and mean daily ground-water levels at (A) North Fork

Green Run and (B) Green Run for the period July 15, 1999, through May 23, 2000 . . . . . 55

30-35. Generalized sections showing:

30. Distribution of dissolved nitrate and ammonia concentrations in surface and ground water at Green Run during March $1999 \ldots \ldots \ldots \ldots \ldots \ldots \ldots$

31. Distribution of dissolved oxygen, excess nitrogen $\left(\mathrm{N}_{2}\right)$ gas, and methane $\left(\mathrm{CH}_{4}\right)$ concentrations in ground water at Green Run during March 1999 and general description of subsurface sediments . . . . . . . . . . 56

32. Distribution of dissolved nitrate and ammonia concentrations in surface and ground water at North Fork Green Run during March 1999 . . . . . . . . . . . . 57

33. Distribution of dissolved oxygen, excess nitrogen $\left(\mathrm{N}_{2}\right)$ gas, and methane $\left(\mathrm{CH}_{4}\right)$ concentrations in ground water at North Fork Green Run during March 1999

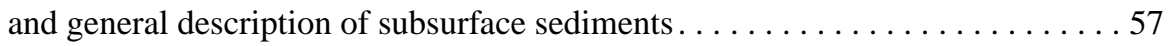

34. Distribution of dissolved nitrate and ammonia concentrations in surface and ground water at Wayne Tull's Farm Ditch during March 1999 . . . . . . . . . . . 58

35. Distribution of dissolved oxygen, excess nitrogen $\left(\mathrm{N}_{2}\right)$ gas, and methane $\left(\mathrm{CH}_{4}\right)$ concentrations in surface and ground water at Wayne Tull's Farm Ditch during March 1999, and general descriptions of subsurface sediments. . . . . . 58

36-37. Graphs showing:

36. Comparison of the concentrations of (A) CFC-11 and CFC-12, (B) CFC-113 and CFC-12, (C) ${ }^{3} \mathrm{H}$ and CFC-12, and (D) ${ }^{3} \mathrm{H}$ and CFC-113 in water samples from North Fork Green Run (NFGR wells), Wayne Tull's Farm Ditch site (WT wells), and Green Run (Green Run Wells)

37. Comparison of the concentrations of (A) CFC-11 and $\mathrm{SF}_{6}$, (B) CFC-12 and $\mathrm{SF}_{6}$, (C) CFC-113 and $\mathrm{SF}_{6}$, and (D) ${ }^{3} \mathrm{H}$ and $\mathrm{SF}_{6}$ in water samples from North Fork Green Run (NFGR wells), Wayne Tull's Farm Ditch site (WT wells), and Green Run (Green Run wells).

38-40. Generalized sections showing:

38. Date of recharge of ground water discharging to Green Run during March 1999 . . . 63

39. Date of recharge of ground water discharging to North Fork Green Run during March 1999 ... . . . . . . . . . . . . . . . . . . . . . . . . . . . 64

40. Date of recharge of ground water discharging to Wayne Tull's Farm Ditch during March 1999 


\section{IUUSTRATIONS-CONIINUED}

Figures 41-42. Graphs showing:

41. Relation between ground-water recharge date and "reconstructed" initial nitrate concentration in samples collected in the North Fork Green Run Watershed . . . 65

42. Relation between ground-water recharge date and actual nitrate concentration in samples collected in the North Fork Green Run Watershed ............ 66

43. Conceptual model of the distribution of flow paths, hydraulic head, and age of groundwater seepage surrounding a stream channel.......................... 67

44. Graph showing total nitrate concentrations at the gage at North Fork Green Run, January 1997 through April 1999 . . . . . . . . . . . . . . . . . . . . . . . . . 68

45. Map showing location of study area and well transect A-A', Polecat Creek Watershed, Va... . . . 71

46. Geohydrologic section A-A' with well locations and land use, Polecat Creek Watershed, Va. . . . 72

47. Graph showing ground-water levels at well cluster 50M2, Polecat Creek Watershed, Va., June 1, 1997, through December 1, 2000 . . . . . . . . . . . . . . . . . . . . . . . . . 75

48. Geohydrologic section showing distribution of reconstructed nitrate and field-measured dissolved-oxygen concentrations in ground water in the surficial aquifer, April 1999

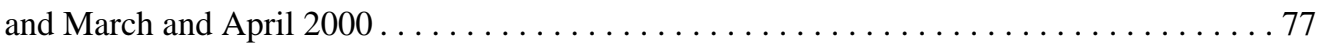

49-50. Graphs showing:

49. Comparison of concentrations of chlorofluorocarbon-11 (CFC-11), chlorofluorocarbon-12 (CFC-12), chlorofluorocarbon-113 (CFC-113), tritium $\left({ }^{3} \mathrm{H}\right)$, and sulfur hexafluoride $\left(\mathrm{SF}_{6}\right)$ in water from wells in the Polecat Creek Watershed, Va. . . . . . . . . . . . . . . . . . . . . . . . . . . . . 79

50. Distribution in apparent chlorofluorocarbon (CFC) and sulfur hexafluoride $\left(\mathrm{SF}_{6}\right)$ age of ground water in the surficial aquifer in the Polecat Creek Watershed, April 1999 and April 2000 ...................................... 80

51. Schematic showing shallow ground-water flow during high (A) and low (B) ground-water levels. . . . . . . . . . . . . . . . . . . . . . . . . . . . . . . . . . . . . . 81

52-53. Graphs showing:

52. Relation of apparent chlorofluorocarbon (CFC) and sulfur hexafluoride $\left(\mathrm{SF}_{6}\right)$ age to silica concentration in ground water in the surficial aquifer in the Polecat Creek Watershed, April 1999 and April 2000 . . . . . . . . . . . . 82

53. Relation of apparent recharge date to reconstructed nitrate concentrations (A) and to silica concentration (B) in ground water in the surficial aquifer, of the Polecat Creek Watershed, Va., April 1999 and April 2000 . . . . . . . . . . . . . 84

54. Map showing location of the study area, sampling sites, geohydrologic section A-A', and land use in the Muddy Creek Watershed, Va. . . . . . . . . . . . . . . . 88

55. Geohydrologic section A-A' and observation well locations, Muddy Creek, Va. . . . . . . . . . 89 


\section{IUUSTRATIONS-CONIINUED}

Figures 56. Graph showing nitrate concentrations of streamwater compared to the nitrate concentrations of spring water (A) and ground-water sample collection compared to streamwater nitrate concentration (A) and streamflow (B) in the Muddy Creek Watershed, Va. . . . . . . 93

57. Map showing spatial distribution of reconstructed nitrate concentration in ground water and surface water in the Muddy Creek Watershed, Va., April 1999 . . . . . . . . . . . . . 95

58. Geohydrologic section showing reconstructed nitrate concentration in water from observation wells in the local-scale study area in April 1999, Muddy Creek Watershed, Va. . . . . . . . . 96

59-61. Graphs showing:

59. Relation of well depth to reconstructed nitrate concentration (A) and to constructed nitrate concentration adjusted for mixing (B) in ground water, April 1999 and April 2000, Muddy Creek Watershed, Va. . . . . . . . . . . . . 97

60. Concentrations of $\delta^{15}$ nitrogen of nitrate in water from domestic wells, observation wells, and springs, Muddy Creek Watershed, Va., April 1999. . . . . 98

61. Comparison of concentrations of chlorofluorocarbon-11 (CFC-11), chlorofluorocarbon-12 (CFC-12), chlorofluorocarbon-113 (CFC-113), and tritium $\left({ }^{3} \mathrm{H}\right)$ in water from wells and springs in the Muddy Creek Watershed, Va. . . . . . . . . . . . . . . . . . . . . . . . . . . . . . . . 999

62. Map showing spatial distribution of apparent age of ground water in Muddy Creek

Watershed, Va., April 1999 . . . . . . . . . . . . . . . . . . . . . . . . . . . . . . 100

63. Geohydrologic section showing apparent age of water from observation wells in the local-scale study area in Muddy Creek Watershed, Va., April 1999 . . . . . . . . . . . . . 102

64-65. Graphs showing:

64. Relation of well depth to apparent chlorofluorocarbon (CFC) age of young ground water (A) and to percent young ground water (B) in Muddy Creek Watershed, Va., April 1999 and April 2000 ...................... 103

65. Relation of apparent chlorofluorocarbon (CFC) recharge date to reconstructed nitrate concentration (A) and to reconstructed nitrate adjusted for mixing (B) for ground water in Muddy Creek Watershed, Va., November 1998, April 1999, and April 2000............................. 105

66-68. Maps showing:

66. Land use within the East Mahantango Creek Watershed, Pa............... 108

67. Land use and sampling sites within the WE-38 subwatershed of the East Mahantango Creek Watershed ........................... 110

68. Geology of the East Mahantango Creek Watershed ..................... 111

69. Schematic fracture framework of the Broad Mountain anticlinorium 


\section{IUUSTRATIONS-CONINUED}

70. Graphs showing total fractures and fracture density in cores collected within the WE-38

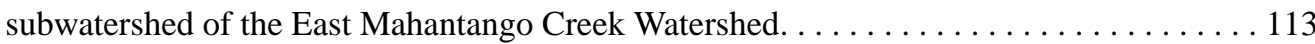

71. Diagram showing ground-water-flow systems in the WE-38 subwatershed as shown by (A) flow controlled by layering hypothesis and (B) flow controlled by fractureorientation hypothesis

72. Geohydrologic section showing hypothetical movement of water in relation to fracture orientation and actual water levels in the east piezometer transect of WE-38 subwatershed .................................. 115

73. Map showing topography, geology, and location of piezometer transects in WE-38

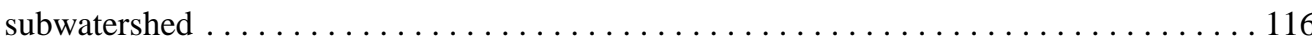

74. Cross sections through east and west piezometer transects, showing orientation of bedding and cleavage, East Mahantango Creek Watershed, Pennsylvania . . . . . . . . . . . . 118

75. Graphs showing monthly precipitation, water levels in observation well 37, and streamflow at WE-38 weir from January 1998 to December 2000, in WE-38 subwatershed, East Mahantango Creek Watershed, Pennsylvania . . . . . . . . . . . . . . . . . . . 119

76. Cross sections showing distribution of nitrate in east and west transects, May 1999,

East Mahantango Creek Watershed, Pennsylvania . . . . . . . . . . . . . . . 120

77. Map showing land use near the east and west transects in 1998, East Mahantango Creek, Pa.. . . 121

78. Cross sections showing distribution of concentrations of dissolved oxygen, excess nitrogen gas, and methane in the east and west transects, May 1999, East Mahantango Creek

Watershed, Pa. . . . . . . . . . . . . . . . . . . . . . . . . . 122

79-80. Graphs showing:

79. Comparison of concentrations of CFC-11, CFC-12, CRC-113 and ${ }^{3} \mathrm{H}$ in samples collected in the East Mahantango Creek Watershed, Pa. . . . . . . . . . . 123

80. Comparison of CFC-11, CFC-12, CFC-113, and ${ }^{3} \mathrm{H}$ concentrations to $\mathrm{SF}_{6}$ concentrations in samples collected in the East Mahantango Creek

Watershed, Pa. . . . . . . . . . . . . . . . . . . . . 124

81. Cross sections showing distribution of apparent ground-water ages in the east and west transects, May 1999, East Mahantango Creek Watershed, Pa. . . . . . . . . . . . . 126

82-83. Graphs showing:

82. Relation between dissolved bicarbonate and dissolved sodium concentrations from samples collected in the East Mahantango Creek Watershed, Pa. . . . . . 128

83. Relation between dissolved sodium concentrations and apparent ground-water age from samples containing more than 70 percent of water of the given age collected in the East Mahantango Creek Watershed, Pa. . 


\section{IUUSTRATIONS-CONIINUED}

Figures 84-86. Graphs showing:

84. County fertilizer sales for Northumberland County, Pa., 1945 to 1991 . . . . . . . . . 129

85. Relation between nitrate concentration and apparent recharge dates in east and west transects of WE-38 subwatershed, East Mahantango Creek Watershed,

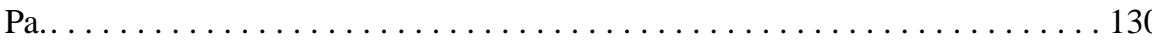

86. Relation between reconstructed nitrate concentration and apparent recharge date in east and west transects of WE-38 subwatershed, East Mahantango Creek Watershed, Pa. ................................... 131

87-88. Cross sections showing:

87. Results of cross-sectional simulations of ground-water flow from the model of Gburek and Folmar (A) and modifications including increasing the porosity to simulate an average residence time of 10 years (B) . . . . . . . . . 134

88. Results of cross-sectional simulations of ground-water flow with a porosity to simulate an average residence time of 10 years (A) and simulating the effects of fracture orientation by varying the hydraulic conductivity in the second, third and fourth model layers (B) $\ldots \ldots \ldots \ldots \ldots \ldots \ldots \ldots \ldots \ldots$

89. Graph showing relation of average nitrate and sodium concentration to stream base flow . . . . 139

90. Graph showing possible response of nitrate concentrations in base-flow discharge to

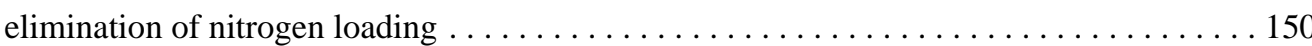

91. Map showing yields of total nitrogen applied to the land surface from manure (a) and fertilizer (b). The yield of total nitrogen delivered to the Bay from all sources (c) . . 151

\section{TABIES}

Table 1. Distribution of apparent ages (residence times) of water from springs in different hydrogeomorphic

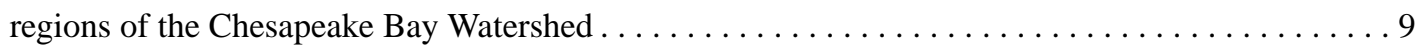

2. Hydrogeomorphic regions and targeted watersheds chosen for study $\ldots \ldots \ldots \ldots \ldots \ldots \ldots \ldots \ldots \ldots$

3. Summary of apparent ages for ground-water samples collected in wet and dry years $\ldots \ldots \ldots \ldots \ldots 44$

4. Comparison of apparent age of ground water based on analyses of samples for

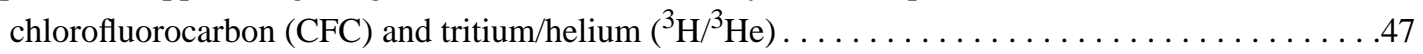

5. Total nitrogen concentrations in streamwater samples, January 1997 through April 1999 . . . . . . . . 68

6. Results of Wilcox rank-sum analysis (p values) for reconstructed nitrate concentrations, $\delta^{15}$ nitrogen, and apparent chlorofluorocarbon age of water from springs compared to those from all wells, domestic wells, and observation wells, Muddy Creek Watershed, Va. . . . . . 94

7. Model input parameters used for MODPATH and ZONEBUDGET simulations, showing original values from Gburek and Folmar and the modifications for simulations in this study . . . . . . . 133 


\section{CONVERSON FACTORS, ABBREVIATIONS, AND VERTICALDATUM}

Multiply

inch (in.)
inch (in.)
foot (ft)
mile (mi)

acre

square mile $\left(\mathrm{mi}^{2}\right)$

gallon (gal)

inch per year (in/yr)

foot per day $(\mathrm{ft} / \mathrm{d})$

cubic foot per second $\left(\mathrm{ft}^{3} / \mathrm{s}\right)$

cubic foot per day $\left(\mathrm{ft}^{3} / \mathrm{d}\right)$

degree Fahrenheit $\left({ }^{\circ} \mathrm{F}\right)$
By

Length

25.4

0.3048

1.609

Area

0.4047

2.590

Volume

3.785

Flow rate

25.4

0.3048

0.02832

0.02832

Temperature

${ }^{\circ} \mathrm{C}=5 / 9 \times\left({ }^{\circ} \mathrm{F}-32\right)$ $\underline{\text { To obtain }}$

micron

millimeter

meter

kilometer

hectare

square kilometer

liter

millimeter per year meter per day cubic meter per second cubic meter per day

degree Celsius $\left({ }^{\circ} \mathrm{C}\right)$

\section{OTHER ABBREVIATIONS}

ARS Agricultural Research Service

HGMR hydrogeomorphic region

CBP Chesapeake Bay Program

IAEA International Atomic Energy Agency

K hydraulic conductivity

MD DNR Maryland Department of Natural Resources

MRL minimum reporting level

NAWQA National Water-Quality Assessment

SPARROW Spatially-Referenced Regression on Watershed Attributes

SAV submerged aquatic vegetation

Sy specific yield

USDA United States Department of Agriculture

NWIS USGS National Water Inventory System database

NWQL USGS National Water-Quality Laboratory 


\section{CONVERSION FACTORS, ABBREVIATIONS, AND VERTICALDATUM-CONTINUED}

\section{CHEMICAL SYMBOLS}

$\begin{array}{ll}{ }^{3} \mathrm{H} /{ }^{3} \mathrm{He} & \text { tritium, helium } \\ \mathrm{SF}_{6} & \text { Sulfur hexaflouride } \\ \mathrm{NO}_{2}^{-} & \text {nitrite } \\ \mathrm{NO}_{3}^{-} & \text {nitrate } \\ \mathrm{NH}_{4}^{+} & \text {ammonium } \\ \mathrm{Ar} & \text { argon } \\ \mathrm{CH}_{4} & \text { methane } \\ \mathrm{CFC}^{+} & \text {Chlorofluorocarbon } \\ \mathrm{Cl}^{-} & \text {Chloride } \\ \mathrm{CO}_{2} & \text { Carbon dioxide } \\ \mathrm{H}_{2} \mathrm{O} & \text { Water } \\ \mathrm{HCO}_{3}^{-} & \text {Bicarbonate } \\ \mathrm{Na}_{-} \mathrm{HCO}_{3} & \text { Sodium bicarbonate } \\ \mathrm{N}_{2} & \text { Nitrogen gas } \\ \mathrm{N}_{2} \mathrm{O} & \text { Nitrous oxide } \\ \mathrm{Ne} & \text { Neon }\end{array}$

Abbreviated units used in report:

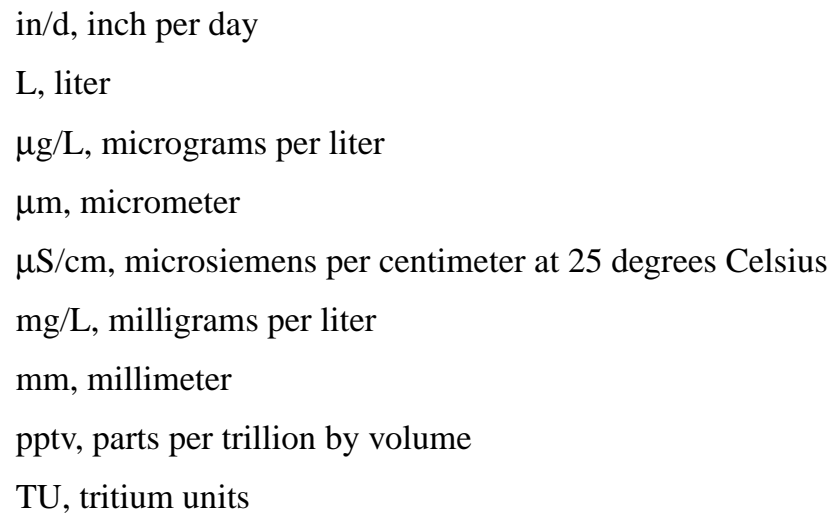

Vertical coordinate information is referenced to the North American Vertical Datum of 1988 (NAVD 88); horizontal coordinate information is referenced to the North American Datum of 1927 (NAD 27). 


\title{
Residence Times and Nitrate Transport in Ground Water Disc harging to Streams in the Chesapeake Bay Watershed
}

\author{
by Bruce D. Lindsey, Scott W. Phillips, Colleen A. Donnelly, Gary K. Speiran, \\ L. Niel Plummer, John-Karl Böhlke, Michael J. Focazio, \\ William C. Burton, and Eurybiades Busenberg
}

\begin{abstract}
One of the major water-quality problems in the Chesapeake Bay is an overabundance of nutrients from the streams and rivers that discharge to the Bay. Some of these nutrients are from nonpoint sources such as atmospheric deposition, agricultural manure and fertilizer, and septic systems. The effects of efforts to control nonpoint sources, however, can be difficult to quantify because of the lag time between changes at the land surface and the response in the base-flow (ground water) component of streams. To help resource managers understand the lag time between implementation of management practices and subsequent response in the nutrient concentrations in the base-flow component of streamflow, a study of ground-water discharge, residence time, and nitrate transport in springs throughout the Chesapeake Bay Watershed and in four smaller watersheds in selected hydrogeomorphic regions (HGMRs) was conducted. The four watersheds were in the Coastal Plain Uplands, Piedmont crystalline, Valley and Ridge carbonate, and Valley and Ridge siliciclastic HGMRs.
\end{abstract}

A study of springs to estimate an apparent age of the ground water was based on analyses for concentrations of chlorofluorocarbons in water samples collected from 48 springs in the Chesapeake Bay Watershed. Results of the analysis indicate that median age for all the samples was 10 years, with the 25 th percentile having an age of 7 years and the 75 th percentile having an age of 13 years. Although the number of samples collected in each HGMR was limited, there did not appear to be distinct differences in the ages between the HGMRs. The ranges were similar between the major HGMRs above the Fall Line (modern to about 50 years), with only two HGMRs of small geographic extent (Piedmont carbonate and Mesozoic Lowland) having ranges of modern to about 10 years. The median values of all the HGMRs ranged from 7 to 11 years. Not enough samples were collected in the Coastal Plain for comparison. Spring samples showed slightly younger water under wet conditions than under dry conditions.
The apparent age of water from wells, springs, and other ground-water discharge points in the four targeted watersheds was modern to 60 years, which was similar to the apparent ages from the spring study. In the Pocomoke River Watershed in the Coastal Plain Uplands HGMR, the apparent age of ground-water samples ranged from 0 to 60 years; the ages in the vicinity of the streams ranged from 0 to 23 years. The apparent ages of ground water in the Polecat Creek Watershed in the Piedmont crystalline HGMR ranged from 2 to 30 years. The apparent ages of water from wells in the Muddy Creek Watershed in the Valley and Ridge carbonate HGMR ranged from 10 to 20 years (except for a single sample that was 45 years). The ages in the East Mahantango Creek Watershed in the Valley and Ridge siliciclastic HGMR ranged from 0 to 50 years. The distribution in apparent age of water from wells in the targeted watersheds, however, generally is older than that for water from the springs. The median age of water from wells in the Muddy Creek Watershed, for example, was 15 years, compared to 11 years for the water from the springs in that watershed, and less than 10 years for water from all springs in the spring study. The similarity in the ranges in apparent age of water from the wells and from the springs shows that the samples from the targeted watersheds and springs have bracketed the range of apparent ages that would be expected in the shallow ground-water-flow systems throughout the Chesapeake Bay Watershed.

The apparent age of water from individual wells does not necessarily represent the entire distribution of ages of the discharging ground water, and it is this distribution of ages that affects the response of nutrient concentrations in stream base flow. Nutrient-reduction scenarios were modeled for two watersheds for which the distribution of apparent ground-water ages was available, the East Mahantango Creek Watershed in the Valley and Ridge siliciclastic HGMR and the Locust Grove Watershed in the Coastal Plain Uplands HGMR. A nutrient-reduction scenario was created for East Mahantango Creek, where the average residence time 
was determined to be approximately 10 years on the basis of the output of particle tracking from a groundwater-flow model. This scenario showed decreases of nearly 50 percent in base-flow concentrations of nitrate in streams within the first year after the reduction in nitrogen input; smaller reductions in nitrate concentration occurred in each subsequent year. A second scenario for that same watershed, in which the same 10-year average residence time was assumed and an exponential model was used for analysis, showed that a 50 -percent reduction in base-flow concentrations of nitrate could take up to 5 years. For the Locust Grove Watershed, in which an average residence time of 32 years was assumed, simulation with the exponential model showed that it may take more than 20 years to achieve a 50-percent reduction in base-flow concentrations of nitrate. Although it was not possible to construct such scenarios for all watersheds, these examples show the range of possible responses to changes in nutrient inputs in two very different types of watersheds.

Findings from this study include information on factors that affect ground-water age, spatial distribution of ages, and nitrogen transport. In the East Mahantango Creek Watershed and the Polecat Creek Watershed, the residence time varied spatially depending on the position of the flow path, and temporally depending on the recharge conditions. Generally, ground water in areas near the stream had short residence times and the water in upland areas had longer residence times. Water traveling through deep layers had longer residence times than water traveling through shallow layers, and residence times were faster under high recharge conditions than low recharge conditions. Ground water in the Pocomoke Watershed exhibits a similar pattern: younger water discharges to small order streams in headwater basins and older water discharges to larger streams near the basin outlet.

Factors affecting nitrogen transport in ground water include spatial and temporal variation in input sources, ground-water age, and aquifer processes that lead to denitrification. Spatial and temporal variations in nitrogen sources affect all the watersheds. Tributaries with higher inputs of nitrogen have higher concentrations in stream base flow. Areas where nitrogen application rates have increased over time show an age-nitrate relation in ground-water samples. The age-nitrate relation can be affected by denitrification, which occurs in Pocomoke and East Mahantango Creeks but is not evident in Polecat and Muddy Creeks. In East Mahantango Creek, the level of denitrification is significant in water with residence times greater than 20 years, but because this is a small component of overall ground-water discharge to a stream, it may not remove a significant quantity of nitrogen from the system. Denitrification in Pocomoke Creek is significant and appears to affect mostly older water discharging to streams. Therefore, if most of the nitrogen entering these two streams is associated with the discharge of younger ground water, denitrification may not greatly affect the overall nitrogen delivery to these streams.

Other findings of this study show that nitrate in ground water discharging along preferential flow paths may not be affected by natural processes, such as denitrification or uptake by riparian vegetation. Seeps to swales and ditches beneath the north uplands at Polecat Creek indicate a shallow water table and discharge of young ground water whereas the absence of such seeps on the south side indicates a deep water table and a lack of young ground water. Similarly, discharge at the base of the slope and to the valley wetland south of the creek but not north of the creek indicates a different role for the riparian forest on the two sides of the creek. In many of the systems where water discharges at the base of slopes to wetlands, ditches have been dug to drain the valley. Such drainage circumvents possible removal of nitrate by riparian vegetation.

Because ground-water residence times do not appear directly related to the HGMRs, the targeting of management practices will achieve the most rapid response in water quality if directed at 1) watersheds with large agricultural sources of nitrate, 2) areas with the shortest ground-water-flow paths and 3) areas not affected by significant denitrification. The fastest response in stream base-flow concentrations of nitrogen to implementation of management practices would be to implement practices in those areas with the highest loads rather than attempt to target practices on the basis of HGMR stratification. Overall findings of the study indicate that 1) ground-water contributions to nitrogen in streamflow are significant, 2) some response to management practices should be evident in base-flow concentrations of nitrogen and loads within 1 to 5 years in watersheds with the shortest average residence times, but response time may be closer to 20 years in watersheds with longer average ground-water residence times, 3) the majority of the response in ground-water discharge to any changes in management practices will be distributed over a 10-year time period even in the watersheds with the fastest response times, and 4) given that half the streamflow is from ground-water discharge and the other half is runoff or soil water, about 90 percent of total water being discharged to a stream will be 
less than about a decade old; therefore, full implementation of nutrient reductions may result in improved streamwater quality in about a decade. In the morelikely scenario of gradual source reduction, the reduction in concentrations of nitrate in streams and aquifers would take longer than the examples shown here.

\section{INTRODUCTION}

\section{Problems Facing the Nation's Largest Estuary}

The Chesapeake Bay is the Nation's largest estuary and historically supports one of the most productive fisheries in the world. The Bay serves as the spawning ground for 70 to 90 percent of the striped bass in the Atlantic Ocean. The 64,000- $\mathrm{mi}^{2}$ watershed of the Bay (fig. 1) provides vital habitat for migratory birds using the Atlantic Flyway. In addition to supporting aquatic communities and wildlife, the Bay's watershed serves the economic and recreational needs of 15 million people. The fertile soils of the watershed support large agricultural production. The agricultural products and other goods produced in the watershed are shipped through ports on the Bay, such as Baltimore, Md., and Norfolk, Va., to the world. Unfortunately, the commercial, economic, and recreational value of the Bay and its watershed has been degraded by poor water quality, loss of habitat, and over-harvesting of living resources.

One of the biggest water-quality problems in the Bay is an overabundance of nutrients (U.S. Environmental Protection Agency, 1999). These nutrients occur naturally in the watershed but also are found in human and

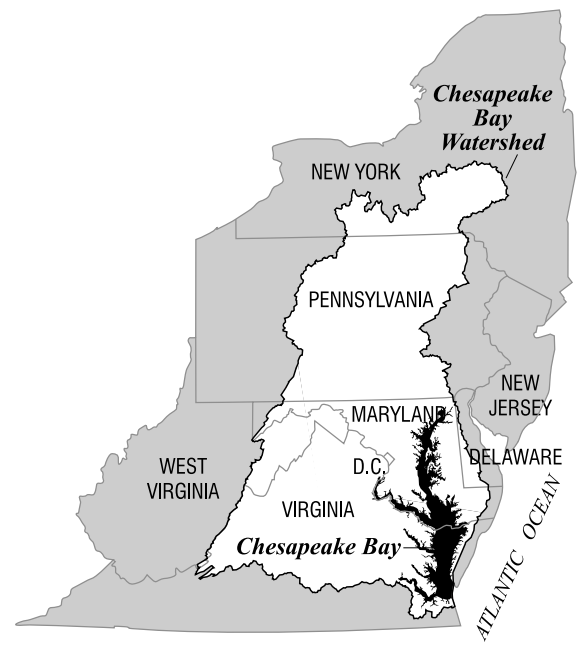

Figure 1. Chesapeake Bay Watershed and surrounding area. animal wastes and commercial fertilizer. As human population has increased in the watershed, with the accompanying growth in agriculture, an overabundance of nutrients has been entering the Bay. Excess nutrients stimulate algal blooms that consume dissolved oxygen as they decompose and have caused large areas of low concentrations of dissolved oxygen in the Bay. The low concentrations of dissolved oxygen have killed many bottom-dwelling organisms. The algal blooms, along with sediment eroding from the land, also block sunlight needed by underwater grasses (also known as submerged aquatic vegetation, or SAV). Without sunlight, the Bay grasses die, removing an important habitat for fish and shellfish and food for waterfowl. Because of the continued problems with excess nutrients and sediment, the Bay was listed as an "impaired water body" in 1999 under regulatory status related to the Clean Water Act. The Act specifies that water quality in the Bay must be improved by 2010 .

Ground water plays an important role in the delivery of nutrients from the watershed to the Bay. The U.S. Geological Survey (USGS) conducted a study from 1996 to 2001 to improve the understanding of the discharge, associated nitrate $\left(\mathrm{NO}_{3}^{-}\right)$load, and residence time of ground water in the Chesapeake Bay Watershed. The study had several components. Component 1 was to determine the discharge and associated $\mathrm{NO}_{3}^{-}$loads to streams and their relation to hydrogeomorphic regions (HGMRs) (summarized in Bachman and others, 1998). HGMRs are areas of different rock type and physiography. Component 2 was to estimate the apparent age and residence time of ground water on the basis of a sampling of springs in different HGMRs (Focazio and others, 1998). Component 3 was to determine the factors affecting the residence time and associated $\mathrm{NO}_{3}^{-}$in ground water discharging to streams in the Bay Watershed (the focus of this report). These scientific findings are being used by the Chesapeake Bay Program (CBP), which is a partnership between Maryland, Virginia, Pennsylvania, the District of Columbia, the Federal Government, and the Chesapeake Bay Commission, to help formulate and implement restoration goals related to nutrient reductions.

\section{Purpose and Scope}

This report presents information about the factors affecting the discharge, associated $\mathrm{NO}_{3}^{-}$concentration, and residence time of ground water in the Chesapeake Bay Watershed. To determine the factors affecting residence time and $\mathrm{NO}_{3}^{-}$concentrations in ground water at regional and local scales, data were collected from 
springs in 1997 and from wells, springs, and other ground-water discharge points in four small watersheds during 1998-2000. The springs were part of a network established in 1996 to determine the influence of different HGMRs and land use on ground-water residence time and the occurrence of $\mathrm{NO}_{3}^{-}$in ground water on a regional scale. The small watersheds were selected to better understand the physical and chemical processes controlling residence time and $\mathrm{NO}_{3}^{-}$transport to streams on a local scale. Therefore, each watershed was in an area of agricultural land and in a different HGMR to help understand the influence of physiographic setting and rock type on residence time.

Different types of atmospheric gases and isotopic substances were measured in ground water to interpret the apparent age and residence time (summarized in "Approaches for ground-water dating"). Chemical and isotopic species of nitrogen $(\mathrm{N})$ were measured to help determine the sources, transport, and reaction of $\mathrm{NO}_{3}^{-}$ in the ground water ("Sources, transport, and reaction of nitrate"). The results of the ground-water data collection were used to help understand the processes controlling residence time and $\mathrm{NO}_{3}^{-}$in the springs and the four small watersheds ("Ground-water residence time and nitrogen concentration"). The results from the springs and watersheds were integrated with results from the previous components of the study to identify common factors affecting the residence time of, and $\mathrm{N}$ in, ground water discharging to streams in the Chesapeake Bay Watershed ("Factors affecting the residence time of, and nitrate transport in, ground water discharging to streams in the Chesapeake Bay Watershed") and address the implications for management actions to reduce $\mathrm{N}$ into the Bay ("Implications for management").

\section{Ground Water in the Chesapeake Bay Watershed}

Ground water enters the Chesapeake Bay in two ways - as base flow to streams and rivers that drain to the Bay or as discharge from shallow aquifers directly to the Bay and its tidal tributaries. For purposes of this report, stream water is defined to consist of overland flow, interflow, and ground-water discharge (fig. 2). Overland flow is rain or snowmelt that flows directly over the land surface and into streams. In general, overland flow is a small fraction of the water in streams and enters the streams within hours or days of a storm or snowmelt event. Interflow, which is water moving though the soil zone, is delivered to a stream during, or shortly after, storms. Ground-water discharge, or base flow, enters the streams from an aquifer and provides the

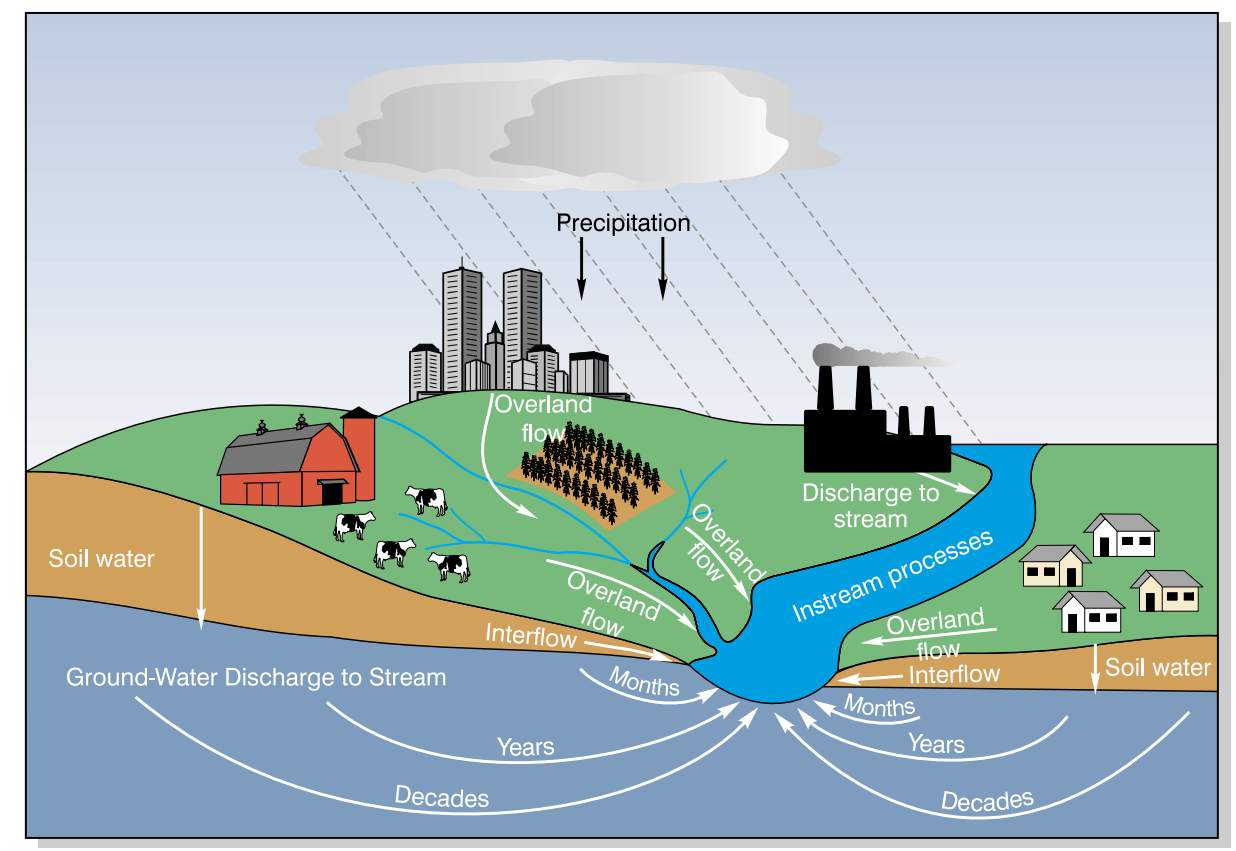

Figure 2. Movement of water through the hydrologic cycle. 
largest percentage of the streams' annual flow (more than 50 percent on average) in the Chesapeake Bay Watershed. The residence time of the ground water in an aquifer can range from months to decades before discharging to streams.

The first two components of the USGS study focused on ground water that discharges to streams and rivers as base flow rather than direct discharge to the Bay, since base flow is considered the larger of the two sources of ground water contributing to the Bay. Component 2 of the study also focused on estimating the apparent age and associated residence time of ground water because it is the least understood of the components affecting the age of water in a stream. Understanding the residence time of ground water, coupled with information about overland flow and interflow, can provide an insight to the concept of "lag time" between implementation of management actions to reduce nutrient loads and a distinguishable improvement in surfacewater quality. The results of the first two components of the USGS study are summarized in the following sections.

\section{Previous USGS Estimates of Ground-Water Discharge and Nitrate Load to Streams}

Streamflow data collected at 276 sites in the Chesapeake Bay Watershed (fig. 3) were analyzed by Bachman and others (1998) using hydrograph-separation techniques (Sloto and Crouse, 1996) to estimate the total streamflow contributed by ground water. All sites had at least 4 years of streamflow data; some sites had 25 years of data. Ground-water contributions to total streamflow ranged from 16 to 92 percent at these sites; the median contribution was 54 percent. Thus, in an average year, of the 50 billion gallons of streamflow that enter the Bay each day, nearly 27 billion gallons are from ground water.

The underlying rock type and physiographic provinces influence the range of ground-water discharge values. Bachman and others (1998, p. 9-13) used the characteristics of rock type and physiographic province to divide the Chesapeake Bay Watershed into 11 hydrogeomorphic regions (HGMRs) (fig. 3). The characteristics of the rock type in each HGMR provide a surrogate for permeability and mineral composition of aquifers. The four major rock types used were unconsolidated, crystalline, carbonate, and siliciclastic. The physiographic province serves as a surrogate for slope and relief and thus hydrologic gradients in each HGMR.
The five major physiographic provinces were the Coastal Plain, Piedmont, Blue Ridge, Valley and Ridge, and Appalachian Plateau.

The largest contribution of ground-water discharge to total streamflow (fig. 4) was in the Valley and Ridge carbonate HGMR, followed by regions of unconsolidated rock (Coastal Plain HGMRs) and crystalline bedrock (Piedmont and Blue Ridge HGMRs). The smallest amounts of ground-water discharge were in the Mesozoic Lowland HGMR. Large amounts of groundwater discharge to streams in the Coastal Plain HGMR are related to relatively well-drained soil and flat topography, which favor infiltration of precipitation into shallow aquifers. The underlying unconsolidated sediments, which are a combination of sands, silts, and clays, are relatively permeable and therefore capable of yielding large quantities of water. In contrast, ground water west of the Fall Line (the zone between unconsolidated sediments and bedrock, shown on fig. 3) flows through fractures in consolidated bedrock and regolith (weathered bedrock). The amount of ground water in shallow bedrock aquifers is influenced by the thickness of the overlying regolith, the amount and interconnectiveness of fractures or solution channels, and the topographic relief. The large amounts of ground-water discharge to streams in carbonate rocks of the Valley and Ridge HGMR are caused by ground-water flow in solutionenlarged fractures, permeable soils, and generally flat relief. Although ground water in the crystalline rocks (Piedmont Crystalline and Blue Ridge HGMRs) infiltrates less because of steeper topography, a mantle of regolith generally covers the slopes of hills and acts as a reservoir for ground water. Areas underlain by siliciclastic rocks (Appalachian Plateau Siliciclastic and Mesozoic Lowland HGMRs) have lesser amounts of groundwater discharge to streams because of poorly drained soils, bedrock with low fracture connectivity, and steep topography that promotes overland runoff. The two HGMRs also may have very little regolith in some areas, which would result in a small potential for ground-water storage.

The amount of ground water contributing to total streamflow also varies with the amount of annual precipitation (Bachman and others, 1998, p. 21). The percentage of total streamflow contributed by ground-water discharge is greater in dry years than it is in wet years. Variation in annual precipitation causes a fluctuation of 10 to 20 percent in ground-water contributions to total streamflow. 
EXPLANATION

(Streamflow was measured at all stations shown.)

A STATIONS FOR WHICH ONLY STREAM DISCHARGE WAS MEASURED

$\triangle$ STATIONS FOR WHICH LOADS WERE COMPUTED FOR BASE-FLOW NITRATE, TOTAL-FLOW NITRATE, OR TOTAL-FLOW TOTAL NITROGEN

- STATIONS FOR WHICH LOADS WERE COMPUTED FOR BASE-FLOW NITRATE AND TOTAL-FLOW NITRATE ONLY

$\nabla$ STATIONS FOR WHICH LOADS WERE COMPUTED FOR BASE-FLOW NITRATE AND TOTAL-FLOW NITROGEN ONLY

$\nabla$ STATIONS FOR WHICH LOADS WERE COMPUTED FOR BASE-FLOW NITRATE, TOTAL-FLOW NITRATE, AND TOTAL-FLOW TOTAL NITROGEN

HYDROGEOMORPHIC REGIONS

APPALACHIAN PLATEAU CARBONATE

APPALACHIAN PLATEAU SILICICLASTIC

VALLEY AND RIDGE CARBONATE

VALLEY AND RIDGE SILICICLASTIC

BLUE RIDGE

CRYSTALLINE

MESOZOIC LOWLAND

SILICICLASTIC

PIEDMONT

CARBONATE

PIEDMONT

CRYSTALLINE

COASTAL PLAIN

DISSECTED UPLAND

COASTAL PLAIN

LOWLAND

COASTAL PLAIN

UNDISSECTED

UPLAND

$$
\text { SECTED }
$$
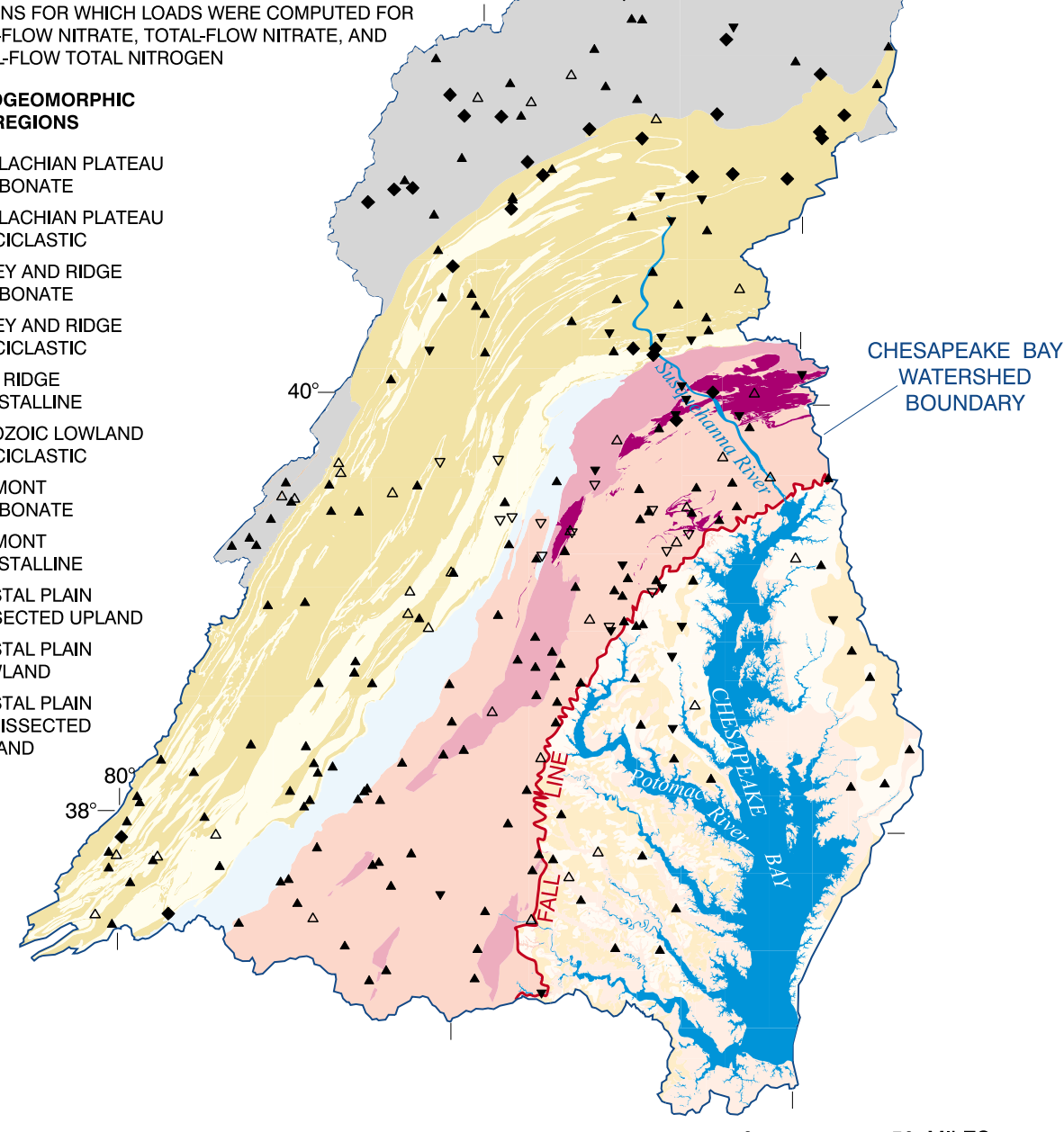

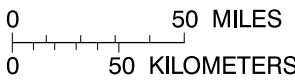

Figure 3. Locations of stations with streamflow measurements and loads estimates, and hydrogeomorphic regions within the Chesapeake Bay Watershed (modified from Bachman and others, 1998.) 

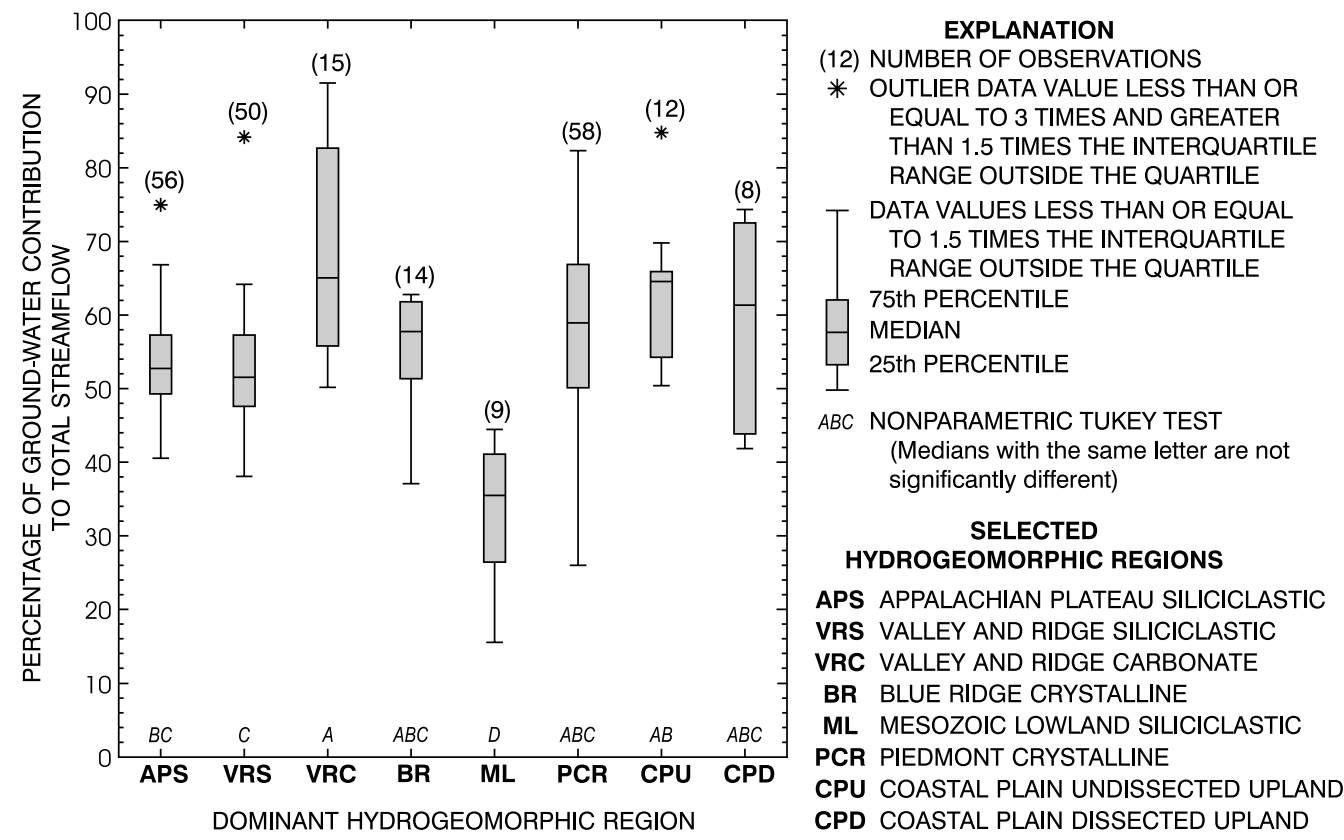

Figure 4. Distribution of ground-water flow by hydrogeomorphic region (from Bachman and others, 1998).

The amount of $\mathrm{N}$ in ground water will depend on the overlying land use, soil characteristics, topography, and aquifer composition (Speiran and others, 1998, p. 2). For example, $\mathrm{N}$ inputs generally are larger in urban and agricultural areas than in forested areas. $\mathrm{N}$ is present in several species in ground water depending on the availability of dissolved oxygen, which is influenced by the soil and aquifer composition. The amount of organic material in soil and aquifer sediments affects water chemistry. Organic material reacts with dissolved oxygen, removing it from the water. Fine-grained soils and aquifer material commonly contain larger amounts of organic materials and therefore less dissolved oxygen. Where dissolved oxygen is abundant, bacteria chemically oxidize (nitrify) ammonia to $\mathrm{NO}_{3}^{-} \cdot \mathrm{NO}_{3}^{-}$is a concern because it is the main form that dissolves in, and flows with, ground water. Where dissolved oxygen is limited, $\mathrm{NO}_{3}^{-}$will not form, and bacteria will chemically reduce (denitrify) $\mathrm{NO}_{3}^{-}$that is already present to $\mathrm{N}_{2}$ gas or to ammonia if sufficient organic material is present.

An average of 48 percent of the $\mathrm{N}$ load entering the Bay from streams has been discharged from ground water; the load ranges from 17 to 80 percent (Bachman and others, 1998, p. 17). The ground-water loads were estimated by using the ground-water discharge information and associated surface-water-quality data to deter- mine the $\mathrm{N}$ concentration in streamflow during baseflow conditions (ground-water discharge) and stormflow conditions (Langland and others, 1995). Bachman and others (1998) converted the loads to yields (load divided by drainage area) to compare different HGMRs and their respective land use. Yields of $\mathrm{NO}_{3}^{-}$in ground water showed a positive correlation with increased agricultural land use in the Valley and Ridge carbonate and the Piedmont crystalline HGMRs. The lowest yield of $\mathrm{NO}_{3}^{-}$in ground water was in the Appalachian Plateau siliciclastic HGMR, which has a low percentage of agricultural land use.

There are several limitations in trying to use surface-water data to estimate ground-water $\mathrm{NO}_{3}^{-}$loads for the entire Chesapeake Bay Watershed and in comparing loads among HGMRs. First, ground-water samples from many sites were not analyzed for all the $\mathrm{N}$ species; therefore, loads of dissolved $\mathrm{NO}_{3}^{-}$were used as a surrogate for loads of total $\mathrm{N}$ (Bachman and others, 1998, p. 5). Secondly, ground-water $\mathrm{NO}_{3}^{-}$load and total $\mathrm{N}$ loads data were available for far fewer stations (about 48) than were used to compute ground-water discharge, and therefore, the data set could not be used to statistically test relations between ground-water loads and HGMRs. Thirdly, instream processes that may release or take up $\mathrm{N}$ can influence the $\mathrm{NO}_{3}^{-}$concentrations during base-flow conditions. 


\section{Previous USGS Estimates of Ground-Water Residence Times and Apparent Ages}

Focazio and others (1998) used several approaches to estimated ground-water residence times and ages. The most direct approach was to collect and analyze water samples for isotopic tracers to determine the age of the water. Chlorofluorocarbons (CFCs) were the primary tracer used in a study of springs conducted in 1996. The CFC technique is described in Busenberg and Plummer (1992) and in a subsequent section of this report. CFCs have entered the atmosphere since the 1940s and are transported to ground water as precipitation recharges the water table. The CFC concentration can be used as an estimate of an "apparent" age of ground water, which is the time that elapsed since the time when the water entered the ground-water system and was isolated from the atmosphere.

In 1996, 60 water samples were collected from 48 springs in the Chesapeake Bay Watershed for analysis of CFC concentration. Because a spring is a discharge point for a number of converging ground-waterflow paths of different ages in an aquifer, the apparent age of a single sample collected from a spring may be considered a representative, or average, residence time for water in an aquifer. The apparent ages of water collected from springs ranged from modern ( $0-4$ years) to more than 50 years old (fig. 5) (Focazio and others, 1998). The apparent age of water from 75 percent of the springs was less than 10 years old; another 10 percent were between 10 and 20 years. The remaining ages were greater than 20 years and included two samples collected from geothermal springs, which would indicate the presence of water from deeper ground-water-flow systems. About 20 percent of the springs were contaminated by local sources of CFCs and could not be dated (Concentrations were higher than could be explained by atmospheric sources of CFCs). The samples collected in 1996 were during an unusually high-flow period and thus may be younger than those under normal flow conditions. Additional samples were collected in 1997 to test the difference in ages in response to flow conditions and are presented in this report with the data presented in the Appendixes A-D.

The apparent age of the samples from the springs varied within an HGMR as much as between the HGMRs (table 1), but not enough data were collected to permit statistical tests of variance of apparent ages between HGMRs. Where enough existing apparent age data from wells were available in a local study area, the ages from wells were averaged to supplement the spring data in different HGMRs. The largest range in apparent age of the spring waters was in the Valley and Ridge

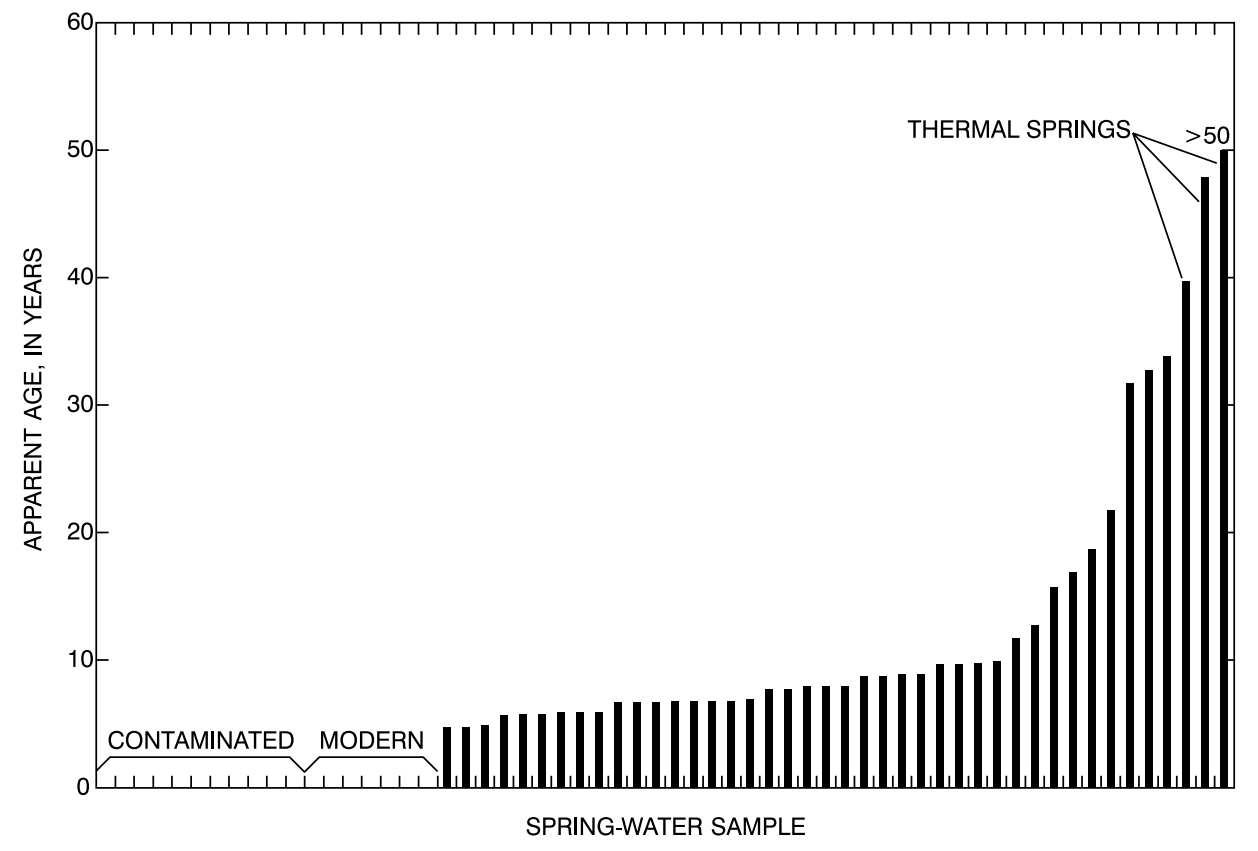

Figure 5. Apparent ages (residence time) of water collected from springs in the Chesapeake Bay Watershed in September and November 1996 (from Focazio and others, 1998). 
Table 1. Distribution of apparent ages (residence times) of water from springs in different hydrogeomorphic regions of the Chesapeake Bay Watershed (from Phillips and others, 1999)

\begin{tabular}{lc}
\hline \multicolumn{1}{c}{ Hydrogeomorphic region } & Apparent age of water (years) \\
\hline Coastal Plain & $6-12$ \\
Piedmont crystalline & Modern (0-4 years) to 34 \\
Piedmont carbonate & Modern to 7 \\
Mesozoic Lowland siliciclastic & Modern to 9 \\
Blue Ridge crystalline & Modern to 8 \\
Valley and Ridge siliciclastic & Modern to 33 \\
Valley and Ridge carbonate & Modern to 32 \\
\hline
\end{tabular}

HGMRs (modern to 33 years) and the Piedmont crystalline HGMR (modern to 34 years) (Focazio and others, 1998). A smaller range of ages (modern to about 10 years) was seen in the remaining HGMRs sampled: Coastal Plain, Piedmont carbonate, Mesozoic Lowland siliciclastic, and Blue Ridge crystalline.

Focazio and others (1998) also examined tritium $\left({ }^{3} \mathrm{H}\right)$ data (another tracer that can be used to estimate ground-water residence times) collected in a previous study in the Potomac and Susquehanna River Basins (Michel, 1992). Long-term ${ }^{3} \mathrm{H}$ records were used to calculate residence times for water in seven river basins in the United States and to determine the percentage of annual runoff attributed to "within-year runoff" (analogous to interflow) and the percentage from "long-term reservoirs" (ground water). This is a similar concept to using hydrograph separation to estimate the amount of ground-water contribution to a stream. Water samples from the Potomac River Basin at Point of Rocks, Md., had the longest residence time (20 years) of all seven basins. The Potomac River water comprises a small percentage of within-year runoff (46 percent) and a correspondingly large percentage of water from long-term reservoirs (54 percent). For the other site in the Chesapeake Bay Watershed, the Susquehanna River at Harrisburg, Pa., Michel (1992) calculated a residence time of 10 years; 20 percent of the water was in the long-term reservoir and 80 percent was within-year runoff Focazio and others (1998, p. 13-14) applied a similar approach for the Susquehanna River and estimated a residence time of 10-20 years and about even percentages between the within-year and long-term reservoirs. Unfortunately, ${ }^{3} \mathrm{H}$ data from rivers are very limited from the 1960s and 1970s and concentrations are too low in recent rainfall, so this technique cannot be applied to more rivers in the Chesapeake Bay Watershed (Focazio and others, 1998, p. 16).

\section{Acknowledgments}

This project was made possible by the efforts and contributions of many individuals. We would like to thank all of those who contributed to the success of the project, beginning with all of the landowners and homeowners who gave us permission to collect samples.

We also thank Tyler Coplen, USGS, Reston, Va., for stable isotope data, and Robert L. Michel, USGS, Menlo Park, Calif., for tritium measurements. Field assistance from Julian Wayland, Gerolamo Casile, and Wandee Kirkland (USGS, Reston, Va.) is gratefully acknowledged. We thank Gerolamo Casile and Julian Wayland for chlorofluorocarbon analyses, Peggy Widman for dissolved $\mathrm{N}_{2}$ and Ar analyses, Wandee Kirkland for $\mathrm{SF}_{6}$ analyses, and Michael Doughten for waterchemistry analyses. The tritium/helium-3 measurements were made at the Noble Gas Laboratory of LamontDoherty Earth Observatory of Columbia University, Palisades, N.Y., under the direction of Dr. Peter Schlosser. Nitrogen isotope analyses were done by Janet Hannon, Stan Mroczkowski, Haiping Qi, and Maureen Reilly.

The study of the Polecat Creek Watershed was coordinated with ongoing monitoring and research conducted by the USGS in cooperation with the Chesapeake Bay Local Assistance Department of the Commonwealth of Virginia.

Contributions to the study of the East Mahantango Creek Watershed were made by William Gburek and Gordon Folmar of the U.S. Department of Agriculture, Agricultural Research Service (ARS), University Park, Pa. The assistance from the ARS staff at Klingerstown, Pa., is gratefully acknowledged as well.

\section{STUDY DESGN AND DATA-COШECTION METHODS}

Data were collected from springs and four small watersheds to study the factors affecting residence time and $\mathrm{NO}_{3}^{-}$concentrations in ground water at regional and local scales (fig. 6). The springs sampled were from a network established in 1996 to determine the influence of different HGMRs and land use on residence time and $\mathrm{NO}_{3}^{-}$occurrence in ground water. The same springs were sampled again in 1997 to determine the influence of two very different hydrologic conditions on the apparent age and residence time in ground water. In 1996, above-average amounts of precipitation resulted in high base flow throughout the year; a drought occurred in 1997. Sample collection for the springs followed the procedures previously reported in Focazio and others (1998). 


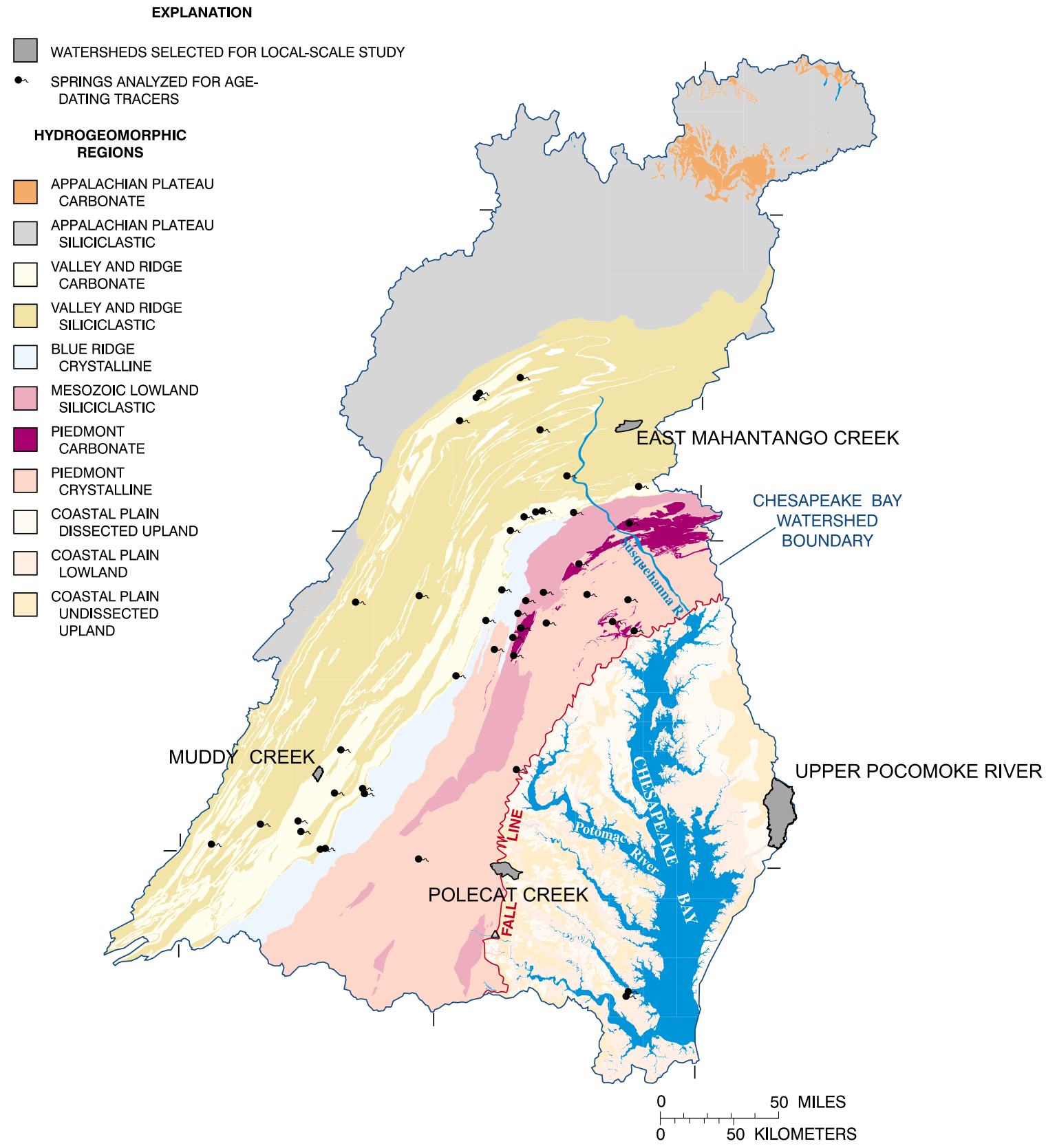

Figure 6. Locations of springs and targeted watersheds in the Chesapeake Bay Watershed. 
The small watersheds were selected for study to enhance understanding of the physical and chemical process controlling residence time and $\mathrm{N}$ transport to streams. The four watersheds represent predominately agricultural areas in different HGMRs (table 2). Agricultural land use was chosen to increase the potential for having $\mathrm{NO}_{3}^{-}$in the ground water. The selection of the watersheds also was predicated on having existing well networks to maximize the use of project resources. Relying on existing networks, however, required the sampling design to be unique for each watershed. In two watersheds (Polecat Creek and Pocomoke River), additional wells were installed as part of this study. Initial sampling of selected wells in each watershed was conducted in 1998. Sampling of the entire network of wells was conducted in 1999. Additional samples were collected in 2000 from selected wells in each network to determine the influence of hydrologic variability on ground-water residence time. An overview of the data collection for the watershed is provided below, and unique aspects of each network are presented in the sections on the respective watersheds.

Table 2. Hydrogeomorphic regions and targeted watersheds chosen for study

\begin{tabular}{ll}
\hline \multicolumn{1}{c}{ Hydrogeomorphic Region } & \multicolumn{1}{c}{ Watershed and Location } \\
\hline Coastal Plain Uplands & Upper Pocomoke River, \\
& Whaleysville, Md. \\
Piedmont crystalline & Polecat Creek, Carmel Church, Va. \\
Valley and Ridge carbonate & Muddy Creek, Harrisonburg, Va. \\
Valley and Ridge siliciclastic & East Mahantango Creek, \\
& Klingerstown, Pa. \\
\hline
\end{tabular}

In the Upper Pocomoke River Watershed, samples were collected during August and September 1998, March and September 1999, and March 2000. Portable minipiezometers, 2-in.-inside diameter stainless steel piezometers, and existing 6-in.-inside diameter stainless steel monitoring wells were used to obtain samples in this watershed. The 2-in. piezometers were installed in early March 1999 with the use of a tripod with a cat head and slide hammer and with the use of a sledge hammer or 2-man hammer where necessary. The piezometers were steam cleaned prior to installation to prevent samples from being contaminated by oils or other manufacturing materials. Prior to sampling, water levels in the piezometers and wells were measured and water was pumped out with a peristaltic or submersible gas-driven pump. Each piezometer or well was purged of three volumes of water or until field readings of $\mathrm{pH}$, specific conductance, and concentrations of dissolved oxygen were stable. Prior to sampling from the portable minipiezometers, the hydraulic head of ground water was measured with a flexible-tube manometer (Winter and others, 1988) and was compared to the stream stage to ensure the ground-water head was higher than the stream level. Streams were not wide enough or deep enough to warrant depth- and width-integrated sampling. Streamwater samples were collected with a peristaltic pump after field readings were stable.

In the Polecat Creek Watershed, samples were collected from 2-in.-inside diameter PVC piezometers during April 1999 and April 2000. Prior to sampling, water levels were measured, and water was pumped out with a submersible, gas-driven pump. Each piezometer was purged of three volumes of water or until field readings of $\mathrm{pH}$, specific conductance, and concentrations of dissolved oxygen were stable.

In the Muddy Creek Watershed, 6-in.-inside diameter PVC monitoring wells, homeowners' wells, and springs were sampled during November 1998, April 1999, and April 2000. Prior to sampling the monitoring wells, water levels were measured, and water was pumped out with a submersible gas-driven pump. Homeowners' wells were sampled at a point at or before the pressure tank with the pump running constantly. Springs were sampled by inserting a submersible gasdriven pump as close as possible to the discharging water. Each well was purged of three volumes of water or until field readings of $\mathrm{pH}$, specific conductance, and concentrations of dissolved oxygen were stable. Spring water was purged until the field readings were stable. Streamwater samples were collected with a peristaltic pump after field readings were stable.

In the East Mahantango Creek Watershed, 6-in. diameter steel-cased observation wells were sampled during June 1998, May 1999, and May 2000. Prior to sampling each well, water levels were measured, and the well was purged of three volumes of water with a (Grundfos) submersible pump. A submersible gasdriven pump was then used to collect samples to monitor field readings of $\mathrm{pH}$, specific conductance, and concentrations of dissolved oxygen until they were stable and to sample the well. Streamwater samples were collected with a peristaltic pump after field readings were stable.

All $\mathrm{N}$ species analyzed are presented in this report in milligrams per liter as $\mathrm{N}$ (Appendix B). Ground-water samples typically were collected and processed over a period of 1-2 hours as follows: (1) unfiltered samples were collected for field measurements of $\mathrm{pH}$, concentrations of dissolved oxygen, specific conductance, and temperature. (2) Filtered $(0.45 \mu \mathrm{m})$ samples were collected for laboratory measurements of cations (acidified), anions (chilled), $\mathrm{N}$ and 
phosphorus species (chilled), and $\mathrm{N}$ isotopes (chilled). (3) Unfiltered samples were collected for laboratory measurements of dissolved gasses, ${ }^{3} \mathrm{H}$, and stable hydrogen $(\mathrm{H})$ and oxygen $(\mathrm{O})$ isotopes. (4) Five unfiltered samples were sealed in glass ampules for laboratory age-dating analysis of CFCs (as described by Busenberg and Plummer, 1992). (5) Two unfiltered samples were sealed in special copper tubes for laboratory analysis of the tritium/helium $\left({ }^{3} \mathrm{H} /{ }^{3} \mathrm{He}\right.$ ) ratio (as described by USGS Technical Memoranda 97.04 and 97.04S) (Plummer and Mullin, 1997a, b). (6) A 1-L, unfiltered sample was collected for laboratory measurement of sulfur hexafluoride $\left(\mathrm{SF}_{6}\right)$ (as described by Busenberg and Plummer, 2000). Streamwater samples were collected for laboratory analyses of cations, anions, and $\mathrm{N}$ species only.

Samples collected for analysis of nutrients were shipped to the USGS National Water-Quality Laboratory (NWQL), Denver, Colo. Samples for analysis of ${ }^{3} \mathrm{H} /{ }^{3} \mathrm{He}$ were collected in copper tubes, archived, and analyzed by the Lamont-Doherty Earth Observatory of Columbia University, Palisades, N.Y., if ages based on $\mathrm{CFCs}$ were inconclusive. All other samples were analyzed by the USGS National Research Program (NRP) Isotope Laboratory, Reston, Va., using the protocols outlined in USGS Water-Quality Technical Memorandum 95.02 (Alley and Rickert, 1995).

Quality-assurance samples were collected and consisted of a duplicate analysis for each of the constituents monitored. All data are stored in the USGS National Water Inventory System (NWIS) database.

\section{APPROACHES FOR GROUND-WATER DATING}

\section{By L. Niel Plummer, John-Karl Böhlke, and Eurybiades Busenberg}

Measurements of the concentrations of atmospheric gases and isotopic substances in ground water were used to interpret the age of shallow ground water in the Chesapeake Bay Watershed. Ground-water age is defined as the time elapsed since recharge-when the water entered the ground-water system. All ages are regarded as apparent ages because they are based on an interpretation of measured concentrations of environmental tracers in ground water. Several dating techniques are used, each of which has advantages and limitations (Plummer and others, 1993; Cook and Solomon, 1997; Solomon and Cook, 1999; Plummer and Busenberg, 1999). Therefore, greater confidence in apparent age commonly is realized as multiple dating techniques are applied to the same sample. Furthermore, by examining the relations among the various tracers, some physiochemical processes affecting the tracers become apparent. In the present study, concentrations of chlorofluorocarbons (CFCs), sulfur hexafluoride $\left(\mathrm{SF}_{6}\right)$, tritium $\left({ }^{3} \mathrm{H}\right)$, and tritium/helium-3 $\left({ }^{3} \mathrm{H} /{ }^{3} \mathrm{He}\right)$ ratio were used to interpret ground-water ages.

The relation between estimates of the atmospheric concentrations of CFCs and $\mathrm{SF}_{6}$ (Plummer and Busenberg, 1999) and ${ }^{3} \mathrm{H}$ in precipitation at Washington, D.C., is shown in figure 7 (R.L. Michel, U.S. Geological Survey, written commun., 1999). Meteoric water recharged within the Chesapeake Bay Watershed during the past 50 years contains these tracers, and the concentrations in ground-water recharge have varied with time, making it possible to use this variation to estimate ground-water age. Dating methods that depend in part on solubilities of atmospheric gases in ground water (CFC, $\mathrm{SF}_{6}$, and to a lesser extent, ${ }^{3} \mathrm{H} /{ }^{3} \mathrm{He}$ dating) require evaluation of the recharge temperature. 


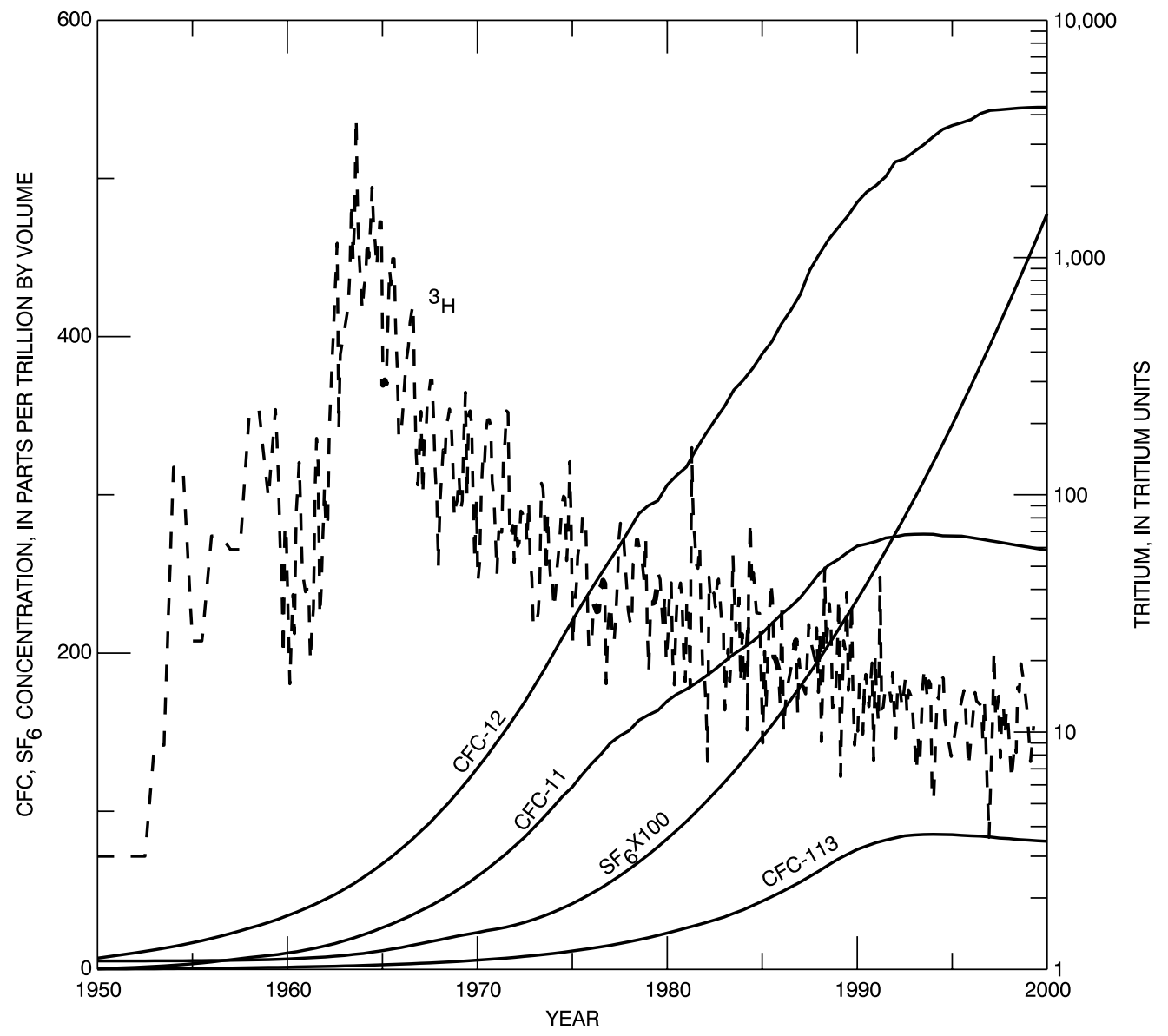

Figure 7. Chlorofluorocarbon (CFC) and sulfur hexafluoride $\left(\mathrm{SF}_{6}\right)$ air-mixing ratios for North American Air based on National Oceanic and Atmospheric Administration data from Niwot Ridge, Colo., and tritium $\left({ }^{3} \mathrm{H}\right)$ in precipitation measured at Washington, D.C. (from R.L. Michel, U.S. Geological Survey, unpub. data, 1999).

\section{Recharge Temperatures, Excess Air, and Quantities of Nitrogen from Denitific ation}

Recharge temperature is the temperature at the water table during recharge. Recharge temperatures were determined for individual samples using dissolved $\mathrm{N}_{2}$ gas and Ar concentrations (Heaton, 1981; Heaton and Vogel, 1981; Heaton and others, 1983; Busenberg and others, 1993; Stute and Schlosser, 1999). The accuracy of this method is typically $\pm 0.5^{\circ} \mathrm{C}$ on laboratory standards. Recharge temperatures of ground-water samples determined from concentrations of dissolved $\mathrm{N}_{2}$ gas and Ar have larger uncertainties than those for laboratory standards because of uncertainty in recharge elevation (barometric pressure during recharge) and the presence of excess air. Because the recharge elevation of most samples from the Chesapeake Bay Watershed probably is known to within $\pm 300 \mathrm{ft}$, this source of uncertainty in recharge temperatures probably is less than $\pm 1{ }^{\circ} \mathrm{C}$ in most cases. In reducing waters, denitrification processes can reduce dissolved $\mathrm{NO}_{3}^{-}$to $\mathrm{N}_{2}$ gas. If not recognized and corrected for, denitrification leads to a warm bias in the calculated recharge temperature, an overestimation of excess air in ground-water samples, and an underestimation of total $\mathrm{NO}_{3}^{-}$initially recharged in ground water. Several procedures were utilized to refine recharge temperatures, excess air, and amounts of denitrification. 
(1) In aerobic samples, with concentrations of dissolved oxygen greater than approximately 1-2 $\mathrm{mg} / \mathrm{L}$, it generally was assumed denitrification had not occurred, and in most cases, the samples were not mixtures of anaerobic and aerobic waters. The recharge temperature and excess air were calculated directly from the dissolved $\mathrm{N}_{2}$ gas and Ar data, using the sample elevation as an estimate of the recharge elevation. The quantity of $\mathrm{N}_{2}$ gas derived from denitrification was assumed to be zero.

(2) In waters with concentrations of dissolved oxygen less than approximately $1-2 \mathrm{mg} / \mathrm{L}$, there is potential for denitrification. For samples of these waters, several additional procedures were used to estimate recharge temperature, excess air, and amounts of $\mathrm{N}_{2}$ derived from denitrification. The quantity of excess air could be calculated within $\pm 0.1 \mathrm{~cm}^{3} \mathrm{~kg}^{-1}$ water from dissolved Ne data, because the solubility of $\mathrm{Ne}$ in water is relatively insensitive to temperature variations in shallow ground water (Stute and Schlosser, 1999). Having defined the excess air quantity from the $\mathrm{Ne}$ data, the Ar and $\mathrm{N}_{2}$ gas data were then used to determine the recharge temperature and amount of denitrification. If no $\mathrm{Ne}$ data were available, average quantities of excess air or average recharge temperatures were assumed, on the basis of results from aerobic samples in the watershed or results from local samples that had Ne analyses, and then used with the dissolved $\mathrm{N}_{2}$ gas and Ar data to estimate quantities of denitrification. The procedure usually led to consistent results for a given watershed.

\section{Dating with Chlorofluorocarbons}

Ground-water dating with chlorofluorocarbons (CFCs) is based on historical data for the atmospheric mixing ratios of these compounds over the past 50 years (fig. 7), the Henry's Law solubilities of CFCs in water, and measurements of CFC concentrations in water samples (Busenberg and Plummer, 1992; Plummer and Busenberg, 1999). Anthropogenic sources of CFCs (in addition to that of the atmosphere) cause a young bias in apparent age or result in samples with CFC concentrations that are larger than those possible for equilibrium of water with modern air (termed "contaminated"). Samples with low concentrations of dissolved oxygen may have lost CFCs because of microbial degradation, particularly CFC-11, leading to an old bias in age. The turnover in air-mixing ratios for CFC-11 and CFC-113 in the 1990s (fig. 7) also leads to ambiguity in age, with apparently modern ages that span the 1990s. The slow rise in CFC-12 air-mixing ratios during this study permitted age interpretation of modern waters but required measurement of recharge temperature for individual samples. The CFC-12 ages of waters recharged in the 1990s thus had uncertainties larger than those associated with $\mathrm{SF}_{6}$ or ${ }^{3} \mathrm{H} /{ }^{3} \mathrm{He}$.

\section{Dating with Sulfur Hexafluoride}

Sulfur hexafluoride $\left(\mathrm{SF}_{6}\right)$ is accumulating rapidly in the atmosphere; the current growth rate is about 6 percent per year (Busenberg and Plummer, 2000). SF 6 can be analyzed to a precision of 1-3 percent, and, even though atmospheric mixing ratios are small (currently about 5 pptv), dating with $\mathrm{SF}_{6}$ is possible for waters recharged from about 1970 to the present (Busenberg and Plummer, 2000). $\mathrm{SF}_{6}$ provides a useful alternative to $\mathrm{CFC}$ dating in the late 1990s because CFC air-mixing ratios leveled off or declined. The historical air-mixing ratio of $\mathrm{SF}_{6}$ (fig. 7) has been reconstructed from production records and atmospheric measurements (Maiss and others, 1996, Geller and others, 1997; Maiss and Brenninkmeijer, 1998).

Apparent ground-water ages based on $\mathrm{SF}_{6}$ concentrations can be fairly sensitive to quantities of excess air trapped and dissolved during recharge. An iterative procedure (Busenberg and Plummer, 2000) was used to resolve ages on the basis of $\mathrm{SF}_{6}$ utilizing the measured amount of excess air and subtraction of the excess air from the sample with gas composition corresponding to the age of the sample. Natural, low-level, terrigenic sources of $\mathrm{SF}_{6}$ also are present in some crystalline rocks (Busenberg and Plummer, 2000). Water samples containing excess $\mathrm{SF}_{6}$ from rocks have apparent ages that are too young. This process may have affected waters from some wells sampled in the Chesapeake Bay Watershed. $\mathrm{SF}_{6}$ apparently is not affected by microbial degradation in ground water (Busenberg and Plummer, 2000).

\section{Thitium Dating}

Large amounts of tritium $\left({ }^{3} \mathrm{H}\right)$ were injected into the stratosphere from atmospheric testing of nuclear weapons, primarily in the mid-1960s (Rozanski and others, 1991). This bomb-related ${ }^{3} \mathrm{H}$ continues to rain out worldwide but at much lower concentrations than during the mid-1960s. Following recharge, ${ }^{3} \mathrm{H}$ decays in ground water with a half-life of 12.4 years. Reconstruction of local ${ }^{3} \mathrm{H}$ records for precipitation can be used, to a first approximation, to infer some aspects of ground- 
water age. For example, a smoothed record of ${ }^{3} \mathrm{H}$ in precipitation at Washington, D.C. is shown in figure 8. A series of parallel lines define the decay paths of points along the precipitation input function over time. For example, water recharged prior to the 1950s should contain, in the year 2000, less than $0.1 \mathrm{TU}$. Water recharged in the year 1965 would now contain approximately 70 TU. The ${ }^{3} \mathrm{H}$ input function of figure 8 is greatly smoothed at half-year intervals. In actuality, ${ }^{3} \mathrm{H}$ in precipitation is quite variable between seasons and between individual precipitation events (fig. 7). It also is apparent that, because of the multiple peaks in ${ }^{3} \mathrm{H}$ content of precipitation, decay lines (fig. 8) can intercept multiple possible years of recharge. During the past 25 years, the ${ }^{3} \mathrm{H}$ content of precipitation decreased at approximately the same rate as ${ }^{3} \mathrm{H}$ decay and, consequently, meteoric water recharged since about 1975 and sampled in the late 1990s to 2000 contains about $10 \mathrm{TU}$ in the Washington, D.C., area (fig. 8); thus, dating with ${ }^{3} \mathrm{H}$ alone is qualitative at best. Still, the ${ }^{3} \mathrm{H}$ data can be quite useful in recognizing post-bomb waters, and together with other atmospheric tracers, the ${ }^{3} \mathrm{H}$ concentration can be very useful in recognizing ground-water mixtures. Furthermore, terrigenic sources of ${ }^{3} \mathrm{H}$ are negligible, and ${ }^{3} \mathrm{H}$ is not affected by microbial degradation processes.

Because of various meteorological processes and atmospheric moisture sources (Rozanski and others, 1991), it generally is necessary to construct a local record of "3 $\mathrm{H}$-in-precipitation" for a particular region being studied. Several scaling procedures exist for reconstruction of local ${ }^{3} \mathrm{H}$ records on the basis of records from parts of the United States (Michel, 1989) and reports from the International Atomic Energy Agency (IAEA). In this study, the ${ }^{3} \mathrm{H}$ record at Washington, D.C., was multiplied by a scaling factor determined from local measurements of ${ }^{3} \mathrm{H}$ in recent recharge. For example, the Washington, D.C., record was multiplied by a scaling factor of 0.73 to estimate a long-term ${ }^{3} \mathrm{H}$ record in the Blue Ridge in Shenandoah National Park (Plummer and others, 2001).

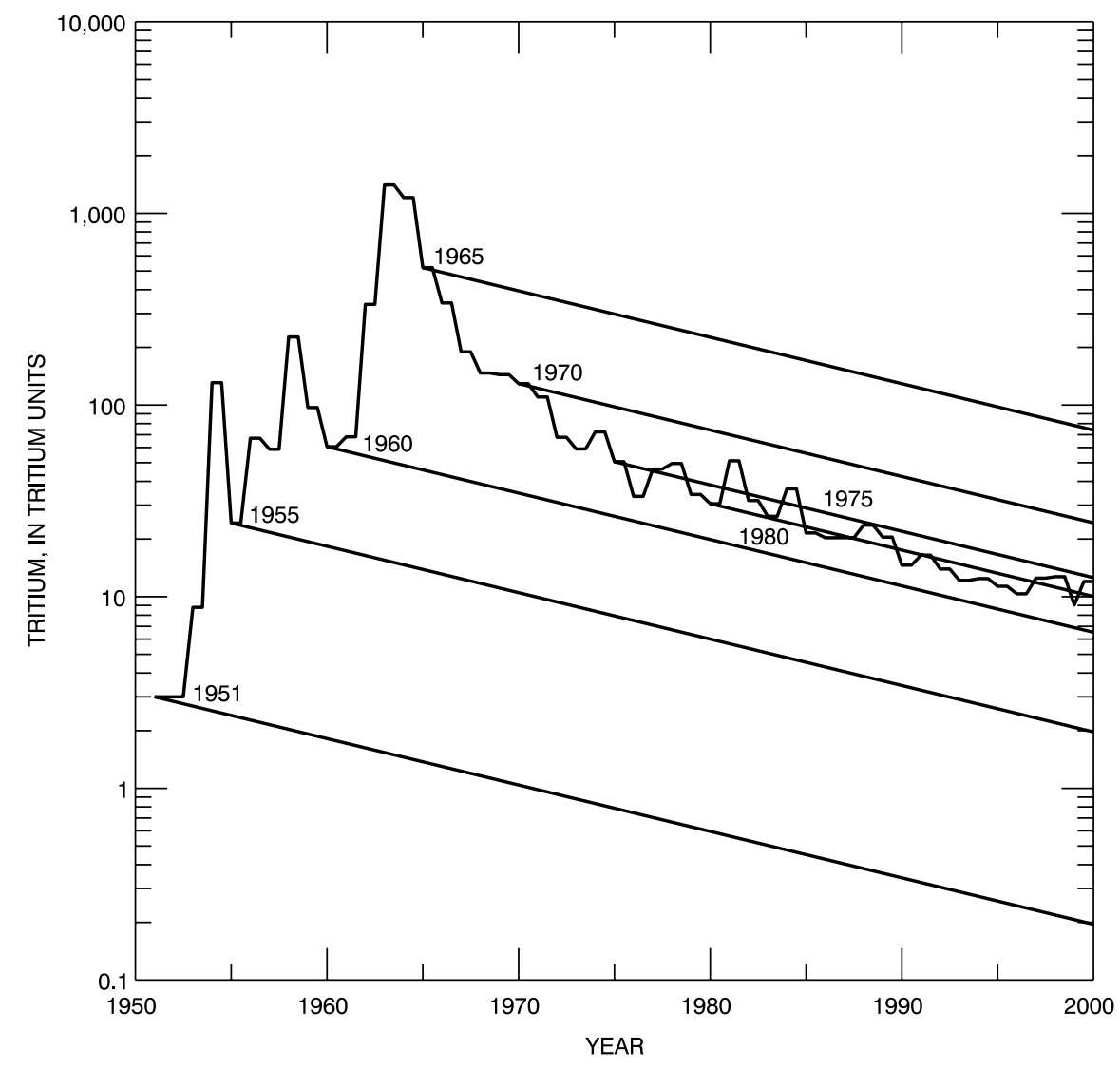

Figure 8. A smoothed record of tritium in precipitation at Washington, D.C. Parallel lines show the path of decay of tritium in ground water if recharged from precipitation in the years 1951, 1955, 1960, 1965, 1970, 1975, and 1980. 


\section{Thitum/Helium-3 Dating}

Tritium/helium- $3\left({ }^{3} \mathrm{H} /{ }^{3} \mathrm{He}\right)$ dating is based on the radioactive decay of ${ }^{3} \mathrm{H}$ (half-life 12.4 years). In closed systems, determination of both ${ }^{3} \mathrm{H}$ and tritiogenic ${ }^{3} \mathrm{He}$ (the daughter product of ${ }^{3} \mathrm{H}$ decay) in ground water can define the initial ${ }^{3} \mathrm{H}$ content and allow calculation of the ${ }^{3} \mathrm{H} /{ }^{3} \mathrm{He}$ age. Details of ${ }^{3} \mathrm{H} /{ }^{3} \mathrm{He}$ dating procedure are given in Schlosser and others (1988, 1989), Poreda and others (1988), Solomon and Sudicky (1991), Solomon and others (1993), Ekwurzel and others (1994), and Solomon and Cook (1999).

${ }^{3} \mathrm{H} /{ }^{3} \mathrm{He}$ dating has two advantages over dating with atmospheric gases. First, the age is based on an isotope ratio, so mixing of young and old, ${ }^{3} \mathrm{H}$-free (prebomb), water does not, in principle, affect the apparent age of the young fraction. Secondly, by measuring ${ }^{3} \mathrm{H}$ and tritiogenic ${ }^{3} \mathrm{He}$, the initial ${ }^{3} \mathrm{H}$ content is determined analytically. The most serious limitations specific to ${ }^{3} \mathrm{H} /{ }^{3} \mathrm{He}$ dating of ground water in the Chesapeake Bay Watershed are addition of terrigenic helium from crystalline rock sources and loss of ${ }^{3} \mathrm{He}$ by degassing during sampling.

\section{Mixing Models}

Water pumped from a well or discharging from a spring is a mixture of the waters from all the flow lines reaching the discharge point. The age frequency distribution and mean age of the mixture affect the interpretation of the ground-water dating methods as well as the interpretation of other ground-water contaminant fluxes (Böhlke, 2002; this section). Three hypothetical mixing models that can be used to describe some of the variation normally seen in ground-water mixtures are piston flow, exponential mixing, and binary mixing (Cook and Böhlke, 1999). In some cases, the water reaching the open interval of a well or discharging at a shallow watertable spring is nearly uniform in age and can be approximated with a piston-flow model, as if the water flowed through a pipe from the point of recharge to the point of discharge without mixing during transit. Exponential mixing can describe discharge of water from well-mixed reservoirs, such as some lakes, or discharge from an unconfined aquifer receiving uniform areal recharge (Eriksson, 1958; Vogel, 1967; Maloszewski and Zuber, 1982; Maloszewski and others, 1983). One of the simplest mixing models to consider, and perhaps the most important in many fractured-rock environments, is binary mixing of young water with old (pre-tracer) water. In this case, a simple dilution occurs because the old fraction is assumed to be free of the tracer and, consequently, the age of the young fraction can be calculated from the ratio of two tracers.

The ratios of CFCs and $\mathrm{SF}_{6}$ over time are shown in figure 9. If the old fraction is CFC-free, and no other processes affect $\mathrm{CFC}$ concentrations other than airwater equilibrium, then the CFC-11/CFC-12 ratio will define the age of the young fraction if the ground water recharged between the late 1940s and about 1977 (fig. 9). Similarly, the CFC-113/CFC-12 ratio will define the age of the young fraction if the ground water recharged in the 1980s to the early 1990s (fig. 9). The ratio $\mathrm{SF}_{6} / \mathrm{CFC}-12$ also may prove useful in dating mixtures of young and old water. Once the age of the young fraction is determined (using tracer ratios), the fraction of young water in the mixture is determined from the ratio of the tracer concentration in the sample to the concentration expected for an un-mixed sample of age corresponding to the young-fraction age.

Because the various environmental tracers considered here have differing temporal patterns to their input functions, plots of one tracer against another can be useful in distinguishing hypothetical mixing processes that may affect the samples, in addition to recognizing samples affected by microbial degradation and (or) anthropogenic contamination. In the plots used in this report, the $\mathrm{CFC}$ and $\mathrm{SF}_{6}$ concentrations were expressed as the atmospheric gas-mixing ratios (in parts per trillion by volume) that would be in equilibrium with the measured concentrations in the water at the $\mathrm{N}_{2}$-Arbased recharge temperature, adjusted for the effect of recharge elevation. The normalized gas-mixing ratios are preferred to the measured concentrations because the normalization removes effects of local variations in recharge temperature and elevation and permits direct comparison of the data to regional records of atmospheric-mixing ratios.

Theoretical variations in the concentrations of $\mathrm{CFCs}, \mathrm{SF}_{6}$, and ${ }^{3} \mathrm{H}$ in response to piston flow, exponential mixing, and binary mixing are shown in figure 10 . Measured values for water samples will plot within the areas in the diagrams bounded by the curves representing the different concentrations of the modeled tracer, if no other processes have affected them. Samples with tracer concentrations that plot far outside the bounded areas may be contaminated or degraded. For example, it is relatively common for anaerobic ground waters to plot below the curves in figure 10; relatively low CFC-11/CFC-12 ratios indicating degradation of CFC-11. Water from many springs in the Chesapeake 


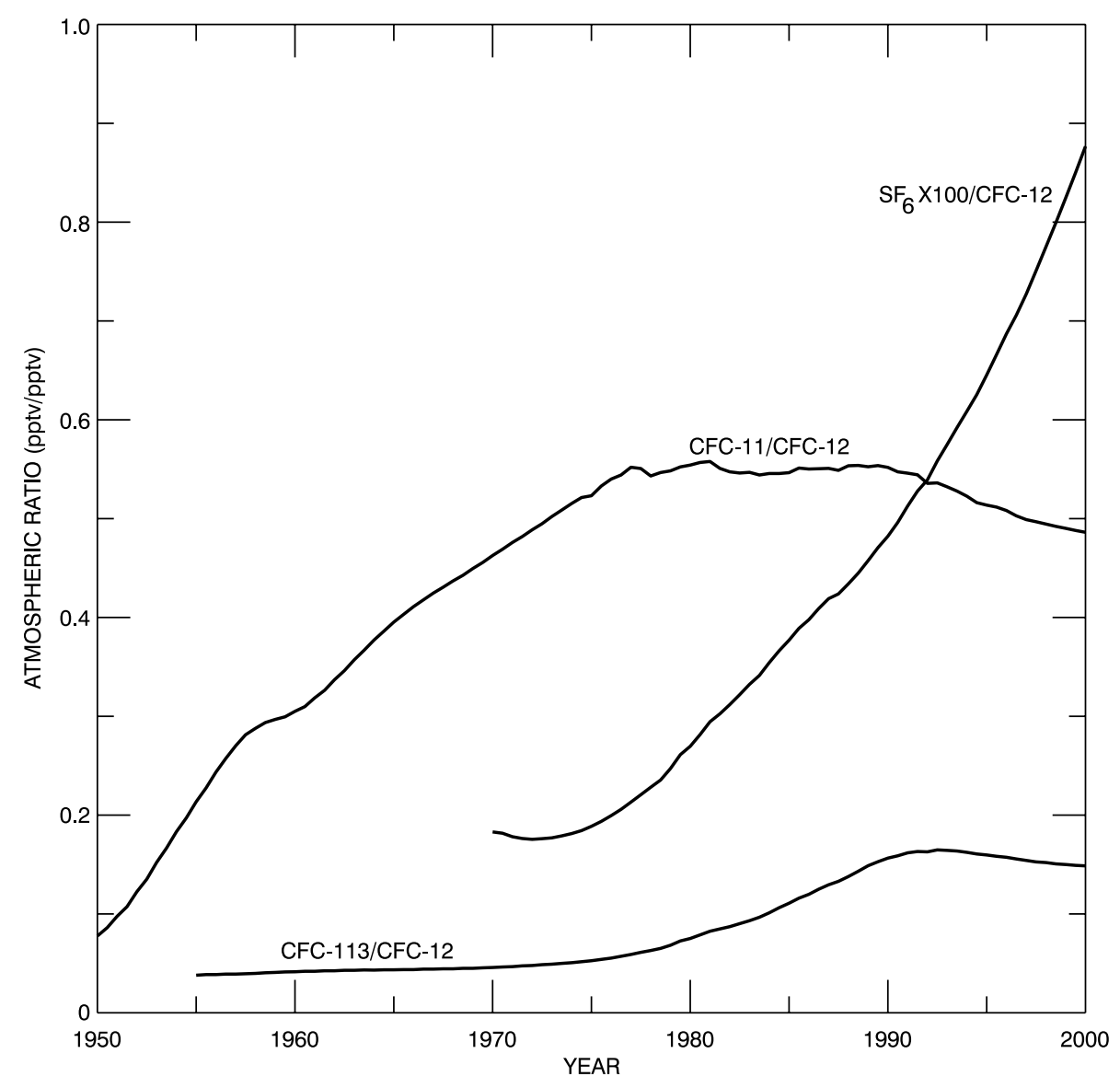

Figure 9. Atmospheric ratios of chlorofluorocarbon (CFC) and sulfur hexafluoride $\left(\mathrm{SF}_{6}\right)$ used in dating water or in dating the young fraction in mixtures of young water and old (tracer-free) water.

Bay Watershed plot outside the curves because of local $\mathrm{CFC}$ or $\mathrm{SF}_{6}$ contamination. The model calculations for CFCs are nearly insensitive to expected variations in the amount of excess air, but similar calculations involving $\mathrm{SF}_{6}$ are sensitive to variations in excess air because of the low Henry's law solubility of $\mathrm{SF}_{6}$ relative to solubilities of CFCs.

If all tracers were reliable (no contamination, no degradation), it should be possible to derive information about the age frequency distribution and the magnitude of the mean age in a sample. A water sample that is not a mixture should plot somewhere along the solid pistonflow curves for all the tracers at points corresponding to the single age of the water. For example, point A would represent the composition of water recharged in 1984, with an age of 15 years when collected in 1999 (fig. 10). Samples that do not plot on the piston-flow curves are more likely to represent mixtures. An exponential mixture should plot somewhere along the exponential-mix- ing curves at points corresponding to a single mean age. For example, point $\mathrm{B}$ would represent the composition of water with an exponential model mean age of 25 years when collected in 1999 (fig. 10). Binary mixtures could plot almost anywhere within the bounded area depending on the ages of the end members. The simplest case (represented by the heavy dashed line in figure 10) would be a binary mixture of modern (1999) water and old (pre-tracer) water. For a sample plotting on this limiting mixing line, the fractions of the two end members could be determined by the lever rule. For example, point $\mathrm{C}$ would represent the composition of a binary mixture consisting of 50 percent 1999 water and 50 percent pre-tracer water). Mean ages for binary mixtures of this type are not known because the age of the old fraction is not known. However, minimum mean ages for binary mixtures can be derived from the mixing fractions and the minimum age of the appropriate tracerfree water (for example, a sample plotting at point $\mathrm{C}$, 

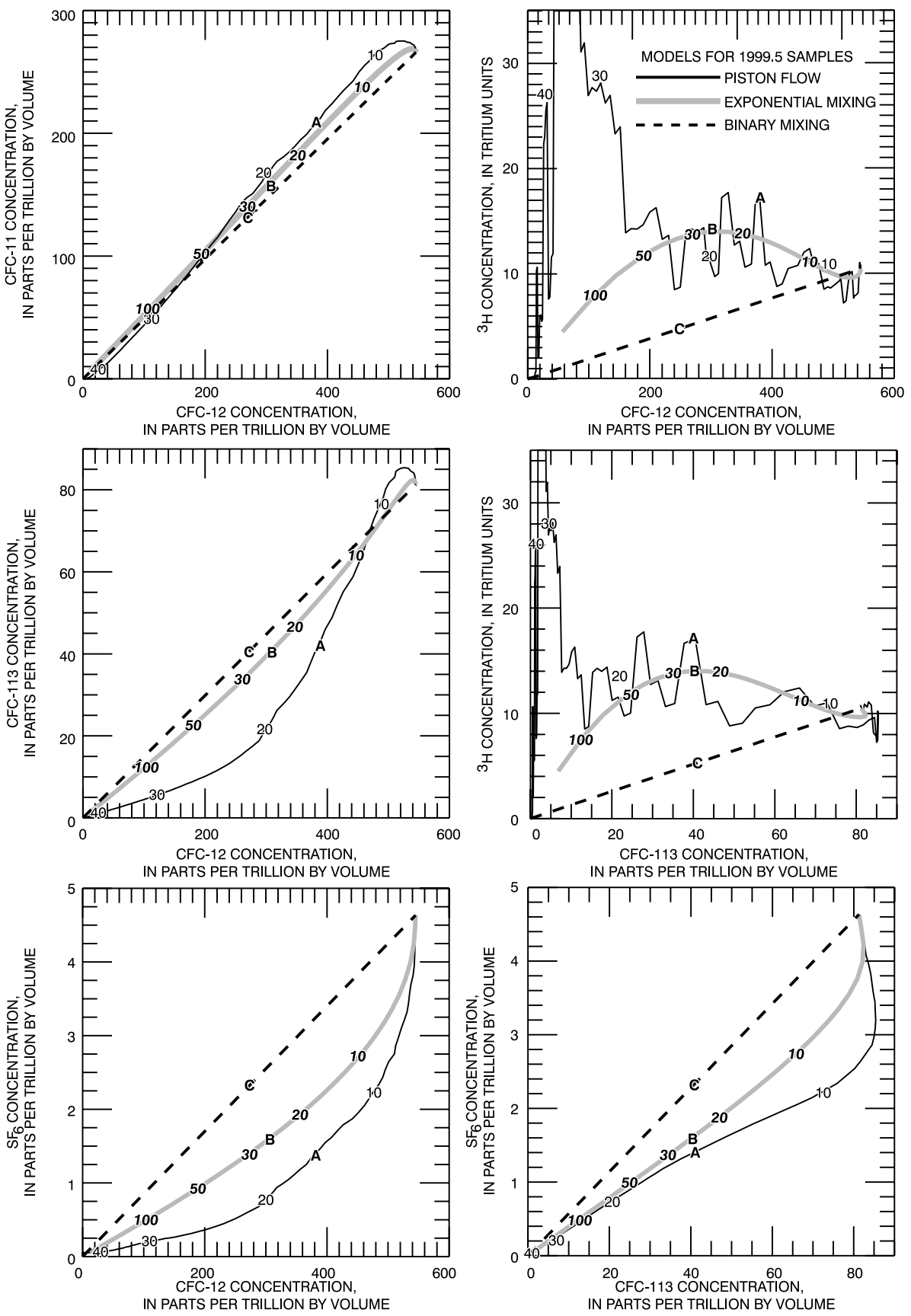

Figure 10. Environmental tracers in ground waters sampled in 1999. Abundance of tracer pairs are shown as continuous curves corresponding to different ground-water mixing models: (1) Thin solid lines (including points "A") indicate compositions of discrete water parcels with single ages (corresponds to the "piston-flow" model); numbers in normal type indicate compositions corresponding to apparent ages ranging from 0 to 40 years. (2) Heavy curves (including points "B") indicate compositions of mixtures with exponential age distributions ("exponential model"); numbers in bold italics indicate compositions corresponding to mean ages ranging from 0 to 100 years.

(3) Dashed lines (including points " $\mathrm{C}$ ") indicate compositions of binary mixtures with varying fractions of "young" water with age of 0 years and "old" water that has no detectable tracer (for example, age $>47$ years for ${ }^{3} \mathrm{H},>60$ years for $\mathrm{CFC}-12$, etc.). 
halfway between the limiting end members for CFC-12 and ${ }^{3} \mathrm{H}$, would have a minimum mean age corresponding to $[0.5 \times 0]+[0.5 \times 60]=30$ years $)$.

The most common assumption made about binary mixtures in the Chesapeake Bay samples is that they contain a fraction of old (pre-tracer) water and a fraction of younger water with a piston-flow age somewhere between the pre-tracer age and the date of collection (Plummer and Busenberg, 1999). A sample of this type would plot on a mixing line from the origin to a point on the piston-flow curve corresponding to the age of the young fraction. The slope of a mixing line emanating from the origin would be equal to the tracer ratio shown in figure 9 for the young fraction. For example, ages of young fractions in many of the waters from fractured-rock environments in the Chesapeake Bay Watersheds (such as at the Mahantango Creek Watershed and the Muddy Creek Watershed) were calculated using the CFC-113/CFC-12 ratio, and the fraction of the young water in the mixture was calculated from the ratio of the measured parts per trillion by volume to that corresponding to the recharge year. It is evident from figure 10 that the uncertainties in calculated ages of mixing fractions will depend on the tracer used and on the value of the age of the young fraction. For example, it would not be possible to distinguish from the CFC-113/CFC-12 ratio of a binary mixture whether the young fraction had an age of 0 or 10 years (fig. 10). Also, because of the way the different tracer concentrations in the atmosphere have changed over time, it may not be possible to distinguish between mixing models for some combinations. For example, because CFC-11 and CFC-12 have similar historical records, the pistonflow, exponential-mixing, and binary-mixing models all yield similar curves (fig. 10) despite the fact they could represent very different age distributions and magnitudes.

Some of the most useful indicators of binary mixtures of old and young waters are combinations of ${ }^{3} \mathrm{H}$ and gas-tracer data. Because atmospheric ${ }^{3} \mathrm{H}$ concentrations have been elevated for a long time, old-water components can be identified by anomalously low ${ }^{3} \mathrm{H}$ concentrations in comparison with $\mathrm{CFCs}$ or $\mathrm{SF}_{6}$ (for example, point C). Similarly, apparent piston-flow ages based on $\mathrm{CFCs}$ and $\mathrm{SF}_{6}$, if not corrected for mixing with old water in fractured-rock systems, can be biased old relative to ${ }^{3} \mathrm{H} /{ }^{3} \mathrm{He}$ ages. Because of ambiguities in distinguishing age-distribution models, and the possibility of degradation or contamination of various constituents, it is important to consider simultaneously as many different tracer measurements as possible in a single sample to determine its history and age.

\section{Environmental Tracer Data fiom the Chesapeake Bay Watersheds}

Age information obtained as a part of this study was based on CFCs, $\mathrm{SF}_{6},{ }^{3} \mathrm{H}$, and ${ }^{3} \mathrm{H} /{ }^{3} \mathrm{He}$. Most tracer measurements are compared in figures 11 and 12. Samples with elevated concentrations of CFCs (CFC-11 > 300 pptv, CFC-12 > 600 pptv, and CFC-113> 100 pptv) and $\mathrm{SF}_{6}$ (> 5 pptv) were considered "contaminated," could not be used for dating purposes, and are not shown on figures 11 and 12. Sources of CFC contamination usually are anthropogenic in nature (Plummer and Busenberg, 1999), and $\mathrm{SF}_{6}$ concentrations in excess of air-water equilibrium and excess air values are usually from terrigenic sources.

Concentrations of $\mathrm{CFCs}_{\text {and }} \mathrm{SF}_{6}$ in figures 11 and 12 are expressed in parts per trillion by volume, which was calculated from the measured concentration in water at the $\mathrm{N}_{2}$-Ar-based recharge temperature and estimated recharge elevation. Concentrations of $\mathrm{SF}_{6}$ were corrected for the presence of excess air, assuming a piston-flow model (Busenberg and Plummer, 2000). ${ }^{3} \mathrm{H}$ concentrations are in tritium units and are compared to the record of ${ }^{3} \mathrm{H}$ in precipitation at Washington, D.C., decayed to the year 1999. Each plot compares one tracer to another. Model lines are included for piston flow, exponential mixing, and binary mixing of modern (1999) and old (pre-tracer) water. The "+" signs on the piston-flow line indicate specific recharge dates and the dots along the exponential-mixing lines correspond to mean residence times. Similar plots are presented in later sections of this report showing data specific to each watershed.

Examination of all samples from the Chesapeake Bay Watershed suggests some general features regarding applicability of particular tracers for dating. Overall, CFC-11 tends to be depleted relative to CFC-12

(fig. 11A) and may be degraded microbially relative to CFC-12 (Plummer and Busenberg, 1999) in soils or in ground-water environments with low concentrations of dissolved oxygen. Except in a few specific cases, CFC-11 data generally were not used for dating the samples from the Chesapeake Bay Watershed. Many water samples have CFC-12 and CFC-113 concentrations that plot within regions bounded by piston flow and binary mixing of young and old water (fig. 11B) and may be useful for dating. Many samples plot parallel to 

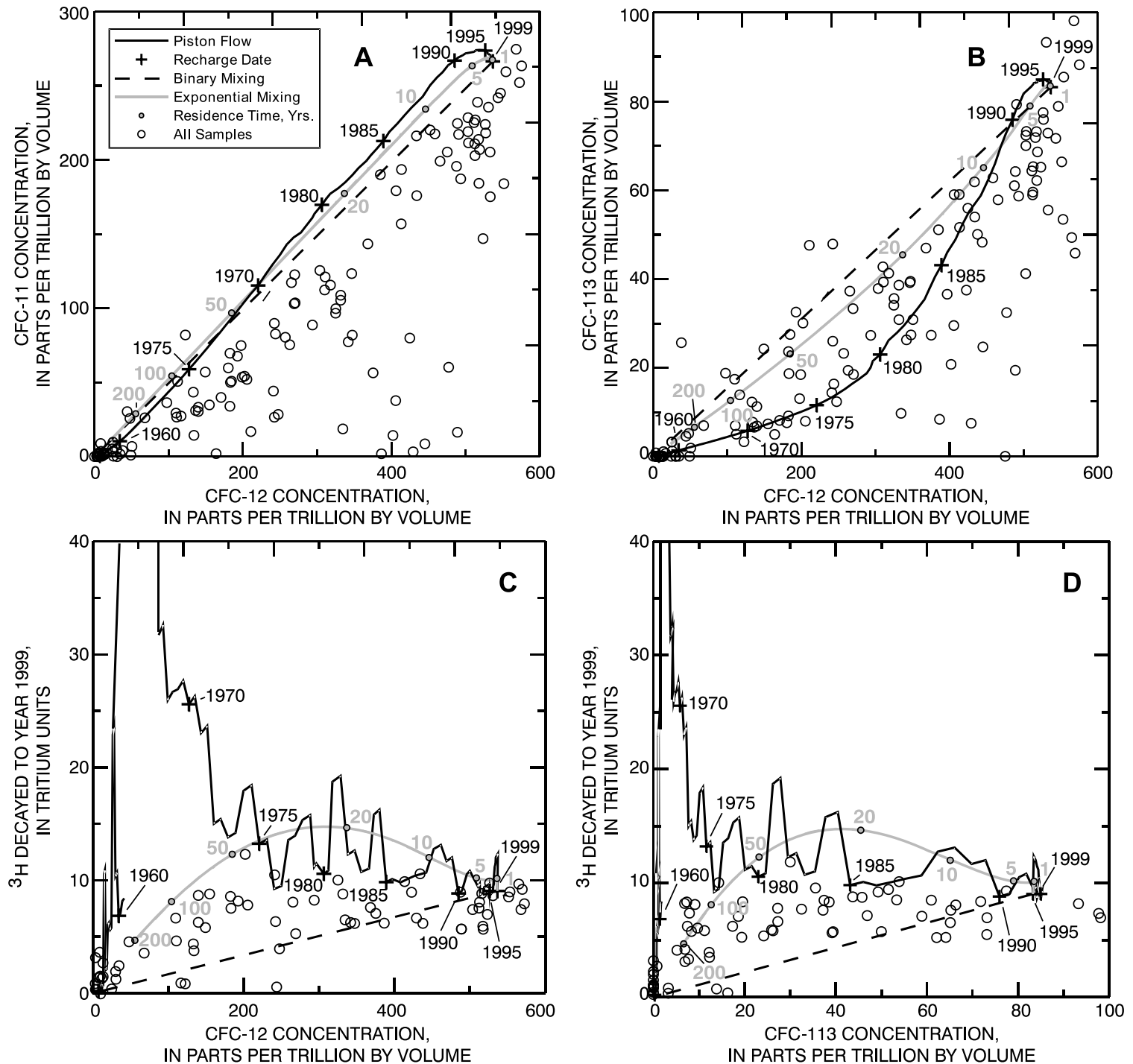

Figure 11. Relation between concentrations of environmental tracers in waters from the Chesapeake Bay Watersheds. A. CFC-11 and CFC-12; B. CFC-113 and CFC-12; C. ${ }^{3} \mathrm{H}$ and CFC-12; and D. ${ }^{3} \mathrm{H}$ and CFC-113. Model lines are included for piston flow, exponential mixing and binary mixing of modern (1999) and old (pre-tracer) water. The "+" signs on the piston-flow line indicate specific recharge dates and the dots along the exponential-mixing lines correspond to mean residence times. 

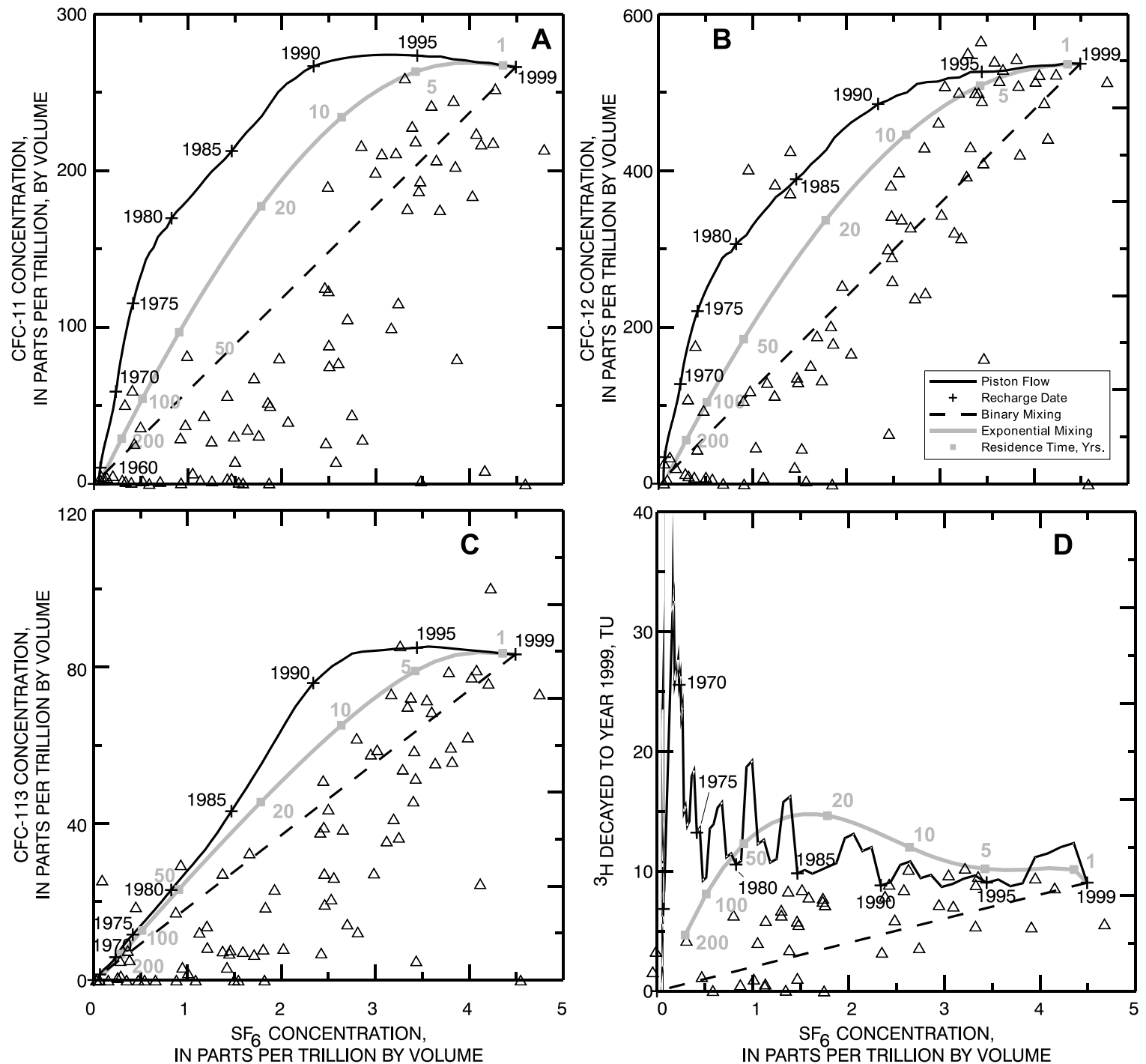

Figure 12. Relation between concentrations of environmental tracers in waters from the Chesapeake Bay Watersheds. A. CFC-11 and $\mathrm{SF}_{6}$; B. CFC-12 and $\mathrm{SF}_{6}$; C. CFC-113 and $\mathrm{SF}_{6}$; and D. ${ }^{3} \mathrm{H}$ and $\mathrm{SF}_{6}$. Model lines are included for piston flow, exponential mixing and binary mixing of modern (1999) and old (pre-tracer) water. The "+" signs on the piston-flow line indicate specific recharge dates and the dots along the exponential-mixing lines correspond to mean residence times. 
the piston-flow line but are somewhat elevated in CFC-12 relative to CFC-113 (fig. 11B), especially for the relatively young samples (post-1985 recharge dates). Plummer and others (2001) observed enrichment of approximately 2 percent on average in CFC- 12 in air samples from Shenandoah National Park, Va., relative to that at Niwot Ridge, Colo., during the course of this study. Although local enrichment of air may account for some elevation in CFC-12, many samples are enriched by 10 percent or more in CFC-12 relative to Niwot Ridge, an enrichment greater than that measured in air samples at Shenandoah National Park. Because the piston-flow line for CFC-113 turns over in post-1995 samples, many samples that appear enriched in CFC-12 could be mixtures of recent and somewhat older water. Only a few samples appear to be elevated in CFC-113 relative to $\mathrm{CFC}-12$; a greater proportion of samples are depleted in CFC-113 relative to CFC-12 (fig. 11B). There may be a removal process that preferentially lowers CFC-113 relative to CFC-12-possibly sorption onto organic matter in shallow ground water. Not all samples appear to be affected by this process.

Another group of samples from the Chesapeake Bay Watershed appears to be very old, based on the low concentrations of CFC-113 and CFC-12, though these samples also could be from methanogenic environments where all CFCs can be degraded microbially. Dissolved $\mathrm{CH}_{4}$ was measured routinely for the Chesapeake Bay samples and is used in later sections of this report to screen those samples that could have concentrations of CFC-113 and CFC-12 lowered by microbial degradation. Further evidence for old water in samples with low $\mathrm{CFC}$ concentrations is low ${ }^{3} \mathrm{H}$ activities (figs. 11C and 11D). Other samples plot very close to the pistonflow line, particularly those with apparent recharge dates between 1970 and 1975, and may be largely unmixed. Other samples are consistent with binary mixtures of modern (1999) water and old, pre-CFC and pre- ${ }^{3} \mathrm{H}$ water. Most other samples appear to be mixtures, some with apparent exponential (mean residence time) ages of $10-20$ years (fig. 11B).

The relations between ${ }^{3} \mathrm{H}$ and $\mathrm{CFC}-12$ (fig. 11C) and CFC-113 (fig. 11D) show that most samples from the Chesapeake Bay Watershed can be interpreted as mixtures that lie between the lines for piston flow and binary mixing of modern and old (pre- ${ }^{3} \mathrm{H}$ and pre-CFC) water. Strong evidence for mixing (of any type) is indicated by the absence of any samples retaining the decayed, initial ${ }^{3} \mathrm{H}$ activity from the mid- and late-1960s bomb peak (figs. 11C and 11D).
Concentrations of CFC-11, CFC-12, CFC-113, and ${ }^{3} \mathrm{H}$ are compared to $\mathrm{SF}_{6}$ concentrations in figures $12 \mathrm{~A}-12 \mathrm{D}$ for all the samples from the Chesapeake Bay Watershed. Although there are specific cases where $\mathrm{SF}_{6}$ appears to be a useful tracer, its application to dating is complicated by potential, unknown amounts of excess $\mathrm{SF}_{6} . \mathrm{SF}_{6}$ concentrations can be elevated in samples with low concentrations of CFCs and ${ }^{3} \mathrm{H}$ (fig. 12A-12D). This suggests that $\mathrm{SF}_{6}$ accumulates in water samples with increasing age, presumably from terrigenic sources. Many samples from the Chesapeake Bay Watershed probably have elevated $\mathrm{SF}_{6}$ concentrations (fig. 12). In the comparison of $\mathrm{SF}_{6}$ and CFC-12, which is the CFC least affected by microbial degradation, the youngest samples plot within the region bounded by the piston-flow and simple binary-mixing curves (fig. 12B), but with increasing age (lower CFC-12 concentration), many samples are shifted off the piston-flow line with elevated $\mathrm{SF}_{6}$ concentrations that exceed that of simple binary mixing of modern and old water (fig. 12B). A few samples from the Chesapeake Bay Watershed plot along the piston-flow lines for CFC-12 relative to $\mathrm{SF}_{6}$ and $\mathrm{CFC}-113$ relative to $\mathrm{SF}_{6}$ (figs. 12B and 12C) and may be unaffected by terrigenic $\mathrm{SF}_{6}$. The least useful combination of tracers is CFC-11 and $\mathrm{SF}_{6}$, where effects of microbial degradation on CFC- 11 and contamination of $\mathrm{SF}_{6}$ from terrigenic sources combine to shift most samples from the Chesapeake Bay Watershed outside of the regions bounded by any possible mixing models (fig. 12A).

Figure $12 \mathrm{D}$ compares ${ }^{3} \mathrm{H}$ to $\mathrm{SF}_{6}$ and was constructed using the ${ }^{3} \mathrm{H}$ record for precipitation in Washington, D.C. These data are probably better suited for application to the Muddy Creek, Va., and Mahantango Creek, Pa., Watersheds, than for watersheds south and east of Washington, D.C. In moving south and east of Washington, D.C., moisture from continental air masses apparently mixes with greater proportions of Atlantic moisture, resulting in a general lowering of ${ }^{3} \mathrm{H}$ content of precipitation. Consequently, points south and east of Washington, D.C. (such as at the Polecat Watershed, central Virginia), and particularly on the Delmarva, Eastern shore region (areas of Green Run, Forth Fork Green Run, and Wayne Tulls Farm) probably have ${ }^{3} \mathrm{H}$ concentrations in precipitation that are lower than those recorded at Washington, D.C. It will be shown later that most of the relatively young points plotting below the binary-mixing line on figure 12D are from the Delmarva, Eastern shore region, and if a lowered ${ }^{3} \mathrm{H}$ in precipitation input function is used, these samples plot in the modern region or along the simple mixing line 
between modern and old water. Along the Delmarva Eastern shore region, a ${ }^{3} \mathrm{H}$ function was estimated by multiplying the Washington, D.C., record by the factor 0.66 . Inspection of figure $12 \mathrm{D}$ suggests that, in general, samples from the Chesapeake Bay Watersheds that are older than about 20 years may be more significantly affected by excess sources of $\mathrm{SF}_{6}$ than samples younger than 20 years.

Lithology is probably an important consideration in determining regions best suited for application of $\mathrm{SF}_{6}$ to dating. Busenberg and Plummer (2000) found excess $\mathrm{SF}_{6}$ in ground waters from crystalline rocks and Paleozoic limestones but not in sand aquifers such as in the Delmarva, Eastern shore region. Of the four regions investigated, $\mathrm{SF}_{6}$ appears least suited for dating in the siliciclastics of the Mahantango Creek Watershed and the Paleozoic carbonates at Muddy Creek, Va., and better suited for dating water in the Piedmont regolith of the Polecat Creek Watershed and best for dating water in the sands of the Delmarva, Eastern shore region.

Age information specific to individual watersheds is discussed separately in later sections of this report and tabulated in the appendixes.

\section{References Cited}

Böhlke, J.K., 2002, Groundwater recharge and agricultural contamination: Hydrogeology Journal, v. 10, p. 153-179. [Erratum: Hydrogeology Journal, v. 10, p. 438-439.]

Busenberg, Eurybiades, and Plummer, L.N., 1992, Use of chlorofluorocarbons $\left(\mathrm{CCI}_{3} \mathrm{~F}\right.$ and $\left.\mathrm{CCl}_{2} \mathrm{~F}_{2}\right)$ as hydrologic tracers and age-dating tools-Example - The alluvium and terrace system of central Oklahoma: Water Resources Research, v. 28, p. 2,257-2,284.

2000, Dating young groundwater with sulfur hexafluoride-Natural and anthropogenic sources of sulfur hexafluoride: Water Resources Research, v. 36, p. 3,011-3,030.

Busenberg, Eurybiades, Weeks, E.P., Plummer, L.N., and Bartholemay, R.C., 1993, Age dating ground water by use of chlorofluorocarbons $\left(\mathrm{CCl}_{3} \mathrm{~F}\right.$ and $\mathrm{CCl}_{2} \mathrm{~F}_{2}$ ), and distribution of chlorofluorocarbons in the unsaturated zone, Snake River Plain aquifer, Idaho National Engineering Laboratory, Idaho: U.S. Geological Survey Water-Resources Investigations Report 93-4054, 47 p.
Cook, P.G., and Böhlke, J.K., 2000, Determining timescales for groundwater flow and solute transport, in Cook, P., and Herczeg, A., eds., Environmental tracers in subsurface hydrology: Boston, Mass., Kluwer Academic Publishers, p. 1-30.

Cook, P.G., and Solomon, D.K., 1997, Recent advances in dating young groundwater-chlorofluorocarbons, ${ }^{3} \mathrm{H} /{ }^{3} \mathrm{He}$, and ${ }^{85} \mathrm{Kr}$ : Journal of Hydrology, v. 191, p. $245-265$.

Ekwurzel, B., Schlosser, P., Smethie, W., Jr., Plummer, L.N., Busenberg, E., Michel, R.L., Weppernig, R., and Stute, M., 1994, Dating of shallow groundwater-Comparison of the transient tracers ${ }^{3} \mathrm{H} /{ }^{3} \mathrm{He}$, chlorofluorocarbons and ${ }^{85} \mathrm{Kr}$ : Water Resources Research, v. 30, p. 1,693-1,708.

Eriksson, Erik, 1958, The possible use of tritium for estimating groundwater storage: Tellus, v. 10, p. 472-478.

Geller, L.S., Elkins, J.W., Lobert, J.M., Clarke, A.D., Hurst, D.F., Butler, J.H., and Myer, R.C., 1997, Tropospheric $\mathrm{SF}_{6}$-Observed latitudinal distribution and trends, derived emissions and interhemispheric exchange time: Geophysical Resources Letters, v. 24, p. 675-678.

Heaton, T.H.E., 1981, Dissolved gases-Some applications to groundwater research: Transactions of the Geological Society of South Africa, v. 84, p. 1-97.

Heaton, T.H.E., Talma, A.S., and Vogel, J.C., 1983, Origin and history of nitrate in confined groundwater in the Western Kalahari: Journal of Hydrology, v. 62 , p. 243-262.

Heaton, T.H.E., and Vogel, J.C., 1981, "Excess air" in groundwater: Journal of Hydrology, v. 50, p. 201-216.

Maiss M., and Brenninkmeijer, C.A.M., 1998, Atmospheric $\mathrm{SF}_{6}$ - Trends, sources, and prospects: Environmental Science and Technology, v. 32, p. 3,077-3,086.

Maiss, M., Steele, L.P., Francey, R.J., Fraser, P.J., Langenfelds, R.L., Trivett, N., and Levin, I., 1996, Sulfur hexafluoride-A powerful new atmospheric tracer: Atmospheric Environment, v. 30, p. 1,621-1,229.

Maloszewski, P., Rauert, W., Stichler, W., and Herrmann, A., 1983, Application of flow models to an Alpine catchment area using tritium and deuterium data: Journal of Hydrology, v. 66, p. 319-330. 


\section{References Cited-Continued}

Maloszewski, P., and Zuber, A., 1982, Determining the turnover time of groundwater systems with the aid of environmental tracers-1. Models and their applicability: Journal of Hydrology, v. 57, p. 207-231.

Michel, R.L., 1989, Tritium deposition over the continental United States, 1953-1983, in Delleur, J.W., ed., Atmospheric Deposition: Wallingford, UK, International Association of Hydrological Sciences, p. 109-115.

Plummer, L.N., and Busenberg, Eurybiades, 1999, Chlorofluorocarbons, in Cook, P., and Herczeg, A., eds., Environmental tracers in subsurface hydrology: Boston, Mass., Kluwer Academic Publishers, p. 441-478.

Plummer, L.N., Busenberg, Eurybiades, Böhlke, J.K., Nelms, D.L., Michel, R.L., and Schlosser, P., 2001, Groundwater residence times in Shenandoah National Park, Blue Ridge Mountains, Virginia, USA-A multi-tracer approach: Chemical Geology, v. 179/1-4, p. 93-111.

Plummer, L.N., Michel, R.L., Thurman, E.M., and Glynn, P.D., 1993, Environmental tracers for agedating young ground water, in Alley, W.M., ed., Regional ground-water quality: New York, Van Nostrand Reinhold, p. 255-294.

Poreda, R.J., Cerling, T.E., and Solomon, D.K, 1988, Tritium and helium isotopes as hydrologic tracers in a shallow unconfined aquifer: Journal of Hydrology v. 103, p. 1-9.
Rozanski, K., Gonfiantini, R., and Araguas-Araguas, L., 1991, Tritium in the global atmosphere-Distribution patterns and recent trends: Journal of Physics G: Nuclear and Particle Physics, v. 17, p. S523-S536.

Schlosser, P., Stute, M., Dorr, H., Sonntag, C., and Munnich, K.O., 1988, Tritium $/{ }^{3} \mathrm{He}$ dating of shallow groundwater: Earth and Planetary Science Letters, v. 89 , p. $353-362$.

Schlosser, P., Stute, M., Sonntag, C., and Munnich, K.O., 1989, Tritiogenic ${ }^{3} \mathrm{He}$ in shallow groundwater: Earth and Planetary Sciences Letters, v. 94, p. 245-256.

Solomon, D.K., and Cook, P.G., 1999, ${ }^{3} \mathrm{H}$ and ${ }^{3} \mathrm{He}$, in Cook, P., and Herczeg, A., eds., Environmental tracers in subsurface hydrology: Boston, Mass., Kluwer Academic Publishers, p. 397-424.

Solomon, D.K., Schiff, S.L., Poreda, R.J., and Clark, W.B., 1993. A validation of the ${ }^{3} \mathrm{H} /{ }^{3} \mathrm{He}$ method for determining groundwater recharge: Water Resources Research, v. 29, p. 2,951-2,962.

Solomon, D.K., and Sudicky, E.A., 1991, Tritium and helium 3 isotope ratios for direct estimation of spatial variations in groundwater recharge: Water Resources Research, v. 27, p. 2,309-2,319.

Stute, M., and Schlosser, P., 1999, Atmospheric noble gases, in Cook, P., and Herczeg, A., eds., Environmental tracers in subsurface hydrology: Boston, Mass., Kluwer Academic Publishers, p. 349-377.

Vogel, J.C., 1967, Investigation of groundwater flow with radiocarbon, in Isotopes in hydrology: Vienna, International Atomic Energy Agency, Nov. 14-18, 1966 [Proceedings], p. 355-369. 


\section{SOURCES, TRANSPORT, AND REACTION OF NITRATE}

\author{
by John-Karl Böhlke
}

Nitrate $\left(\mathrm{NO}_{3}^{-}\right)$is one of the most widespread contaminants in ground water and surface water in the Chesapeake Bay Watershed as it is in many other areas of the world. Elevated concentrations of $\mathrm{NO}_{3}^{-}$may be toxic in drinking water and they may contribute to overproduction in $\mathrm{N}$-limited ecosystems like parts of the Chesapeake Bay. $\mathrm{NO}_{3}^{-}$can enter ground-water systems from a variety of natural and anthropogenic sources such as atmospheric deposition, excess manure or artificial fertilizer application, weathering of organic-rich soils, and wastewater disposal. The rate and efficiency of $\mathrm{NO}_{3}^{-}$transport through aquifers to ground-water discharge areas like streams, lakes, and estuaries depends on local hydrogeologic features including (1) groundwater-flow paths, velocities, and residence times, and (2) distributions and rates of biogeochemical $\mathrm{N}$ transformation reactions. For example, where ground-water residence times are relatively long, changes in the $\mathrm{NO}_{3}^{-}$ loads in discharge may lag behind changes in the recharge loads. Differences between recharge and discharge loads also may be caused by natural remediation reactions in the aquifers. One of the most important natural remediation processes for $\mathrm{NO}_{3}^{-}$contamination is microbial reduction of the $\mathrm{NO}_{3}^{-}$to neutral $\mathrm{N}_{2}$ gas (denitrification). When differences are observed between the recharge and discharge fluxes of $\mathrm{NO}_{3}^{-}$in a watershed, it commonly is difficult to resolve the various processes contributing to the difference. But they must be resolved before reliable predictions can be made about watershed responses to changes in land-use and water-use practices.

Some of the processes controlling the distribution and movement of $\mathrm{NO}_{3}^{-}$in ground water of the Chesapeake Bay Watershed were investigated by measuring environmental tracers and isotopes in springs and targeted local aquifers (see other sections in this report). The concentrations and $\mathrm{N}$ isotopic compositions of various $\mathrm{N}$ species were evaluated to determine likely sources of $\mathrm{N}$ contamination and to document production or consumption of $\mathrm{N}$ species in ground water. Groundwater ages and $\mathrm{NO}_{3}^{-}$concentrations were used to reconstruct variations in the recharge loads of $\mathrm{NO}_{3}^{-}$after screening and adjustment of the data to remove the effects of denitrification. Simple models were used to illustrate discharge responses to the combined effects of historical input variations and ground-water residence times in aquifers. The purpose of the current section is to summarize briefly some of the principles and techniques used to investigate the sources, transport, and reaction of $\mathrm{NO}_{3}^{-}$in ground water in the Chesapeake Bay Watershed (see also Böhlke, 2002). Other sections give more detailed information about each of the study areas, and an overview of techniques used to estimate ground-water residence times.

\section{Chemical and Isotopic Species of Nitrogen}

Major chemical species involved in the distribution and isotopic composition of $\mathrm{N}$ in the environment include organic $\mathrm{N}$ (e.g., proteins and heterocyclic compounds), ammonium $\left(\mathrm{NH}_{4}^{+}\right), \mathrm{NO}_{3}^{-}$, and $\mathrm{N}_{2}$ gas, which are related by reactions such as:

Air equilibration [physicochemical]

$$
\mathrm{N}_{2} \text { (gas) } \Leftrightarrow \mathrm{N}_{2} \text { (aqueous) }
$$

Nitrogen fixation [biochemical]

$$
\mathrm{N}_{2} \Rightarrow \text { [N-org] }
$$

Mineralization [biochemical, physicochemical]

$$
\text { [N-org] } \Rightarrow \mathrm{NH}_{4}^{+}
$$

Ammonia volatilization [physicochemical]

$$
\mathrm{NH}_{4}^{+} \Leftrightarrow \mathrm{NH}_{3} \text { (gas) }+\mathrm{H}^{+}
$$

Nitrification [biochemical]

$\mathrm{NH}_{4}^{+}+2 \mathrm{O}_{2} \Rightarrow \mathrm{NO}_{3}^{-}+2 \mathrm{H}^{+}+\mathrm{H}_{2} \mathrm{O}$

Denitrification [biochemical]

$$
\begin{gathered}
4 \mathrm{NO}_{3}^{-}+5 \mathrm{C}+3 \mathrm{H}_{2} \mathrm{O} \Rightarrow \\
2 \mathrm{~N}_{2}+5 \mathrm{HCO}_{3}^{-}+\mathrm{H}^{+} \\
6 \mathrm{NO}_{3}^{-}+2 \mathrm{FeS}_{2}+2 \mathrm{H}_{2} \mathrm{O} \Rightarrow \\
3 \mathrm{~N}_{2}+2 \mathrm{FeOOH}+4 \mathrm{SO}_{4}=+2 \mathrm{H}^{+} \\
2 \mathrm{NO}_{3}^{-}+10 \mathrm{FeO}+2 \mathrm{H}^{+}+4 \mathrm{H}_{2} \mathrm{O} \Rightarrow \\
\mathrm{N}_{2}+10 \mathrm{FeOOH}
\end{gathered}
$$


Some of these overall net chemical mass balance equations represent simplifications of more complex multi-step processes that may include other minor $\mathrm{N}$ species. For example, nitrous oxide $\left(\mathrm{N}_{2} \mathrm{O}\right)$ and nitrite $\left(\mathrm{NO}_{2}^{-}\right)$commonly exist in measurable concentrations as intermediate species in a sequence of oxidation-reduction reactions during nitrification and denitrification. Although intermediate species such as these may be interesting in their own right, and they may be interpreted as signals of active redox processes, they generally are not present in high enough concentrations to be significant in the overall mass balance of $\mathrm{N}$ in aquifers. Some equations (specifically the redox reactions) also are simplified in the sense that they include results of complex intracellular biochemical transformations as they commonly are measured in the external environment. Nevertheless, it is not unreasonable for some purposes to consider these as balanced geochemical reactions for which bacteria or other organisms serve largely as catalysts.

The ${ }^{15} \mathrm{~N} /{ }^{14} \mathrm{~N}$ isotope ratio of a given $\mathrm{N}$ species in a given environment may vary as a function of the source(s) of the species and the reactions that have altered the abundance of the species. The $\mathrm{N}$ isotope ratio generally is expressed as:

$$
\delta^{15} \mathrm{~N}=\left\{272 \cdot\left[{ }^{15} \mathrm{~N} /{ }^{14} \mathrm{~N}\right]-1\right\} \cdot 1000 \%,
$$

which is equal to $0 \%$ ofor $\mathrm{N}_{2}$ gas in air, which has ${ }^{15} \mathrm{~N} /{ }^{14} \mathrm{~N}=1 / 272$. The isotopes may be fractionated by free-energy minimization at equilibrium (equilibrium fractionation associated mainly with physicochemical reactions) or by differences in irreversible reaction rates (kinetic fractionation associated with both physicochemical and biochemical reactions). Common expressions of the magnitudes of these isotope fractionations include:

$$
\begin{gathered}
\alpha=\left({ }^{15} \mathrm{~N} /{ }^{14} \mathrm{~N}\right) \text { product } /\left({ }^{15} \mathrm{~N} /{ }^{14} \mathrm{~N}\right) \text { reactant, and }(10) \\
\varepsilon=(\alpha-1) \cdot 1000 \% \text { 。 }
\end{gathered}
$$

For the biochemical reactions such as nitrification, denitrification, and nitrogen fixation, reaction rates generally are slightly higher for reactant molecules with lighter isotopes than for those with heavier isotopes, so kinetic isotope fractionation results in products with relatively low $\delta^{15} \mathrm{~N}$ and residual reactants with relatively high $\delta^{15} \mathrm{~N}$. Progressive isotope fractionation by these processes commonly can be represented by a form of the "Rayleigh equation," which was derived initially to describe fractionation of mixed gases during distillation.
Rayleigh distillation as a description of isotope behavior during denitrification is given for the reactant by (Vogel and others, 1981):

$$
\begin{gathered}
\delta^{15} \mathrm{~N}\left[\mathrm{NO}_{3}^{-}\right]= \\
\left(\delta^{15} \mathrm{~N}\left[\mathrm{NO}_{3}^{-}\right]^{\circ}+1000\right) \cdot(1-\xi)^{[\alpha-1]}-1000
\end{gathered}
$$

and for the accumulated product by (from mass balance):

$$
\begin{gathered}
\delta^{15} \mathrm{~N}\left[\mathrm{~N}_{2} \text {-excess }\right]= \\
\left(\delta^{15} \mathrm{~N}\left[\mathrm{NO}_{3}^{-}\right]^{\circ}-\delta^{15} \mathrm{~N}\left[\mathrm{NO}_{3}^{-}\right] \cdot 1 / \xi\right) /(1-1 / \xi),
\end{gathered}
$$

where $\left[\mathrm{NO}_{3}^{-}\right]$refers to the $\mathrm{NO}_{3}^{-}$present in the sample, $\left[\mathrm{NO}_{3}^{-}\right]^{\circ}$ refers to the $\mathrm{NO}_{3}^{-}$present initially before reaction, and $\xi$ is the fractional progress or extent of the reaction $\left.\left(\xi=1-\mathrm{C}\left[\mathrm{NO}_{3}^{-}\right] / \mathrm{C}_{\mathrm{NO}_{3}^{-}}\right]^{\circ}\right)$, with $\mathrm{C}$ indicating concentration. A commonly used approximation for equation 12 for the reactant is (Mariotti and others, 1988):

$$
\begin{gathered}
\delta^{15} \mathrm{~N}\left[\mathrm{NO}_{3}^{-}\right]= \\
\delta^{15} \mathrm{~N}\left[\mathrm{NO}_{3}^{-}\right]^{\circ}+\varepsilon \cdot \ln \left(\mathrm{C}\left[\mathrm{NO}_{3}^{-}\right] / \mathrm{C}\left[\mathrm{NO}_{3}^{-}\right]^{\circ}\right)
\end{gathered}
$$

Partly because of these fractionation effects, and partly in spite of them, isotope data may be used to distinguish some of the natural and anthropogenic sources of $\mathrm{N}$ and to examine the fate and interrelations of $\mathrm{N}$ species in aquatic systems. Common variations in the $\delta^{15} \mathrm{~N}$ values of $\mathrm{NO}_{3}^{-}$from different sources and having experienced isotope fractionation in the environment are of the order of 1-100\%o, compared to typical analytical uncertainties of around 0.1-0.3\%o.

\section{Nitrate Source Identification by Isotope Methods}

The concepts involved in the use of $\mathrm{N}$ isotopes to identify sources of ground-water $\mathrm{NO}_{3}^{-}$contamination have been developed over the last several decades. Kohl and others (1971) used variations in $\delta^{15} \mathrm{~N}$ to argue that $\mathrm{NO}_{3}^{-}$in surface waters in Illinois came from roughly equal amounts of fertilizer $\mathrm{N}$ and natural soil $\mathrm{N}$. The argument was based on the observation that the average $\delta^{15} \mathrm{~N}$ value of the surface-water $\mathrm{NO}_{3}^{-}$was about halfway between the $\delta^{15} \mathrm{~N}$ values of fertilizer $\mathrm{N}$ and of soil $\mathrm{NO}_{3}^{-}$, which also were analyzed in the study. Some assumptions made in developing that argument were criticized severely by Hauck and others (1972). Criticism was focused in part on the fact that various processes in the biogeohydrologic cycle can alter the 
isotopic composition of $\mathrm{N}$ to such an extent that the source characteristics may be unrecognizable. Since that early literature exchange, a large number of studies have indicated that (1) some sources can be distinguished locally in some situations, and (2) there can be considerable uncertainty owing to fractionation effects. That is, both the original idea and its criticism have received additional support. Some useful summaries of relevant principles and data have been published (Kreitler, 1975; Wolterink, 1979; Letolle, 1980; Heaton, 1986; Hübner, 1986; Fogg and others, 1998; Kendall and Aravena, 2000), but it is difficult to define a simple set of rules that generally is applicable to all field situations.

Isotopic analyses of $\mathrm{NO}_{3}^{-}$in the Chesapeake Bay Watershed indicate a variety of different sources (fig. 13). In this study, the measured values of $\delta^{15} \mathrm{~N}\left[\mathrm{NO}_{3}^{-}\right]$were evaluated with respect to potential $\mathrm{NO}_{3}^{-}$sources only if dissolved gas analyses indicated that denitrification in the saturated zone was unlikely $\left(\mathrm{O}_{2}>60 \mu \mathrm{mol} / \mathrm{L}\right.$, or $\left.>2 \mathrm{mg} / \mathrm{L}\right)$ or that the $\mathrm{N}_{2}$ gas product of denitrification was undetectable (excess $\mathrm{N}_{2}$ $<20 \mu \mathrm{mol} / \mathrm{L}$, or $<0.5 \mathrm{mg} / \mathrm{L}$ ). For samples exhibiting evidence of denitrification, the measured $\delta^{15} \mathrm{~N}\left[\mathrm{NO}_{3}^{-}\right]$ values either were not used in source identification or the data were adjusted by use of measured values of $\delta^{15} \mathrm{~N}\left[\mathrm{~N}_{2}\right.$-excess] to give the initial $\left.\delta^{15} \mathrm{~N}^{-} \mathrm{NO}_{3}^{-}\right]$values. In a few cases, the initial $\delta^{15} \mathrm{~N}\left[\mathrm{NO}_{3}^{-}\right]$values of samples containing no $\mathrm{NO}_{3}^{-}$were estimated entirely from the $\mathrm{N}_{2}$ gas values. The procedures used to make these adjustments are described below.

Atmospheric deposition at the Big Meadows monitoring station in Shenandoah National Park, sampled approximately monthly from open (wet plus dry) collectors between August 1997 and July 2000, yielded $\left.\delta^{15} \mathrm{~N} \mathrm{NO}_{3}^{-}\right]$values that varied between about -4 and +4 \%o (fig. 13; J.K. Böhlke, unpub. data). The bulk weighted average over the 3 -year period was $0 \pm 2 \%$. Values of $\left.\delta^{15} \mathrm{~N} \mathrm{NH}_{4}^{+}\right]$in a subset of those samples ranged from about -6 to $0 \%$; the average was around $-3 \%$ o, slightly lower than the $\mathrm{NO}_{3}^{-}$average. These values are reasonably consistent with results of several other isotope studies of $\mathrm{NO}_{3}^{-}$and $\mathrm{NH}_{4}^{+}$in atmospheric deposition in the mid-Atlantic region of the United States (Garten, 1992; Paerl and Fogel, 1994; Garten, 1996). For example, Paerl and Fogel (1994) report average values of $+1.0 \%$ for $\left.\delta^{15} \mathrm{~N} \mathrm{NO}_{3}^{-}+\mathrm{DON}\right]$ and $-3.1 \%$ for $\left.\delta^{15} \mathrm{~N} \mathrm{NH}_{4}^{+}\right]$in precipitation in coastal North Carolina; whereas Garten (1992) reports average values of $+2.3 \%$ or $\left.\delta^{15} \mathrm{~N} \mathrm{NO}_{3}^{-}\right]$and $-3.4 \%$ or $\delta^{15} \mathrm{~N}\left[\mathrm{NH}_{4}^{+}\right]$ in precipitation and throughfall at a low-elevation site in northeast Tennessee and $+1.4 \%$ and $-5.5 \%$, respec- tively, in cloud water at a high-elevation site in southwest Virginia. However, the data from this region and elsewhere (Freyer, 1978; Heaton, 1987, 1990; Freyer, 1991) also indicate substantial seasonal and local variability that may be related to variations in both the sources of the $\mathrm{N}$ and the atmospheric chemical reactions affecting the $\mathrm{N}$ during transport. It is considered likely that the average $\delta^{15} \mathrm{~N}$ values for $\mathrm{NO}_{3}^{-}$and $\mathrm{NH}_{4}^{+}$collected at the Big Meadows station are similar to regional average values throughout the Chesapeake Bay Watershed to within a few per mil, but that significant local and seasonal variations may exist.

$\mathrm{NO}_{3}^{-}$in discharging ground water from high-elevation springs sampled in Shenandoah National Park in 1997-99 had $\delta^{15} \mathrm{~N}\left[\mathrm{NO}_{3}^{-}\right]=+1$ to $+3 \%$, averaging about $+2 \%$ (fig. 13) (Plummer and others, 2000). Those values are only slightly higher than the average for atmospheric deposition at Big Meadows and are interpreted to result largely from atmospheric $\mathrm{N}$ sources and forest $\mathrm{N}$ cycling. The atmospheric sources can include both $\mathrm{N}$ deposition and biologic $\mathrm{N}_{2}$ fixation, which typically yields biomass with $\delta^{15} \mathrm{~N}$ values of around $-1 \pm 1 \%$ (Hübner, 1986). It is possible that the data from springs in Shenandoah National Park do not reflect long-term steady-state conditions in the forests, because some streams draining the Park exhibited an abrupt increase in $\mathrm{NO}_{3}^{-}$concentrations around 1992, shortly after a major gypsy-moth defoliation event (Eshleman and others, 1998). Nevertheless, the high-elevation springs in the Park are considered to represent a potential ground-water $\mathrm{NO}_{3}^{-}$endmember for forested land in the region; $\mathrm{NO}_{3}^{-}$concentrations and $\delta^{15} \mathrm{~N}$ values are only slightly higher than those of atmospheric deposition (fig. 13).

Major sources of $\mathrm{N}$ in agricultural soils include pre-existing soil organic matter, fixation of $\mathrm{N}_{2}$ gas by leguminous crops, artificial fertilizers, crop residues, and manures, all of which may contribute to $\mathrm{NO}_{3}^{-}$in recharging ground water. Thus, it is necessary to adopt rather careful language for describing agricultural effects on ground-water $\mathrm{NO}_{3}^{-}$concentrations and isotopes (Keeney, 1986). Artificial fertilizers applied to cropland generally have $\delta^{15} \mathrm{~N}$ values of around $0 \pm 4 \%$ o (Freyer and Aly, 1974; Hübner, 1986). Reduced forms of $\mathrm{N}$ such as ammonia and urea in major fertilizers commonly have $\delta^{15} \mathrm{~N}$ values slightly less than 0 . Yet, contaminated soil waters and ground waters beneath agricultural land receiving artificial $\mathrm{N}$ fertilizers typically have $\delta^{15} \mathrm{~N}_{\mathrm{NO}_{3}^{-}}^{-}$values between about +2 and $+6 \%$, even where there is a good correlation between $\mathrm{NO}_{3}^{-}$recharge rates and $\mathrm{N}$ fertilizer application rates 


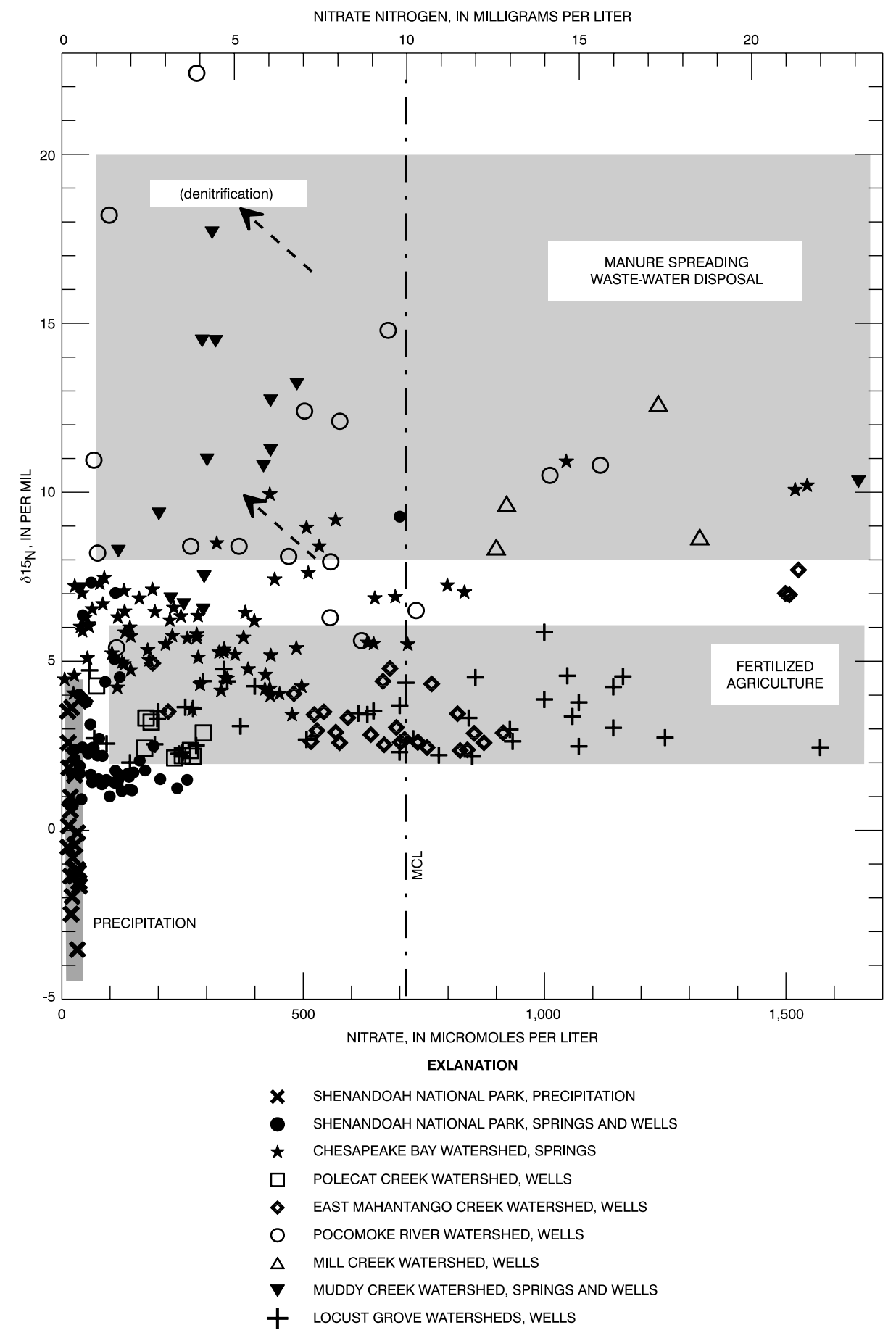

Figure 13. Summary of nitrate $\left(\mathrm{NO}_{3}^{-}\right)$concentrations and $\delta^{15} \mathrm{~N}$ values of precipitation, springs, and ground waters in the Chesapeake Bay Watershed. Data are from O'Connell (1998); Böhlke and Denver (1995); Focazio and others (1998); Plummer and others (2000); this report; and J.K. Böhlke, unpublished data. All plotted data are for samples that were either undenitrified or were adjusted to remove the effects of denitrification (see text). Arrows point in the general direction of changes that would be associated with denitrification. Shaded areas indicate typical ranges of $\delta^{15} \mathrm{~N}$ values for nitrate in different source environments. Typical analytical uncertainties of the $\delta^{15} \mathrm{~N}$ values are around $0.1-0.3 \%$. "MCL" refers to the maximum contaminant level permissible in drinking water $(714 \mu \mathrm{mol} / \mathrm{L}=10 \mathrm{mg}-\mathrm{N} / \mathrm{L})$. 
(Wolterink, 1979; Böhlke and Denver, 1995; Fogg and others, 1998; Kendall and Aravena, 2000; Böhlke and others, 2002). Differences between the $\delta^{15} \mathrm{~N}$ values of fertilizer $\mathrm{N}$ and recharging $\mathrm{NO}_{3}^{-}$have been attributed to (1) isotope fractionation during ionization and volatilization of $\mathrm{NH}_{3}$ gas from reduced $\mathrm{N}$ fertilizer (especially in alkaline soils, see eqn. 4), leaving ${ }^{15} \mathrm{~N}$-enriched $\mathrm{NH}_{4}^{+}$to be nitrified, (2) mixing of excess fertilizer $\mathrm{N}$ with other soil $\mathrm{N}$ prior to nitrification and recharge, or (3) denitrification in soils, leaving ${ }^{15} \mathrm{~N}$-enriched $\mathrm{NO}_{3}^{-}$to be recharged (Kreitler, 1975, 1979; Heaton, 1986; Hübner, 1986). Thus, in the absence of isotopic tracer experiments, it may be difficult to determine from $\mathrm{N}$ isotope measurements alone if the $\mathrm{N}$ in the recharging $\mathrm{NO}_{3}^{-}$was once fertilizer $\mathrm{N}$. In addition, pore-water $\mathrm{NO}_{3}^{-}$and soil organic $\mathrm{N}$ from unfertilized soils also commonly have $\delta^{15} \mathrm{~N}$ values in the range of +2 to $+6 \%$, which may be similar to those of fractionated fertilizers. Relatively low $\delta^{15} \mathrm{~N}$ values near $0 \%$ have been reported for groundwater $\mathrm{NO}_{3}^{-}$that was recharged in agricultural areas where $\mathrm{N}_{2}$-fixing crops such as alfalfa were grown continuously with little or no fertilizer (Böhlke and others, 2002).

Despite the potential for variability and uncertainty, the available data from the Chesapeake Bay Watershed indicate that $\delta^{15} \mathrm{~N}\left[\mathrm{NO}_{3}^{-}\right]$values of around +2 to $+6 \%$ may be typical of recharge beneath welldrained fields receiving excess artificial $\mathrm{N}$ fertilizer, and that significantly higher $\delta^{15} \mathrm{~N}$ values commonly indicate either other sources or the effects of denitrification. $\delta^{15} \mathrm{~N}$ values between +2 and $+5 \%$ are common, for example, in high- $\mathrm{NO}_{3}^{-}$ground waters at the Locust Grove site in the coastal plain of Maryland and the Mahantango Creek Watershed in the Valley and Ridge Siliciclastic Province of Pennsylvania (fig. 13). At these sites, $\mathrm{NO}_{3}^{-}$contamination of ground water and baseflow stream water has been related to agricultural fertilizer use locally by association with other chemical constituents, by spatial correlations with land use, and by analysis of long-term trends retrieved from groundwater records (Pionke and Urban, 1985; Böhlke and Denver, 1995; Gburek and Folmar, 1999) (see other sections in this report). Similar values were obtained from agriculturally contaminated ground waters at the Smithsonian Environmental Research Center in the Maryland coastal plain on the western shore of Chesapeake Bay (O'Connell, 1998).

In contrast, $\mathrm{NO}_{3}^{-}$recharged under septic systems and manure applications typically has $\delta^{15} \mathrm{~N}$ values around $+8 \%$ or higher (Kreitler, 1975; Wolterink, 1979;
Heaton, 1986; Aravena and others, 1993; McMahon and Böhlke, 1996; Schroeder and others, 1996; Fogg and others, 1998; Kendall and Aravena, 2000). Data from a number of sites indicate there may be a tendency for $\mathrm{NO}_{3}^{-}$in seepage from septic systems to be nearer the lower end of the range ( +8 to +11$)$ and $\mathrm{NO}_{3}^{-}$in leachate from manure spreading to range toward higher values with more variability (commonly +10 to +25 ). Cravotta (1997) reports analyses of various classes of manures and organic fertilizers in the Susquehanna River Watershed; mean $\delta^{15} \mathrm{~N}$ values ranged from about +2 to $+12 \%$. Much of the variability in the organic source materials and the resulting $\mathrm{NO}_{3}^{-}$probably is caused by fractionation before nitrification (for example, by $\mathrm{NH}_{3}$ volatilization; Kreitler, 1975) and may be related to the handling of the material as well as climate, soil chemistry, and other environmental variables. Despite these variables, results from the Chesapeake Bay Watershed (fig. 13) support the interpretation that $\delta^{15} \mathrm{~N}\left[\mathrm{NO}_{3}^{-}\right]$values higher than +8 in ground waters that have not been affected by denitrification generally indicate that manure spreading, sewage disposal, or other animalwaste sources of $\mathrm{N}$ were a major source of the $\mathrm{NO}_{3}^{-}$. For example, in the Muddy Creek Watershed in the Virginia Valley and Ridge carbonate $\mathrm{HGMR}, \delta^{15} \mathrm{~N}\left[\mathrm{NO}_{3}^{-}\right]$values of around +7 to $+18 \%$ o were obtained from undenitrified ground waters in an area of pasture and cropland with a poultry-feeding facility. Similarly, in the Mill Creek Watershed in the Pennsylvania Piedmont carbonate HGMR, $\left.\delta^{15} \mathrm{~N} \mathrm{NO}_{3}^{-}\right]$values of around +8 to $+13 \%$ o were obtained from ground waters in an area where manure spreading is an important source of crop nutrients (partially denitrified samples had $\left.\delta^{15} \mathrm{~N} \mathrm{NO}_{3}^{-}\right]$values ranging up to at least $+23 \%$ ). In the upper Pocomoke River Watershed in the Maryland Coastal Plain, both artificial fertilizers and poultry manure are used on crops, and $\delta^{15} \mathrm{~N}\left[\mathrm{NO}_{3}^{-}\right]$values range from about +6 to $+22 \%$ in ground waters that have not been denitrified. Similar values ranging from about +5 to $+13 \%$ o were derived from dissolved gas analyses of denitrified samples from the upper Pocomoke River Watershed.

The concentrations and isotopic compositions of $\mathrm{NO}_{3}^{-}$from a large number of springs in the Chesapeake Bay Watershed occupy a field in figure 13 that is roughly in the middle of the wider ranges of values obtained from the targeted ground-water studies. This is interpreted to result in part from the fact that many springs had recharge areas that included more than one type of land use, whereas the targeted watershed sampling more commonly captured individual source characteristics. Most springs had $\delta^{15} \mathrm{~N}$ values between about 
+3 and $+8 \%$, equal to or slightly higher than the values attributed to fertilized agricultural sources but also attributable to various mixtures of sources including mineralization of pre-existing soil organic matter. Some springs had $\delta^{15} \mathrm{~N}$ values higher than $+8 \%$, which are interpreted to indicate major $\mathrm{N}$ contributions from manure spreading or wastewater disposal. For example, the highest $\mathrm{NO}_{3}^{-}$concentrations in the springs survey were obtained from Donegal Spring near Lancaster, Pa., which had $\delta^{15} \mathrm{~N}$ values of around $+10 \%$, possibly indicating contamination by manure derived from animalfeeding operations that are abundant in the area around the spring. Denitrification is not considered to have had a major effect on the $\delta^{15} \mathrm{~N}$ values of the springs because the springs generally had high concentrations of dissolved oxygen (most $>60 \mu \mathrm{mol} / \mathrm{L}$ ) and low abundance of excess $\mathrm{N}_{2}$ gas (undetectable at the limit of $20 \mu \mathrm{mol} / \mathrm{L}$ ). Also, the $\delta^{18} \mathrm{O}$ values of the $\mathrm{NO}_{3}^{-}$in a representative subset of the springs were relatively constant (J.K. Böhlke and K. Revesz, unpublished data), indicating that the $\delta^{15} \mathrm{~N}$ variation was not primarily the result of denitrification (Böttcher and others, 1990). Samples with high concentrations of dissolved oxygen, absence of excess $\mathrm{N}_{2}$ gas (see "Detection and quantification of denitrification"), and constant values of $\delta^{18} \mathrm{O}\left[\mathrm{NO}_{3}^{-}\right]$are most likely to have $\delta^{15} \mathrm{~N}$ values that reflect the $\mathrm{NO}_{3}^{-}$ source characteristics.

Local effects of different $\mathrm{NO}_{3}^{-}$sources on surface-water $\delta^{15} \mathrm{~N}\left[\mathrm{NO}_{3}^{-}\right]$values are illustrated by the results of a stream base-flow survey of the Mahantango WE-38 Watershed in Pennsylvania in May 1999 (fig. 14). At least three different water types controlling the distribution of $\mathrm{NO}_{3}^{-}$in stream base flow can be distinguished by contrasting concentrations and $\delta^{15} \mathrm{~N}$ values: (1) low $\mathrm{NO}_{3}^{-}$with low $\delta^{15} \mathrm{~N}$ from upland forest recharge areas; (2) high $\mathrm{NO}_{3}^{-}$with low $\delta^{15} \mathrm{~N}$ from fertilized agricultural recharge areas; and (3) high $\mathrm{NO}_{3}^{-}$with high $\delta^{15} \mathrm{~N}$ from recharge areas near animal-feeding operations. The signatures of the different $\mathrm{NO}_{3}^{-}$sources are relatively distinctive in the first-order streams but converge toward intermediate values in the second- and third-order streams. This pattern demonstrates clearly the small scales of water-quality observation and landuse information that are needed to detect major differences in sources in this watershed. At larger scales, the streams have relatively homogeneous characteristics because they are mixtures of waters from different sources.

The data summarized in figure 14 also illustrate how stream water can have an isotope signature substantially different from that of discharging ground water within a given stream reach. For example, $\mathrm{NO}_{3}^{-}$-rich ground waters sampled near the discharge area at the eastern ground-water transect site generally had $\delta^{15} \mathrm{~N}$ values between about +2 and $+4 \%$ (Appendix $\mathrm{C}$ ), presumably reflecting recharge in nearby fertilized agricultural areas; whereas the stream water passing by the eastern transect in May 1999 had $\delta^{15} \mathrm{~N}$ values of +6.3 to $+6.4 \%$ (fig. 14). In the absence of other information, this contrast could be interpreted as a possible effect of denitrification, which has been detected in some local ground waters; however, the spatial data set indicates clearly that the isotopic composition of the stream $\mathrm{NO}_{3}^{-}$ at the eastern transect site reflects ground-water discharge from a variety of land-use settings in the headwater areas (fig. 14). The relatively high $\delta^{15} \mathrm{~N}$ value of the stream at the eastern transect apparently resulted from manure-source $\mathrm{NO}_{3}^{-}$contributions from the headwaters of some western tributaries. Direct discharge of ground water in the high-order stream reaches generally has relatively little effect on the stream composition because the local ground-water fluxes are small in comparison to the sum of the upstream tributary contributions.

\section{Detec tion and Quantification of Denitrific ation}

Denitrification refers to microbial reduction of $\mathrm{NO}_{3}^{-}$to $\mathrm{N}_{2}$. The overall process requires several steps with intermediate species including $\mathrm{NO}_{2}^{-}$and $\mathrm{N}_{2} \mathrm{O}$. Some of the gaseous products could escape from open systems like unsaturated soils. In closed systems like most ground-water-flow paths, however, the $\mathrm{NO}_{3}^{-}$lost is balanced ultimately by the accumulated $\mathrm{N}_{2}$ gas. Denitrification is a dissimilatory process from which organisms derive energy rather than biomass. The energy is derived from the chemical potential that results from having $\mathrm{NO}_{3}^{-}$(an oxidant, or electron acceptor) brought into contact with an electron donor such as organic carbon, sulfide, ferrous iron, etc. The energy is released when the $\mathrm{NO}_{3}^{-}$is reduced and the electron donor is oxidized, bringing the external environment closer to equilibrium. Thus, denitrification is a result of physical processes that bring electron donors and acceptors together as well as the presence of organisms capable of catalyzing the reaction. Within the Chesapeake Bay Watershed, there is evidence that a variety of electron donors can contribute to denitrification, depending on the local geology and mineralogy of the aquifers. In addition to organic carbon, which is a common electron donor for denitrification in many environments, some other phases that have been implicated in denitrification in the Chesapeake Bay region include pyrite $\left(\mathrm{FeS}_{2}\right)$ and glauconite (an Fe-bear- 


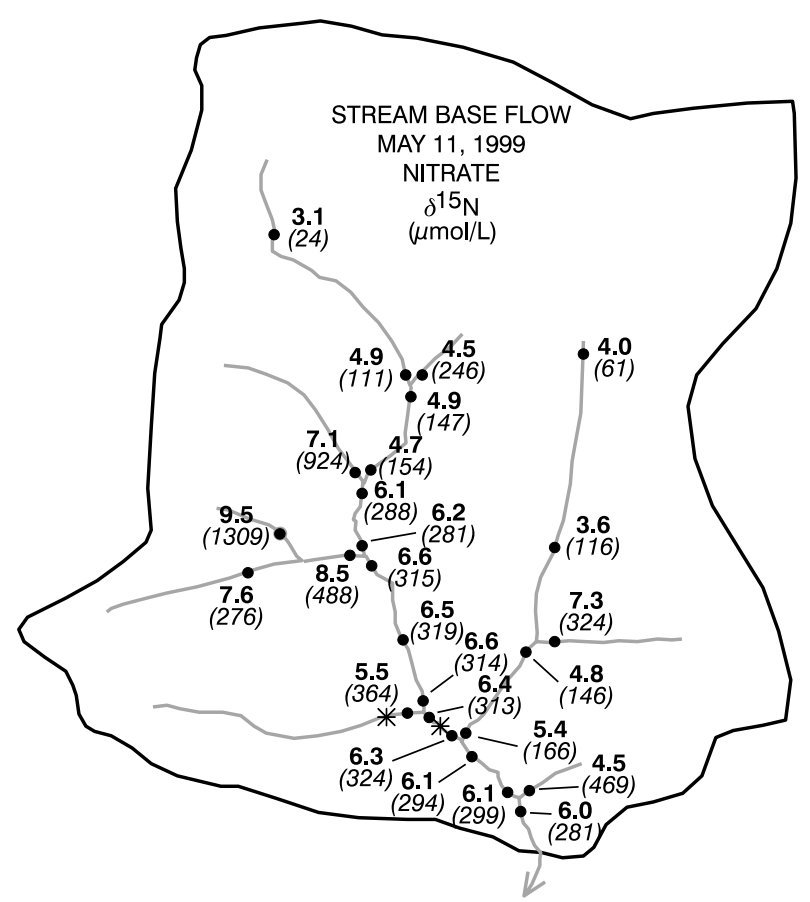

B

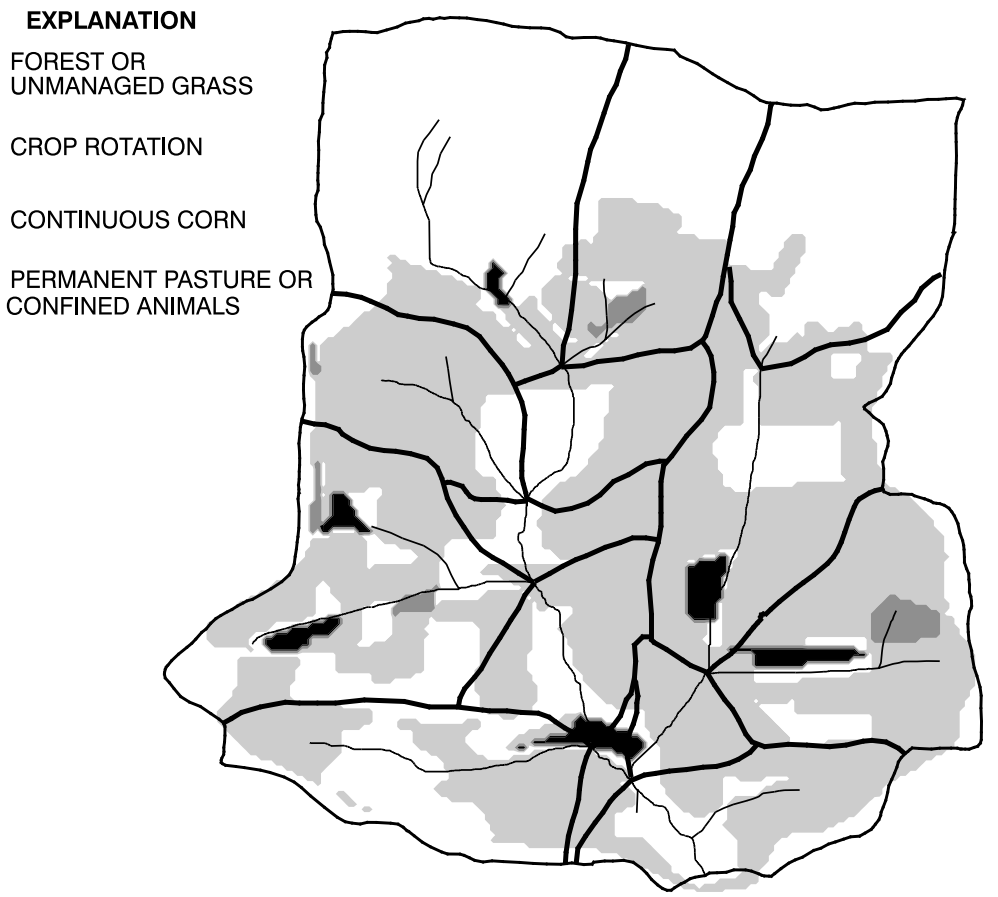

Figure 14. [A] Nitrate concentrations and nitrogen-isotopic compositions during a synoptic survey of streams in the Mahantango WE-38 Watershed in May 1999. Large bold numbers are $\delta^{15} \mathrm{~N}$ values of $\mathrm{NO}_{3}^{-}$in \%; smaller italicized numbers in parentheses are $\mathrm{NO}_{3}^{-}$concentrations in $\mu \mathrm{mol} / \mathrm{L}(71 \mu \mathrm{mol} / \mathrm{L}=1 \mathrm{mg}-\mathrm{N} / \mathrm{L})$. Star symbols indicate the locations of the eastern and western ground-water transects (see "Ground water residence time and nitrogen concentration-East Mahantango Creek Watershed"). [B] Land-use map of the WE-38 Watershed, modified from Gburek and Folmar (1999). 
ing K-Al phyllosilicate) (Böhlke and Denver, 1995; O'Connell, 1998), both of which are common in some types of Coastal-Plain sediments. The overall reactions between $\mathrm{NO}_{3}^{-}$and the various potential electron donors can be represented by equations such as equations 6-8.

Denitrification was detected in several different ways in the current study, including (1) presence of transient intermediate product $\mathrm{N}_{2} \mathrm{O}$, (2) fractionation of the $\mathrm{NO}_{3}^{-}-\mathrm{N}$ isotopes, and (3) high concentrations of the stable product $\mathrm{N}_{2}$ gas. Of these three types of observations, only the third can be used to quantify the overall progress of the reaction (to determine how much $\mathrm{NO}_{3}^{-}$ has reacted). Concentrations of $\mathrm{N}_{2} \mathrm{O}$ (and $\mathrm{NO}_{2}^{-}$) vary widely within regions of active denitrification as a result of variations in the rates of intermediate reaction steps but largely independently of the cumulative amount or rate of denitrification. Isotope fractionation factors also may vary substantially as a result of varying reaction rates, substrate characteristics, identity of the microbial "catalyst," etc., so that a given amount of isotope fractionation cannot reliably be associated with a specific amount of reaction. Other evidence for denitrification could include enrichment in some of the other products of denitrification like sulfate, dissolved inorganic carbon, etc. (equations 6-8), or it could include decreases in the ratio of $\mathrm{NO}_{3}^{-}$to a conservative constituent like chloride. But those other constituents also can vary independently of denitrification, and the effects of denitrification may be small compared to the variations in the absence of denitrification.

The dissolved $\mathrm{N}_{2}$ gas in the ground-water samples from the Chesapeake Bay Watershed consists of three main components, two of which are of atmospheric origin: (1) $\mathrm{N}_{2}$ gas acquired during recharge by equilibrium with air, (2) $\mathrm{N}_{2}$ gas acquired during recharge by incorporation of excess air, and (3) nonatmospheric excess $\mathrm{N}_{2}$ gas produced after recharge by denitrification (fig. 15). In a water sample that has behaved as a closed system since recharging, all three of those gas components can be resolved from measurements of $\mathrm{Ne}$, $\mathrm{Ar}$, and $\mathrm{N}_{2}$, but only two components can be resolved from measurements of $\mathrm{Ar}$ and $\mathrm{N}_{2}$. If only $\mathrm{Ar}$ and $\mathrm{N}_{2}$ data are available, the concentration of excess non-atmospheric $\mathrm{N}_{2}$ in a sample can be estimated by assuming a value for the equilibration temperature or by assuming a value for the amount of excess air (fig. 15; see also Plummer, Böhlke, and Busenberg, this report). In a water sample that has behaved as an open system, for example by degassing or re-equilibrating with air, the atmospheric and non-atmospheric components of $\mathrm{N}_{2}$ gas may be more difficult to resolve. This means that denitrification in the unsaturated zone, or in the saturated zone near the water table, might be undetected or underestimated.

The presence of non-atmospheric $\mathrm{N}_{2}$ gas also can be detected from measurements of $\delta^{15} \mathrm{~N}\left[\mathrm{~N}_{2}\right]$. The $\mathrm{N}$ isotope behavior of typical ground-water parcels undergoing denitrification is illustrated in figure 15. In one hypothetical case, the water is assumed to have recharged with $714 \mu \mathrm{mol} / \mathrm{L}$ of $\mathrm{NO}_{3}^{-}(10 \mathrm{mg} / \mathrm{L}$ as N, equal to the maximum contaminant level for drinking water) with a $\left.\delta^{15} \mathrm{~N} \mathrm{NO}_{3}^{-}\right]^{\circ}$ value equal to $+10 \%$ (for example, beneath a field receiving manure fertilizer). The atmospheric $\mathrm{N}_{2}$ gas acquired by the water during recharge has a concentration of $650 \mu \mathrm{mol} / \mathrm{L}(9.1 \mathrm{mg} / \mathrm{L})$ and a $\delta^{15} \mathrm{~N}\left[\mathrm{~N}_{2}\right]$ value of $+0.7 \%$, which are the values for dissolved $\mathrm{N}_{2}$ gas in equilibrium with humid air at around $10^{\circ} \mathrm{C}$ (Weiss, 1970; Hübner, 1986). Because of kinetic isotope fractionation (assumed to be characterized by $\varepsilon=-20 \%$ ), the $\mathrm{N}_{2}$ gas produced by denitrification initially has a $\delta^{15} \mathrm{~N}$ value of $-10.2 \%$, approximately $20 \%$ lower than that of the $\mathrm{NO}_{3}^{-}$. Adding increasing amounts of the denitrification component of $\mathrm{N}_{2}$ gas to the larger amount of atmospheric $\mathrm{N}_{2}$ gas in the ground water causes the $\delta^{15} \mathrm{~N}$ value of the total $\mathrm{N}_{2}$ gas to decrease from $+0.7 \%$ to more negative values while the $\mathrm{Ar} / \mathrm{N}_{2}$ ratio of the water decreases (fig. $15 \mathrm{C}$ ). As the reaction proceeds, the $\delta^{15} \mathrm{~N}$ value of the $\mathrm{NO}_{3}^{-}$ increases (fig. 15A) and the $\delta^{15} \mathrm{~N}$ value of the $\mathrm{N}_{2}$ gas product also increases, so as the ratio of $\mathrm{Ar} / \mathrm{N}_{2}$ decreases further, the $\delta^{15} \mathrm{~N}$ value of the total $\mathrm{N}_{2}$ gas eventually becomes positive again. When the reaction is complete, the $\delta^{15} \mathrm{~N}$ value of the excess $\mathrm{N}_{2}$ gas component produced by denitrification is equal to the initial $\delta^{15} \mathrm{~N}$ value of the $\mathrm{NO}_{3}^{-}$before denitrification. At every point along the reaction curve shown in figure $15 \mathrm{C}$, the $\mathrm{N}_{2}$ gas in the sample is a mixture of the atmospheric component and the denitrification component. The $\delta^{15} \mathrm{~N}$ value of the denitrification component in each sample can be determined from a straight mixing line in figure 15 or by isotope mass balance:

$$
\begin{gathered}
\delta^{15} \mathrm{~N}\left[\mathrm{~N}_{2} \text {-excess }\right]=\left\{\left(\delta^{15} \mathrm{~N}\left[\mathrm{~N}_{2} \text {-tot }\right] \cdot \mathrm{C}\left[\mathrm{N}_{2} \text {-tot }\right]\right)-\right. \\
\left.\left(\delta^{15} \mathrm{~N}\left[\mathrm{~N}_{2} \text {-equil }\right] \cdot \mathrm{C}\left[\mathrm{N}_{2} \text {-equil }\right]\right)\right\} \\
/\left\{\mathrm{C}\left[\mathrm{N}_{2} \text {-excess }\right]\right\}
\end{gathered}
$$

For Chesapeake Bay Watershed ground waters in which all the relevant quantities were known, the concentrations and $\delta^{15} \mathrm{~N}$ values of the excess $\mathrm{N}_{2}$ gas were combined with the concentrations and $\delta^{15} \mathrm{~N}$ values of the $\mathrm{NO}_{3}^{-}$in the samples to calculate the concentrations and $\delta^{15} \mathrm{~N}$ values of the $\mathrm{NO}_{3}^{-}$originally in the ground waters before denitrification. These calculated quantities 

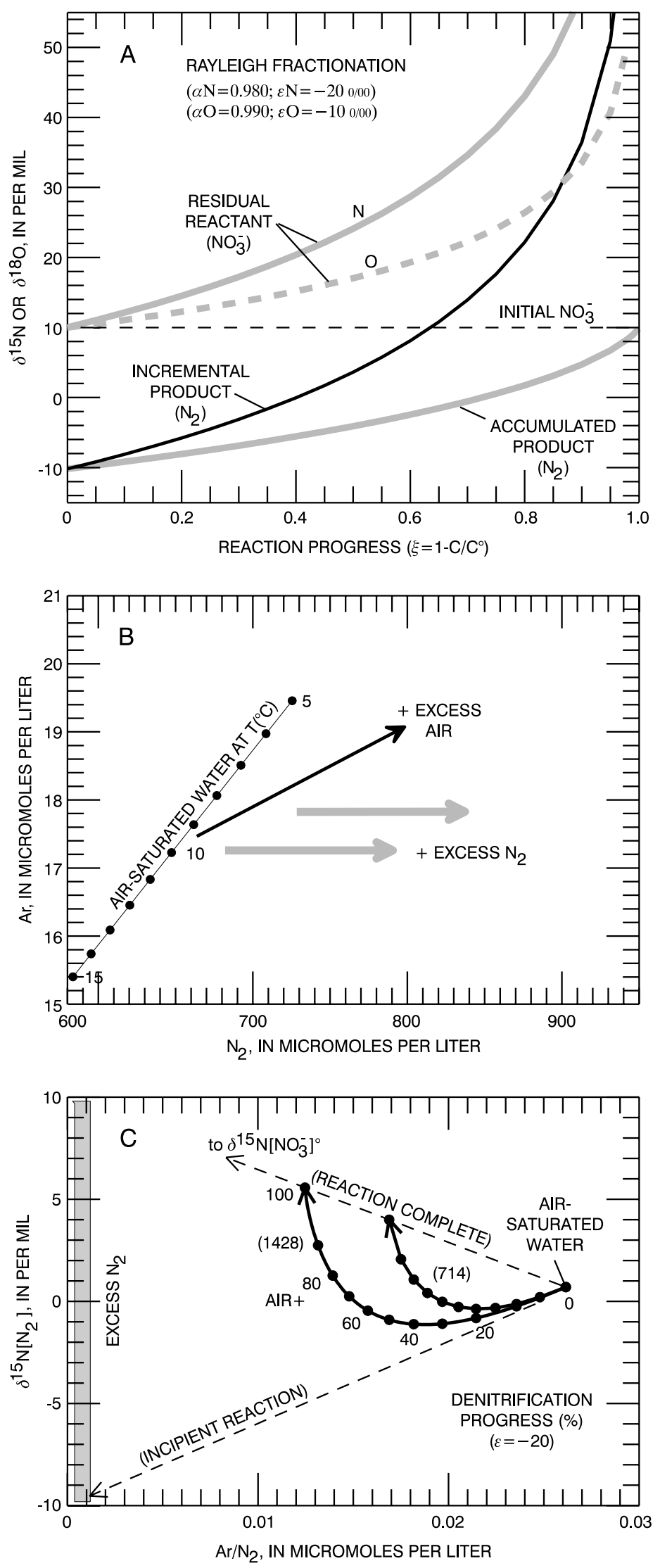

Figure 15. Schematic diagrams illustrating isotopic fractionation and gas mixing accompanying denitrification (from Böhlke, 2002). [A] Progressive variation of $\delta^{15} \mathrm{~N}$ and $\delta^{18} \mathrm{O}$ in the reactant $\mathrm{NO}_{3}^{-}$and product $\mathrm{N}_{2}$ during denitrification in a closed system with typical isotope fractionation factors (see equations 12 and 13). [B] Components of dissolved $\mathrm{Ar}$ and $\mathrm{N}_{2}$ in ground water, including "excess $\mathrm{N}_{2}$ " produced by denitrification. [C] Progressive variation of $\mathrm{Ar} / \mathrm{N}_{2}$ and $\delta^{15} \mathrm{~N}$ of the total dissolved $\mathrm{N}_{2}$ in ground water undergoing denitrification (see equation 15). The curves indicate reaction paths in closed denitrifying systems with initial $\mathrm{NO}_{3}^{-}$concentrations equal to the maximum contaminant level (MCL) $(714 \mu \mathrm{mol} / \mathrm{L}=10 \mathrm{mg}-\mathrm{N} / \mathrm{L})$ and two times the MCL $(1,428 \mu \mathrm{mol} / \mathrm{L}=20 \mathrm{mg}-\mathrm{N} / \mathrm{L})$. 
were then used to evaluate sources of $\mathrm{NO}_{3}^{-}$(by isotopes) and changes in the recharge rate of $\mathrm{NO}_{3}^{-}$(the concentration input function). In practice, however, there were relatively few samples for which all of these calculations were done. Of the ground waters that displayed evidence of denitrification, most were analyzed for excess $\mathrm{N}_{2}$ gas concentrations but only a subset of those were analyzed for $\delta^{15} \mathrm{~N}\left[\mathrm{~N}_{2}\right]$. Some samples were denitrified completely, in which case the recharge concentration and $\delta^{15} \mathrm{~N}$ value of the $\mathrm{NO}_{3}^{-}$were derived entirely from the gas data. Some ground waters had large concentrations of $\mathrm{CH}_{4}$ that caused partial degassing, which precluded reliable reconstructions of initial $\mathrm{NO}_{3}^{-}$concentrations and $\delta^{15} \mathrm{~N}$ values.

\section{Rec onstructing Trends of Nitrate Inputs and Outputs}

Long-term changes in $\mathrm{NO}_{3}^{-}$concentrations and fluxes in recharge generally are not known from groundwater monitoring data. Trends in surface waters may be related only poorly or indirectly to trends in recharging ground water because of instream losses, denitrification, or residence time in the saturated zone. In this study, two different types of data were used to reconstruct historical records of $\mathrm{NO}_{3}^{-}$concentrations in recharge: (1) initial $\mathrm{NO}_{3}^{-}$concentrations in dated ground waters, and (2) historical records of watershed $\mathrm{N}$ loading rates combined with recent $\mathrm{NO}_{3}^{-}$concentrations in recharge. The first of these is the most direct but requires a large number of samples from reasonably well-characterized wells. The second may be less expensive but it is more difficult to apply locally and it has large uncertainties associated with the transfer of $\mathrm{N}$ from the land surface to the water table. In both methods, it is useful to be able to distinguish effects of different land uses from effects of changing practices within a given land use.

For a set of ground-water samples representing discrete parcels with well-defined recharge dates, the variation of $\mathrm{NO}_{3}^{-}$concentrations in recharge over time can be determined relatively simply after correction for denitrification. If the dated waters are from the recharge area, they also can be used to determine the recharge rate of water, and the history of $\mathrm{NO}_{3}^{-}$fluxes in recharge can be compared directly to the history of known or estimated $\mathrm{N}$ loading rates from various sources to the land surface. An example of this approach is summarized in figure 16 . The general trend of increasing $\mathrm{NO}_{3}^{-}$concentrations with decreasing ground-water age at Locust Grove, Md., is similar to the regional trend of increasing fertilizer $\mathrm{N}$ application rates between 1950 and 1990. The overall trend in ground-water $\mathrm{NO}_{3}^{-}$is relatively well-defined because of the high proportion of fertilized agricultural land use in the recharge areas to the wells; nevertheless, local variations in land use, agricultural practices, or hydrogeologic conditions apparently resulted in anomalously high and low $\mathrm{NO}_{3}^{-}$concentrations in some wells. These types of records are more difficult to obtain from analyses of discharging ground waters because those samples do not yield recharge rates directly and because they are more likely to include mixtures of waters of different ages and to have been geochemically altered. Furthermore, because their recharge areas are relatively uncertain, effects of different land uses are more difficult to resolve. Nevertheless, data from discharging ground waters at several sites in the Chesapeake Bay Watershed (this report) yielded reasonable records of decadal trends in recharging $\mathrm{NO}_{3}^{-}$ concentrations.

For the Chesapeake Bay ground waters, if the dating tracers indicated binary mixtures of young components with old (pre-tracer) components (see Plummer and others, this report), it was assumed that the old components had virtually no $\mathrm{NO}_{3}^{-}$when recharged. This assumption is not exactly correct, but it is supported by low measured or calculated $\mathrm{NO}_{3}^{-}$concentrations in most samples recharged before about 1960. In this case, the $\mathrm{NO}_{3}^{-}$concentration of the whole sample was divided by the fraction of young water in the sample to obtain the $\mathrm{NO}_{3}^{-}$concentration of the young fraction. The calculated $\mathrm{NO}_{3}^{-}$concentration of the young fraction was then assigned to the recharge year indicated by the age of the young fraction. If the young fraction was 100 percent of the sample, the apparent age and the $\mathrm{NO}_{3}$ concentration of the whole sample and the young fraction were the same. All these calculations were done on the "initial" $\mathrm{NO}_{3}^{-}$concentrations after adjustments for the effects of denitrification based on dissolved-gas data.

Ground-water records of recharging $\mathrm{NO}_{3}^{-}$concentrations were constructed for the period of time represented by the dated samples. The ground-water data were smoothed to obtain a $\mathrm{NO}_{3}^{-}$input curve; the input curve was used to calculate hypothetical $\mathrm{NO}_{3}^{-}$discharge curves by making simple assumptions about the age distributions in the discharge. These calculations illustrate the potential effects of ground-water residence times on stream base-flow responses to changing recharge characteristics in the absence of other processes affecting $\mathrm{NO}_{3}^{-}$, such as denitrification.

For a uniform unconsolidated aquifer receiving distributed recharge, a common approach is to model the ground-water system as if it were a well-mixed reservoir with equal and constant recharge and discharge 


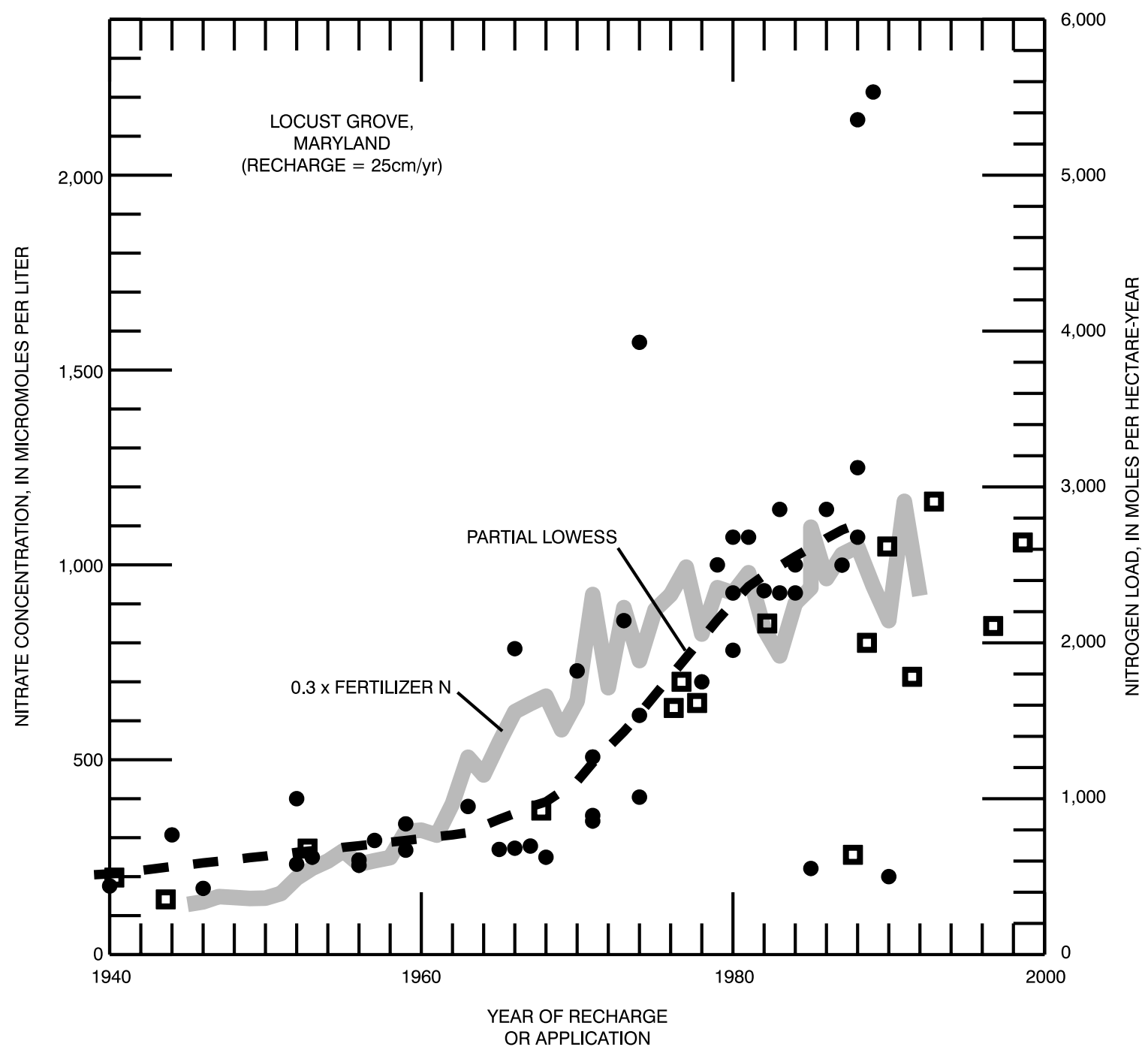

Figure 16. Ground-water record of concentrations of nitrate in recharge beneath agricultural land near Locust Grove, Md. Data shown as filled circles are from Dunkle and others (1993) and Böhlke and Denver (1995); data shown as open squares are from Bachman and others (2002). The partial LOWESS curve is a locally-weighted moving average (Cleveland, 1979) derived from the data set of Böhlke and Denver (1995).

rates, thereby yielding an exponential age distribution. In this case, changes in concentration over time can be approximated numerically by successive calculations of

$$
\begin{gathered}
\text { Cres }(\mathrm{ti})= \\
\operatorname{Cres}(\mathrm{ti}-1)+[1 / \tau] \cdot[\operatorname{Cin}(\mathrm{ti})-\operatorname{Cres}(\mathrm{ti}-1)]
\end{gathered}
$$

for a series of time steps, where Cres(ti) is the concentration in the mixed reservoir at the time of interest (ti), Cres(ti-1) is the concentration in the reservoir at the previous time step, $\mathrm{Cin}(\mathrm{ti})$ is the concentration in the new added recharge, and $\tau$ is the mean age or turnover time of the exponential reservoir.
Despite the fact that the ground-water system may not be mixed, the geometry of flow and the distribution of ages in the aquifer may be such that the concentration in discharge is equal to Cres(ti) (Zuber, 1986; Cook and Böhlke, 2000). This exponential-mixing approach was used by Böhlke and Denver (1995) to show that the difference between the recharge flux and the base-flow discharge flux of $\mathrm{NO}_{3}^{-}$in a watershed near Locust Grove, Md., could be accounted for by the transient nature of the agricultural contamination on a decadal time scale. In contrast, if all discharge at any time had a 
single age (also designated as $\tau$, the piston-flow residence time), the concentration of $\mathrm{NO}_{3}^{-}$in discharge at time ti would be given by:

$$
\operatorname{Codis}(\mathrm{ti})=\operatorname{Cin}(\mathrm{ti}-\tau)
$$

If discharge were a binary mixture of (1) an old base-flow component or denitrified base-flow component with no $\mathrm{NO}_{3}^{-}$and (2) a young component with a given age and corresponding $\mathrm{NO}_{3}^{-}$recharge history, then the stream response could be modeled by reversing the procedure used to evaluate recharge characteristics of binary mixtures. In this case, the discharge $\mathrm{NO}_{3}^{-}$concentration would be given by:

$$
\mathrm{Cmix}=\mathrm{C}^{\circ} \text { young } \cdot \text { Xyoung, }
$$

that is, the recharge $\mathrm{NO}_{3}^{-}$concentration of the young component multiplied by the fraction of the young component of water in the mixture. Some sample calculations for these three models (piston flow, exponential mixing, and binary mixing) are illustrated with input data from Locust Grove, Md., in figure 17.
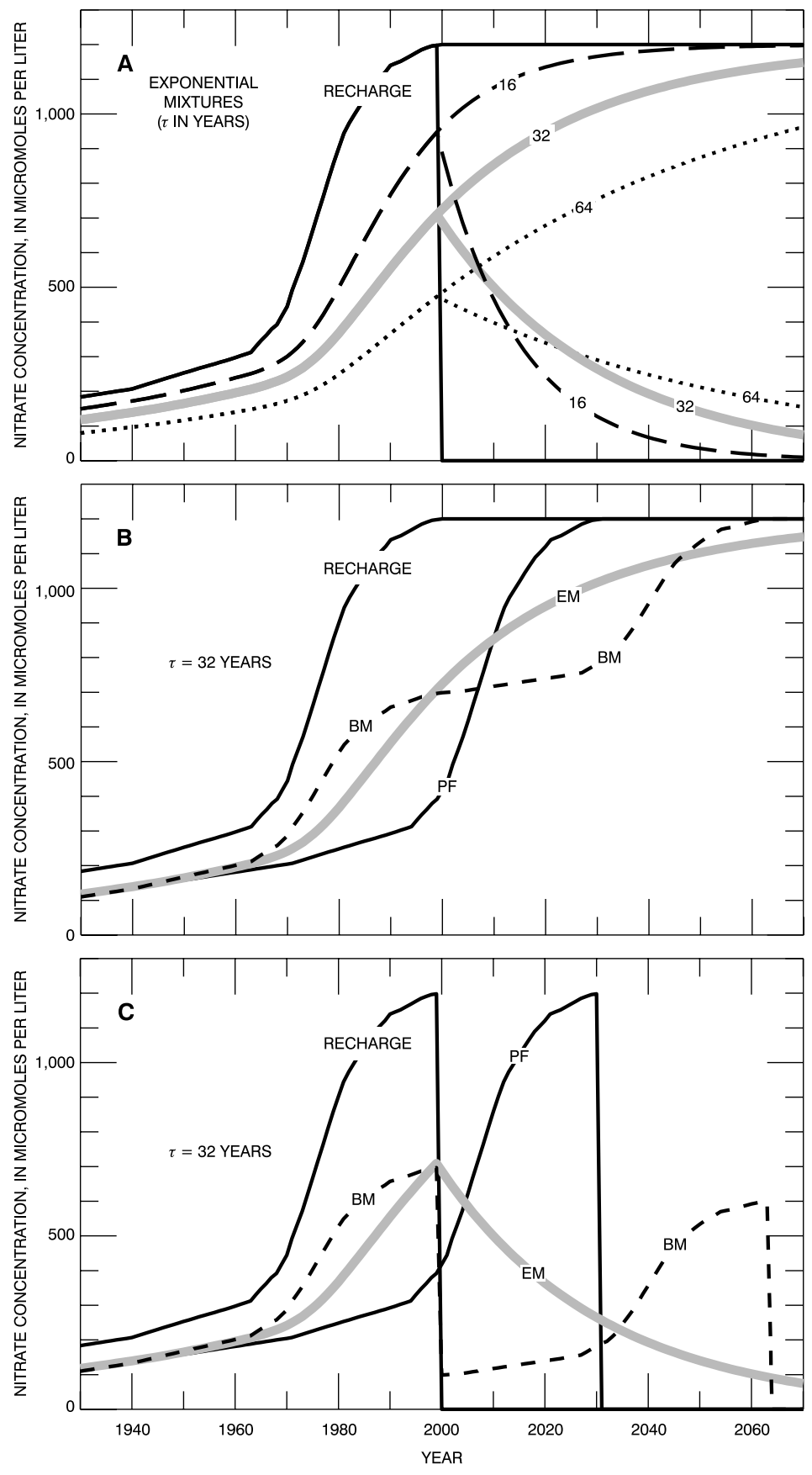

Figure 17. Simplified record of nitrate $\left(\mathrm{NO}_{3}^{-}\right)$inputs to recharge and resulting hypothetical $\mathrm{NO}_{3}^{-}$responses in discharge. The recharge input history is from the smoothed curve in figure 16, extended to the year 1999, after which two different future scenarios are plotted: continuing at the 1999 value and dropping to zero in 2000 and beyond. Discharge age distribution models correspond to piston flow (PF), exponential mixing (EM), and binary mixing (BM). Mean age or residence time is designated as $\tau$ (in years). [A] Responses of exponential mixtures with varying mean residence times to the past $\mathrm{NO}_{3}^{-}$recharge history and two alternative future $\mathrm{NO}_{3}^{-}$recharge scenarios. [B] and [C] Responses of various types of mixtures with the same mean residence time (32 years) to the past $\mathrm{NO}_{3}^{-}$recharge history and two alternative future recharge scenarios. 
These calculations indicate that even in the absence of denitrification and other $\mathrm{NO}_{3}^{-}$removal processes, ground water discharging from surficial aquifers can have $\mathrm{NO}_{3}^{-}$concentrations that are substantially different from those of contemporaneous recharge. Furthermore, the $\mathrm{NO}_{3}^{-}$concentrations and trends in discharge depend strongly on the age frequency distributions even in aquifers with the same mean residence time. These features result from changes in the recharging $\mathrm{NO}_{3}^{-}$ concentration on time scales that are comparable to, or shorter than, the ground-water turnover times.

\section{References Cited}

Aravena, R., Evans, M.L., and Cherry, J.A., 1993, Stable isotopes of oxygen and nitrogen in source identification of nitrate from septic systems: Ground Water, v. 31, p. 180-186.

Bachman, L.J., Krantz, D.E., and Böhlke, J.K., 2002, Hydrogeologic framework, groundwater geochemistry, and assessment of nitrogen yield from base flow in two agricultural watersheds, Kent County, Maryland: U.S. Environmental Protection Agency, EPA/600/R-02/008, 93 p.

Böhlke, J.K., 2002, Groundwater recharge and agricultural contamination: Hydrogeology Journal, v. 10, p. 153-179. [Erratum: Hydrogeology Journal, v. 10, p. 438-439.]

Böhlke, J.K., and Denver, J.M., 1995, Combined use of groundwater dating, chemical, and isotopic analyses to resolve the history and fate of nitrate contamination in two agricultural watersheds, Atlantic coastal plain, Maryland: Water Resources Research, v. 31, p. 2,319-2,339.

Böhlke, J.K., Wanty, R., Tuttle, M., Delin, G., and Landon, M., 2002, Denitrification in the recharge area and discharge area of a transient agricultural nitrate plume in a glacial outwash sand aquifer, Minnesota: Water Resources Research, v. 38(7), 10.1029/2001WR000663, 200238, p. 10.1-10.26.

Böttcher, J., Strebel, O., Voerkelius, S., and Schmidt, H.L., 1990, Using isotope fractionation of nitratenitrogen and nitrate-oxygen for evaluation of microbial denitrification in a sandy aquifer: Journal of Hydrology, v. 114, p. 413-424.

Cleveland, W.S., 1979, Robust locally weighted regression and smoothing scatterplots: Journal of the American Statistical Association, v. 74, p. 829836.
Cook, P.G., and Böhlke, J.K., 2000, Determining timescales for groundwater flow and solute transport, in Cook, P.G., and Herczeg, A., eds., Environmental tracers in subsurface hydrology:

Boston, Mass., Kluwer Academic Publishers, p. 1-30.

Cravotta, C.A., 1997, Use of stable isotopes of carbon, nitrogen, and sulfur to identify sources of nitrogen in surface waters in the lower Susquehanna River Basin, Pennsylvania: U.S. Geological Survey Water-Supply Paper 2497, 99 p.

Dunkle, S.A., Plummer, L.N., Busenberg, Eurybiades, Phillips, P.J., Denver, J.M., Hamilton, P.A., Michel, R.L., and Coplen, T.B., 1993, Chlorofluorocarbons $\left(\mathrm{CCl}_{3} \mathrm{~F}\right.$ and $\left.\mathrm{CCl}_{2} \mathrm{~F}_{2}\right)$ as dating tools and hydrologic tracers in shallow ground water of the Delmarva Peninsula, Atlantic Coastal Plain, United States: Water Resources Research, v. 29 , p. $3,837-3,860$.

Eshleman, K.N., Morgan, R.P.I., Webb, J.R., Deviney, F.A., and Galloway, J.N., 1998, Temporal patterns of nitrogen leakage from mid-Appalachian forested watersheds-Role of insect defoliation: Water Resources Research, v. 34, p. 2,005-2,116.

Focazio, J.J., Plummer, L.N., Böhlke, J.K., Busenberg, Eurybiades, Bachman, L.J., and Powars, D.S., 1998, Preliminary estimates of residence times and apparent ages of ground water in the Chesapeake Bay watershed, and water-quality data from a survey of springs: U.S. Geological Survey Water-Resources Investigations Report 974225, 75 p.

Fogg, G.E., Rolston, D.E., Decker, D.L., Louie, D.T., and Grismer, M.E., 1998, Spatial variation in nitrogen isotope values beneath nitrate contamination sources: Ground Water, v. 36, p. 418426.

Freyer, H.D., 1978, Seasonal trends of $\mathrm{NH}_{4}^{+}$and $\mathrm{NO}_{3}^{-}$ nitrogen isotope composition in rain collected at Julich, Germany: Tellus, v. 30, p. 83-92.

1991, Seasonal variation of ${ }^{15} \mathrm{~N} /{ }^{14} \mathrm{~N}$ ratios in atmospheric nitrate species: Tellus, v. 43B, p. 30-44.

Freyer, H.D., and Aly, A.I.M., 1974, Nitrogen-15 variations in fertilizer nitrogen: Journal of Environmental Quality, v. 3, p. 405-406. 


\section{References Cited-Continued}

Garten, C.T., Jr., 1992, Nitrogen isotope composition of ammonium and nitrate in bulk precipitation and forest throughfall: International Journal of Environmental Analytical Chemistry, v. 47, p. 3345.

1996, Stable nitrogen isotope ratios in wet and dry nitrate deposition collected with an artificial tree: Tellus, v. 48B, p. 60-64.

Gburek, W.J., and Folmar, G.J., 1999, Flow and chemical contributions to streamflow in an upland watershed-A baseflow survey: Journal of Hydrology, v. 217, p. 1-18.

Hauck, R.D., Bartholomew, W.V., Bremner, J.M., Broadbent, F.E., Cheng, H.H., Edwards, A.P., Keeney, D.R., Legg, J.O., Olsen, S.R., and Porter, L.K., 1972, Use of variations in natural nitrogen isotope abundance for environmental studiesA questionable approach: Science, v. 177, p. 453-454.

Heaton, T.H.E., 1986, Isotopic studies of nitrogen pollution in the hydrosphere and atmosphereA review: Chemical Geology, v. 59, p. 87-102. $1987,{ }^{15} \mathrm{~N} /{ }^{14} \mathrm{~N}$ ratios of nitrate and ammonium in rain at Pretoria, South Africa: Atmospheric Environment, v. 21, p. 843-852.

$1990,{ }^{15} \mathrm{~N} /{ }^{14} \mathrm{~N}$ ratios of NOx from vehicle engines and coal-fired power stations: Tellus, v. 42B, p. 304-307.

Hübner, H., 1986, Isotope effects of nitrogen in the soil and biosphere, in Fritz, P., and Fontes, J.C., eds., Handbook of environmental geochemistry, v. 2, The terrestrial environment B: Amsterdam, Elsevier, p. 361-425.

Keeney, D.R., 1986, Sources of nitrate to ground water: CRC Critical Reviews in Environmental Control, v. 16, p. 257-304.

Kendall, C., and Aravena, R., 2000, Nitrate isotopes in groundwater systems, in Cook, P.G., and Herczeg, A.L., eds., Environmental tracers in subsurface hydrology: Boston, Mass., Kluwer Academic Publishers, p. 261-297.

Kohl, D.H., Shearer, G.B., and Commoner, B., 1971, Fertilizer nitrogen-Contribution to nitrate in surface water in a corn belt watershed:

Science, v. 174, p. 1,331-1,334.
Kreitler, C.W., 1975, Determining the source of nitrate in ground water by nitrogen isotope studies: University of Texas, Bureau of Economic Geology Report of Investigations 83, $57 \mathrm{p}$.

1979, Nitrogen-isotope ratio studies of soils and groundwater nitrate from alluvial fan aquifers in Texas: Journal of Hydrology, v. 42, p. 147-170.

Letolle, R., 1980, Nitrogen-15 in the natural environment, in Fritz, P., and Fontes, J.C., eds., Handbook of environmental isotope geochemistry, v. 1. The terrestrial environment, A: Amsterdam, Elsevier, p. 407-433.

Mariotti, A., Landreau, A., and Simon, B., 1988, N isotope biogeochemistry and natural denitrification process in groundwater-Application to the chalk aquifer of northern France: Geochimica et Cosmochimica Acta, v. 52, p. 1,869-1,878.

McMahon, P.B., and Böhlke, J.K., 1996, Denitrification and mixing in a stream-aquifer system-Effects on nitrate loading to surface water: Journal of Hydrology, v. 186, p. 105-128.

O'Connell, M.E., 1998, Processes affecting the discharge of nitrate from a small agricultural watershed over a range of flow conditions, Maryland coastal plain: University of Maryland, unpub. Ph.D. thesis, $325 \mathrm{p}$.

Paerl, H.W., and Fogel, M.L., 1994, Isotopic characterization of atmospheric nitrogen inputs as sources of enhanced primary production in coastal Atlantic Ocean waters: Marine Biology, v. 119, p. 635-645.

Pionke, H.B., and Urban, J.B., 1985, Effect of agricultural land use on groundwater quality in a small Pennsylvania watershed: Ground Water, v. 23, p. 68-80.

Plummer, L.N., Busenberg, Eurybiades, Böhlke, J.K., Carmody, R.W., Casile, G.C., Coplen, T.B., Doughten, M.W., Kirkland, W., Michel, R.L., Nelms, D.L., Norton, B.C., Plummer, K.E., Qi, H., Revesz, K., Schlosser, P., Spitzer, S., Wayland, J.E., and Widman, P.K., 2000, Chemical and isotopic composition of water from springs, wells, and streams in parts of Shenandoah National Park, Virginia, and vicinity, 1995-1999: U.S. Geological Survey Open-File Report 00-373, $70 \mathrm{p}$. 


\section{References Cited-Continued}

Schroeder, R.A., Martin, P., and Böhlke, J.K., 1996, Chemical, isotopic, and microbiological evidence for denitrification during transport of domestic wastewater through a thick unsaturated zone in the Mojave Desert: U.S. Geological Survey Water-Resources Investigations Report 94-4015, p. 917-926.

Vogel, J.C., Talma, A.S., and Heaton, T.H.E., 1981, Gaseous nitrogen as evidence for denitrification in groundwater: Journal of Hydrology, v. 50, p. 191-200.

Weiss, R.F., 1970, The solubility of nitrogen, oxygen, and argon in water and seawater: Deep-Sea Research, v. 17, p. 721-735.

Wolterink, T.J., 1979, Identifying sources of subsurface nitrate pollution with stable nitrogen isotopes: U.S. Environmental Protection Agency, EPA-600/4-79-050, $150 \mathrm{p}$.

Zuber, A., 1986, Mathematical models for the interpretation of environmental radioisotopes in groundwater systems, in Fritz, P., and Fontes, J.C., eds., Handbook of Environmental Geochemistry, v. 2, The Terrestrial Environment B: Amsterdam, Elsevier, p. 1-59.

\section{GROUND-WATER RESIDENCE TIME AND NTIROG EN CONCENIRATION}

The following sections describe the results of the analyses of ground-water samples collected in the Chesapeake Bay Watershed. A description of the results from springs sampled in the Chesapeake Bay Watershed is followed by sections describing results from sampling in the Pocomoke River Watershed, Polecat Creek Watershed, Muddy Creek Watershed, and East Mahantango Creek Watershed. Similar methods were used to collect and analyze water samples for age-dating tracers and $\mathrm{N}$ in each of these areas; the unique characteristics as well as similarities of each study area, however, are described and synthesized to provide an overall depiction of ground-water residence time and $\mathrm{N}$ concentrations throughout the Watershed.

\section{Springs in the Chesapeake Bay Watershed}

\author{
by Michael J. Focazio
}

Water discharging from a pumped well or spring is usually a mixture of waters of different ages and chemistry originating from different contributing areas (Franke and others, 1998). The convergence of flow paths at a spring provides unique sampling locations to easily collect ground-water samples representative of age mixtures in ground-water discharge and, potentially, base flow to streams. However, interpretation of chemical and environmental tracer data of these mixtures can be quite complicated (see, "Approaches for GroundWater Dating," this report). Forty-eight springs were selected to represent ground-water discharges throughout the Chesapeake Bay Watershed and water samples were analyzed for a variety of environmental tracers. Focazio and others (1998) described the range of hydrogeologic settings, discharge amounts, and land uses associated with the springs sampled for this study throughout the Chesapeake Bay Watershed.

The hydrologic condition and time of sampling may affect the mixture of water collected from a given spring. The chemical responses of springs to storms and seasonality vary among types of springs (conduit or diffuse flow) and local hydrogeologic conditions (White, 1993). The hydrologic response time of some springs is related directly to individual storm events; others respond to seasonal or long-term variations (White, 1993). One plausible hypothesis would suggest that shallow ground-water-flow paths contributing to springs (presumably dominated by younger water) would become less significant during low base-flow periods and therefore ground-water discharge at the spring would be dominated by the deeper flow paths (presumably dominated by older water that has been in storage and (or) has been flowing for longer time periods). Conversely, during high base-flow periods, the shallower (younger) flow paths would tend to make a more significant contribution to the mixture of water at a spring discharge location. In the absence of detailed information on the flow field associated with a spring, one way to estimate a representative range of water (and age) mixtures is to collect samples during extreme low and high base-flow periods. Results of this type of sampling could represent "end members" in the distribution of the possible mixtures of ages in the aquifer or part of the aquifer associated with a given spring under base-flow conditions. This reasoning can be extended over larger areas so that as the number of springs from various hydrogeologic environments (presumably including shallow and deeper flow systems with diffuse as well as conduit flow) increases, a variety of mixtures of ground 
waters (and ages) presumably would be represented. For these reasons, the springs were sampled during two contrasting regional flow regimes, during late summer of 1996 and again in late summer of 1997. The late summer is typically a low-flow season in the Chesapeake Bay Watershed because, although monthly rainfall amounts do not vary much over the year, evapotranspiration is at its highest. Thus, the high and low flow (hereafter called wet and dry year, respectively) sampled for this study represent end members for late summer (or seasonally low) base-flow conditions. Results of analyses for three different CFC compounds (CFC-12, CFC-111, and CFC-113), $\mathrm{SF}_{6}$, and ${ }^{3} \mathrm{H} /{ }^{3} \mathrm{He}$ ratios were compared to derive information about ground-water residence times (see "Approaches for Ground-Water Dating," this report). Concentrations and isotopic composition of $\mathrm{NO}_{3}^{-}$were evaluated with respect to residence time, local land use, and different flow conditions to assess sources of $\mathrm{N}$ in ground-water discharge.

\section{Results of Spring Sampling}

The wet-year samples were collected during late summer base-flow conditions in 1996 shortly after total river flow to the Chesapeake Bay was nearly 35 billion gallons per day (bgd), 50 percent above the average inflow of $23.5 \mathrm{bgd}$ (U.S. Geological Survey Office of Outreach, written commun. 2002). In contrast, the dryyear samples were collected during late summer baseflow conditions in 1997 shortly after total river flow into the Chesapeake Bay was about 16.2 bgd, 31 percent below the normal inflow (U.S. Geological Survey Office of Outreach, written commun., 2002). The approximate times of sampling are shown in figure 18 on a graph of the measured streamflow hydrograph for Difficult Run, a representative stream in the Chesapeake Bay Watershed with over 65 years of record. For perspective, the $25^{\text {th }}$ and $75^{\text {th }}$ daily-flow percentiles also are shown.

A percentile is a value on a scale of 100 that indicates the percentage of a distribution that is equal to or below it. For example, on a given day the $90^{\text {th }}$ percentile streamflow value represents a value that is equal to or

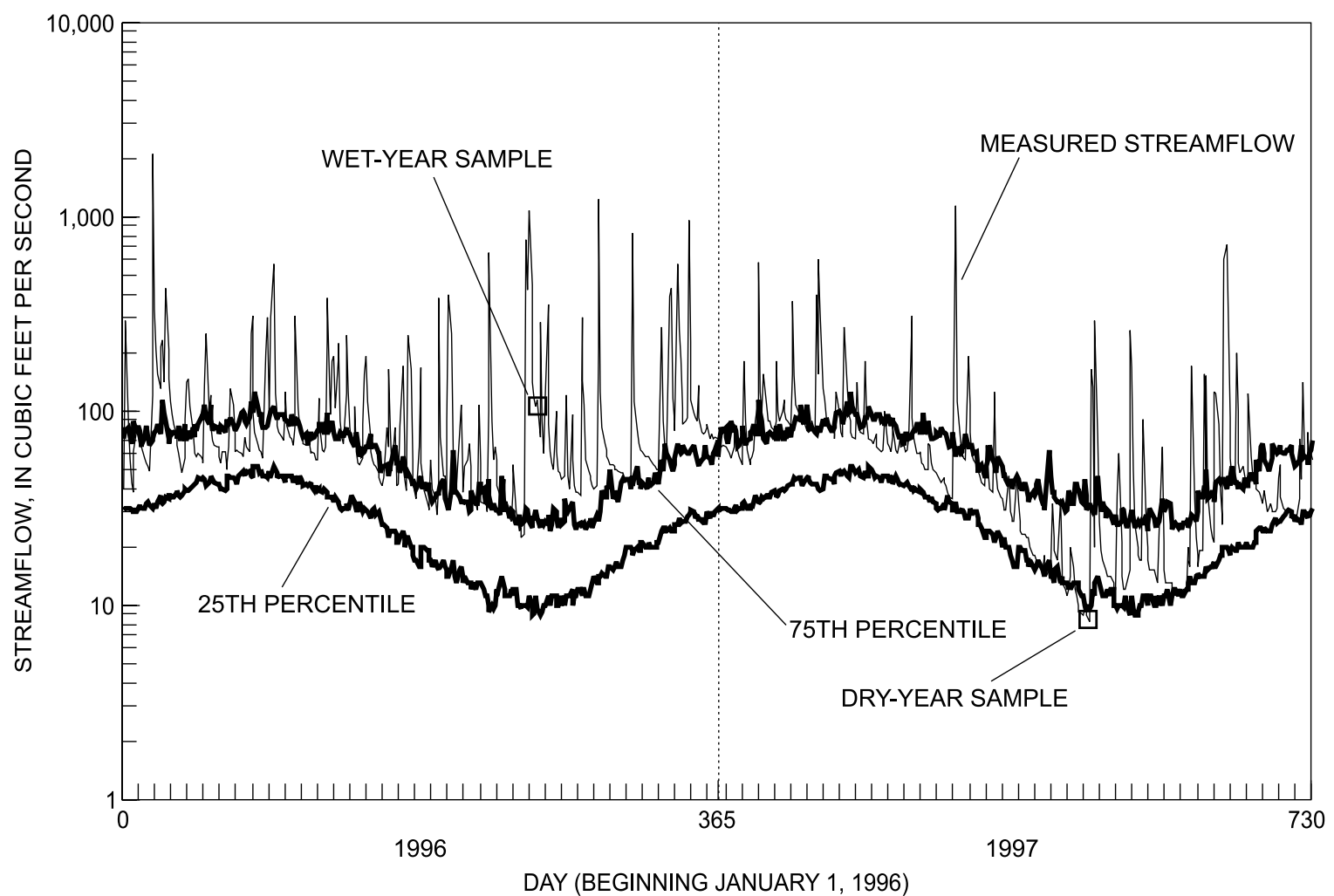

Figure 18. Measured daily streamflow at Difficult Run near Great Falls, Va., used as an indication of general hydrologic condition. The wet- and dry-year sampling events are shown in relation to the $25^{\text {th }}$ and $75^{\text {th }}$ percentiles. Values below the $25^{\text {th }}$ percentile are less than normal streamflow and values above the $75^{\text {th }}$ percentile are greater than normal streamflow. 
greater than 90 percent of the streamflow values recorded on that day of the year during all years that measurements have been made. In addition, a percentile greater than 75 is considered above normal, a percentile between 25 and 75 is considered normal, and a percentile less than 25 is considered below normal.

The contributing areas to each spring could not be determined, therefore land use within a 1-mi radius of each spring was quantified as a surrogate measure of potential land areas associated with each spring. Types of specific land use/land covers investigated include the following: high, medium, and low intensity residential; row crop; hay/pasture; deciduous forest; evergreen forest; mixed forest; emergent wetland; water bodies; and commercial/industrial. The potential point and nonpoint sources of excess $\mathrm{NO}_{3}^{-}$to ground water in the Chesapeake Bay Watershed are likely to be associated with agricultural and urban land use. The major potential nonpoint sources of $\mathrm{NO}_{3}^{-}$in the Chesapeake Bay Watershed are agricultural fertilizer and manure inputs that vary depending on type of crop practice. In general, $\mathrm{NO}_{3}^{-}$concentrations increase with percentage agricultural land use (fig. 19A). Although a slight increase in $\mathrm{NO}_{3}^{-}$was associated with agricultural land use within the 1-mi radius of each spring, a relation between $\mathrm{NO}_{3}^{-}$ and urban land use is more difficult to discern (fig. 19B). Pasture and crop land are the two major agricultural land uses in the basin and are plotted in figure $19 \mathrm{C}$ in relation to $\delta^{15} \mathrm{~N}$ values. For samples with relatively high $\mathrm{NO}_{3}^{-}$ concentrations ( $>2 \mathrm{mg} / \mathrm{L}$ as N), $\delta^{15} \mathrm{~N}$ values of the $\mathrm{NO}_{3}^{-}$range from about +3 to $+10 \%$ (fig. $19 \mathrm{C}$ and 19D). These data are consistent with fertilized agricultural land uses as major sources of high $\mathrm{NO}_{3}^{-}$concentrations in many of the springs, with substantial contributions from septic or manure sources in some of the springs. Samples with low $\mathrm{NO}_{3}^{-}$concentrations $(<2 \mathrm{mg} / \mathrm{L}$ as $\mathrm{N})$ have a similar range of $\delta^{15} \mathrm{~N}$ values that could indicate smaller (more diluted) overall contributions from similar sources, as well as possibly larger proportions of other biologic and atmospheric sources. (see "Sources, Transport, and Reaction of Nitrate").

Without detailed information on the actual contributing area of each spring, it is not possible to ascertain the accuracy of each surrogate contributing area. Consequently, the actual relations of land use and $\mathrm{N}$ concentrations may not be possible to determine; however, the elevated concentrations of $\mathrm{NO}_{3}^{-}$in several springs are good indications that springs are an important pathway for the transport and discharge of $\mathrm{N}$ throughout the watershed.
With the exception of a thermal spring, concentrations of dissolved oxygen typically were above $2 \mathrm{mg} / \mathrm{L}$ and were not correlated with $\mathrm{NO}_{3}^{-}$concentrations. The relatively high concentrations of dissolved oxygen and low concentrations of excess $\mathrm{N}_{2}$ gas (see Appendix) are interpreted as evidence that denitrification generally did not affect the $\mathrm{NO}_{3}^{-}$concentrations of the ground water discharging at the springs sampled for this study. The variations in $\mathrm{NO}_{3}^{-}$concentration among the springs mainly are because of variations in groundwater age, land use in the recharge areas, and mixing (see "Sources, Transport, and Reaction of Nitrate").

\section{Nitrogen, field parameters, and apparent age comparisons between the wet and dny years}

Nitrogen.-Generally, the $\mathrm{NO}_{3}^{-}$concentrations were slightly higher during the wet year than the dry year (fig. 20A). The higher concentrations of $\mathrm{NO}_{3}^{-}$ and higher flows observed during the wet year indicate the total mass of $\mathrm{NO}_{3}^{-}$discharged by the springs was higher than it was in the dry year. However, the $\delta^{15} \mathrm{~N}$ values generally were similar (no consistent bias) between the two hydrologic conditions (fig. 20B) indicating that the $\mathrm{NO}_{3}^{-}$sources remained relatively constant; the loads were a function of hydrologic conditions.

\section{Field measurements and recharge} temperatures.-Comparisons of field constituents between the wet and dry years are provided for perspective on the general similarities in water quality for the two events. To the extent that mineralization increases as ground water remains in contact with source material, older ground water tends to contain more dissolved minerals than younger water. The specific conductance was similar for the wet and dry years and therefore does not corroborate the preceding sentence. However, specific conductance may not be an accurate indication of mineralization in these waters, and contact time is only one factor controlling mineralization. Consequently, the only conclusion made from the comparison of specific conductance between the two events is, in general, the salinity did not significantly change. The median temperatures for the spring water were 13.0 and $12.6^{\circ} \mathrm{C}$ for the wet and dry years, respectively. Overall, the temperatures did not vary much between the two sampling years, although the wet-year temperatures were slightly higher. Estimates of the recharge temperatures were slightly warmer during the wet year and not as well cor- 

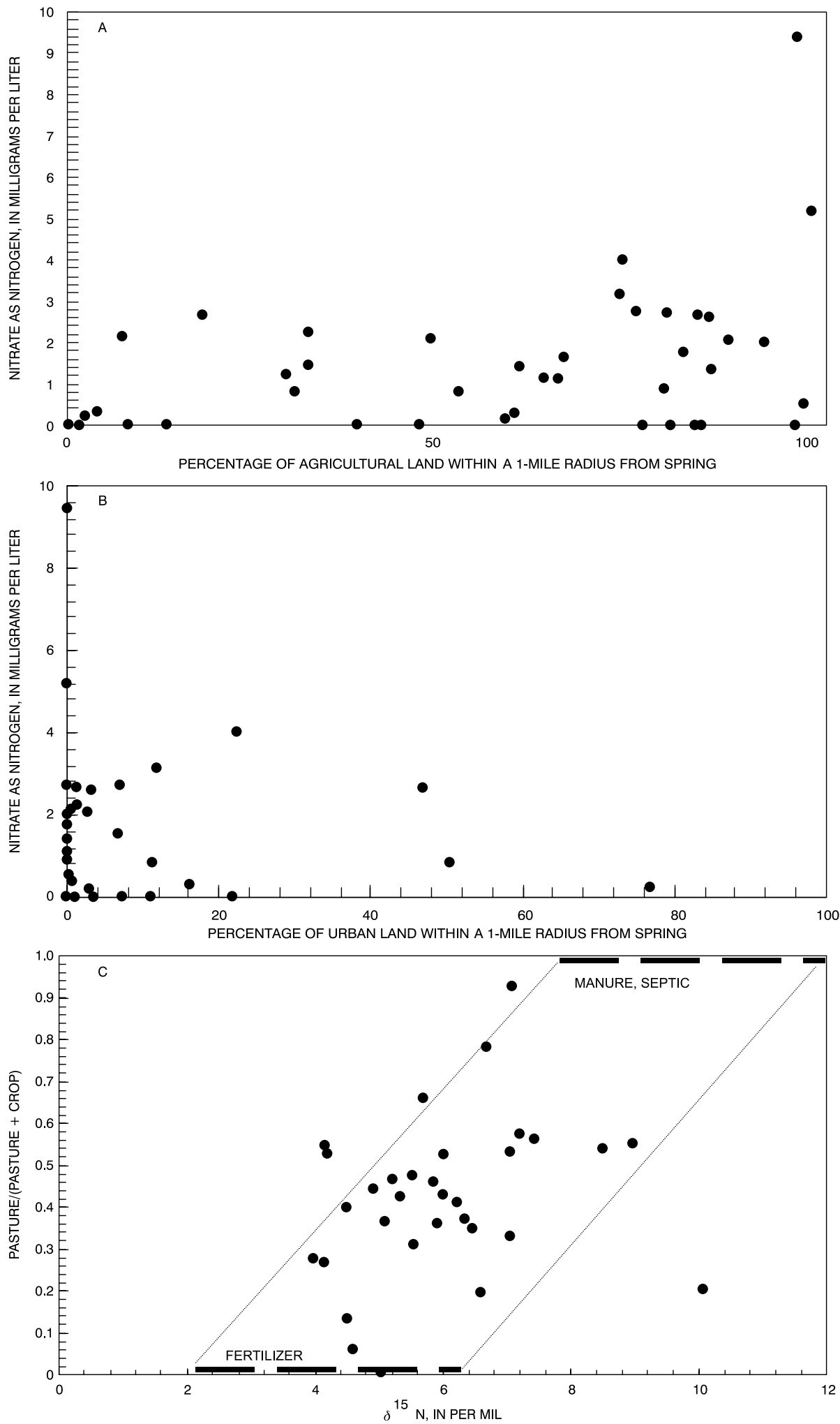

Figure 19. Nitrate concentrations as a function of: agricultural land use within a 1-mile radius from each spring (A), urban land use within a 1-mile radius from each spring (B), and relation of $\delta^{15} \mathrm{~N}$ to agricultural land use (C). In the Chesapeake Bay Watershed, $\delta^{15} \mathrm{~N}$ values between +2 and $+6 \%$ in ground water typically are associated with agricultural fields contaminated by excess artificial nitrogen fertilizer; $\delta^{15} \mathrm{~N}$ values greater than $+8 \%$ 。 are typical of ground water contaminated with septic systems and manure (see "Sources, Transport, and Reaction of Nitrate"). 

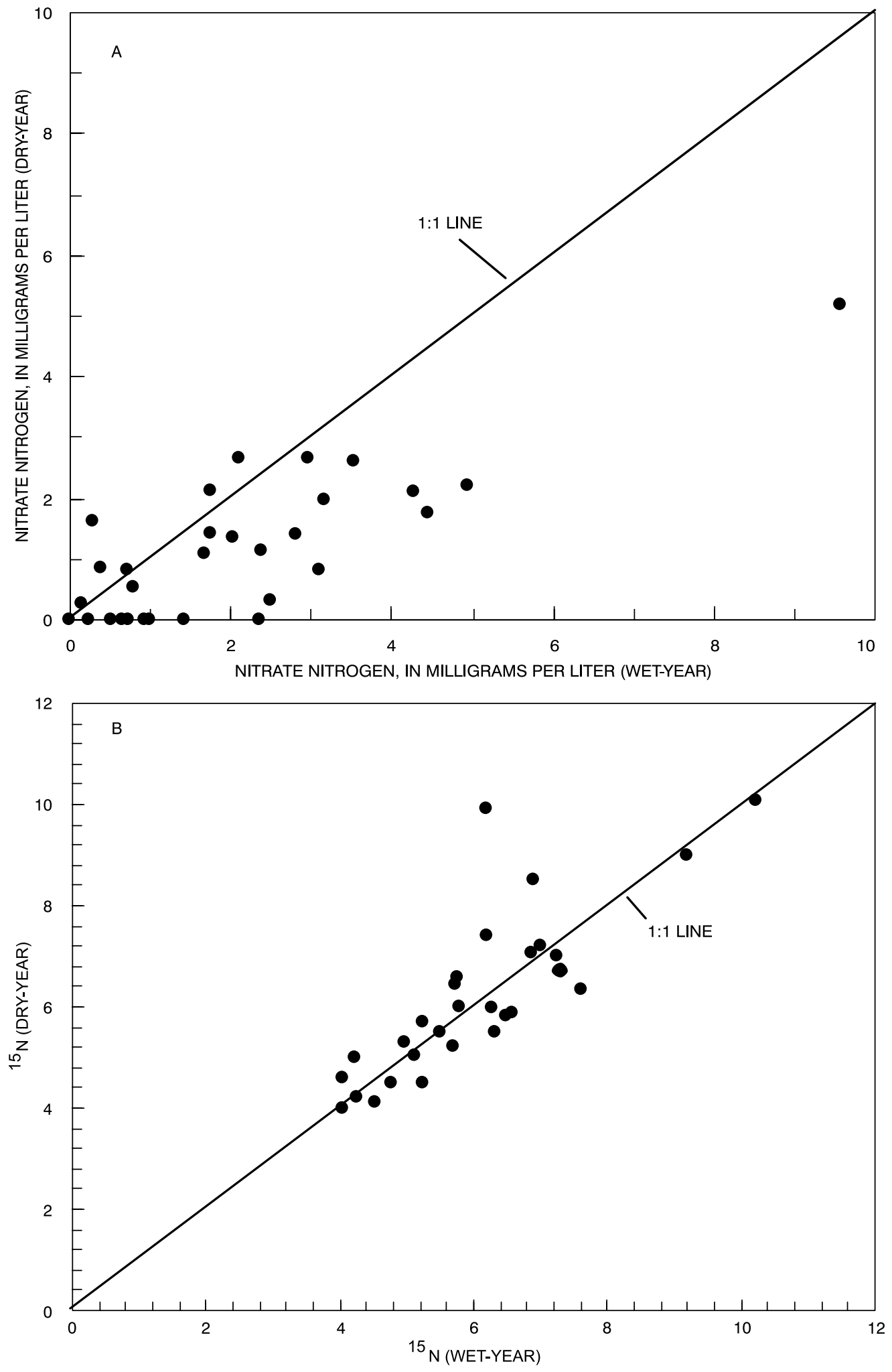

Figure 20. Dry- and wet-year comparisons of nitrate concentrations $(A)$ and $\delta^{15} \mathrm{~N}$ values (B). 
related. In addition, spring-water temperatures consistently were warmer than the estimated recharge temperatures regardless of flow condition. This can be caused by 1) a warming of the water as it moves through an aquifer from recharge location to discharge location, or 2) collecting samples during months that are warmer than those associated with the most significant recharge events. The former would require flow paths to travel deep enough to be affected by the natural geothermal gradient, which clearly is evident in the few water samples collected from the thermal springs. However, because much of the mixtures discharging from the nonthermal springs is dominated by younger water (as discussed later in this section), the slight increases in discharge-water temperatures are most likely the result of recharge that occurred during the cooler months in the Chesapeake Bay Watershed. The cooler, winter months in this climate are associated with the lowest rates of evapotranspiration and therefore the opportunity for recharge is greatest. The general similarities in field constituents between the two events is an indication, although not sufficient, that the mixtures of waters (and thus, ages) are not significantly different.

Apparentage_-All spring-water samples were analyzed for CFC-11, CFC-12, and CFC-113, and apparent ages were assigned (table 3 ) on the basis of the most appropriate tracer (see "Approaches for GroundWater Dating,” this report). In addition, water samples from selected springs were analyzed for ${ }^{3} \mathrm{H} /{ }^{3} \mathrm{He}$ and $\mathrm{SF}_{6}$ for comparative purposes and where local contaminant sources of CFC precluded age estimates by CFC analysis.

Table 3. Summary of apparent ages for ground-water samples collected in wet and dry years [>, greater than]

\begin{tabular}{lcc}
\hline \multicolumn{1}{c}{ Statistic } & Wet Year & Dry Year \\
\hline Number of samples & 43 & 43 \\
Number of analyses & 28 & 29 \\
Maximum age, in years & $>50$ & $>50$ \\
Minimum age, in years & 4.7 & 4.6 \\
Number of samples & 43 & 43 \\
Number of modern samples & 5 & 4 \\
Number of contaminated samples & 10 & 10 \\
Percentage modern & 11.6 & 9.3 \\
Percentage contaminated & 23.3 & 23.3 \\
\hline
\end{tabular}

Several theoretical mixing models of tracers analyzed in this study including $\mathrm{CFC}, \mathrm{SF}_{6},{ }^{3} \mathrm{H}$, and ${ }^{3} \mathrm{H} /{ }^{3} \mathrm{He}$ were constructed assuming piston flow, exponential mixing, and binary mixing (see "Approaches for Ground-Water Dating,” this report). About two-thirds of the measured concentrations of CFCs that are not above the modern saturation values tend to be in the range of concentrations where the models behave similarly (fig. 11). These data points are associated with very young or modern waters (about 10 years or less) regardless of which model is used (Focazio and others, 1998). Additional mixing-model analyses were completed where possible with the other tracers used in this study and all had similar results. Therefore, unless otherwise noted, apparent ages were determined with piston-flow assumptions and generally CFC-12 or CFC-113 was used because of the large percentage of contamination by CFC-11 and the small amount of data on other tracers. For a more complete description of the mixingmodel approach and how apparent ages are assigned when local sources of contamination are evident see “Approaches for Ground-Water Dating” this report.

The concentrations of CFCs (see "Approaches for Ground-Water Dating," this report) varied slightly between the 2 years of sample collection (fig. 21), and a large percentage ( 23 percent) of samples were contaminated by local sources of CFCs. Samples collected during the dry year had slightly older apparent ages determined by $\mathrm{CFCs}_{\text {and }} \mathrm{SF}_{6}$ than samples collected during the wet year (fig. 22A). The percentage of samples contaminated by local sources of CFCs remained the same for the two sampling periods. The high percentage of CFC-contaminated samples indicates a component of relatively recent recharge events, but determination of ages is not possible. Neglecting the contaminated samples, the median age for all the samples was 10 years, with the 25 th percentile having an age of 7 years and the 75 th percentile having an age of 13 years. Although the number of samples collected in each HGMR was limited, there did not appear to be distinct differences in the ages between the HGMRs. The ranges were similar between the major HGMRs above the Fall Line (modern to about 50 years), with only two HGMRs of small geographic extent (Piedmont carbonate and Mesozoic Lowland) having ranges of modern to about 10 years. The median value of all the HGMRs ranged from 7 to 11 years. Not enough samples were collected in the Coastal Plain for comparison. 


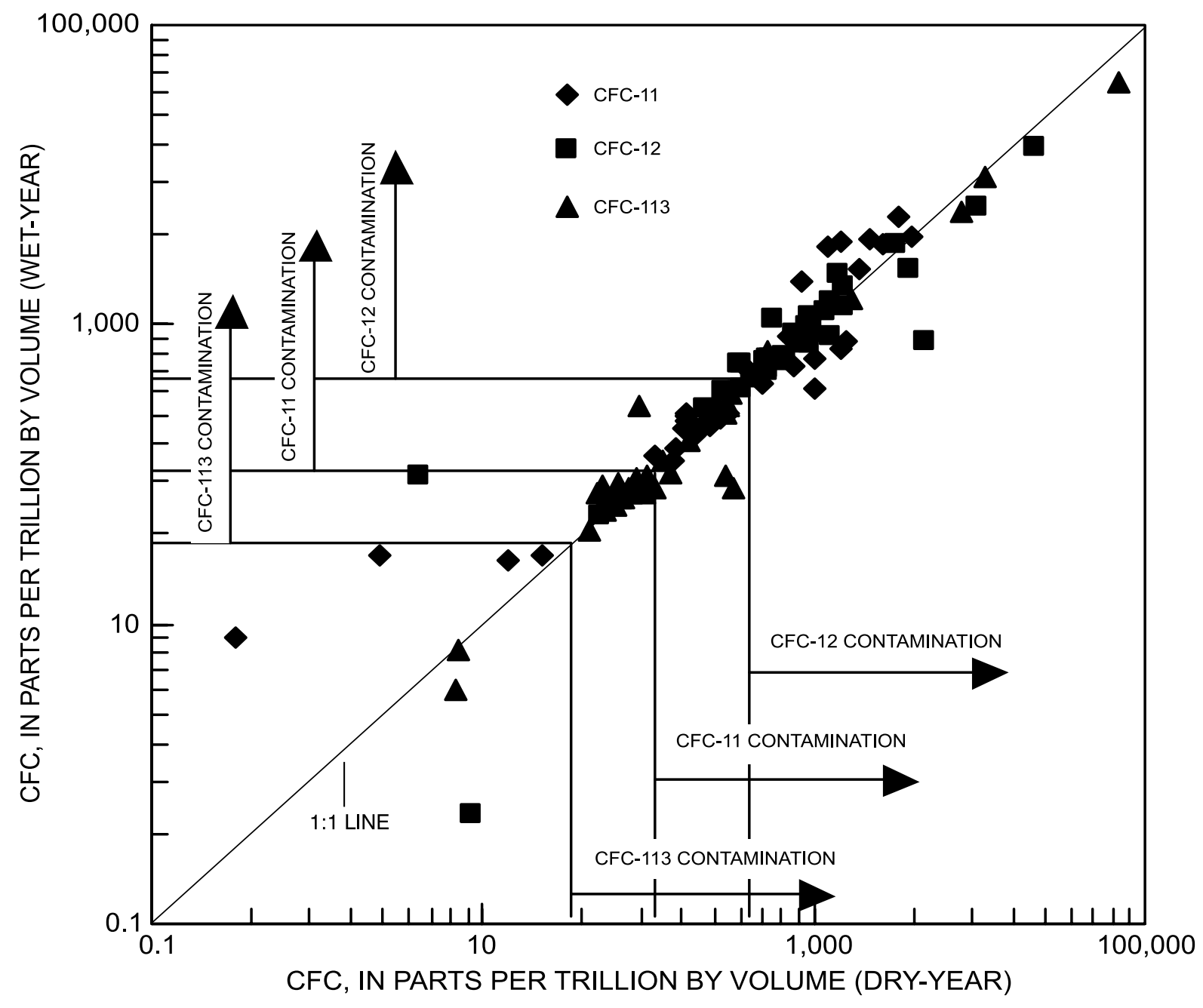

Figure 21. The relation between chlorofluorocarbon concentrations in water samples from all springs sampled during the dry and wet years. 

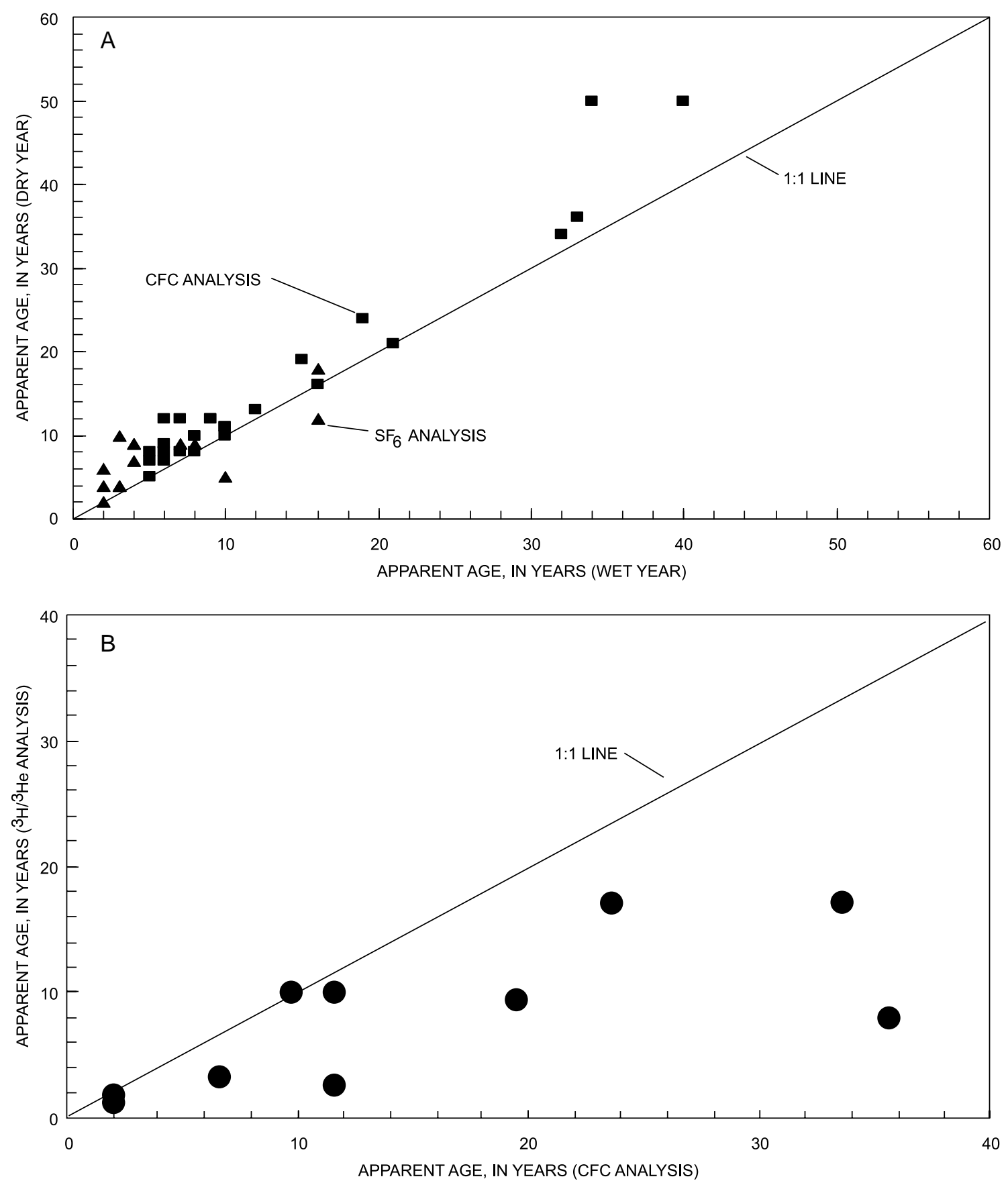

Figure 22. The relations between apparent ages determined by chlorofluorocarbon (CFC) and sulfur hexafluoride $\left(\mathrm{SF}_{6}\right)$ analysis during the wet and dry years $(\mathrm{A})$, and chlorofluorocarbon (CFC) and tritium/helium $\left({ }^{3} \mathrm{H} /{ }^{3} \mathrm{He}\right)$ age-dating analyses $(\mathrm{B})$ for all uncontaminated samples and samples older than "modern." 
Comparison of ages determined with chlorofluorocarbon and tritium/helium.-

Generally, the apparent ages determined by CFCs are older than those determined by ${ }^{3} \mathrm{H} /{ }^{3} \mathrm{He}$ (fig. 22b), because the ${ }^{3} \mathrm{H} /{ }^{3} \mathrm{He}$ ages are based on an isotope ratio that is little affected by mixing with old (pre-nuclear detonation) water (see "Approaches for Ground-Water Dating," this report). Therefore, apparent ages of the mixtures quantified with CFCs are equal to (indicating no dilution from mixing with old water) or older than the ${ }^{3} \mathrm{H} /{ }^{3} \mathrm{He}$ ages.
The "young fraction" of water in spring samples was calculated by dividing the measured value of CFC-12 (or CFC-113) used to make the apparent-age estimate by the concentration of CFC-12 (or CFC-113) taken from the air-equilibrium curve corresponding to the recharge date as determined by the ${ }^{3} \mathrm{H} /{ }^{3} \mathrm{He}$ analysis for each sample (table 4). This method assumes the "old fraction" is devoid of the tracer; accordingly, the young fraction of a mixture is defined as water recharged after atmospheric testing of nuclear weapons. The young fraction of water in six of the seven springs analyzed accounted for the majority (60 percent or greater) of the age mixture. This limited number of analyses suggest that the mixture of water discharging from most springs in the watershed is likely dominated by younger water.

Table 4. Comparison of apparent age of ground water based on analyses of samples for chlorofluorocarbon (CFC) and tritium/helium $\left({ }^{3} \mathrm{H}^{\beta} \mathrm{He}\right)$

\begin{tabular}{lccc}
\hline \multicolumn{1}{c}{ Spring name $^{\mathbf{1}}$} & $\begin{array}{c}\text { Apparent age in years } \\
\text { (CFC analysis) }\end{array}$ & $\begin{array}{c}\text { Apparent age in years } \\
\left.\mathbf{(}^{\mathbf{3}} \mathbf{H}^{\mathbf{3}} \mathbf{H e} \text { analysis }\right)\end{array}$ & $\begin{array}{c}\text { Fraction of } \\
\text { young water }\end{array}$ \\
\hline Alexander & Contaminated & 11.6 & Not applicable ${ }^{2}$ \\
Arthur Weiss & 6.7 & 3.4 & 0.94 \\
Arthur Weiss & 7.9 & 2.9 & .89 \\
Arthur Weiss & 11.6 & 8.8 & .87 \\
Bear Lithia & 23.6 & 16.2 & .70 \\
Benner & Contaminated & 6.1 & Not applicable \\
Blue Hole & 11.6 & 2.4 & .58 \\
Clouser & 6.7 & Not quantified & Not applicable \\
Clouser & Modern & Not quantified & Not applicable \\
Donegal & Modern & 1.3 & Not applicable \\
Donegal & Modern & .6 & Not applicable \\
Elkton & 33.6 & Not quantified & Not applicable \\
Gardner & 19.6 & 9.2 & .62 \\
Jefferson Davis & 35.6 & 6.4 & .10 \\
Manchester & Contaminated & 8.1 & Not applicable \\
Mount Rock & 9.7 & 10.3 & 1.0 \\
Pennrythe & Contaminated & 3.8 & Not applicable \\
Phillips & 11.6 & 8.0 & .97 \\
Retirement Center & Contaminated & Not quantified & Not applicable \\
South of Gum & Modern & Not quantified & Not applicable \\
Trout & Contaminated & 5.7 & Not applicable \\
Trout & Contaminated & 5.4 & Not applicable \\
\hline
\end{tabular}

\footnotetext{
${ }^{1}$ For more information on individual springs see Focazio and others (1998).

${ }^{2}$ Not applicable because of contamination, modern, or unquantifiable ages.

${ }^{3}$ Not quantified because of lost sample or limitation of method (see "Approaches for Ground Water Dating").
} 
Comparison of nitrate concentrations and apparent ages of spring water- $\mathrm{NO}_{3}^{-}$ concentrations generally were negligible in water with ${ }^{3} \mathrm{H}$ concentrations below about 6 TU. As the ${ }^{3} \mathrm{H}$ concentrations increased, $\mathrm{NO}_{3}^{-}$concentrations were detected at elevated levels. To the extent that low ${ }^{3} \mathrm{H}$ concentrations (6 TU and lower) are associated with old water (pre-atmospheric nuclear detonation), this observation suggests that the oldest waters discharging from the springs are not affected by anthropogenic $\mathrm{NO}_{3}^{-}$sources. In contrast, the post-atmospheric nuclear detonation and modern waters generally have elevated $\mathrm{NO}_{3}^{-}$concentra- tions. These observations are refined when apparent ages determined by CFCs are compared to $\mathrm{NO}_{3}^{-}$concentrations (fig. 23). The samples with apparent ages greater than about 30 years have little or no $\mathrm{NO}_{3}^{-}$and most samples with $\mathrm{NO}_{3}^{-}$concentrations above $2 \mathrm{mg} / \mathrm{L}$ (considered to indicate anthropogenic sources) were recharged within the past 15 years. Sufficient data were available to calculate the age and fraction of young water in six samples, and for these samples, the data indicate that $\mathrm{NO}_{3}^{-}$concentrations in ground water from the Chesapeake Bay Watershed increased following the mid-1980s (fig. 23).

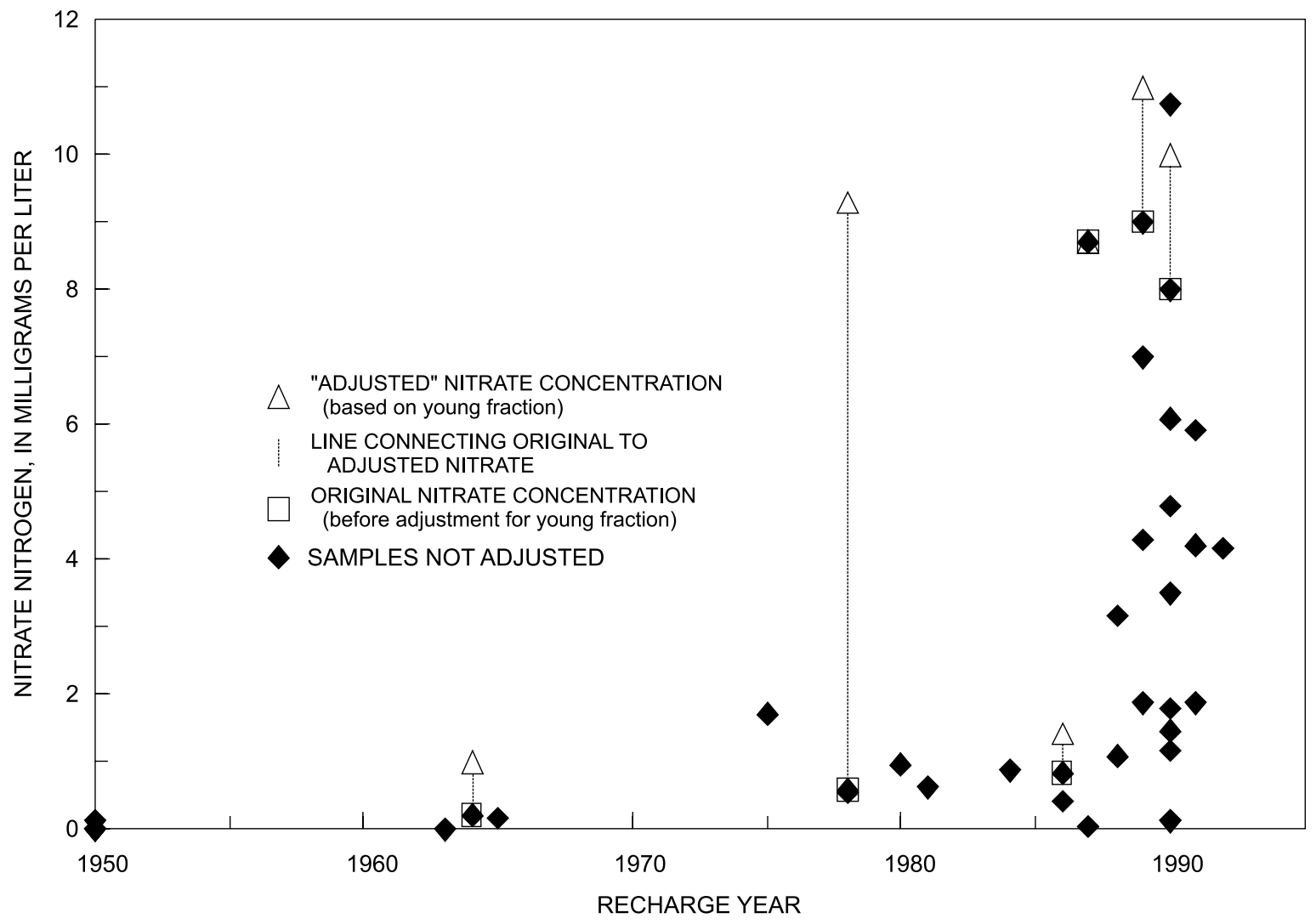

Figure 23. Nitrate concentrations in spring discharge as a function of recharge year. Recharge year is the apparent (piston flow) age determined, in most cases, from the concentration of a single CFC compound (solid diamonds). For these samples the recharge year may be biased old and the nitrate concentration of the young fraction may be underestimated. Sufficient data were available to calculate the age and fraction of young water in six samples, and for these, the open triangles and open squares show the measured nitrate and estimated nitrate concentration of the young fraction, respectively, as a function of the mean age of the young fraction. Contaminated and 'modern' samples are omitted from the analysis. 


\section{Summary}

$\mathrm{NO}_{3}^{-}$concentrations were elevated (above $2 \mathrm{mg} / \mathrm{L}$ ) in water discharged by many springs in this study and were slightly larger in samples collected during the wet year than during the dry year. Although further investigation is necessary to accurately determine the relation between $\mathrm{NO}_{3}^{-}$concentrations and hydrologic conditions, one plausible explanation for this observation is that increases in base-flow conditions are associated with increases in the contributing areas to springs, thereby including more land areas with $\mathrm{N}$ sources. In addition, the wet-year samples consist of lower proportions of older water that were shown to be associated with lower $\mathrm{NO}_{3}^{-}$concentrations. Interestingly, although the $\mathrm{N}$ mass increased slightly with greater flows, the $\delta^{15} \mathrm{~N}$ values did not, suggesting that the types and relative percentage of contributions of $\mathrm{N}$ sources (such as animal manure, inorganic fertilizer, etc.) remained approximately the same during the two extreme hydrologic events.

The estimated recharge temperatures exhibited no bias between the 2 years of sampling, indicating that the dissolved gases and other factors used in calculating recharge temperatures were not affected appreciably by the hydrologic regimes. Although values of field-measured constituents were not significantly different between the wet and dry years, the distribution of apparent ages determined by CFC analyses were biased slightly towards older ages during the dry year. This is consistent with the hypothesis that there is an increase in the proportion of longer flow paths and releases of older stored water in spring discharge during a dry year. This is particularly important for ground-water discharge areas such as springs that represent a mixture of converging short and long flow paths. Although the longer, older flow paths may have become a more significant contribution to the springs during the dry summer, the absolute difference in the apparent ages is measured in one to a few years at most. Neglecting the contaminated samples, the 25th percentile of apparent ages was 7 years, the median was 10 years, and the 75 th percentile was 13 years. These findings are collaborated by further analysis of multiple tracers from a limited number of springs (table 4) that indicated most samples were dominated by the "young" fraction (post 1940s) of water. In addition, it was shown that $\mathrm{NO}_{3}^{-}$concentrations generally decrease with ground-water age indicat- ing an increase in sources of $\mathrm{N}$ reaching the ground water during more recent times (mid-1980s) throughout the watershed.

\section{Conclusion}

This study has shown that apparent ages of mixtures of ground water discharging from springs in the Chesapeake Bay Watershed tends to be only a few years old with most less than 13 years old. Although data were sufficient in only a few samples, it was shown that the age mixtures are dominated by the young fraction. $\mathrm{NO}_{3}^{-}$concentrations generally are lower in samples with older apparent ages and increase in water recharged after the 1980s. From a water-resource management perspective with planning horizons of many years, the apparent ages of mixtures of ground-water discharging from the springs does not vary much between a wet or dry year. Although it was not possible to provide additional insights by mixing models, the apparent ages have provided representative ranges on spring discharge ages and perspective on design and interpretation of the subsequent targeted watershed studies. The individual watershed studies reported in subsequent sections of this report provide the opportunity to target specific locations within ground-water-flow fields for age-dating analyses, describe local processes, and develop more specific conclusions whereas the spring analyses are useful in providing a general overview of the ranges of apparent ages most likely to be found in the shallow ground-water discharging in the Chesapeake Bay Watershed.

\section{References Cited}

Franke, O.L., Reilly, T.E., Pollock, D.W., and LaBaugh, J.W., 1998, Estimating areas contributing recharge to wells, Lessons from previous studies: U.S. Geological Survey Circular 1174, 14 p.

Focazio, M.J., Plummer, L.N., Bohlke, J.K., Busenberg, Eurybiades, Bachman, L.J., and Powars, D.S., 1998, Preliminary estimates of residence time and apparent ages of ground water in the Chesapeake Bay Watershed, and water quality data from a survey of springs: U.S. Geological Survey Water-Resources Investigations Report 974225, $75 \mathrm{p}$.

White, W.B., 1993, Analysis of karst aquifers, in Alley W.M., ed., Regional ground water quality: New York, Van Nostrand Reinhold, p. 471-489. 


\section{UpperPocomoke River Watershed}

\section{By Scott W. Phillips}

and Colleen A. Donnelly

The Upper Pocomoke River Watershed was selected to represent the Coastal Plain Upland HGMR. This HGMR typically is underlain by sandy and finegrained deposits and is poorly drained. The watershed was selected on the basis of previous studies and some ongoing data collection. The USGS Delmarva National Water Quality Assessment (NAWQA) Project originally studied the ground-water system underlying the watershed from 1987-91 (Hamilton and others, 1993). Work in this watershed utilized the NAWQA results and collected additional data to understand the ground-water age dates and associated $\mathrm{N}$ concentrations in the Upper
Pocomoke River Watershed. Further, the Maryland Department of Natural Resources (MDDNR) is conducting a study to determine the effectiveness of nutrient-management actions in the Upper Pocomoke Watershed. The MDDNR study is measuring surfacewater nutrient loads in the watershed, and the current USGS study was designed to compliment surface-water data-collection sites of the MDDNR study.

\section{Description of Study Area and Sampling Network}

The Upper Pocomoke River Watershed is on the Delmarva Peninsula, in eastern Wicomico County, Md., western Worcester County, Md., and southern Sussex County, Del. (fig. 24). The size of the watershed above

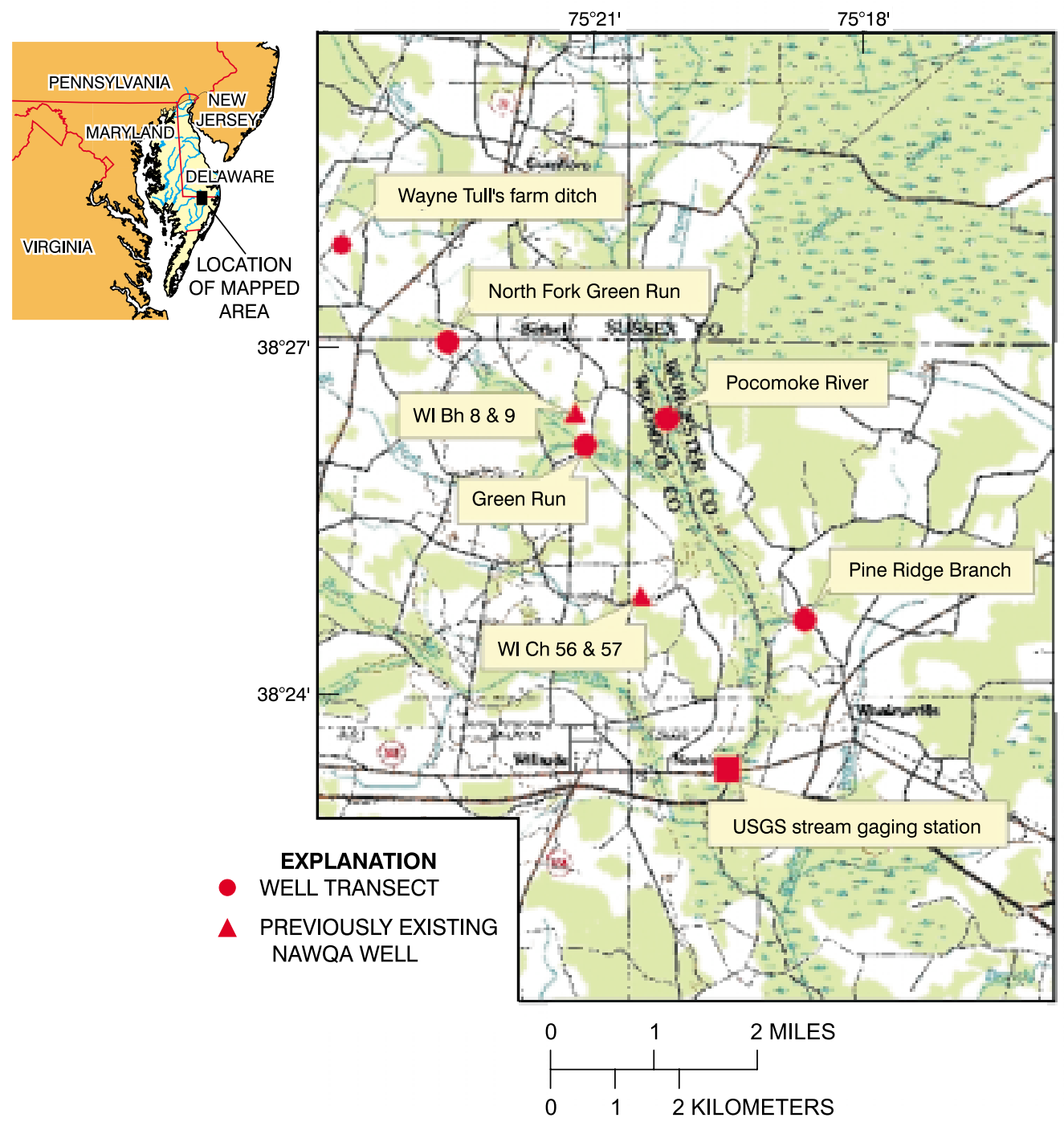

Figure 24. Upper Pocomoke River Watershed study area and sampling locations. 
the USGS streamflow-gaging station at Willards, Md., is approximately $60 \mathrm{mi}^{2}$. Within that area lies the Green Run Watershed, a 12.8- $\mathrm{mi}^{2}$ sub-watershed where the most sampling was conducted. In general, soils in the Upper Pocomoke River Watershed are poorly drained. The water table is shallow ( 0 to $10 \mathrm{ft}$ below land surface and generally less than $5 \mathrm{ft}$ during wet periods) and the streams flow sluggishly through low-gradient, hummocky terrain. Land-surface elevations throughout the study area range from approximately 25 to $75 \mathrm{ft}$ above sea level. Land use in the Upper Pocomoke River Watershed is 45 percent agricultural, including mixed cash grain, vegetable crops, and livestock. Corn, soybeans, and small grains are the predominant mixed cash crops, and poultry is the main livestock. Within the Green Run Watershed, crop area constitutes 58 percent of land use, and chicken production approaches 3.5 million birds per year (Maryland Department of Natural Resources,

\section{Hydrogeology}

Unconsolidated sediments of the Atlantic Coastal Plain Physiographic Province underlie the Delmarva Peninsula, which includes the Upper Pocomoke River Watershed. In the area underlying the study area, a series of confined aquifers and confining units are overlain by an extensive surficial aquifer that is unconfined over most of the peninsula and was termed the "surficial confined region" by Hamilton and others (1993) (fig. 25). The thickness of the surficial aquifer in the study area is approximately $100 \mathrm{ft}$ (Bachman, 1984). Precipitation in the area averages approximately 44 in/year. Focazio and others (1998) calculated an average recharge rate into the water table of $0.8 \mathrm{ft} /$ year on the Delmarva Peninsula on the basis of several previous studies.

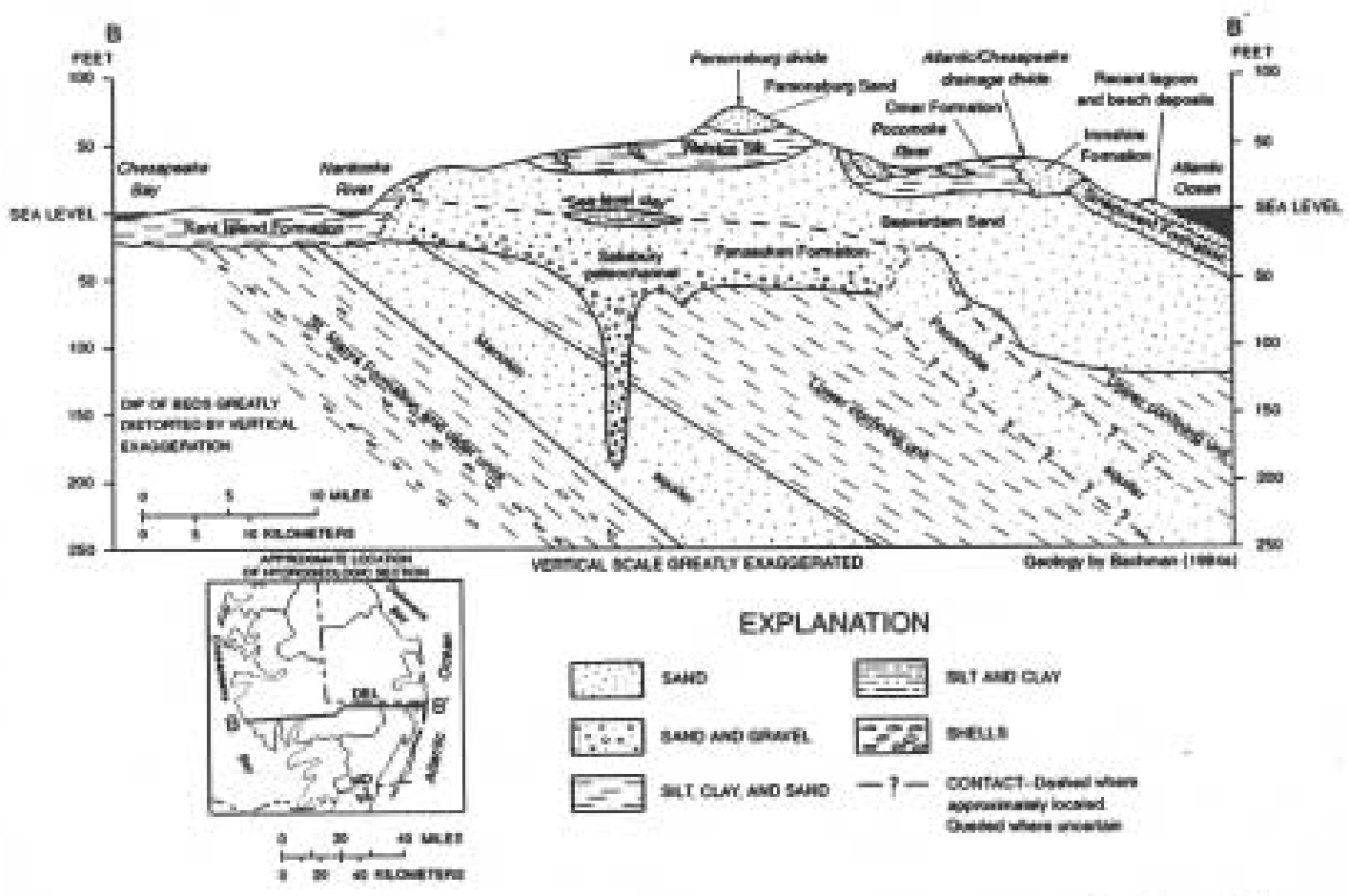

Figure 25. Unconsolidated sediments of the Atlantic Coastal Plain Physiographic Province underlying the Delmarva Peninsula (from Bachman, 1984). 


\section{Hydrogeologic framework}

The surficial aquifer underlying the study area is complex and heterogeneous (Hamilton and others, 1993). The aquifer comprises the Beaverdam Formation (sand) and the Parsonsburg Sand, separated from each other in places by discontinuous clay and silt deposits of the Walston Silt, Omar Formation, and Kent Island Formation (fig. 25). The surficial aquifer consists of the Beaverdam Sand at its base, overlain by 10 to $30 \mathrm{ft}$ of clay and silt of the Walston Silt and Omar Formation. These formations are overlain by 10 to $25 \mathrm{ft}$ of the Parsonsburg Sand (Hamilton and others, 1993). The shallow portion of this framework was further explored during the current study and found to contain generally sandy sediments interspersed with clay and silt deposits (fig. 26). Organic-rich materials, including peaty soils and organic-rich loamy sand and silt, were observed in the shallow subsurface sediments during the installation of piezometers and sampling with minipiezometers. In some locations, there was mottling in clayey sediments. The soils overlying the aquifer are characterized by a combination of poorly and very poorly drained soils that have a permeable subsoil of sandy loam or sandy clay loam and excessively drained soils that have a rapidly permeable subsoil. Most soils are naturally wet and require artificial drainage before they can be utilized for farming.

\section{Ground-water flow}

Ground-water flow in the surficial aquifer is influenced by the hydrogeologic framework and location of discharge areas (fig. 27). In the deeper part of the aquifer, ground water generally follows the regional topographic gradient and eventually discharges to the
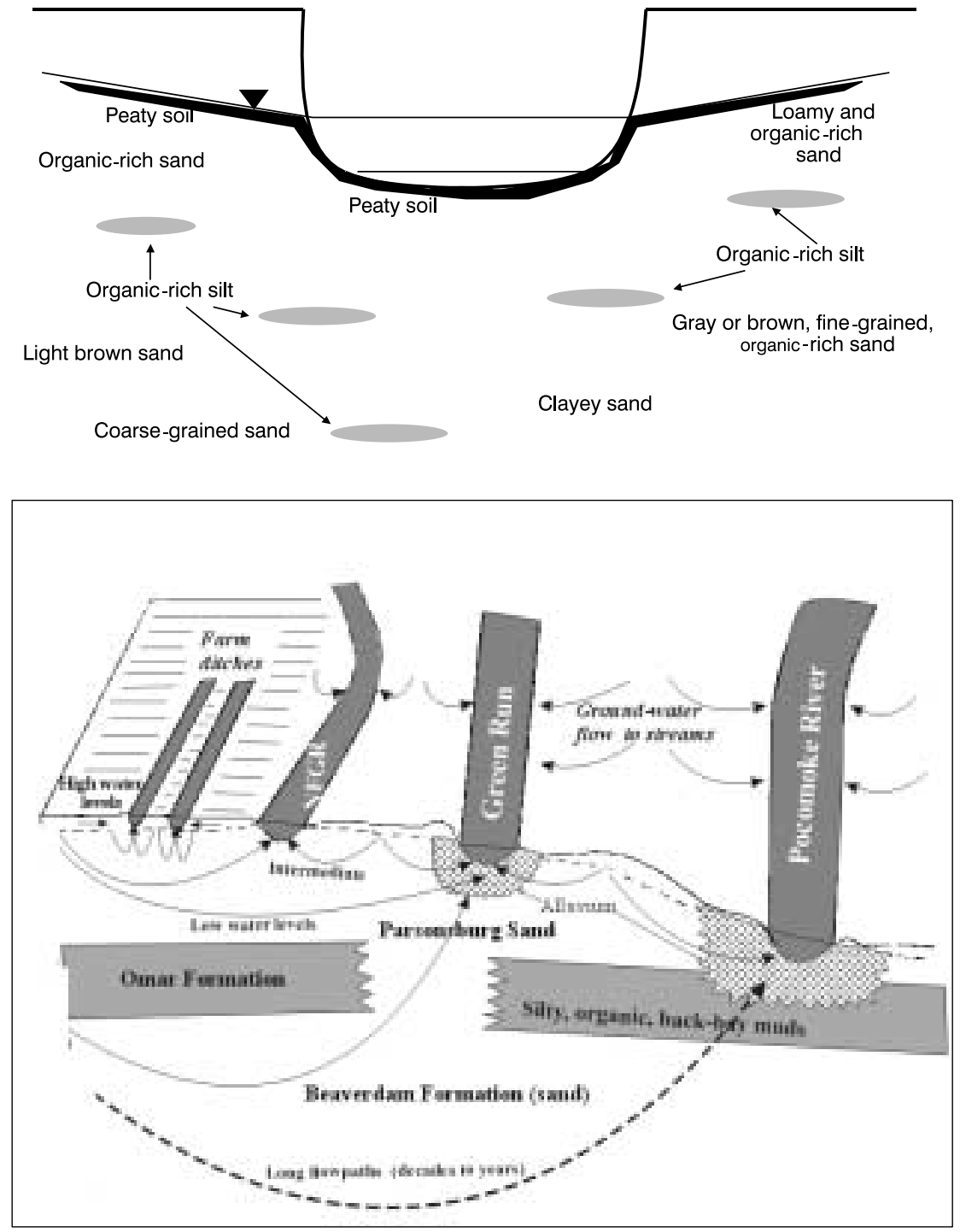

Figure 26. Generalized section showing subsurface materials present at local ground-water sampling areas, Upper Pocomoke River Watershed, Md.
Figure 27. Conceptual model of ground-water-flow paths discharging to streams in the Upper Pocomoke River Watershed. 
Pocomoke River and its tributaries, or recharges deeper, confined aquifers. An extensive network of drainage ditches influences ground-water flow in the upper part of the aquifer (Hamilton and others, 1993). The ditches are designed to lower the water table to make fields suitable for farming. In these areas, some of the ground water moves along fairly short flow paths and discharges into the drainage ditches. This situation occurs mostly during the late fall into early spring, when ground-water recharge is the highest and evapotranspiration is low. During late spring to early fall, ground-water recharge to the ditches is lower because evapotranspiration causes a decrease in the amount of water entering the aquifer. In this situation, a larger part of the ground water moves along longer paths and discharges to larger streams. The percentage of total streamflow contributed by ground water at the outlet of the Upper Pocomoke River Watershed is estimated to be about 60 percent (Bachman and others, 1998). This value is within the range (42 to 74 percent) of other Coastal Plain sites.

\section{Sample network and collection}

Sample network.-The sampling network was designed to collect samples from several types of the ground-water-flow paths underlying the Upper Pocomoke River Watershed (fig. 27) and supplement the existing NAWQA well network. To the extent possible, the ground-water sampling sites were co-located with surface-water sampling sites established by the MDDNR. Final locations of the ground-water study sites were based on reconnaissance sampling conducted

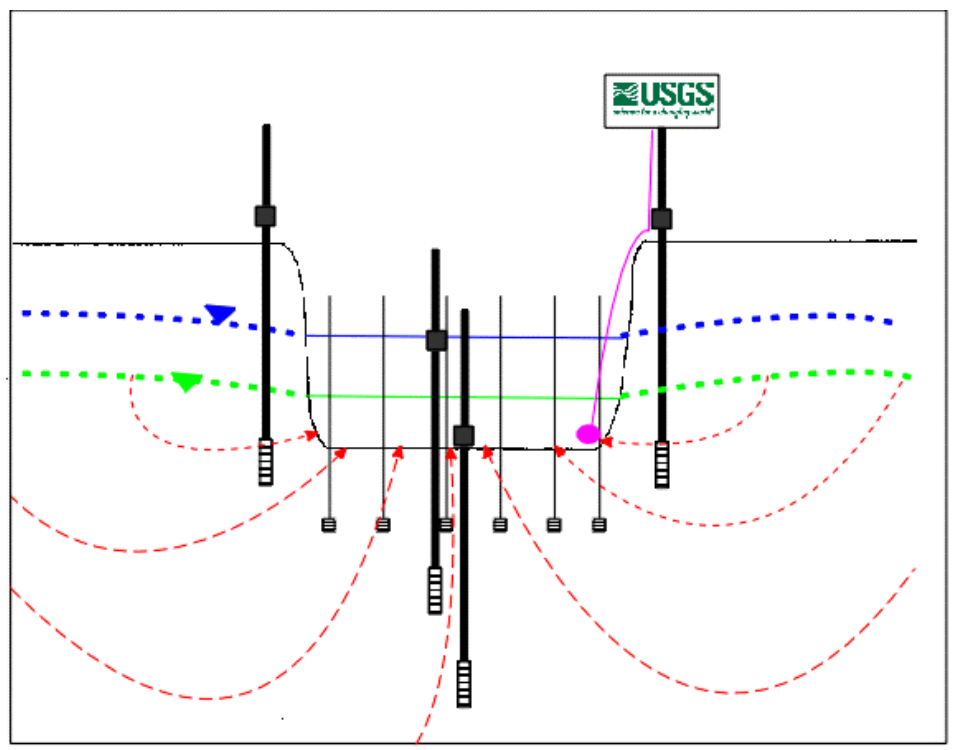

at five locations in the Upper Pocomoke River Watershed during August and September 1998.

Three sites where ground water discharged to surface water were chosen for study: (1) unnamed ditch to North Fork Creen Run near Whitesville, Del. (hereafter referred to as Wayne Tull's Farm Ditch), (2) a site at North Fork Green Run near Whitesville, Del. (hereafter referred to as North Fork Green Run), and (3) a site at Green Run near Careytown, Md. (hereafter referred to as Green Run) (fig. 24). Wayne Tull's Farm Ditch, draining an area of $0.05 \mathrm{mi}^{2}$, was chosen to represent conditions near a typical farm field where ground-water-flow paths are relatively short. The North Fork Green Run and Green Run sites, draining areas 3.66 and $12.8 \mathrm{mi}^{2}$, respectively, were chosen to represent intermediate and longer ground-water-flow paths expected as watershed drainage area increased. Additionally, existing monitoring wells (WI Bh 8, WI Bh 9, WI Ch 56, and WI Ch 57) from the NAWQA study were resampled to represent ground-water conditions deeper in the aquifer. Data on the existing wells can be found in Hamilton and others (1993).

At each site, four 2-in.-diameter stainless steel piezometers with 1-ft-long, 0.010-in.-slot screens were installed. Two were installed on opposite sides of the stream with the bottom of the screen installed approximately to the elevation of the streambed. Two were installed near the center of the stream to depths of 4 and $6 \mathrm{ft}$ below the streambed (fig. 28). Additionally, stainless steel, 0.25-in.-inside-diameter minipiezometers
Figure 28. Diagram of 2-inch-diameter piezometer installation (heavy lines) and portable minipiezometers (thin lines) in streambed locations. Dashed lines show conceptualized ground-water flow to stream. 
were used to collect samples at approximately 2 -ft intervals from below the streambed. The 2-in.-long screened end of the minipiezometer was inserted approximately 2-3 $\mathrm{ft}$ into the streambed sediments, perpendicular to streamflow, with the midpoint of each transect approximately at the midpoint of the stream. During July 1999, one piezometer at each of the three sites was instrumented with a pressure transducer and programmed to record continuous water levels at 15-minute intervals. The Study Design and Approach section of this report describes the sampling procedures in detail.

Sampling methods, timing, and hydrologic conditions.-The primary sampling period at the three sites was March 1999. Additional samples were collected in September 1999 and March 2000 to help develop an understanding of the effect of seasonal changes on ground-water ages and $\mathrm{N}$ concentrations. Reconnaissance sampling was conducted at one of the ground-water sites (North Fork Green Run) and other sites in September 1998. The ground-water samples were collected as described in the Study Design and Approach section. Samples were analyzed for field constituents, inorganic ion and nutrient concentrations, nitrogen isotopes, $\delta \mathrm{O}-18$ isotopes, ${ }^{3} \mathrm{H}$, and age-dating analyses using $\mathrm{CFCs}, \mathrm{SF}_{6}$, and ${ }^{3} \mathrm{H} /{ }^{3} \mathrm{He}$. Only a select subset of samples collected during March was submitted for further age-dating analyses using isotope ratios of ${ }^{3} \mathrm{H} /{ }^{3} \mathrm{He}$. The ${ }^{3} \mathrm{H} /{ }^{3} \mathrm{He}$ analyses were intended to provide supplementary data where the $\mathrm{CFC}$ and $\mathrm{SF}_{6}$ age-dating analyses were not conclusive. Surface-water samples were collected at each of the three field sites as described previously.

The March 1999 sampling was intended to represent typical late winter/early spring "high" water-table conditions. The difference in hydraulic head between the ground water and surface water prior to sampling was positive (ground-water head higher than surface water) at all three sites, indicating the streams were gaining flow from ground water. This positive head was highest at the outlet, Green Run. However, water-table conditions were probably lower than usual because of a relatively small amount of precipitation during fall 1998. A precipitation event approximately 1 week before sample-collection activities did cause an increase in the water table.

During September 1999, only the 2-in.-diameter stainless steel piezometers (fig. 28) were re-sampled. The hydrologic conditions were influenced by Hurricane Floyd. Mean daily ground-water levels, measured continuously in one well at each site, rose between 1.5 and $3.5 \mathrm{ft}$ following rains caused by Hurricane Floyd, which provided almost $4.5 \mathrm{in}$. of rain at nearby Salisbury, Md. (September 16 and 17, 1999; fig. 29) and up to $9 \mathrm{in}$. of rain elsewhere in the area. This was the largest rise in water levels prior to sample-collection activities observed during the study. At Green Run, only wells \#1 and \#4 were sampled during September 1999 because the streamwater was too high to enter safely. Despite the influence of the hurricane, water levels in the piezometers were low and the ground-water heads were about even with the stream stages at all three sampling sites.

The March 2000 sampling period was intended to represent high base-flow conditions usually expected during the late winter and early spring, however, the lack of rain prior to sampling caused extremely low water levels in all the wells (fig. 29). As a result of this and other problems encountered in the field, not all wells were sampled in March 2000. Of those wells that were sampled during March 2000, complete suites of samples were not collected, again because of a lack of water. On March 13 and 14, 2000, only selected 2-in.diameter piezometers were used to collect ground-water samples (fig. 28; appendixes A-D). This sampling period was probably more representative of low baseflow conditions.

\section{Distribution of Nitrogen, Dissolved Oxygen, and Methane in the Ground-Water System}

Field measurements and nutrient concentrations are listed in Appendixes A and B, respectively, for all samples collected. Methane $\left(\mathrm{CH}_{4}\right)$ data are listed in Appendix C. Nitrate $\left(\mathrm{NO}_{3}^{-}\right)$and ammonium $\left(\mathrm{NH}_{4}^{+}\right)$ were the primary $\mathrm{N}$ species detected in samples from the Upper Pocomoke River Watershed. Concentrations of dissolved oxygen were low (less than $1 \mathrm{mg} / \mathrm{L}$ ) in many samples. $\mathrm{CH}_{4}$ was detected in some samples that had very low concentrations of dissolved oxygen. The results from samples collected during March 1999 are emphasized in the following discussion. The results from the two subsequent sampling periods are presented to assess variability with the March 1999 results.

\section{Green Run}

In March 1999, the $\mathrm{NO}_{3}^{-}$in the wells and minipiezometers ranged from less than $0.050 \mathrm{mg} / \mathrm{L}$ (below laboratory detection level) to $10.3 \mathrm{mg} / \mathrm{L}$ (fig. 30). Subsequent sampling of the wells in September 1999 and March 2000 showed little variation from the March 1999 sampling results. In most samples, $\mathrm{NH}_{4}^{+}$concentrations were higher than the $\mathrm{NO}_{3}^{-}$concentration in 

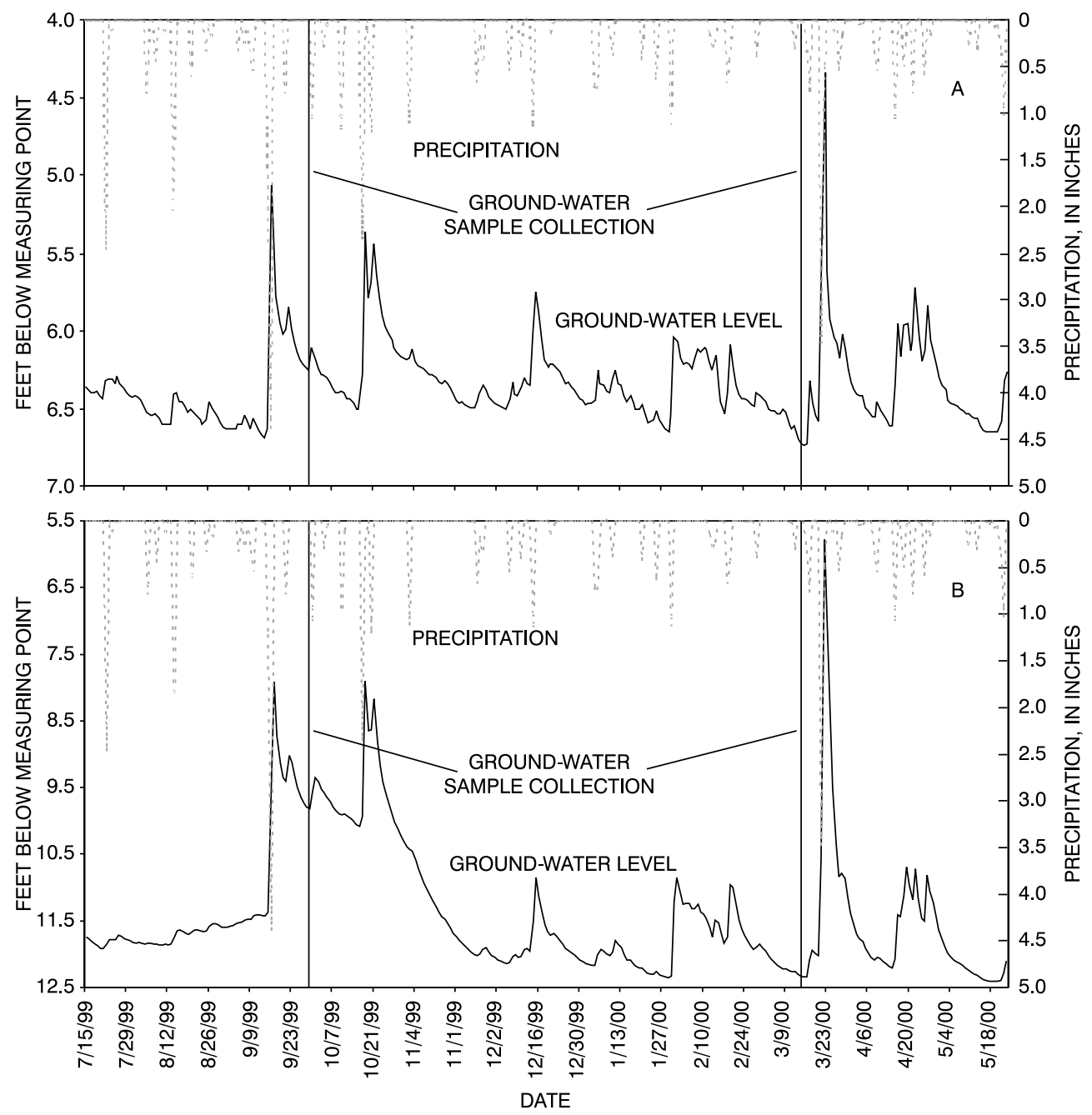

Figure 29. Daily precipitation and mean daily ground-water levels at (A) North Fork Green Run and (B) Green Run for the period July 15, 1999, through May 23, 2000. 
March 1999 (ranged from 0.040 to $1.33 \mathrm{mg} / \mathrm{L}$ and many concentrations were near $1 \mathrm{mg} / \mathrm{L}$ ) (fig. 30). Similar concentrations were observed in the two subsequent sampling periods. $\mathrm{NO}_{3}^{-}$concentrations in the surface water at this site were $4.4 \mathrm{mg} / \mathrm{L}$ in March 1999 and there was variation in the other two sampling periods (1.12 and $2.19 \mathrm{mg} / \mathrm{L}$ in September 1999 and March 2000, respectively; Appendix B).
Low concentrations of dissolved oxygen (less than $0.5 \mathrm{mg} / \mathrm{L}$ ) and the presence of $\mathrm{CH}_{4}$ indicate reducing conditions exist to promote denitrification at this site (fig. 31). Excess $\mathrm{N}_{2}$ gas ranged from 0.00 to $5.65 \mathrm{mg} / \mathrm{L}$; detectable concentrations were measured in minipiezometers 1, 2, and 7 and in well \#4, indicating the occurrence of denitrification in many of the samples collected from this site. Only well \#1 $\left(\mathrm{NO}_{3}^{-}\right.$concentration of $10.3 \mathrm{mg} / \mathrm{L}$ and a dissolved oxygen concentration of $1.1 \mathrm{mg} / \mathrm{L}$ ) probably was not affected by denitrification.
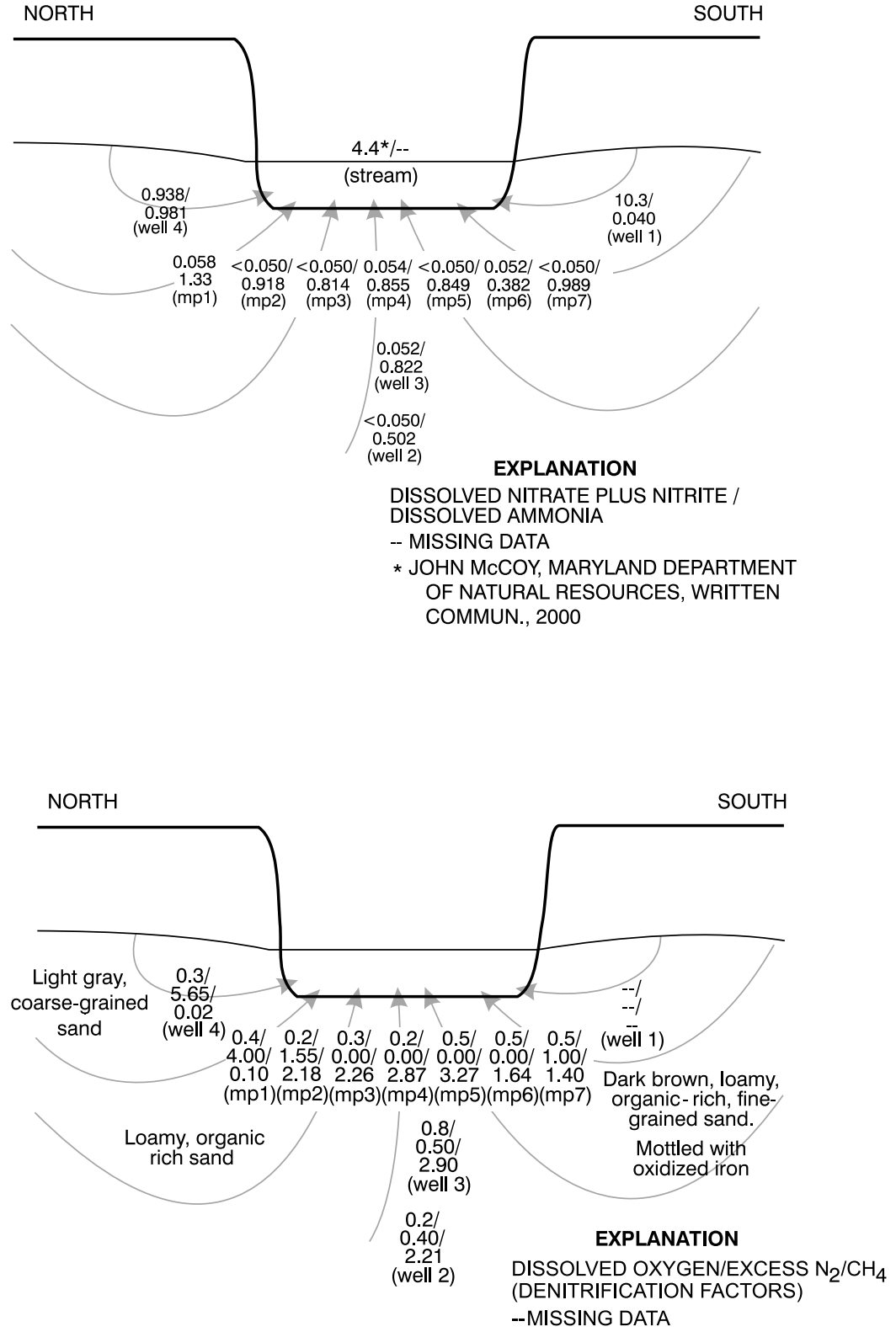

Figure 30. Distribution of dissolved nitrate and ammonia concentrations in surface and ground water at Green Run during March 1999.
Figure 31. Distribution of dissolved oxygen, excess nitrogen $\left(\mathrm{N}_{2}\right)$ gas, and methane $\left(\mathrm{CH}_{4}\right)$ concentrations in ground water at Green Run during March 1999 and general description of subsurface sediments. 


\section{North Fork Green Run}

In March 1999, $\mathrm{NO}_{3}^{-}$concentrations in all ground-water samples collected at this site were about $0.2 \mathrm{mg} / \mathrm{L}$ or less; only three samples were above the laboratory MRL (fig. 32). There was very little seasonal variation of $\mathrm{NO}_{3}^{-}$concentrations in the subsequent sampling periods (Appendix B). $\mathrm{NH}_{4}^{+}$was the primary $\mathrm{N}$ species; concentrations ranged from 0.138 to $2.47 \mathrm{mg} / \mathrm{L}$. Stream concentrations of $\mathrm{NO}_{3}^{-}$were $5.23 \mathrm{mg} / \mathrm{L}$ and
$0.055 \mathrm{mg} / \mathrm{L}$ of $\mathrm{NH}_{4}^{+}$in March 1999. $\mathrm{NO}_{3}^{-}$concentrations in the stream varied during subsequent sampling periods; $\mathrm{NH}_{4}^{+}$concentrations did not vary.

Low concentrations of dissolved oxygen (less than or equal to $0.8 \mathrm{mg} / \mathrm{L}$ ) and the presence of $\mathrm{CH}_{4}$ in all samples indicate reducing conditions exist to promote denitrification at this site (fig. 33). Concentrations of excess $\mathrm{N}_{2}$ gas were detected in all but one sample, indicating denitrification was occurring at this site.

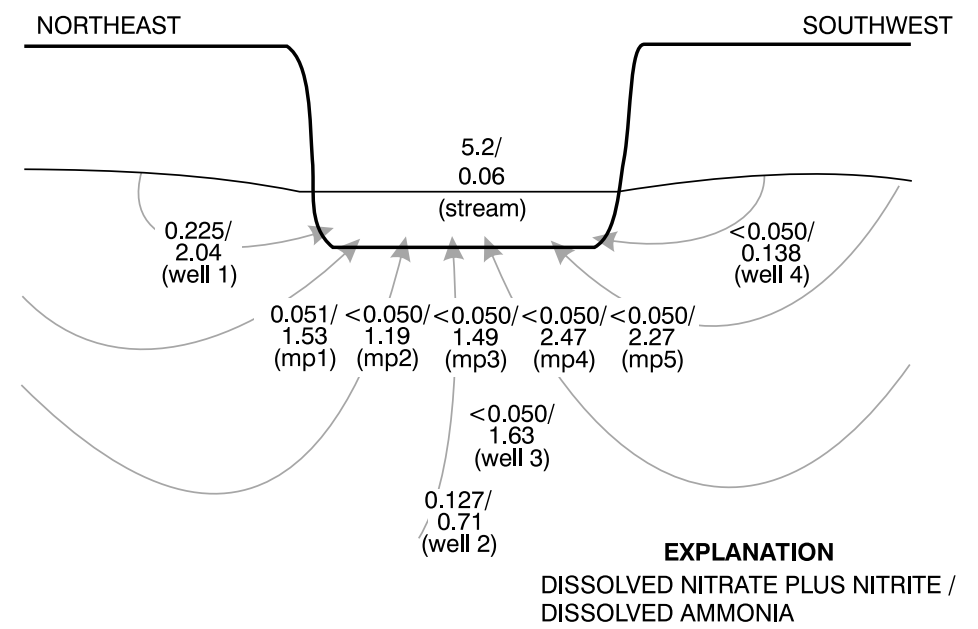

DISSOLVED AMMONIA

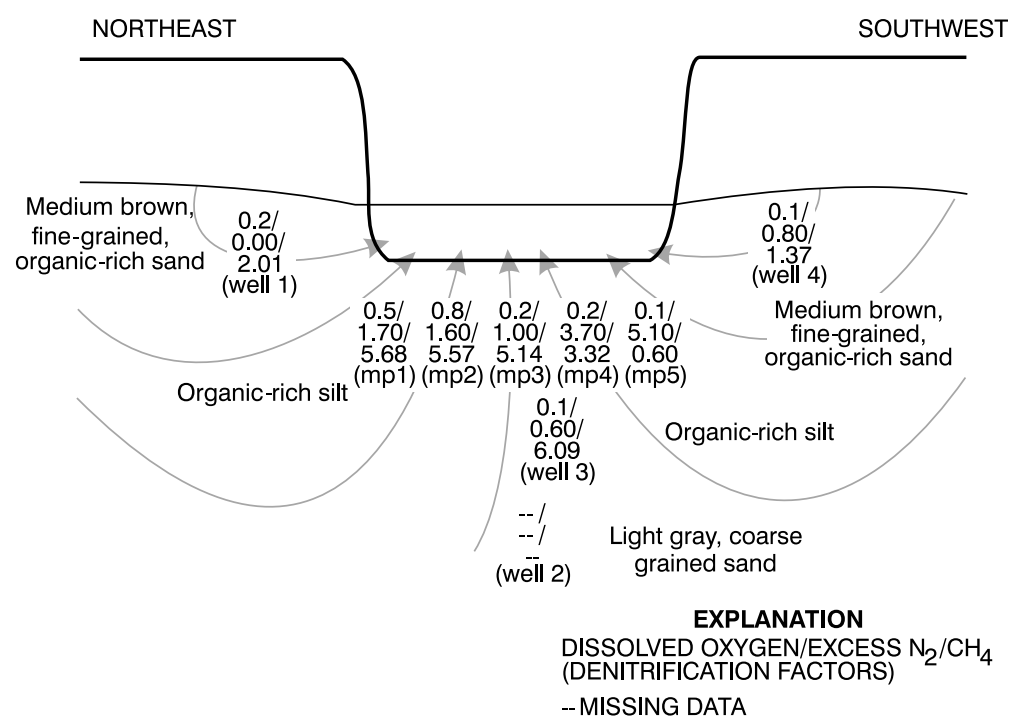

Figure 32. Distribution of dissolved nitrate and ammonia concentrations in surface and ground water at North Fork Green Run during March 1999.
Figure 33. Distribution of dissolved oxygen, excess nitrogen $\left(\mathrm{N}_{2}\right)$ gas, and methane $\left(\mathrm{CH}_{4}\right)$ concentrations in ground water at North Fork Green Run during March 1999 and general description of subsurface sediments. 


\section{Wayne Tull's Farm Ditch}

Very large $\mathrm{NO}_{3}^{-}$concentrations of 15.6 and $68.4 \mathrm{mg} / \mathrm{L}$ were measured in samples from wells \#1 and \#2, respectively, at this site during March 1999 (fig. 34). Samples from these wells also exhibited a strong variation with $\mathrm{NO}_{3}^{-}$concentration dropping to 0.942 and $7.79 \mathrm{mg} / \mathrm{L}$ in wells \#1 and \#2, respectively, in September 1999 and back to higher levels the following March. The deeper wells and minipiezometers had much lower concentrations of $\mathrm{NO}_{3}^{-}$and showed little variation over the sampling periods. Concentrations in surface water were $14.2 \mathrm{mg} / \mathrm{L}$ in March 1999 and also showed a strong seasonal variation. Concentrations of $\mathrm{NH}_{4}^{+}$were very low in all samples, ranging from 0.02 to $0.19 \mathrm{mg} / \mathrm{L}$ in ground water and $0.02 \mathrm{mg} / \mathrm{L}$ in the stream.

Denitrification appears to be occurring in much of the aquifer under the streambed but not in the shallow part of the aquifer near the water table. Concentrations of dissolved oxygen were always greater than $2 \mathrm{mg} / \mathrm{L}$ in the wells with nitrogen concentrations over $1 \mathrm{mg} / \mathrm{L}$ indicating conditions for denitrification did not exist. However, low concentrations of dissolved oxygen (less than $0.5 \mathrm{mg} / \mathrm{L}$ ) and the presence of excess $\mathrm{N}_{2}$ gas concentrations (wells \#3 and \#4; fig. 35) indicates denitrification was responsible for low $\mathrm{NO}_{3}^{-}$concentrations in some of the sample points under the stream.

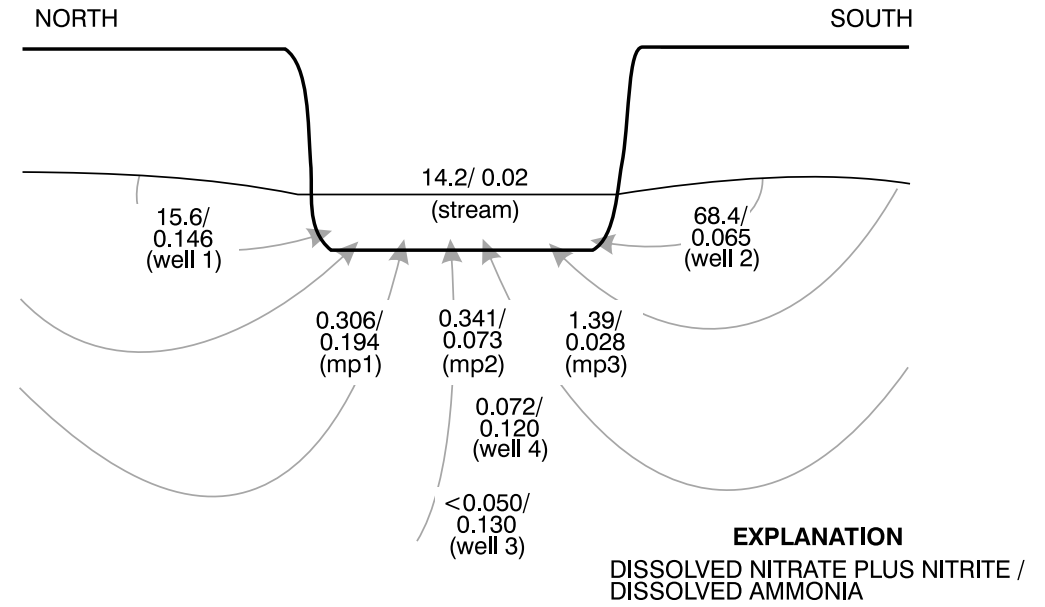

NORTH

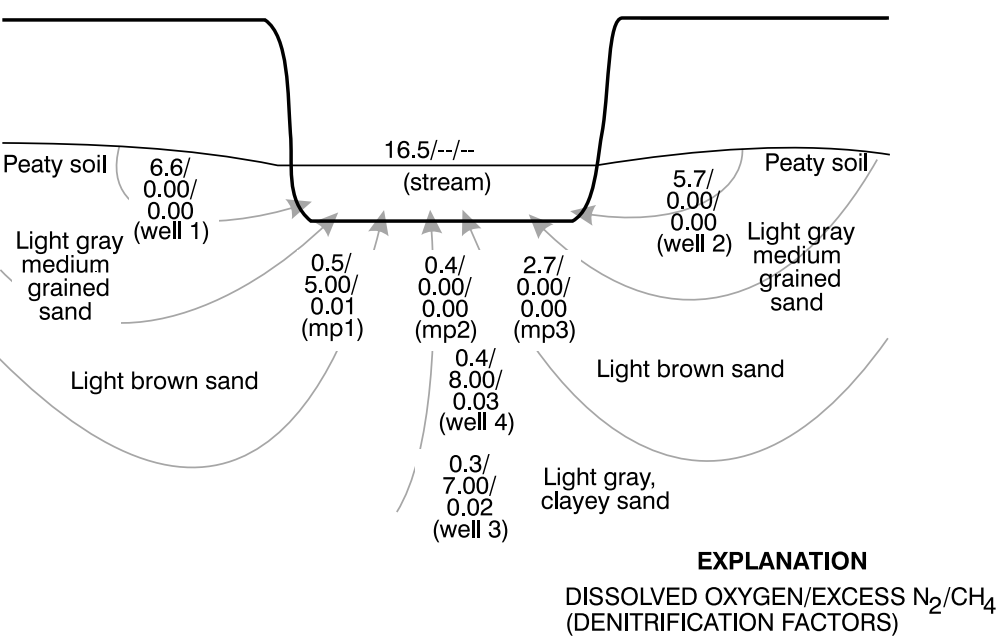

Figure 34. Distribution of dissolved nitrate and ammonia concentrations in surface and ground water at Wayne Tull's Farm Ditch during March 1999.
Figure 35. Distribution of dissolved oxygen, excess nitrogen $\left(\mathrm{N}_{2}\right)$ gas, and methane $\left(\mathrm{CH}_{4}\right)$ concentrations in surface and ground water at Wayne Tull's Farm Ditch during March 1999 and general descriptions of subsurface sediments. 


\section{Deeperwells}

Samples from wells WI Bh 8 and WI Bh 9, which are near the Green Run sampling site, had low concentrations of $\mathrm{NO}_{3}^{-}$(less than $0.06 \mathrm{mg} / \mathrm{L}$ ) for samples collected in March 1999 (Appendix B). In the more shallow of the two wells, WI Bh 8 (11 ft deep), the concentration of $\mathrm{NH}_{4}^{+}(3.49 \mathrm{mg} / \mathrm{L})$ was much greater than the concentration detected in the deeper well (0.15 mg/L).

Low concentrations of dissolved oxygen (about $1.0 \mathrm{mg} / \mathrm{L}$ or less) and the presence of $\mathrm{CH}_{4}$ in all samples indicate reducing conditions exist to promote denitrification in these wells. However, concentrations of excess $\mathrm{N}_{2}$ gas were not detected, suggesting reducing conditions exist, but there was no $\mathrm{NO}_{3}^{-}$in the deeper part of the aquifer to be denitrified.

In contrast to the wells near the Green Run site, two other wells sampled during September 1998 did have elevated $\mathrm{NO}_{3}^{-}$concentrations. Samples collected from wells WI Ch 56 and WI Ch 57 (15 and $47 \mathrm{ft}$ deep, respectively) (fig. 24) had between 3 to $4 \mathrm{mg} / \mathrm{L} \mathrm{NO}_{3}^{-}$ (Appendix B). Samples from both wells had low concentrations of dissolved oxygen and no $\mathrm{CH}_{4}$ (Appendixes $\mathrm{A}$ and $\mathrm{C}$ ). The deeper well had much more $\mathrm{N}_{2}$ gas (13.3 $\mathrm{mg} / \mathrm{L}$ compared to $0.90 \mathrm{mg} / \mathrm{L}$ in the shallow well), indicating the samples from the deeper well had undergone more denitrification than the shallow well.

\section{Distribution of Apparent Ages in the Ground-Water System}

Sulfur hexafluoride $\left(\mathrm{SF}_{6}\right)$ was the primary tracer used to assign apparent ages to ground-water samples. CFCs could not be used to determine apparent ages because reducing conditions in the aquifer were degrading CFCs. A piston-flow model was used to estimate the apparent age of the water for most samples, which precluded the determination of mixing ratios in each sample (see section on "Approaches for Ground-Water Dating”). However, some samples also were analyzed for ${ }^{3} \mathrm{H}$, and determinations of mixing ratios were attempted for these samples. The analysis of which tracers were valid in the study areas is presented in the following section, "Methods used to determine apparent ages of ground water.” The results of the March 1999 sampling period with comparisons to results for the two subsequent sampling periods (September 1999 and March 2000) are presented in the subsequent section.

\section{Methods used to determine apparentages of ground water}

Dating of the Pocomoke waters was based on $\mathrm{CFCs}, \mathrm{SF}_{6},{ }^{3} \mathrm{H}$, and ${ }^{3} \mathrm{H} /{ }^{3} \mathrm{He}$ methods; however, each tracer may have been affected by one or more processes that potentially limited its application. Nearly all of the ${ }^{3} \mathrm{H} /{ }^{3} \mathrm{He}$ samples appear to be "fractionated." Fractionated samples are samples that have been partially degassed and are recognized by He excesses relative to solubility equilibrium $(\Delta \mathrm{He}$, in $\%)$ that are smaller than the $\mathrm{Ne}$ excess relative to solubility equilibrium $(\Delta \mathrm{Ne}$, in $\%$ ), i.e., $\Delta \mathrm{He}<\Delta \mathrm{Ne}$. Sample collection using a peristaltic pump may have caused partial degassing of water samples resulting in micro-bubble formation and partial gas stripping. Also, some samples have elevated concentrations of dissolved $\mathrm{CH}_{4}$, and, if occurring near the water table, may have been partially stripped by bubbles of $\mathrm{CH}_{4}$ gas. Fractionated samples will have lost tritiogenic ${ }^{3} \mathrm{He}$ (helium-3 produced from the radioactive decay of ${ }^{3} \mathrm{H}$ ), and consequently, have calculated ${ }^{3} \mathrm{H} /{ }^{3} \mathrm{He}$ ages that are too young. Degassing will also lower concentrations of $\mathrm{SF}_{6}$ and $\mathrm{CFCs}$ in water samples resulting in $\mathrm{CFC}$ and $\mathrm{SF}_{6}$ based ages that are biased old in gasstripped samples. Potentially valid ${ }^{3} \mathrm{H} /{ }^{3} \mathrm{He}$ samples will have values of $\Delta \mathrm{He}>\Delta \mathrm{Ne}$. Only one ${ }^{3} \mathrm{H} /{ }^{3} \mathrm{He}$ sample had a value of $\Delta \mathrm{He}>\Delta \mathrm{Ne}$ (Green Run, Well \#2, sampled on March 30, 1999). After correction for the presence of terrigenic He, this particular sample had ${ }^{3} \mathrm{H} /{ }^{3} \mathrm{He}$ age of 23.4 years, which compared favorably to the piston flow $\mathrm{SF}_{6}$ based age of 20.7 years. All the rest of the $\mathrm{SF}_{6}-{ }^{3} \mathrm{H} /{ }^{3} \mathrm{He}$ co-dated samples indicate ${ }^{3} \mathrm{H} /{ }^{3} \mathrm{He}$ ages that are significantly younger than those piston-flow ages based on $\mathrm{SF}_{6}$. Two processes could cause $\mathrm{SF}_{6}$ ages to appear older than the ${ }^{3} \mathrm{H} /{ }^{3} \mathrm{He}$ age: (1) gas stripping that would remove some of the $\mathrm{SF}_{6}$, and (2) mixing of young and old water, which would dilute the $\mathrm{SF}_{6}$ in the young fraction. Although samples with piston flow $\mathrm{SF}_{6}$ apparent ages greater than the ${ }^{3} \mathrm{H} /{ }^{3} \mathrm{He}$ age could indicate degassing or mixing of young and old (pre-SF ${ }_{6}$ ) waters, many of the calculated values of the ${ }^{3} \mathrm{H} /{ }^{3} \mathrm{He}$ ages are actually negative numbers, indicating problems with the ${ }^{3} \mathrm{H} /{ }^{3} \mathrm{He}$ data. Addition of terrigenic $\mathrm{SF}_{6}$ from lithic sources would result in a young bias in the $\mathrm{SF}_{6}$ apparent ages, which would minimize the differences between the ${ }^{3} \mathrm{H} /{ }^{3} \mathrm{He}$ and $\mathrm{SF}_{6}$ ages. Terrigenic sources of $\mathrm{SF}_{6}$ probably are small in the Delmarva samples (Busenberg and Plummer, 2000) but could possibly account for the small difference in $\mathrm{SF}_{6}$ and ${ }^{3} \mathrm{H} /{ }^{3} \mathrm{He}$ age for the one sample apparently correctly dated by the ${ }^{3} \mathrm{H} /{ }^{3} \mathrm{He}$ method (Green Run, Well \#2, sampled on March 30, 1999). 
Samples from Green Run, North Fork Green Run, wells WI Bh 8 and Wi Bh 9, and those along the Pocomoke River all contained dissolved $\mathrm{CH}_{4}$, of as much as $6 \mathrm{mg} / \mathrm{L}$, indicating methanogenic conditions and environments that can like result in microbial degradation of all three CFCs (CFC-11, CFC-12, and CFC-113). In contrast, all of the samples from Wayne
Tull's Farm Ditch site were aerobic and nearly free of dissolved $\mathrm{CH}_{4}$, limiting the potential for degradation of CFC-12 and CFC-113. SF 6 is not known to degrade under methanogenic conditions (Busenberg and Plummer, 2000). CFC and ${ }^{3} \mathrm{H}$ concentrations in the water samples from Green Run, North Fork Green Run, and the Wayne Tull's Farm Ditch site are shown in figure 36.
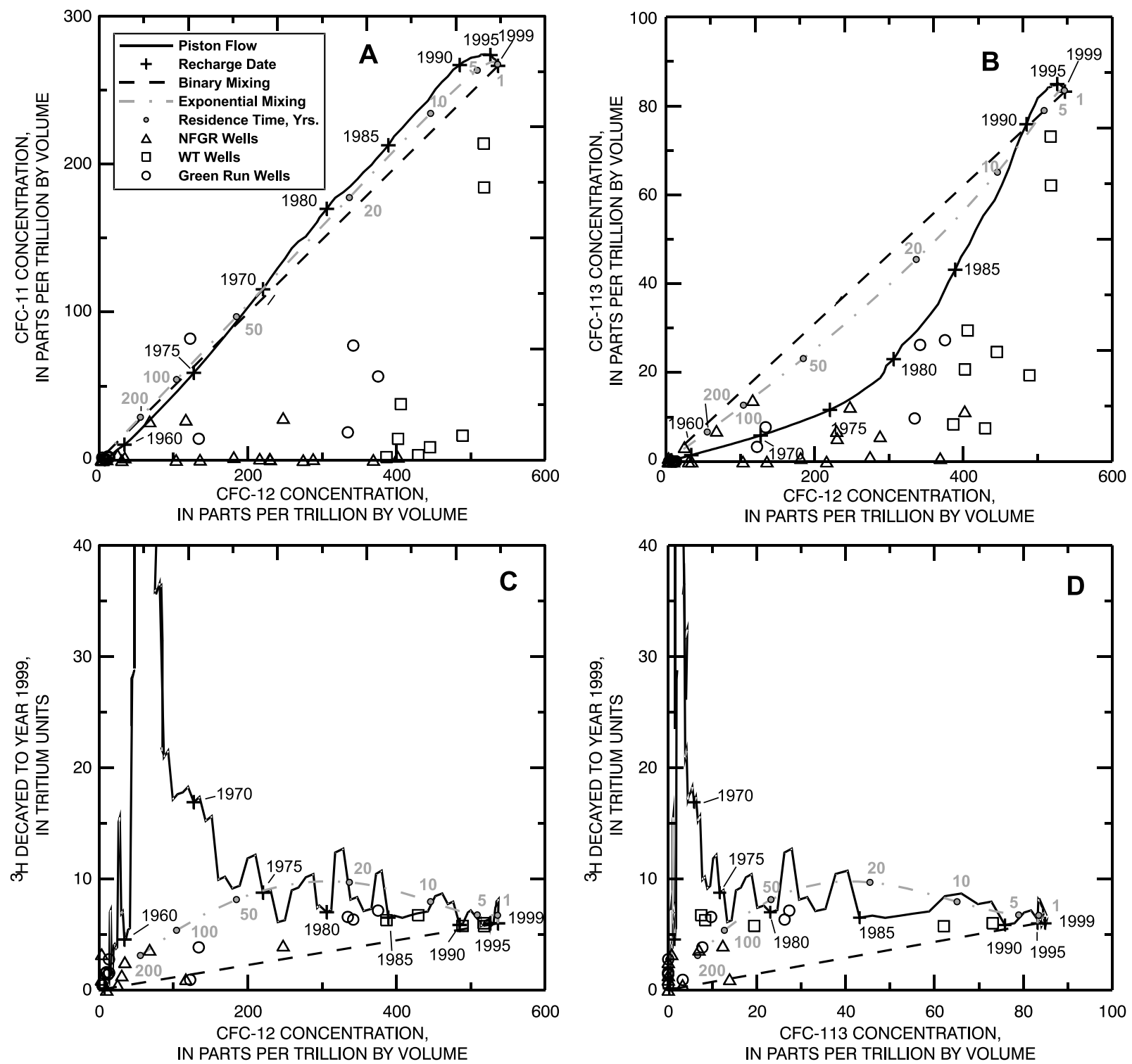

Figure 36. Comparison of the concentrations of (A) CFC-11 and CFC-12, (B) CFC-113 and CFC-12, (C) ${ }^{3} \mathrm{H}$ and CFC-12, and (D) ${ }^{3} \mathrm{H}$ and CFC-113 in water samples from North Fork Green Run (NFGR wells), Wayne Tull's Farm Ditch site (WT wells), and Green Run (Green Run Wells). A local tritium input function was constructed by scaling the tritium in precipitation data for Washington D.C. by the factor 0.66 . 
CFC-11 appears to be degraded relative to CFC-12 in all samples (fig. 36A), even in most of the aerobic samples from the Wayne Tull's Farm Ditch site. Similarly, CFC-113 is depleted relative to CFC-12 in most samples, including aerobic samples from the Wayne Tull's Farm Ditch site (fig. 36B). CFC-113 can be strongly adsorbed onto organic matter (Plummer and Busenberg, 1999). It is possible that CFC-113 is degraded in the methanogenic samples and depleted by sorption onto organic matter, where present. Samples from the Wayne Tull's Farm Ditch site and several of the samples from Green Run plot near the piston flow line as a function of ${ }^{3} \mathrm{H}$ and CFC-12 (fig. 36C). These samples probably are not affected by microbial degradation of CFC-12 and appear to be unmixed waters. In the rest of the samples (fig. 36C), CFC-12 probably has been lowered relative to ${ }^{3} \mathrm{H}$ by microbial degradation under methanogenic conditions. As CFC-113 was depleted relative to CFC-12 (fig. 36B), it also is depleted relative to ${ }^{3} \mathrm{H}$ (fig. 36D), possibly as a result of sorption of CFC-113 onto organic matter. On the basis of the results of figure 36 , it is likely that ${ }^{3} \mathrm{H}$ data are valid in all the Pocomoke samples and the CFC-12 data may be used for dating the samples from the Wayne Tull's Farm Ditch site.

The relations between $\mathrm{SF}_{6}$ data and $\mathrm{CFC}$ and ${ }^{3} \mathrm{H}$ data in the Pocomoke samples are shown in figure 37. Most samples have $\mathrm{SF}_{6}$ concentrations within the possible range of dating indicating apparent ages from the early 1970s to modern (1999), but are mostly depleted in CFC-11 (fig. 37A), suggesting degradation of CFC-11. Except for one sample from the Wayne Tull's Farm Ditch site, which plots along the piston-flow line in CFC-113 and $\mathrm{SF}_{6}$ (fig. 37C), all of the Pocomoke samples are depleted in $\mathrm{CFC}-113$ relative to $\mathrm{SF}_{6}$. In contrast, most samples from the Wayne Tull's Farm Ditch site plot near or in the region bounded by piston flow and binary mixing as a function of $\mathrm{CFC}-12$ and $\mathrm{SF}_{6}$, suggesting both tracers may be valid for dating samples from this site. Most methanogenic samples from the North Fork Green Run and Green Run areas, however, appear to be degraded in CFC-12 (fig. 37B). Again, it can be suggested that $\mathrm{CFC}-113$ is depleted in most Pocomoke samples by sorption onto organic matter.

It is likely that both ${ }^{3} \mathrm{H}$ and $\mathrm{SF}_{6}$ are stable tracers in Pocomoke samples. Although the ${ }^{3} \mathrm{H}$ input function is too variable for dating post-1970 water, the relation between ${ }^{3} \mathrm{H}$ and $\mathrm{SF}_{6}$ suggests that the Pocomoke samples are in two groups. In the first group, the samples from the Wayne Tull's Farm Ditch site and four samples from Green Run have ${ }^{3} \mathrm{H}$ and $\mathrm{SF}_{6}$ concentrations consistent with piston flow. The second group plots near the simple binary-mixing line for mixing of modern water (1999) and old, pre- $\mathrm{SF}_{6}$ and pre- ${ }^{3} \mathrm{H}$ water. The apparent mixtures are from Green Run and North Fork Green Run; most piston-flow samples are from Green Run and the Wayne Tull's Farm Ditch site. Unfortunately, ${ }^{3} \mathrm{H}$ and $\mathrm{SF}_{6}$ data were not collected at all sites, and in many cases, only ${ }^{3} \mathrm{H}$ or only $\mathrm{SF}_{6}$ data are available (see appendixes $\mathrm{C}$ and $\mathrm{D}$ ). The cluster of samples with $\mathrm{SF}_{6}$ concentrations in the range of 0.5 to $1.5 \mathrm{pptv}$, if actually mixtures of modern (1999) water and old, pre- $\mathrm{SF}_{6}$ and pre- ${ }^{3} \mathrm{H}$ water, contain about 30 percent of 1999 water and the two samples from North Fork Green Run plotting along the binary-mixing line (fig. 37D) contain about 65 percent of modern water.

Because the ${ }^{3} \mathrm{H}$ and $\mathrm{SF}_{6}$ data are not complete for all samples, all apparent ages discussed here are based on piston flow. Consequently, for samples that are simple binary mixtures, the apparent age is overestimated and the initial $\mathrm{NO}_{3}^{-}$concentration is underestimated. For example, the samples that seem to contain only 30 percent of 1999 water plotting along the mixing line (fig. 37D) have apparent (piston flow) ages of 1983, but if mixtures, the young fraction (recharge date of approximately 1999) will have an initial $\mathrm{NO}_{3}^{-}$concentration approximately 3 -fold larger than reported here. Because of insufficient data, these differences cannot be resolved for most samples. The result will, however, shift some points with (piston flow) apparent ages in the range of 0 -20 years to younger ages with higher initial concentrations of dissolved $\mathrm{NO}_{3}^{-}$.

\section{Apparent Ages of Ground Water}

\section{Green Run}

At the Green Run site, apparent recharge dates for ground water were between 1977 and 1995; the majority of samples have ages between 1977 to 1985 (fig. 38). However, some samples with dates of 1985 and older may be mixtures of younger water (late 1990s) and older water (pre-1970s) (fig. 37D). While samples that plot along the piston-flow line probably are not mixtures, samples that plot along the binary-mixing may be mixtures. Some Green Run samples may be 30 percent "young" water (late 1990s) and 70 percent "old" (pre-1970s) water. The possibility of discharge of older ground water to the stream would be feasible on the basis of the aquifer framework and older water moving in the deeper part of the aquifer and discharging to larger streams (conceptual model shown in figure 27). Samples collected (from Well \#4 only) during the two later periods showed little variation in apparent age. 

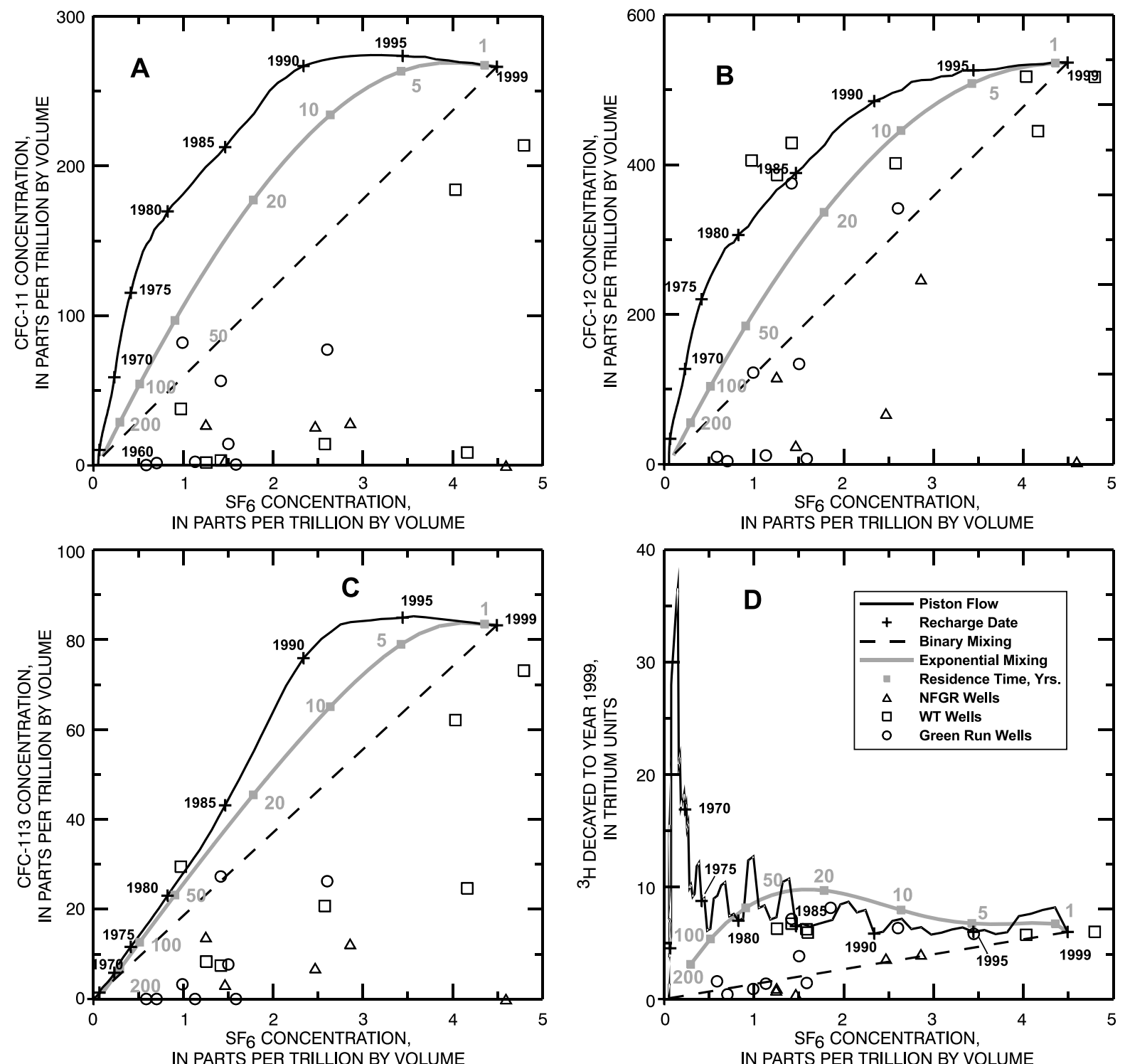

Figure 37. Comparison of the concentrations of $(\mathrm{A}) \mathrm{CFC}^{-11}$ and $\mathrm{SF}_{6}$, (B) CFC-12 and $\mathrm{SF}_{6}$, (C) CFC-113 and $\mathrm{SF}_{6}$, and $(D){ }^{3} \mathrm{H}$ and $\mathrm{SF}_{6}$ in water samples from North Fork Green Run (NFGR wells), Wayne Tull's Farm Ditch site (WT wells), and Green Run (Green Run wells). A local tritium input function was constructed by scaling the tritium in precipitation data for Washington, D.C., by the factor 0.66 . 


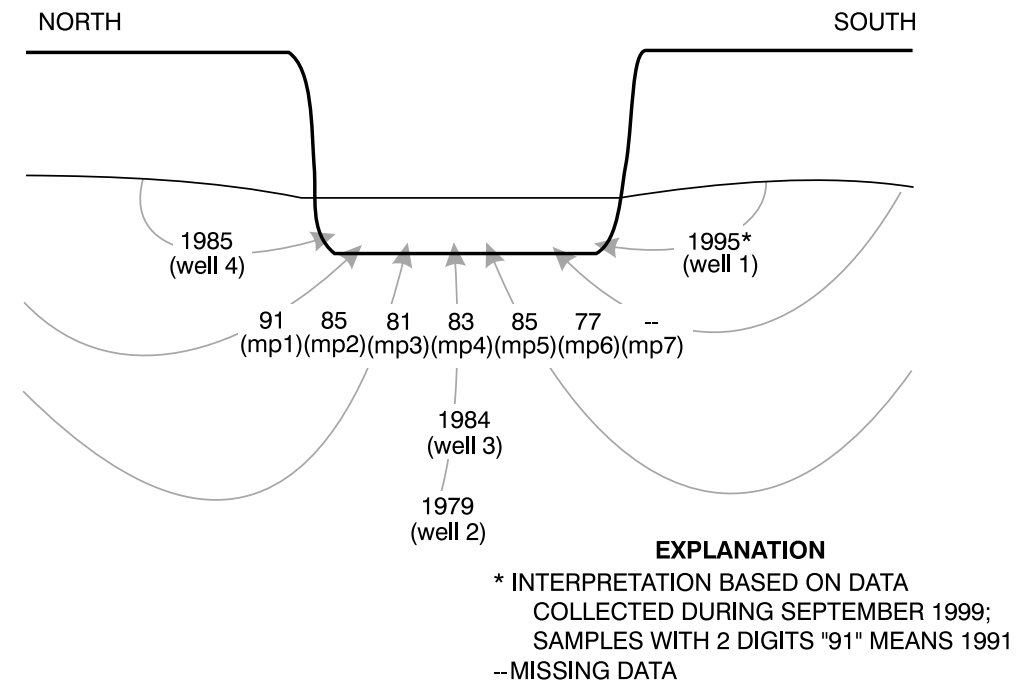

Figure 38. Date of recharge of ground water discharging to Green Run during March 1999.

\section{North Fork Green Run}

Apparent ages could not be determined for all samples collected at North Fork Green Run (fig. 39). Apparent ages of ground-water recharge ranged from 1984 to 1999 on the basis of using the piston-flow model. However, some of these samples may be a mixtures of "young" (late 1990s) and "old" (pre 1970s) water; two of the samples have about equal mixtures of "young" and "old" water, and the other two samples have a higher amount of "old" water (fig. 37D). Only one well had samples collected during later time periods and showed very little variation in apparent age (Appen$\operatorname{dix} C)$.

\section{Wayne Tull's Farm Ditch}

At the Wayne Tull's Farm Ditch, apparent ages were between 1981 and 2000 (fig. 40) with no mixing of "old" (pre-1960s) water (fig. 37D). A distribution of the ages was evident with water having apparent recharge dates of 1980s discharging into the center of the ditch, whereas younger water discharged further toward the banks of the streams. Subsequent sampling during September 1999 showed dates similar to those collected in March 1999.

Samples collected during March 1999 for deeper monitoring wells WI Bh 8 and WI Bh 9 give apparent recharge dates of 1957 and 1941, respectively. Dunkle and others (1993) used CFC-12 to interpret apparent recharge dates of 1958 and 1940, respectively, for these same wells working in conjunction with the NAWQA study. Recharge dates for wells WI Ch 56 and WI Ch 57 were 1993 and 1988, respectively.

On the basis of all the data, the apparent age of ground water in the surficial aquifer ranged from 60 years to almost modern. The oldest ages were from two wells screened deeper (10 and $40 \mathrm{ft}$ below land surface) in the aquifer. The range of apparent ages in the vicinity of the streams ranged from 23 years to modern; some samples from North Fork and Green Run also have a component of older (pre-1960s) water. In general, the range of ages were youngest at the Wayne Tull's Farm Ditch site, older at North Fork Green Run, and oldest at Green Run at Bethel Road. Having a range of ages at each site infers that both shorter and longer ground-water-flow paths are discharging into the streams. In general, ground water discharging to the first order streams (such as Wayne Tull's Farm Ditch) will have shorter flow paths and younger water. As the drainage area to a stream becomes larger, the ground water discharging to the stream has a greater percentage of older apparent ages because of longer ground-waterflow paths. The two larger basins in the study area exhibited this pattern. The apparent age along the flow path also will be affected by the hydrologic framework and associated hydraulic conductivity of the aquifer. 

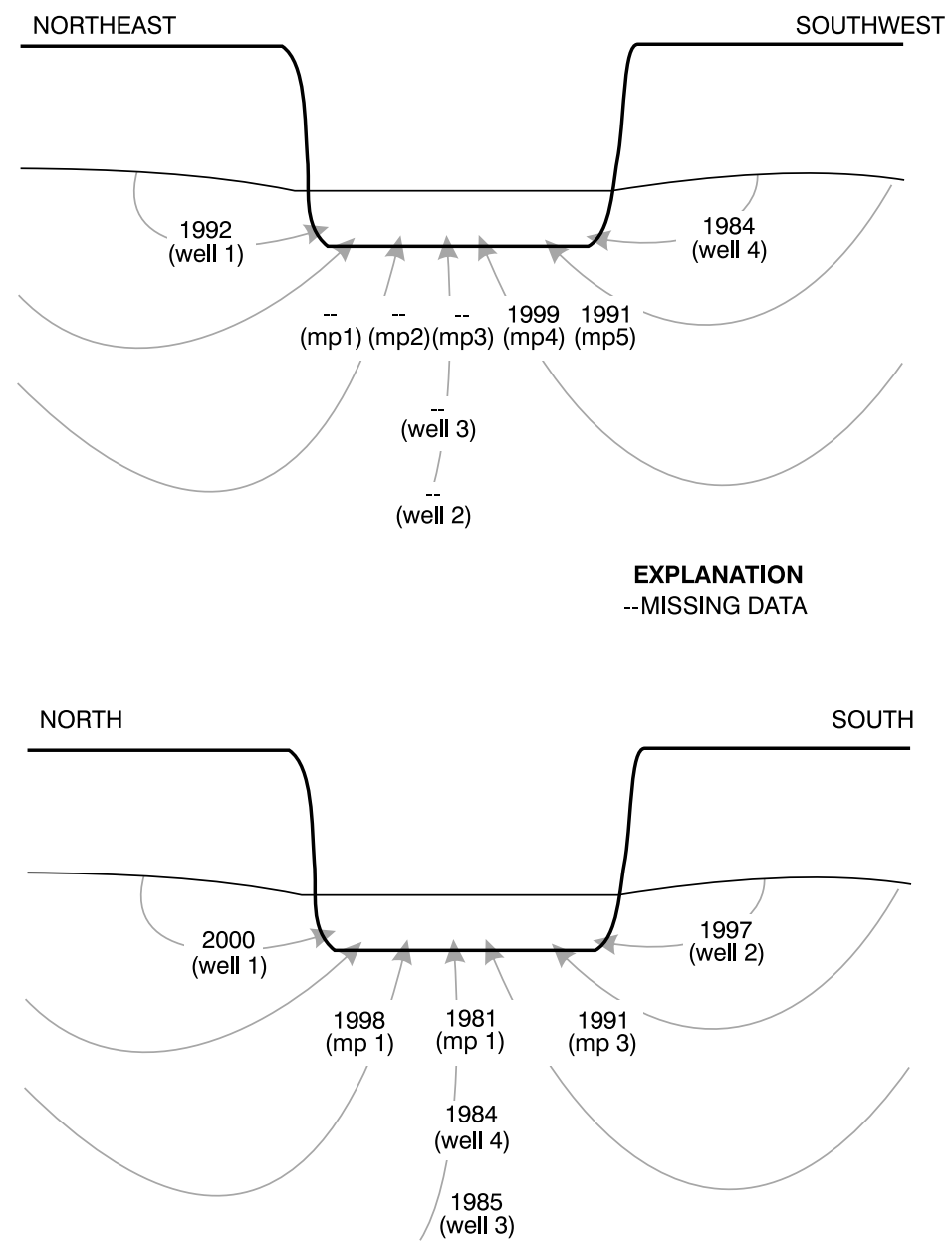

Figure 39. Date of recharge of ground water discharging to North Fork Green Run during March 1999.
Figure 40. Date of recharge of ground water discharging to Wayne Tull's Farm Ditch during March 1999.

\section{Relation of Apparent Ages to Nitrogen Concentrations and Sources}

Agricultural areas and activities are the primary sources of nutrients in the Upper Pocomoke River Watershed (Brakebill and others, 2001). Agricultural sources made up almost 95 percent of all N sources; atmospheric deposition, septic tanks, and point sources contribute the remaining 5 percent. Of the agricultural sources, manure contributed the largest amount of $\mathrm{N}$ (about 55 percent of the total input); most of the manure was from poultry (83 percent) (Maryland Department of Natural Resources, 2000). Synthetic fertilizers make up the second largest source of $\mathrm{N}$ (about 40 percent of the total input).

A surplus of $\mathrm{N}$ applied to the land surface is available to infiltrate into the ground water. Work by the Maryland Department of Natural Resources (1999, p. 15) indicates total annual $\mathrm{N}$ inputs average approximately $300 \mathrm{lb}$ of $\mathrm{N}$ per acre of cropland, or 423,000 lb of
$\mathrm{N}$ for all acres in the North Fork Green Run Watershed. Removal of nutrients through grain harvesting is the largest export of nutrients from the watershed; annual $\mathrm{N}$ uptake ranges from 102 to $144 \mathrm{lb} \mathrm{N}$ per acre, or 139,000 to $195,000 \mathrm{lb}$ of $\mathrm{N}$ total. From 1995 through 1997, N surpluses ranged from 134 to $218 \mathrm{lb}$ of $\mathrm{N}$ per acre of cropland, averaging $168 \mathrm{lb}$ of $\mathrm{N}$ per acre of cropland, or $229,000 \mathrm{lb}$ of $\mathrm{N}$ for the entire watershed (Maryland Department of Natural Resources, 1999). The surplus N may be bound in the soil zone, runoff into surface water during storms, or infiltrate into the ground water.

The agricultural sources contributed to elevated concentrations of $\mathrm{NO}_{3}^{-}$in the ground water underlying the three study sites in the Upper Pocomoke River watershed. $\mathrm{NO}_{3}^{-}$concentrations ranged from below detection to near $70 \mathrm{mg} / \mathrm{L}$; the highest concentrations were directly underlying an agricultural field at the Wayne Tull's Farm Ditch site. In the NAWQA study of the entire Delmarva Peninsula, the highest $\mathrm{NO}_{3}^{-}$con- 
centrations also were found in shallow ground water below agricultural fields (Hamilton and others, 1993). On the basis of the analyses of $\delta^{15} \mathrm{~N}$ concentrations, the $\mathrm{NO}_{3}^{-}$in the ground water collected from the Wayne Tull's Farm Ditch site and another ditch area (Pine Branch sampled in 1998) appears heavily influenced by animal manure (fig. 13). The Green Run site had isotope values suggesting a mixture of fertilizer and manure sources have influenced $\mathrm{NO}_{3}^{-}$concentrations. This site has the largest drainage area $\left(13 \mathrm{mi}^{2}\right)$, so a mixture of both sources would be feasible. The $\delta^{15} \mathrm{~N}$ data also supported that denitrification was occurring in parts of the surficial aquifer at all three study sites.

In addition to $\mathrm{NO}_{3}^{-}, \mathrm{NH}_{4}^{+}$also was present in the ground-water samples and was the predominant $\mathrm{N}$ species in some samples. $\mathrm{N}$ applied to the land surface as manure or commercial fertilizer is comprised of inorganic $\mathrm{N}$. Typically the $\mathrm{N}$ is converted to $\mathrm{NH}_{3}$ and to $\mathrm{NH}_{4}^{+}$in the soil zone, where it is not very mobile, and usually is converted to $\mathrm{NO}_{3}^{-}$if oxygen is available. $\mathrm{NO}_{3}^{-}$, which is mobile in water, usually infiltrates in the ground water and is the predominant $\mathrm{N}$ species. However, in the study area both $\mathrm{NO}_{3}^{-}$and $\mathrm{NH}_{4}^{+}$were detected in the ground-water samples. $\mathrm{NH}_{4}^{+}$was present in samples from several sites at concentrations greater than $\mathrm{NO}_{3}^{-}$. The presence of $\mathrm{NH}_{4}^{+}$in the shallow ground water could be because of anaerobic conditions in soils (Mitsch and Gosselink, 1986). The lack of oxygen in the soils would prevent conversion of $\mathrm{NH}_{4}^{+}$to $\mathrm{NO}_{3}^{-}$and result in a build up of $\mathrm{NH}_{4}^{+}$in the saturated soils and shallow aquifer zones. Hamilton and others
(1993) noted in the general area that includes the Upper Pocomoke River Watershed that reducing conditions in the soils and aquifer commonly inhibit the conversion of $\mathrm{N}$ species to $\mathrm{NO}_{3}^{-}$. The $\mathrm{NH}_{4}^{+}$present in the groundwater samples probably did not enter the ground water when it is recharged but was formed during anaerobic degradation of organic matter in the saturated zone, especially near the streambeds (J.K. Böhlke, U.S. Geological Survey, written commun., 2002). The $\mathrm{NH}_{4}^{+}$ probably was introduced into the ground water as it moved into the vicinity of the discharge areas (streams and ditches). Therefore, the $\mathrm{NH}_{4}^{+}$does not represent historical inputs of $\mathrm{N}$ to the ground-water system.

In addition to the soil zone, reducing conditions also were present in much of the aquifer, which promoted denitrification and loss of $\mathrm{NO}_{3}^{-}$from the ground water. Denitrification was occurring in varying amounts at all three study sites. $\mathrm{NO}_{3}^{-}$concentrations were low under almost all the streambeds but excess $\mathrm{N}_{2}$ gas in these samples indicated denitrification had converted $\mathrm{NO}_{3}^{-}$to $\mathrm{N}_{2}$ gas.

The relation of changes in $\mathrm{NO}_{3}^{-}$, denitrification, and apparent ages of ground water are shown on figure 41 (reconstructed $\mathrm{NO}_{3}^{-}$) and figure $42\left(\mathrm{NO}_{3}^{-}\right.$). Reconstructed $\mathrm{NO}_{3}^{-}$is a combined value of the measured $\mathrm{NO}_{3}^{-}$concentration and an estimate of the $\mathrm{NO}_{3}^{-}$ lost through denitrification (as measured with excess $\mathrm{N}_{2}$ gas). Figure 41 indicates a lack of significant $\mathrm{NO}_{3}^{-}$in the ground water prior to the increases in the mid-1980s. This increase can be related to the use of fertilizer and

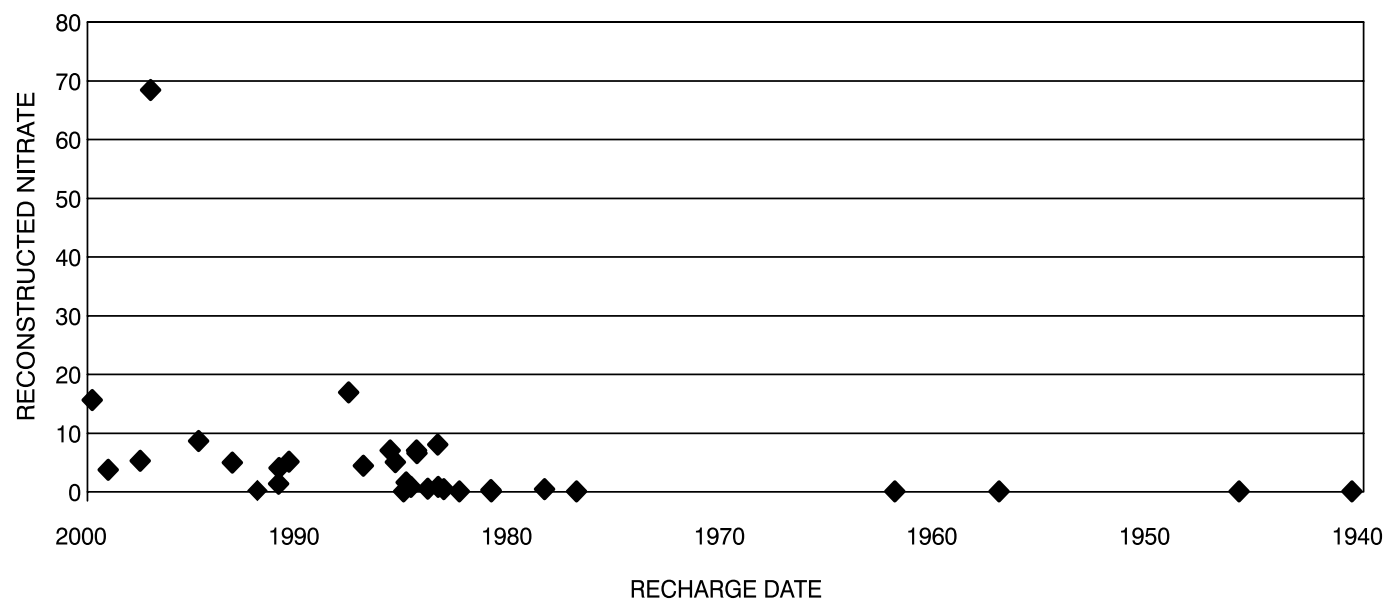

Figure 41. Relation between ground-water recharge date and "reconstructed" initial nitrate concentration in samples collected in the North Fork Green Run Watershed. 


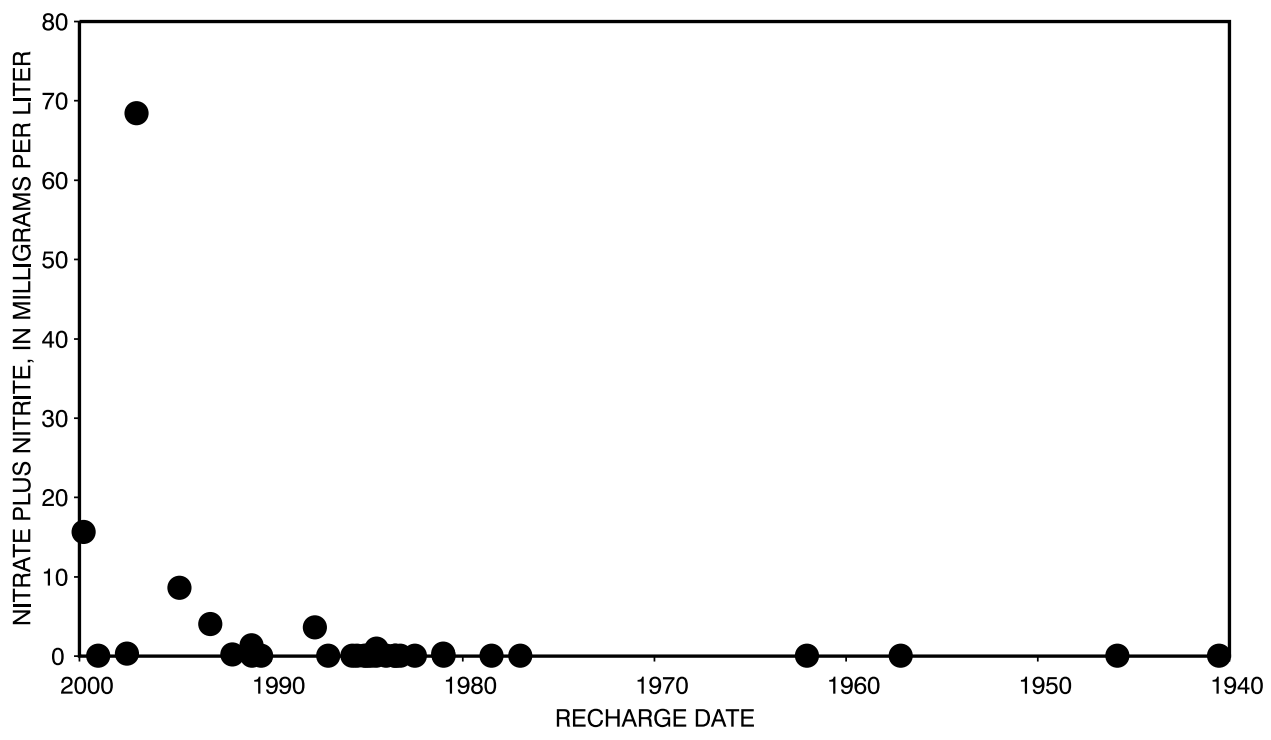

Figure 42. Relation between ground-water recharge date and actual nitrate concentration in samples collected in the North Fork Green Run Watershed.

manure on the Delmarva Peninsula. Commercial fertilizer sales in the Pocomoke Basin area began in the mid-1940s and steadily increased to almost 3 million pounds per year by 1980 (Alexander and Smith, 1990). Since 1980, the sales have fluctuated between 2 and 3 million pounds each year. The poultry industry began on the Eastern Shore in the 1960s and has grown to surpass commercial fertilizer in terms of $\mathrm{N}$ generation with annual manure production near 4 million pounds (Puckett and others, 1998). The increase in the $\mathrm{NO}_{3}^{-}$in ground water beginning in the mid-1980s is related to the increase of $\mathrm{N}$ being applied to the land surface. The "lag time" between when $\mathrm{N}$ began to be applied to the land surface (late 1940s) and its presence in the groundwater system may be related to several factors including (1) the anaerobic conditions in the soil zone prevented $\mathrm{NO}_{3}^{-}$from being formed; (2) the surficial-aquifer confining unit prevented $\mathrm{NO}_{3}^{-}$from being recharged into many areas of the aquifer (Hamilton and others, 1993) and (3) the time needed for $\mathrm{N}$ to build up in the soil zone to an extent that excess $\mathrm{NO}_{3}^{-}$was available to be recharged into the ground water.

The effect of denitrification in the ground-water system can be seen in figure 42 , which shows only the measured $\mathrm{NO}_{3}^{-}$concentrations. $\mathrm{NO}_{3}^{-}$concentrations are low in all water prior to 1995 , indicating that $\mathrm{NO}_{3}^{-}$ is removed from the ground water moving along longer flow paths. The longer flow paths have a greater chance to encounter reducing conditions in the aquifer where denitrification will convert $\mathrm{NO}_{3}^{-}$to excess $\mathrm{N}_{2}$ gas. Some of the $\mathrm{NO}_{3}^{-}$in younger ground water also has been affected by denitrification but other $\mathrm{NO}_{3}^{-}$along other short flow paths shows no effect of denitrification. This infers that the reducing conditions in the aquifer will affect most of the $\mathrm{NO}_{3}^{-}$that moves along longer flow paths. $\mathrm{NO}_{3}^{-}$that moves along shorter flow paths in the shallowest part of the aquifer is not always affected by denitrification. These shorter flow paths probably are the primary pathway for $\mathrm{NO}_{3}^{-}$discharge into ditches and streams.

\section{Factors Affecting Apparent-Age Distribution, Nitrogen Oc currence, and Discharge to Streams}

The data from the Upper Pocomoke River Watershed indicate that the factors affecting the apparent age of, and associated $\mathrm{N}$ in, ground water include length of the ground-water-flow paths, which is controlled by locations of the discharge areas; hydrologic framework; the hydraulic conductivity of the aquifer; nutrient sources; and reducing conditions in the soil zone and aquifer. Once $\mathrm{N}$ has been discharged to a stream, seasonal conditions in the stream also affect the concentrations and their delivery to downstream water bodies and the Chesapeake Bay.

The findings suggest the primary factor affecting the apparent age of ground water in the Upper Pocomoke Watershed is the length of ground-water-flow paths, which is influenced by the location of the recharge and discharge areas, the hydrologic framework, and the hydraulic conductively of the aquifer. The 
length of the flow path is determined by the relation of the recharge area to the location of the streams receiving the discharge. As the drainage area to a stream becomes larger, the ground water discharging to the stream has a greater percentage of older apparent ages because of longer ground-water-flow paths. These findings are consistent with studies conducted in similar Coastal Plain settings. Modica and others (1998) documented that the apparent ages of ground water discharging to streams originates from both near and far from the stream. The age of ground water discharging to a stream increases from its banks to its center and becomes progressively older with distance downstream (fig. 43). The heterogeneities of the aquifer and stream-channel patterns can shift the source contribution area and distributions of ground-water residence times. A similar pattern was seen between the three study sites in the Upper Pocomoke River Watershed. Previous USGS studies on the Delmarva Peninsula found the ground-water-flow paths can range from several $100 \mathrm{ft}$ to several miles (Shedlock and others, 1999). The length of the flow paths depend on aquifer thickness and conductivity and topography affecting the hydrologic gradient and surface drainage. In the region of the Upper Pocomoke Watershed, flow paths are shorter in the upper part of the aquifer and up to several miles in the lower unit of the aquifer (Shedlock and others, 1999). These results are consistent with current study findings of very young ground water in the uppermost part of the surficial aquifer and water moving along longer flow paths of the lower part of the aquifer that eventually discharges as older ground water to larger streams.
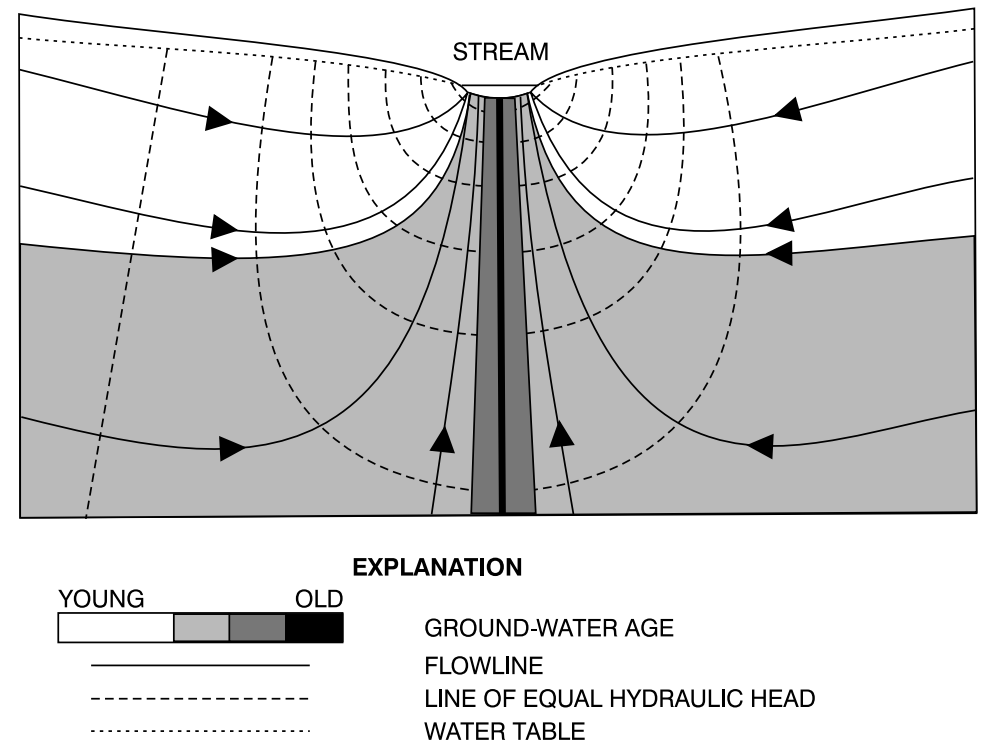

The primary source of nutrients in the Upper Pocomoke River Watershed is agricultural sources. On the basis of studies by MDDNR (1999), excess N is available to reach the water table. The primary factor influencing the infiltration of $\mathrm{N}$ into the aquifer is the anaerobic conditions in the soils. Data suggest that $\mathrm{N}$ is converted to ammonium but not $\mathrm{NO}_{3}^{-}$in ground-water recharge areas overlain by anaerobic soils. $\mathrm{NH}_{4}^{-}$is much less mobile in the ground-water system and will result in less movement of $\mathrm{N}$ into and through the ground-water system. These areas correspond to soils with high organic content and low permeability. In these areas, management actions to reduce nutrients will not have a significant influence on the $\mathrm{NO}_{3}^{-}$in ground water because the anaerobic conditions already are limiting its generation in the soil zone.

For the $\mathrm{N}$ that is converted to $\mathrm{NO}_{3}^{-}$and reaches the water table, anaerobic conditions promote denitrification in much of the surficial aquifer. This process will result in much of the $\mathrm{NO}_{3}^{-}$being converted to $\mathrm{N}_{2}$ gas before it has an opportunity to discharge into farm ditches or streams. Results indicate that only ground water with young apparent recharge (mid 1990s to 2000) still contains $\mathrm{NO}_{3}^{-}$that may discharge to streams. Therefore, management practices to reduce the amount of excess $\mathrm{N}$ on the land surface in areas of aerobic conditions in the soils and aquifer may have a fairly rapid effect (within 5 years) of reducing $\mathrm{N}$ in the ground water that will discharge to streams.
Figure 43. Conceptual model of the distribution of flow paths, hydraulic head, and age of ground-water seepage surrounding a stream channel (from Modica and others, 1998). 
Once $\mathrm{N}$ enters the farm ditches and streams, other biogeochemical processes influence the concentration that eventually reaches the tidal waters and the Chesapeake Bay. $\mathrm{NO}_{3}^{-}$concentrations in stream water at all three sites showed a strong variation between the sampling periods (table 5). Concentrations were greater in both March sampling periods than in September. Additionally, concentrations are greater in the first-order stream (Wayne Tull's Farm Ditch site) than in the higher order streams. This suggests that the greatest concentrations of $\mathrm{NO}_{3}^{-}$enter the first-order streams that drain agricultural land.

Table 5. Total nitrogen concentrations in streamwater samples, January 1997 through April 1999

$[<$, less than; $\mathrm{mg} / \mathrm{L}$, milligrams per liter]

\begin{tabular}{lccc}
\hline & $\begin{array}{c}\text { Green Run } \\
(\mathbf{m g} / \mathbf{L})\end{array}$ & $\begin{array}{c}\text { North Fork } \\
\text { Green Run } \\
(\mathbf{m g} / \mathbf{L})\end{array}$ & $\begin{array}{c}\text { Wayne Tull's } \\
\text { Farm Ditch } \\
(\mathbf{m g} / \mathbf{L})\end{array}$ \\
\hline March 1999 & ${ }^{1} 4.40$ & 5.23 & 14.2 \\
September 1999 & 1.12 & 2.30 & $<.050$ \\
March 2000 & 2.19 & 3.49 & 9.49 \\
\hline
\end{tabular}

1 John McCoy, Maryland Department of Natural Resources, written commun., 2000.
Data collected by MDDNR at North Fork Green Run site (fig. 44) (table 5) show a strong seasonal pattern of $\mathrm{NO}_{3}^{-}$concentrations, which are reduced each spring and summer. The reduction most likely is related to several factors including (1) the delivery of ground water and $\mathrm{N}$ to the streams, (2) uptake of $\mathrm{N}$ by biomass in the stream, and (3) the timing of fertilizer application. The delivery of ground water and the associated $\mathrm{NO}_{3}^{-}$ will vary seasonally. In the late fall through early spring, the highest amount of ground water will discharge to the stream because of lack of evapotranspiration from crops and trees. The highest recharge of $\mathrm{NO}_{3}^{-}$into the aquifer also will occur in the late winter and spring when fertilizer is spread on the land surface. During the growing season, the amount of ground water and associated $\mathrm{NO}_{3}^{-}$entering a stream decreases because of evapotranspiration. In addition to the reduced input of $\mathrm{NO}_{3}^{-}$ to a stream, the $\mathrm{NO}_{3}^{-}$already in the stream will be affected by plant growth and algal blooms in the drainage ditches during the spring and summer. At the North Fork Green Run site, dissolved oxygen concentrations are lower in the summer than during other seasons (appendix A) but not low enough for denitrification to occur. However, at the Wayne Tull's Farm Ditch site, concentrations of dissolved oxygen were less than $1 \mathrm{mg} / \mathrm{L}$ during September 1999, suggesting denitrification could be a secondary process removing oxygen

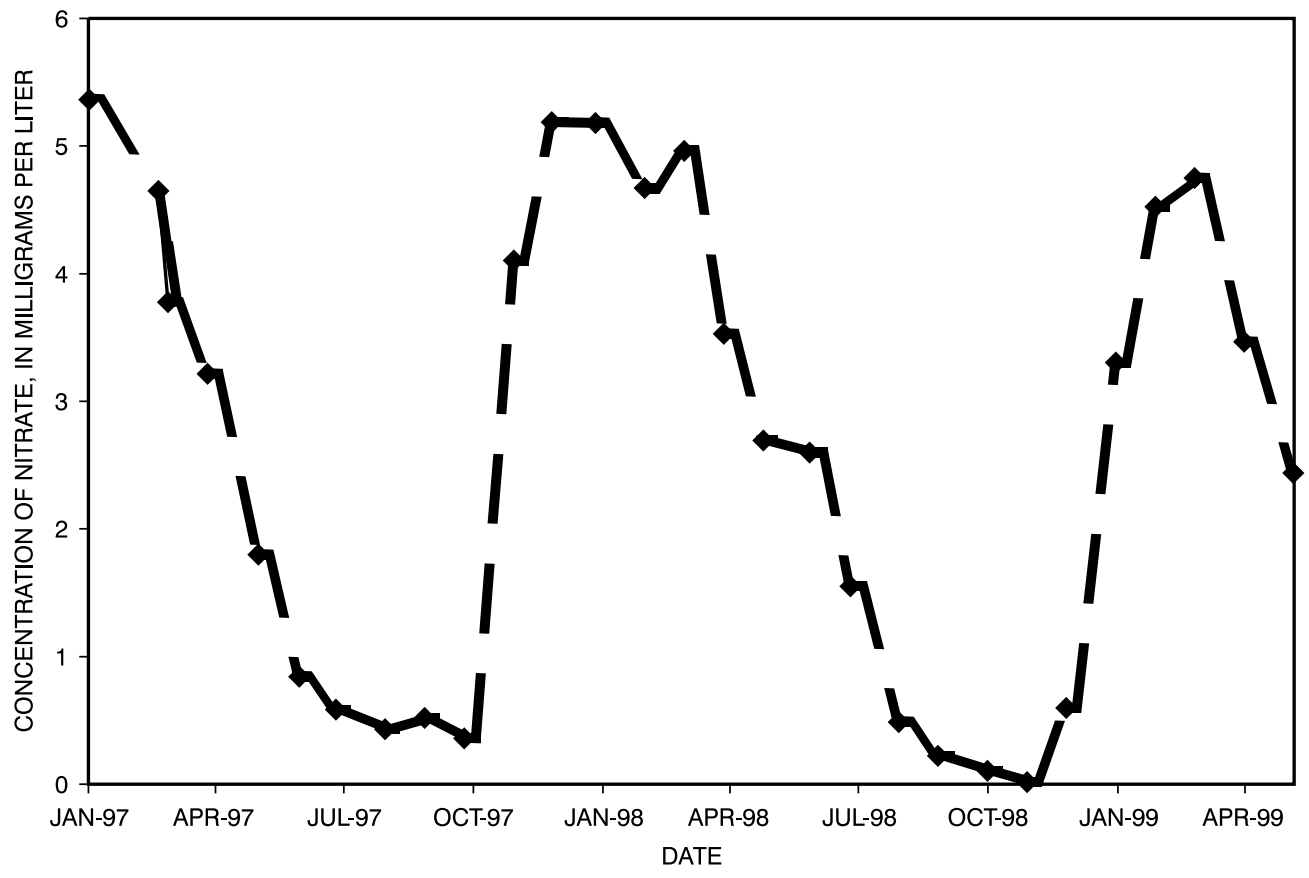

Figure 44. Total nitrate concentrations at the gage at North Fork Green Run, January 1997 through April 1999. 
from the surface water. This seasonal variation in nutrient inputs to a stream suggests management actions to reduce the amount of $\mathrm{NO}_{3}^{-}$entering the ground-water system during the nongrowing season will have the greatest effect in reducing the amount of $\mathrm{NO}_{3}^{-}$entering the stream from ground water.

Findings from this study of the Upper Pocomoke River Watershed agree with previous findings in other poorly drained areas of the Delmarva Peninsula (Hamilton and others, 1993). However, the reducing conditions in the Upper Pocomoke Watershed are not typical of all the Delmarva Peninsula and Coastal Plain. In many areas of the Delmarva Peninsula, the surficial aquifer consists of sandy deposits and the ground water contains dissolved oxygen (Hamilton and others, 1993). The $\mathrm{NO}_{3}^{-}$concentrations were elevated in agricultural and residential areas in these areas. Conversely, nutrient concentrations were lower in agricultural and residential areas underlain by aquifers with a high degree of clay and silt deposits that contained anaerobic water. The silt and clay deposits in the aquifer and overlying soils can cause lower $\mathrm{NO}_{3}^{-}$concentrations for several reasons: the anaerobic conditions may either cause denitrification or prevent nitrification of $\mathrm{NH}_{4}^{+}$; the clay and silt can inhibit downward movement of fertilizers from the land surface into the water table; and clay and silt have abundant exchange sites for $\mathrm{NH}_{4}^{+}$, reducing the amount of $\mathrm{NO}_{3}^{-}$available to reach the water table (Hamilton and others, 1993). Similar findings were reported in an area of the Coastal Plain in southern Maryland west of Chesapeake Bay (Bachman and Krantz, 2000). Ator and others (2000) analyzed data from the entire Mid-Atlantic Coastal Plain to assess the controls on $\mathrm{NO}_{3}^{-}$concentrations in ground water. The study concluded shallow ground-water quality in the Coastal Plain is affected by natural hydrogeologic conditions (including texture, permeability, drainage, and chemical composition of the surficial sediments) as well as land use and soil properties. Findings revealed that when concentrations of dissolved oxygen in an aquifer were low (less than $1.4 \mathrm{mg} / \mathrm{L})$, the $\mathrm{NO}_{3}^{-}$concentration rarely exceeded 2 or $3 \mathrm{mg} / \mathrm{L}$, even if other constituents suggested the water was affected by agricultural land use. Where dissolved oxygen is abundant (greater than $7.7 \mathrm{mg} / \mathrm{L}$ ), $\mathrm{NO}_{3}^{-}$concentrations commonly exceed $10 \mathrm{mg} / \mathrm{L}$. The study concluded that the distribution in the ground water apparently is controlled more by the natural aquifer redox conditions than by land use.

\section{References Cited}

Alexander, R.B., and Smith, R.A., 1990, County-level estimates of nitrogen and phosphorus fertilizer use in the United States, 1945-1985: U.S. Geological Survey Open-File Report 90-130, 12 p.

Ator, S.W., Denver, J.M., and Hancock, T.C., 2000, Relating shallow ground-water quality to surficial hydrogeology in the Mid-Atlantic coastal Plain: National Water-Quality Monitoring Conference Proceedings, April 25-27, 2000, p. 409-423.

Bachman, L.J., 1984, The Columbia Aquifer of the eastern shore of Maryland, part 1-Hydrogeology: Maryland Geological Survey Report of Investigations no. 40, $34 \mathrm{p}$.

Bachman, L.J., and Krantz, D.E, 2000, The potential for denitrification of ground water by coastal plain sediments in the Patuxent River Basin, Maryland: U.S. Geological Survey Fact Sheet 00-053, 4 p.

Bachman, L.J., Lindsey, B.D., Brakebill, J.W., and Powars, D.S., 1998, Ground-water discharge and base-flow nitrate loads of nontidal streams, and their relation to a hydrogeomorphic classification of the Chesapeake Bay Watershed, middle Atlantic coast: U.S. Geological Survey WaterResources Investigations Report 98-4059, 71 p.

Brakebill, J.B., Preston, S.D., and Martucci, S., 2001, Digital data used to relate nutrient inputs to water quality in the Chesapeake Bay Watershed, version 2.0: U.S. Geological Survey Open-File Report 01-251, 17 p.

Busenberg, Eurybiades, and Plummer, L.N., 2000, Dating young groundwater with sulfur hexafluoride-Natural and anthropogenic sources of sulfur hexafluoride: Water Resources Research, v. 36, p. 3,011-3,030.

Dunkle, S.A., Plummer, L.N., Busenberg, Eurybiades, Phillips, P.J., Denver, J.M., Hamilton, P.A., Michel, R.L., and Coplen, T.B., 1993, Chlorofluorocarbons $(\mathrm{CCl} 3 \mathrm{~F}$ and $\mathrm{CCl} 2 \mathrm{~F} 2)$ as dating tools and hydrologic tracers in shallow groundwater of the Delmarva Peninsula, Atlantic Coastal Plain, United States: Water Resources Research, v. 29, no. 12, p. 3,837-3,860. 


\section{References Cited-Continued}

Focazio, M.J., Plummer, L.N., Böhlke, J.K., Busenberg, Eurybiades, Bachman, L.J., Powars, D.S., 1998, Preliminary estimates of residence times and apparent ages of ground water in the Chesapeake Bay Watershed, and water-quality data from a survey of springs: U.S. Geological Survey Water-Resources Investigations Report 97-4225, $75 \mathrm{p}$.

Hamilton, P.A., Denver, J.M., Phillips, P.J., and Shedlock, R.J., 1993, Water-quality assessment of the Delmarva Peninsula, Delaware, Maryland, and Virginia-Effects of agricultural activities on, and distribution of, nitrate and other inorganic constituents in the surficial aquifer: U.S. Geological Survey Open-File Report 93-40, 87 p.

Maryland Department of Natural Resources, 1999, Upper Pocomoke calibration of the agricultural BMP evaluation 1994-1998: CCWS-WRDMN-99-02, 64 p.

2000, Lower eastern shore conservation and restoration action strategy, Phase I-Program description and atlas of environmental indicators: $88 \mathrm{p}$.
Mitsch, W.J., and Gosselink, J.G., 1986, Wetlands: New York, Van Nostrand Reinhold Company Inc., 539 p.

Modica, E., Buxton, H.T., and Plummer, L.N., 1998, Evaluating the source and residence times of ground water seepage to streams, New Jersey Coastal Plain: Water Resources Research, v. 34 , no. 11 , p. $2,797-2,810$.

Plummer, L.N., and Busenberg, Eurybiades, 1999, Chlorofluorocarbons, in Cook, P., and Herczeg, A., eds., Environmental tracers in subsurface hydrology: Boston, Mass., Kluwer Academic Publishers, p. 441-478.

Puckett, L.J., Hitt, K.J., and Alexander, R.B., 1998, County-based estimates of nitrogen and phosphorus content of animal manure in the United States for 1982, 1987, and 1992, version 1.0.0: U.S. Geological Survey, accessed May 1999, at http://water.usgs.gov/lookup/getspatial?manure

Shedlock, R.J., Denver, J.M., Hayes, M.A., Hamilton, P.A., Koterba, M.T., Bachman, L.J., Phillips, P.J., and Banks, S.L., 1999, Water-quality assessment of the Delmarva Peninsula, Delaware, Maryland, and Virginia-Results of investigations-1987-

91: U.S. Geological Survey Water-Supply Paper 2355-A, $41 \mathrm{p}$. 


\section{Polecat Creek Watershed, Virginia}

\section{by Gary K. Speiran}

The Polecat Creek Watershed was selected to represent the Piedmont crystalline HGMR. The eastern part of the watershed also includes the Coastal Plain HGMR but was not a focus for this investigation. The Polecat Creek Watershed was selected on the basis of an existing study that already had installed monitoring wells. The existing study was being conducted by the Virginia Chesapeake Bay Local Assistance Department (CBLAD) and the USGS to assess the effects of changing land use on water quality. The information from this existing study provided an initial understanding of the ground-water-flow system and chemistry.

\section{Description of Study Area and Sampling Network}

Polecat Creek drains a primarily rural watershed that covers approximately $46.9 \mathrm{mi}^{2}$ in west-central Caroline County, Va. (fig. 45). Land use and cover of the watershed consist of 73.5 percent forest, 14.2 percent agriculture, 9.9 percent urban development (residential and commercial), and 2.5 percent water bodies (Ram Gupta, Chesapeake Bay Local Assistance Department, oral commun., 2001). The study site primarily consists of forest, pasture, and fields and has several nearby homes. A riparian-forest buffer covers the valley on both sides of Polecat Creek and extends about $350 \mathrm{ft}$ north and $450 \mathrm{ft}$ south of the creek (fig. 46). A pasture borders the forest buffer north of the creek. Six to eight horses grazed in the pasture and also were allowed to roam through the forest buffer on both sides of the creek. A gravel driveway from the main road to a home separates the pasture from an adjacent cultivated field. A cultivated field also borders the forest buffer to the south. Both fields are cultivated in a corn, soybean, and winter wheat crop rotation. Land-surface elevation is about $210 \mathrm{ft}$ above sea level in the valley and rises to about 240 to $250 \mathrm{ft}$ above sea level in the upland fields. South of the creek, the valley wall slopes sharply, and the valley floor is nearly level. North of the creek, the slope of the valley wall is more gradual, and the slope of the valley floor is greater than that south of the creek.

\section{Hydrogeology}

Ground water flows along various pathways before discharging by different mechanisms to surface waters, which affects the quantity and quality of water in Polecat Creek. Most ground water flows through a surficial aquifer, but some water likely flows through a deeper fractured-bedrock aquifer before discharging to the creek.

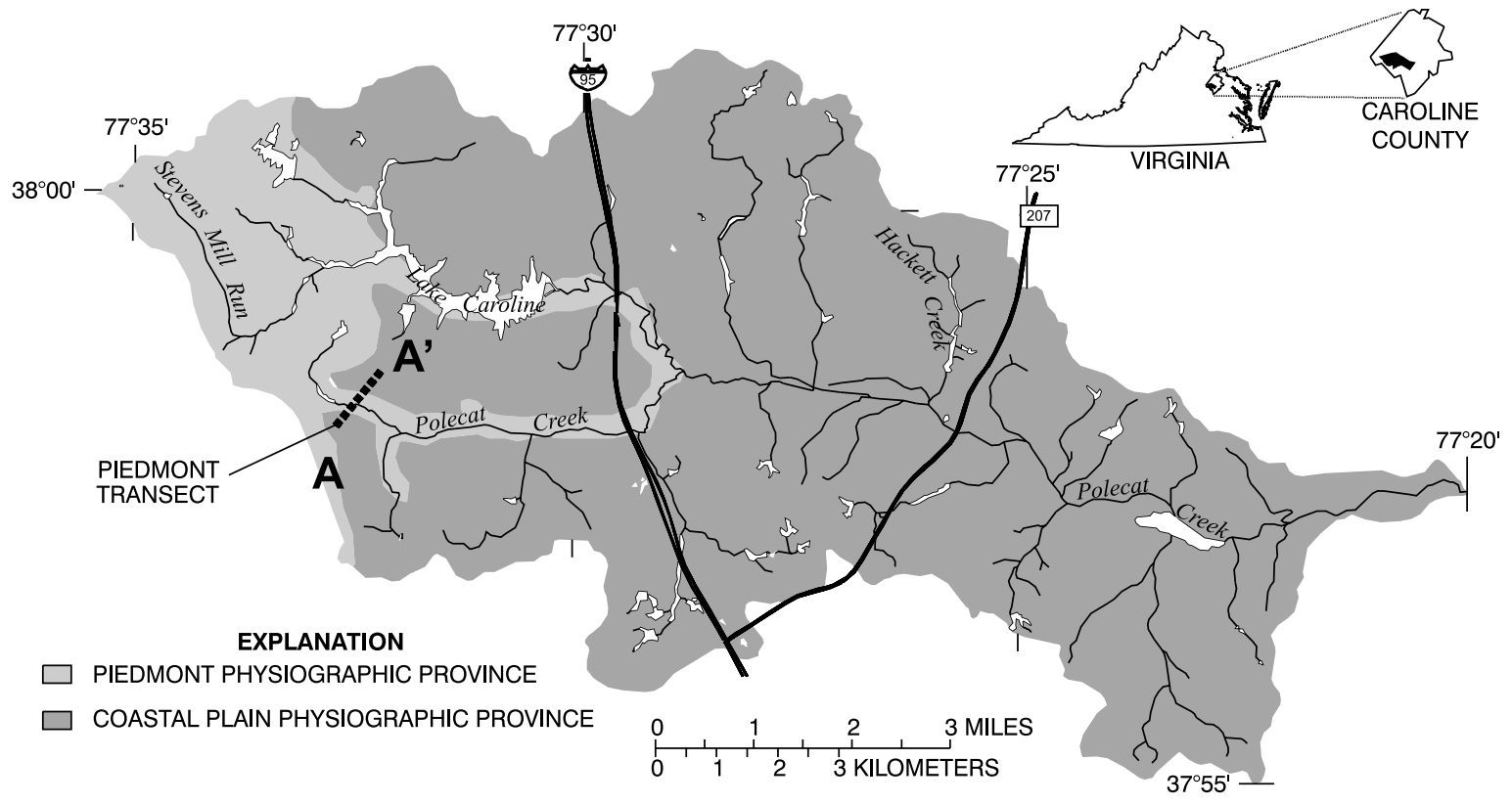

Figure 45. Location of study area and well transect A-A', Polecat Creek Watershed, Va. 


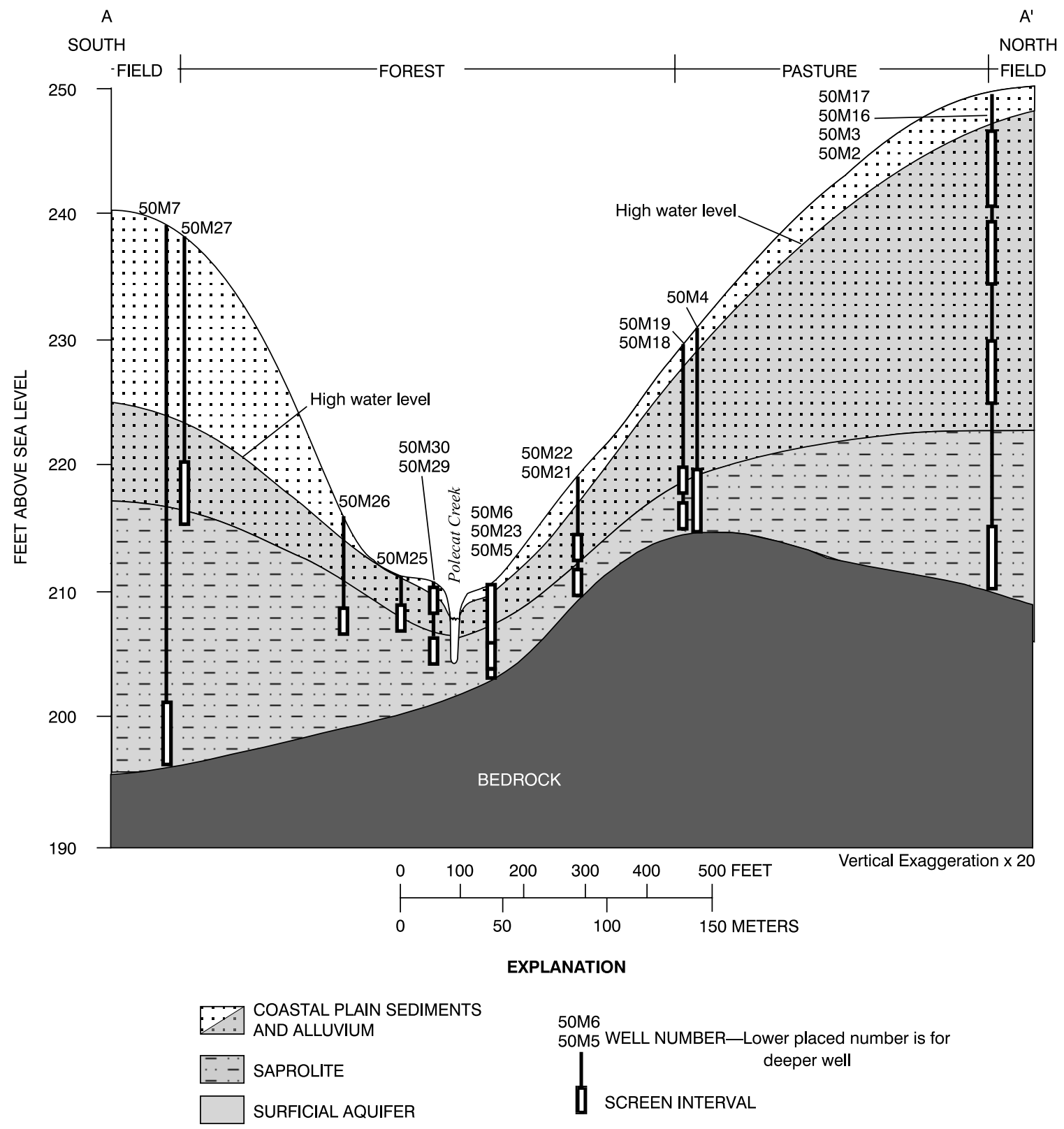

Figure 46. Geohydrologic section A-A' with well locations and land use, Polecat Creek Watershed, Va. 
Hydrogeologic framework.-The geology

of the area has not been studied in detail locally but has been described and mapped in general by Mixon and others (1989) and the Virginia Division of Mineral Resources (1993). The study site is underlain by bedrock that is covered by saprolite, an unconsolidated, weathered rock derived from bedrock. Because the site is at the eastern edge of the Piedmont, Coastal Plain sediments overlie the saprolite in the uplands. Beneath the flood plain, alluvial sediments overlie the saprolite and bedrock.

At the study site, bedrock consists of a garnetbiotite gneiss (Virginia Division of Mineral Resources, 1993). The bedrock likely is fractured, but the amount, distribution, and size of fractures are not known. The saprolite is a mixture of silt and clay with some sand formed by weathering of the bedrock and contains zones of less-weathered rock. Outcrops of saprolite in the banks of Polecat Creek indicate the saprolite and bedrock dip to the west (upstream). Because of its finegrained characteristics, the saprolite has a relatively low permeability. The Coastal Plain sediments consist of fine- to coarse-grained sand and gravel in a clayey silt matrix that is slightly more permeable than the saprolite. The alluvial sediments consist of a heterogeneous mixture of gravel, sand, silt, and clay having a predominantly silt and clay matrix that also appears to be slightly more permeable than the saprolite.

The altitude of the top of bedrock varies by about $20 \mathrm{ft}$ across the study site (fig. 46). A ridge in the bedrock near the edge of the pasture and forest buffer is about $215 \mathrm{ft}$ above sea level. The location of the top of this ridge is not certain but is likely between well clusters 50M4 and 50M21. The altitude decreases to about $210 \mathrm{ft}$ above sea level to the north and $195 \mathrm{ft}$ above sea level to the south The depth to bedrock varies as a result of the differences in the combined thickness of the saprolite, Coastal Plain sediments, and alluvium. Depth to bedrock ranges from less than $4 \mathrm{ft}$ beneath the creek to $46 \mathrm{ft}$ beneath the uplands south of the creek.

The thickness of the saprolite, Coastal Plain sediments, and alluvium vary across the study site (fig. 46). The thickness of the Coastal Plain sediments is as great as $26 \mathrm{ft}$ beneath the uplands; Coastal Plain sediments, however, are likely absent beneath the valley. The alluvium is present only beneath the valley; its thickness generally is less than $4 \mathrm{ft}$. The depth of the creek channel is about 4 to $5 \mathrm{ft}$; the channel generally incises through the alluvium into the saprolite but does not incise to bedrock at the study site.
The saprolite, Coastal Plain sediments, and alluvium form a surficial aquifer that generally is unconfined at the study site (fig. 46). The water table forms the upper boundary and bedrock forms the lower boundary of the aquifer. The hydrologic role of the bedrock is not certain but can differ locally and is likely that of a low permeability aquifer and (or) a confining unit. This role is affected by the amount, distribution, and size of fractures at the top of the bedrock that likely vary across the study site and by ground-water pumpage from the bedrock. Because no substantial ground-water pumping is known to exist near the study site, ground-water flow at the site reflects natural, unstressed conditions. These unstressed conditions could partly limit ground-water flow through the bedrock. Should appreciable groundwater pumping from the bedrock begin near the site, flow through the bedrock could substantially increase.

Ground-waterflow.-Precipitation infiltrates the soil and percolates to the water table to recharge the ground water across most of the watershed. Ground water recharged through the uplands originally was presumed to flow beneath the forest buffer toward the creek, where it would discharge. Although flow in the surficial aquifer south of the Polecat Creek appears to follow this pattern, flow north of the creek differs substantially from the originally presumed pattern.

South of the creek, ground water recharges through the upland field and forest buffer and flows toward the creek. The aquifer thickness decreases from the field toward the creek because of the rise in the elevation of bedrock and the decrease in the elevation of the water table (fig. 46). When ground-water levels are high, ground water flows along a combination of short, shallow paths and longer, deeper paths. Water that flows along short, shallow paths discharges to land surface at the base of the valley slope and to the valley floor to form a wetland near the valley wall. This water discharges when land surface intercepts the water table because of the steep valley wall and flat valley floor. A shallow ditch at the base of the slope drains part of this discharged water to Polecat Creek. Ground water also discharges through this area as evapotranspiration. Water that flows along deep, long paths flows toward the creek where it discharges. When water levels are low, ground water primarily flows along the deep, long paths and does not discharge to land surface in the wetland but discharges through evapotranspiration or flows to the creek where it discharges. Precipitation can recharge the ground water through the wetland at these times. Discharge to the creek is directly through the streambed or 
through seeps in the streambank. Seeps are generally along zones of contrasting permeability in the clayey bank sediments.

North of the creek, ground water recharges through the field, the pasture, and the forest buffer. Unlike south of the creek, little water recharged through the field and pasture flows through the surficial aquifer beneath the forest buffer. Flow appears to be limited by a barrier likely caused by the ridge in the bedrock. This barrier is indicated by several factors: (1) the greater saturated thickness of the aquifer beneath the uplands north of the creek than south of the creek, (2) periods during which the full thickness of aquifer sediments beneath parts of the forest buffer are unsaturated, and (3) patterns in ground-water quality beneath the uplands and forest buffer north of the creek. These patterns are reflected in concentrations of silica, $\mathrm{NO}_{3}^{-}$, and $\mathrm{N}_{2}$ gas; recharge temperature; and apparent ground-water age.

The flow paths of ground water recharged beneath the north uplands is uncertain; part of the water discharges to ditches and swales in the uplands when water levels are high; such discharge is evident for several weeks after precipitation. Other water could flow along deep paths through fractures in the bedrock aquifer or through the shallow aquifer along paths nearly parallel to the ridge in bedrock until a break in the ridge allows the water to flow to the creek. Because of this barrier to flow, recharge through the forest buffer appears to be the main source of ground water beneath the buffer. Ground-water levels beneath the buffer generally are not shallow enough to intercept the land surface and discharge ground water in the buffer because of the barrier to flow from the uplands and because of the gradual slope in the valley wall and valley floor. Ground water recharged through the forest buffer either discharges as evapotranspiration or flows to the creek, where it discharges directly through the streambed or through seeps in the streambank similar to those on the south side of the creek.

Ground-water discharge is an important source of streamflow in the Piedmont of the Polecat Creek Watershed. Ground-water discharge at four continuous-record streamflow-gaging stations in Piedmont watersheds near the Polecat Creek Watershed ranged from 6.65 to $6.86 \mathrm{in}$. per year on the basis of records published by the USGS before 1984 (Nelms and others, 1997). This was 50 to 54 percent of the total annual streamflow at these sites (Nelms and others, 1997; Prugh and others, 1985). Ground-water discharge at a partial-record streamflowgaging station operated by the USGS in the Piedmont of the Polecat Creek Watershed was 5.47 in. per year. Analysis of streamflow record collected from 1995 to 2000 by Virginia Polytechnic Institute and State University at the same Polecat Creek site (Saied Mostaghimi, Virginia Polytechnic Institute and State University, written commun., 2001) indicates ground-water discharge averaged 6.41 in. per year or 52 percent of the total annual streamflow. Thus, approximately half of the streamflow in the Polecat Creek Watershed is groundwater discharge.

\section{Sample network and collection}

Samples were collected from a network of wells open to the surficial aquifer. The primary sample-collection period was in April 1999.

Sampling network.-Samples were collected from a network of 19 wells constructed in a transect along the originally presumed regional ground-waterflow path. This transect extends from the uplands north of Polecat Creek across the creek to the uplands south of the creek (fig. 46). Wells were installed as individual wells or as clusters of two to four wells. Wells consisted of 2-in.-diameter polyvinyl-chloride casings and screens. The bottom of the screen of the deepest well at each cluster was placed near the bottom of the surficial aquifer wherever possible. Additional shallower wells were constructed to provide vertical resolution from the water table to the bottom of the surficial aquifer. All wells, except wells 50M5 and 50M28, which are open holes, were constructed having 1.3 - to 5 - $\mathrm{ft}$ long screens that have 0.010 or 0.020 -in.-wide slots. Screen length depends on aquifer thickness and local hydrologic conditions. All clusters in the Polecat Creek Watershed are referenced in this report by the identification number of the deepest well (lowest numbered well) at each cluster (cluster 50M2 for example).

Cluster 50M2 was installed upgradient of most of the pasture and downgradient of the cultivated field north of Polecat Creek and was intended to represent the effects of recharge through the cultivated field. Cluster 50M4 was installed at the boundary between the pasture and the riparian forest buffer north of the creek and was intended to represent the effects of recharge through the pasture and the cultivated field.

Cluster 50M21 was installed in the forest buffer about halfway between cluster 50M4 and the creek. Cluster 50M5 was installed in the forest buffer adjacent to the north side of the creek. These wells were intended to represent the combined effects of recharge through 
the forest buffer and through the upland field and pasture as it flows beneath the forest buffer and discharges to the creek.

Cluster 50M24 was constructed in the forest buffer adjacent to the north side of Polecat Creek, downstream from cluster 50M5, for a comparison with the water quality at cluster 50M5. This cluster is not along the presumed regional ground-water-flow path and is not included in figures showing the geohydrologic section.

Cluster 50M29 was constructed about $20 \mathrm{ft}$ from the south bank of Polecat Creek in the riparian forest buffer. Well 50M25 is in the forest buffer in the middle of the south valley floor about three quarters of the distance from the upland field to the creek. Well 50M26 is in the forest buffer on the lower part of the south valley slope. This well is about half the distance from the upland field to the creek. These wells were intended to represent the effects of recharge through the forest buffer and the upland fields to the south as it flows beneath the forest buffer and discharges to Polecat Creek.

Well 50M7 is near the downgradient limit of the southern upland field but in a grassed area between the field and a road. Although well 50M7 was intended to represent the effects of recharge through the field, effects of the field probably are limited because of the well depth and location. Well 50M27 was constructed between the field and the forest buffer away from the road and well 50M7 and was intended to represent the effects of recharge through the field.

\section{Sampling methods, timing, and}

hydrologic conditions.-Ground-water samples were collected by use of methods described in the introduction to this report with no significant modifications. In addition to the routine analyses performed, samples from wells 50M5, 50M25, 50M26, 50M29, and 50M30 were analyzed for ${ }^{3} \mathrm{H} /{ }^{3} \mathrm{He}$ to help verify apparent ages determined from the concentrations of CFCs.

Samples were collected from 17 wells in April 1999. Well cluster 50M29 was installed after results from this sampling were obtained in hopes of collecting water of an age between that of the young and old water sampled in 1999. Water was collected from wells in this cluster in April 2000. Water from well 50M27 was analyzed for nutrient concentrations in March 2000 as a part of the ongoing Polecat Creek project; this well did not yield sufficient water for CFC analysis.

Hydrologic conditions in 1999 and 2000 were variable and did not reflect the seasonal conditions typical for Virginia in which ground-water levels are high in the spring and low in the summer and fall; 1998 probably represents hydrologic conditions of a typical year better than 1999 or 2000 (fig. 47). Samples were

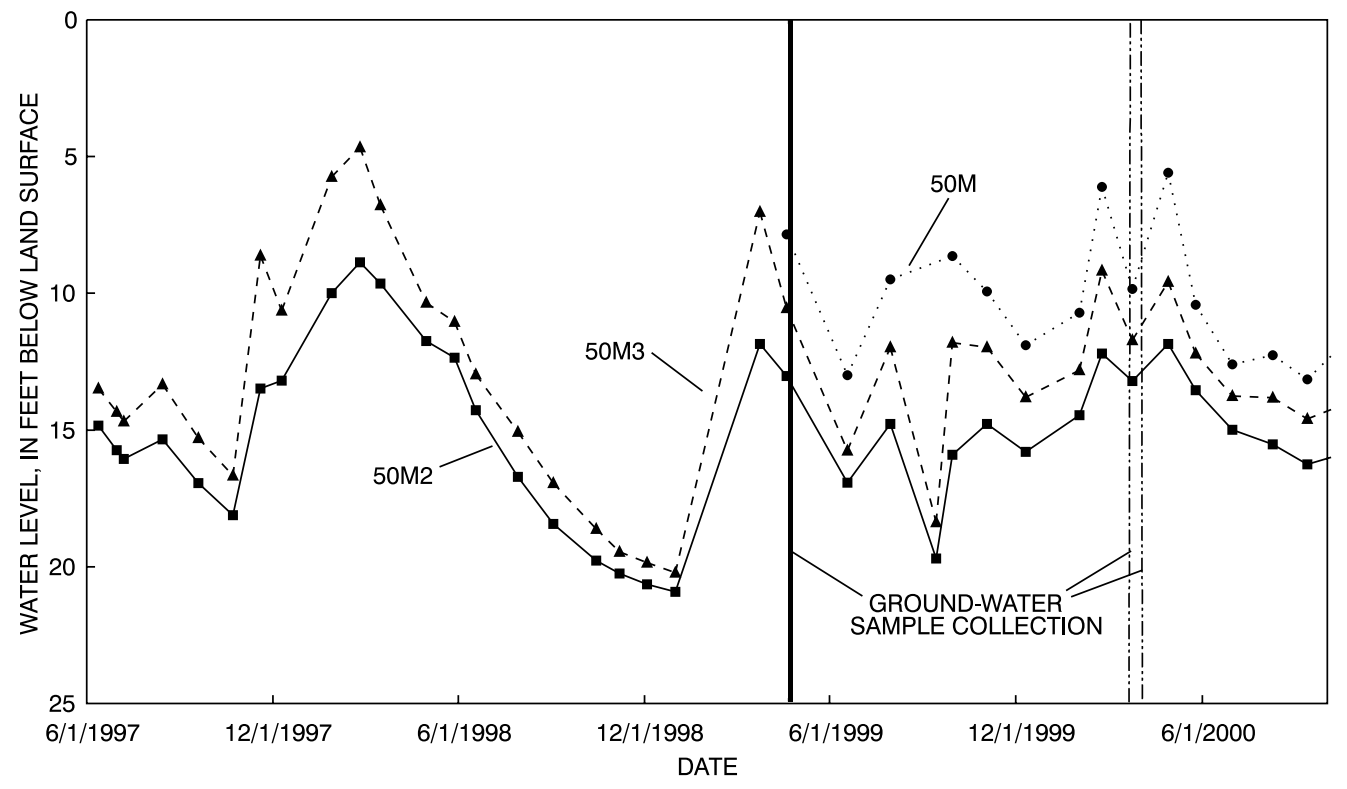

Figure 47. Ground-water levels at well cluster 50M2, Polecat Creek Watershed, Va., June 1, 1997, through December 1, 2000. 
collected in 1999 shortly after the seasonal high in ground-water levels. Water levels during the 2000 sample collection were similar to those when samples were collected in 1999.

\section{Distribution of Nitrogen, Dissolved Oxygen, and Methane in Ground Water}

$\mathrm{NO}_{3}^{-}$is the dominant nongaseous $\mathrm{N}$ species in ground water of the Polecat Creek Watershed; concentrations of ammonia plus organic $\mathrm{N}, \mathrm{NH}_{3}$, and $\mathrm{NO}_{2}^{-}$ were near the respective MRLs. In the following discussions, concentration of each $\mathrm{N}$ species is reported as the concentration of $\mathrm{N}$ rather than that of the respective $\mathrm{N}$ species. Concentrations of ammonia plus organic $\mathrm{N}$ were less than $0.100 \mathrm{mg} / \mathrm{L}$ in water from all except four wells (app. B); the maximum concentration was 0.380 $\mathrm{mg} / \mathrm{L}$ in water from well 50M27. Concentrations of $\mathrm{NH}_{3}$ were less than or equal to $0.020 \mathrm{mg} / \mathrm{L}$ in water from all except four wells; the maximum concentration was $0.063 \mathrm{mg} / \mathrm{L}$ in water from well 50M23. Similarly, concentrations of $\mathrm{NO}_{2}^{-}$were $0.013 \mathrm{mg} / \mathrm{L}$ or less in water from all wells. Thus, concentrations of $\mathrm{NO}_{2}^{-}$-plus- $\mathrm{NO}_{3}^{-}$ consisted almost entirely of $\mathrm{NO}_{3}^{-}$in all samples.

Concentrations of dissolved oxygen and $\mathrm{CH}_{4}$ generally indicate the ground water is well oxygenated and denitrification is not likely to have occurred at the Polecat Creek site. Concentrations of dissolved oxygen ranged from $0.3 \mathrm{mg} / \mathrm{L}$ in water from well 50M6 to $8.9 \mathrm{mg} / \mathrm{L}$ in water from well 50M17 (app. A and fig. 48). The only concentrations less than $1.50 \mathrm{mg} / \mathrm{L}$ were in water from wells in clusters 50M5, 50M24 (not along the well transect), and 50M29. These clusters are adjacent to the creek, near the end of the ground-waterflow paths. $\mathrm{CH}_{4}$ concentrations were less than the MRL of $0.01 \mathrm{mg} / \mathrm{L}$ in water from all wells except well 50M30 (app. C). The concentration in water from that well was $0.03 \mathrm{mg} / \mathrm{L}$.

$\mathrm{N}_{2}$ gas in water from all wells at the Polecat Creek site was at concentrations that reflect equilibrium with the atmosphere at the time of recharge. This lack of excess $\mathrm{N}_{2}$ gas indicates denitrification has not substantially affected the $\mathrm{NO}_{3}^{-}$concentration in water from any wells in the transect. The absence of denitrification is consistent with the abundance of dissolved oxygen throughout most of the shallow aquifer. Thus, $\mathrm{NO}_{3}^{-}$ concentrations reconstructed for excess $\mathrm{N}_{2}$ gas are the same as measured $\mathrm{NO}_{3}^{-}$concentrations. Because of the low concentrations of all $\mathrm{N}$ species except $\mathrm{NO}_{3}^{-}, \mathrm{NO}_{3}^{-}$ concentrations essentially reflect the $\mathrm{N}$ derived from land use in the recharge areas plus sources in aquifer sediments.

Concentrations of $\mathrm{NO}_{3}^{-}$were greatest in water from shallow wells in the upland fields and pasture and in the riparian forest buffer south of Polecat Creek; concentrations were least in water from deep wells in the uplands, from wells in the forest buffer north of the creek, and from the shallow well adjacent to the south side of the creek (fig. 48). Concentrations ranged from less than $0.050 \mathrm{mg} / \mathrm{L}$ in water from well $50 \mathrm{M} 30$ to $7.42 \mathrm{mg} / \mathrm{L}$ in water from well 50M27.

Beneath the upland south of Polecat Creek, the $\mathrm{NO}_{3}^{-}$concentration in water from well 50M7 was only $0.230 \mathrm{mg} / \mathrm{L}$ (fig. 48). The concentration in water from well 50M27, the shallower well at the edge of the field, however, was $7.42 \mathrm{mg} / \mathrm{L}$, greater than that in water from any other wells in the transect. Concentrations in water from wells in the forest buffer south of the creek except well 50M30 (wells 50M25, 50M26, and 50M29) were elevated and decreased from the field to the creek.

Beneath the upland cluster north of the creek (cluster 50M2), concentrations of $\mathrm{NO}_{3}^{-}$were similar in water from the shallowest two wells (3.74 and $3.82 \mathrm{mg} / \mathrm{L}$ ) and decreased with depth to $0.252 \mathrm{mg} / \mathrm{L}$ (fig. 48). Concentrations in water at cluster 50M4 were slightly less than those in water from the shallow wells at cluster 50M2, ranging from 2.41 to $3.51 \mathrm{mg} / \mathrm{L}$. Concentrations of $\mathrm{NO}_{3}^{-}$in water from wells in the forest buffer north of the creek, however, were less than those in water from any wells beneath the uplands and varied little, ranging from 0.094 to $0.109 \mathrm{mg} / \mathrm{L}$.

\section{Distribution of Apparent Ages and Residence Times in Ground Water}

The apparent age of ground water can be determined by use of various tracers. Because of local conditions in the Polecat Creek Watershed, natural and anthropogenic sources of individual tracers appear to elevate concentrations of those tracers slightly; degradation, sorption, or other processes also can reduce concentrations of a tracer. Thus, different tracers and combinations of tracers were used to determine the apparent ground-water age of different ground-water samples. 
A

$A^{\prime}$

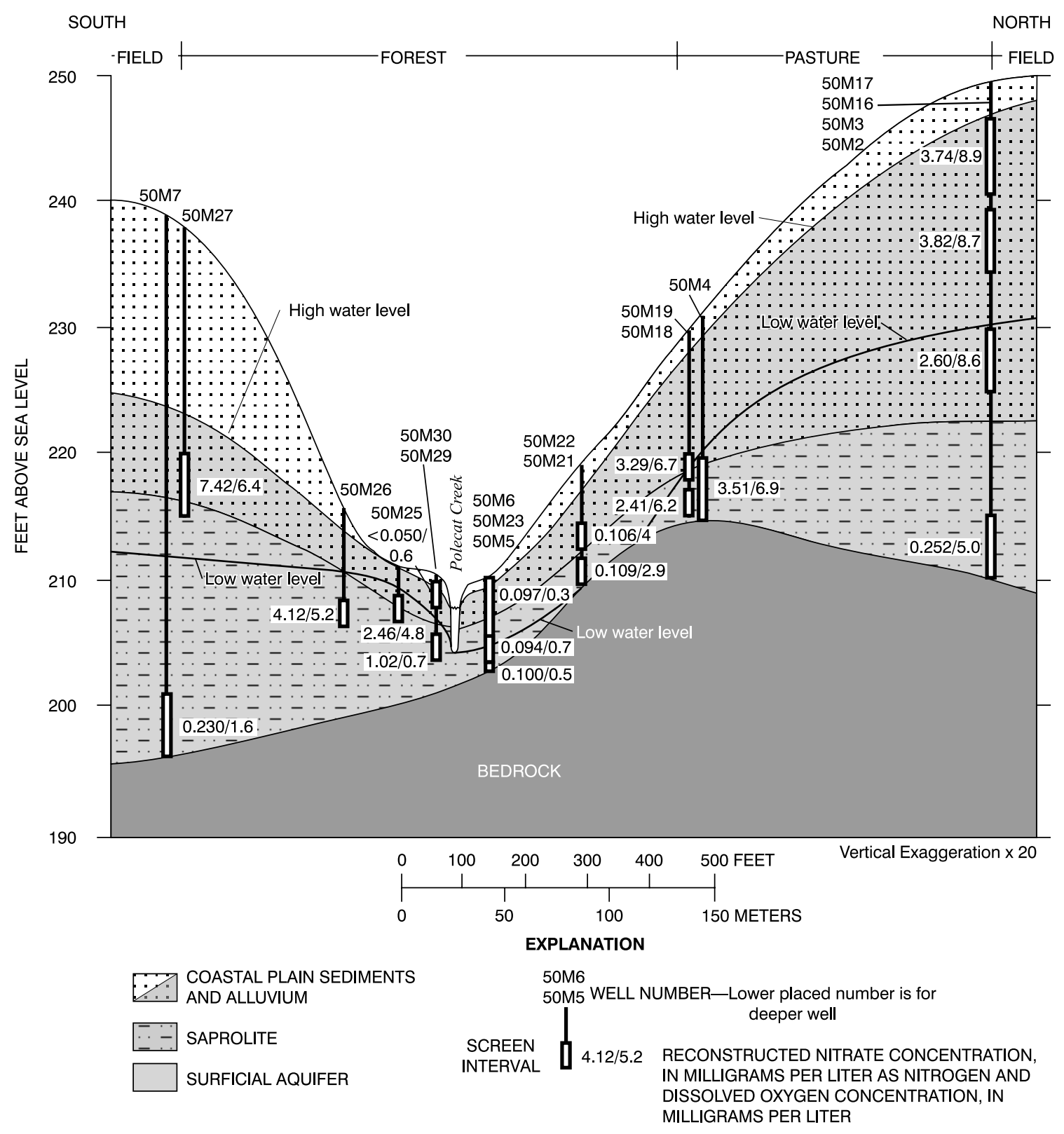

Figure 48. Distribution of reconstructed nitrate and field-measured dissolved-oxygen concentrations in ground water in the surficial aquifer, April 1999 and March and April 2000. 


\section{Methods used for determining a pparent ages}

Concentrations of CFC-11, CFC-12, CFC-113, ${ }^{3} \mathrm{H}$, and $\mathrm{SF}_{6}$ in water from wells in the Polecat Creek Watershed are compared with model calculations based on piston flow, binary mixing of young and blank (old) water, and exponential mixtures in figure 49. As is characteristic of most water samples from the Chesapeake Bay targeted watersheds, CFC-11 is depleted relative to CFC-12, presumably because of microbial degradation (fig. 49A). Most samples for CFC-12 and CFC-113 from the Polecat Creek Watershed plot close to the piston-flow line (fig. 49B). Most of the samples from the late 1980s to modern appear to be somewhat elevated in CFC-12, plotting approximately parallel to the pistonflow line. Somewhat elevated concentrations of CFC-12 also were observed at the Mahantango Creek and Muddy Creek Watersheds and may reflect enrichment in CFC-12 in air in the eastern United States, as has been measured in air from Shenandoah National Park in Virginia (Plummer and others, 2001). The limited ${ }^{3} \mathrm{H}$ data in relation to CFC-12 and CFC-113 indicate mixtures.

The apparent age of ground water in the Polecat Creek Watershed was determined primarily from concentrations of CFC-12, CFC-113, and $\mathrm{SF}_{6}$ (app. C). The data for $\mathrm{CFC}-11$ were used only in combination with data for CFC-12 and CFC-113 in water from well $50 \mathrm{M} 2$. The tracers used for determination of apparent age for a given water sample were selected because they appeared to be the tracers least likely to be contaminated, degraded, or adsorbed to sediment. In water from all wells except wells 50M3 and 50M5, two tracers could be used because their concentrations either appear to reflect piston flow or a mixture of at least two ages (fig. 49). The use of the piston-flow model for the two samples for which only one tracer was used, however, does not mean the samples were not mixtures, only that the possibility of mixtures could not be evaluated.

Although the apparent age of water from all except two wells could be calculated with the binarymixing model, water from many wells reflect piston flow (100 percent the young fraction) and contained no pre-CFC water. The wells in which water consisted of mixtures generally were in the riparian forest buffer where the area temporally alternated between being a recharge and discharge area.

\section{Apparent ages of ground water}

The apparent age of ground water at the Polecat Creek site was oldest near the base of the surficial aquifer and youngest near the water table and beneath the forest buffer north of the creek. The oldest water was 30 years from well 50M2; the youngest waters were mixtures that likely included modern water from wells $50 \mathrm{M} 21,50 \mathrm{M} 22$, and 50M6 in the forest buffer north of the creek (fig. 50).

Beneath the upland south of Polecat Creek, the apparent age of water from well 50M7 at the bottom of the surficial aquifer was 27 years, similar to that of water from wells 50M2 and 50M5; the apparent age of water from well 50M27 was not determined because the well would not yield sufficient water to collect a representative CFC sample.

South of the creek, the apparent age of water from wells beneath the forest buffer was younger than that of water from well 50M7. The apparent age of water from wells 50M 25 and 50M 26 was 5 and 6 years, respectively. Water from wells 50M29 and 50M30 contained mixtures; the young fractions were 15 to 16 years old in water from both wells. Approximately 88 percent of the water from well $50 \mathrm{M} 29$ was the young fraction, whereas only 64 percent of the water from well 50M30, the shallower well, was the young fraction. In the valley south of the creek, shallow ground water discharges to the surface when water levels are high and is recharged when water levels are low (fig. 51). Consequently, water recharged through the fields that flows beneath the forest buffer likely mixes with water recharged through the forest buffer. Because of the infinite number of possible mixtures, a binary mixture of water containing no CFCs and the youngest water possible was assumed. In waters beneath the forest buffer having elevated $\mathrm{NO}_{3}^{-}$concentrations, however, it is likely the water contains young water recharged through the upland field mixed with even younger water recharged through the forest buffer. The age distribution of water recharged through the buffer likely ranges from modern to the time the water was recharged through the field. The apparent age determined from ${ }^{3} \mathrm{H} /{ }^{3} \mathrm{He}$ substantiates the likelihood of recharge by such young water through the forest buffer (fig. 49).

In the uplands north of the creek, the apparent age of water from wells in cluster 50M2 increased with depth from 3 to 30 years, reflecting the effects of recharge at the water table and downward flow through the aquifer. The apparent age of the water from all wells at cluster 50M4 was older than the shallow water at cluster 50M2 and differed little among wells in the cluster, ranging from 9 to 11.3 years. 

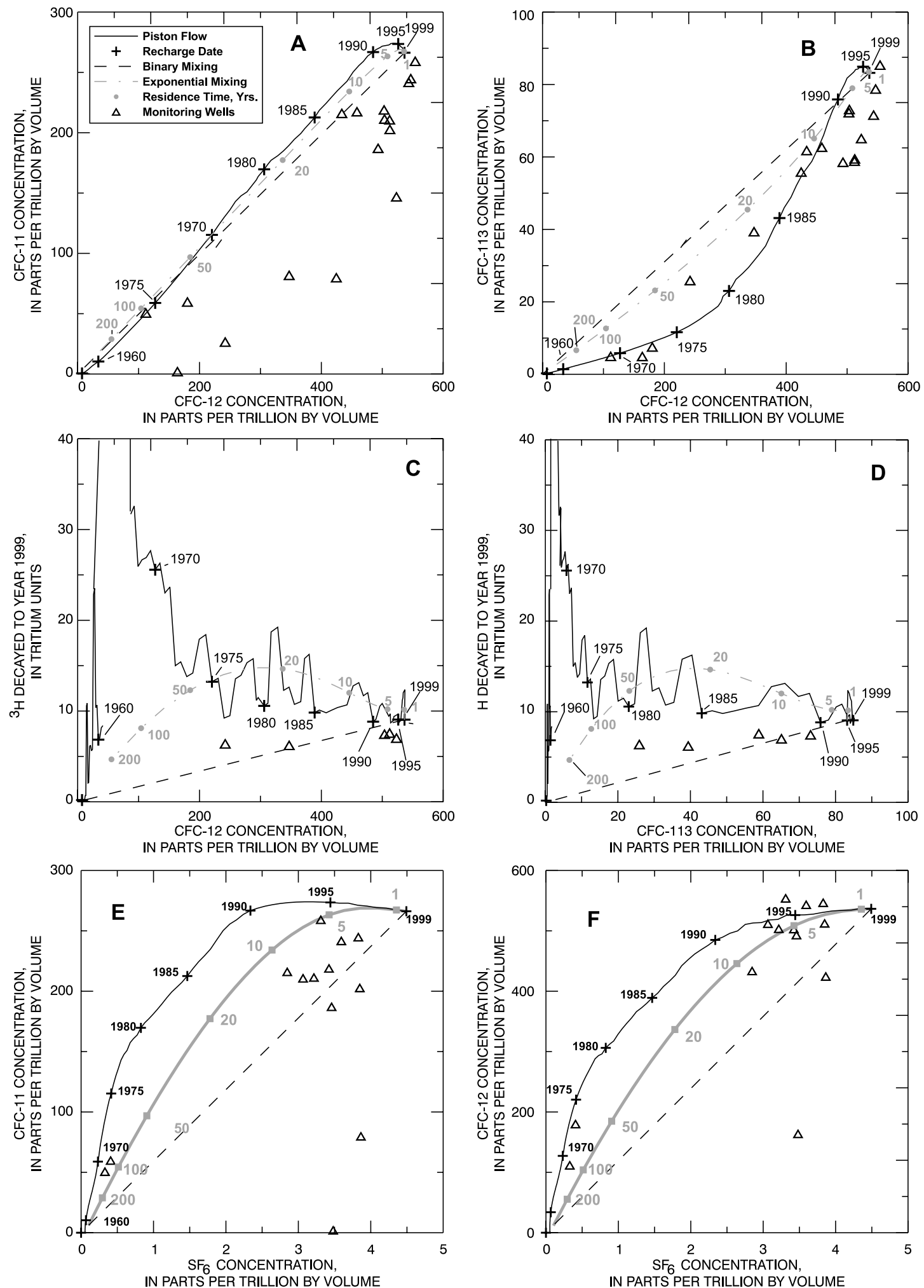

Figure 49. Comparison of concentrations of chlorofluorocarbon-11 (CFC-11), chlorofluorocarbon-12 (CFC-12), chlorofluorocarbon-113 (CFC-113), tritium $\left({ }^{3} \mathrm{H}\right)$, and sulfur hexafluoride $\left(\mathrm{SF}_{6}\right)$ in water from wells in the Polecat Creek Watershed, Va. 


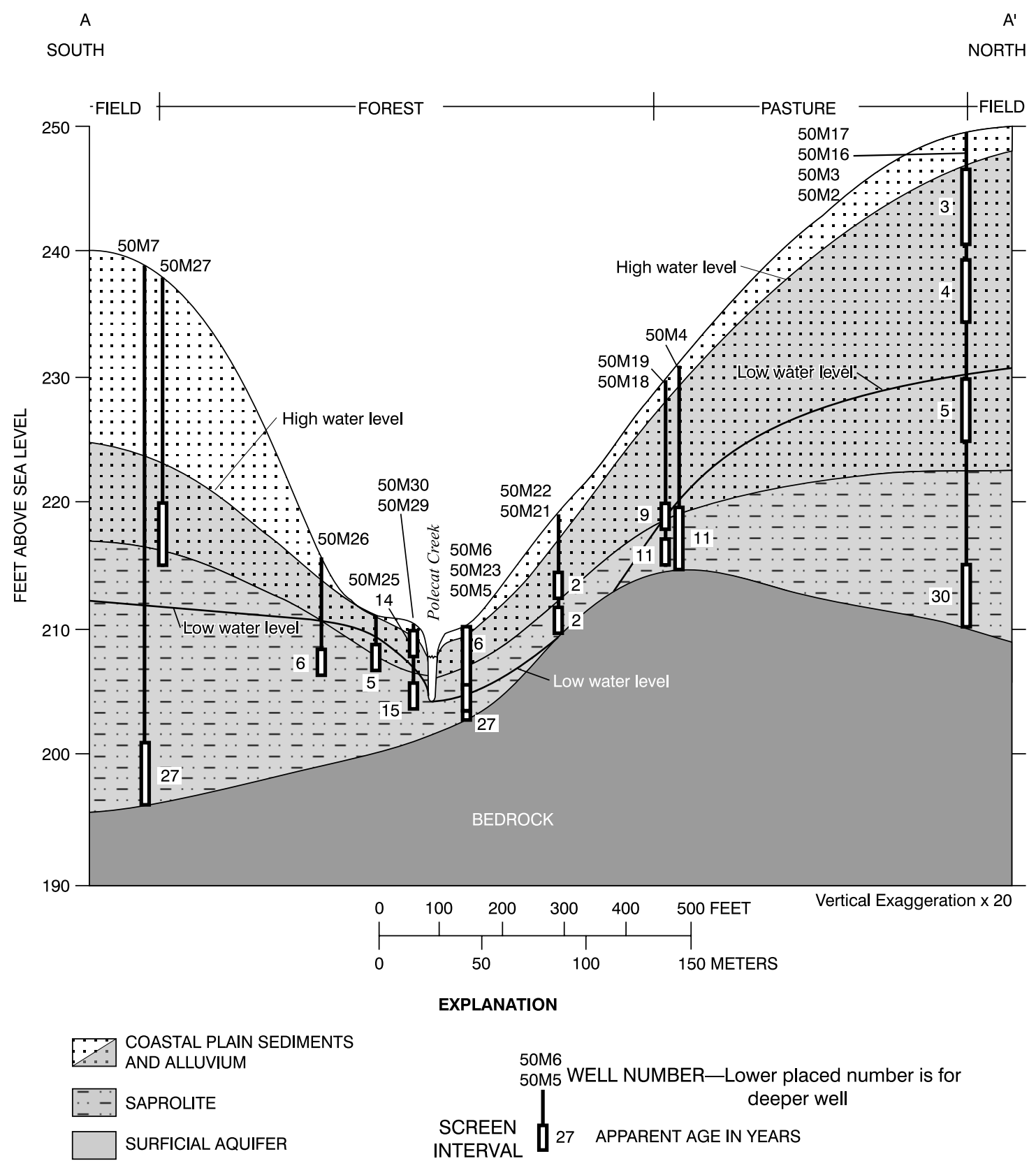

Figure 50. Distribution in apparent chlorofluorocarbon (CFC) and sulfur hexafluoride $\left(\mathrm{SF}_{6}\right)$ age of ground water in the surficial aquifer in the Polecat Creek Watershed, April 1999 and April 2000. 

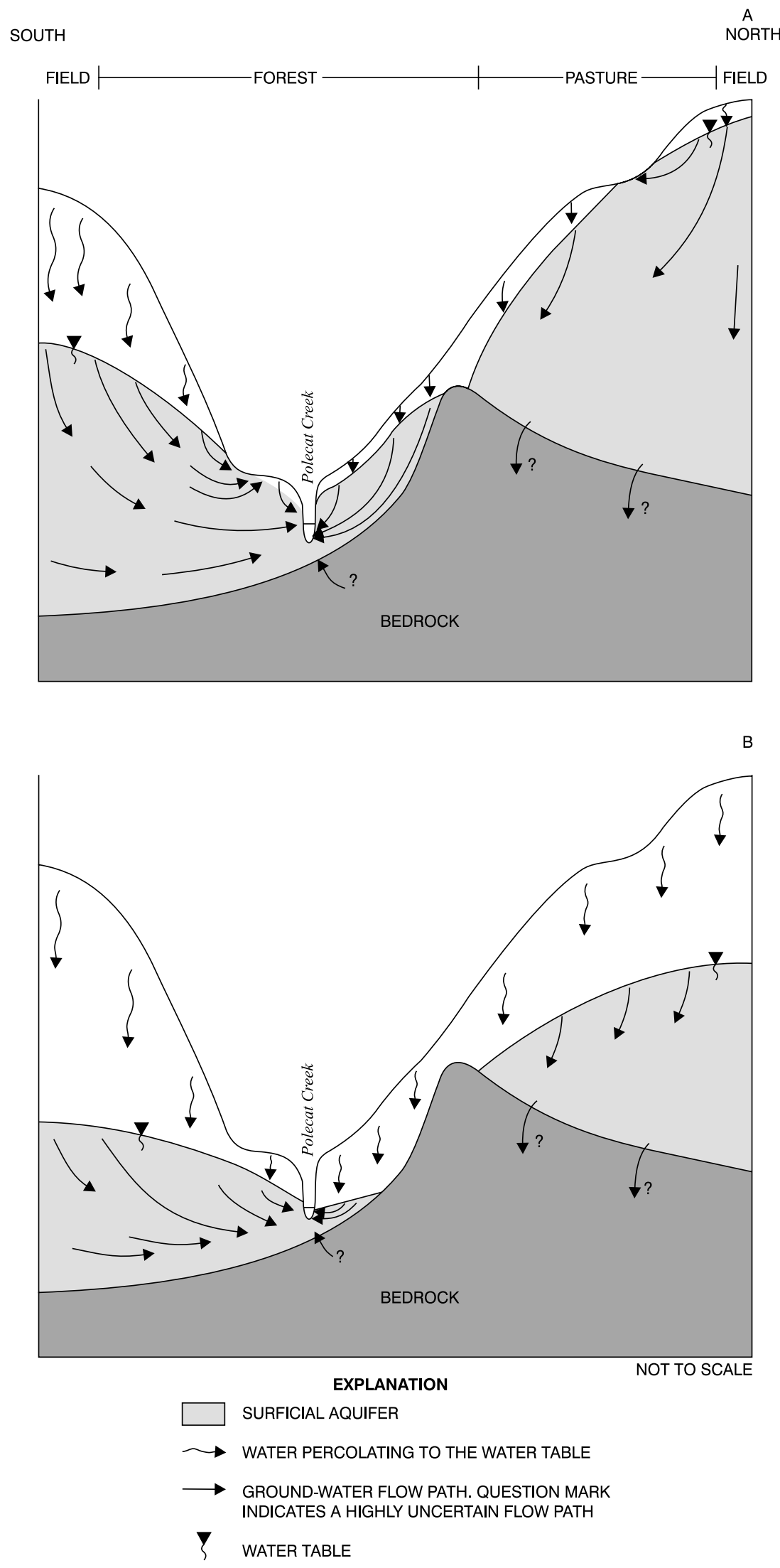

Figure 51. Schematic showing shallow ground-water flow during high (A) and low (B) ground-water levels. 
The apparent age of the ground water beneath the north riparian forest reflects the effects of recharge through the buffer. The water from both wells in cluster 50M21 was modern, about 93 percent of the water from the deep well was modern, and 96 percent from the shallow well was modern. At cluster 50M5, the apparent age of water from well 50M5 was 27 years; 94 percent of the water from well 50M6 was modern. The presence of modern water results from recharge through the forest buffer and is consistent with part of the aquifer becoming unsaturated through its full thickness from the summer into early winter then being locally recharged through the buffer. The presence of modern water also indicates the lack of flow from cluster 50M4 (10-yearold water) beneath the forest buffer.

The apparent age and silica concentration of water from all wells indicate water from well 50M5 likely has encountered different conditions than water from other wells at the Polecat Creek site. The apparent age of ground water from all wells except well 50M5 is correlated positively $\left(\mathrm{R}^{2}=0.86\right)$ with concentrations of dissolved silica in the ground water (fig. 52). Water from well 50M5 deviates from this relation more than water from any other well. The silica concentration in the water from this well is low for the apparent age of the water and could result from the water flowing through the bedrock a large part of the time since it was recharged. The contact area between the water and aqui- fer material would likely be less in the bedrock than in the unconsolidated sediments of the surficial aquifer. The mineral composition of the bedrock aquifer also could differ from that of the shallow aquifer. These factors could limit the rate of silica dissolution in ground water in the bedrock aquifer.

\section{Relation of Nitrogen Concentrations, Apparent Age, and Sources}

$\mathrm{N}$ in ground water can be derived from several potential sources. Atmospheric deposition is a source that contributes about 20 percent of the $\mathrm{N}$ to the Polecat Creek Watershed (Preston and Brakebill, 1999). This source likely is distributed somewhat evenly across the watershed. Organic material in aquifer sediments can be another source of N. Saprolite, however, typically contains little organic material; Coastal Plain sediments at the site also contain little organic material. Alluvial sediments contain variable amounts of organic material depending on conditions at the time of deposition. Additional $\mathrm{N}$ sources depend on the land use where the ground water is recharged. $\mathrm{N}$ derived from the riparian forest buffer primarily would leach from decaying plant material in the organic litter on the forest floor and in the soil. Residential sources (septic-tank seepage and fertilizer) contribute about 6 percent of the $\mathrm{N}$ to the watershed (Preston and Brakebill, 1999) but probably are

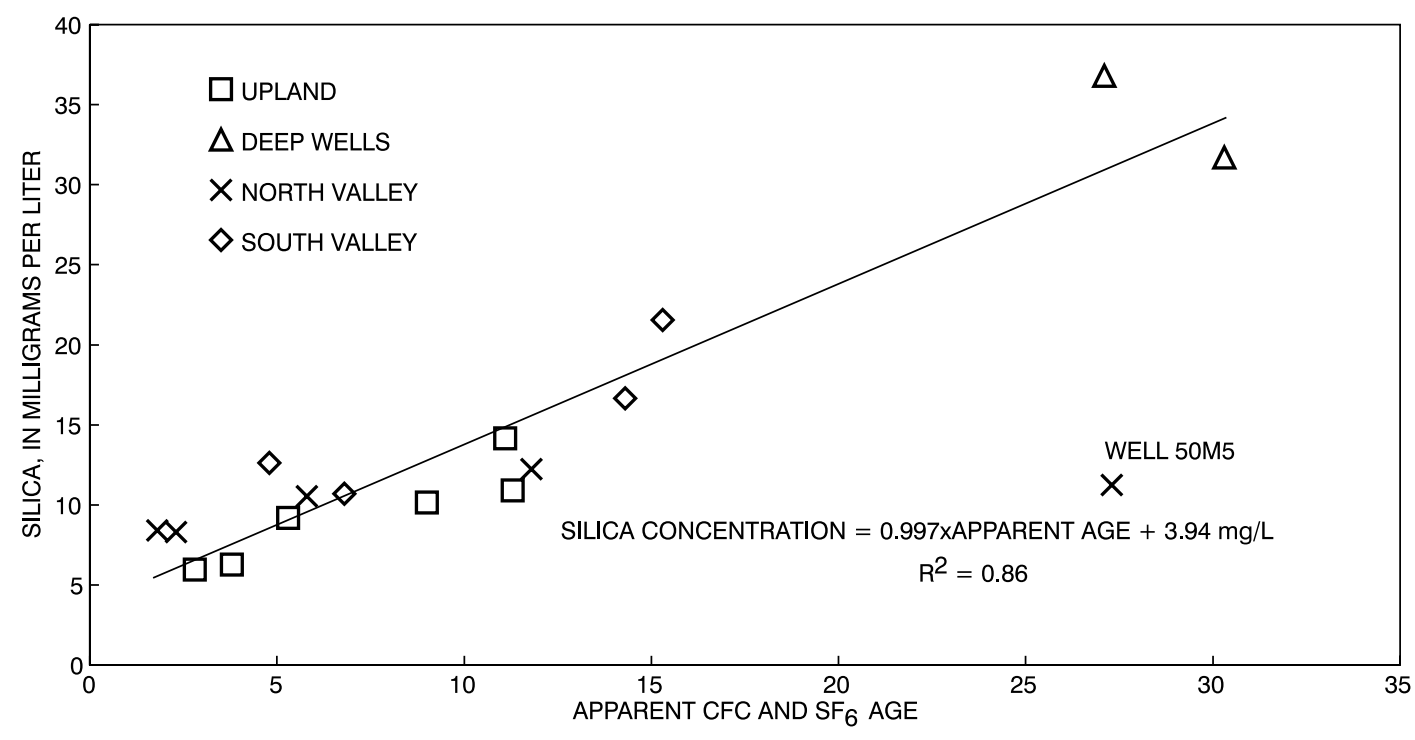

Figure 52. Relation of apparent chlorofluorocarbon (CFC) and sulfur hexafluoride $\left(\mathrm{SF}_{6}\right)$ age to silica concentration in ground water in the surficial aquifer in the Polecat Creek Watershed, April 1999 and April 2000. 
limited in the transect because no homes are along the apparent ground-water-flow paths. $\mathrm{N}$ derived from the cultivated fields would leach primarily from commercial fertilizer applied to fields and decaying crop litter on the land surface and in the soil; commercial fertilizer contributes about 46 percent of the $\mathrm{N}$ to the watershed (Preston and Brakebill, 1999). N derived from the pasture would leach primarily from animal manure from horses allowed to graze in the pasture and from decaying plant material in the pasture; animal manure contributes about 28 percent of the $\mathrm{N}$ to the watershed (Preston and Brakebill, 1999).

The low concentrations of $\mathrm{NO}_{3}^{-}$in ground water beneath the north forest buffer appear to reflect background concentrations. The $\delta^{15} \mathrm{~N}$ of $\mathrm{NO}_{3}^{-}$could not be determined on ground water from beneath the north riparian forest buffer because of the low $\mathrm{NO}_{3}^{-}$concentrations in these waters. The low concentrations of $\mathrm{NO}_{3}^{-}$ and the lack of excess $\mathrm{N}_{2}$ gas in water from wells in the north riparian forest buffer indicate little effect from commercial fertilizer application and a lack of denitrification. Thus, the young age of the water, low $\mathrm{NO}_{3}^{-}$concentration, and the absence of excess $\mathrm{N}_{2}$ gas collectively indicate the lack of ground-water flow from the pasture beneath the forest buffer. Because of the young apparent age of this water, these low $\mathrm{NO}_{3}^{-}$concentrations reflect recent inputs to the ground water. $\mathrm{NO}_{3}^{-}$in water from wells beneath the forest buffer likely was derived from atmospheric deposition, the organic litter in the forest recharge area, and the organic material in the alluvial sediments. The low concentrations of $\mathrm{NO}_{3}^{-}$in water from these wells reflect background concentrations and indicate input from these sources to the ground water at the local scale is small even though atmospheric deposition contributes about 20 percent of the $\mathrm{N}$ to the watershed. A large part of the contribution by atmospheric deposition appears to be removed by the forest vegetation.

Low concentrations of $\mathrm{NO}_{3}^{-}$in water from deep wells beneath the uplands indicate the water was probably recharged through the fields before significant application of commercial fertilizer or was recharged through adjacent forested areas. The $\delta^{15} \mathrm{~N}_{\text {of }} \mathrm{NO}_{3}^{-}$could not be determined in samples from the deep wells beneath the uplands because of the low $\mathrm{NO}_{3}^{-}$concentrations in these waters.

The $\delta^{15} \mathrm{~N}$ composition of the $\mathrm{NO}_{3}^{-}$(app. B) in shallow ground water beneath the uplands and in water beneath the south forest buffer indicates commercial fertilizer is likely the primary source of elevated $\mathrm{NO}_{3}^{-}$in the ground water at the Polecat Creek site. The $\delta^{15} \mathrm{~N}$ of $\mathrm{NO}_{3}^{-}$in water from these wells ranged from 2.1 to $4.3 \%$. This is in the range for $\mathrm{N}$ derived from commercial fertilizers and naturally occurring plant material and also indicates the lack of fractionation of the $\delta^{15} \mathrm{~N}$ from denitrification. The low $\delta^{15} \mathrm{~N}$ values in water from cluster 50M4 indicate $\mathrm{NO}_{3}^{-}$at this cluster is derived primarily from commercial fertilizer and is affected little by animal manure. Thus, elevated $\mathrm{NO}_{3}^{-}$in the ground water appears to be derived primarily from commercial fertilizer applied to the fields; little $\mathrm{N}$ appears to be derived from the horses that grazed in the pasture and in the forest.

A comparison of the apparent recharge date and reconstructed $\mathrm{NO}_{3}^{-}$concentrations of these waters indicates an increase in the $\mathrm{NO}_{3}^{-}$contribution to ground water recharged through the fields that possibly occurred around 1985 (fig. 53). In water recharged before 1985, concentrations were about $0.25 \mathrm{mg} / \mathrm{L}$ or less. After 1985, concentrations increased to greater than $2.5 \mathrm{mg} / \mathrm{L}$. Because of the lack of samples of water recharged between 1972 and 1985, however, the timing of the increase in $\mathrm{N}$ is uncertain.

The relation between silica concentrations and apparent ground-water age (fig. 52) and between reconstructed $\mathrm{NO}_{3}^{-}$concentration and apparent ground-water age (fig. 53A) are reflected in a strong relation $\left(\mathrm{R}^{2}=0.82\right)$ between silica concentration and reconstructed $\mathrm{NO}_{3}^{-}$concentration (fig. 53B). Although silica concentrations were not measured in water from the creek, the strength of these relations indicates the potential for future use of silica concentrations as an indicator of the average age of ground-water discharge in the creek and relating this age to $\mathrm{NO}_{3}^{-}$in the discharging ground water.

\section{Factors Affecting Residence-Time Distribution, Nitrogen Oc currence, and Disc harge to Streams}

Land use in the recharge area, combined with the physical constraints of the ground-water-flow system, are the primary factors affecting ground-water discharge to Polecat Creek and the distribution in apparent age and $\mathrm{NO}_{3}^{-}$concentrations in the ground-water discharge. The characteristics of the physical constraints differ between the uplands and the valley; such differences likely are typical of many watersheds in the Piedmont crystalline HGMR and other HGMRs having a surficial aquifer underlain by a shallow confining unit. Physical characteristics south of the creek also differ from those north 

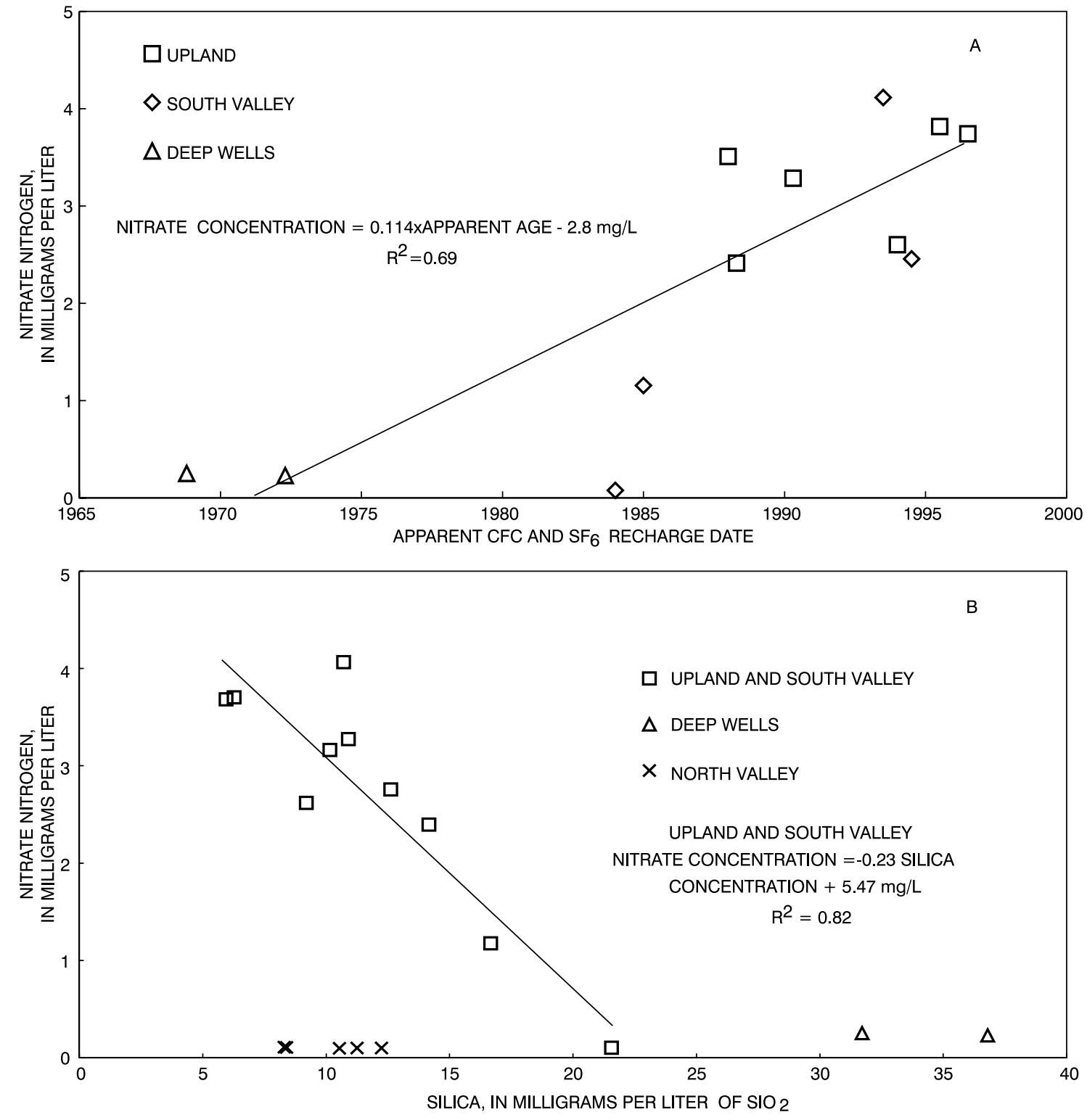

Figure 53. Relation of apparent recharge date to reconstructed nitrate concentrations $(A)$ and to silica concentration (B) in ground water in the surficial aquifer of the Polecat Creek Watershed, Va., April 1999 and April 2000. 
of the creek; such differences demonstrate, in part, the range in conditions that likely can be encountered in such systems.

The physical constraints result primarily from the effects that geology and topography have on aquifer permeability and thickness. Although the Coastal Plain sediments present at the Polecat Creek site typically are not present in most of the Piedmont Physiographic Province, the grain size and resulting permeability of the Coastal Plain sediments appear to differ little from those of the saprolite. Consequently, the Polecat Creek site likely is representative of conditions in the Piedmont where Coastal Plain sediments are absent and the saprolite largely consists of fine-grained sediment as it does at this site.

The depth to bedrock is a major factor that affects ground-water flow and discharge. Because of the greater depth to bedrock south of the creek than north of the creek, the water table generally remains more than $20 \mathrm{ft}$ beneath land surface and ground water does not discharge to land surface beneath the uplands south of the creek (fig. 51). When ground-water levels are high, ground water discharges at the base of the valley slope and to the valley south of the creek. This discharge likely is the shallow, young water that recharged through the forest buffer between the valley and the upland field. The age of this water is unknown but likely ranges from less than a year to several years old. Such water would have low $\mathrm{NO}_{3}^{-}$concentrations. If water recharged through the field and having high $\mathrm{NO}_{3}^{-}$concentrations discharges to the valley, it likely would discharge closer to the creek, not at the base of the valley slope.

Processes in the riparian forest, particularly denitrification in the forest soil, can reduce $\mathrm{NO}_{3}^{-}$concentrations in ground water discharging to the valley. Ditches at the base of slopes and in the valleys, however, likely enhance ground-water discharge and provide a short-circuit drain to the creek. Discharge to the creek through ditches likely reduces the effects of the riparian processes on $\mathrm{NO}_{3}^{-}$concentrations. The magnitude of the effects of riparian processes and discharge through ditches, however, are not certain. Filling the ditches can reduce the effects of short-circuiting.

Part of the water that does not discharge to land surface discharges through evapotranspiration. The fate of $\mathrm{NO}_{3}^{-}$in this water is uncertain. Part of the $\mathrm{NO}_{3}^{-}$is incorporated into plant tissue; this $\mathrm{N}$ ultimately would be released when the plant dies and decomposes. It is uncertain whether the remaining $\mathrm{NO}_{3}^{-}$taken up by the plants is released to the atmosphere with evaporating water or remains on leaves when the water evaporates from the leaves. $\mathrm{N}$ released to the atmosphere would be transported elsewhere and redeposited as atmospheric deposition. $\mathrm{N}$ remaining on the leaves would be washed from the leaves by precipitation to be recycled into the system or denitrified in the organic forest soils.

Water that flows beneath the riparian forest to the creek discharges though the streambed and through seeps in the streambank. Many of these seeps appear to be near the contacts of zones having slightly contrasting permeability. Such contrasts appear to result from slight differences in the silt and clay content of the sediment. Water from wells in cluster 50M29 indicates shallow water flowing beneath the south valley and discharging to the creek is of intermediate apparent age (15 years) and has low $\mathrm{NO}_{3}^{-}$concentrations; water older than 15 years, however, likely is present at depths greater than that of well 50M29. Consequently, the distribution in the age of the ground-water discharge to the creek remains unknown.

North of Polecat Creek, the physical constraints differ substantially because of the shallower bedrock and the apparent barrier to ground-water flow. During seasonally high water levels, the water table approaches land surface beneath much of the uplands and intersects land surface at swales and ditches (fig. 51). During these times, ground water discharges to the swales and ditches; such discharge is likely young water and has high $\mathrm{NO}_{3}^{-}$concentrations. The age of this water is unknown but likely ranges from less than a year to several years old. Because the seasonally high water table was not as high in 1999 and 2000 as in 1998, little water discharged to the swales and ditches. Consequently, samples of such discharge could not be collected and analyzed for apparent age and $\mathrm{NO}_{3}^{-}$concentration. Discharge to the swales and ditches likely removes a large part of the recently recharged water; water that remains in the aquifer flows through the deeper parts of the aquifer system. The ultimate flow path for water recharged through the north uplands that remains in the aquifer system, however, remains uncertain. Unlike the south side of the creek, this water does not appear to discharge to land surface at the base of the valley slope near the transect.

Although forest buffers commonly are credited with reducing $\mathrm{NO}_{3}^{-}$concentrations in ground water that flows beneath them (Lowrance, 1992; Jordan and others, 1993), factors other than uptake by the buffer also appear to cause the low $\mathrm{NO}_{3}^{-}$concentrations in ground water beneath the buffers. The abundance of dissolved 
oxygen, the lack of excess $\mathrm{N}_{2}$ gas, and the $\delta^{15} \mathrm{~N}_{\text {of }} \mathrm{NO}_{3}^{-}$ at the Polecat Creek site indicate denitrification is a minimal factor in the forest buffer on either side of Polecat Creek. Recharge through the buffer, however, was clearly an important factor causing low concentrations of $\mathrm{NO}_{3}^{-}$in the ground water beneath the buffer north of the creek. Concentrations of $\mathrm{NO}_{3}^{-}$in water recharged through the forest buffer were only about $0.1 \mathrm{mg} / \mathrm{L}$. Beneath the forest buffer south of the creek, the decrease in $\mathrm{NO}_{3}^{-}$concentration from the upland fields to the creek results in part from the increased apparent age of the water and associated lower rate of $\mathrm{NO}_{3}^{-}$input when the older water recharged the aquifer. Dilution by recharge through the forest buffer likely is a factor south of the creek also, particularly in water from well 50M30. Dilution by recharge through the buffer does not decrease the load of $\mathrm{NO}_{3}^{-}$discharged with the ground water to the streams. Such recharge increases the amount of ground water that ultimately discharges; the $\mathrm{NO}_{3}^{-}$concentration of this discharge, however, is low.

Ground-water discharge pathways can affect the $\mathrm{NO}_{3}^{-}$concentration and load discharged to streams seasonally and over the years. When ground-water levels are high, much of the ground water flows along short, shallow paths and discharges to ditches, swales, the base of the valley slope, and lowlands. Such water likely is young and reflects recent, nearby land use. Consequently, these discharges quickly (several years or less) reflect changes in land use. High ground-water levels that produce these discharges are typical in the late winter and spring during periods of surface runoff and high base flow.

Whether ground-water levels are high or low, water that flows along long, deep paths to the streams discharges as seeps or directly to the streambed. This is a discharge pathway throughout the year but is the primary discharge pathway when water levels are low, typically in the late summer and fall. Because of the limited amount of organic material in the saprolite, denitrification is not likely to decrease the $\mathrm{NO}_{3}^{-}$concentration in ground water that flows along this path. Denitrification is possible in ground water that flows through the alluvium if the alluvium contains sufficient organic material; the role of such denitrification, however, appears to be limited. Controlling the source of $\mathrm{NO}_{3}^{-}$is likely the principle mechanism of controlling $\mathrm{NO}_{3}^{-}$in the groundwater discharge that flows along long, deep paths.

Water that flows along the long, deep paths and discharges to the creek is older than water discharging to the uplands and valley and reflects land use away from the discharge area. Consequently, discharge along these paths to the creek can take decades to reflect changing land use in the uplands. Thus, as the high $\mathrm{NO}_{3}^{-}$water flows from the fields to the creek, the $\mathrm{NO}_{3}^{-}$concentration in discharging ground water likely will increase in the future.

Overall, ground-water discharge is an important component of streamflow affecting both the quantity and quality of water in the Polecat Creek Watershed. Ground-water discharge contributes an average of 50 to 55 percent of the streamflow in the watershed. The median concentration of $\mathrm{NO}_{3}^{-}$in streamwater at the study site was $0.10 \mathrm{mg} / \mathrm{L}$ (Saied Mostaghimi, written commun., 2001), similar to concentrations in ground water recharged through the riparian forest north of Polecat Creek but much less than concentrations in agriculturally influenced ground water. Such concentrations in the streamwater are reasonable because forests cover most of the watershed upstream of the site. Because of agriculturally influenced ground-water discharge, $\mathrm{NO}_{3}^{-}$ concentrations likely increase as the creek flows through the study site.

Effective management of $\mathrm{N}$ in the Piedmont crystalline HGMR can incorporate a combination of natural processes and human-controlled activities. To effectively use natural processes, management techniques need to account for the flow paths of discharging ground water and the likely processes along each path. Because the saprolite that forms the shallow aquifer through which much of the ground water flows contains little organic material, $\mathrm{NO}_{3}^{-}$concentrations likely will be reduced little by denitrification in the aquifer. Denitrification likely is an important process only where ground water discharges through abundant organic material such as forest soils, some alluvium, and parts of streambeds. Elsewhere, control of the $\mathrm{N}$ sources and other practices will be necessary. Because of the slow rate of ground-water flow, implementation of management practices to reduce $\mathrm{NO}_{3}^{-}$concentrations can take years to be fully observed in streamwater quality. 


\section{References Cited}

Jordan, T.E., Correll, D.L., and Weller, D.E., 1993, Nutrient interception by a riparian forest receiving inputs from adjacent cropland: Journal of Environmental Quality, v. 22, no. 3 p. 467-473.

Mixon, R.B., Berquist, C.R., Jr., Newell, W.L., Johnson, G.H., Powars, D.S., Schindler, J.S., and Rader, E.K., 1989, Geologic map and generalized cross sections of the Coastal Plain and adjacent parts of the Piedmont, Virginia: U.S. Geological Survey Miscellaneous Investigations Series, Map I-2033, 2 pls.

Nelms, D.L., Harlow, G.E., Jr., and Hayes, D.C., 1997, Base-flow characteristics of streams in the Valley and Ridge, Blue Ridge, and Piedmont Physiographic Provinces of Virginia: U.S. Geological Survey Water-Supply Paper 2457, 48 p.

Plummer, L.N., Busenberg, Eurybiades, Böhlke, J.K., Nelms, D.L., Michel, R.L., and Schlosser, P., 2001, Groundwater residence times in Shenandoah National Park, Blue Ridge Mountains, Virginia, USA - A multi-tracer approach: Chemical Geology, v. 179/1-4, p. 93-111.

Preston, S.D., and Brakebill, J.W., 1999, Application of spatially referenced regression modeling for the evaluation of total nitrogen loading in the Chesapeake Bay Watershed: U.S. Geological Survey Water-Resources Investigations Report 99-4054, $8 \mathrm{p}$.

Prugh, B.J., Jr., Easton, F.J., and Lynch, D.D., 1985, Water-resources data, Virginia-Water year 1984: U.S. Geological Survey Water-Data Report VA-84-1, 405 p.

Virginia Division of Mineral Resources, 1993, Geologic map of Virginia: Department of Mines, Minerals, and Energy, 80 p., 1 pl.

\section{Muddy Creek Watershed, Virginia}

\author{
by Gary K. Speiran
}

The Muddy Creek Watershed was selected to represent the Valley and Ridge carbonate HGMR but also includes part of the Valley and Ridge siliciclastic HGMR. The watershed was selected on the basis of previous studies and some ongoing data collection. The USGS Potomac NAWQA Project originally studied the ground-water system underlying the watershed from 1992-96. The work presented in this section utilized the NAWQA results and collected additional data to understand the ground-water age dates and associated $\mathrm{N}$ concentrations in the watershed.

\section{Description of Study Area and Sampling Network}

Muddy Creek drains a rural watershed covering approximately $14.2 \mathrm{mi}^{2}$ in central Rockingham County, Va. (fig. 54). The Muddy Creek Watershed is characterized by narrow valleys, rolling uplands, and ridges. Little North Mountain forms a ridge that is the northwest boundary of the watershed (fig. 54). Elevation along this ridge ranges from about 2,200 to $2,740 \mathrm{ft}$ above sea level. Hopkins Ridge forms the southeast boundary of the watershed and ranges from 1,600 to $1,950 \mathrm{ft}$ above sea level. Elsewhere, land-surface elevation ranges from $1,320 \mathrm{ft}$ above sea level at a surface-water station at Mount Clinton (station 01621050) to more than 1,600 ft above sea level.

The watershed contains 73 percent agricultural, 22 percent forested, and 5 percent residential land (Anderson and others, 1976; U.S. Geological Survey, 1979) (fig. 54). Agricultural land includes cropland, pastures, livestock-raising areas (primarily poultry and cattle), and orchards. Forests cover small areas throughout the watershed but primarily cover the slopes of Hopkins Ridge and Little North Mountain. Residential land is scattered throughout the watershed. The small $\left(0.55 \mathrm{mi}^{2}\right)$ watershed of an unnamed tributary having headwaters on Little North Mountain is the site of a local-scale study area that was monitored more intensively than elsewhere in the Muddy Creek Watershed (fig. 54). Land use of this watershed is 52 percent agricultural, 48 percent forested, and less than 1 percent residential land. The forested area primarily covers Little North Mountain in the western part of the watershed. 


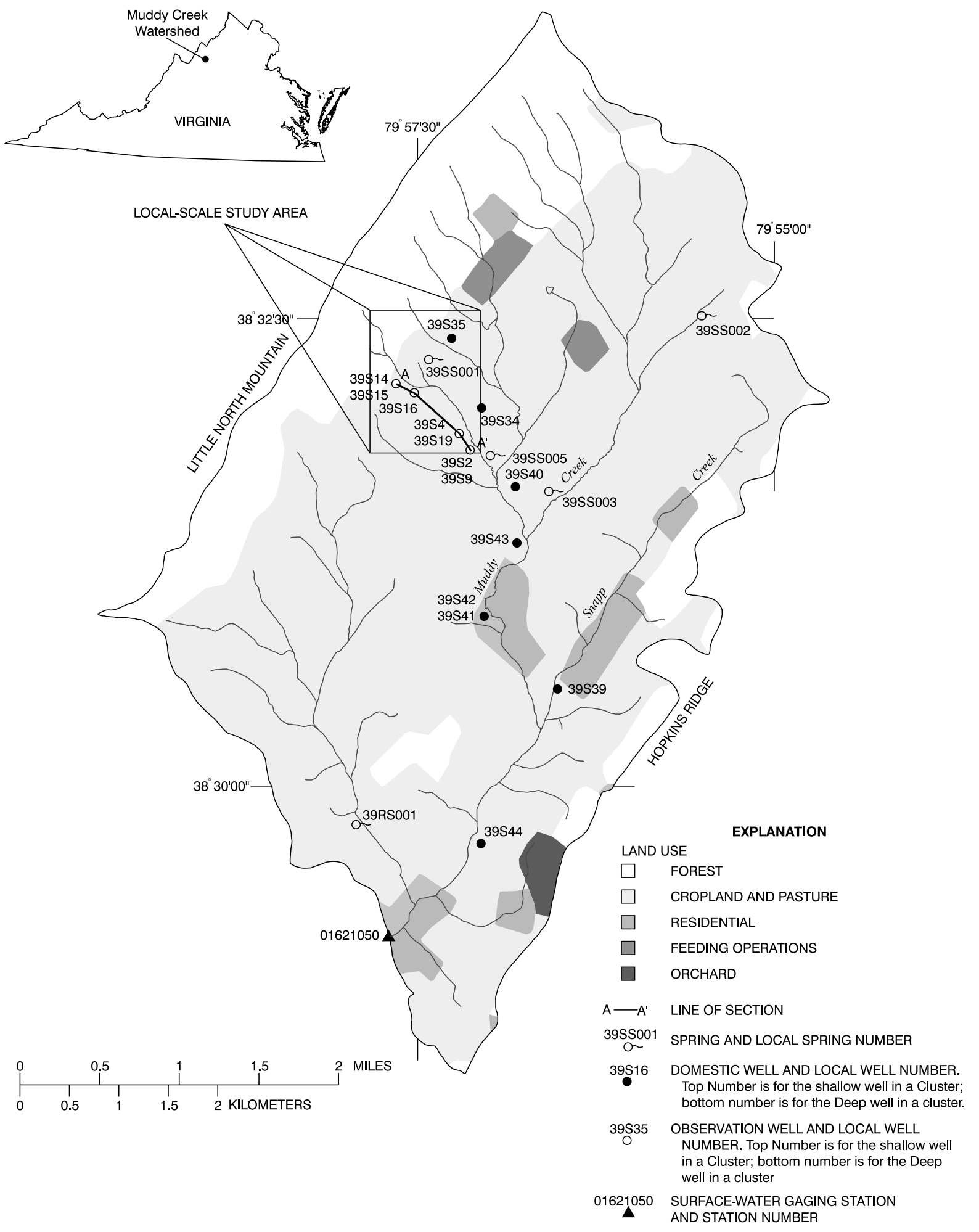

Figure 54. Location of the study area, sampling sites, geohydrologic section A-A', and land use in the Muddy Creek Watershed, Va. 


\section{Hydrogeology}

Ground water in the Muddy Creek Watershed flows through a bedrock and regolith aquifer system that is well-connected to the surface-water system. Vertical and lateral variability in the hydraulic characteristics of the aquifer system control ground-water flow.

\section{Hydrogeologic framework.-The Muddy}

Creek Watershed is underlain by bedrock that is covered by a mantle of unconsolidated rock called regolith. The regolith consists of saprolite, colluvium, and alluvium. The saprolite is derived from weathered bedrock. Colluvium consists of sediment eroded from slopes and subsequently deposited by gravity near the base of the slopes. Alluvium consists of sediment eroded from the land, transported by streams, and deposited in the stream valleys.
In the southeastern three quarters of the watershed, the bedrock consists primarily of limestone and dolomite (carbonate rock) formations of Middle Cambrian to Middle Ordovician age (Orndorff, 1995). Siliciclastic sandstone and shale of Middle Ordovician to Upper Devonian age form bedrock in the extreme western part of the watershed. These formations generally dip to the southeast and increase in age toward the northwest (fig. 55). The strike of the bedrock is to the northeast. The North Mountain fault zone is a major geologic structure in the western part of the watershed that passes through the local-scale study area (fig. 55). This zone consists of fault slivers of older rock thrust over younger rock.

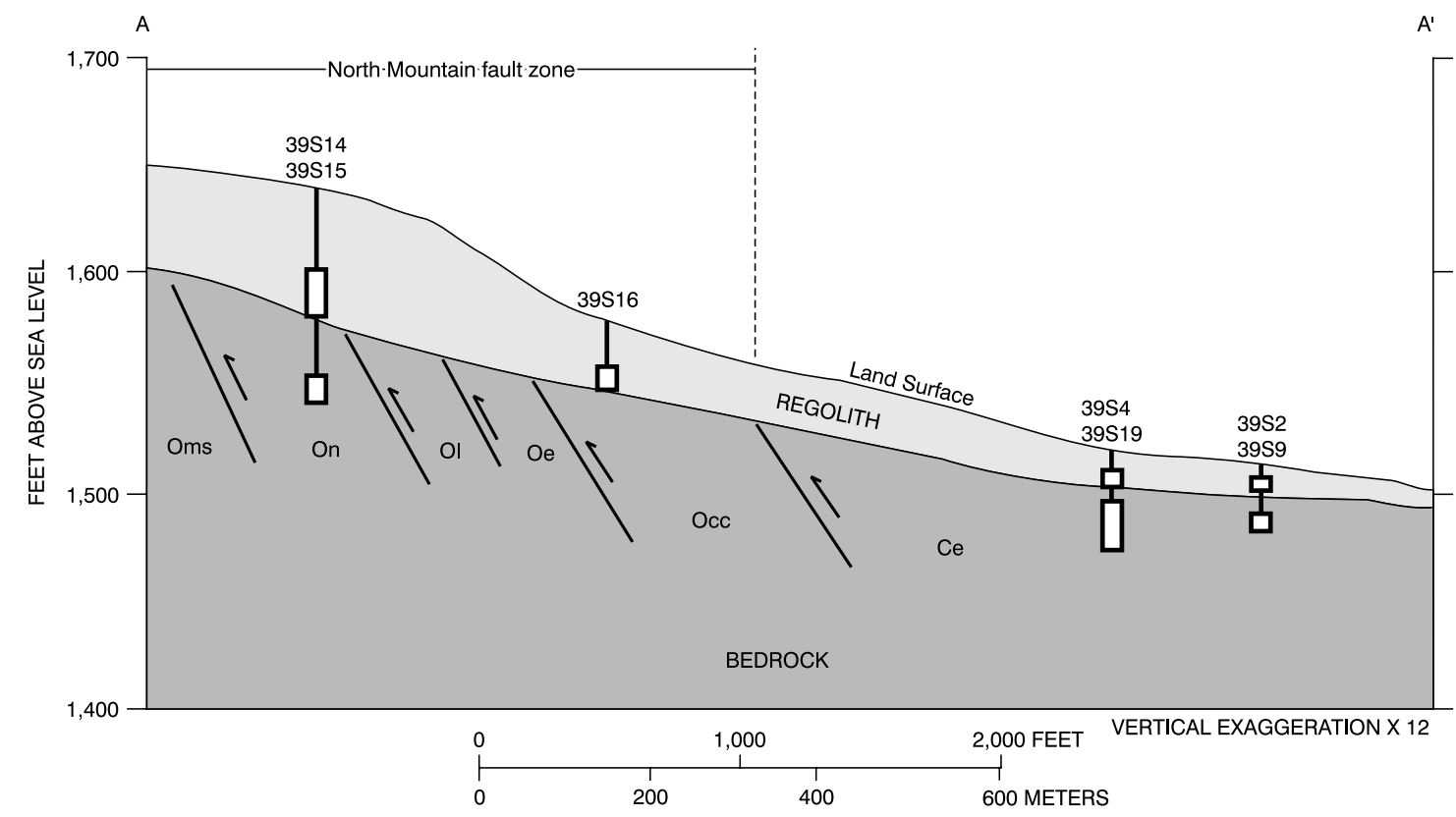

EXPLANATION
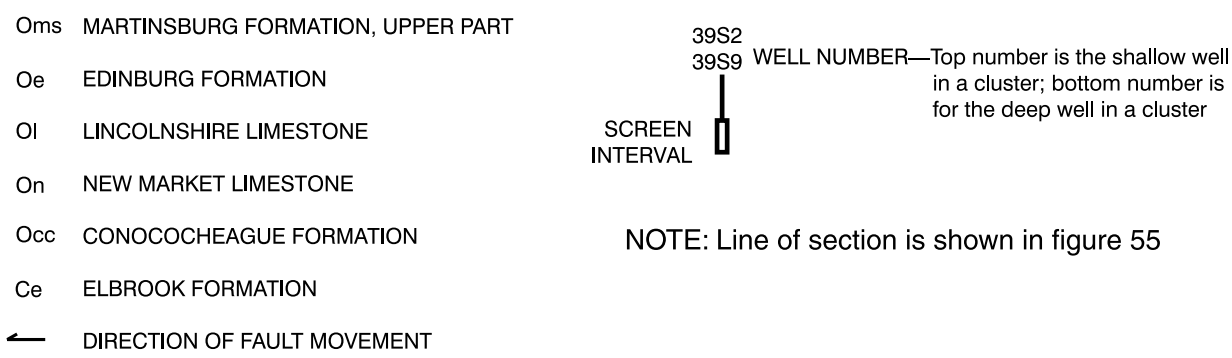

NOTE: Line of section is shown in figure 55

$\longleftarrow$ DIRECTION OF FAULT MOVEMENT

Figure 55. Geohydrologic section A-A' and observation well locations, Muddy Creek, Va. 
Bedrock contains secondary permeability formed by joints, fractures, and bedding planes. Once formed in the siliciclastic rock, such features generally change little relative to similar features in carbonate rock. In the carbonate rock, dissolution of rock along these features creates enlarged solution channels that are conduits for the rapid flow of water and transport of contaminants. These channels have not been studied locally in the Muddy Creek Watershed so only general conclusions can be drawn. The North Mountain fault zone likely is an area of great variability in the joints, fractures, and bedding planes because of the effect of the faulting and because of numerous changes in the formations present over short distances.

The thickness and composition of the regolith depend on the composition of the bedrock that weathers to form the saprolite and the amount and type of sediment subsequently eroded and deposited as colluvium and alluvium. The thickness of the saprolite is greatest where the carbonate rock contains substantial amounts of sand, silt, and clay; the thickness of the saprolite can be tens of feet in these areas. Where the bedrock weathers slowly or the carbonate bedrock contains few impurities, bedrock is near land surface and can even crop out at the surface. Colluvium can be thick at the base of hills from which large amounts of sediments have eroded; colluvium is thick particularly at the base of Little North Mountain (R.C. Orndorff, U.S. Geological Survey, oral commun., 2001). Thick regolith is common in the watershed; the greatest thickness of regolith observed in the watershed was $78 \mathrm{ft}$ (M.J. Ferrari, U.S. Geological Survey, written commun., 2001).

The composition of the regolith and dissolution of bedrock can appreciably affect the ground-water-flow system. Although joints, fractures, and bedding planes are common in the bedrock, effects of these features are likely absent in the saprolite where large amounts of silt and clay remain (R.C. Orndorff, U.S. Geological Survey, oral commun., 2001). Dissolution of the carbonate bedrock commonly forms cavities that can result in the collapse of the bedrock and overlying regolith; this collapse can form sinkholes, springs, and other karst features. Although many springs are present throughout the watershed, few other karst features are evident at land surface in many areas, probably because of the thick regolith.

The hydraulic characteristics of the bedrock and regolith are not well documented in the watershed. Horizontal hydraulic conductivity of the regolith calculated from results of slug tests at the local-scale study area ranged from 0.073 to $14.1 \mathrm{ft} / \mathrm{d}$ (M.J. Ferrari, U.S. Geological Survey, written commun., 2001). The horizontal hydraulic conductivity of the shallow bedrock at the local-scale study area was similar, ranging from 0.064 to $14.2 \mathrm{ft} / \mathrm{d}$.

The bedrock and regolith form an aquifer system that generally is well connected to the surface-water system. The nature of the hydraulic connection between the bedrock and the regolith is unknown but likely varies spatially. Land-surface elevation and the orientation, interconnection, and enlargement by dissolution of the joints, fractures, and bedding planes likely control ground-water flow in the bedrock.

Ground-waterflow.-Ground-water flow is not well documented in the Muddy Creek Watershed; general conclusions about the flow can be derived from existing information across the watershed and in the local-scale study area combined with flow concepts for similar hydrologic systems. Because the dissolution of the carbonate rock surrounding the joints, fractures, and bedding planes increases the permeability of the bedrock and because much of the regolith has a high content of silt and clay, a large part of the ground water likely flows through the bedrock, particularly over long distances. Analysis at the local-scale study area indicates 90 percent of the ground water flows through the bedrock and only 10 percent flows through the regolith (M.J. Ferrari, U.S. Geological Survey, written commun., 2001).

Precipitation that infiltrates the soil and percolates through the regolith to the water table recharges ground water across the Muddy Creek Watershed. Ground water flows vertically and laterally through the regolith and the bedrock to areas of ground-water discharge. A large part of the natural discharge from the aquifer system is to the numerous springs throughout the watershed. Discharge also occurs directly through the streambeds and through evapotranspiration where ground water is shallow. Ground-water discharge through springs and directly through streambeds contributes a large part of the streamflow in the Muddy Creek Watershed. Analysis of streamflow at the Mount Clinton surface-water station for water years 1994 through 2000 indicates the median annual ground-water discharge is $9.22 \mathrm{in}$. or 71.4 percent of the total annual streamflow.

Topography and the orientation and interconnection of the solution channels likely control the direction of ground-water flow. Ground water typically flows in the direction of the regional horizontal hydraulic gradient where the horizontal hydraulic conductivity of an aquifer is uniform in all directions. This gradient is in 
the direction of decreasing land-surface elevation in most ground-water systems. Orientation of the solution channels, however, causes extreme directional differences in the horizontal hydraulic conductivity of carbonate-bedrock aquifers. This locally controls the direction of ground-water flow, commonly forcing flow in directions other than that of the regional horizontal hydraulic gradient. Such flow is possible because only a small hydraulic gradient is required for substantial flow through solution channels whereas a substantial hydraulic gradient is required to produce only a little flow between solution channels.

At the local-scale study area, for example, the horizontal hydraulic gradient in the bedrock and the regolith are to the southeast, approximately parallel to the unnamed tributary and perpendicular to the strike of the bedrock. The direction of ground-water flow throughout this area, however, is unknown. Structure in the bedrock that results from faulting of the North Mountain fault zone forms solution channels likely oriented along the strike of the bedrock. Such orientation of solution channels in the bedrock would direct flow in directions other than the direction of the regional hydraulic gradient. The likelihood of such flow is supported by the response of water levels in wells at the local-scale study area; the characteristics of hydrographs are quite different from wells only a couple of hundred feet from each other. These wells are open to different formations (fig. 55). An analysis of flow through the regolith in approximately the lower quarter of the local-scale study area further demonstrates this uncertainty. Flow down the regional hydraulic gradient increased from 18 to $460 \mathrm{ft}^{3} / \mathrm{d}$ as a result of combined recharge from land surface and discharge from the bedrock (M.J. Ferrari, U.S. Geological Survey, written commun., 2001). Although flow through the regolith increased about $442 \mathrm{ft}^{3} / \mathrm{d}$ through this interval, only $18 \mathrm{ft}^{3} / \mathrm{d}$ of water flowed from the upgradient area that covered about three times the area of the evaluated interval. Such little flow from the upgradient area indicates that recharge to the upgradient area flows in directions other than down the regional hydraulic gradient. Thus, many uncertainties remain about the direction of ground-water flow in the watershed.

The amount of ground-water flow between the bedrock and saprolite also is unknown. At the localscale study area, the vertical gradient generally is upward from the bedrock to the regolith, indicating the potential for upward flow. The ground-water quality and apparent age, however, indicate that locally little water flows from the bedrock to the regolith. Thus, the upward hydraulic gradient likely indicates the presence of a local barrier to, rather than the presence of, appreciable upward flow. The absence of fractures in the upper part of the bedrock at many of the well clusters (screens of bedrock wells are open to the uppermost fractures) at the local-scale study area further indicates the presence of such a local barrier to vertical flow.

Although ground-water discharge sustains base streamflow throughout the watershed, contributions of ground water to streamflow vary spatially and temporally. In the stream at the local-scale study area, for example, flow is derived from spring discharge near the base of Little North Mountain and is augmented by discharge from spring 39SS001 (fig. 54). During brief periods of high ground-water levels, the hydraulic gradient is from the ground water to the stream, indicating ground-water discharge to the stream. During most of the year, however, the water table is below the bed of the stream such that stream water discharges to the regolith, and streamflow decreases downstream. During many low-flow periods, the stream becomes dry before discharge from spring 39SS001 enters the stream. Intervals of streams that lose flow to underlying aquifers are common in carbonate aquifer systems.

\section{Sample network and collection}

Samples were collected during three periods from a network of wells and springs throughout the watershed. The primary sample-collection period was in April 1999. Samples also were collected monthly and during storms at a surface-water station at the outlet of the watershed.

Sampling network.-The ground-water sampling network consists of a combination of eight domestic wells, seven observation wells, and five springs (figs. 54 and 55). The surface-water station was toward the lower end of the watershed at Mount Clinton (station 01621050).

The domestic wells are along an approximate north-south line through the center of the watershed to determine the apparent age and $\mathrm{NO}_{3}^{-}$concentrations in water at different depths in the aquifer system. The depths of the domestic wells range from 30 to $375 \mathrm{ft}$. Although little other construction information is available for these wells, it is likely the shallow wells are open to the regolith and the deep wells are open to the bedrock. Single zones or multiple zones at different depths can contribute water to the bedrock wells; the 
depth of zones contributing water to each well, however, is unknown. Wells 39S41 and 39S42 are shallow and deep domestic wells near each other.

The observation wells were installed in 1994 in the local-scale study area as a part of the USGS Potomac River Basin NAWQA study (fig. 55). These wells were installed to target the effects of the local agricultural practices. The observation wells consist of 6-in.diameter, stainless-steel casings that have single screens with lengths from 5 to $20 \mathrm{ft}$ depending on the hydrologic conditions at the site. Six of the wells are in three clusters having a shallow and a deep well. The screen of each shallow well is open near the bottom of the regolith. The screen of each deep well is open to the shallowest fractured interval in the bedrock. Clustered well pairs include wells 39S2 and 39S9, wells 39S4 and 39S19, and wells 39S14 and 39S15.

The springs are scattered throughout the watershed and were sampled to characterize ground water that discharges to the streams. Although water from wells can be used to characterize water in the aquifer, the distribution of water of different ages in ground water discharging to the streams cannot be readily determined from wells. Springs, however, are formed by discharging ground water and, therefore, can be used to characterize discharging ground water.

\section{Sampling methods, timing, and} hydrologic conditions.-The sampling methods described in the introduction to this report were used at all sites in the Muddy Creek Watershed. Although water samples were collected from all wells and springs, only selected samples were analyzed for ${ }^{3} \mathrm{H} /{ }^{3} \mathrm{He}$.

Samples were first collected from four of the springs on November 9-10, 1998, to test the sampling methods and to obtain initial information on the apparent age of discharging ground water. This was in the middle of an extended dry period having low streamflow; streamflow averaged about $1.7 \mathrm{ft}^{3} / \mathrm{s}$ at the Mount Clinton station during sample collection (White and others, 2000) (fig. 56).

The main sample-collection period was April 1217, 1999; samples were collected from all domestic wells, observation wells, and springs. Spring 39SS005 was added to the network at this time. The 1999 water year was extremely dry; the annual mean streamflow of $2.97 \mathrm{ft}^{3} / \mathrm{s}$ (White and others, 2000) was the lowest for the 8 years of record for the Mount Clinton station (White and others, 2001). Although the sample-collection period was near the end of the seasonal high streamflow period, daily flow averaged only $2.3 \mathrm{ft}^{3} / \mathrm{s}$ compared to an average annual flow of $12.7 \mathrm{ft}^{3} / \mathrm{s}$ and median annual flow of $5.4 \mathrm{ft}^{3} / \mathrm{s}$ for the period of record (fig. 56).

Samples were collected again from the observation wells and from spring 39SS001 on April 17-18, 2000 , for comparison with results from previous analyses. Although the 2000 water year was another dry year, annual flow averaged $5.4 \mathrm{ft}^{3} / \mathrm{s}$, equal to the median streamflow for the period of record (White and others, 2001). Daily mean streamflow increased from 2.7 to $6.7 \mathrm{ft}^{3} / \mathrm{s}$ during sample collection. Although some illustrations include data from all sample-collection periods, the following discussion focuses on results of the April 1999 sample collection.

\section{Distribution of Nitrogen, Dissolved Oxygen, and Methane in Ground Water}

$\mathrm{NO}_{3}^{-}$was the dominant nongaseous $\mathrm{N}$ species in ground water of the Muddy Creek Watershed in April 1999 (app. B); concentrations of ammonia plus organic $\mathrm{N}, \mathrm{NH}_{3}$, and $\mathrm{NO}_{2}^{-}$were near the respective MRLs. In the following discussions, concentration of each $\mathrm{N}$ species is reported as the equivalent concentration of $\mathrm{N}$ rather than that of the respective $\mathrm{N}$ species. Concentrations of ammonia plus organic $\mathrm{N}$ were less than $0.1 \mathrm{mg} / \mathrm{L}$ in water from seven of the eight domestic wells, two of the seven observation wells, and three of the five springs; the maximum concentration was $0.338 \mathrm{mg} / \mathrm{L}$. Concentrations of $\mathrm{NH}_{3}$ were less than $0.020 \mathrm{mg} / \mathrm{L}$ in water from seven of the eight domestic wells and all of the observation wells and springs; the maximum concentration was $0.097 \mathrm{mg} / \mathrm{L}$. Similarly, concentrations of $\mathrm{NO}_{2}^{-}$were less than $0.01 \mathrm{mg} / \mathrm{L}$ in water from all of the domestic wells and springs and five of the seven observation wells; the maximum concentration was $0.015 \mathrm{mg} / \mathrm{L}$. Because concentrations of $\mathrm{NO}_{2}^{-}$plus- $\mathrm{NO}_{3}^{-}$consisted almost entirely of $\mathrm{NO}_{3}^{-}$in all samples for which $\mathrm{NO}_{2}^{-}$concentrations were less than the MRL, concentrations of $\mathrm{NO}_{2}^{-}$-plus- $\mathrm{NO}_{3}^{-}$are equivalent to $\mathrm{NO}_{3}^{-}$concentrations for these samples.

The abundance of dissolved oxygen (app. A) and low $\mathrm{CH}_{4}$ concentrations (app. C) indicate most ground water of the Muddy Creek Watershed is well oxygenated; abundant dissolved oxygen indicates denitrification of $\mathrm{NO}_{3}^{-}$is not likely. Concentrations of dissolved oxygen were $1.5 \mathrm{mg} / \mathrm{L}$ or greater, and $\mathrm{CH}_{4}$ concentrations were $0.01 \mathrm{mg} / \mathrm{L}$ or less in all water except that from well 39S43. The concentration of dissolved oxygen in water from this well was $0.1 \mathrm{mg} / \mathrm{L}$; the $\mathrm{CH}_{4}$ concentration was $0.02 \mathrm{mg} / \mathrm{L}$. Accordingly, no appreciable 

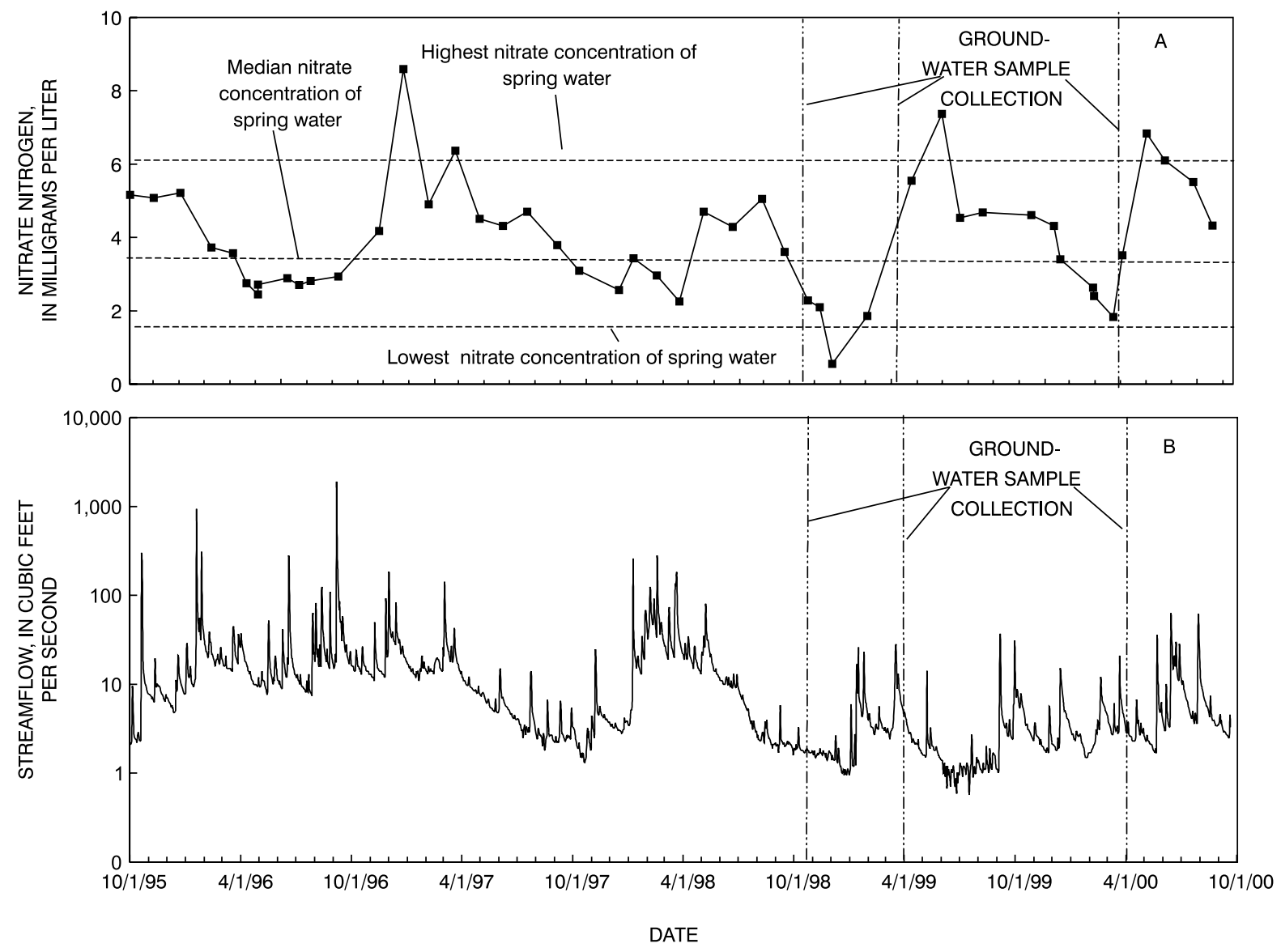

Figure 56. Nitrate concentrations of streamwater compared to the nitrate concentrations of spring water (A) and ground-water sample collection compared to streamwater nitrate concentration $(A)$ and streamflow $(B)$ in the Muddy Creek Watershed, Va. 
concentrations of excess $\mathrm{N}_{2}$ gas were measured in water from any of the springs. Concentrations of excess $\mathrm{N}_{2}$ gas, however, were measured in water from four domestic wells (wells 39S41, 39S42, 39S43, and 39S44) and three observation wells (wells 39S2, 39S4, and 39S9) (app. B). Thus, denitrification appears to be a factor in part of the ground water although it would not be expected on the basis of concentrations of dissolved oxygen. The presence of excess $\mathrm{N}_{2}$ gas in samples having abundant dissolved oxygen could result from mixing water having elevated concentrations of dissolved oxygen and no excess $\mathrm{N}_{2}$ gas with water having low concentrations of dissolved oxygen and abundant excess $\mathrm{N}_{2}$ gas.

Measured $\mathrm{NO}_{3}^{-}$concentrations ranged from less than 0.050 to $22.3 \mathrm{mg} / \mathrm{L}$ (app. $\mathrm{B}$ ); $\mathrm{NO}_{3}^{-}$concentrations reconstructed for production of excess $\mathrm{N}_{2}$ gas ranged from 0.34 to $23.1 \mathrm{mg} / \mathrm{L}$. The range in reconstructed $\mathrm{NO}_{3}^{-}$concentrations in water from the domestic wells was greater than that in water from the observation wells and springs, which were similar to each other. Reconstructed $\mathrm{NO}_{3}^{-}$concentrations in water from the domestic wells ranged from 0.34 to $23.1 \mathrm{mg} / \mathrm{L}$ (median $4.13 \mathrm{mg} / \mathrm{L}$ ), from the observation wells ranged from 1.94 to $6.82 \mathrm{mg} / \mathrm{L}$ (median $4.36 \mathrm{mg} / \mathrm{L}$ ), and from the springs ranged from 1.64 to $6.06 \mathrm{mg} / \mathrm{L}$ (median $3.54 \mathrm{mg} / \mathrm{L})$. Results of the Wilcox rank-sum test, which is a nonparametric comparison to determine if two sets of data are different (Ott, 1988), indicate reconstructed $\mathrm{NO}_{3}^{-}$concentrations of water from the springs were less than those of water from all wells collectively $(\mathrm{p}=0.01)$ and from the observation wells $(\mathrm{p}=0.05)$ (table 6)

(MathSoft, Inc., 1999). Concentrations in spring water, however, were not shown to differ from those in water from the domestic wells $(\mathrm{p}=0.10)$. Concentrations of $\mathrm{NO}_{3}^{-}$in water from the springs generally were within the range of concentrations observed in water at the surface-water gage at Mount Clinton (fig. 56), indicating that the $\mathrm{NO}_{3}^{-}$concentrations of the spring water represent those of ground-water discharge well.
Table 6. Results of Wilcox rank-sum analysis ( $p$ values) for reconstructed nitrate concentrations, $\delta^{15}$ nitrogen, and apparent chlorofluorocarbon age of water from springs compared to those from all wells, domestic wells, and observation wells, Muddy Creek Watershed, Va. (MathSoft, Inc., 1999)

\begin{tabular}{lccc}
\hline \multirow{1}{*}{$\begin{array}{c}\text { Water-quality } \\
\text { variable }\end{array}$} & All wells & $\begin{array}{c}\text { Domestic } \\
\text { wells }\end{array}$ & $\begin{array}{c}\text { Observation } \\
\text { wells }\end{array}$ \\
\cline { 2 - 4 } & 0.0000 & 0.3233 & 0.0175 \\
\hline $\begin{array}{c}\text { Reconstructed nitrate } \\
\text { concentration }\end{array}$ & & & \\
$\delta^{15}$ nitrogen & .0091 & .0612 & .0082 \\
Apparent age & .0021 & .0785 & .0009 \\
\hline
\end{tabular}

Concentrations of reconstructed $\mathrm{NO}_{3}^{-}$show no clear spatial pattern except that the two deepest domestic wells having reconstructed $\mathrm{NO}_{3}^{-}$concentrations of $0.5 \mathrm{mg} / \mathrm{L}$ or less are in the center of the watershed (fig. 57). At the three observation well clusters and the pair of shallow and deep domestic wells, reconstructed $\mathrm{NO}_{3}^{-}$concentrations in water from the regolith wells consistently were greater than concentrations in water from the adjacent bedrock wells (fig. 58 and app. B). The higher concentrations in the regolith, however, do not reflect a consistent relation between concentration and well depth throughout the watershed, because of the variability in concentrations of reconstructed $\mathrm{NO}_{3}^{-}$in water from shallow observation wells (fig. 59A). Concentrations, however, are more likely to be low in water from deep wells than from shallow wells. The maximum reconstructed $\mathrm{NO}_{3}^{-}$concentration adjusted for mixing, however, appears to decrease with well depth (fig. 59B).

The $\delta^{15} \mathrm{~N}_{\text {of }} \mathrm{NO}_{3}^{-}$in the Muddy Creek Watershed was highly variable, ranging from 6.52 to $19.86 \%$ o (app. B). The $\delta^{15} \mathrm{~N}$ of $\mathrm{NO}_{3}^{-}$nitrogen from domestic wells ranged from 7.15 to $15.06 \%$ (median $11.15 \%$ ), from the observation wells ranged from 10.77 to $19.86 \%$ (median $12.91 \%$ ), and from springs ranged from 6.52 to $11.24 \%$ (median $6.85 \%$ ) (fig. 60).

Results of the Wilcox rank-sum test indicate the $\delta^{15} \mathrm{~N}$ of $\mathrm{NO}_{3}^{-}$in water from springs is less than that in water from all wells collectively $(\mathrm{p}=0.01)$, from the domestic wells $(\mathrm{p}=0.10)$, and from the observation wells $(\mathrm{p}=0.01)$ (table 6) (MathSoft, Inc., 1999). 


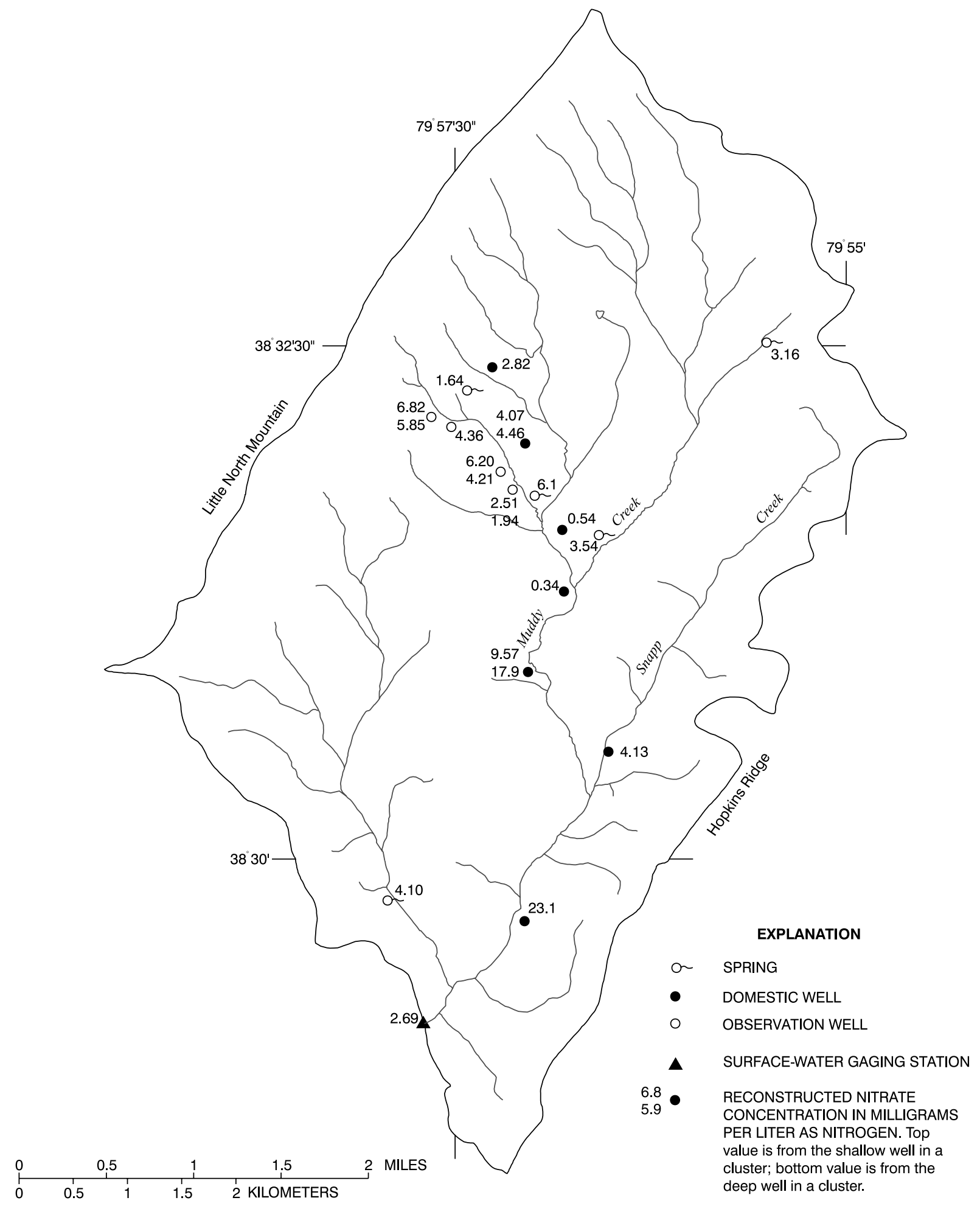

Figure 57. Spatial distribution of reconstructed nitrate concentration in ground water and surface water in the Muddy Creek Watershed, Va., April 1999. 


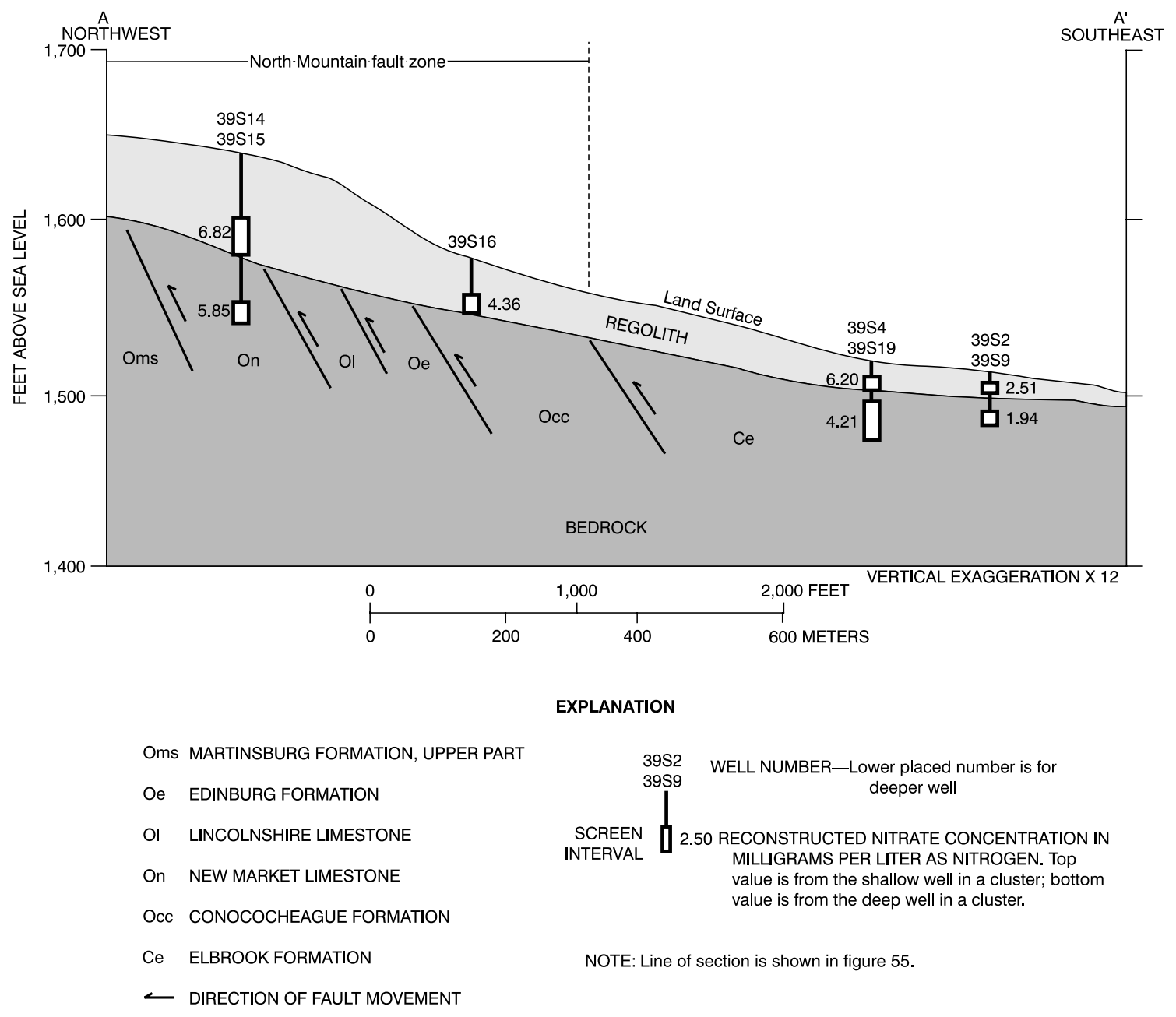

Figure 58. Reconstructed nitrate concentration in water from observation wells in the local-scale study area in April 1999, Muddy Creek Watershed, Va. 

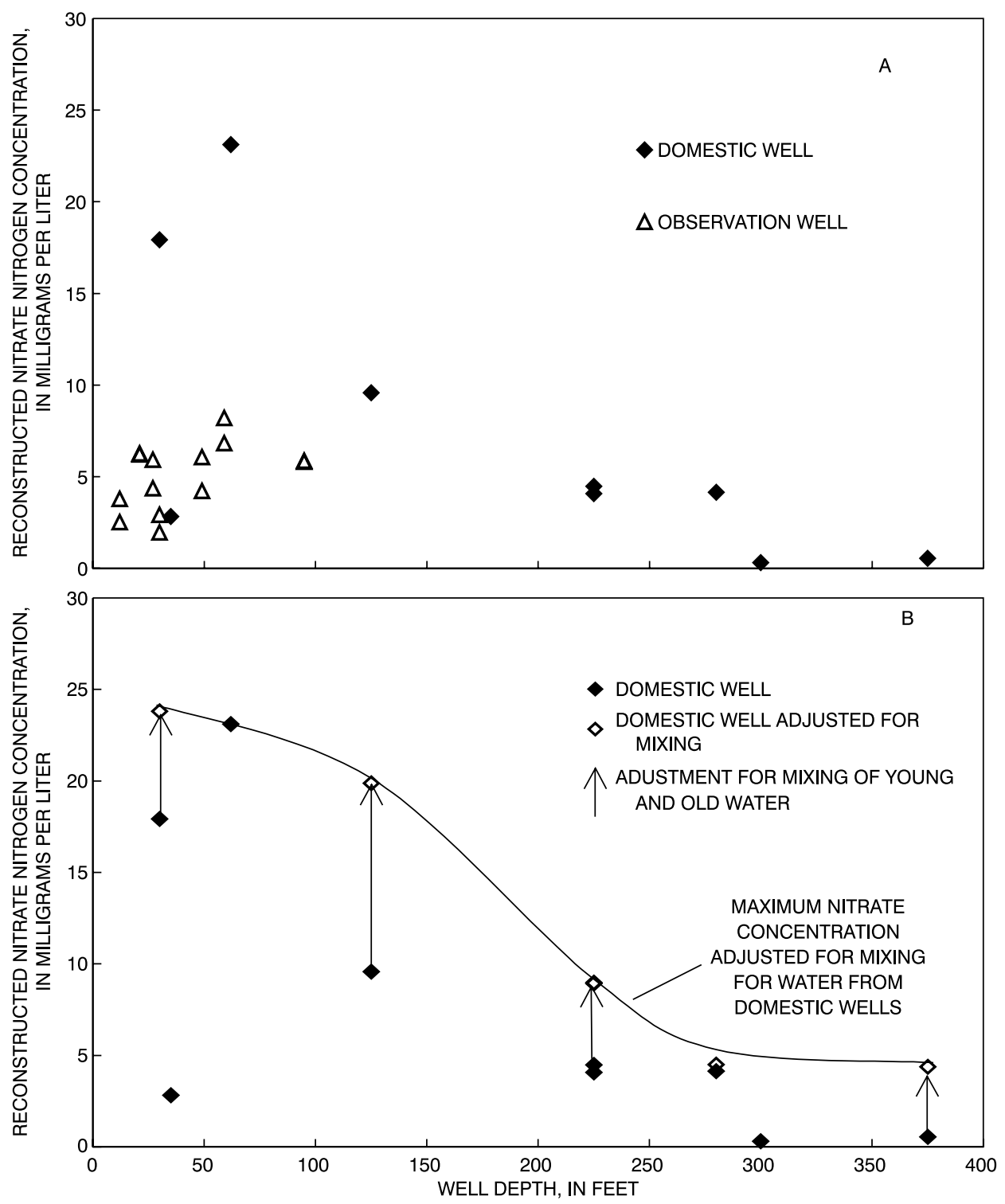

Figure 59. Relation of well depth to reconstructed nitrate concentration $(A)$ and to constructed nitrate concentration adjusted for mixing (B) in ground water, April 1999 and April 2000, Muddy Creek Watershed, Va. 


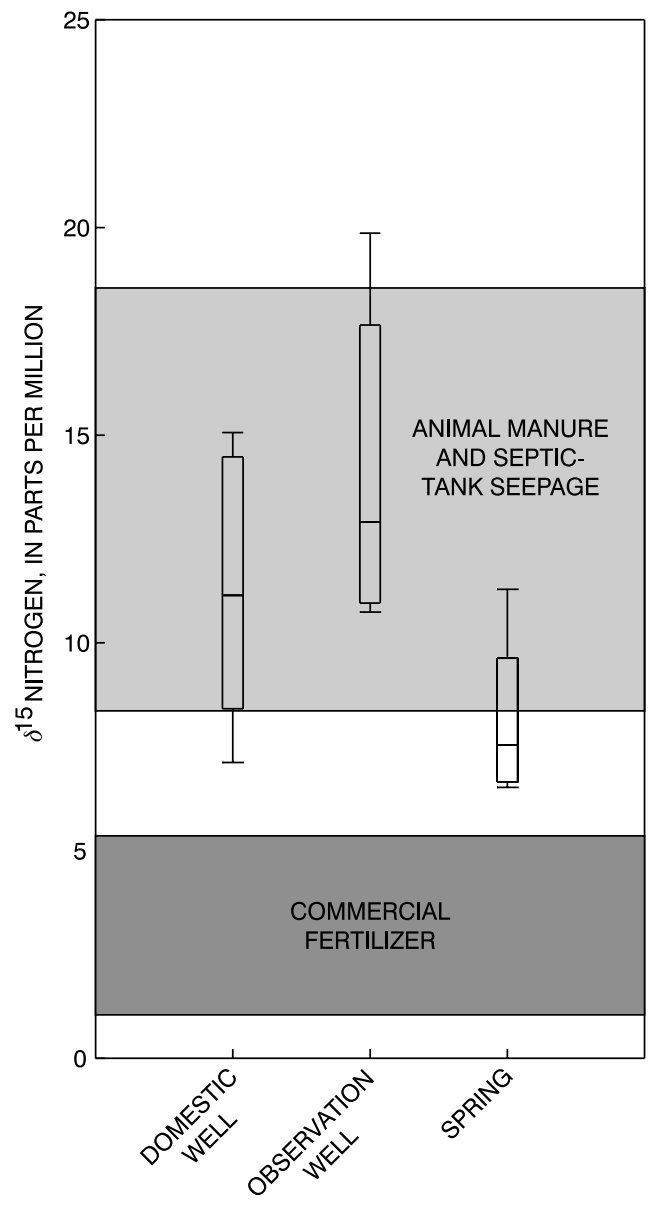

Figure 60. Concentrations of $\delta^{15}$ nitrogen of nitrate in water from domestic wells, observation wells, and springs, Muddy Creek Watershed, Va., April 1999.

\section{Distribution of Apparent Ages and Residence Times in Ground Water}

The apparent ages of ground water can be determined by use of various tracers. Because of local conditions in the Muddy Creek Watershed, natural and anthropogenic sources of an individual tracer can elevate concentrations of that tracer; degradation, sorption, or other processes can reduce concentrations of a tracer. Thus, different tracers or combinations of tracers commonly must be used to determine the apparent groundwater age of different water samples.

\section{Methods used for determining apparent ages}

The apparent age of ground water in the Muddy Creek Watershed was determined from analysis of CFC's, as well as ${ }^{3} \mathrm{H} /{ }^{3} \mathrm{He}$. Because ${ }^{3} \mathrm{H} /{ }^{3} \mathrm{He}$ ages were determined for only a quarter of the samples ( 5 of the 20 samples in 1999) and the ${ }^{3} \mathrm{H} /{ }^{3} \mathrm{He}$ ages are uncertain, ${ }^{3} \mathrm{H} /{ }^{3} \mathrm{He}$ ages are discussed only briefly and apparent $\mathrm{CFC}$ ages are emphasized. Limited $\mathrm{SF}_{6}$ data also was available (app. D), and concentrations may have been elevated somewhat because of terrigenic sources. Consequently, no age information is based on $\mathrm{SF}_{6}$ concentrations.

Concentrations of CFC-11, CFC-12, CFC-113 and ${ }^{3} \mathrm{H}$ in ground water of the Muddy Creek Watershed are compared with model calculations assuming piston flow, binary mixing of modern (1999) and old (blank) water, and exponential mixtures in figure 61. Concentrations of CFC-11 appear somewhat depleted relative to those of CFC-12 (fig. 61A), consistent with a removal or degradation process affecting the CFC- 11 concentrations. Consequently, no age information was based on CFC-11. Many of the samples plot close to the pistonflow line as a function of CFC-12 and CFC-113 (fig. 61B); age for these samples, therefore is based on the piston-flow model. Five of the CFC analyses show an apparent excess in CFC-12 or removal of CFC-113 that necessitates the use of the piston-flow model. Use of the piston-flow model for these samples, however, does not preclude the possibility that the samples are mixtures. The rest of the samples appear to be mixtures, based on CFC-12 and CFC-113. In terms of ${ }^{3} \mathrm{H}$, the CFC-12 and CFC-113 data also indicate piston flow and mixtures (figs. 61C and 61D). One unusually low ${ }^{3} \mathrm{H}$ value is probably an erroneous analysis, because the sample plots close to the piston-flow line as a function of CFC-12 and CFC-113.

Consequently, the apparent CFC age of water from all wells and springs in the Muddy Creek Watershed was calculated from concentrations of CFC-113 or concentrations of CFC-12 and CFC-113. For the 1999 sampling, the apparent age of water from six domestic wells, one observation well, and one spring assumes binary mixing. Apparent age of the remaining wells and springs assumes piston flow.

\section{Apparentages of ground water}

The range in the apparent CFC age of water from the different sources generally was small. The apparent CFC age of water from well 39S43 was 45.0 years; the apparent age of water from all other sites ranged from 

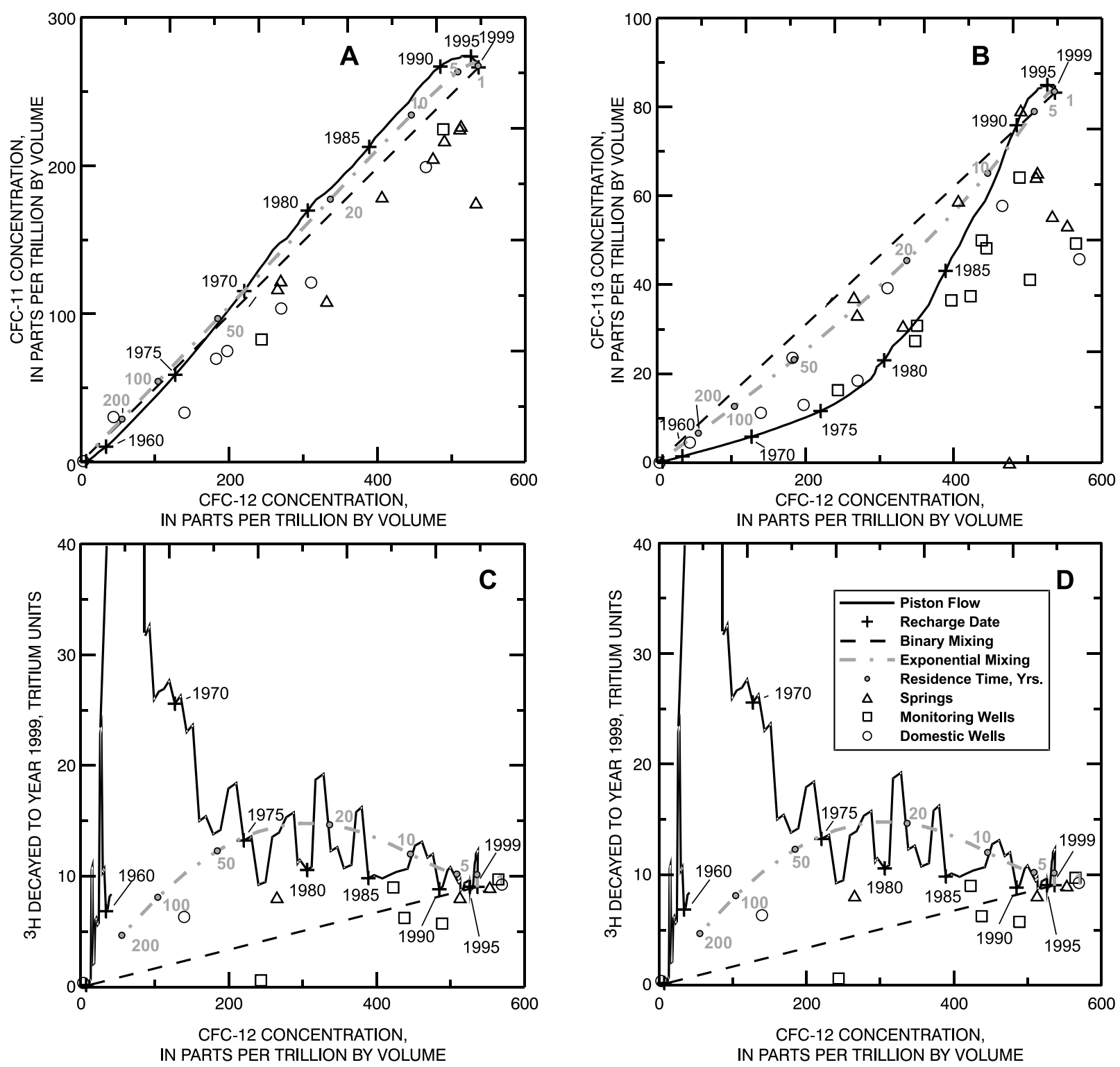

Figure 61. Comparison of concentrations of chlorofluorocarbon-11 (CFC-11), chlorofluorocarbon-12 (CFC-12), chlorofluorocarbon-113 (CFC-113), and tritium $\left({ }^{3} \mathrm{H}\right)$ in water from wells and springs in the Muddy Creek Watershed, Va. 
9.3 to 20.3 years and shows no clear spatial pattern (app. C and fig. 62). The apparent CFC age of water from the domestic wells except well 39S43 ranged from 11.0 to 20.3 years (median 15.0 years), from the observation wells ranged from 12.4 to 18.3 years (median 14.6 years), and from the springs ranged from 9.3 to
12.8 years (median 11.3 years). Results of the Wilcox rank-sum test indicate the apparent CFC age of water from springs is younger than that of water from all wells collectively ( $\mathrm{p}=0.01)$, from the domestic wells $(\mathrm{p}=0.10)$, and from the observation wells $(\mathrm{p}=0.01)$ (table 6$)$

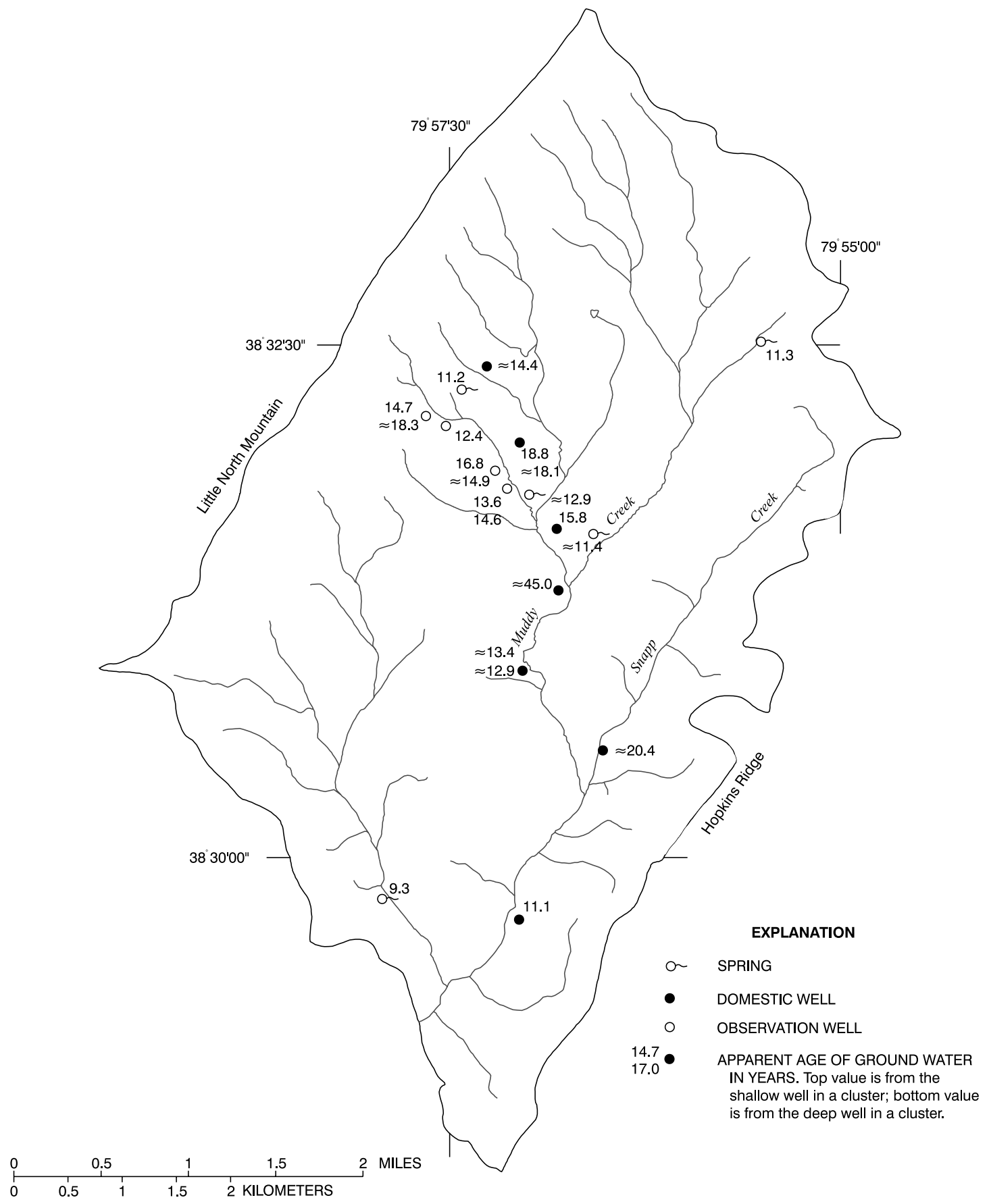

Figure 62. Spatial distribution of apparent age of ground water in Muddy Creek Watershed, Va., April 1999. 
(MathSoft, Inc., 1999). Consequently, on the basis of data for the springs, ground water discharging to the streams is younger than water from wells, indicating that water from springs primarily flows along short, shallow paths or flows rapidly along longer, deeper paths through solution channels.

For the one spring sample collected in 1999 identified as a binary mixture, 61.3 percent of the water was the young fraction; 39 percent of the water was assumed to be pre-CFC water. For the three springs that could be evaluated for mixing in the 1998 sample collection, $67.0,91.9$, and 96.5 percent of the water was the young fraction. Thus, assuming binary mixtures, a variable, but, from some springs, an appreciable part of the discharge can be old water. Although the apparent ages assume either binary mixing or piston flow, it is possible that these samples are mixtures of waters of several ages that can include modern water. In a study in the Valley and Ridge Physiographic Province about $60 \mathrm{mi}$ northeast of the Muddy Creek Watershed, dye dumped into sinkholes discharged from springs several miles from the sinkholes within 4 months (Wright, 1990). These results indicate not only the potential for modern water in spring discharge but also demonstrate the rapid flow of water over long distances in karst ground-water systems.

The range in apparent ${ }^{3} \mathrm{H} /{ }^{3} \mathrm{He}$ age was greater than that for CFCs. The apparent ${ }^{3} \mathrm{H} /{ }^{3} \mathrm{He}$ ages were younger than the apparent $\mathrm{CFC}$ ages for 9 of the 13 samples from all sample-collection periods. The apparent ${ }^{3} \mathrm{H} /{ }^{3} \mathrm{He}$ age ranged from 1.6 years to older than can be determined by the method (about 35 years); the median age was 7.1 years. The apparent CFC age for the same samples analyzed for ${ }^{3} \mathrm{H} /{ }^{3} \mathrm{He}$ ranged from 11.0 to 45.0 years; the median age was 14.6 years. The causes of the differences between apparent ${ }^{3} \mathrm{H} /{ }^{3} \mathrm{He}$ and CFC ages is uncertain but could result from degradation of the CFCs, the effects of mixing of waters of different ages on tracer concentrations, or other factors. The remaining discussion focuses on apparent CFC ages.

Analysis of the distribution in apparent CFC age of water from the observation wells in the local-scale study area likely is complicated by the effects of the fault zone on the local hydrology, by the effects of flow through solution channels, and, in some instance, by the small differences in the apparent age of the ground water. In the bedrock aquifer, the oldest water is from the well farthest up the horizontal hydraulic gradient (well 39S15); the apparent age decreases and then increases downgradient (fig. 63). If these wells were along a ground-water-flow path, the apparent age would continuously increase along the path. This observed pattern could result from the effects of well-screen depth below the top of the bedrock but also could result from the direction of ground-water flow caused by the orientation of the solution channels. Solution channels were observed during well drilling at this site and likely are oriented close to perpendicular to the horizontal hydraulic gradient. Where this orientation occurs, bedrock wells in the transect would be on different groundwater-flow paths. Similarly, the apparent age of water in the regolith decreases, increases, and decreases again down the horizontal hydraulic gradient.

At two of the three well clusters, the apparent age of water from the bedrock well was older than that of water from the regolith well for both the 1999 and 2000 samples. Although the difference in apparent age at one cluster in 1999 was within the 2-year error of the apparent age determination, the others were not. Water should be older in the regolith because the vertical hydraulic gradient generally is upward at these clusters, indicating possible upward flow. This discrepancy in the vertical apparent-age distribution can result from a locally limited, vertical hydraulic connection such that little water flows from the bedrock into the regolith near the well clusters. At all three clusters, the uppermost permeable part of the bedrock is as great as $26 \mathrm{ft}$ below the top of the bedrock. Consequently, a large part of the water in the regolith could be from local recharge, whereas water in the bedrock could have been recharged away from the sites. Controls on ground-water flow, possibly created by the orientation of solution channels like that at the local-scale study area, also can affect ground-water flow and apparent-age distribution throughout the watershed.

Another common concept for most groundwater-flow systems is that the age of the ground water increases with depth in the aquifer. With the exception of water from well 39S43, the apparent age of the young fraction of water from the wells in the Muddy Creek Watershed does not relate to depth for wells to depths of $375 \mathrm{ft}$ (fig. 64A). The percentage of young water, however, tends to decrease with depth (fig. 64B); the coefficient of determination $\left(\mathrm{R}^{2}\right)$ for this relation is 0.40 .

The mechanism for the mixing of young and old water is unknown. Samples for which mixing could be evaluated were primarily from the domestic wells, which likely have long open intervals for which the depth of contributing water zones is unknown. Consequently, water can be contributed by one or more zones 


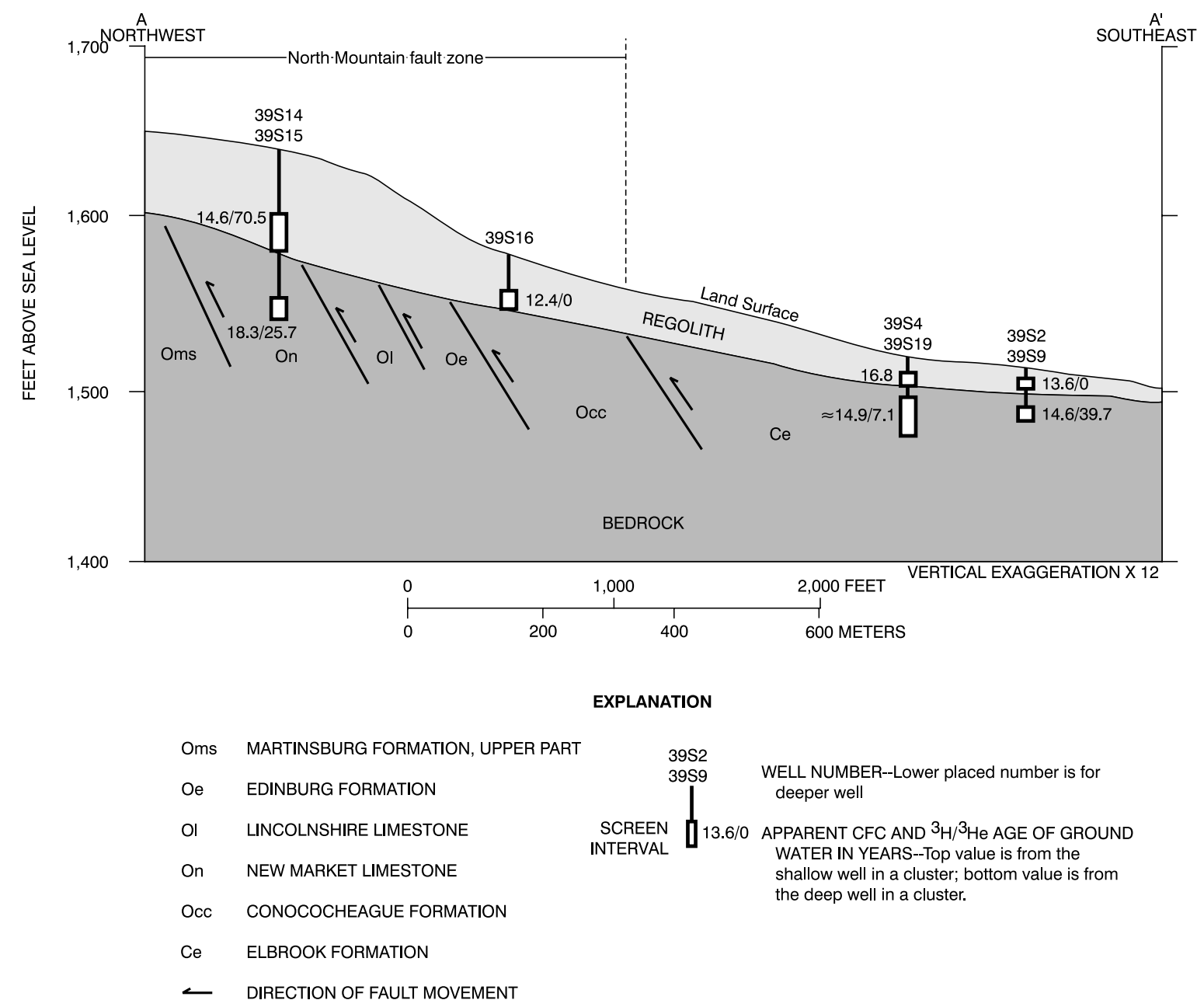

Figure 63. Apparent age of water from observation wells in the local-scale study area in Muddy Creek Watershed, Va., April 1999. 

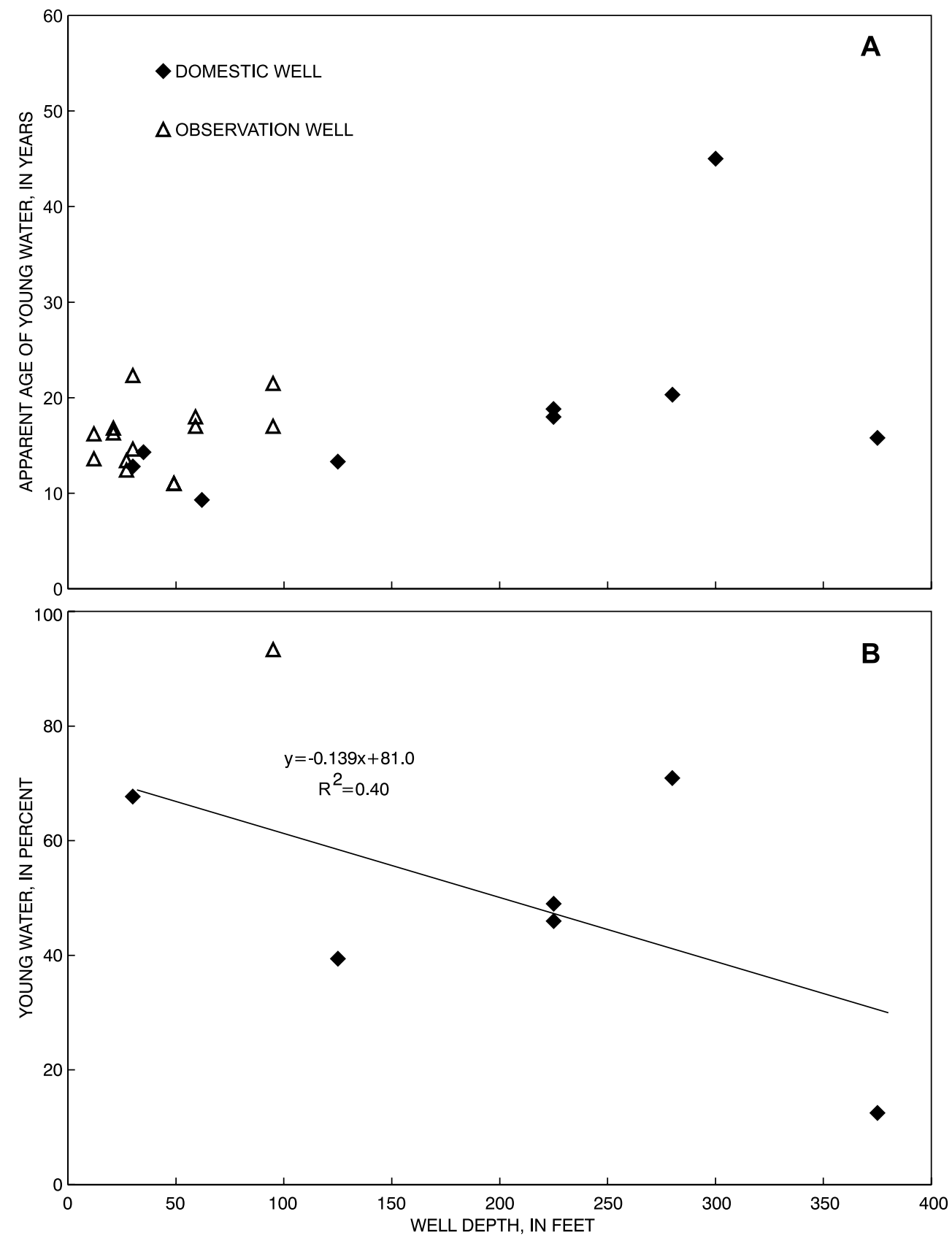

Figure 64. Relation of well depth to apparent chlorofluorocarbon (CFC) age of young ground water (A) and to percent young ground water (B) in Muddy Creek Watershed, Va., April 1999 and April 2000. 
that contain a mixture of different age waters or from multiple zones each having water of a single age different from that of other contributing zones.

\section{Relation of Nitrogen Concentrations, Apparent Age, and Sources}

$\mathrm{N}$ is derived from several sources that have varied effects on the $\mathrm{NO}_{3}^{-}$concentrations in the ground water. The primary $\mathrm{N}$ sources in the Muddy Creek Watershed include atmospheric deposition (8.6 percent), forests (not determined), combined septic-tank seepage and residential fertilizer application (1.5 percent), commercial fertilizer applied to fields (21.3 percent), and animal manure (68.6 percent) (Preston and Brakebill, 1999).

Atmospheric deposition can be a source of $\mathrm{N}$ to ground water across the watershed. $\mathrm{N}$ derived from the forested areas primarily leaches from decaying plant material in the organic litter of the forest floor and organic material in the soil. $\mathrm{N}$ concentrations derived from atmospheric deposition and forests typically are low compared to concentrations derived from residential and agricultural sources. Effects of atmospheric deposition and forests on $\mathrm{NO}_{3}^{-}$concentrations cannot be evaluated with available data for the Muddy Creek Watershed because no well or spring is known to solely represent water derived from these sources.

Septic-tank seepage and residential fertilizer application are additional sources of $\mathrm{N}$ in the watershed. These sources likely have little effect on ground water in this watershed because of the limited extent and number of residential areas. Effects of these sources on $\mathrm{NO}_{3}^{-}$ concentrations could not be evaluated with available data for the Muddy Creek Watershed because no well or spring is known to solely represent water derived from these sources.

Agriculture is the primary $\mathrm{N}$ source (nearly 90 percent) in the Muddy Creek Watershed. $\mathrm{N}$ derived from cropland leaches primarily from commercial fertilizer applied to cropland, animal manure, and decaying crop litter in the soil and on land surface. $\mathrm{N}$ derived from pastures and livestock-raising areas leaches primarily from animal manure and from decaying plant material on the land. Although annual application rates for commercial fertilizer are not available for the watershed, annual sales information is available for all of Rockingham County. Assuming changes in annual fertilizer sales accurately reflect changes in annual application rates, annual agricultural application of commercial fertilizer in Rockingham County steadily increased from an estimated 1.25 million pounds of $\mathrm{N}$ in 1945 to more than 6 million pounds of $\mathrm{N}$ in the late 1970s (Alexander and Smith, 1990; Battaglin and Goolsby, 1994). Application rates generally varied between 5 and 7 million pounds from the late 1970s until 1991 and totaled 6.6 million pounds of $\mathrm{N}$ in 1991. Puckett (1994) indicates annual production of animal manure in the county contributes an estimated 33 million pounds of $\mathrm{N}$. Thus, animal manure contributes approximately five to seven times the $\mathrm{N}$ applied as commercial fertilizer.

The $\delta^{15} \mathrm{~N}_{\text {of }} \mathrm{NO}_{3}^{-}$in ground water throughout the watershed appears to be heavily influenced by animal manure (fig. 60). The $\delta^{15} \mathrm{~N}_{\text {of }} \mathrm{NO}_{3}^{-}$from the domestic and observation wells is in the range of that for animal manure, whereas that of spring water possibly indicates a mix of manure and commercial-fertilizer sources. The high values for wells are consistent with the much higher contribution of $\mathrm{N}$ by manure compared to commercial fertilizer in the watershed. Although the $\delta^{15} \mathrm{~N}$ of $\mathrm{NO}_{3}^{-}$can increase because of fractionation from denitrification, no strong relation could be identified between the $\delta^{15} \mathrm{~N}$ of $\mathrm{NO}_{3}^{-}$and concentrations of excess $\mathrm{N}_{2}$ gas, reconstructed $\mathrm{NO}_{3}^{-}$, or the ratio of excess $\mathrm{N}_{2}$ gas to reconstructed $\mathrm{NO}_{3}^{-}$. The absence of identifiable relations likely results from (1) variability in the rate of $\mathrm{N}$ contribution by manure compared to commercial fertilizer, (2) variability in the $\delta^{15} \mathrm{~N}$ of $\mathrm{N}$ in the manure, and (3) subsequent fractionation of $\mathrm{N}$ leached from the manure to the ground water.

Although agricultural sources contribute most of the $\mathrm{NO}_{3}^{-}$to ground water in the Muddy Creek Watershed, no relation could be identified between apparent recharge date and reconstructed $\mathrm{NO}_{3}^{-}$concentration (fig. 65A). Neither could a relation be identified between apparent recharge date and the reconstructed $\mathrm{NO}_{3}^{-}$concentration adjusted for the mixing of young and old water (fig. 65B). The lack of such a relation likely results from the limited range in apparent groundwater age combined with spatial and temporal variability in the rate that $\mathrm{NO}_{3}^{-}$leaches from cultivated fields and livestock-raising areas. The large range in the $\mathrm{NO}_{3}^{-}$ concentrations indicates appreciable spatial variability in land use and the resulting rate $\mathrm{NO}_{3}^{-}$leaches from source areas. Even if commercial fertilizer were a major source of $\mathrm{NO}_{3}^{-}$, no relation with apparent age is likely because of the lack of a trend in application rates since the late 1970s; water from only one well was recharged before this time. 

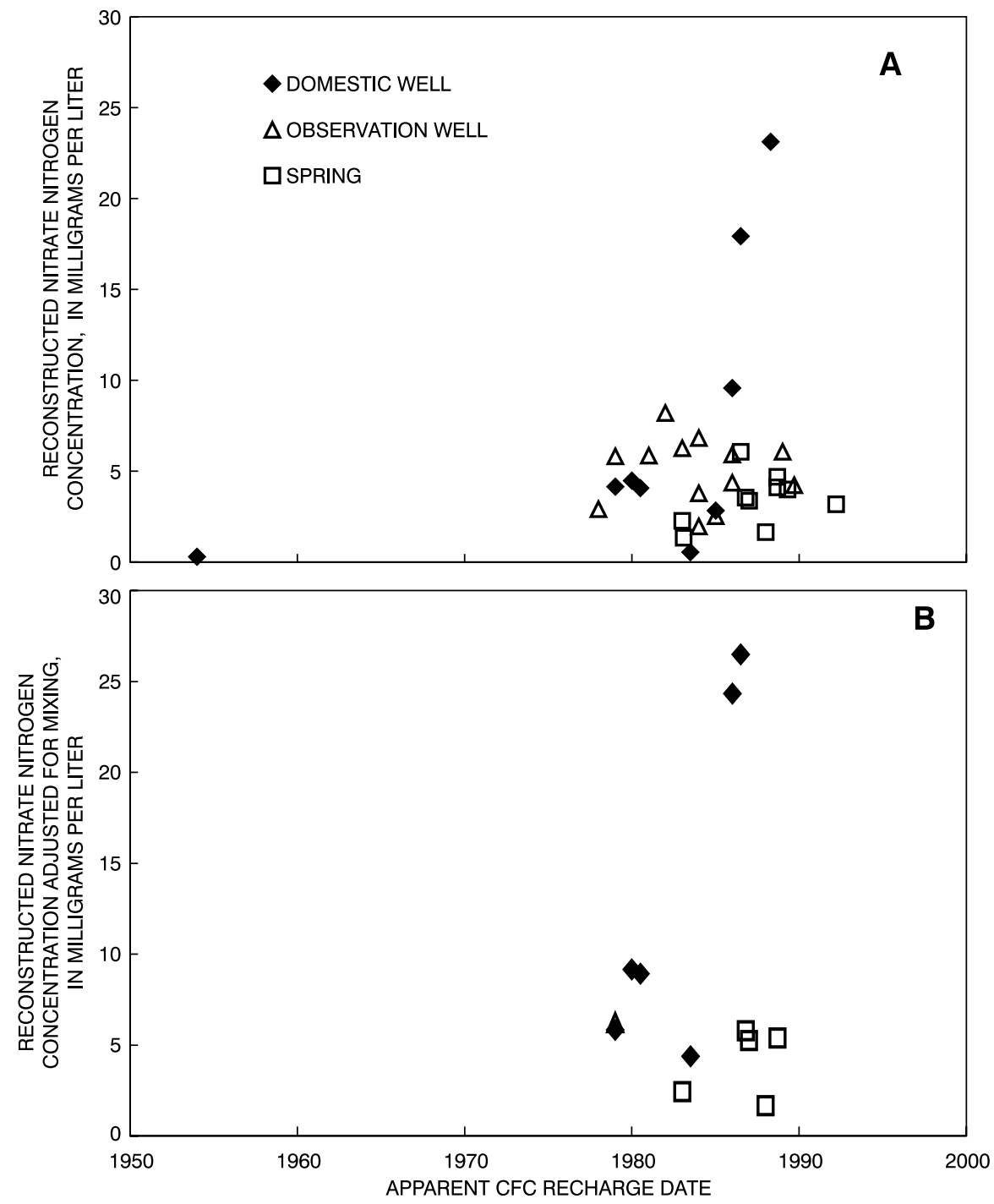

Figure 65. Relation of apparent chlorofluorocarbon (CFC) recharge date to reconstructed nitrate concentration $(A)$ and to reconstructed nitrate adjusted for mixing (B) for ground water in Muddy Creek Watershed, Va., November 1998, April 1999, and April 2000. 


\section{Factors Affecting Residence-Time Distribution, Nitrogen Occ urrence, and Discharge to Streams}

Land use and ground-water flow through solution channels in the carbonate aquifers likely control residence-time distribution, $\mathrm{N}$ occurrence, and discharge to streams in the Muddy Creek Watershed. Because the range in the apparent age of the ground water generally is small and the range in $\mathrm{NO}_{3}^{-}$concentrations in ground water is large (fig. 65), spatial rather than temporal differences in land use are likely the main causes of the range in $\mathrm{NO}_{3}^{-}$concentrations in the ground water. Because animal manure appears to be the primary source of $\mathrm{NO}_{3}^{-}$in the ground water, spatial differences in the amount of manure deposited on the land surface likely control $\mathrm{NO}_{3}^{-}$concentrations. Determination of the area through which ground water was recharged, however, is difficult because flow though solution channels formed along joints, fractures, and bedding planes can transport $\mathrm{NO}_{3}^{-}$substantial distances. Although such flow must be down the hydraulic gradient, it is not necessarily in the direction of the steepest hydraulic gradient because of the effects of solution channels on flow direction. Consequently, water from shallow wells open to the regolith, as well as from wells open to the bedrock, can be from either local or distant sources. The young apparent age of spring water can result from a combination of rapid flow along long, deep paths through solution channels and flow along short, shallow paths.

Although deep wells can be recharged locally, they are the wells most likely to have water recharged through distant land use. Recharge through forests on the slopes of Little North Mountain can account for the low $\mathrm{NO}_{3}^{-}$concentrations in water from the two deepest wells (wells 39S40 and 39S43) even though they are near the center of the watershed. Such low $\mathrm{NO}_{3}^{-}$concentrations also could result from dilution from mixing of high- $\mathrm{NO}_{3}^{-}$young water with low- $\mathrm{NO}_{3}^{-}$old water. Adjusting the reconstructed $\mathrm{NO}_{3}^{-}$concentration for water from well 39S40 for mixing of young and old water increases the $\mathrm{NO}_{3}^{-}$concentration from 0.547 to $4.4 \mathrm{mg} / \mathrm{L}$ (fig. 59B). Such an adjustment, however, is not appropriate if the assumptions are incorrect that the binary mixture contains only young and pre-CFC water and that only the young water contains $\mathrm{NO}_{3}^{-}$. The $\delta^{15} \mathrm{~N}$ of the sample from well $39 \mathrm{~S} 40$ was $7.15 \%$, the lowest for all samples from wells in the Muddy Creek Watershed. This value is on the low side for $\delta^{15} \mathrm{~N}$ for animal manure and on the high side for that from commercial fertilizer and natural plant material. The water contained no excess $\mathrm{N}_{2}$ gas so that fractionation from denitrification is unlikely. This water, therefore, could contain a mixture of $\mathrm{N}$ from different sources or even could represent background concentrations. Low concentrations of $\mathrm{NO}_{3}^{-}$could result from recent recharge through forested areas on Little North Mountain.

$\mathrm{NO}_{3}^{-}$concentrations (not corrected for excess $\mathrm{N}_{2}$ gas or mixing) in water from the wells and springs indicate sampled ground water likely represents $\mathrm{NO}_{3}^{-}$concentrations in ground water discharged to the streams of the Muddy Creek Watershed (fig. 56). $\mathrm{NO}_{3}^{-}$concentrations in streamwater at the Mount Clinton station could not be statistically differentiated from concentrations in water from the domestic wells, observation wells, or springs ( $\mathrm{p}=0.01$ using the Wilcox rank-sum test). $\mathrm{NO}_{3}^{-}$ concentrations in Muddy Creek from October 1995 through September 2000 generally were within the range of concentrations in spring waters in April 1999 (fig. 56).

Ground water in the Muddy Creek Watershed flows in a manner typically expected of an area underlain by a carbonate-bedrock aquifer. The apparent age of the ground water was young and generally varied little among springs because of flow through solution channels in the bedrock aquifer. The apparent CFC age of water discharging from the springs ranged from 7.3 to 12.8 years with 61 to 100 percent of the water being the young fraction of the water. Conversely, up to 39 percent of the water would be pre-CFC water on the basis of the binary-mixing model. It is possible, however, that spring discharge consists of more than two age components and that part of this discharge is modern water and contains little if any pre-CFC water. The young ${ }^{3} \mathrm{H} /{ }^{3} \mathrm{He}$ ages indicate the likelihood of modern water. Rapid flow through the aquifers also has been shown in the study northeast of the Muddy Creek Watershed where dye discharged from springs about 4 months after being dumped into sinkholes several miles from the springs (Wright, 1990).

Ground-water discharge provides a major part of the streamflow in the Muddy Creek Watershed, contributing a median of 71 percent of the annual flow. Ground-water discharge is from springs and directly through streambeds. Such discharge provides part of the flow during stormflow periods and all of the natural flow during base-flow periods.

In summary, the large variations in $\mathrm{NO}_{3}^{-}$concentrations in the ground water indicate considerable spatial variation in land use although the watershed contains primarily agricultural land. This variation in land use 
affects $\mathrm{NO}_{3}^{-}$contributed by different recharge areas. Thus, local differences in the use and management of manure, the apparent primary source of $\mathrm{NO}_{3}^{-}$in the watershed, likely control $\mathrm{NO}_{3}^{-}$concentrations. Concentrations of $\mathrm{NO}_{3}^{-}$in most wells and springs appear to represent $\mathrm{NO}_{3}^{-}$concentrations in ground water currently discharging to the surface waters. Because a large part of the ground water is at least several years old, several years could pass before appreciable changes in $\mathrm{NO}_{3}^{-}$concentrations are observed in the base flow of streams in response to changing land use.

\section{References Cited}

Alexander, R.B., and Smith, R.A., 1990, County-level estimates of nitrogen and phosphorus fertilizer use in the United States, 1945 to 1985: U.S. Geological Survey Open-File Report 90-130, $12 \mathrm{p}$.

Anderson, J.R., Hardy, E.E., Roach, J.T., and Witmer, R.E., 1976, A land use and land cover classification system for use with remote sensor data: U.S. Geological Survey Professional Paper 964, $28 \mathrm{p}$.

Battaglin, W.A., and Goolsby, D.A., 1994, Spatial data in geographic information system format on agricultural chemical use, land use, and cropping practices in the United States: U.S. Geological Survey Water-Resources Investigations Report 94-4176, $87 \mathrm{p}$.

MathSoft, Inc, 1999, S-PLUS 2000, modern statistic and advanced graphics-Guide to statistics, v. 1: Seattle, Wash., 638 p.

Orndorff, R.C., 1995, Geologic map of the Muddy Creek drainage basin within the Singers Glen quadrangle, Rockingham County, Virginia: U.S. Geological Survey Open-File Report 95629, 1 sheet.
Ott, Lyman, 1988, An introduction to statistical methods and data analysis (3d ed.): Boston, Mass., PWS-Kent Publishing Company, 835 p.

Preston, S.D., and Brakebill, J.W., 1999, Application of spatially referenced regression modeling for the evaluation of total nitrogen loading in the Chesapeake Bay Watershed: U.S. Geological Survey Water-Resources Investigations Report 99-4054, $8 \mathrm{p}$.

Puckett, L.J., 1994, Nonpoint and point sources of nitrogen in major watersheds in the United States: U.S. Geological Survey Water-Resources Investigations Report 94-4001, 9 p.

U.S. Geological Survey, 1979, Land use and cover, 1973-1977, Charlottesville, Virginia, West Virginia: U.S. Geological Survey Land Use Series, Open-File Report 79-403-1, 1 sheet, scale 1:250,000.

White, R.K., Hayes, D.C., Eckenweiler, M.R., and Herman, P.E., 2000, Water resources data, Virginia, water year 1999-Volume 1, surface-water discharge and surface-water quality records: U.S. Geological Survey Water-Data Report VA-99-1, $546 \mathrm{p}$.

2001, Water resources data, Virginia, water year 2000_-Volume 1, surface-water discharge and surface-water quality records: U.S. Geological Survey Water-Data Report VA-00-1, 547 p.

Wright, W.G., 1990, Ground-water hydrology and quality in the Valley and Ridge and Blue Ridge Physiographic Provinces of Clarke County, Virginia: U.S. Geological Survey Water-Resources Investigations Report 90-4134, 61 p. 
East Mahantango Creek Watershed

by Bruce D. Lindsey and William C. Burton

The East Mahantango Creek Watershed (fig. 66) was selected to represent the Valley and Ridge siliciclastic HGMR. This watershed was selected on the basis of the previous studies conducted here and the existing infrastructure. East Mahantango Creek was sampled as part of the Lower Susquehanna River Basin NAWQA Project. The NAWQA Project was a comprehensive study of ground- and surface-water chemistry, stream ecology, contaminants in streambed sediment and fish

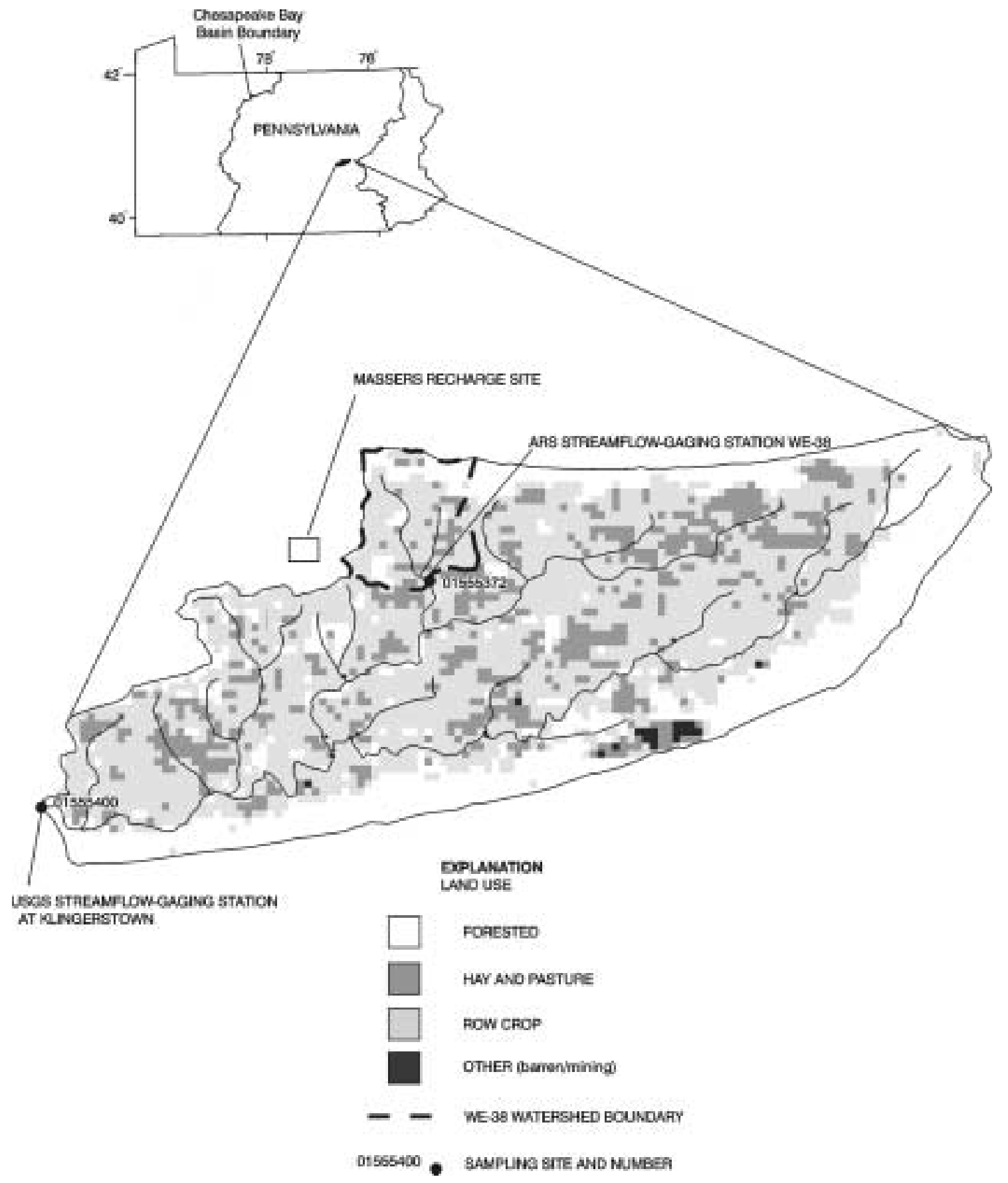

Figure 66. Land use within the East Mahantango Creek Watershed, Pa. 
tissue, and stream habitat throughout the Lower Susquehanna River Basin from 1993 to 2000. One reason the East Mahantango Creek Watershed was selected for the NAWQA study was because of the data and other information available from detailed hydrologic studies conducted over a 35-year period by the U.S. Department of Agriculture (USDA) - Agricultural Research Service (ARS) in a subwatershed of the East Mahantango Creek Watershed. The NAWQA study applied the base of knowledge about how the local system functioned to the larger watershed and used this information to help explain the water-quality data collected. Sampling plans and results of the NAWQA study are described in Siwiec and others (1997) and in Lindsey and others (1997).

\section{Description of Study Area and Sampling Network}

The East Mahantango Creek Watershed above the Klingerstown streamflow-gaging station (USGS station 01555400 ) has a drainage area of $44 \mathrm{mi}^{2}$. Land use in the watershed is 39 percent row crop, 17 percent hay, and 44 percent forested (fig. 66) (Vogelman and others, 1998a; 1998b). Continuous streamflow data were collected at the Klingerstown station from October 1992 to December 1994 and from October 1996 to September 2000. Water samples collected at the Klingerstown site on a monthly or biweekly basis throughout this time period were analyzed for nutrients, major ions, and pesticides (during summer months only) (Siwiec and others, 1997).

The subwatershed of East Mahantango Creek where most sampling for this project occurred was a 3.5- $\mathrm{mi}^{2}$ watershed called WE-38. Land use in WE-38 subwatershed is 48 percent row crop, 14 percent hay, and 36 percent forest; barren land makes up a small percentage of the area (figs. 66 and 67). A large volume of hydrologic data are available in WE-38. Continuous rainfall, runoff, and meteorological data have been collected in the WE-38 subwatershed since 1967; groundwater-level data have been collected since 1972; and soil moisture and root-zone percolate data also are available. Detailed studies in this subwatershed include rock-core analysis, seismic investigations, hydraulic-conductivity testing, (Gburek and Urban, 1990), ground-water modeling (Gburek and others, 1998), and numerous studies of the relations between ground- and surface-water quality and land use (Schnabel and others, 1993; Pionke and others, 1996; Pionke and Urban, 1985).

\section{Hydrogeology}

Regional ground-water-flow systems in the Valley and Ridge siliciclastic HGMR are controlled significantly by the topography of the region. The region is an area of intensely folded sandstone and shale rocks in sequences of synclines and anticlines. Sandstone formations of Ordovician to Devonian age are more resistant to weathering and form the linear ridges in this region that define the surface-water drainage boundaries. Ground-water flow generally is constrained by the ridges as well. Shales of Cambrian and Ordovician age and other less resistant rocks commonly are found in the valleys. Some primary porosity exists in these aquifers; however, intense folding and faulting of the rocks produced significant secondary porosity. The thickness of these aquifers depends on the thickness of the regolith and the depth and interconnectedness of the fracture and bedding-plane zones.

East Mahantango Creek is within the classic fold belt of the Valley and Ridge Physiographic Province of central Pennsylvania. The East Mahantango Creek Watershed is underlain by the Broad Mountain anticlinorium, an upright, east-west-trending, gently eastplunging fold composed of Devonian and Mississippian shale, siltstone, and sandstone (fig. 68). The limbs of the fold and the boundary of the watershed are outlined by more resistant, ridge-forming sandstone and conglomerate. The geology of the watershed was mapped in detail as part of three 7.5-minute geologic quadrangle maps by Trexler and Wood (1968a; 1968b) and Wood and Trexler (1968) and is included within an area described by Wood and others (1969).

Streamflow in this region is affected significantly by ground-water discharge. The ratio of base flow to total streamflow ranges from 37 to 64 percent (Bachman and others, 1998). The $\mathrm{NO}_{3}^{-}$load associated with this base-flow discharge ranges from 48 to 80 percent of the total $\mathrm{NO}_{3}^{-}$load. The aquifer thickness is estimated to range from 50 to $300 \mathrm{ft}$. Estimates of annual recharge rates range from 0.9 to $1.5 \mathrm{ft}$.

Hydrogeologic framework.-The USGS Bedrock Regional Aquifer Systematics Study (BRASS) project conducted an assessment of geologic structure and it's effect on hydrology within this area. The data from the BRASS project includes a detailed assessment of the fracture orientation in the geologic units, which proved to be an essential element in interpretation of the hydrology of the system. The geologic study of this area included an assessment of the number, orientation, and 


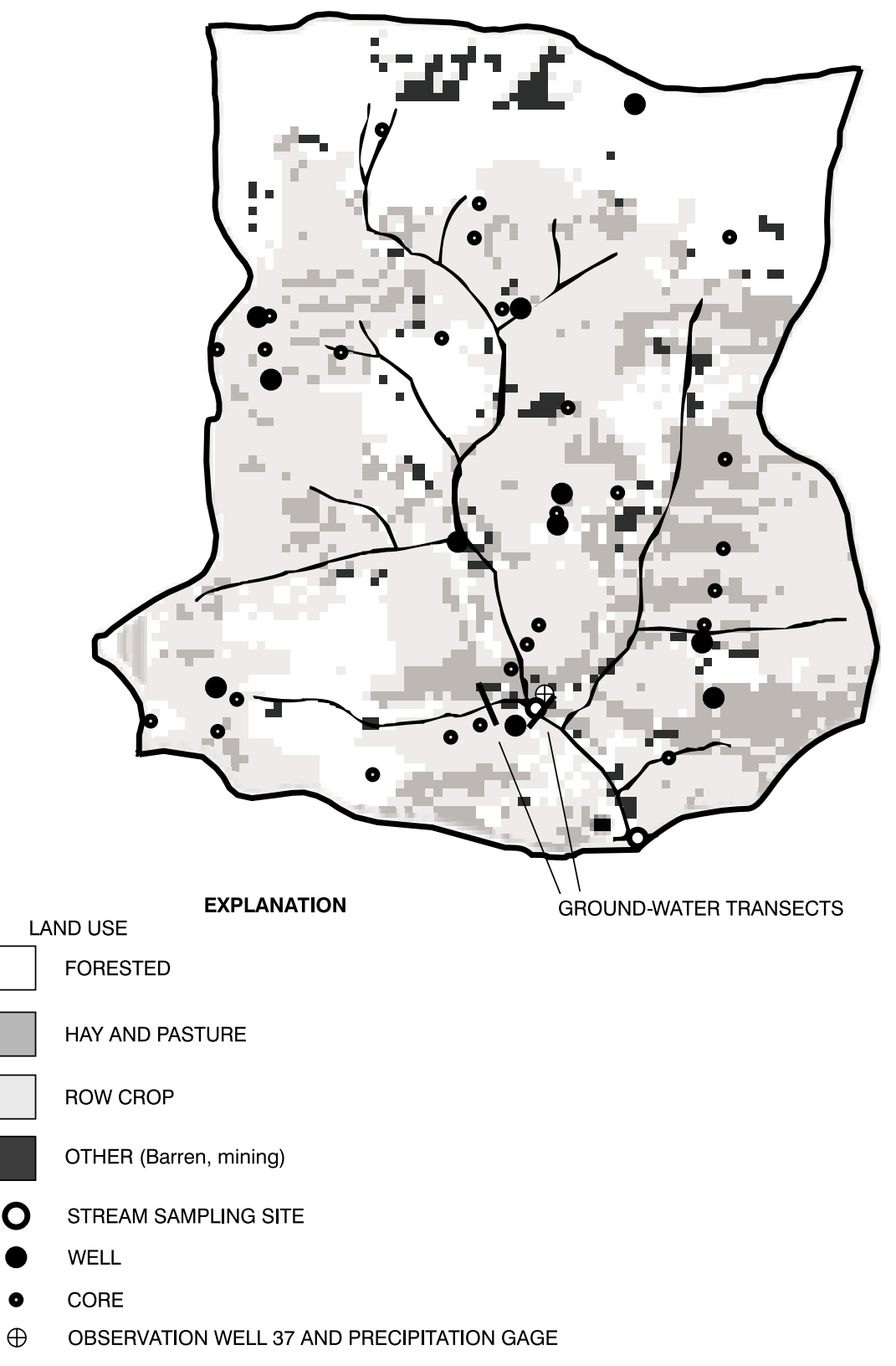

Figure 67. Land use and sampling sites within the WE-38 subwatershed of the East Mahantango Creek Watershed. 


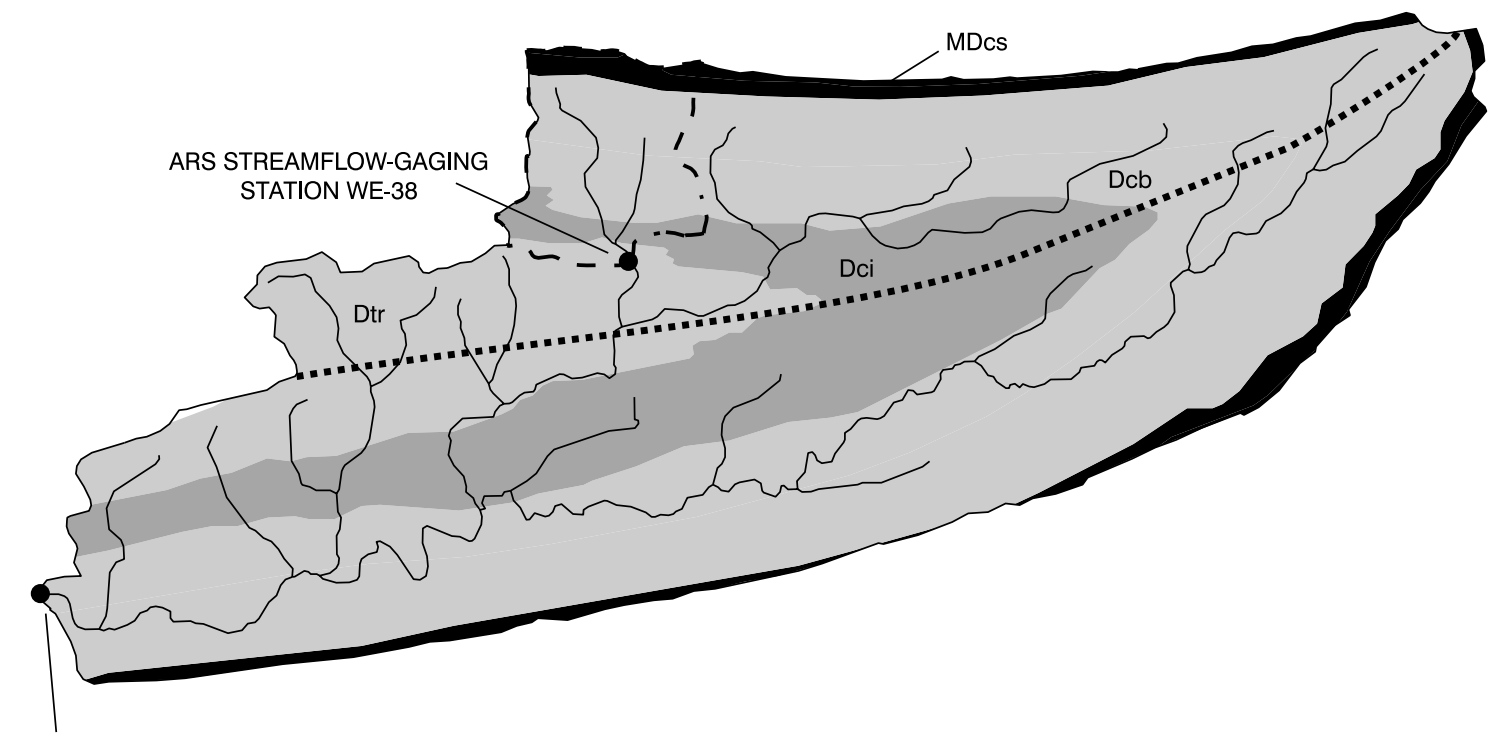

USGS STREAMFLOW-GAGING STATION AT KLINGERSTOWN

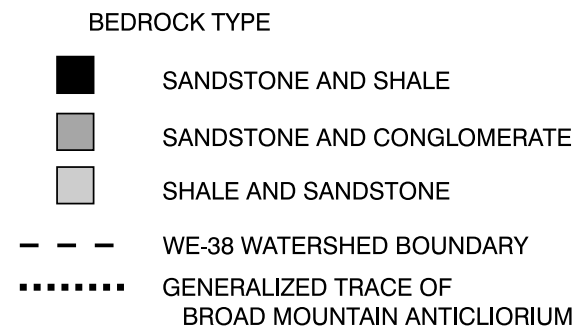

EXPLANATION

GEOLOGIC FORMATION

MDcS SPECHTY KOPF MEMBER OF CATSKILL FORMATION

Dcb BUDDY'S RUN MEMBER OF CATSKILL FORMATION

Dci IRISH VALLEY MEMBER OF CATSKILL FORMATION

Dtr TRIMMERS ROCK FORMATION

Figure 68. Geology of the East Mahantango Creek Watershed.

type of fractures at all outcrops in the East Mahantango Creek Watershed. The study also analyzed the number, orientation, and type of fracture for each of 29 cores collected previously by ARS.

Two dominant sets of fractures and a third less dominant set are present in these rocks: one set, bedding-plane parting, is closely spaced (centimeters to decimeters) and parallel to bedding in the sedimentary rocks; the other set, spaced cleavage, ranges from closely spaced (centimeters) to more widely spaced (decimeters to meters), is at high angles to bedding, and is subparallel to the vertical, east-west-striking axial plane of the Broad Mountain anticlinorium. A third, more widely spaced set of cross-joints (meters to tens of meters) is subvertical and generally north-south striking, and perpendicular to the axial plane and spaced cleavage of the anticlinorium.
A conceptual diagram of the fracture geometry of the Broad Mountain anticlinorium, drawn on the basis of field observations, is shown in figure 69. It shows that bedding-plane parting, which ranges in orientation from south-dipping to sub-horizontal to north-dipping, is more closely spaced in the Trimmers Rock Sandstone than the two overlying units the Irish Valley and Buddy's Run Members of the Catskill Formation. Cleavage spacing, in contrast, is influenced by position relative to the fold as well as lithology; it is subvertical and more concentrated along the axial plane of the fold, while fanning out towards the limbs of the fold, and is more concentrated in shale and siltstone layers than sandstone layers. The symmetry of the two high-angle fracture sets (spaced cleavage and cross-joints) with respect to the overall fold geometry suggests they likely were created during formation of the anticlinorium, 


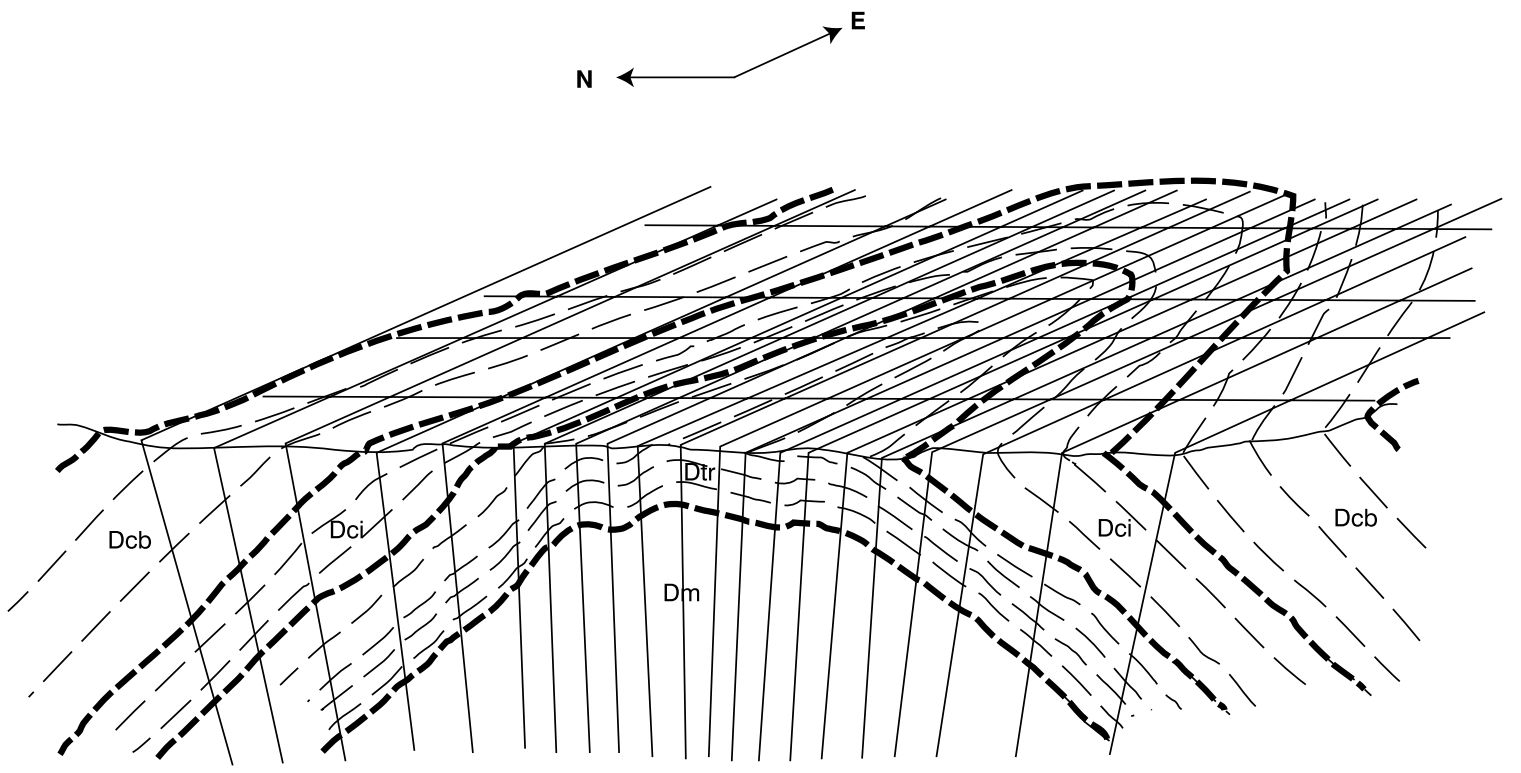

EXPLANATION

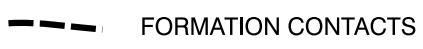

- BEDDING-PLANE PARTING

AXIAL-PLANE CLEAVAGE

Dcb BUDDY'S RUN MEMBER OF CATSKILL FORMATION

DCi IRISH VALLEY MEMBER OF CATSKILL FORMATION

Dtr TRIMMERS ROCK FORMATION

Dm MAHANTANGO FORMATION

Figure 69. Schematic fracture framework of the Broad Mountain anticlinorium.

whereas formation of bedding-plane parting may in part predate folding. The subwatershed WE-38 is on the north limb of the fold (fig. 69).

Fractures measured at outcrops in the East Mahantango Creek Watershed are typical for a fold with the orientation of the Broad Mountain anticlinorium. In addition to the ones already discussed, a set of relatively rare, widely spaced, northeast-southwest-striking crossjoints have an unknown origin with respect to the Broad Mountain anticlinorium but may postdate formation of the fold. Probably neither the north-south trending nor northeast-southwest trending cross-joints play as important a role in regional ground-water flow as beddingplane parting and cleavage. All the units have very low primary porosity; hydraulic flow within bedrock is therefore governed by secondary (fracture) porosity (Gburek and Urban, 1990).
Gburek and others (1998) developed a hydrogeologic framework for their studies of ground water within the WE-38 subwatershed. They showed the aquifer consists of highly fractured zones controlling local groundwater flow superimposed on a less-fractured regionalflow system. The top $10 \mathrm{ft}$ was considered to be a highly permeable overburden layer. The highly fractured bedrock zone extends from about 10 to $30 \mathrm{ft}$, the moderately fractured zone extends from 30 to $75 \mathrm{ft}$, and the depth of the regional aquifer is about 75 to $270 \mathrm{ft}$. This fracture distribution was based on results of seismic surveys, observations of bedrock core, and the stress-relief fracture model discussed by Wyrick and Borchers (1981), which describes a more highly fractured zone close to the surface in areas of significant topographic relief. 
Bedding-plane parting is the predominant fracture set (fig. 70). Unpublished data from bedrock cores drilled in the WE-38 subwatershed show bedding-plane parting and spaced cleavage represent 76 and 24 percent, respectively, of the fractures under WE-38. The existence of these two fracture sets and the prevalence of bedding-plane parting were acknowledged in previous work, but relative abundances were not quantified (Gburek and Urban, 1990).

Ground-water flow .-Findings from some of the previous studies in the WE-38 subwatershed are relevant to the study of ground-water flow and residence time. Gburek and Folmar (1999b) published findings of ground-water-flow modeling that indicated relatively short ground-water residence times (less than 1 year). Schnabel and others (1993) used water-quality data in the $3.5-\mathrm{mi}^{2}$ watershed to indicate the shallow layer of the aquifer may contribute the higher $\mathrm{NO}_{3}^{-}$concentrations under high base-flow conditions; the deeper layer of the aquifer contributes the lower concentrations of $\mathrm{NO}_{3}^{-}$under lower flow conditions. Schnabel's observations on variations in $\mathrm{N}$ concentrations in stream base flow were consistent with findings of Lindsey and others (1997) in the 44- $\mathrm{mi}^{2}$ East Mahantango Creek Watershed. Apparent ages of water from the seven springs analyzed in the Valley and Ridge siliciclastic HGMR ranged from 5 to 40 years (Focazio and others, 1998). These previous studies of the local system (Gburek and Folmar, 1999b) and the regional system (Focazio and others, 1998) are used as a starting point to formulate a conceptual model for the ground-water-flow system.
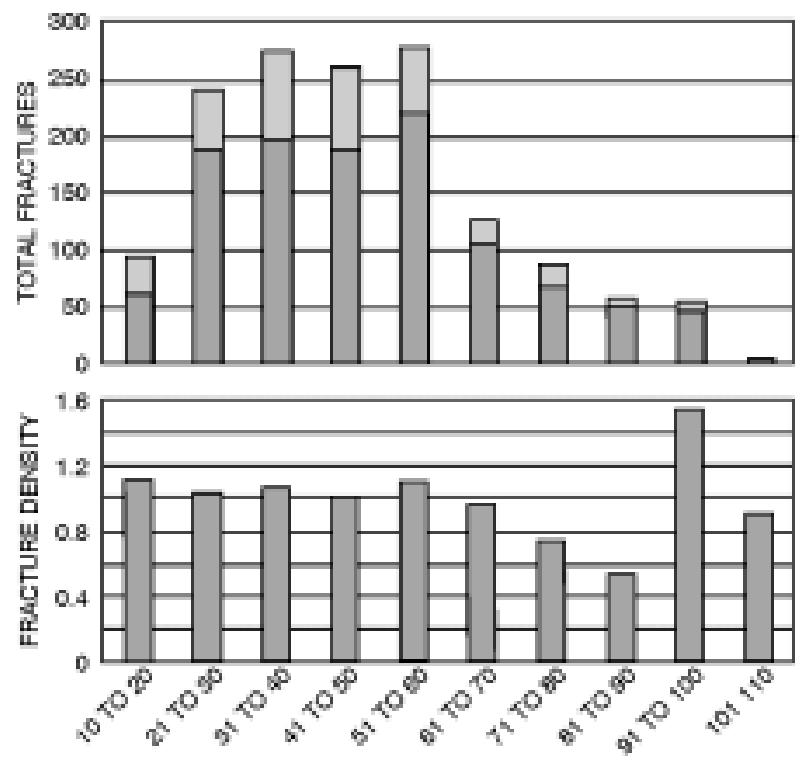

DEPTH, IN FEET
Hydrologic data indicate a possible departure from the homogeneous layered aquifer proposed by Gburek and others (1998) (fig. 71). Analysis of outcrops and cores showed the dominant fracture set was the bedding-plane fractures. To determine whether or not the dominance in numbers of fractures controlled groundwater flow, borehole geophysical logging was conducted on five wells. The combination of caliper logs, heatpulse-flowmeter logs, and acoustic-televiewer logs were used to identify the orientation of the fractures and the water-producing zones. Of the 90 fractures analyzed in the 5 wells, 47 were identified as bedding-plane fractures, 33 were identified as cleavage fractures, and 10 were cross fractures. Heatpulse-flowmeter logs showed two thirds of the fractures that produced water were bedding-plane fractures and one third were cleavage fractures. None of the cross fractures produced water. This information led to the hypothesis that fracture orientation may have a key role in ground-water flow (fig. 71). Other data available to evaluate this possibility were water levels from the piezometer transects across the watershed oriented parallel to the strike of the dipping beds as in figure 72 . These water levels indicate higher water levels on the north side of the transect than on the south side of the transect. Although this could be a result of other causes, this pattern matches the general head distribution that would be expected if the hydraulic conductivity on the north side of the transect was lower than that on the south side of the transect.

EXPLANATION

BEDOING PLANE PARTNG

OTHER FRACTURES

Figure 70. Total fractures and fracture density in cores collected within the WE-38 subwatershed of the East Mahantango Creek Watershed. 
A

NORTHEAST

SOUTHWEST

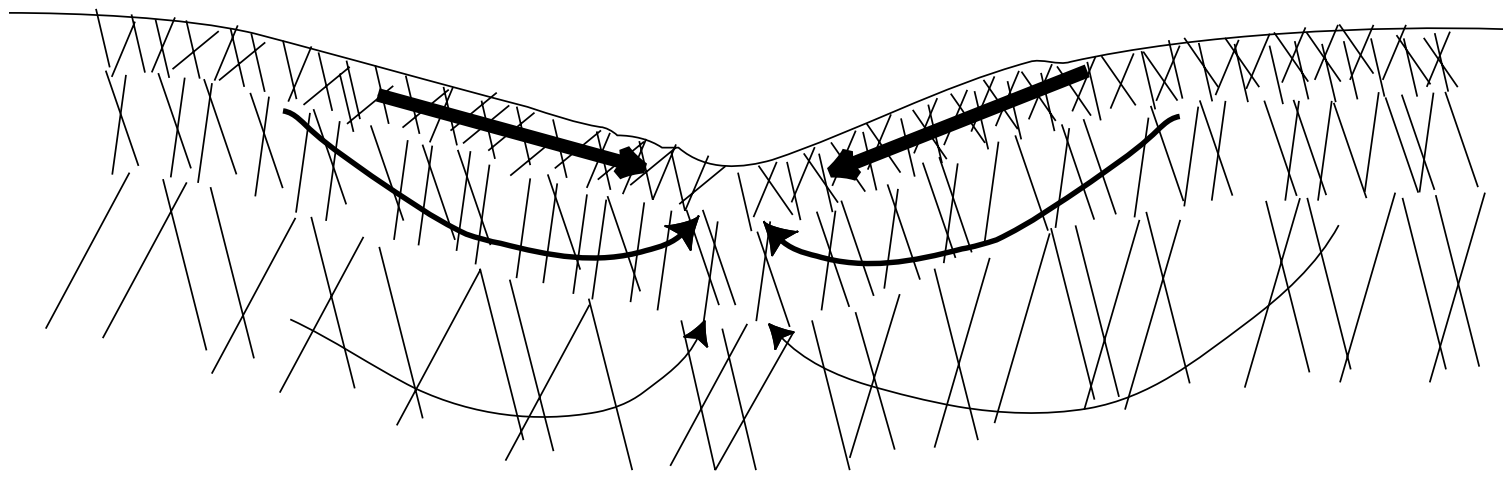

NORTHEAST

SOUTHWEST

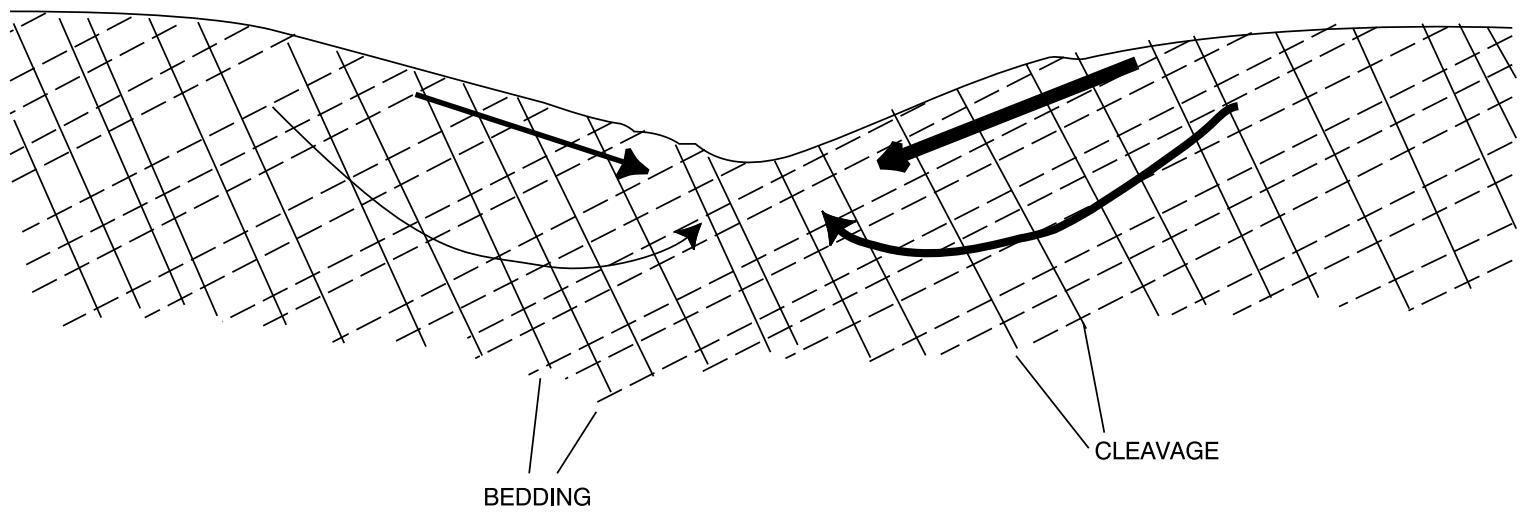

Figure 71. Ground-water-flow systems in the WE-38 subwatershed as shown by (A) flow controlled by layering hypothesis and (B) flow controlled by fracture-orientation hypothesis. 


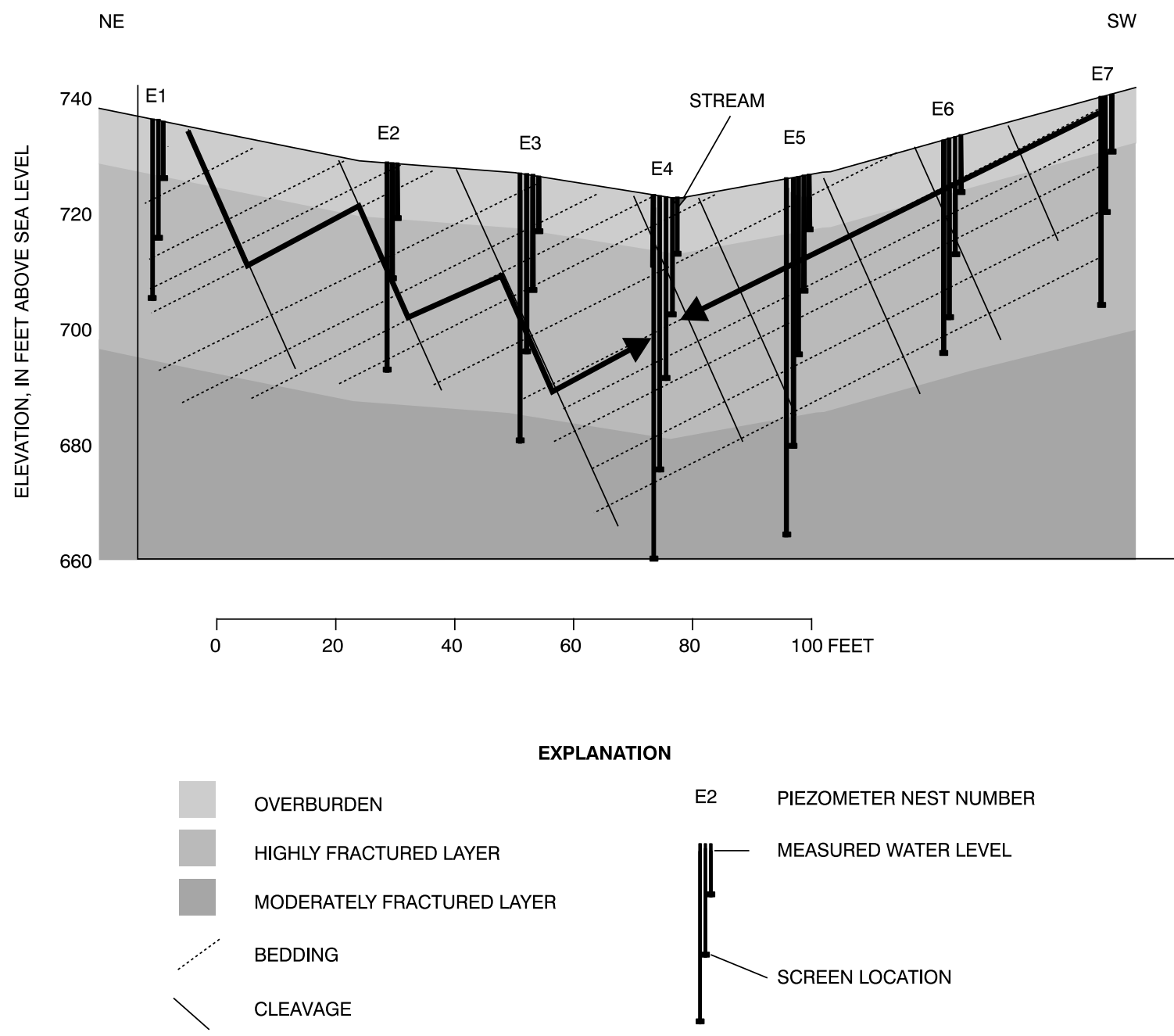

Figure 72. Hypothetical movement of water in relation to fracture orientation and actual water levels in the east piezometer transect of WE-38 subwatershed.

\section{Sample network and collection}

Sample collection for this study focused on preexisting wells or piezometers. Attempts were made to install minipiezometers in the streams to sample direct ground-water discharge; however, the streambed consists of a thin layer of sediment overlying bedrock. This did not allow the minipiezometer approach to work at this location. Shallow (5 ft deep) wells were drilled on the streambanks to attempt to obtain samples from the shallowest layer, which according to Gburek and others (1998) has a high hydraulic conductivity and transmits much of the water. The four wells drilled in these locations were not sampled because they were above the water table or were completed in a material that pro- duced water too slowly to collect a representative sample. Therefore, the decision was made to use only the existing piezometers in the watershed.

\section{Sampling network.-The USDA-ARS}

research station within this targeted watershed provided a large number of potential sampling locations for hydrologic studies. Some of the infrastructure for hydrologic characterization included: 12 wells with continuous water-level measurements, a weir with continuous streamflow measurements, 29 cores, 26 stream-sampling locations, and 2 sets of nested piezometers in transects across the stream with a total of 48 piezometers (fig. 73). The nest of piezometers in the transects were particularly well-suited for use by this project and were the primary wells sampled for age-dating tracers. 


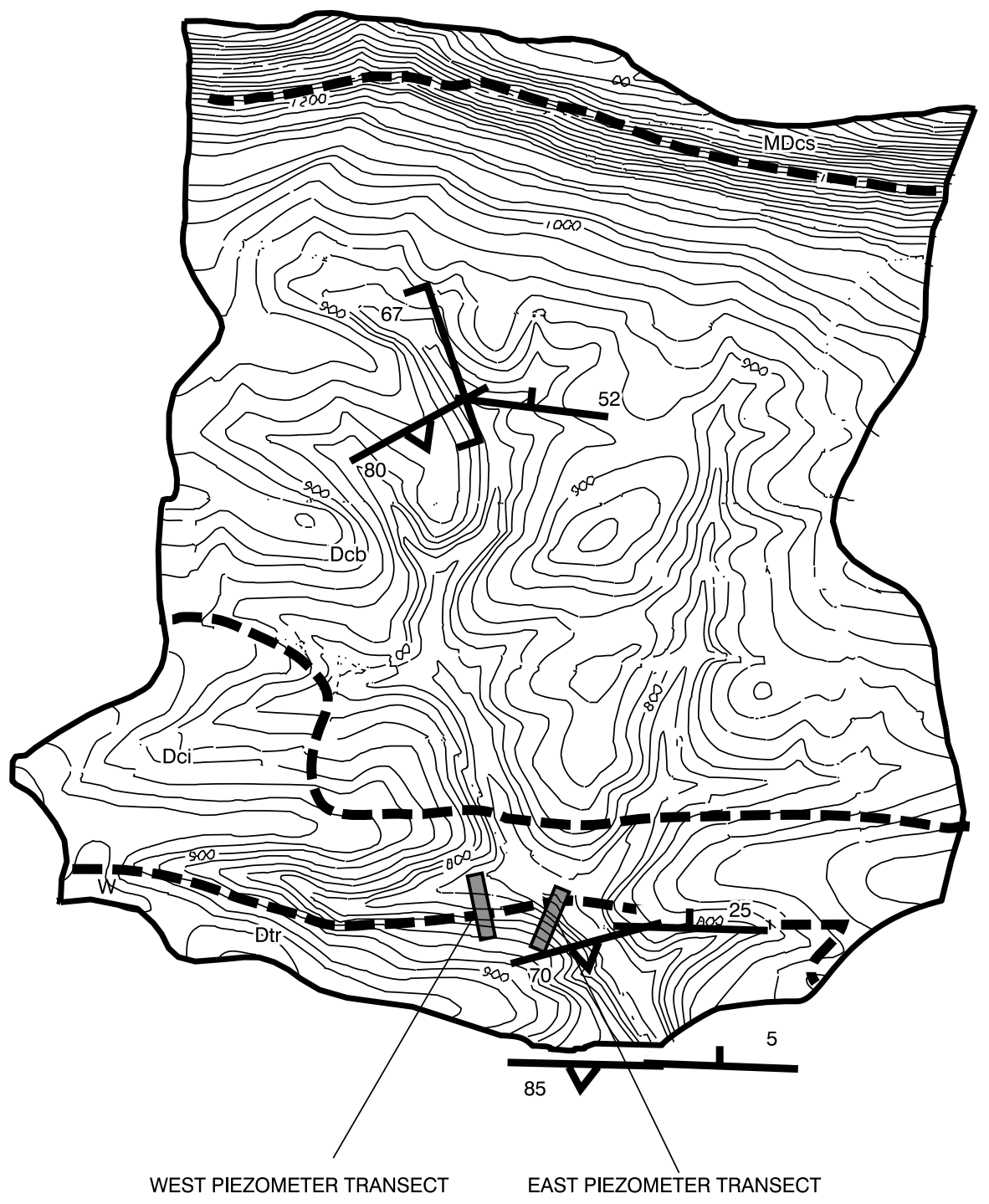

EXPLANATION

GEOLOGIC STRUCTURE SYMBOLS

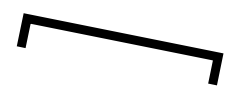

CROSS FRACTURES

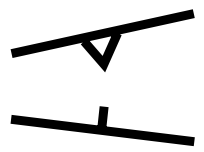

GEOLOGIC FORMATIONS

Dtr TRIMMERS ROCK FORMATION

DCI IRISH VALLEY MEMBER, CATSKILL FORMATION

Dcb BUDDY'S RUN MEMBER, CATSKILL FORMATION

MDcS SPECHTY KOPF MEMBER, CATSKILL FORMATION

Figure 73. Topography, geology, and location of piezometer transects in WE-38 subwatershed. 
The ARS research team provided access to all flow, precipitation, water-level, and water-quality data that were available.

Of the two permanent piezometer networks in WE-38, one transects a permanent stream (east piezometer transect) and one transects an intermittent stream (west piezometer transect) (Gburek and Urban, 1990). Each transect contains nested arrays of piezometers of different depths arranged parallel to the drainage. Each piezometer consists of a 6-in. diameter hole cased down to the nominal depth, below which an unscreened 4 in. diameter hole extends $2 \mathrm{ft}$ (Gburek and Urban, 1990). A typical nest has piezometers of $10,20,30,45$, and $60 \mathrm{ft}$ (app. 1).

The positions of the two transects are shown on figure 73 . The transects are oriented roughly perpendicular to both bedding and cleavage and cross the contact between Trimmers Rock Sandstone and the Irish Valley member of the Catskill Formation, which is exposed in an outcrop just east of the transects (fig. 73). In this outcrop, the strike of bedding is N. $87^{\circ} \mathrm{W}$. and the dip is $25^{\circ} \mathrm{NE}$., and the bedding-plane parting has an approximate average spacing of $20 \mathrm{~mm}$. Spaced cleavage strikes N. $75^{\circ}$ E., dips $77^{\circ}$ SE., and has an average spacing of $25 \mathrm{~mm}$ but is generally not through-going; individual fractures terminate at bedding-plane partings.

The arrangement of piezometers in cross section with respect to drainage and fracture network for both the east and west transects is shown in figure 74. Shown schematically are the apparent dips (as seen in the line of section) and relative frequency of the two main fracture sets, bedding-plane parting and spaced cleavage. Note that the dominant set, bedding-plane parting, dips northward in both sections. The use of existing piezometer nests instead of minipiezometers in the stream mean that the samples collected did not represent the direct discharge of water to the stream, rather, they represent a distribution of ages in the aquifer near the transect. The transect spanned about 75 to $80 \mathrm{ft}$ on either side of the receiving stream.

\section{Sampling methods, timing, and} hydrologic conditions.-The methods used for sampling in this watershed are described in the Study Design and Approach section. Sampling for age-dating tracers was conducted in 1998, 1999, and 2000. The sampling conducted in 1998 included only three piezometer nests across the east transect within the WE-38 subwatershed. This was done as a reconnaissance and was followed by a full sampling effort in 1999, in which all the piezometers in both the east and west transects that produced water were sampled. In the sampling for 2000, a targeted sampling approach was followed. Samples were collected from piezometers or nests in the east and west transects where additional data were needed. In 2000, additional wells were sampled outside the two transects. One of these sets of additional samples was from a nearby study site where wells had been drilled on a hilltop to study recharge (Massers Recharge site, fig. 67). Two nests of deep and shallow piezometers were sampled here where recharge was nearly vertical. Two samples were collected in areas within the WE-38 subwatershed where recharge was assumed to be local and representative of a single $\mathrm{N}$ source. Water-level measurements from each transect were recorded at various times of the year during 1999-2000 to observe the changes in hydrologic conditions. Additionally, continuous water-level measurements from a $100 \mathrm{ft}$ deep open borehole well near the $\mathrm{E} 3$ piezometer nest in the east transect (well 37) were available to characterize the hydrologic conditions (fig. 75).

Sampling was in mid to late spring of each year. The sampling in 1999 and 2000 was earlier in the spring and was intended to represent conditions of high base flow; however, hydrologic conditions of these sampling events indicate sampling in each of the 3 years was conducted under conditions where water levels and streamflow were low (fig. 75). The sampling period during 1999 was during the onset of a drought.

\section{Distribution of Nitrogen, Dissolved Oxygen, and Methane in the Ground-Water System}

The distribution of $\mathrm{N}$ in the ground-water system will be discussed with respect to dissolved $\mathrm{NO}_{3}^{-}$as $\mathrm{N}$. On the basis of the comparison of the $\mathrm{NO}_{3}^{-}$plus $\mathrm{NO}_{2}^{-}$ to $\mathrm{NO}_{2}^{-}, \mathrm{NO}_{3}^{-}$concentration will be assumed to be equivalent to the value measured as $\mathrm{NO}_{3}^{-}$plus $\mathrm{NO}_{2}^{-}$, the term " $\mathrm{NO}_{3}^{-}$" will be used for concentrations analyzed as $\mathrm{NO}_{3}^{-}$plus $\mathrm{NO}_{2}^{-}$as $\mathrm{N}$. In addition, because nearly all of the $\mathrm{N}$ in the system is in the form of $\mathrm{NO}_{3}^{-}$, the analysis of the distribution of $\mathrm{N}$ in ground water will focus on $\mathrm{NO}_{3}^{-}$. Concentrations of $\mathrm{NH}_{3}$ ranged from less than the MRL to $3.69 \mathrm{mg} / \mathrm{L}$; however, that maximum concentration was the only sample exceeding $0.5 \mathrm{mg} / \mathrm{L}$ (app. B). Most concentrations of $\mathrm{NH}_{3}$ were less than $0.1 \mathrm{mg} / \mathrm{L}$. Concentrations of dissolved $\mathrm{NH}_{3}$ plus organic $\mathrm{N}$ ranged from less than the MRL to $4.2 \mathrm{mg} / \mathrm{L}$, and again the concentrations in the majority of the samples were at or near the MRL. Concentrations of $\mathrm{NO}_{2}^{-}$ ranged from less than the MRL to $0.029 \mathrm{mg} / \mathrm{L}$. Concen- 

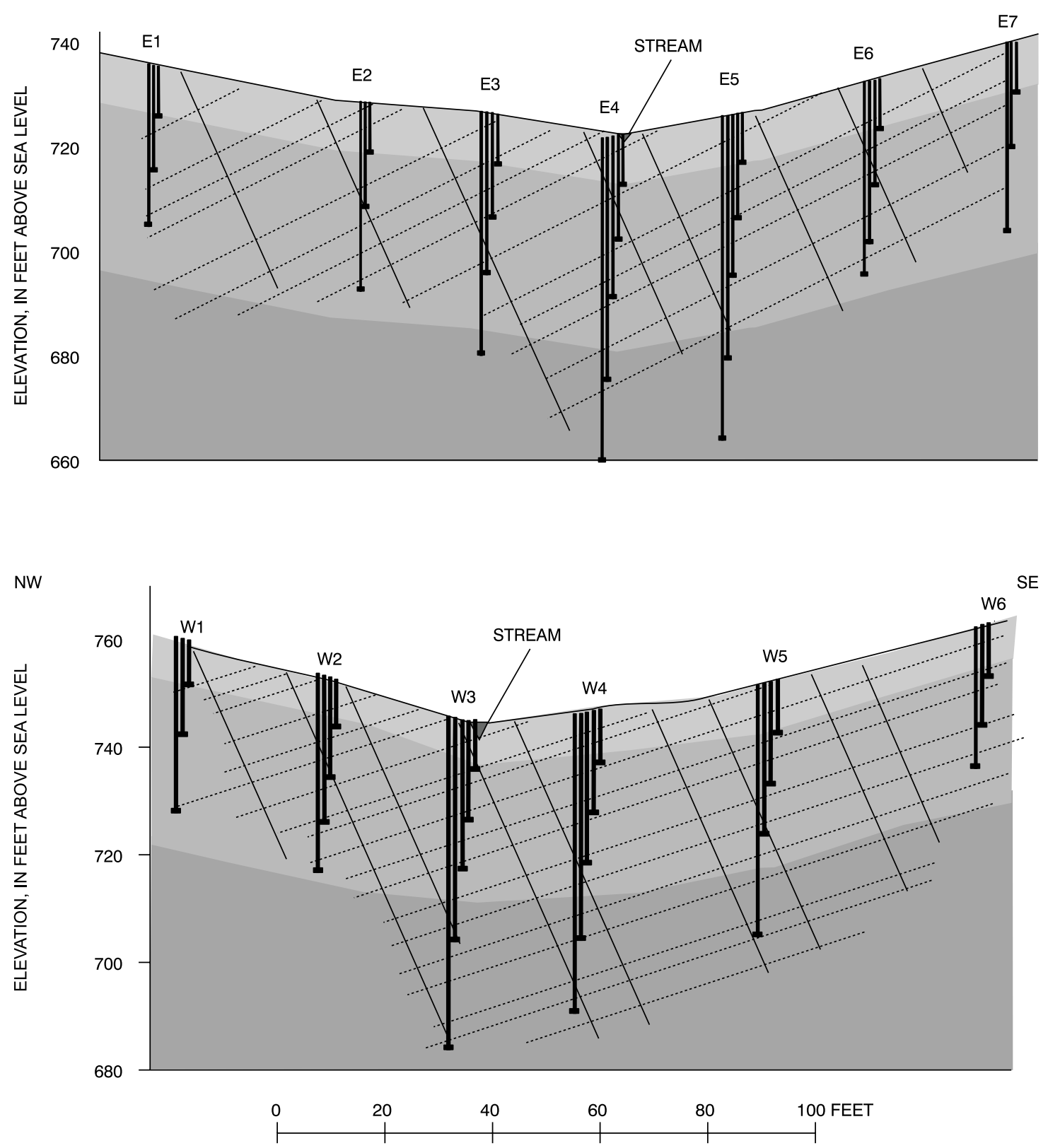

EXPLANATION

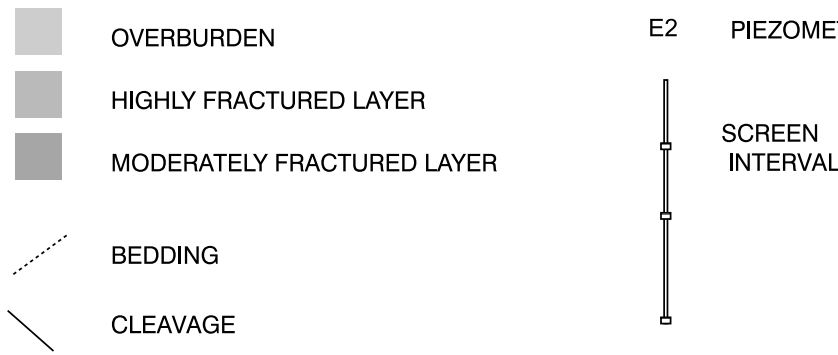

Figure 74. Cross sections through east and west piezometer transects, showing orientation of bedding and cleavage, East Mahantango Creek Watershed, Pennsylvania. 


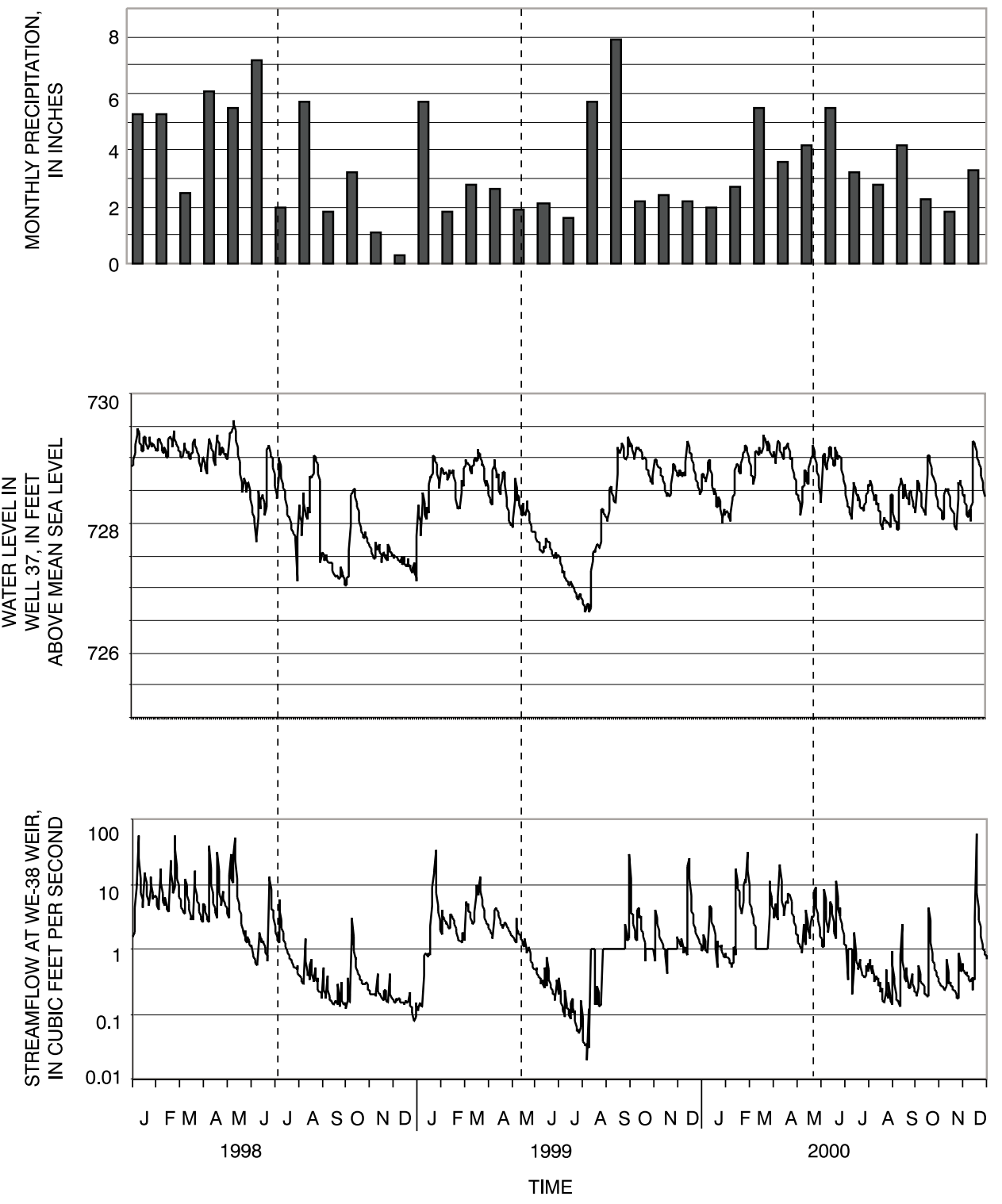

Figure 75. Monthly precipitation, water levels in observation well 37, and streamflow at WE-38 weir from January 1998 to December 2000, in WE-38 subwatershed, East Mahantango Creek Watershed, Pennsylvania. Vertical dashed lines indicate sampling periods. (Gordon Folmar, U.S. Department of Agriculture, written commun., 2001)

trations of $\mathrm{NO}_{3}^{-}$plus $\mathrm{NO}_{2}^{-}$ranged from less than the MRL to $12.3 \mathrm{mg} / \mathrm{L}$ as $\mathrm{N}$; most samples had measurable concentrations.

Concentrations of $\mathrm{NO}_{3}^{-}$showed similar patterns from year to year. $\mathrm{NO}_{3}^{-}$data from 1999 , the year with the most complete data set, are shown in figure 76. In $1998, \mathrm{NO}_{3}^{-}$concentrations ranged from less than 0.050 to $11.8 \mathrm{mg} / \mathrm{L}$. In 1999 in the east transect, concentra- tions ranged from less than 0.050 to $11.6 \mathrm{mg} / \mathrm{L}$, in the west transect, $\mathrm{NO}_{3}^{-}$concentrations ranged from 0.687 to $12.3 \mathrm{mg} / \mathrm{L}$. The data from 2000 showed a range of less than 0.050 to $12.3 \mathrm{mg} / \mathrm{L}$ in the east transect, and a range of 0.479 to $11.5 \mathrm{mg} / \mathrm{L}$ in the west transect.

The distribution of $\mathrm{NO}_{3}^{-}$in the ground-water system is systematic. Initial observations of the distribution of concentrations of $\mathrm{NO}_{3}^{-}$show significantly 

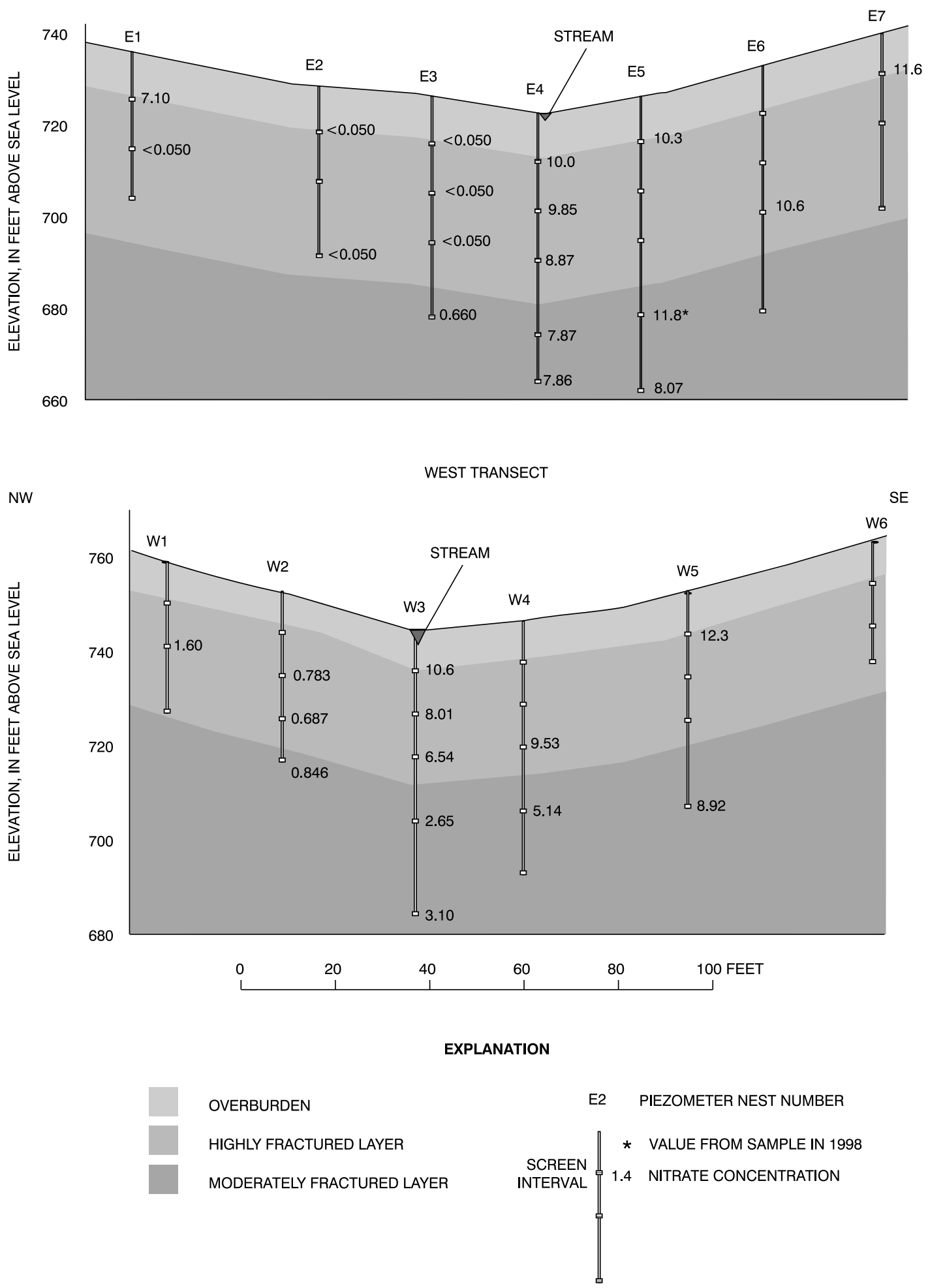

Figure 76. Distribution of nitrate in east and west transects, May 1999, East Mahantango Creek Watershed, Pa. 
greater $\mathrm{NO}_{3}^{-}$concentrations on the south sides of both transects (fig. 76). These differences could be explained partially by differences in $\mathrm{N}$ sources on each side of the transect, as suggested by Gburek and Urban (1990). The north side of each transect contains pasture with cropland and minor amounts of forested land. The south side of these transects is predominantly cropland with some pasture (fig. 77). The implication is that the cropland would contribute a larger amount of $\mathrm{N}$ to the groundwater system. The actual land use as shown in figure 77, however, shows the differences in sources in the immediate contributing area are not that great and do not completely explain the differences in $\mathrm{NO}_{3}^{-}$concentrations. Dissolved gas analyses (app. C) showed excess N concentrations on the north side of the transect, which indicate possible denitrification (fig. 78). Dissolved oxygen concentrations (app. A) also show significant differences on the north and south sides of the transects (fig. 78). Methane gas was only detected on the north side of the east transect where dissolved oxygen was depleted. These differences show, in addition to possible $\mathrm{N}$ source differences, indications that denitrification is causing some of the differences seen in $\mathrm{NO}_{3}^{-}$concentrations across each transect.

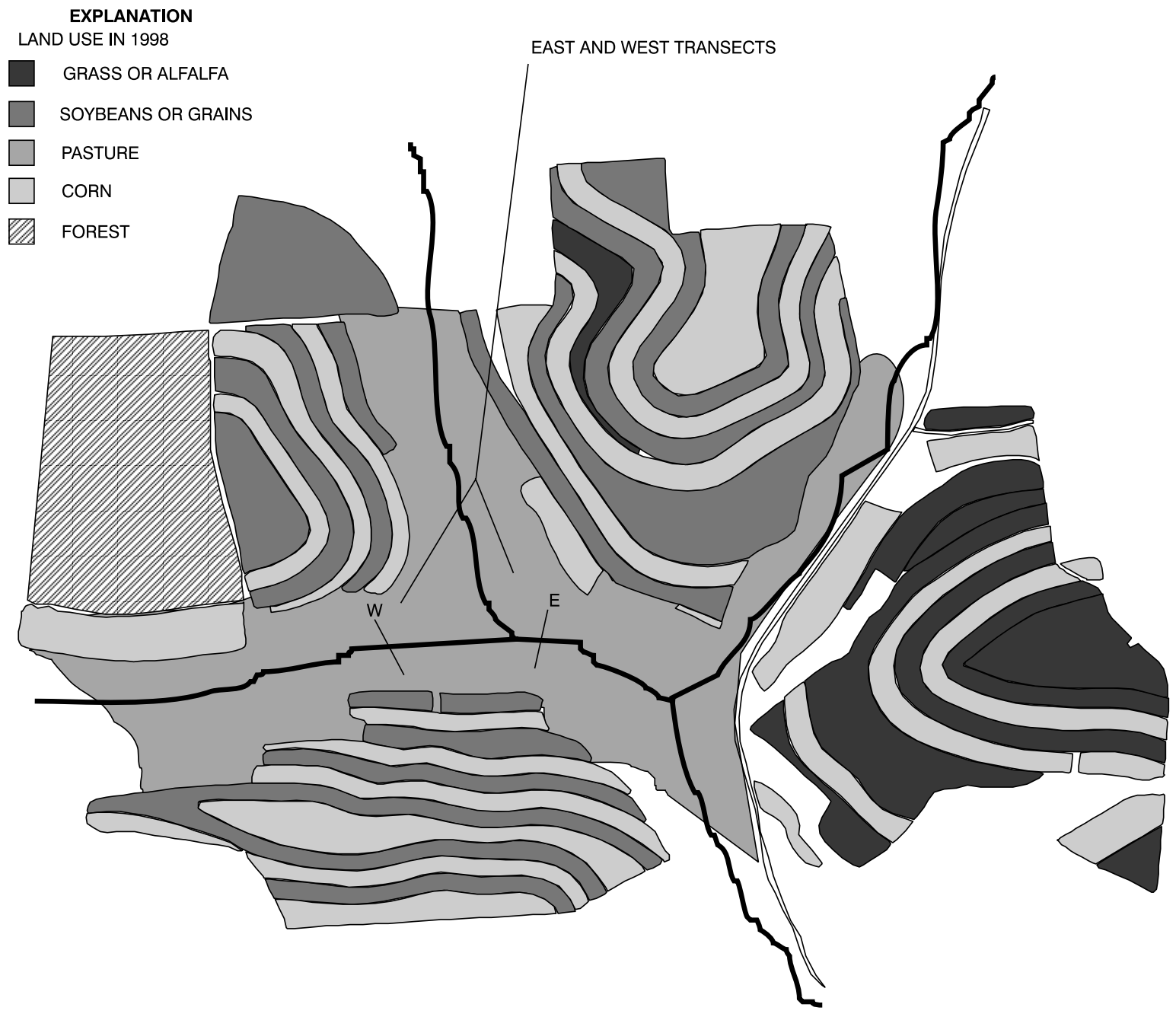

Figure 77. Land use near the east and west transects in 1998, East Mahantango Creek, Pa. (James Richards, U.S. Department of Agriculture/Agricultural Research Service, written commun., 2001). 
NE
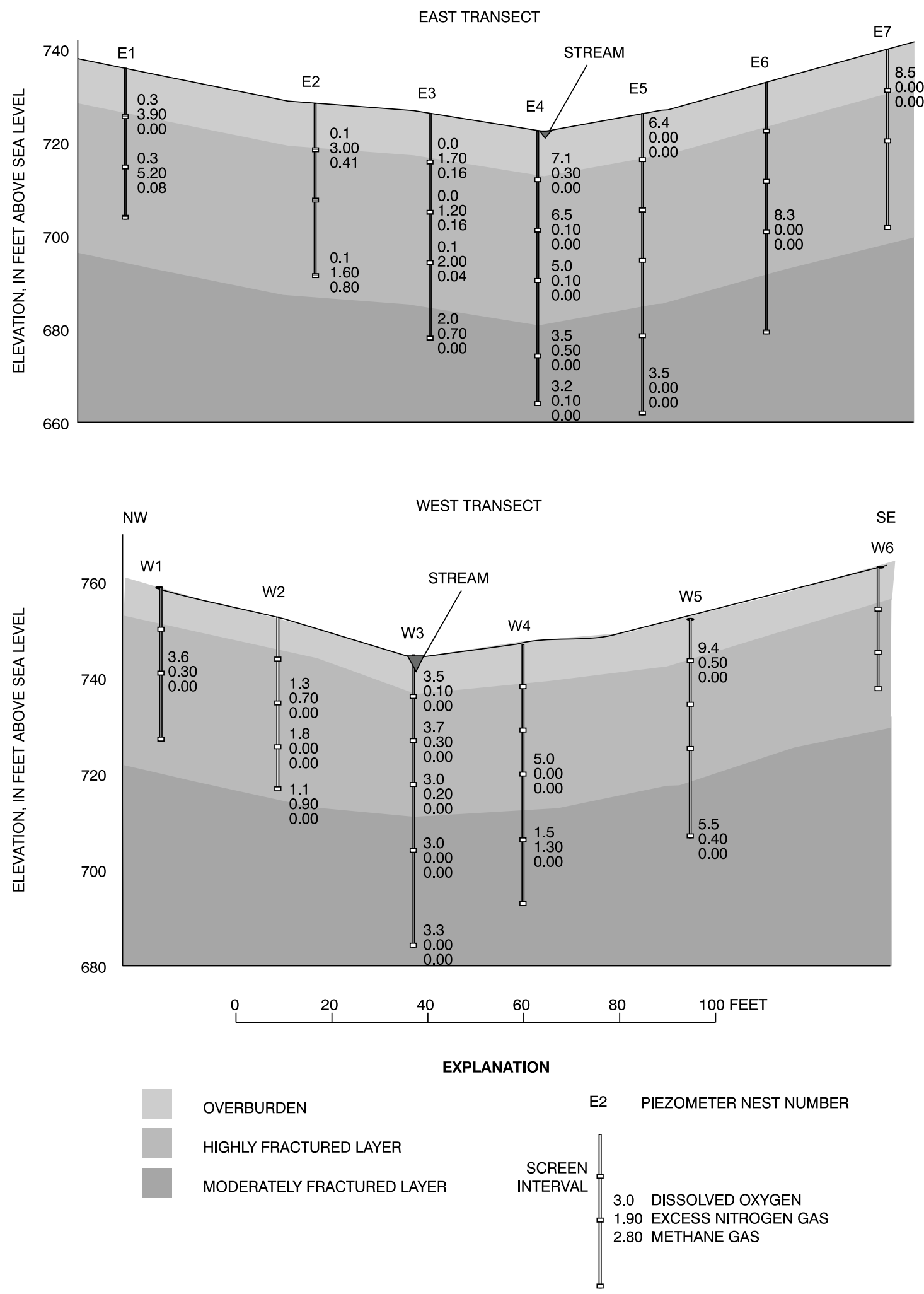

Figure 78. Distribution of concentrations of dissolved oxygen, excess nitrogen gas, and methane in the east and west transects, May 1999, East Mahantango Creek Watershed, Pa. 
One way to evaluate the $\mathrm{NO}_{3}^{-}$concentrations is to add the excess $\mathrm{N}_{2}$ gas concentration to the measured $\mathrm{NO}_{3}^{-}$concentration (app. B), giving the initial or reconstructed $\mathrm{NO}_{3}^{-}$concentration. This is a way to evaluate the $\mathrm{NO}_{3}^{-}$distribution that results from factors other than denitrification. This calculation shows $\mathrm{N}$ concentrations are still significantly greater on the south side than on the north side.
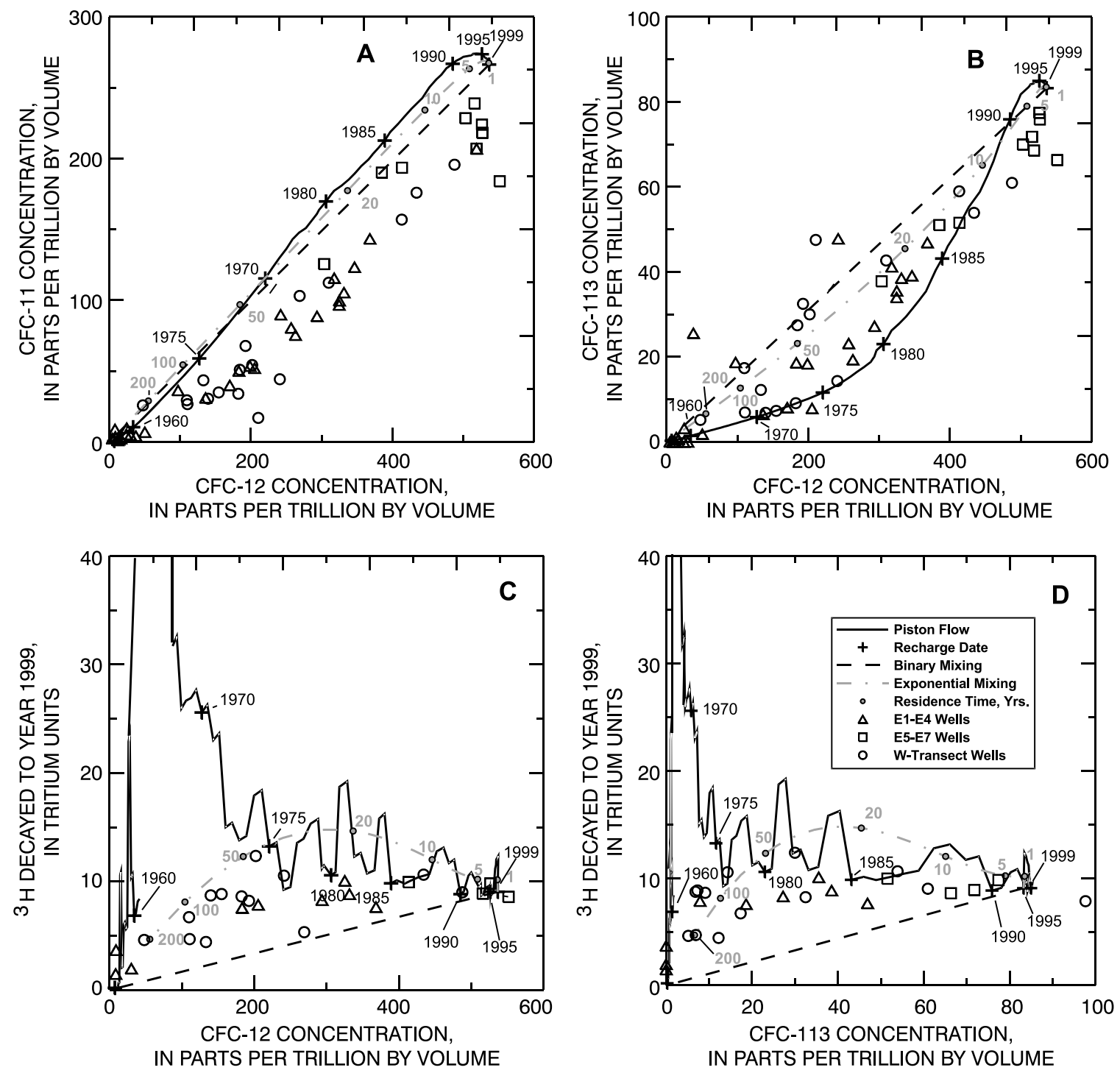

Figure 79. Comparison of concentrations of CFC-11, CFC-12, CFC-113 and ${ }^{3} \mathrm{H}$ in samples collected in the East Mahantango Creek Watershed, Pa. 
CFC-11 concentrations are systematically lowered relative to that of $\mathrm{CFC}-12$, probably indicating microbial degradation of CFC-11 (fig. 79A). In contrast, the CFC- 12 concentrations are greatest in the samples from the E5-E7 transects and lowest in the E1-E4 transects. Samples from the west-transect wells span the range from apparently modern to 1960 and older. The CFC-113 and CFC-12 data are largely consistent (fig. 79B) with expected concentrations for samples affected by piston flow and mixing. Some samples from the west transect may be elevated in CFC-12, though many of these samples plot along binary mixing of mod- ern and mid-1980s waters (fig. 79B). The ${ }^{3} \mathrm{H}$ data (figs. 79C and 79D) indicate that many of the Mahantango samples are mixtures.

Many of the Mahantango samples appear to be influenced by somewhat elevated concentrations of $\mathrm{SF}_{6}$, presumably from terrigenic sources (fig. 80). While CFC-12 and CFC-113 concentrations were mostly consistent with expected values for samples affected by piston flow and binary mixing (fig. 79B), most of the CFC-12 and CFC-113 values are low relative to their $\mathrm{SF}_{6}$ concentration, as would occur in samples affected
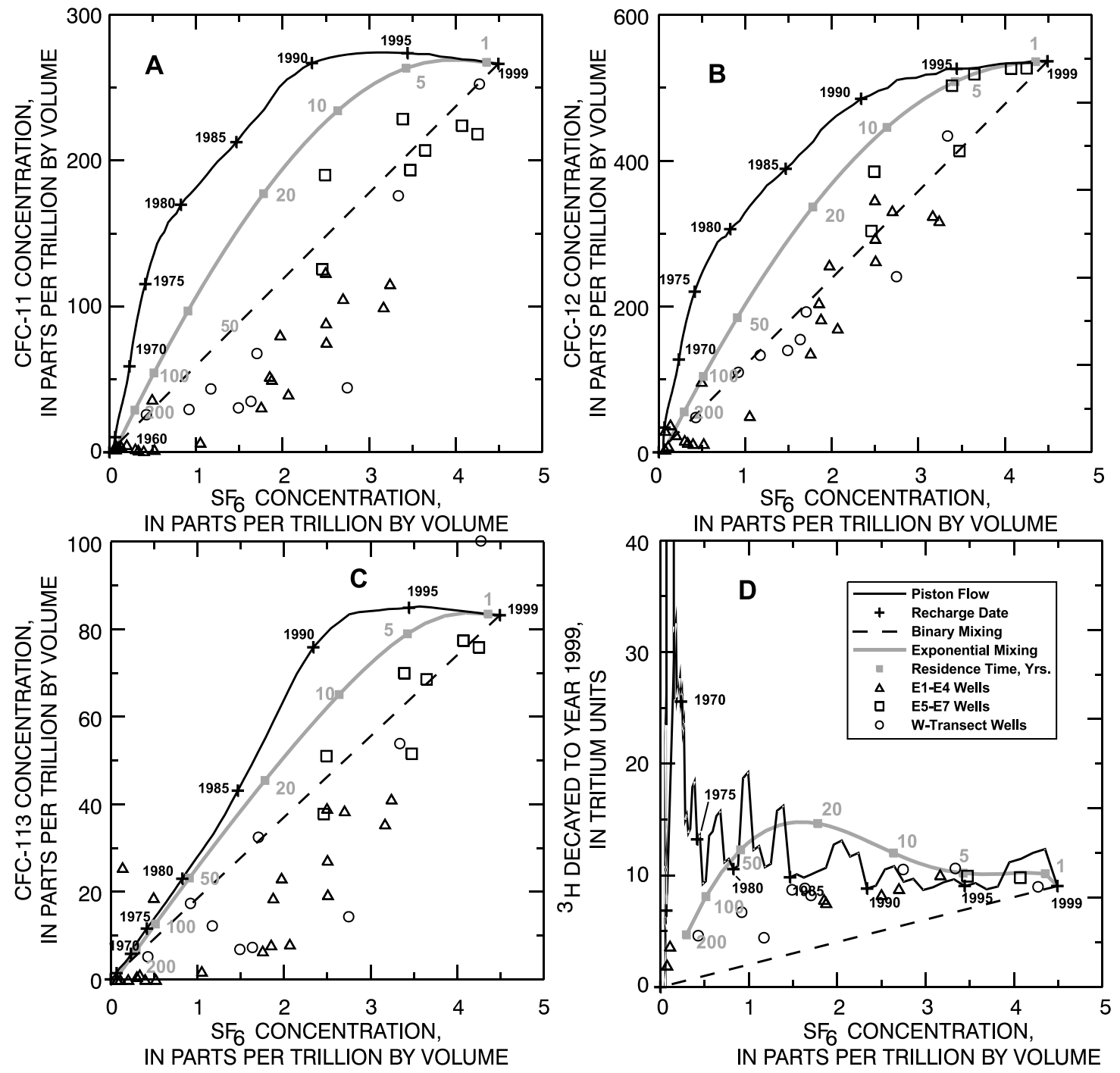

Figure 80. Comparison of CFC-11, CFC-12, CFC-113, and ${ }^{3} \mathrm{H}$ concentrations to $\mathrm{SF}_{6}$ concentrations in samples collected in the East Mahantango Creek Watershed, Pa. 
by low-level terrigenic sources of $\mathrm{SF}_{6}$. There are relatively few ${ }^{3} \mathrm{H}-\mathrm{SF}_{6}$ pairs, but among these (fig. 80D) they indicate piston flow and mixtures.

Most Mahantango samples have CFC-11 concentrations that plot below the piston-flow line and below those lines for binary mixtures, which is an indication of microbial degradation of CFC-11 relative to $\mathrm{CFC}-12$ (fig. 79A). Therefore, CFC-11 was not used for the determination of apparent ages. Most CFC-12 and CFC-113 mixing ratios plot within the region bounded by binary-mixing lines for mixing of young and old water and the line corresponding to piston flow (fig. 79B). This indicates microbial degradation may not have greatly affected the CFC-12 and CFC-113 concentrations. Previous studies have shown that in anaerobic waters, CFC-12 and CFC-113 are less affected by microbial degradation than CFC-11 (Plummer and Busenberg, 1999). Three samples (E3-30, E3-45, and W3-45) from the 1999 sampling apparently contain a small excess of CFC-113 relative to CFC-12. Several samples were collected for ${ }^{3} \mathrm{H} /{ }^{3} \mathrm{He}$ analysis and had good agreement with the apparent ages based on CFCs.

Most of the water samples with CFC-113 and CFC-12 analyses that plot within the boundaries of binary mixing and piston flow can be interpreted as binary mixtures of young and old (pre-CFC) water. The binary-mixing ages and the calculated percent of water of the young fraction in the mixtures in 1999 are shown on figure 81 . The distribution of ground-water apparent ages shows a distinct pattern. In the east transect, the combination of piston-flow age of the water and the binary-mixture age of the young fraction shows older ages on the north side of the transect than on the south side (fig. 81). The apparent ages on the north side of the east transect ranged from 20 to 50 years, and the ages on the south side of the east transect ranged from 5 to 13 years (the E4 nest was not included in either side because of potential mixing of converging flow paths from either side). In the west transect, this pattern is not quite as strong. The ages on the north side of the west transect ranged from 9 to 28 years; on the south side of the west transect, the ages ranged from modern to 22 years. Although these samples represented mixtures, the percentage of young water is greater on the south side than on the north side. Because this watershed had a ground-water-flow model, the age distribution will be used to modify and update the model. The final interpretation of the significance of these age dates will follow the discussion of the updates to the model.
Some samples containing CFC-113 and CFC-12 plot very close to the line corresponding to piston flow (fig. 79), with recharge dates in the 1970s through mid1980s. This suggests that some of the samples are not mixed, or contain only very small fractions of old water. Several samples have CFC-12 and CFC-113 concentrations near that of modern water, or appear to be mixtures of modern water (1998-99) with small amounts of water from the early to mid-1980s (line "A" on fig. 79).

Although samples that plot within the bounds of piston flow or binary mixing on fig. 79 were dated, they may still be affected by trace CFC contamination or minor CFC degradation. The uncertainties in the model CFC ages are discussed in Plummer and Bohlke, chapter 2. Appendix $\mathrm{C}$ includes a summary evaluation of the "recommended model age," which is based on either the CFC-113/CFC-12 ratio (with the associated percentage of young water in the mixture) or the piston-flow model. There is good agreement in results from the replicate samples from 1998, 1999, and 2000 (app. C).

Some of the more uncertain CFC-based ages are those from piezometer nests E1-E3 where waters have low concentrations of dissolved oxygen and contain dissolved $\mathrm{CH}_{4}$. Although the apparent $\mathrm{CFC}$ ages could be biased old in these samples by microbial degradation, other evidence indicates the samples are indeed old. Most E1-E3 samples contain very low or no $\mathrm{SF}_{6}$ (fig. 80B), which indicates water recharged prior to the early 1970s (Busenberg and Plummer, 2000). He accumulation in ground water is another age indicator (Heaton 1984; Solomon and others, 1996). The two samples with the largest concentrations of dissolved $\mathrm{He}$ are from the E2 nest (app. D), indicating relatively older water at E2 that is older than water from E4, E6, and the west transect. Water samples from the E1-E3 nests appear to be relatively old (in the 20- to 50-year age range), are mostly free of CFC-113, and contain little or no fractions of younger water. Most of the ages from the 1998 samples at transects E3-E5 were in good agreement with ages from the 1999 and 2000 sampling of these wells (app. C) with only minor CFC degradation. One exception to this agreement can be seen in the E3-10 sample. The 1998 and 1999 ages were dated by use of the piston-flow model and had ages near 47 to 50 years. The 2000 sampling at E3-10 showed the age of the young fraction of water to be 12 years with a very high percentage of pre-CFC water based on the CFC-113/CFC-12 ratio. These results still show a large amount of old water in the 2000 sample and for the purposes of this project these samples are not significantly different. 
$\mathrm{NE}$
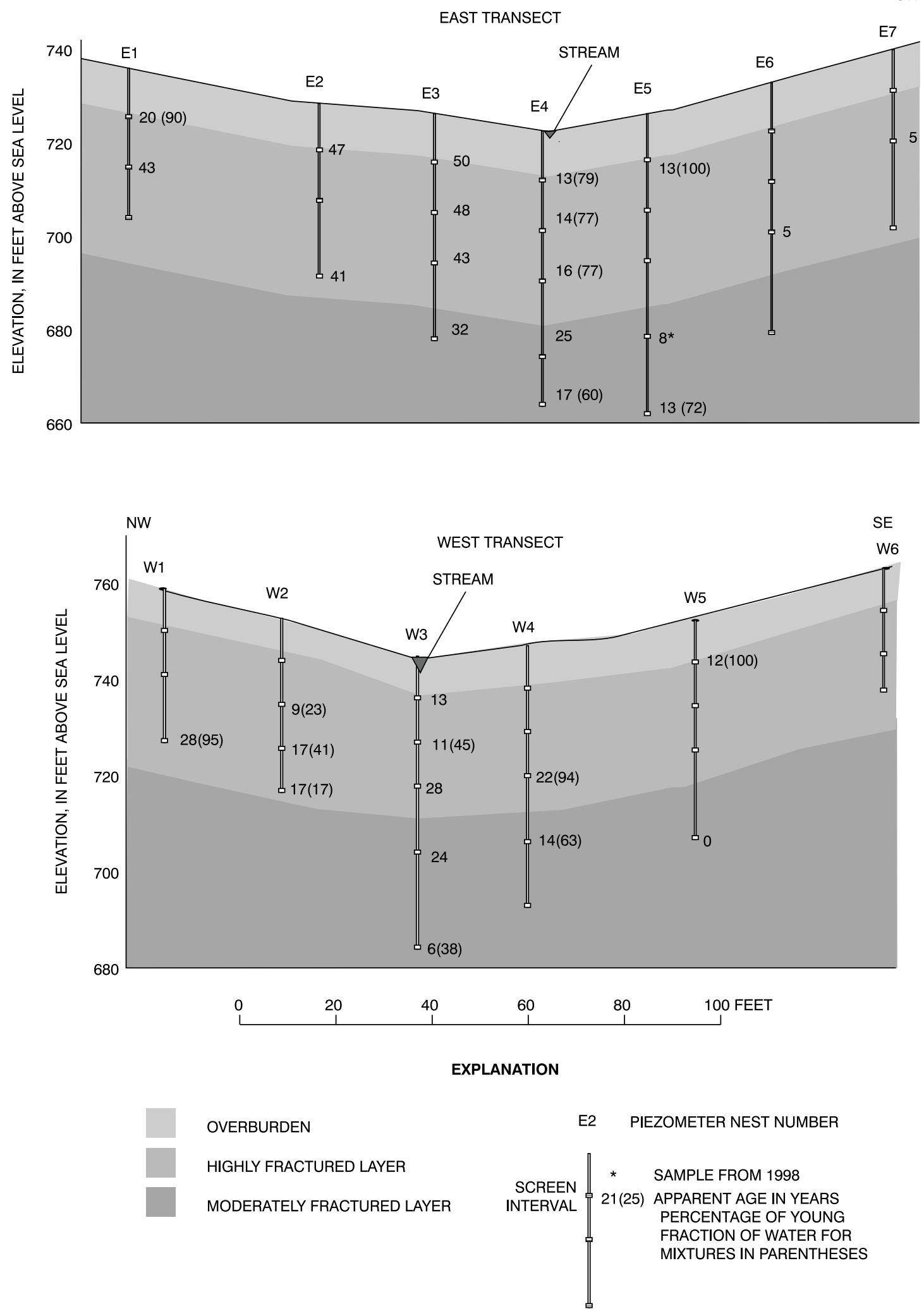

Figure 81. Distribution of apparent ground-water ages in the east and west transects, May 1999, East Mahantango Creek Watershed, Pa. 
Eleven of the samples analyzed for CFCs (app. E) also were analyzed for ${ }^{3} \mathrm{H} /{ }^{3} \mathrm{He}$, and about half contained excesses of terrigenic He. Two samples (E2-10, E2-35) had He concentrations that were approximately 30 times larger than the solubility of $\mathrm{He}$ in water, and their ${ }^{3} \mathrm{H} /{ }^{3} \mathrm{He}$ model ages could not be calculated. In five samples, He of terrigenic origin accounted for as much as half of the total dissolved He (E4-10, E4-20, E4-30, E4-45, E4-60), and their ${ }^{3} \mathrm{H} /{ }^{3} \mathrm{He}$ model ages were calculated assuming the ${ }^{3} \mathrm{He} /{ }^{4} \mathrm{He}$ ratio of the terrigenic helium source was $2 \times 10^{-8}$. This ratio is produced by the radioactive decay of $U$ and $T h$ in rocks and does not contain a mantle component. $\mathrm{A}{ }^{3} \mathrm{He} /{ }^{4} \mathrm{He}$ ratio of $8 \times 10^{-8}$ was calculated from the well E2-10 that contained virtually no ${ }^{3} \mathrm{H}$ and 96 percent of the He in the water was of terrigenic origin (app. E). ${ }^{3} \mathrm{H} /{ }^{3} \mathrm{He}$ ages of the water samples calculated assuming terrigenic ${ }^{3} \mathrm{He} /{ }^{4} \mathrm{He}$ ratios of $2 \times 10^{-8}$ and $8 \times 10^{-8}$ are summarized in Appendix E. The uncertainty in age is relatively small and approximately twice the age error based on propagation of analytical errors (app. E). The total dissolved He in samples E6-35, W3-45, W5-10, and W5-45 (app. E) is derived from solubility equilibrium with air and entrainment of excess air during recharge, and therefore a correction for terrigenic $\mathrm{He}$ is not needed. The ${ }^{3} \mathrm{H} /{ }^{3} \mathrm{He}$ model ages of these samples (E6-35, W3-45, W5-10, and W5-45) are designated as "uncorrected" ages in Appendix E.

Model ages from ground water that are based on concentrations of environmental tracers do not necessarily represent the hydraulic age of ground water. Differences can result from a number of factors, including hydrodynamic dispersion, and from the diffusion of the tracers from fractures into the rock matrix. Hydrodynamic dispersion can cause a spreading of the ${ }^{3} \mathrm{H}$ bomb peak to older pre-bomb waters, resulting in a young bias in waters with hydraulic age greater than that the mid1960s, and an old bias in some post-1960s water (Solomon and Sudicky, 1991; Solomon and others, 1993; Plummer and others, 1993; Ekwurzel and others, 1994; Solomon and Cook, 1999). Because of the relatively smooth and increasing input function for CFCs, hydrodynamic dispersion probably effects CFC apparent ages to a lesser extent than those based on ${ }^{3} \mathrm{H} /{ }^{3} \mathrm{He}$ dating (Plummer and others, 1993; Ekwurzel and others, 1994).

The diffusion of the tracers from fractures into the rock matrix causes an apparent retardation of the solute tracer relative to the water (see for example Cook and others, 1996; Cook and Simmons, 2000; Shapiro,
2001) leading to an old bias in apparent age. Although Gburek and Urban (1990) report that the total porosity of the bedrock in the WE-38 subwatershed is predominantly from fracture porosity, and the bedrock matrix does not constitute a significant transport medium because of its low hydraulic conductivity, the values they measured for matrix porosity ( 0.09 to 0.5 percent) indicate that matrix porosity is large enough for matrix diffusion to occur. The apparent solute velocity is related to the velocity in the fractures by the ratio of fracture porosity to total porosity. With a total porosity of 1 percent based on the adjusted ground-water-flow model discussed below, the ratio of fracture porosity to total porosity could range from 0.5 to 0.9 . Therefore, matrix diffusion cannot be ruled out as a possible factor affecting the apparent ages based on tracers.

In this study, ${ }^{3} \mathrm{H} /{ }^{3} \mathrm{He}$ and CFCs appear to yield reasonably concordant model ages of the young fractions in mixtures, even though the diffusion coefficients of ${ }^{3} \mathrm{H}, \mathrm{He}$, and CFCs in water vary by as much as a factor of 7 (Cook and Herczeg, 1999). The agreement among the tracer ages does not necessarily disprove the existence of matrix diffusion, however, and it cannot be ruled out as a factor that would make the age-dating tracers artificially old by some unknown amount. Nevertheless, as discussed below, the significant findings of this study rely on the differences in ages on either side of the stream. Matrix diffusion may change the magnitude of those differences but should not affect the pattern.

Further evidence of mixing and ground-water age can be obtained from data on the concentrations of dissolved solutes in ground water. The chemical data indicate that the ground waters evolve by combined effects of calcite dissolution and calcium-sodium ion exchange, resulting in dilute sodium-bicarbonate waters near calcite saturation. Geochemical mass-balance calculations made by the model NETPATH (Plummer and others, 1994) indicate that the extent to which the reactions proceed is limited by the amount of soil gas $\mathrm{CO}_{2}$ in the initial recharge waters and the availability of calcite for dissolution (presumably as trace calcite cement in the predominantly siliciclastic rocks). Most waters lie along a relatively narrow evolutionary path as a function of dissolved sodium and bicarbonate concentration (fig. 82), resulting in dilute $\mathrm{Na}-\mathrm{HCO}_{3}$ waters at the E1-E3 nests. Several samples plot along hypothetical mixing lines between the dilute initial waters and the evolved $\mathrm{Na}-\mathrm{HCO}_{3}$ waters, as was found using the $\mathrm{CFC}$ data. 
Concentrations of dissolved sodium are correlated strongly with ground-water age (fig. 83) in samples from transects E4-E7 and W1-W5. Samples in which sodium concentration is affected by mixing were eliminated by plotting in figure 83 only those samples that, based on CFCs, contain more than 70 percent of the dated fraction. Apparently, dissolved sodium concentration increases nearly linearly with age in the pre-
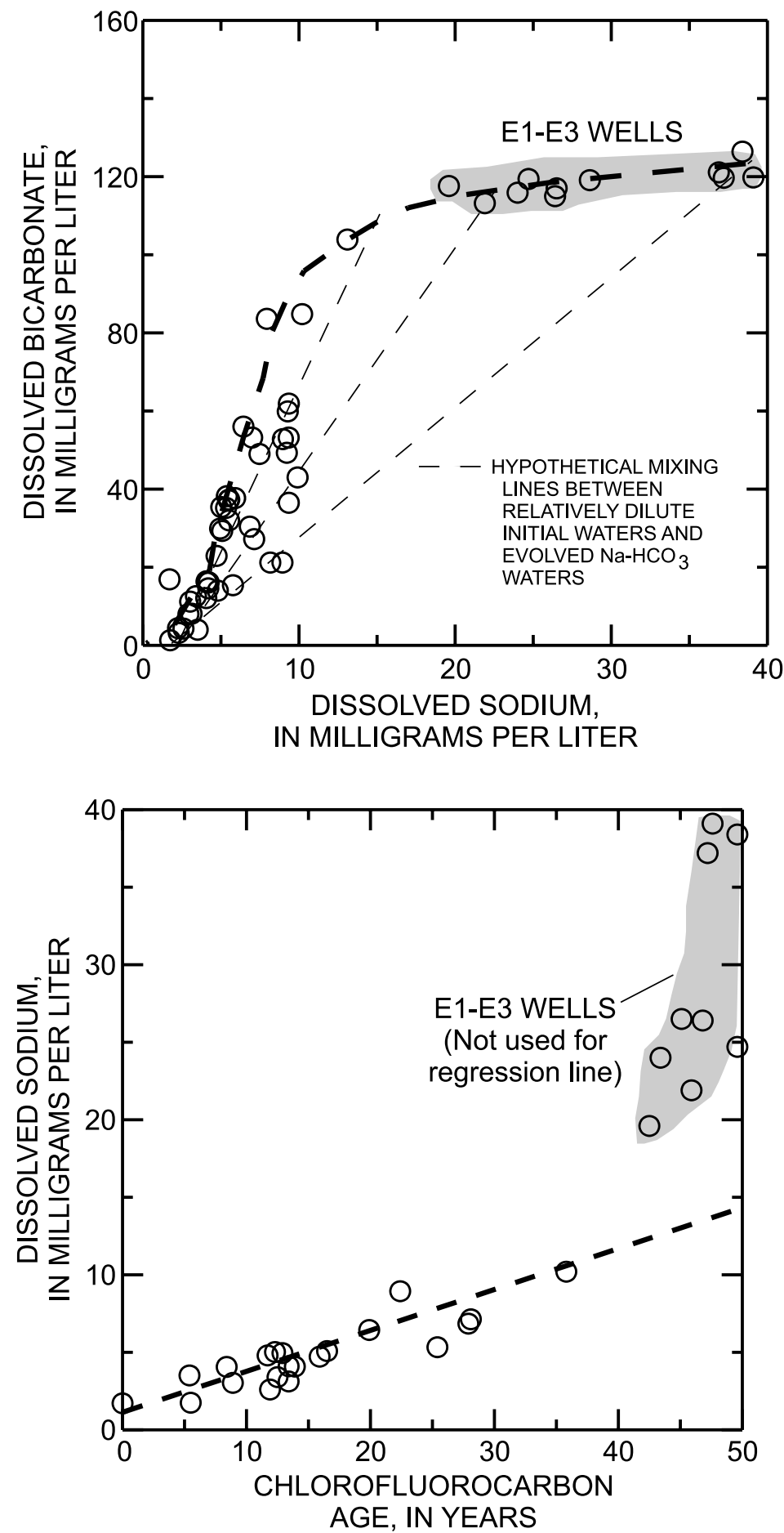

dominantly unmixed samples at a rate of about $0.3 \mathrm{mg} / \mathrm{L}$ per year. In contrast, the samples from the E1-E3 transects, which have ages near the limits of the CFC dating method, contain relatively high sodium content. If the dissolved sodium-age relation established among the more reliably-dated waters (fig. 83) can be applied to the E1-E3 waters, ground-water ages of more than
Figure 82. Relation between dissolved bicarbonate $\left(\mathrm{HCO}_{3}\right)$ and dissolved sodium (Na) concentrations from samples collected in the East Mahantango Creek Watershed, $\mathrm{Pa}$.
Figure 83. Relation between dissolved sodium concentrations and apparent groundwater age from samples containing more than 70 percent of water of the given age collected in the East Mahantango Creek Watershed, $\mathrm{Pa}$. 
100 years are suggested on the E1-E3 transects. Apparently, the waters along the E1-E3 transects are predominantly old water, with ages of approximately 100 years and have mixed with small fractions of post-1940s water.

Although it is apparent from several lines of evidence $\left({ }^{3} \mathrm{H}, \mathrm{CFCs},{ }^{4} \mathrm{He}, \mathrm{Na}\right.$, etc. $)$ that the water samples from the East Mahantango Creek Watershed represent ground-water mixtures, questions remain regarding how the mixtures were produced. The concentrations of environmental tracers measured in the water samples apply to the discharge from the wells, but not necessarily to the overall ground-water reservoir. It is possible that the mixtures identified in this study were created, at least in part, by the sampling process. The piezometers were all cased within the bottom $2 \mathrm{ft}$ of the boreholes and likely intercept one or only a few water-bearing fractures. During well purging and sampling, the local hydraulic gradients in the fracture network in the vicinity of the well are disturbed. Depending on connections within the fracture network, various proportions of water are withdrawn from different parts of the aquifer. Clearly though, lower water ages and a greater proportion of young water are obtained when water is pumped from piezometers in the E4-E7 arrays than in the E1-E3 arrays.

\section{Relation of Nitrogen Concentration, Apparent Age, and Sources}

Data from numerous sources, including atmospheric deposition, animal manure, and fertilizer have been compiled for the Spatially Referenced Regression on Watershed Attributes (SPARROW) model for the Chesapeake Bay (Preston and Brakebill, 1999). Manure and fertilizer contribute most of the $\mathrm{N}$ generated in this watershed; 49 percent originates as manure and 42 percent originates as fertilizer. Smaller amounts can be attributed to other sources such as atmospheric deposition ( 6 percent) and septic systems ( 2 percent). No point-source discharges are present in this watershed. The data on Northumberland County fertilizer sales (Alexander and Smith, 1990; Battaglin and Goolsby, 1995) show a steadily increasing trend in fertilizer sales from 1946 to 1991 (fig. 84). Although these data are for

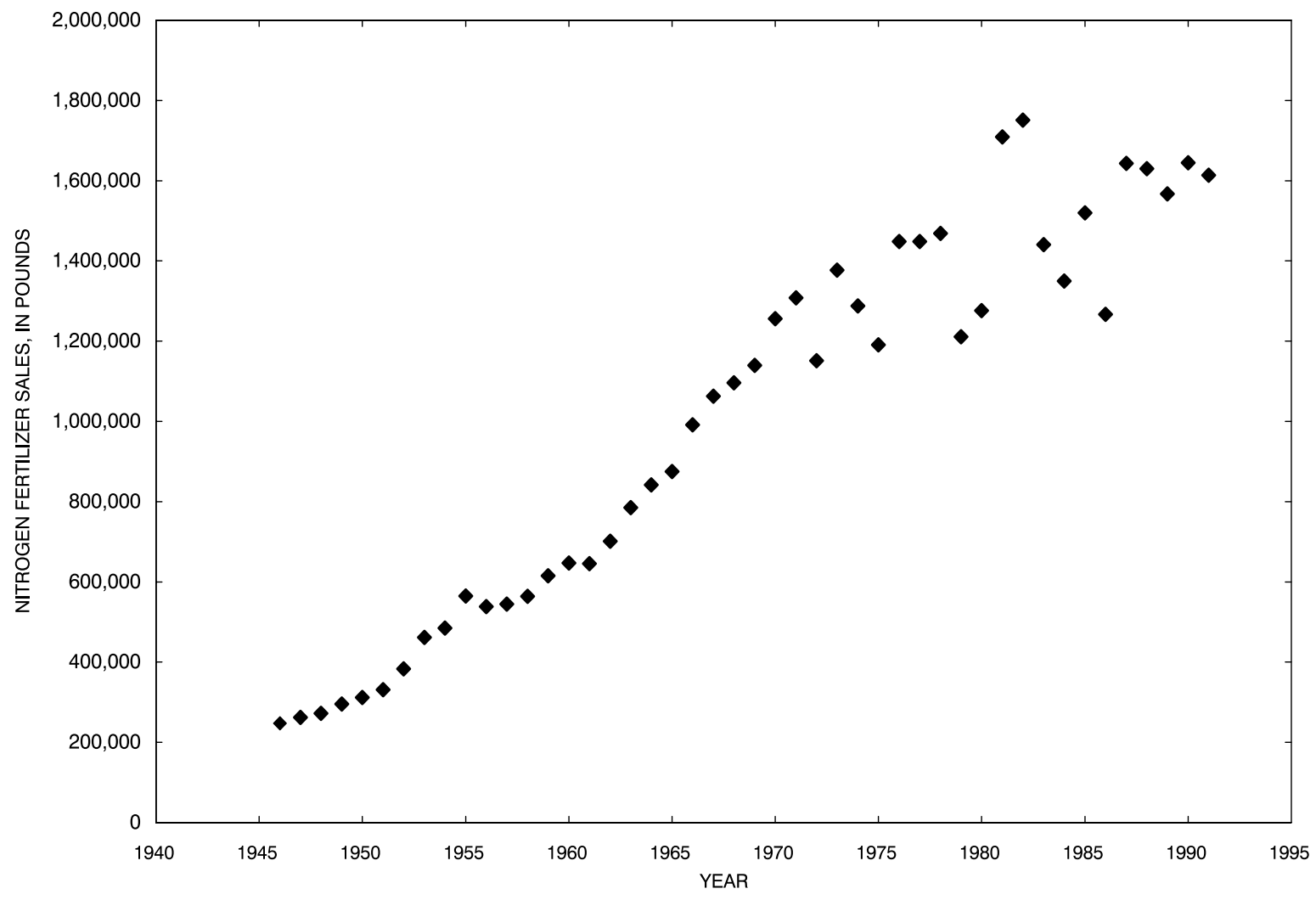

Figure 84. County fertilizer sales for Northumberland County, Pa., 1945 to 1991. Data for the period 1946-1984 from Alexander and Smith (1990). Data for the period 1985-1991 from Battaglin and Goolsby (1995). 
the entire county, a steady increase in the amount of fertilizer can be seen here. This data does not account for changes in amount of cropland; however, the number of acres in cropland has not changed significantly over this period, so the data generally indicate application rates have increased over this period as well.

Measured $\mathrm{NO}_{3}^{-}$concentrations are related inversely to the age of the ground water. $\mathrm{NO}_{3}^{-}$concentrations in modern or nearly modern water are in the range of 8 to $12 \mathrm{mg} / \mathrm{L}$. The oldest samples have nearly no $\mathrm{NO}_{3}^{-}$. To examine whether this is a result of variation in $\mathrm{N}$ input over time, land-use patterns, or denitrification, the individual well samples are plotted on figure 85 . Although the age- $\mathrm{NO}_{3}^{-}$relation is not absolute, a general pattern of increasing $\mathrm{NO}_{3}^{-}$concentration over time can be seen. Some wells fall completely out of the relation. The wells shown by the triangle symbol were samples on the north side of the west transect. These wells are the only ones with a recharge area having a significant amount of forested land use. Therefore, it is reasonable to conclude these samples do not fit the age- $\mathrm{NO}_{3}^{-}$pattern because of lower $\mathrm{N}$ input in the recharge area.

The issue of denitrification can be analyzed by observing the relation between reconstructed $\mathrm{NO}_{3}^{-}$and recharge date (fig. 86). This figure shows that some older samples in which $\mathrm{NO}_{3}^{-}$was not present actually have undergone denitrification, and the reconstructed $\mathrm{NO}_{3}^{-}$concentrations move these samples into the pattern indicating a change in source over time. The implication from this is that the age- $\mathrm{NO}_{3}^{-}$relation is due to a time-variable input source of $\mathrm{N}$ to the system, and that those samples not fitting that pattern are the result of variable sources or dentrification.

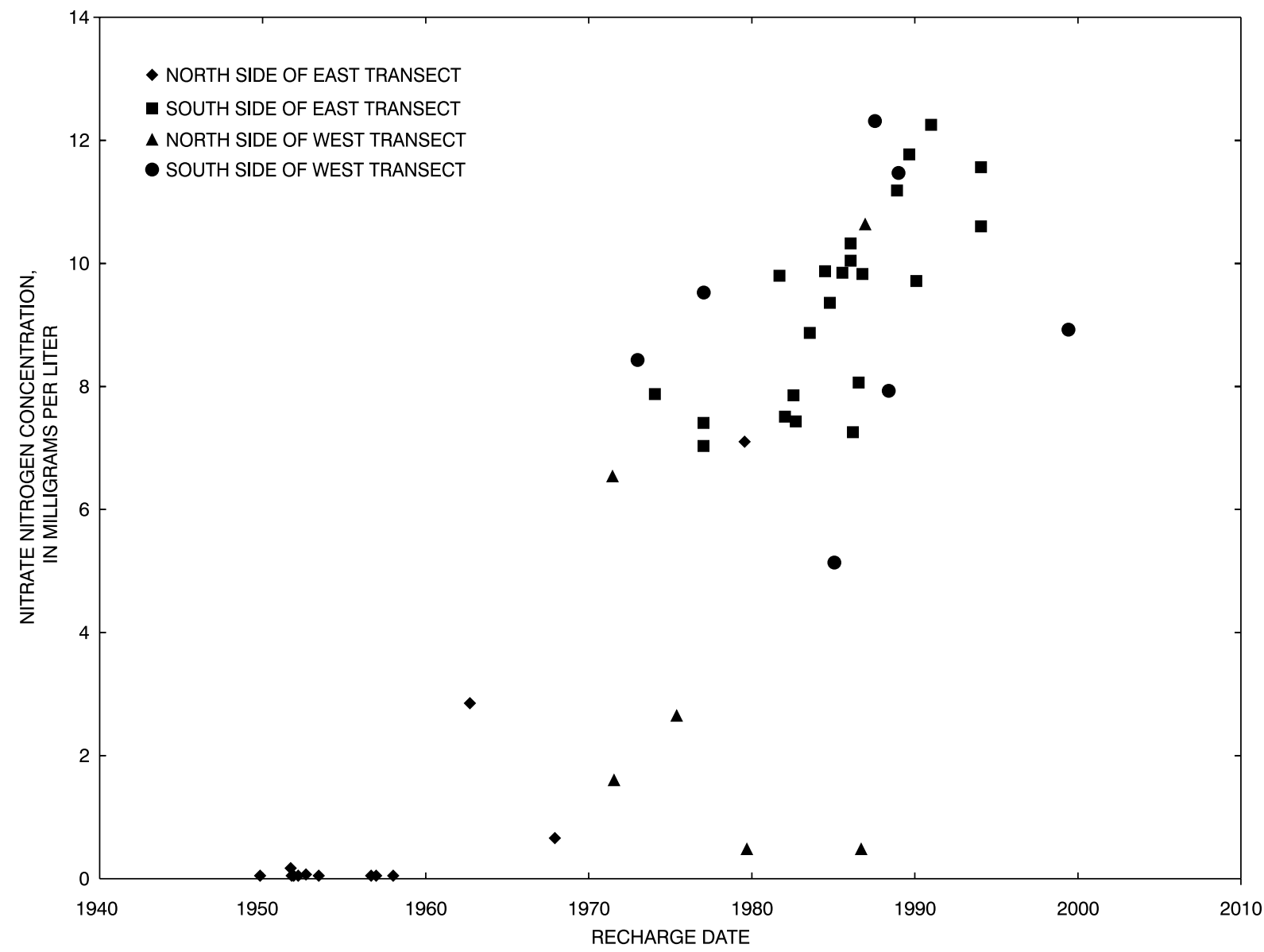

Figure 85. Relation between nitrate concentration and apparent recharge dates in east and west transects of WE-38 subwatershed, East Mahantango Creek Watershed, Pa. (Only samples determined to be piston-flow or samples with greater than 50 percent of the dated fraction for mixtures are included on plot.) 


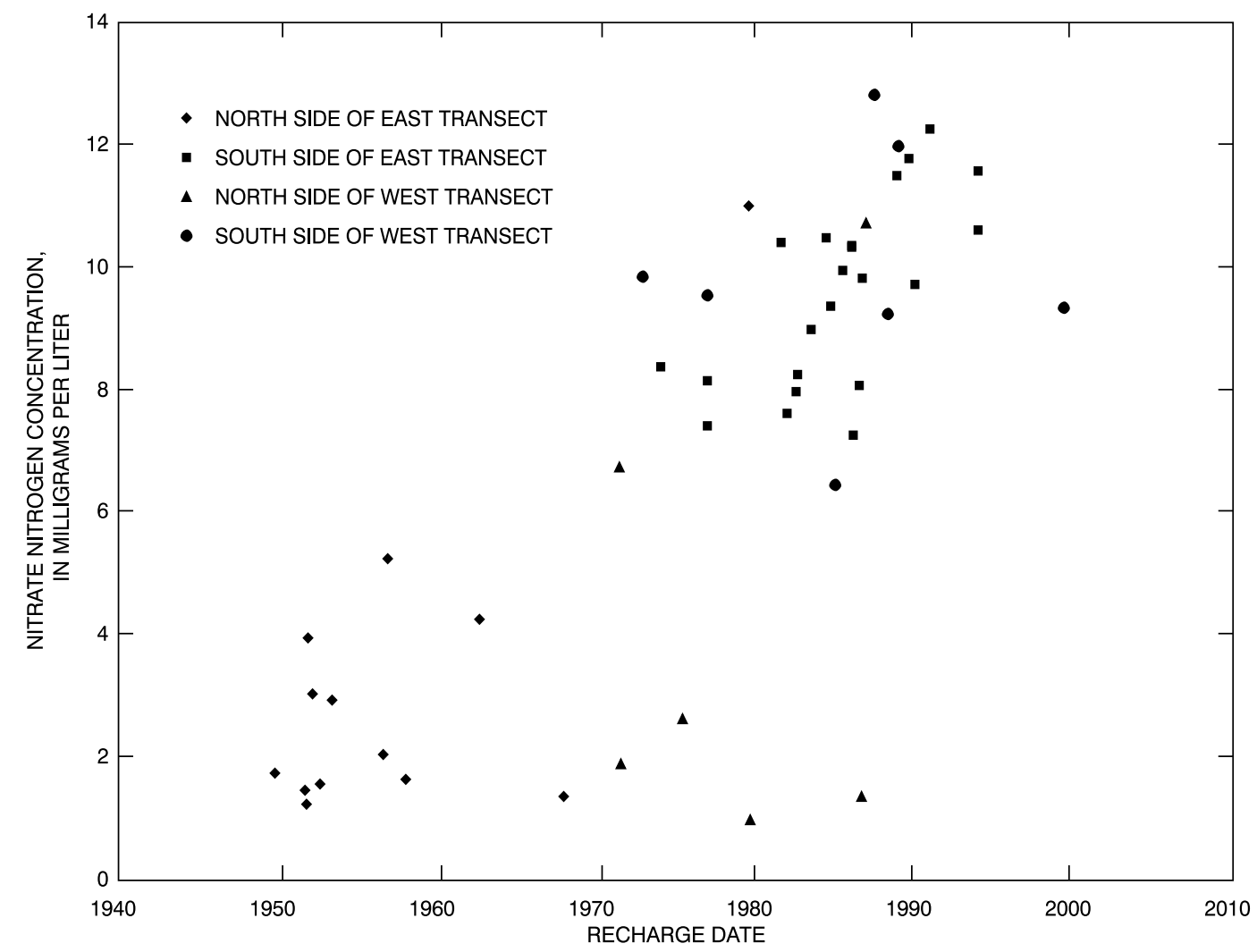

Figure 86. Relation between reconstructed nitrate concentration and apparent recharge date in east and west transects of WE-38 subwatershed, East Mahantango Creek Watershed, Pa. (Only samples determined to be piston flow or samples with greater than 50 percent of the dated fraction for mixtures are included on plot.)

\section{Nitrogen Sources}

The objective of studying the lag time of groundwater discharge to streams is to determine the response of the nutrient loads associated with ground-water discharge. It is important, therefore, to understand the input sources of $\mathrm{N}$ to the hydrologic system and how the sources change over time. Data to make these observations come from numerous sources in this watershed. On a long-term basis, data from county fertilizer sales are available to track the general trend in $\mathrm{N}$ application rates for agricultural use.

Because of the detailed studies in the WE-38 watershed, more information is available about the $\mathrm{N}$ sources in the immediate area around the transects where samples were collected. For example, in the general area surrounding the transects, data on a field scale are available for each year since 1990 . Field-scale landuse data from 1998 are shown in figure 77. Data from the ARS field surveys show chemical fertilizer was the primary source of $\mathrm{N}$ applied to the crops grown here until the mid 1990s. N isotope data from the groundwater samples indicates the $\mathrm{N}$ source is most likely from the input of chemical $\mathrm{N}$ fertilizer applied to the fields.

\section{Model Estimates of Age Distribution of Ground-Water Disc harge}

Several patterns emerge when the apparent age of water in each of the transects is analyzed. First of all, almost all the CFC-based ages are older than those modeled by Gburek and Folmar (1999b) for the WE-38 subwatershed. The data also indicate older water northeast of the transects than to the southwest. The local topography (fig. 73) suggests that for the east piezometer transect, the ground-water-flow paths could be longer on the north side of the drainage than on the south side, thus causing the older apparent ages. This topographic disparity does not apply to the west transect, which also has younger ages and a higher percentage of young water to the southwest. Therefore, the fact that this pattern is found in both piezometer transects suggests it 
could be created by a subsurface anisotropy caused by fracture orientation, and these differentially affects ground-water age and traveltimes.

The work by Gburek and Folmar (1999b) was intended to emphasize the generalities of the groundwater-flow system at the watershed scale and acknowledged the possibility for refinements to this model. Gburek and others (1998) modeling and hydrologic characterization within the WE-38 watershed initially was used as a basis for the conceptual model of the hydrogeologic framework in the targeted watershed for the Valley and Ridge siliciclastic HGMR. The premise of Gburek's work was based on a system in which aquifer layers followed the land-surface contours. The model included 4 layers; the layer thicknesses were determined by analysis of data from 29 rock cores and 230 seismic transects. The hydraulic conductivities (K) of the layers (table 7) were determined by 159 pressure injection packer tests, including 132 double-packer tests to investigate the relations between seismic velocity, fracture frequency, and K. Gburek and others (1998) used the MODFLOW (Harbaugh and McDonald, 1996) code to construct a model to simulate ground-water flow. The model was calibrated by adjusting the values of $\mathrm{K}$ to obtain a best fit between simulated and observed water levels. Calibration for specific yield $\left(\mathrm{S}_{\mathrm{y}}\right)$ was then conducted by comparing a transient solution of a simulation of continuous drainage of the watershed with a master base-flow recession of the measured outflow of WE-38 under a range of conditions. Gburek and Folmar (1999b) continued this modeling effort to simulate traveltimes. Porosity was assumed to be equal to $S_{\mathrm{y}}$. Their MODPATH (Pollock, 1994) simulations predicted traveltimes ranging from 30 days to about 1 year under a range of distances and flow conditions. Initial findings of Focazio and others (1998), however, showed much older water discharging from springs in this HGMR on the basis of CFCs and a variety of other age-dating techniques. The spring sampling was the initial reconnaissance effort of the Chesapeake Bay Ecosystem project and initiated the collection of additional data in the WE-38 watershed to explore the differences between the MODPATH predicted traveltimes and the age dates obtained from sampling springs. Some of the data were physical (analysis of cores, fracture orientation, borehole logs) and other information was chemical (age-dating tracers, dissolved gasses and isotopes). In addition, the MODFLOW model was modified to incorporate the new findings.
The Gburek and others (1998) MODFLOW model was strong in the areas where field data for initial parameter estimation and data for calibration were available. The layer configuration, $\mathrm{K}$, and $\mathrm{S}_{\mathrm{y}}$ were based on field data and calibrated to observed water levels and a master base-flow recession. The parameters and basis of their modeling efforts were accepted as correct unless additional data gathered by this project showed a reason to revisit the underlying assumptions or findings. Although Gburek and Folmar (1999b) noted the bedding-plane fracture set was the more numerous of the major fracture sets, an initial assumption of an isotropic media was made for the model. This affects the MODFLOW model and the MODPATH traveltime results. They also acknowledged several caveats on the traveltimes. The first caveat was that their simulations represented the range of high and low recharge and that the annual averages will be somewhere between these extremes. The second caveat of their simulation of traveltimes, however, was that the calibrated values of $S_{\mathrm{y}}$. were not based on independent field verification for the top three layers and that the porosity was assumed to be equivalent to $S_{y}$. Also, the effect of interconnectedness of fractures and tortuosity of flow paths was not considered, which would be important in characterizing the porosity of the aquifers. Gburek and Folmar (1999b) acknowledged that these factors would tend to increase traveltimes but could not be quantified without field testing or further data.

The differences in apparent ground-water ages at the local scale make it difficult to determine the average residence time of ground water being discharged to the stream. The knowledge gained from the age-dating tracers, however, can be used to adjust the parameters in the MODFLOW model to obtain a better simulation of traveltime of water at the sampling locations. Once adjusted, the model could then provide better information on the overall residence time in the watershed. The approach to adjusting the MODFLOW model was to use the parameters of Gburek and others (1998), except in cases where new information was available to adjust the parameters. For the layer configuration, $\mathrm{K}$, and $\mathrm{S}_{\mathrm{y}}$, the values used were directly from Gburek and others (1998) for the basic model. Adjustments were made to $\mathrm{K}$ for modeling the effects of anisotropy caused by orientation of the bedding planes. Adjustments also were made to the porosity in the model so that model-generated ages more closely matched the ages measured by the age-dating tracers. The changes to the model were run to specifically address the issues of residence time, mass flux of water through layers of the aquifer, and the 
affects of anisotropy; therefore, the only MODFLOW packages discussed herein are the ZONEBUDGET (Harbaugh, 1990) and MODPATH.

The first modification to the model was to adjust the parameters to simulate an older average residence time, and then observe the distribution of residence times produced by that simulation (table 7). The MODPATH simulations were used to determine average and maximum residence times, as well as the distribution of all traveltimes of all pathlines. Parameters in the Gburek and Folmar (1999b) model were used as a basis for the MODPATH simulation. Their simulations used a range of high $(0.11 \mathrm{in} / \mathrm{d})$ and low $(0.0011 \mathrm{in} / \mathrm{d})$ recharge to simulate high spring base-flow conditions and low summer base-flow conditions. For these simulations, however, an average annual recharge rate of $0.016 \mathrm{in} / \mathrm{d}$ was used. The average annual recharge rate calculated by hydrograph separation (assuming long-term base flow is equivalent to recharge) is $0.028 \mathrm{in} / \mathrm{d}$; however, the lower value was used because it better represents conditions during the time of sampling (outflow from MODFLOW $=1.35 \mathrm{ft}^{3} / \mathrm{s}$, measured outflow for 1999 sample date $=1.38 \mathrm{ft}^{3} / \mathrm{s}$ ). The only other parameter modified for this simulation was the porosity. Initial estimates of porosity were based on the assumption that porosity was equal to $S_{y}$; however, porosity can be larger than $\mathrm{S}_{\mathrm{y}}$. All porosities were adjusted upward,

Table 7. Model input parameters used for MODPATH and ZONEBUDGET simulations, showing original values from Gburek and Folmar (1999b) and the modifications for simulations in this study

\begin{tabular}{|c|c|c|c|c|c|}
\hline & \multirow{2}{*}{ Layer } & \multirow{2}{*}{$\begin{array}{l}\text { Gburek and } \\
\text { Folmar, } \\
(1999 b)\end{array}$} & \multirow{2}{*}{$\begin{array}{l}\text { Simulation } 1 \\
\text { Modification } \\
\text { for age only }\end{array}$} & \multicolumn{2}{|c|}{$\begin{array}{c}\text { Simulation } 2 \\
\text { Modification } \\
\text { for age and anisotropy }\end{array}$} \\
\hline & & & & $\begin{array}{l}\text { "Normal" } \\
\text { cell }\end{array}$ & $\begin{array}{l}\text { Cell with flow } \\
\text { moving north } \\
\text { to south }\end{array}$ \\
\hline \multicolumn{6}{|c|}{ Model input } \\
\hline \multirow[t]{4}{*}{ Depths to bottom of model layers (feet) } & 1 & 10 & 10 & 10 & 10 \\
\hline & 2 & 30 & 30 & 30 & 30 \\
\hline & 3 & 75 & 75 & 75 & 75 \\
\hline & 4 & 270 & 270 & 270 & 270 \\
\hline \multirow[t]{4}{*}{ Hydraulic conductivity (feet per day) } & 1 & 65.6 & 65.6 & 65.6 & 16.4 \\
\hline & 2 & 16.4 & 16.4 & 16.4 & 3.28 \\
\hline & 3 & .33 & .33 & .33 & .065 \\
\hline & 4 & .033 & .033 & .033 & .006 \\
\hline \multirow[t]{4}{*}{ Specific Yield } & 1 & .01 & .01 & .01 & .01 \\
\hline & 2 & .005 & .005 & .005 & .005 \\
\hline & 3 & .001 & .001 & .001 & .001 \\
\hline & 4 & .0001 & .0001 & .0001 & .0001 \\
\hline \multirow[t]{4}{*}{ Porosity } & 1 & .01 & .03 & .03 & .03 \\
\hline & 2 & .005 & .01 & .01 & .01 \\
\hline & 3 & .001 & .01 & .01 & .01 \\
\hline & 4 & .0001 & .01 & .01 & .01 \\
\hline Recharge (inches per day) & & .0016 & .0016 & .0016 & .0016 \\
\hline \multicolumn{6}{|c|}{ Model output } \\
\hline Maximum traveltime & & 3.7 years & 355 years & 503 years & \\
\hline Average traveltime & & 54 days & 7.2 years & 8.9 years & \\
\hline $\begin{array}{l}\text { Percentage of particles with traveltimes less } \\
\text { than average }\end{array}$ & & 74 & 82 & 87 & \\
\hline \multirow[t]{4}{*}{ Percentage of water traveling through layer } & 1 & & 100 & 100 & \\
\hline & 2 & & 87 & 85 & \\
\hline & 3 & & 51 & 46 & \\
\hline & 4 & & 20 & 18 & \\
\hline
\end{tabular}


because the previous simulations showed traveltimes much faster than those ages calculated on the basis of CFC data would allow. An initial target was to simulate an average age of about 10 years, on the basis of the sodium concentrations measured in stream base flow of about $3 \mathrm{mg} / \mathrm{L}$ and the observation that sodium concentration increases nearly linearly with age in the predominantly unmixed samples at a rate of about $0.3 \mathrm{mg} / \mathrm{L} / \mathrm{yr}$. The simulations were conducted in a manner by which the porosities were modified proportionally in each of the layers; however, the sensitivity of the model to changes in porosity dictated that three of the layers ended up with the same porosity. A porosity of 0.03 in layer 1 with porosities of 0.01 in layers 2,3 , and 4 pro- duced an average residence time of 9 years. The point of this simulation was to determine the distribution of pathlines if the average residence time was in the range of 10 years. For the porosity to be significantly greater than $\mathrm{S}_{\mathrm{y}}$, the field capacity of the aquifer material (the volume of water remaining in the unsaturated zone when the water is gravity drained) would have to be quite large.

The first simulation conducted was a cross-sectional model similar to that shown in Gburek and Folmar (1999b). Two cross-sectional models used to illustrate the effects of porosity and fracture orientation on traveltime are shown in figure 87. This is the same cross-section of the model used by Gburek and Folmar
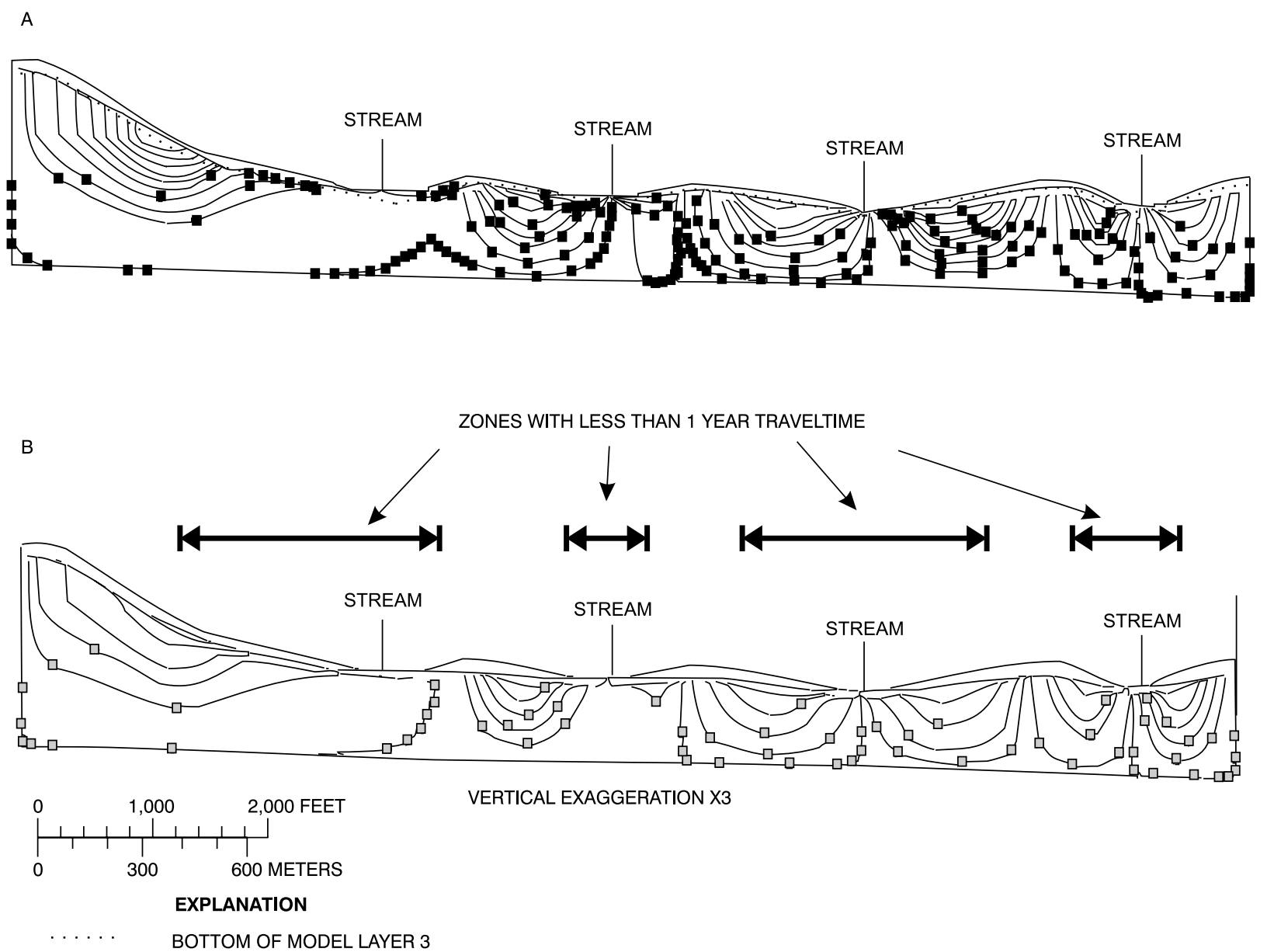

VERTICAL EXAGGERATION X3

30-DAY TIME INCREMENT
10-YEAR TIME INCREMENT

Figure 87. Results of cross-sectional simulations of ground-water flow from the model of Gburek and Folmar (1999b) (A) and modifications including increasing the porosity to simulate an average residence time of 10 years (B). 
(1999b) and is in an area where the four streams that cross the section are nearly orthogonal to the section, and flow paths generally are parallel to the section. This cross-section is a two dimensional representation of a three-dimensional flow system. The first illustration (fig. 87A) shows the time increments presented by Gburek and Folmar (only modified to reflect a recharge rate of $0.016 \mathrm{in} / \mathrm{d}$ for consistency) and the second (fig. 87B) shows that same section with the changes in porosity noted previously. The scale representing time increments on this figure had to be shown in 30-day increments (fig. 87A) and 10-year increments (fig. 87B) to portray the traveltimes. This representation, however, is the result when the porosity in model is raised to show an average residence time of 10 years and is not based on any new measurements of the porosity.

This simulation shows what happens in the ground-water system in a scenario that yields longer traveltimes. The significant thing to remember is that, as shown earlier, many pathlines still have a traveltime of less than 1 year. The 1-year increments makes it easy to see that the distribution of these pathlines on the ground is systematic (fig. 87B). The water particles in the pathlines originating near the streams have less than a year traveltime and those in the pathlines originating near the hilltops or recharge areas have the traveltimes in the range of tens of years. The zones highlighted on fig. 87B illustrate the systematic nature of this distribution by pointing out those areas where water flowing along pathlines originating at the water table on the cross-section discharges to the stream in less than a year.

Gburek and Folmar (1999b) stated that a caveat on their model calibrations is the presence of a fracture system may introduce anisotropy in the aquifer, which was an unknown factor in their analysis. The waterlevel, age-dating, and water-quality data suggest that the fracture system presents a level of anisotropy in the aquifer. When modeling with MODFLOW, however, the term to account for anisotropy in an aquifer allows a variation in $\mathrm{K}$ between the $\mathrm{x}$ and $\mathrm{y}$ directions. The situation presented in this aquifer is that the anisotropy varies in the positive and negative y direction, depending on the direction that the water is flowing. To model this situation, a variable $\mathrm{K}$ was entered on a cell-by-cell basis. A lower $\mathrm{K}$ was assigned to those cells where groundwater flow was determined to be opposite the dip direction.

The possible effects of anisotropy on groundwater traveltimes is shown in figure 88. The model is modified by reducing the $\mathrm{K}$ in the model by a factor of five in the lower three layers in areas of the cross-section where the water travels in a direction opposite the dip of the bedding planes. No changes are made to $\mathrm{K}$ where the water is traveling in the same direction as the dip of the bedding planes. The factor of five was selected because the ages on the north side of the transects are about five times greater than the ages on the south side of the transects. Again this cross-sectional model is the easiest way to represent this, because the flow is parallel to the section and each cell is in a location where the flow is either opposite the dip direction or the same as the dip direction. The simulation of this in three dimensions is much more difficult because flow direction is not always perpendicular to the strike of the dipping bedding planes. The higher porosities are used for this simulation as well.

The illustration of this simulation shows that if the bedding planes create a situation where the $\mathrm{K}$ is lower on one side of a stream than the other, the result will be slower traveltimes on the side traveling against the bedding planes. The west transect is near the section noted by A-A' (fig. 88). The simulation that does not take into account the anisotropy induced by the orientation of the bedding planes shows a range of 0 to 30 years on both sides of the transect (with the exception of the boundary pathline). The simulation that includes anisotropy shows a range of 0 to 30 years on the 'fast' side and a range of 0 to 50 years on the 'slow' side. The ages measured in this area all fell into this range and reflected the general distribution of ages across the transect.

Cross-sections illustrate the effect of modifying the model to simulate higher porosities and anisotropy; however, a simulation of the entire watershed is needed to quantify these differences. Areal modeling of the entire watershed was done by use of the increased porosities and also accounting for anisotropy. The effect of the layering in the model is shown by the results of these simulations. Although the maximum ages are much greater than those shown by Gburek and Folmar (1999b), many traveltimes are still less than 1 year. The distribution of residence times from this simulation shows that even under these simulated conditions, the distribution of residence times is skewed toward the younger end in the ground-water system. The MODPATH simulation of the entire watershed accounting for anisotropy also shows the effects of the layering. The maximum age in this simulation is almost twice the maximum age for the isotropic simulation (table 7); however, the average age is not much greater than the average age for the isotropic simulation. The reason for this is that the overburden layer was assumed to be 


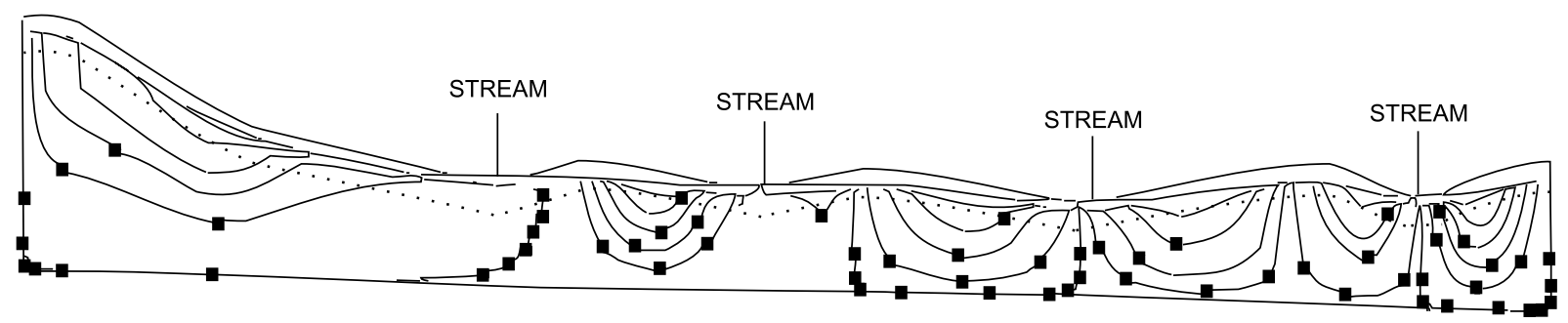

B

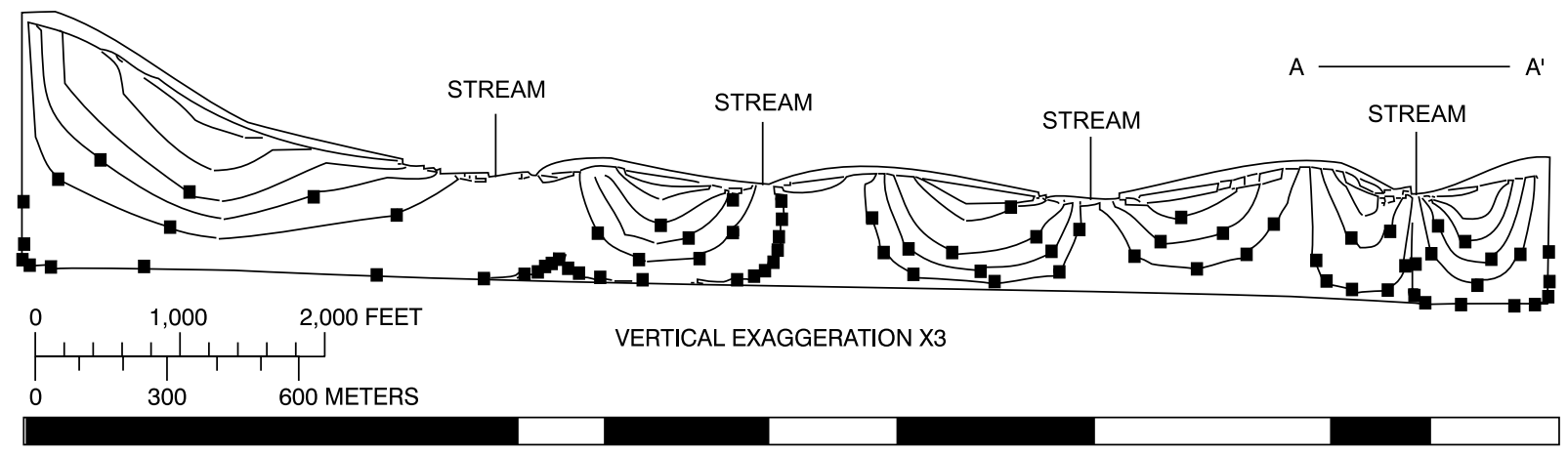

EXPLANATION

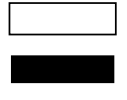

HYDRAULIC CONDUCTIVITY FROM AGRICULTURAL RESEARCH SERVICE MODEL

HYDRAULIC CONDUCTIVITY REDUCED BY A FACTOR OF 0.2

..... BOTTOM OF MODEL LAYER 3

- 10-YEAR TIME INCREMENT

Figure 88. Results of cross-sectional simulations of ground-water flow with a porosity to simulate an average residence time of 10 years $(A)$ and simulating the effects of fracture orientation by varying the hydraulic conductivity in the second, third and fourth model layers (B).

unaffected by the fracture orientation and therefore was unchanged. This highly permeable zone becomes a preferred flow path when the lower layers have their $\mathrm{K}$ reduced. Therefore, the water that flows into the lower layers moves much slower, but much of the water is 'short-circuited' through the upper layer, resulting in greater distribution of traveltimes at both the old and young ends.

Initial estimates for the average age of groundwater discharge were based on a "piston-flow" age for the entire ground-water system of about 10 years. This was based on the linear increase in sodium concentration of about $0.3(\mathrm{mg} / \mathrm{L}) / \mathrm{yr}$ and about $3 \mathrm{mg} / \mathrm{L}$ of sodium in the stream base-flow samples. This system does not function in a piston-flow manner, however, but has a range of ages from very young to very old. The output files from the MODPATH simulation include the endpoints for every simulated particle and the ending time or discharge time. For a first attempt at a mixing model, the ending time for each particle in this file was assigned a sodium concentration, on the basis of its traveltime from recharge to discharge and $0.3(\mathrm{mg} / \mathrm{L}) / \mathrm{yr}$. The average of all these sodium concentrations was $3.1 \mathrm{mg} / \mathrm{L}$, which is very close to the value measured in the stream. This does not necessarily validate the model, because there are many possible mixing-model solutions that would yield a similar concentration; however, it is an indicator that this could be a reasonable description of the system. 
Modeling of the system with ZONEBUDGET had two purposes. One was to obtain a better understanding of the flux of water through the layers, and the second was to observe the changes to that flux that could be caused by the anisotropy caused by fracture orientation. Because the goal of the study was to determine a practical answer to the question of lag time, it is important to understand the relative volumes of water that move through each layer. For example, it is evident that the water in the deeper layer is older than the water in shallower layers, but it also is important to determine the proportion of the overall water travelling through that layer so that the relative importance of the traveltime for that layer can be determined. For a steady-state simulation of the 4-layer model by Gburek and others (1999b), the ZONEBUDGET simulation showed a significant percentage of the water is only moving through layers 1 and 2. Of the total volumetric budget, all the water moves through layer 1 (from land surface to $10 \mathrm{ft}$ deep) at some point. About 87 percent of the water moves through layer 2 (10 to $30 \mathrm{ft}$ ), whereas 51 percent moves through layer 3 ( 30 to $75 \mathrm{ft}$ ), and about 20 percent moves through layer 4 ( 75 to $270 \mathrm{ft}$ ). When simulating the effect of anisotropy, a slight shift of water away from the lower layers is evident. About 85 percent of the water moves through layer 2 , whereas 46 percent moves through layer 3 , and about 18 percent moves through layer 4 . This is similar to the results shown when comparing the MODPATH simulations with and without the effect of anisotropy and illustrates the "short circuiting" effect referred to whereby a larger percentage of the water travels through the shallower part of the system in those areas where anisotropy affects groundwater flow.

The ZONEBUDGET simulation illustrates the volume of water flowing through the various layers; however, the age-dating results cannot be applied directly to each layer. This is because the samples were collected in a discharge area and do not necessarily represent an average age of the layer in which the sample was collected. Also, no samples were collected in the shallowest layer. Therefore, the ZONEBUDGET results serve to add to the understanding of the way the system functions and the role that anisotropy may play in changing the flow-system characteristics.

Although a more rigorous approach to the modeling effort could refine these findings, many field observations from this watershed are explained by these model results. Ages in the range of several decades with some evidence of water greater than 100 years old were measured in the watershed. These are paths in the deeper part of the system and probably make up about 20 percent of the overall ground-water discharge.

Although denitrification exists in the ground-water system, $\mathrm{NO}_{3}^{-}$may appear to be conservative in the surface water because of the dominance of shallow groundwater flow, as shown by Gburek and Folmar (1999a). A study of stable isotopes in this same watershed was conducted to determine if a seasonal pulse or lag time could be observed in base-flow discharge (McGuire, 1999). These findings indicated a seasonal lag time of less than 1 year. Initially these findings were thought to be contradictory to the findings of the CFC analyses indicating older ages in ground water, however, with the modeling results indicating the high percentage of ground water discharged in less than 1 year, these results are in line with what might be expected of such a study.

\section{Factors Affecting Residence-Time Distribution, Nitrogen Occurrence, and Disc harge to Streams}

The affects of residence time of ground water on the subsequent delivery of $\mathrm{NO}_{3}^{-}$to stream base flow is significant in this watershed. The discharge of ground water to East Mahantango Creek can be quantified by hydrograph-separation techniques (Sloto and Crouse, 1996). Hydrograph separations conducted on this watershed for the 6 years with adequate data (1993-94 and 1997-2000) indicate that base flow ranges from 44 to 57 percent of the total flow in this watershed; the median percentage is 54 percent. During the years of this study, base flow was 45 percent of total flow in 1998, 55 percent in 1999, and 54 percent in 2000. The majority of the ground-water samples used for interpretation were from 1999, which was nearly an average year as far as the base-flow contribution to total flow. Both the residence times of ground water and $\mathrm{N}$ delivered to streams will be discussed in relation to the factors affecting those processes.

The distribution of $\mathrm{N}$ in this system seems to be affected by the land use in the vicinity of the sample, denitrification, and the variation in input of $\mathrm{N}$ over time. Several lines of evidence indicate potential for denitrification in this system. The dissolved gas data show denitrification in many samples. Lack of dissolved oxygen in many of these same samples, as well as low concentrations of $\mathrm{NO}_{3}^{-}$and $\mathrm{CH}_{4}$, indicate denitrification is likely to have occurred. The distribution of the denitrified water is another indication of how this system functions. The age of the water and the location of the sample with regard to the hydrogeologic framework were important factors in the amount of denitrification. 
Several samples were nearly entirely denitrified; however, the samples in this category all had ages greater than 40 years. Another group had undergone denitrification in the order of 50 to 90 percent of the reconstructed $\mathrm{NO}_{3}^{-}$concentration; the samples in this group ranged from 8 to 35 years. The samples retaining greater than 90 percent of their reconstructed $\mathrm{NO}_{3}^{-}$concentration were all less than 28 years old.

The location of the denitrified ground water with respect to the hydrologic framework is important as well. All the samples collected on the south side of the transects retained at least 90 percent of their original $\mathrm{NO}_{3}^{-}$concentration. Samples that were nearly entirely denitrified were all on the north side of the east transect. The partially denitrified samples were on the north side of both transects. This systematic pattern of denitrification is further evidence that the flow system that affects ground-water flow on the north side of each transect is significantly different than the flow system on the south side. The major mechanism that would cause the difference would be the time spent in the aquifer as a result of bedding-plane orientation, and possibly a more tortuous path followed by the water discharging from the north. A more tortuous path may end up with more 'dead zones' or dead ends in a system that would slow traveltimes, probably become anoxic, and allow the denitrification process to proceed.

The importance of denitrification to the streamwater being discharged to the overall system may not be significant. The indications from both flow modeling and mixing models are that a significant percentage of water is discharged in less than a year, and most of the water is discharged in less than 10 years. On the basis of the observations that the samples with significant denitrification were on the order of 40 to 50 years old and that the water with moderate amounts of denitrification were on the order of 8 to 38 years old, it would appear that the significance of denitrification on water discharging to the stream is quite small. This is supported by the work of Gburek and Folmar (1999a), which showed $\mathrm{NO}_{3}^{-}$generally was conserved in the ground-water system.

The concentrations of $\mathrm{N}$ in surface water at the transect are a product of the accumulation of $\mathrm{N}$ from various sources upstream of the transect. Because of the variety of $\mathrm{N}$ sources upstream, the $\mathrm{N}$ in the stream at the transect has different characteristics than the $\mathrm{N}$ in the ground water at the transect. However, information about the ground-water system, including flow paths and distribution of traveltimes, is very helpful in under- standing the functioning of the system. The groundwater/surface-water relations can be evaluated with respect to 1) $\delta^{15} \mathrm{~N}$, 2) spatial distribution of $\mathrm{NO}_{3}^{-}$, and 3) temporal variation in $\mathrm{NO}_{3}^{-}$concentration.

The isotopic composition of the $\mathrm{N}$ sampled in ground water within the transects does not resemble the composition of the $\mathrm{N}$ from the stream sample collected in the center of the transect. This indicates the $\mathrm{N}$ in the stream is from different sources. Higher $\delta^{15} \mathrm{~N}$ of $\mathrm{NO}_{3}^{-}$ in streamwater implies a greater component of manure in the source, whereas lower $\delta^{15} \mathrm{~N}$ of $\mathrm{NO}_{3}^{-}$in wells from the transect imply a greater component of chemical fertilizer is the $\mathrm{N}$ source. $\mathrm{N}$ use near the transect is a combination of poultry litter, dairy manure, and chemical fertilizer used on crops (Terry Troutman, U.S. Department of Agriculture, written commun., 2000). However, the dairy manure is from a small number of cattle (20-30) on the pasture near the stream over a long period of time and manure from a smaller number of calves (8-10) being applied to cropland. Use of poultry litter as fertilizer started in 1995, so many of the groundwater samples predate the use of poultry litter. $\mathrm{N}$ from calf manure is minimal in relation to the amount applied in chemical fertilizers. Pastured areas near the stream are in a zone where most of the water is thought to remain at shallow depth and travel rapidly and, therefore, not be reflected in the isotopic composition of the samples collected in the transects. The isotopic composition of water in the stream samples is most likely from upstream tributaries that are known to have higher percentages of manure application (Gburek and Folmar, 1999a).

Spatial distribution of $\mathrm{NO}_{3}^{-}$within WE-38 shows that $\mathrm{NO}_{3}^{-}$concentration in base flow is related strongly to the land use within the immediate surface-water watershed (Gburek and Folmar, 1999a). Indications from that study showed $\mathrm{NO}_{3}^{-}$concentrations in ground water underlying specific land-use types could be used to predict $\mathrm{NO}_{3}^{-}$concentrations in stream base flow. The information from that study showed that $\mathrm{NO}_{3}^{-}$is largely conservative as it moves through the aquifer and discharges to the stream. This study also indicated most $\mathrm{NO}_{3}^{-}$is discharged within the immediate surface-water watershed, and interbasin transfer is minimal. The work of Gburek and Folmar (1999a) within the WE-38 watershed was used as a basis for an expanded study within the entire East Mahantango Watershed and other watersheds within the Valley and Ridge siliciclastic HGMR (Lindsey and others, 2001). The results of that study 
showed concentrations of $\mathrm{NO}_{3}^{-}$in stream base flow could still be predicted from land use at the larger scale, with adjustments for flow conditions.

The variation of $\mathrm{NO}_{3}^{-}$with respect to flow shows a significant positive relation between streamflow and $\mathrm{NO}_{3}^{-}$concentration under low-flow conditions (fig. 89). This systematic and consistent relation indicates that $\mathrm{NO}_{3}^{-}$delivery processes vary from high to low base flow. A previous theory by Schnabel and others (1993) suggested that water discharged under low base-flow conditions was from a deeper and older part of the aquifer, resulting in lower $\mathrm{NO}_{3}^{-}$concentrations. The idea of older water being discharged under lower flows is supported by an inverse relation between sodium concentration and base flow (fig. 89). Two processes have been identified that would explain why the older water has lower $\mathrm{NO}_{3}^{-}$concentrations. The first process is denitrification. Denitrification is more prevalent in older samples, and as the percentage of old water increases, the proportion of water that has undergone denitrification increases as well. The other issue is that, as we have shown previously, $\mathrm{NO}_{3}^{-}$concentrations have increased over time, making older water lower in $\mathrm{NO}_{3}^{-}$concentration.
Some conclusions that may be drawn from the combinations of current and previous studies can be summarized in relation to the goals of this study. More than 50 percent of the water delivered to these streams is base-flow discharge. The delivery of base-flow discharge to the surface system is controlled by a shallow layer that transmits water rapidly and by deeper layers that transmit water more slowly. The distribution of ages in the ground-water system range from modern to 50 years and possibly older; a large proportion (40 to 50 percent of the base flow or 20 to 30 percent of the total flow) of the water is discharged to the stream within a year. Denitrification occurs in the deeper part of the system; however, $\mathrm{NO}_{3}^{-}$transport appears to be conservative because of the low percentage of the total streamflow represented by these deeper layers. Fracture orientation in the deeper layers of the system has a significant effect on ground-water flow, contaminant transport, and traveltimes. Fracture orientation is more important to conditions within the aquifer than it is to discharge to the stream, because the shallower layers that transmit more of the water is affected less by the orientation of the fracture system.

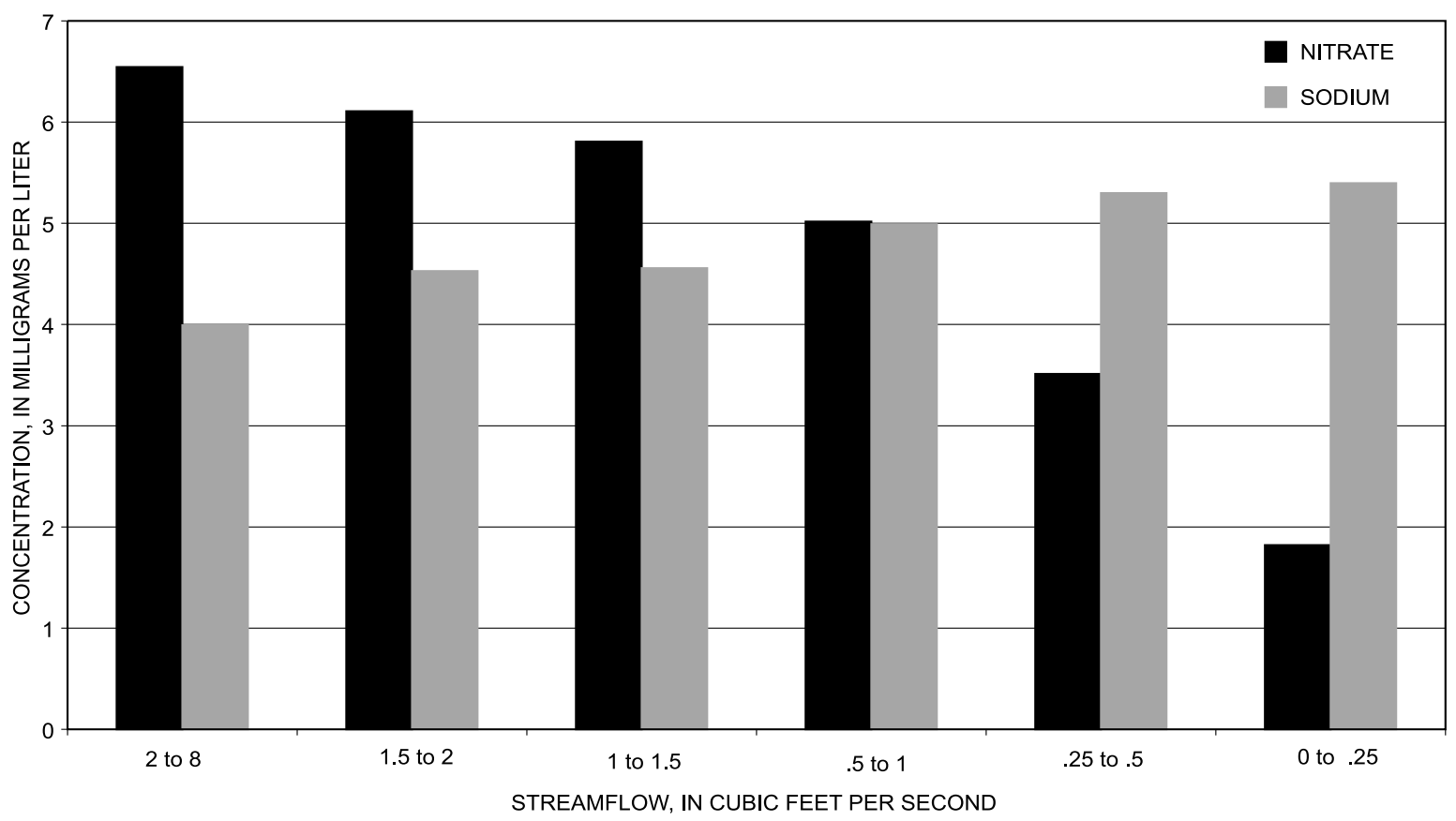

Figure 89. Relation of average nitrate and sodium concentration to stream base flow (Gordon Folmar, U.S. Department of Agriculture/Agricultural Research Service, written commun., 2000) 


\section{References Cited}

Alexander, R.B., and Smith, R.A., 1990, County-level estimates of nitrogen and phosphorus fertilizer use in the United States, 1945-1985: U.S. Geological Survey Open-File Report 90-130, 12 p.

Bachman, L.J., Lindsey, B.D., Brakebill, J.W., and Powars, D.S., 1998, Ground-water discharge and base-flow nitrate loads of nontidal streams, and their relation to a hydrogeomorphic classification of the Chesapeake Bay Watershed, Middle Atlantic Coast: U.S. Geological Survey WaterResources Investigations Report 98-4059, 71 p.

Battaglin, W.A., and Goolsby, D.A., 1995, Spatial data in geographic information system format on agricultural chemical use, land use, and cropping practices in the United States: U.S. Geological Survey Water-Resources Investigations Report 94-4176, 87 p.

Busenberg, Eurybiades, and Plummer, L.N., 2000, Dating young groundwater with sulfur hexafluoride-Natural and anthropogenic sources of sulfur hexafluoride: Water Resources Research, v. 36, p. 3,011-3,030.

Cook, P.G., and Herczeg, A.L., 1999, Appendix 4Liquid and gas-phase diffusion coefficients, in Cook, P., and Herczeg, A., eds., Environmental tracers in subsurface hydrology: Amsterdam, Kluwer Academic Press, p. 521-522.

Cook, P.G., and Simmons, C.T., 2000, Using environmental tracers to constrain flow parameters in fractured rock aquifers, Clare Valley, South Australia, in Faybishenko, B., Witherspoon, P.A., Benson, S.M., eds., Dynamics of fluids in fractured rock: Washington, American Geophysical Union, Geophysical Monograph 122, p. 337-347.

Cook, P.G., Solomon, D.K., Sanford, W.E., Busenberg, Eurybiades, Plummer, L.N., and Poreda, R.J., 1996, Inferring shallow groundwater flow in saprolite and fractured rock using environmental tracers: Water Resources Research, v. 32, no. 6, p. $425-434$.

Ekwurzel, B., Schlosser, P., Smethie, W. Jr., Plummer, L.N., Busenberg, Eurybiades, Michel, R.L., Weppernig, R., and Stute, M., 1994, Dating of shallow groundwater-Comparison of the transient tracers ${ }^{3} \mathrm{H} /{ }^{3} \mathrm{He}$, chlorofluorocarbons and ${ }^{85} \mathrm{Kr}$ : Water Resources Research, v. 30, p. 1,693-1,708.
Focazio, M.J., Plummer, L.N., Bohlke, J.K., Busenberg, Eurybiades, Bachman, L.J., and Powars, D.S., 1998, Preliminary estimates of residence time and apparent ages of ground water in the Chesapeake Bay Watershed, and water quality data from a survey of springs: U.S. Geological Survey Water-Resources Investigations Report 974225, $75 \mathrm{p}$.

Gburek, W.J., and Folmar, G.J., 1999a, Flow and chemical contributions to streamflow in an upland watershed-A baseflow survey: Journal of Hydrology, v. 217, no. 1-2, p. 1-18.

$1999 \mathrm{~b}$, Patterns of contaminant transport in a layered fractured aquifer: Journal of Contaminant Hydrology, v. 37, no. 1-2, p. 87-109.

Gburek, W.J., Folmar, G.J., and Urban, J.B., 1998, Field data and ground water modeling in a layered fractured aquifer: Groundwater, v. 37, no. 2, p. 175184.

Gburek, W.J., and Urban, J.B., 1990, The shallow weathered fracture layer in the near-stream zone: Ground Water, v. 28, no. 6, p. 875-883.

Harbaugh, A.W., 1990, A computer program for calculating subregional water budgets using results from the U.S. Geological Survey modular threedimensional ground-water flow model: U.S. Geological Survey Open-File Report 90-392, $46 \mathrm{p}$.

Harbaugh, A.W., and McDonald, M.G., 1996, User's documentation for MODFLOW-96, an update to the U.S. Geological Survey modular finite-difference ground-water flow model: U.S. Geological Survey Open-File Report 96-485, 56 p.

Heaton, T.H.E., 1984, Rates and sources of ${ }^{4} \mathrm{He}$ accumulation in groundwater: Hydrological Sciences Journal, v. 29, p. 29-47.

Lindsey, B.D., Gburek, W.J., and Folmar, G.J., 2001, Watershed-scaling effects on base flow nitrate concentrations in an upland watershed: Journal of the American Water Resources Association, v. 37 , no. 5 , p. $1,103-1,117$. 


\section{References Cited-Continued}

Lindsey, B.D., Loper, C.A., and Hainly, R.A., 1997, Nitrate in ground water and stream base flow in the Lower Susquehanna River Basin, Pennsylvania and Maryland: U.S. Geological Survey Water-Resources Investigations Report 97-4146, $66 \mathrm{p}$.

McGuire, K.J., 1999, Determining mean residence times of groundwater using oxygen-18 fluctuations in the Mid-Appalachians: University Park, Pa., The Pennsylvania State University, master's thesis, $73 \mathrm{p}$.

Pionke, H.B., Gburek, W.J., Sharpley, A.N., and Schabel, R.R., 1996, Flow and nutrient export patterns for an agricultural hill-land watershed: Water Resources Research, v. 32, p. 1,795-1,804.

Pionke, H.B., and Urban, J.B., 1985, Effects of agricultural land use on ground-water quality in a small Pennsylvania watershed: Groundwater, v. 23, p. $68-80$.

Plummer, L.N., and Busenberg, Eurybiades, 1999, Chlorofluorocarbons, in Cook, P., and Herczeg, A. eds., Environmental tracers in subsurface hydrology: Boston, Mass., Kluwer Academic Publishers, p. 441-478.

Plummer, L.N., Michel, R.L., Thurman, E.M., and Glynn, P.D., 1993, Environmental tracers for agedating young ground water, in Alley, W.M., ed., Regional ground-water quality: New York, Van Nostrand Reinhold, p. 255-294.

Plummer, L.N., Prestemon, E.C., and Parkhurst, D.L., 1994, An interactive code (NETPATH) for modeling NET geochemical reactions along a flow PATH-Version 2.0: U.S. Geological Survey Water-Resources Investigations Report 94-4169, $130 \mathrm{p}$.

Pollock, D.W., 1994, User's guide for MODPATH/ MODPATH-PLOT, version 3-A particle tracking post-processing package for MODFLOW, the U.S. Geological Survey finite-difference groundwater flow model: U.S. Geological Survey Open-File Report 94-464, 6 ch.

Preston, S.D., and Brakebill, J.W., 1999, Application of spatially referenced regression modeling for the evaluation of total nitrogen loading in the Chesapeake Bay Watershed: U.S. Geological Survey Water-Resources Investigations Report 99-4054, $12 \mathrm{p}$.
Schnabel, R.R., Urban, J.B., and Gburek, W.J., 1993, Hydrologic controls in nitrate, sulfate, and chloride concentrations: Journal of Environmental Quality, v. 22, p. 589-596.

Shapiro, A.M., 2001, Effective matrix diffusion in kilometer-scale transport in fractured crystalline rock: Water Resources Research, v. 37, no. 3, p. $507-522$.

Siwiec, S.F., Hainly, R.A., Lindsey, B.D., Bilger, M.D., and Brightbill, R.A., 1997, Water-quality assessment of the Lower Susquehanna River Basin, Pennsylvania and Maryland-Design and implementation of water-quality studies, 1992-95: U.S. Geological Survey Open-File Report 97583, $121 \mathrm{p}$.

Sloto, R.A, and Crouse, M.Y., 1996, HYSEP-A computer program for streamflow hydrograph separation and analysis: U.S. Geological Survey Water-Resources Investigations Report 96-4040, $46 \mathrm{p}$.

Solomon, D.K., and Cook, P.G., 1999, ${ }^{3} \mathrm{H}$ and ${ }^{3} \mathrm{He}$, in Cook, P., and Herczeg, A., eds., Environmental tracers in subsurface hydrology: Boston, Mass., Kluwer Academic Publishers, p. 397-424.

Solomon, D.K., Hunt, A., and Poreda, R.J., 1996, Source of radiogenic helium 4 in shallow aquifers-Implications for dating young groundwater: Water Resources Research, v. 32, no. 6, p. 1,805-1,813.

Solomon, D.K., Schiff, S.L., Poreda, R.J., and Clark, W.B., 1993, A validation of the ${ }^{3} \mathrm{H} /{ }^{3} \mathrm{He}$ method for determining groundwater recharge: Water Resources Research, v. 29, p. 2,951-2,962.

Solomon, D.K., and Sudicky, E.A., 1991, Tritium and helium 3 isotope ratios for direct estimation of spatial variations in groundwater recharge: Water Resources Research, v. 27, p. 2,309-2,319.

Trexler, J.P., and Wood, G.H., Jr., 1968a, Geologic map of the Valley View quadrangle, Schuylkill and Northumberland Counties, Pennsylvania: U.S. Geological Survey Geologic Quadrangle Map GQ-699, scale 1:24,000.

1968b, Geologic map of the Klingerstown quadrangle, Northumberland, Schuylkill and Dauphin Counties, Pennsylvania: U.S. Geological Survey Geologic Quadrangle Map GQ-700, scale $1: 24,000$. 


\section{References Cited-Continued}

Vogelmann, J.E., Sohl, T.L., Campbell, P.V., and Shaw, D.M., 1998a, Regional land cover characterization using Landsat Thematic Mapper data and ancillary data sources: Environmental Monitoring and Assessment 51, p. 415-428.

Vogelmann, J.E., Sohl, T., and Howard, S.M., 1998b, Regional characterization of land cover using multiple sources of data: Photogrammetric Engineering and Remote Sensing 64, p. 45-57.

Wood, G.H., Jr., and Trexler, J.P., 1968, Geologic map of the Tremont quadrangle, Schuylkill and Northumberland Counties, Pennsylvania: U.S. Geological Survey Geologic Quadrangle Map GQ-692, scale 1:24,000.

Wood, G.H., Jr., Trexler, J.P., and Kehn, T. M., 1969, Geology of the west-central part of the Southern Anthracite Field and adjoining areas, Pennsylvania: U.S. Geological Survey Professional Paper 602, $150 \mathrm{p}$.

Wyrick, G.G., and Borchers, J.W., 1981, Hydrologic effects of stress relief fracturing in an Appalachian valley: U.S. Geological Survey WaterSupply Paper 2117, 51 p.

\section{FAC TORS AFFECTING THE RESIDENCE TIME OF, AND NITRATE TRANSPORTIN, GROUND WATER DISCHARGING TO STREAMS IN THE CHESAPEAKE BAY WATERSHED}

$\mathrm{N}$ transport through ground water to streams is an important source of $\mathrm{N}$ in the Chesapeake Bay Watershed. The USGS conducted a study from 1996 to 2001 to improve the understanding of the discharge, associated $\mathrm{N}$ load, and residence time of ground water in the Chesapeake Bay Watershed. The initial components of the study were to (1) determine the discharge and associated $\mathrm{NO}_{3}^{-}$loads to streams and their relation to HGMRs (areas of distinct rock type and physiography), and (2) to estimate the apparent age and residence time of ground water on the basis of a sampling of springs in different HGMRs. The third component was to determine the factors affecting the residence time and associated $\mathrm{NO}_{3}^{-}$in ground water discharging to streams in the Chesapeake Bay Watershed and was accomplished by sampling of springs in 1997 and study of four small watersheds during 1998-2000. The results from the springs and watersheds were integrated with results from the previous components of the study to develop the conclusions presented in the following sections.

\section{Amount and Residence Time of Ground Water Discharge to Streams}

Two major issues involving ground-water discharge were studied. The first was to determine the amount of water discharged to streams draining into the Chesapeake Bay, which indicated the importance of ground water. The second was the residence time of this ground water, which gives insight into the amount of time necessary to see results of changes in management practices.

It is recognized that these studies were conducted in small watersheds, and that longer ground-water-flow paths discharging to higher-order streams may result in older water being discharged to larger watersheds. The studies by Gburek and Folmar (1999) showed that most water in the East Mahantango Creek Watershed discharges to first- and second-order streams. In a study by Bachman and others (1998) of the relation between drainage area and base-flow discharge, it was determined drainage area did not have a significant affect on the percentage of base-flow discharge. The implication of this is that, although longer flow paths discharge older water to higher-order streams, these contributions do not make up a significant percentage of stream base 
flow, and studies of these smaller watersheds are a valid way to study ground-water discharge and residence time in the overall system. This may not be the case in all areas.

\section{Ground Water Disc harge to Streams}

Bachman and others (1998) conducted a regional analysis of 276 streamflow stations and determined that ground water provided a significant contribution to annual streamflow in the Chesapeake Bay Watershed. Ground-water contributions to total streamflow (known as the base-flow index) had a median value of 54 percent and ranged from 16 to 92 percent for the 276 sites. Further analyses indicated the median of the base-flow index was greater than 50 percent in all HGMRs, except the Mesozoic Lowlands, which had a mean of 36 percent. The range of base-flow index also varied in different HGMRs, with the Piedmont crystalline HGMR having the largest range ( 25 to 85 percent). The four watersheds had base-flow indexes in the range identified by Bachman and others (1998) for their respective HGMRs. The base-flow index was nearly 60 percent in the Pocomoke River Watershed, 52 percent in the Polecat Creek Watershed, 71 percent in the Muddy Creek Watershed, and 50 percent in the East Mahantango Creek Watershed. On the basis of results of both the regional analysis and the four studied watersheds, ground-water discharge provides a significant amount of water to streams and therefore can be an important transport pathway for $\mathrm{N}$ to discharge into streams throughout the Bay watershed.

\section{Residence Time and Apparent Age of Ground-Water Discharge to Streams}

Estimates of the amount of ground water discharged to a stream can be represented appropriately as a percentage of the total streamflow; however, the ground water delivered to a stream is a mixture of ages that is not easily represented by one characteristic quantity. Ground-water-flow paths that converge at discharge locations such as a stream are likely to discharge water having a wide range of ages; therefore, knowledge of the distribution of ages of all potential flow paths is necessary to estimate a residence time to understand the influence on a stream. To summarize the distribution of all ages and their associated residence time, streamflow is divided into several components. The first is overland flow or surface runoff, which is water entering a stream after flowing across the land surface during, or shortly after, storms. The second is interflow, which is subsur- face flow that enters the stream without reaching the water table and also is delivered during, or shortly after, storms. The third component is ground-water discharge, which is subsurface flow that percolates to the saturated zone and can be delivered to the stream any time from during storms to years, decades, or more after storms depending on residence time in the aquifer. The residence times for surface runoff and interflow, for the purposes of this study, are considered modern. The apparent ages and associated residence time of the ground-water-discharge component of streamflow is the focus of the remaining discussion.

Ground-water residence times were evaluated by collecting data on the apparent ages of water from springs and four study watersheds. Springs are a discharge point to streams for a number of converging ground-water-flow paths of different ages in an aquifer. Therefore, the apparent age of a spring can be considered representative, or an average, of the residence time for water in an aquifer. Samples collected from wells in the four watersheds are representative of only one point in an aquifer. The apparent-age data are evaluated with other hydrological information from each watershed to estimate the residence time. The apparent ages of ground water were estimated using chemical isotopic tracers. Chlorofluorocarbons were the primary tracers used, but these tracers were compromised in some areas because of their degradation due to reducing conditions or "contamination" from non-atmospheric sources. Future studies would benefit from analyzing multiple isotopic tracers for each sample to estimate the apparent ages of ground water.

The range in apparent ground-water ages and corresponding residence times in springs was from modern to over 50 years; the median age was 10 years. The overall distribution of apparent ages from all the springs provided information about the distribution of residence times throughout the watershed. Neglecting the contaminated samples, the 25th percentile of ages was 7 years, and the 75th percentile was 13 years. Examination of figure 5 shows about 75 percent of the samples had an apparent age of less than 10 years. Samples collected from the springs under low base-flow conditions generally were slightly older by a few years than those samples collected under high base-flow conditions. The distribution and median of residence times for average long-term conditions is probably between these data sets. Differences in apparent age of water from springs during different base-flow conditions indicate that the apparent age also can change during and after storms. These effects were not investigated in this study. 
While hydrologic variability influenced the ages of water issuing from springs, there did not appear to be distinct differences in ages between the HGMRs. The apparent ages of springs had as much variation within an HGMR as between HGMRs with fairly similar medians (between 7 to 11 years), but not enough data were collected to permit statistical tests of variance between the HGMRs. Ranges of ages were from modern to about 50 years in most of the principal HGMRs above the Fall Line. In two of the HGMRs (Piedmont carbonate and Mesozoic Lowland) that cover relatively small geographic areas, the range in age was from modern to about 10 years. Only two springs were sampled in the Coastal Plain, but data are available from other regional studies that provide apparent ages for Coastal Plain settings. Dunkle and others (1993) sampled 109 wells in the surficial aquifer underlying the Delmarva Peninsula. The apparent age of samples from these wells varied from modern to almost 50 years. The data suggest that apparent age is not related to the HGMR, and some common factors that occur in all of the HGMRs control the age. These factors are discussed later in this section.

The range of apparent age of water from the targeted watersheds was similar to the range of apparent ages from the spring-sampling study. Overall, the range in ages from wells in all the targeted watersheds was modern to >50 years. In Pocomoke River Watershed, the apparent age of water in samples ranged from 0 to $>50$ years; the ages in the vicinity of the streams was from 0 to 23 years. The apparent ages measured in the Polecat Creek Watershed ranged from 2 to 30 years. The apparent ages of water from wells in the Muddy Creek Watershed ranged from 10 to 20 years (except for a single sample that was 45 years), and from the five springs ranged from 7 to 13 years. Supplementary tracers indicated some component of the water was modern in the springs. The ages measured in the East Mahantango Creek Watershed ranged from 0 to $>50$ years. The similarity in the range of apparent ages from the targeted watersheds and springs shows the samples have bracketed the range of apparent ages that would be expected in the shallow ground-water-flow systems throughout the Chesapeake Bay Watershed. The apparent age distribution of water from wells represents only individual points in the aquifer, and therefore, does not necessarily represent the distribution of residence times of all ground-water-flow paths discharging to streams.

The distribution of the residence time of ground water discharging to streams also was determined by use of a ground-water-flow model for the East Mahantango Creek Watershed. (The development of flow models for each targeted watershed was beyond the scope of this study.) The flow-model simulation indicates that about half of the water discharges to streams within a year. A study of the WE-38 subwatershed, which is in the East Mahantango Creek Watershed, and another small watershed within the Valley and Ridge siliciclastic HGMR used $\mathrm{O}$ isotope analysis to determine the mean residence time of the water discharging to streams (McGuire and others, 2002). This study indicated a mean residence time of ground water of slightly less than a year for both sites. Although the mean residence time was at the very young end of the scale, the study indicated the existence of older water contributing to the stream base flow. McGuire's study is probably a good indicator that the young (less than 1 year) component of ground-water discharge is significant in the East Mahantango Creek Watershed.

Results from other investigations that utilized flow models provide additional estimates of the distribution of the ground-water residence time. Kauffman and others (2001) used a ground-water-flow model and agedating results to estimate ground-water residence time to streams and wells in a $400-\mathrm{mi}^{2}$ study area in the Coastal Plain of New Jersey. The surficial aquifer ranged between 25 and $300 \mathrm{ft}$ thick. About 80 percent or more of the streamflow is derived from ground water. For all streams in the study, the range of apparent age of ground-water discharge was from less than 1 year to over 100 years. About 30 percent of the water entering streams was less than 5 years old and about $1 / 2$ (47 percent) of the water was less than 10 years old. Another 20 percent was between 10 and 20 years; a similar amount was between 20 and 46 years. Modica and others (1998) studied another small watershed in the Coastal Plain of New Jersey. Different model simulations indicated that all the ground-water discharge into a small first-order stream had residence time of less than 15 years; 70 percent of the ages were less than 5 years. The simulated residence time of ground water discharging to a higher-order stream was mostly less than 20 years; only about 30 percent was less than 5 years. Böhlke and Denver (1995) found that ground waters discharging beneath streams in two small watersheds on the Delmarva Peninsula had an average residence time of about 20 years.

A significant part (30 to 70 percent) of the ground-water discharge less than 5 years old identified in studies with flow models was not in complete agreement with data from samples collected from the Chesapeake Bay Watershed during this study. There are several likely reasons for this lack of detection of large 
amounts of "young" water. First, many of the samples, particularly those from springs, are mixtures that could include a large percentage of modern water, but this percentage could not be computed because of lack of results from multiple isotopic tracers. Secondly, a large part of young water likely discharges as seasonal springs and diffuse discharge to ditches, to depressions in the land surface, and to the streambed when ground-water levels are high, so that short, shallow flow paths are prevalent. Such discharge was observed in the field at both the East Mahantango Creek and Polecat Creek Watersheds, but this water was not sampled.

The information on ground-water residence time, combined with the other flow components (runoff and interflow) contributing to a stream, gives some insight into the age of water discharging to a streams. Runoff and interflow both have very short residence times (months) and supply about 50 percent of the water to a stream. Of the water moving through the ground-water system, about 75 percent may discharged in less than 13 years (with a large percentage less than 5 years). The result is that about 90 percent of total water being discharged to the stream may be less than 13 years old.

\section{Factors Affecting the Discharge of Ground Water to Streams and Associated Residence Time}

Aquifer geometry, permeability, and hydraulic gradient are the factors having the greatest effect on ground-water discharge to streams and the associated residence time in the targeted watersheds. These factors influence the length of the ground-water-flow path between the recharge area and the discharge point to a stream or spring. In each of the targeted watersheds, an upper permeable zone consisting of unconsolidated sediment forms a surficial aquifer having varied importance for ground-water flow. In all except the Pocomoke River Watershed, the surficial, unconsolidated sediments are underlain by consolidated bedrock. In the Pocomoke River and Polecat Creek Watersheds, the surficial aquifer is the primary pathway for ground-water flow. Underlying rock having a lower permeability than the surficial aquifer limits deeper ground-water flow and forms a confining unit. At the Pocomoke River sites, the confining unit consists of unconsolidated silt and clay. The top of the confining unit and land surface slope gradually such that ditches have been dug to accelerate ground-water flow and discharge. The confining unit at the Polecat Creek Watershed consists of consolidated bedrock appearing to have limited fracturing. A ridge in the bedrock north of the creek, a dip in bedrock to the south, and substantial and varied topographic relief cause substantial differences in ground-water flow between the north and south sides of the creek. Unlike bedrock in the Polecat Creek Watershed, bedrock at the East Mahantango Creek site has substantial fracturing such that the thin layer of surficial sediment and bedrock are in good hydraulic connection. Ground water flows through the surficial, unconsolidated sediment; however, the predominant controls on the directions and amounts of ground-water flow are topography and the dip and orientation of bedding planes and changes in the fracture density with depth in the bedrock. These factors cause ground-water flow on one side of the creek to differ from that on the other side of the creek. In the Muddy Creek Watershed, where a substantial thickness of regolith is saturated, most ground water flows through solution channels along joints, fractures, and bedding planes in the bedrock. And like the East Mahantango Creek Watershed, the orientation of these features controls ground-water flow. Unlike that watershed, dissolution of rock along these features (in the Muddy Creek Watershed) forms conduits through which ground water flows rapidly.

Aquifer geometry, permeability, and hydraulic gradient vary greatly within each HGMR, and therefore, a unique set of these properties can not be generalized for each HGMR. Aquifer geometry and the underlying confining unit can slope gently or substantially whether in the Coastal Plain or in a HGMR underlain by consolidated bedrock. The degree of fracturing in the upper part of the bedrock also can vary within an HGMR depending on the type of bedrock and the folding, faulting, and other stress-causing features of a local area. The effects of conduit flow on ground-water discharge and residence time is a characteristic of the Valley and Ridge carbonate HGMR and generally will not be found in large areas of most other HGMRs. Even though all of these factors need to be understood for local study areas to understand the relative control these factors have on ground-water discharge and residence time, some general conclusions can be made about the length of ground-water-flow paths and the associated residence time.

Because of the effects of aquifer hydraulic characteristics and topography, water recharged near streams has short residence times and flows along shallow paths, and water recharged in upland areas has longer residence times and deeper flow paths. In addition, residence times were shorter under high recharge conditions than low recharge conditions. These findings are consistent with the basic principles of ground-water-flow sys- 
tems for several reasons. First of all, for water to flow from a recharge area to a discharge area, deep-flowing water must travel a longer distance than shallow-flowing water. This results in a lower hydraulic gradient, less flow, and older water along the deeper path than along the shallow path. Additionally, if an aquifer is layered, the horizontal hydraulic conductivity typically is greater than the vertical hydraulic conductivity, and hydraulic conductivity commonly decreases with depth. These factors further increase the age and decrease the amount of ground water that flows deeper in the system. In the Muddy Creek Watershed, however, the karst features, which facilitate conduit flow, make it much more difficult to determine the factors affecting ground-water ages. Flow through conduits allows water to flow for long distances through the aquifer with little change in head, whereas flow through poorly fractured zones may cause a great deal of head change in a short distance. Without a good context of the location of a sample in the flow system, the age dates are at best difficult to interpret. Although basic hydraulic principles apply, the ability to identify layers or areas of preferential flow would be a prerequisite to interpreting the ages with respect to spatial and temporal variation.

\section{Nitrogen Transport in Ground Water and Discharge to Streams}

$\mathrm{N}$ transport in ground water and subsequent discharge to streams is significant because this pathway delivers a large quantity of nutrients to the Chesapeake Bay. The study focused on the occurrence of $\mathrm{N}$ in ground water and the factors affecting the delivery of that $\mathrm{N}$ to streams.

\section{Nitrogen Occ urrence in Watersheds and Springs}

The concentrations of $\mathrm{NO}_{3}^{-}$in water from the targeted watersheds is consistent with the concentrations of $\mathrm{NO}_{3}^{-}$from the spring study. In the Muddy Creek Watershed, $\mathrm{NO}_{3}^{-}$concentrations ranged from less than 0.05 to $22 \mathrm{mg} / \mathrm{L}$. The median $\mathrm{NO}_{3}^{-}$concentration in spring water from springs in the Valley and Ridge carbonate HGMR was $4 \mathrm{mg} / \mathrm{L}$. Concentrations of $\mathrm{NO}_{3}^{-}$ measured in the Polecat Creek Watershed ranged from less than 0.05 to $7.4 \mathrm{mg} / \mathrm{L}$. Concentrations of $\mathrm{NO}_{3}^{-}$ from springs in the Piedmont crystalline HGMR averaged $2.5 \mathrm{mg} / \mathrm{L}$. $\mathrm{NO}_{3}^{-}$concentrations measured in water from wells in the East Mahantango Creek Watershed ranged from less than 0.05 to $12 \mathrm{mg} / \mathrm{L}$. The average concentration of $\mathrm{NO}_{3}^{-}$in the Valley and Ridge HGMR was $1 \mathrm{mg} / \mathrm{L}$. In the Pocomoke River Watershed, the
$\mathrm{NO}_{3}^{-}$concentrations in ground-water samples ranged from 0.05 to $25 \mathrm{mg} / \mathrm{L}$. No springs were sampled in the Coastal Plain that could be used for comparison purposes. In all cases where comparisons could be made, the median concentration in springs was within, and at the low end of, the range of concentrations in the targeted watersheds. This is not unexpected, because the springs represent a mixture of land use types, and the targeted watersheds primarily represent agricultural land use. The maximum concentrations in each targeted watershed are not aligned with the median spring concentrations, but this is probably because of the amount of agricultural activity in the vicinity of the wells sampled. The large range of concentrations within the targeted watersheds is the result of sampling a broad spectrum of depths and conditions within the aquifer. The range of ages determined for springs was not as large because springs normally represent discharge from a mixture of flow paths.

Data from several NAWQA Project studies provide further information about the distribution of $\mathrm{NO}_{3}^{-}$ concentrations in the Chesapeake Bay Watershed and Mid-Atlantic Region. Ator and Ferrari (1997) found that wells within the carbonate and crystalline rock had much higher median concentrations of $\mathrm{NO}_{3}^{-}$(6.4 and $4.0 \mathrm{mg} / \mathrm{L}$ respectively) than areas underlain by unconsolidated or siliclastic rocks. The elevated median concentrations were associated with agriculture land use (about $5.0 \mathrm{mg} / \mathrm{L}$ ); lower median concentrations were associated with urban $(2.0 \mathrm{mg} / \mathrm{L})$ and forested lands $(<0.1 \mathrm{mg} / \mathrm{L})$. A study conducted by the NAWQA Program in the Lower Susquehanna River Basin showed the streams in the Valley and Ridge carbonate HGMR had greater median $\mathrm{NO}_{3}^{-}$concentrations in ground-water samples (a median concentration of about $9 \mathrm{mg} / \mathrm{L}$ ) than in the surface-water samples (a median concentration of about $5 \mathrm{mg} / \mathrm{L}$ ) (Lindsey and others, 1997). The same pattern was evident in the Piedmont crystalline HGMR where median $\mathrm{NO}_{3}^{-}$concentrations in ground water were about $7.5 \mathrm{mg} / \mathrm{L}$ and concentrations in stream samples were about $3.5 \mathrm{mg} / \mathrm{L}$. In the Valley and Ridge siliciclastic HGMR, however, this pattern was reversed; surface-water samples had higher median $\mathrm{NO}_{3}^{-}$concentrations (about $3 \mathrm{mg} / \mathrm{L}$ ) than ground-water samples (less than $1 \mathrm{mg} / \mathrm{L}$ ). In a similar study for the NAWQA Project in the Potomac River Basin, ground-water samples collected in the Valley and Ridge carbonate HGMR had a median $\mathrm{NO}_{3}^{-}$concentration of $4.6 \mathrm{mg} / \mathrm{L}$. The median concentration of $\mathrm{NO}_{3}^{-}$in the Piedmont crystalline HGMR was $1.4 \mathrm{mg} / \mathrm{L}$, and the Valley and Ridge siliciclastic HGMR had a median $\mathrm{NO}_{3}^{-}$concentration of less 
than $0.05 \mathrm{mg} / \mathrm{L}$ (Ator and Denis, 1997). In general, these studies showed the largest concentrations in the agricultural areas underlain by carbonate and crystalline rocks, and the lowest concentrations in the siliciclastic and unconsolidated rocks. The low $\mathrm{NO}_{3}^{-}$concentrations in the Valley and Ridge siliciclastic and Coastal Plain HGMR is likely because of the fact that the NAWQA studies sampled domestic supply wells commonly deeper than $150 \mathrm{ft}$; however, the samples for the current study were collected from wells in the range of 10 to $60 \mathrm{ft}$.

\section{Factors Affec ting Nitrogen Transport in Ground Water and Discharge to Streams}

In addition to factors affecting ground-water flow and residence time, factors affecting $\mathrm{N}$ transport to streams include (1) the spatial and temporal variations of the nutrients applied to the land surface and (2) the influence of denitrification. Spatial and temporal variations in $\mathrm{N}$ sources are present in all the watersheds. These variations include differences in the land use and in the transport and geochemical processes that affect $\mathrm{N}$ transport from land surface to the water table. A large part of the difference in land use appears to be spatial differences in the application of commercial fertilizer to cropland and in the input of animal manure from livestock-raising areas and from the application of manure to cropland. Denitrification can decrease the concentrations of $\mathrm{NO}_{3}^{-}$in ground water, thereby decreasing the amount that is discharged to streams. Denitrification is limited, however, to situations where chemical and biological depletion of dissolved oxygen creates conditions in which $\mathrm{NO}_{3}^{-}$can be chemically reduced, generally when mediated by bacterial processes. Typically, these conditions occur where minerals contain components in a reduced oxidation state, and organic carbon in the aquifers and confining units is oxidized by the dissolved oxygen. Such conditions require the appropriate mineral availability and sufficient time for the oxygen to become depleted. Soils with high organic content and denitrification potential also can limit the amount of $\mathrm{NO}_{3}^{-}$that reaches the ground-water system. All of these factors were identified in some or all of the targeted watersheds.

The amount of $\mathrm{N}$ applied over time to the land surface is a major factor affecting the concentration of $\mathrm{N}$ recharging to the ground water. In all of the targeted watersheds, the use of commercial fertilizer and manure has increased in recent years. The increasing input of $\mathrm{N}$ was evident as an increase in the concentration of $\mathrm{NO}_{3}^{-}$ in ground water underlying the targeted watersheds (when corrected for the effects of denitrification).
A relation between ground-water age and $\mathrm{NO}_{3}^{-}$reconstructed to account for denitrification showed the $\mathrm{NO}_{3}^{-}$ concentrations generally below $3 \mathrm{mg} / \mathrm{L}$ in ground water with recharge dates prior to 1985 and generally increase substantially since that time. Although much of the ground-water discharge in the targeted watershed is young water, $\mathrm{NO}_{3}^{-}$concentrations in older ground water can be expected to increase as the recently recharged high $\mathrm{NO}_{3}^{-}$water replaces older, low $\mathrm{NO}_{3}^{-}$water. The effects of older water likely will be greater in discharge to larger streams because they are discharge areas for longer ground-water-flow paths.

Evidence of denitrification is common in ground waters discharging to small streams in the Pocomoke River Watershed, and locally in the East Mahantango Creek Watershed, but denitrification is not a common feature of the analyzed samples from the Polecat Creek and Muddy Creek Watersheds. In East Mahantango Creek, the level of denitrification is significant in water with residence times greater than 20 years. This water typically is water that is recharged and flows through the deeper part of the system. Because this is a small component of overall ground-water discharge to a stream, it may not remove a significant quantity of $\mathrm{N}$ from the system. Denitrification in the Pocomoke River Watershed was fairly extensive, with reducing conditions in much of the aquifer that promoted denitrification. Locally, however, nitrate in short flow paths near streams was not being affected by denitrification. Thus, in both the East Mahantango Creek and Pocomoke River Watersheds, water recharged into the ground-water system through the more distant uplands have the greatest amount of denitrification, which results in lesser amounts of $\mathrm{N}$ being discharged to the stream. In Muddy Creek, evidence of denitrification was observed in some samples. The observation that most $\mathrm{N}$ entering the stream is associated with the discharge of younger ground water suggests that denitrification may not greatly affect the overall $\mathrm{N}$ delivery to a stream in the targeted watersheds.

The availability of dissolved oxygen is an important factor in determining denitrification rates and, in general, older water contains less dissolved oxygen. In the Coastal Plain in particular, formations with abundant organic material are common and promote denitrification. Because of their position in the hydrologic system, these fine-grained organic materials can affect the quality and quantity of discharging ground water as dissolved oxygen is depleted and $\mathrm{NO}_{3}^{-}$is reduced to $\mathrm{N}_{2}$ gas by microbial metabolic processes. Where dissolved oxygen concentrations are low (less than $1.4 \mathrm{mg} / \mathrm{L}$ ) in 
the Coastal Plain, $\mathrm{NO}_{3}^{-}$concentrations rarely exceed 2-3 mg/L (Ator and others, 2000). However, in areas of elevated dissolved oxygen (greater than $7.7 \mathrm{mg} / \mathrm{L}$ ), $\mathrm{NO}_{3}^{-}$concentrations commonly exceed $10 \mathrm{mg} / \mathrm{L}$. In other areas, the alluvium of many stream valleys can contain substantial amounts of organic carbon that will promote denitrification. Denitrification also can be a factor in the concentration of $\mathrm{NO}_{3}^{-}$in ground water that discharges to riparian forest buffers and through the bed of many streams. $\mathrm{NO}_{3}^{-}$in ground water that discharges to forest buffers can denitrify as a result of the effects of the organic forest litter. Although denitrification of ground water discharging through the streambed has been identified in many watersheds, it was not studied in the targeted watersheds. It could, however, have an important effect on concentrations of $\mathrm{NO}_{3}^{-}$in discharged ground water.

Though not a focus of this study, soils also have an influence on the amount of $\mathrm{NO}_{3}^{-}$reaching the water table. In areas of anaerobic soils, ammonium may not be converted to $\mathrm{NO}_{3}^{-}$and therefore will not reach the water table. Ator and others (2000) have demonstrated that where soils in the Coastal Plain have a moderate or high denitrification potential, the underlying median concentration of $\mathrm{NO}_{3}^{-}$in ground water was less than $0.5 \mathrm{mg} / \mathrm{L}$. In areas having soils with a low denitrification potential, the median concentration of $\mathrm{NO}_{3}^{-}$in ground water was almost $3 \mathrm{mg} / \mathrm{L}$. The time it takes $\mathrm{N}$ to move through the soil zone and into the ground water is not well studied, but does represent an additional "lag time" beyond the residence time for the ground water of $\mathrm{NO}_{3}^{-}$to travel through the system. Organic $\mathrm{N}$ is affected by microorganisms in the soil through the process of mineralization (transformation to $\mathrm{NH}_{4}$ and $\mathrm{NO}_{3}^{-}$), and the rate of mineralization may be in excess or deficient with respect to meeting the $\mathrm{N}$ requirements of the crop grown in the field (Baker and others, 1990). In some cases, the amount of organic $\mathrm{N}$ in soils may be sufficient to produce excess inorganic $\mathrm{N}$ for a number of years.

The targeted-watershed approach, coupled with the data collected from springs, helped to document the range of, and factors affecting, the residence time and the $\mathrm{NO}_{3}^{-}$concentrations of ground water discharging to streams in the Chesapeake Bay Watershed. It was determined that local variability in these factors within each targeted watershed is likely to be as great or greater than variability between HGMRs. Consequently, the ability to regionalize the findings from the targeted watersheds to the original HGMR classification is limited. Many factors affecting the ground-water residence time and $\mathrm{NO}_{3}^{-}$transport were common in the targeted water- sheds, however, and these factors can be presented in a regional context of the Chesapeake Bay Watershed and the implications for nutrient-reduction strategies are presented in the following section.

\section{IMPUCATIONS FOR MANAGEMENT}

Findings of this study can be used to help understand the role of ground water on the "lag time" between implementation of management practices and response in water quality of a stream. The range in residence time and $\mathrm{N}$ in ground water was similar among HGMRs. Most factors affecting residence time and $\mathrm{N}$ in ground water are common throughout the Chesapeake Bay Watershed and can be discussed on a regional context to help resource managers better apply the findings of the study to local areas. This section presents the considerations for better targeting nutrient reductions based on (1) the relation between nutrient sources, influence of different ground-water residence time distributions, and streamwater-quality response; (2) the influence of denitrification; and (3) the effect of instream and riparian zone processes on $\mathrm{N}$ discharge from ground water and its delivery to the Chesapeake Bay.

The relation between nutrient sources, influence of different ground-water residence time distributions, and streamwater-quality response is presented using information from the East Mahantango Creek Watershed as an example. The ground water and age-dating results were used to simulate the relation between $\mathrm{N}$ inputs, ground-water concentration, and stream concentrations. Documented changes in the $\mathrm{N}$ sources and related $\mathrm{NO}_{3}^{-}$concentrations of ground-water recharge were combined with hypothetical nutrient-reduction scenarios to simulate past and future trends in stream $\mathrm{NO}_{3}^{-}$concentrations. To illustrate the influence of ground-water residence time, several different groundwater age distributions were combined with past and future changes in $\mathrm{N}$ sources and associated $\mathrm{NO}_{3}^{-}$concentrations in ground water to predict $\mathrm{NO}_{3}^{-}$concentrations discharging to a stream (fig. 91). Past $\mathrm{NO}_{3}^{-}$ concentrations in ground-water recharge were derived from the ground-water $\mathrm{NO}_{3}^{-}$record of the East Mahantango Creek Watershed for 1950-2000, extended back linearly to 0 in 1750 . Two different nutrient-reduction scenarios were chosen to bracket the possible stream responses (1) removing the $\mathrm{NO}_{3}^{-}$source in recharge abruptly in 2001, and (2) holding $\mathrm{N}$ sources and $\mathrm{NO}_{3}^{-}$ recharge at 2000 levels indefinitely. Three different ground-water-age frequency distributions were used in the simulations (fig. 91B), corresponding to (1) results of the heterogeneous particle-tracking flow model of the 
East Mahantango Creek Watershed with a mean groundwater residence time of 9.5 years, (2) a hypothetical exponential age distribution with a mean residence time of 9.5 years, similar to the mean age of the Mahantango flow model, and (3) a hypothetical exponential age distribution with an older mean residence time of 32 years, derived from the aquifer characteristics at the Locust Grove site in the Maryland coastal plain. The calculations were done without provision for denitrification so that the effects of ground-water residence times could be isolated.

In all three model scenarios, the $\mathrm{NO}_{3}^{-}$concentration of the hypothetical stream has increased over the last several decades (1940s to 2000 on figure $90 \mathrm{~A}$ ) as a result of a gradual increase in the concentration of $\mathrm{NO}_{3}^{-}$ in recharging ground water. The increase of $\mathrm{NO}_{3}^{-}$in the ground water is related to the increase in nutrients applied to the land surface. However, the stream concentrations consistently have been less than the groundwater concentrations because the ground water discharging to streams is a mixture of different ages. Some of the older ground water has lower concentration of $\mathrm{NO}_{3}^{-}$than some of the more recent water because of lower nutrient application rates to the land in the 1950s1960s. In these examples, the difference between the recharge and stream discharge concentrations is proportional to the mean residence time of the discharging ground water (9.5 years versus 32 years). In addition, the two models (Particle Tracking Model (PTM) and Exponential Model (EM)) with identical (9.5) mean residence times yield slightly different responses because they have different ground-water-age frequency distributions. These results clearly depend on the specific nutrient-input history used in the calculations; the one used is typical of many agricultural regions of the United States, but could be completely different locally.

When applying the two hypothetical nutrientreduction scenarios, some important implications about resulting concentrations in streams are evident. For example, although both models representing 9.5-year mean ground-water age indicate similar trends in the past, they diverge substantially in their predicted surface-water responses to an abrupt decrease in $\mathrm{N}$ applied to the land surface and associated decrease in the $\mathrm{NO}_{3}^{-}$ concentration recharging the aquifer (figure 90A). The model simulation based on the PTM shows a large reduction in $\mathrm{NO}_{3}^{-}$concentration in the first year because of the high percentage of water less than 1 year old. Following the large reductions in the first year, however, the reductions follow a more gradual path with incremental but small reductions in $\mathrm{NO}_{3}^{-}$concentration each year. These reductions continue until the $\mathrm{NO}_{3}^{-}$ concentrations in the discharge water are virtually the same as the concentrations in the recharge, but most of the reductions are observed within a 10-year period. Similarly, the two exponential mixing models with different mean ages (9.5 and 32 years) have dramatically different responses and each shows a much more gradual reduction in predicted $\mathrm{NO}_{3}^{-}$in surface water (fig. 90). The effects of denitrification of water with residence times in the 20- to 40-year range (not shown in this scenario) would be minimal and difficult to distinguish in this representation.

These predictions have limitations and will vary locally depending on the magnitudes and frequency distributions of discharging ground-water ages and the spatial patterns of land use, unsaturated-zone transport times, reactions such as denitrification in the saturated zone, and instream processes such as denitrification and assimilation. For example, at the Mahantango site, the estimate of $\mathrm{NO}_{3}^{-}$concentration discharging to the stream on the basis of this method comes out to be about $10.2 \mathrm{mg} / \mathrm{L}$. This is much greater than the actual $\mathrm{NO}_{3}^{-}$ concentration in the stream; however, this scenario is for ground water recharged in agricultural areas dominated by row crops only and does not represent the land-use distribution of the whole watershed. The dilution effect of forested areas and areas of lower $\mathrm{N}$ inputs in the watershed reduce the actual $\mathrm{NO}_{3}^{-}$concentration measured in the stream closer to $3 \mathrm{mg} / \mathrm{L}$. The value of $10 \mathrm{mg} / \mathrm{L}$ is in the range expected for cropland on the basis of the work of Gburek and Folmar (1999). The reduction scenario simulated also assumes a management practice that allows no leaching of $\mathrm{NO}_{3}^{-}$from the root zone. An assessment of whether or not the reduction presented in this scenario is feasible is not within the scope of this study.

The $\mathrm{NO}_{3}^{-}$simulation demonstrates the influence of ground-water-age distribution on the delivery of $\mathrm{NO}_{3}^{-}$to a stream. On the basis of data collected in this study, a large percentage (about 75 percent) of the ground water is less than 13 years old, $30-70$ percent of this water is estimated to be less than 5 years old. If the location of the 'short' flow paths with this younger water can be determined systematically, management practices targeted to that part of the watershed would provide the quickest response in stream base-flow concentration. The most likely locations of these areas with the greater amounts of "young" water will be near the small streams that are ground-water discharge points. Higher order streams will have a greater percentage of older ground-water discharge. To put this in another perspective, consider a scenario in which a management practice is implemented whereby all $\mathrm{N}$ is utilized by the crops grown in a given field and no $\mathrm{N}$ leaves via runoff or leaching to the ground water. Given that half the 

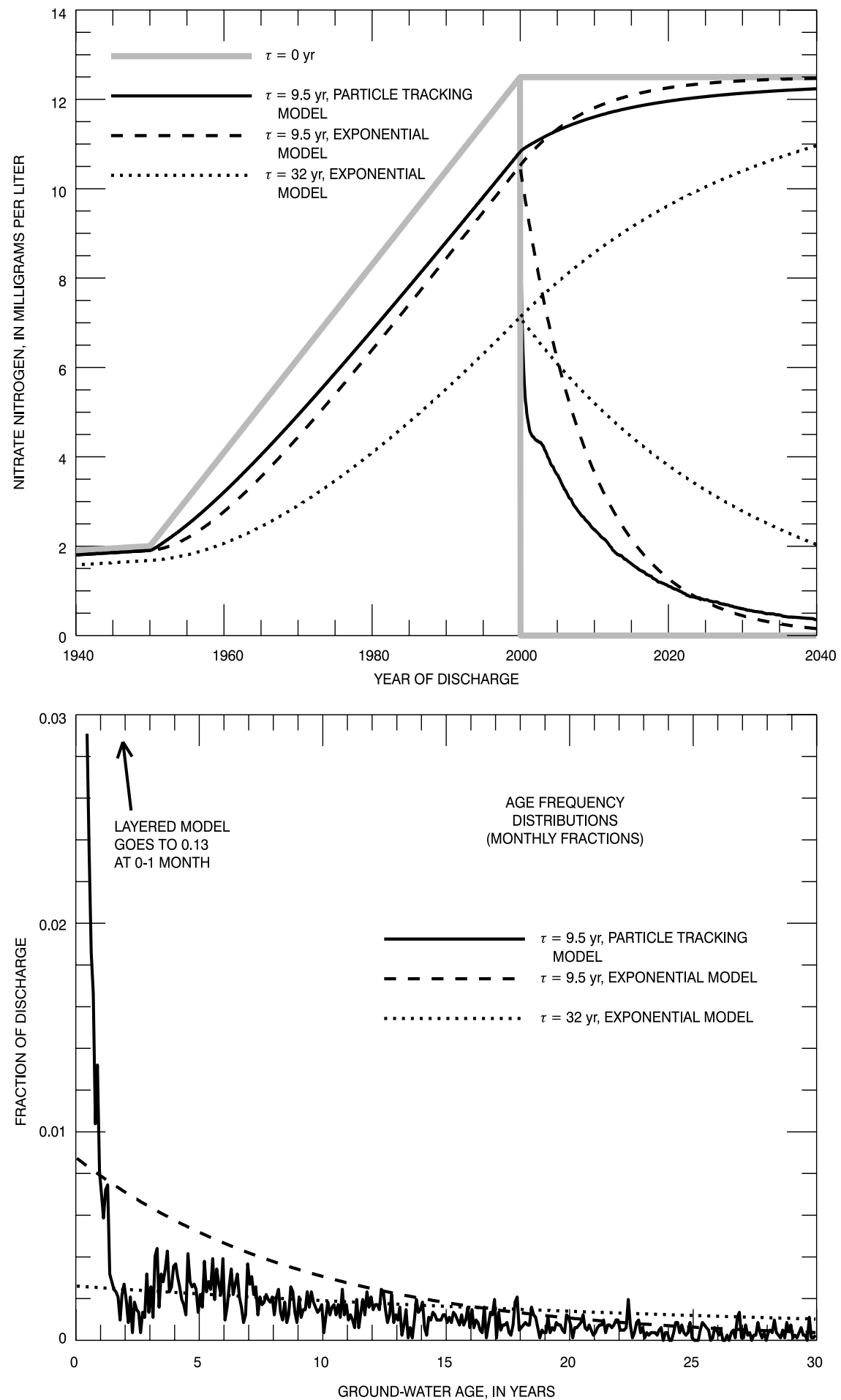

Figure 90. Possible response of nitrate concentrations in base-flow discharge to elimination of nitrogen loading. 
streamflow is from ground-water discharge and the other half is runoff or soil water, the surface-water response to changes in nutrient sources to runoff and soil water would be very rapid (months). Of the water moving through the ground-water system, about 75 percent may discharged in less than 13 years; (a large percentage is discharged in less than 5 years). The result is that about 90 percent of total water being discharged to the stream will be less than 13 years old, and therefore, full implementation of nutrient reductions may result in improved stream-water quality in about a decade. Several other factors, however, including nutrient sources, influence of denitrification, and instream processing of $\mathrm{N}$ must be considered for targeting reduction actions and predicting a surface-water response.

The reduction of nutrient sources in the Chesapeake Bay Watershed is being achieved to improve water quality in the Bay. Of the major sources of $\mathrm{N}$, point-source discharges will not be influenced by ground water, and atmospheric deposition is not managed locally, therefore the application of $\mathrm{N}$ fertilizer and animal manure are the most important sources that are related to ground water. Septic systems are not included in the discussion because they are considered a fairly small source of $\mathrm{N}$. The areas of the Chesapeake Bay Watershed that have the highest loadings of $\mathrm{N}$ from these two major agricultural sources are shown in figure 91A and are based on a regression model developed by the USGS (Preston and Brakebill, 1999). The amount of $\mathrm{N}$ delivered to the Bay from these sources is shown in figure $91 \mathrm{~B}$ and reflects the influence of instream uptake of nutrients. The uptake is greatest in small order streams where biological processes consume N. However, this model does not simulate ground water, so the potential of denitrification also should be considered for targeting management actions.

As stated in the previous chapter, denitrification is an important process in removing $\mathrm{NO}_{3}^{-}$from ground water discharging to streams. In the Coastal Plain, areas with the highest potential denitrification would correspond to poorly drained, impermeable soils with abundant organic matter (Ator and others, 2000). In much of the non-Coastal Plain areas of the watershed, Peper and others (2001) have identified near-surface rock formations that contain high amounts of carbon and sulfur that also would promote denitrification. Resource managers might place less emphasis on reducing nutrient sources in these areas because the denitrification will be reducing the amount of $\mathrm{N}$ discharging from ground water to streams. Practices to reduce $\mathrm{N}$ in direct runoff and soil water to streams would still have to be implemented. In areas not affected by denitrification, resource managers

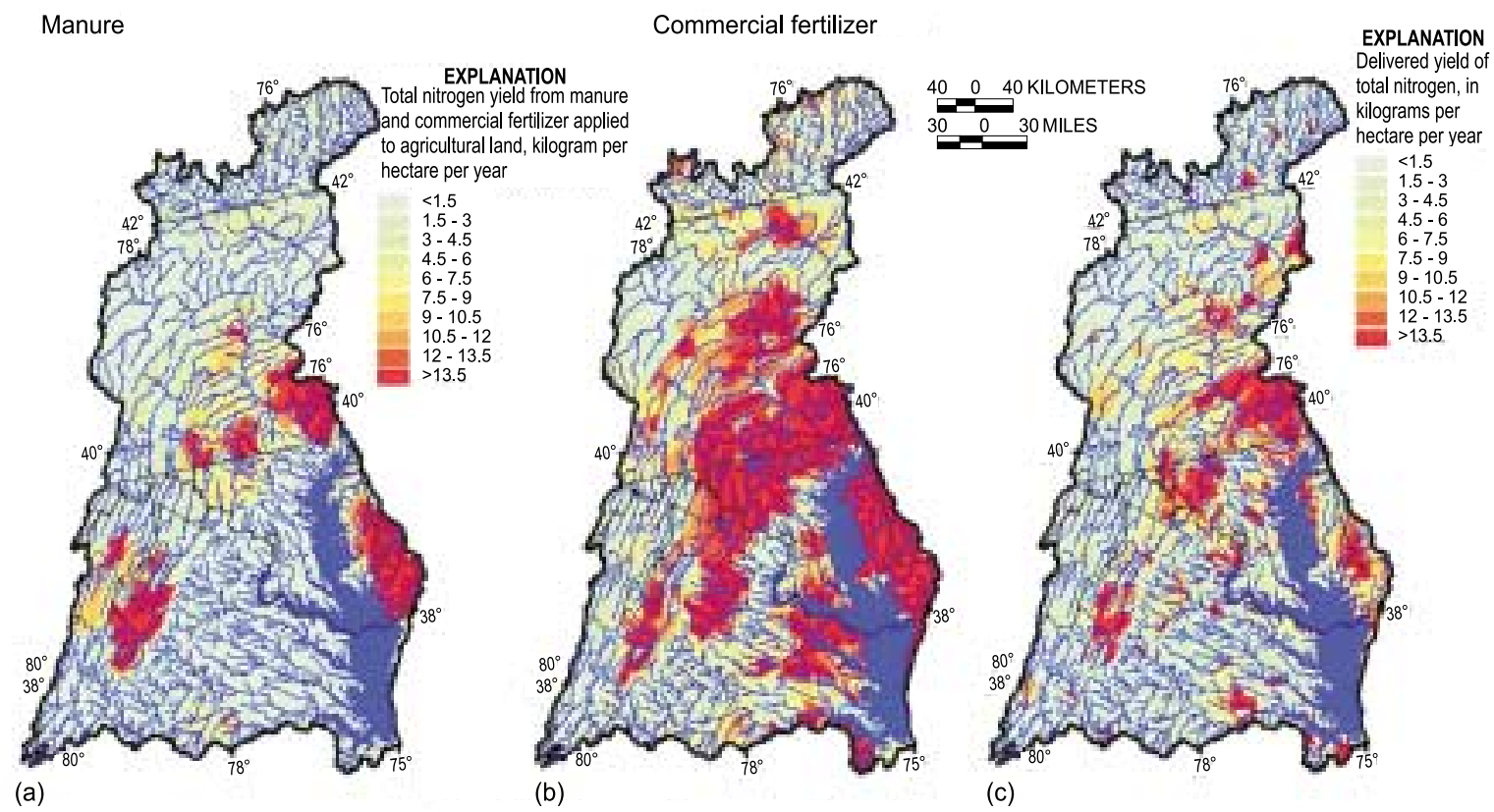

Figure 91. Yields of total nitrogen applied to the land surface from manure (a) and fertilizer (b). The yield of total nitrogen delivered to the Bay from all sources (c). 
might consider implementing management practices in areas with the highest nutrient sources that overlie ground-water recharge areas having short ground-waterflow paths to streams to provide the most rapid response in water quality. Changes in practices in ground-water recharge areas with long, deep flow paths will take the longest time to be reflected in streamwater quality.

The findings of the study described in this report suggest that streamwater-quality responses to changes in land-use practices are likely to be expressed in several ways, including (1) rapid response (within months) in a substantial fraction (about 50 percent) of the total streamflow corresponding to runoff and movement through the soil zone, (2) response time within a few years up to about a decade for the component of groundwater discharge that moves through shallow permeable flow paths or is recharged near the stream, and (3) slow response (decades) in the component of ground water that follows deeper and longer flow paths from recharge to discharge. The first two types of responses may represent about 90 percent of the water being delivered to streams. The data in this report indicate that the groundwater-discharge components commonly contain a record of past decadal changes in recharge conditions and are not in steady state with respect to recent landuse practices. The sum of all of these responses will be modified locally by (1) storage and release of $\mathrm{N}$ from soils and deeper unsaturated zones, (2) natural remediation by denitrification beneath ground-water recharge areas and discharge areas, and (3) natural remediation by various processes within the streams. Management of land-use practices to reduce stream base-flow $\mathrm{NO}_{3}^{-}$ loads would have the largest effect if aimed at (1) watersheds with the agricultural sources, and (2) areas within watersheds that have the shortest ground-water-flow paths, and (3) areas not affected by significant denitrification. These actions would be best targeted where natural stream processes can not provide additional reduction of $\mathrm{N}$ in stream water. Because more of the nutrient reductions will be phased in over time, there will continue to be substantial reservoirs of $\mathrm{NO}_{3}^{-}$-rich ground water in areas with limited denitrification that will discharge $\mathrm{NO}_{3}^{-}$to streams for years to decades. Managers should be aware of the potential variability of stream responses at various time scales, depending on local hydrogeological and biogeochemical conditions, when attempting to target management practices and when evaluating success or failure.

\section{REFERENCES CITED}

Alley, W.M., and Rickert, D.A., 1995, Establishment of U.S. Geological Survey Laboratory for determination of CFCs in air and water samples: U.S. Geological Survey Water-Quality Technical Memorandum 95.02.

Ator, S.W., and Denis, J.M., 1997, Relation of nitrogen and phosphorus in ground water to land use in four subunits of the Potomac River Basin: U.S. Geological Survey Water-Resources Investigations Report 96-4268, 26 p.

Ator, S.W., Denver, J.M., and Hancock, T.C., 2000, Relating shallow ground-water quality to surficial hydrogeology in the Mid-Atlantic coastal plain: National Water-Quality Monitoring Conference Proceedings, April 25-27, 2000, p. 409-423.

Ator, S.W., and Ferrari, M.J., 1997, Nitrate and selected pesticides in ground water of the Mid-Atlantic Region: U.S. Geological Survey Water-Resources Investigations Report 97-4139, 8 p.

Bachman, L.J., Lindsey, B.D., Brakebill, J.W., and Powars, D.S., 1998, Ground-water discharge and base-flow nitrate loads of nontidal streams, and their relation to a hydrogeomorphic classification of the Chesapeake Bay Watershed, Middle Atlantic Coast: U.S. Geological Survey Water-Resources Investigations Report 98-4059, 71 p.

Baker, D.E., Myers, R.G., and Cronce, R.C., 1990, Assessment of field manure nutrient management with regards to surface and groundwater quality:

Middletown, Pa., Pennsylvania Department of Environmental Resources, chap. 3, 20 p.

Böhlke, J.K., and Denver, J.M., 1995, Combined use of groundwater dating, chemical, and isotopic analyses to resolve the history and fate of nitrate contamination in two agricultural watersheds, Atlantic coastal plain, Maryland: Water Resources Research, v. 31, no. 9 , p. 2,319-2,339.

Busenberg, Eurybiades, and Plummer, L.N., 1992, Use of chlorofluorocarbons $(\mathrm{CCl} 3 \mathrm{~F}$ and $\mathrm{CCl} 2 \mathrm{~F} 2)$ as hydrologic tracers and age-dating tools-Example - The alluvium and terrace system of central Oklahoma: Water Resources Research, v. 28, p. 2,257-2,284.

2000 , Dating young groundwater with sulfur hexafluoride - Natural and anthropogenic sources of sulfur hexafluoride: Water Resources Research, v. 36, p. 3,011-3,030.

Dunkle, S.A., Plummer, L.N., Busenberg, E., Phillips, P.J., Denver, J.M., Hamilton, P.A., Michel, R.L., and Coplen, T.B., 1993, Chlorofluorocarbons $\left(\mathrm{CCI}_{3} \mathrm{~F}\right.$ and $\mathrm{CCI}_{2} \mathrm{~F}_{2}$ ) as dating tools and hydrologic tracers in shallow groundwater of the Delmarva Peninsula, Atlantic Coastal Plain, United States: Water Resources Research, v. 29, no. 12, p. 3,837-3,860. 


\section{REFERENCES CITED-CONTINUED}

Focazio, M.J., Plummer, L.N., Böhlke, J.K., Busenberg, Eurybiades, Bachman, L.J., and Powars, D.S., 1998, Preliminary estimates of residence time and apparent ages of ground water in the Chesapeake Bay Watershed, and water-quality data from a survey of springs: U.S. Geological Survey Water-Resources Investigations Report 97-4225, 75 p.

Gburek, W.J., and Folmar, G.J., 1999, Flow and chemical contributions to streamflow in an upland watershed-a baseflow survey: Journal of Hydrology, v. 217 , issue $1-2$, p. 1-18.

Kauffman, L.J., Baehr, A.L., Ayers, M.A., and Stackelberg, P.E., 2001, Effects of land used and travel time on the distribution of nitrate in the Kirkwood-Chansey aquifer system in southern New Jersey: WaterResources Investigations Report 01-4117, 58 p.

Langland, M.J., Lietman, P.L., and Hoffman, Scott, 1995, Synthesis of nutrient and sediment data for watersheds within the Chesapeake Bay drainage basin: U.S. Geological Survey Water-Resources Investigations Report 95-4233, 121 p.

Lindsey, B.D., Loper, C.A., and Hainly, R.A., 1997, Nitrate in groundwater and stream base flow in the Lower Susquehanna River Basin, Pennsylvania and Maryland: U.S. Geological Survey WaterResources Investigations Report 97-4146, 66 p.

McGuire, K.J., DeWalle, D.R., and Gburek, W.J., 2002, Evaluation of mean residence time in subsurface waters using oxygen-18 fluctuations during drought conditions in the mid-Appalachians: Journal of Hydrology, v. 261, no. 1-4, p. 132-149, 15 Apr 2002

Michel, R.A., 1992, Residence times in river basins as determined by analysis of long-term tritium records: Journal of Hydrology, v. 130, p. 367-378.

Modica, Edward, Buxton, H.T., and Plummer, L.N., 1998, Evaluating the source and residence times of ground-water seepage to headwaters streams, New Jersey Coastal Plain: Water Resources Research, v. 34 , p. 2,797-2,810.

Peper, J.D., McCartan, L.B., Horton, J.W., and Reddy, J.E., 2001, Preliminary lithogeochemical map showing near-surface rock types in the Chesapeake Bay Watershed, Virginia and Maryland: U.S. Geological Survey Open-File Report 01-187-A.
Phillips, S.W., Focazio, M.J., and Bachman, L.J., 1999, Discharge, nitrate load, and residence time of ground water in the Chesapeake Bay Watershed: U.S. Geological Survey Fact Sheet FS-150-99, 6 p.

Plummer, L.N., and Mullin, Ann, 1997a, Tritium/helium dating of ground-water samples available through contract with Lamont-Doherty Earth Observatory of Columbia University, Palisades, New York: U.S. Geological Survey Technical Memorandum 97-04, $1 \mathrm{p}$

1997b, Supplementary information collection, processing, and analysis of ground-water samples for tritium/helium-3 dating: U.S. Geological Survey Technical Memorandum 97-04S, 22 p.

Preston, S.D., and Brakebill, J.W., 1999, Application of spatially referenced regression modeling for the evaluation of total nitrogen loading in the Chesapeake Bay Watershed: U.S. Geological Survey Water-Resources Investigations Report 99-4054, $12 \mathrm{p}$.

Prince, K.R., Franke, O.L., and Reilly, T.E., 1988, Quantitative assessment of the shallow ground-water flow system associated with Connetquot Brook, Long Island, New York: U.S. Geological Survey WaterSupply Paper 2309, 28 p.

Sloto, R.A., and Crouse, M.Y., 1996, HYSEP - a computer program for streamflow hydrograph separation and analysis: U.S. Geological Survey WaterResources Investigations Report, 96-4040, 46 p.

Speiran, G.K., Hamilton, P.A., Woodside, M.D., 1998, Natural processes for managing nitrate in ground water discharged to Chesapeake Bay and other surface waters; more than forest buffers: U.S. Geological Survey Fact Sheet 0178-97, 6 p.

U.S. Environmental Protection Agency, 1999, State of the Chesapeake Bay, USEPA Report 903-R99-013, $59 \mathrm{p}$.

Winter, T.C., LaBaugh, J.W., Rosenberry, D.O., 1988, The design and use of a hydraulic potentiomanometer for direct measurement of differences in hydraulic head between groundwater and surface water: Limnology and Oceanography, v. 33 (5), p. 1,2091,214 . 



\section{APPENDIXES}


Appendix A. Site information and field measurements of stream and ground water collected in the Chesapeake Bay Watershed, June 1998 through May 2000 [', degrees; ', minutes; ", seconds; BLS, below land surface; ft, feet; LEW, left edge of water; ${ }^{\circ} \mathrm{C}$, degrees Celsius; DO, dissolved oxygen; mg/L, milligrams per liter; $\mu \mathrm{S} / \mathrm{cm}$, microsiemens per centimeter at $25^{\circ} \mathrm{C}$; mp, minipiezometer; n/a, not applicable; --, missing data]

\begin{tabular}{|c|c|c|c|c|c|c|c|c|c|c|c|c|}
\hline Site name & Local ID & $\begin{array}{c}\text { Latitude } \\
\left({ }^{\circ},{ }^{\prime},{ }^{\prime}\right)\end{array}$ & $\begin{array}{c}\text { Longitude } \\
\left({ }^{\circ},,^{\prime},\right)\end{array}$ & $\begin{array}{c}\text { Depth of } \\
\text { bottom of } \\
\text { screen BLS } \\
\quad \text { (ft) }\end{array}$ & $\begin{array}{c}\text { Distance } \\
\text { from LEW } \\
\text { (ft) }\end{array}$ & Date & Time & $\begin{array}{l}\text { Water-level } \\
\text { elevation } \\
\text { (feet) }\end{array}$ & $\begin{array}{c}\text { Tempera- } \\
\text { ture } \\
\left({ }^{\circ} \mathbf{C}\right) \\
(\mathbf{0 0 0 1 0})\end{array}$ & $\begin{array}{c}\text { pH } \\
(00400)\end{array}$ & $\begin{array}{c}\text { DO } \\
(\mathrm{mg} / \mathrm{L}) \\
(\mathbf{0 0 3 0 0})\end{array}$ & $\begin{array}{c}\text { Specific } \\
\text { conductance } \\
(\mu \mathrm{S} / \mathrm{cm}) \\
(\mathbf{0 0 0 9 5})\end{array}$ \\
\hline \multicolumn{13}{|c|}{ Pocomoke River at Careytown, Md. } \\
\hline Stream & 01484980 & 382609 & 0752016 & $\mathrm{n} / \mathrm{a}$ & $\mathrm{n} / \mathrm{a}$ & $8 / 24 / 98$ & 0900 & $\mathrm{n} / \mathrm{a}$ & 23.0 & 6.4 & 5.4 & 89 \\
\hline WI Bh p1a & mp 1 & 382609 & 0752016 & 3.1 & 4 & $8 / 24 / 98$ & 0915 & $\mathrm{n} / \mathrm{a}$ & 21.0 & 5.2 & 2.9 & 64 \\
\hline WI Bh p1b & $\mathrm{mp} 2$ & 382609 & 0752016 & 3.0 & 5.5 & $8 / 24 / 98$ & 1100 & $\mathrm{n} / \mathrm{a}$ & 24.2 & 5.3 & -- & 58 \\
\hline WI Bh p1c & $\mathrm{mp} 3$ & 382609 & 0752016 & 3.0 & 7 & $8 / 24 / 98$ & 1400 & $\mathrm{n} / \mathrm{a}$ & 24.4 & 5.1 & 4.1 & 58 \\
\hline WI Bh p1d & $\mathrm{mp} 4$ & 382609 & 0752016 & 2.9 & 8.5 & 8/24/98 & 1515 & $\mathrm{n} / \mathrm{a}$ & 25.9 & 5.2 & 6.5 & 57 \\
\hline WI Bh p1e & mp 5 & 382609 & 0752016 & 3.0 & 10 & $8 / 24 / 98$ & 1600 & $\mathrm{n} / \mathrm{a}$ & 24.6 & 5.2 & 2.2 & 64 \\
\hline WI Bh p1f & mp 6 & 382609 & 0752016 & 3.1 & 12 & $8 / 25 / 98$ & 0900 & $\mathrm{n} / \mathrm{a}$ & 23.1 & 5.7 & 2.3 & 152 \\
\hline WI Bh p1g & $\mathrm{mp} 7$ & 382609 & 0752016 & 3.1 & 14 & 8/25/98 & 1015 & $\mathrm{n} / \mathrm{a}$ & 23.6 & 6.1 & 1.3 & 213 \\
\hline WI Bh p1h & mp 8 & 382609 & 0752016 & 3.0 & 16 & 8/25/98 & 1130 & $\mathrm{n} / \mathrm{a}$ & 24.2 & 6.3 & 2.6 & 249 \\
\hline WI Bh p1i & mp 9 & 382609 & 0752016 & 2.9 & 18 & $8 / 25 / 98$ & 1230 & $\mathrm{n} / \mathrm{a}$ & 24.9 & 6.2 & 1.4 & 249 \\
\hline WI Bh plj & $\mathrm{mp} 10$ & 382609 & 0752016 & 2.8 & 20 & 8/25/98 & 1330 & $\mathrm{n} / \mathrm{a}$ & 25.3 & 6.3 & 1.1 & 253 \\
\hline \multicolumn{13}{|c|}{ Pine Ridge Branch near Careytown, Md. } \\
\hline Stream & 01484995 & 382442 & 0751839 & $\mathrm{n} / \mathrm{a}$ & $\mathrm{n} / \mathrm{a}$ & 9/23/98 & 0900 & $\mathrm{n} / \mathrm{a}$ & 18.0 & 6.0 & 2.0 & 233 \\
\hline WO Be p1a & mp 1 & 382442 & 0751839 & 2.9 & 0 & 9/23/98 & 1030 & $\mathrm{n} / \mathrm{a}$ & 20.9 & 5.0 & .9 & 334 \\
\hline WO Be p1b & $\mathrm{mp} 2$ & 382442 & 0751839 & 3.0 & 3 & 9/23/98 & 0830 & $\mathrm{n} / \mathrm{a}$ & 19.6 & 4.8 & 1.2 & 278 \\
\hline WO Be p1c & $\mathrm{mp} 3$ & 382442 & 0751839 & 2.4 & 6.2 & 9/23/98 & 1130 & $\mathrm{n} / \mathrm{a}$ & 20.8 & 5.6 & 1.0 & 198 \\
\hline \multicolumn{13}{|c|}{ North Fork Green Run near Whitesville, Del. } \\
\hline \multirow[t]{4}{*}{ Stream } & 01484981 & 382704 & 0752241 & $\mathrm{n} / \mathrm{a}$ & $\mathrm{n} / \mathrm{a}$ & $9 / 21 / 98$ & 1030 & $\mathrm{n} / \mathrm{a}$ & 20.3 & 6.3 & 2.0 & 152 \\
\hline & & & & & & $3 / 25 / 99$ & 1600 & $\mathrm{n} / \mathrm{a}$ & 15.2 & 6.3 & 7.8 & 144 \\
\hline & & & & & & $9 / 29 / 99$ & 1230 & $\mathrm{n} / \mathrm{a}$ & 21.7 & 6.3 & 5.5 & 136 \\
\hline & & & & & & $3 / 14 / 00$ & 1000 & $\mathrm{n} / \mathrm{a}$ & 11.9 & 6.5 & 8.0 & 139 \\
\hline WI Bx p1a & $\mathrm{mp} 1$ & 382704 & 0752240 & 1.6 & 2.3 & $9 / 21 / 98$ & 0930 & $\mathrm{n} / \mathrm{a}$ & 20.9 & 5.8 & 1.4 & 120 \\
\hline WI Bx p1b & $\mathrm{mp} 2$ & 382704 & 0752240 & 1.6 & 3.8 & 9/21/98 & 1130 & $\mathrm{n} / \mathrm{a}$ & 22.0 & 5.8 & 1.1 & 129 \\
\hline WI Bx p1c & $\mathrm{mp} 3$ & 382704 & 0752240 & 1.6 & 5.3 & 9/21/98 & 1300 & $\mathrm{n} / \mathrm{a}$ & 22.4 & 6.1 & 1.2 & 161 \\
\hline WI Bx p1d & $\mathrm{mp} 4$ & 382704 & 0752240 & 1.9 & 6.8 & 9/21/98 & 1500 & $\mathrm{n} / \mathrm{a}$ & 22.0 & 6.1 & 1.1 & 157 \\
\hline WI Bx p1e & $\mathrm{mp} 5$ & 382704 & 0752240 & 2.1 & 8.3 & 9/21/98 & 1600 & $\mathrm{n} / \mathrm{a}$ & 23.4 & 6.0 & 1.1 & 152 \\
\hline WI Bx p1f & mp 6 & 382704 & 0752240 & 2.3 & 9.8 & 9/22/98 & 0900 & $\mathrm{n} / \mathrm{a}$ & 21.3 & 6.0 & 1.2 & 128 \\
\hline WI Bx p1g & $\mathrm{mp} 7$ & 382704 & 0752240 & 1.9 & 11.3 & 9/22/98 & 1100 & $\mathrm{n} / \mathrm{a}$ & 21.7 & 6.1 & .9 & 135 \\
\hline WI Bx p1h & $\mathrm{mp} 8$ & 382704 & 0752240 & 1.8 & 12.8 & 9/22/98 & 1200 & $\mathrm{n} / \mathrm{a}$ & 21.9 & 6.1 & .9 & 137 \\
\hline WI Bx p1i & mp 9 & 382704 & 0752240 & 1.6 & 14.3 & 9/22/98 & 1300 & $\mathrm{n} / \mathrm{a}$ & 22.4 & 6.0 & 1.1 & 129 \\
\hline
\end{tabular}


Appendix A. Site information and field measurements of stream and ground water collected in the Chesapeake Bay Watershed, June 1998 through May 2000Continued

${ }^{\circ}$, degrees; ', minutes; ", seconds; BLS, below land surface; ft, feet; LEW, left edge of water; ${ }^{\circ} \mathrm{C}$, degrees Celsius; DO, dissolved oxygen; mg/L, milligrams per liter; $\mu \mathrm{S} / \mathrm{cm}$, microsiemens per centimeter at $25^{\circ} \mathrm{C}$; mp, minipiezometer; $\mathrm{n} / \mathrm{a}$, not applicable; --, missing data]

\begin{tabular}{|c|c|c|c|c|c|c|c|c|c|c|c|c|}
\hline Site name & Local ID & $\begin{array}{c}\text { Latitude } \\
\left({ }^{\circ},{ }^{\prime},{ }^{\prime}\right)\end{array}$ & $\begin{array}{c}\text { Longitude } \\
\left({ }^{\circ},{ }^{\prime},{ }^{\prime}\right)\end{array}$ & $\begin{array}{c}\text { Depth of } \\
\text { bottom of } \\
\text { screen BLS } \\
\quad \text { (ft) }\end{array}$ & $\begin{array}{c}\text { Distance } \\
\text { from LEW } \\
(\mathbf{f t})\end{array}$ & Date & Time & $\begin{array}{c}\text { Water level } \\
\text { elevation } \\
\text { (feet) }\end{array}$ & $\begin{array}{c}\text { Tempera- } \\
\text { ture } \\
\left({ }^{\circ} \mathrm{C}\right) \\
(\mathbf{0 0 0 1 0})\end{array}$ & $\begin{array}{c}\text { pH } \\
(00400)\end{array}$ & $\begin{array}{c}\text { DO } \\
(\mathrm{mg} / \mathrm{L}) \\
(00300)\end{array}$ & $\begin{array}{c}\text { Specific } \\
\text { conductance } \\
(\mu \mathrm{S} / \mathrm{cm}) \\
(\mathbf{0 0 0 9 5})\end{array}$ \\
\hline \multicolumn{13}{|c|}{ North Fork Green Run near Whitesville, Del.-Continued } \\
\hline WI Bx p1j & $\mathrm{mp} 10$ & 382704 & 0752240 & 1.6 & 15.8 & $9 / 22 / 98$ & 1430 & $\mathrm{n} / \mathrm{a}$ & 22.8 & 5.9 & 0.9 & 149 \\
\hline \multirow[t]{3}{*}{ WI Bx p2a } & NFGR Well \#1 & 382704 & 0752241 & 6.5 & $\mathrm{n} / \mathrm{a}$ & $3 / 25 / 99$ & 0900 & 3.2 & 17.4 & 5.7 & .2 & 139 \\
\hline & & & & & & $9 / 22 / 99$ & 1500 & 3.5 & 21.4 & 5.6 & .1 & 111 \\
\hline & & & & & & $3 / 14 / 00$ & 0900 & 2.9 & 11.6 & 5.7 & .60 & 96 \\
\hline \multirow[t]{2}{*}{ WI Bx p2b } & NFGR Well \#2 & 382704 & 0752241 & 6.0 & $\mathrm{n} / \mathrm{a}$ & $3 / 25 / 99$ & 1100 & 3.0 & -- & -- & -- & -- \\
\hline & & & & & & $9 / 29 / 99$ & 1100 & 2.9 & 20.7 & 7.4 & 4.5 & 163 \\
\hline \multirow[t]{3}{*}{ WI Bx p2c } & NFGR Well \#3 & 382704 & 0752241 & 4.0 & $\mathrm{n} / \mathrm{a}$ & $3 / 25 / 99$ & 1200 & 2.9 & 12.5 & 6.6 & .1 & 199 \\
\hline & & & & & & 9/29/99 & 1300 & 2.8 & 24.7 & 6.4 & .1 & 151 \\
\hline & & & & & & $3 / 14 / 00$ & 1100 & 2.7 & 12.0 & 6.2 & .0 & 163 \\
\hline \multirow[t]{3}{*}{ WI Bx p2d } & NFGR Well \#4 & 382704 & 0752241 & 6.0 & $\mathrm{n} / \mathrm{a}$ & $3 / 25 / 99$ & 1330 & 3.0 & 14.4 & 6.0 & .1 & 81 \\
\hline & & & & & & $9 / 29 / 99$ & 1500 & 6.3 & 25.2 & 6.0 & .1 & 84 \\
\hline & & & & & & $3 / 14 / 00$ & 1200 & 2.3 & 12.6 & 6.1 & 1.0 & 77 \\
\hline WI Bx p2e & mp 1 & 382704 & 0752241 & 1.8 & 12.0 & $3 / 29 / 99$ & 1400 & $\mathrm{n} / \mathrm{a}$ & 20.3 & 6.3 & .5 & 198 \\
\hline WI Bx p2f & $\mathrm{mp} 2$ & 382704 & 0752241 & 2.0 & 16.0 & $3 / 29 / 99$ & 1200 & $\mathrm{n} / \mathrm{a}$ & 20.4 & 6.5 & .8 & 239 \\
\hline WI Bx p2g & $\mathrm{mp} 3$ & 382704 & 0752241 & 2.0 & 21 & $3 / 25 / 99$ & 1500 & $\mathrm{n} / \mathrm{a}$ & 13.8 & 6.9 & .2 & 230 \\
\hline WI Bx p2h & $\mathrm{mp} 4$ & 382704 & 0752241 & 2.4 & 25.0 & $3 / 26 / 99$ & 1000 & $\mathrm{n} / \mathrm{a}$ & 13.7 & 6.5 & .2 & 188 \\
\hline WI Bx p2i & mp 5 & 382704 & 0752241 & 3.0 & 31.6 & $3 / 26 / 99$ & 0900 & $\mathrm{n} / \mathrm{a}$ & 11.6 & 6.0 & .1 & 161 \\
\hline \multicolumn{13}{|c|}{ Unnamed ditch to North Fork Green Run near Whitesville, Del. (Wayne Tull's Farm) } \\
\hline \multirow[t]{3}{*}{ Stream } & 0148498080 & 382745 & 0752343 & $\mathrm{n} / \mathrm{a}$ & $\mathrm{n} / \mathrm{a}$ & $3 / 23 / 99$ & 1030 & $\mathrm{n} / \mathrm{a}$ & 7.6 & 4.2 & 16.5 & 224 \\
\hline & & & & & & $9 / 24 / 99$ & 1000 & $\mathrm{n} / \mathrm{a}$ & 17.8 & 6.6 & .8 & 135 \\
\hline & & & & & & $3 / 13 / 00$ & 1200 & $\mathrm{n} / \mathrm{a}$ & 10.2 & 5.4 & 4.4 & 227 \\
\hline \multirow[t]{3}{*}{ WI By p1a } & WT Well \#1 & 382745 & 0752343 & 4.5 & $\mathrm{n} / \mathrm{a}$ & $3 / 23 / 99$ & 1230 & 1.2 & 10.3 & 3.3 & 6.6 & 257 \\
\hline & & & & & & 9/23/99 & 1000 & .4 & 16.3 & 4.6 & 4.9 & 147 \\
\hline & & & & & & $3 / 13 / 00$ & 1400 & .6 & 13.5 & 4.6 & 2.5 & 185 \\
\hline \multirow[t]{3}{*}{ WI By p1b } & WT Well \#2 & 382745 & 0752343 & 4.0 & $\mathrm{n} / \mathrm{a}$ & $3 / 23 / 99$ & 1400 & .9 & 9.8 & 2.9 & 5.7 & 532 \\
\hline & & & & & & 9/23/99 & 1300 & .5 & 25.9 & 4.9 & 3.0 & 193 \\
\hline & & & & & & $3 / 13 / 00$ & 1600 & .6 & 11.1 & 4.0 & 2.4 & 646 \\
\hline
\end{tabular}


Appendix A. Site information and field measurements of stream and ground water collected in the Chesapeake Bay Watershed, June 1998 through May $2000-$ Continued

${ }^{\circ}$, degrees;', minutes;", seconds; BLS, below land surface; ft, feet; LEW, left edge of water; ${ }^{\circ} \mathrm{C}$, degrees Celsius; DO, dissolved oxygen; mg/L, milligrams per liter; $\mu \mathrm{S} / \mathrm{cm}$, microsiemens per centimeter at $25^{\circ} \mathrm{C} ; \mathrm{mp}$, minipiezometer; $\mathrm{n} / \mathrm{a}$, not applicable; --, missing data]

\begin{tabular}{|c|c|c|c|c|c|c|c|c|c|c|c|c|}
\hline Site name & Local ID & $\begin{array}{c}\text { Latitude } \\
\left({ }^{\circ},,^{\prime},\right)\end{array}$ & $\begin{array}{c}\text { Longitude } \\
\left({ }^{\circ},{ }^{\prime},{ }^{\prime}\right)\end{array}$ & $\begin{array}{c}\text { Depth of } \\
\text { bottom of } \\
\text { screen BLS } \\
\text { (ft) }\end{array}$ & $\begin{array}{c}\text { Distance } \\
\text { from LEW } \\
\text { (ft) }\end{array}$ & Date & Time & $\begin{array}{l}\text { Water level } \\
\text { elevation } \\
\text { (feet) }\end{array}$ & $\begin{array}{c}\text { Tempera- } \\
\text { ture } \\
\left({ }^{\circ} \mathbf{C}\right) \\
(00010)\end{array}$ & $\begin{array}{c}\text { pH } \\
(00400)\end{array}$ & $\begin{array}{c}\text { DO } \\
(\mathrm{mg} / \mathrm{L}) \\
(\mathbf{0 0 3 0 0})\end{array}$ & $\begin{array}{c}\text { Specific } \\
\text { conductance } \\
(\mu \mathrm{S} / \mathrm{cm}) \\
(\mathbf{0 0 0 9 5})\end{array}$ \\
\hline \multicolumn{13}{|c|}{ Unnamed ditch to North Fork Green Run near Whitesville, Del. (Wayne Tull's Farm) } \\
\hline \multirow[t]{2}{*}{ WI By p1c } & WT Well \#3 & 382745 & 0752343 & 6.0 & $\mathrm{n} / \mathrm{a}$ & $3 / 23 / 99$ & 1000 & 2.0 & 7.8 & 3.4 & 0.3 & 118 \\
\hline & & & & & & 9/23/99 & 1600 & .4 & 20.6 & 4.8 & 1.5 & 107 \\
\hline \multirow[t]{3}{*}{ WI By p1d } & WT Well \#4 & 382745 & 0752343 & 4.0 & $\mathrm{n} / \mathrm{a}$ & $3 / 23 / 99$ & 1200 & 2.0 & 10.5 & 4.4 & .4 & 121 \\
\hline & & & & & & 9/24/99 & 0900 & .1 & 16.3 & 4.8 & .5 & 117 \\
\hline & & & & & & $3 / 13 / 00$ & 1300 & .4 & 11.8 & 4.4 & .2 & 120 \\
\hline WI By p1e & mp 1 & 382745 & 0752343 & 1.3 & 1.2 & 3/24/99 & 1300 & $\mathrm{n} / \mathrm{a}$ & 20.0 & 4.9 & .5 & 128 \\
\hline WI By p1f & $\mathrm{mp} 2$ & 382745 & 0752343 & 2.25 & 2.6 & 3/24/99 & 1030 & $\mathrm{n} / \mathrm{a}$ & 16.2 & 5.0 & .4 & 115 \\
\hline WI By p1g & $\mathrm{mp} 3$ & 382745 & 0752343 & 1.25 & 4.5 & $3 / 24 / 99$ & 1430 & $\mathrm{n} / \mathrm{a}$ & 17.1 & 4.8 & 2.7 & 141 \\
\hline \multicolumn{13}{|c|}{ Green Run near Careytown, Md. (Green Run at Bethel Road) } \\
\hline \multirow[t]{2}{*}{ Stream } & 01484985 & 382611 & 0752106 & $\mathrm{n} / \mathrm{a}$ & $\mathrm{n} / \mathrm{a}$ & 9/30/99 & 1200 & $\mathrm{n} / \mathrm{a}$ & 20.9 & 6.3 & 3.4 & 150 \\
\hline & & & & & & $3 / 14 / 00$ & 1400 & $\mathrm{n} / \mathrm{a}$ & 16.8 & 6.2 & 9.7 & 138 \\
\hline \multirow[t]{2}{*}{ WI Bz p1a } & GR Well \#1 & 382611 & 0752106 & 8 & $\mathrm{n} / \mathrm{a}$ & 3/30/99 & 0830 & -- & 17.0 & 6.0 & -- & 361 \\
\hline & & & & & & $9 / 21 / 99$ & 1200 & -- & 23.5 & 6.3 & 1.1 & 506 \\
\hline WI Bz p1b & GR Well \#2 & 382611 & 0752106 & 6 & $\mathrm{n} / \mathrm{a}$ & 3/30/99 & 0900 & -- & 12.5 & 5.6 & .2 & 132 \\
\hline WI Bz p1c & GR Well \#3 & 382611 & 0752106 & 4 & $\mathrm{n} / \mathrm{a}$ & 3/30/99 & 1000 & -- & 18.2 & 6.0 & .8 & 157 \\
\hline \multirow[t]{3}{*}{ WI Bz p1d } & GR Well \#4 & 382611 & 0752106 & 10 & $\mathrm{n} / \mathrm{a}$ & 3/29/99 & 1500 & 2.8 & 14.9 & 5.6 & .3 & 336 \\
\hline & & & & & & $9 / 22 / 99$ & 1300 & 5.1 & 20.1 & 5.8 & .1 & 301 \\
\hline & & & & & & $3 / 14 / 00$ & 1500 & 2.0 & 13.0 & 5.8 & .4 & 292 \\
\hline WI Bz ple & $\mathrm{mp} 1$ & 382611 & 0752106 & 2.85 & 1 & $3 / 31 / 99$ & 0800 & $\mathrm{n} / \mathrm{a}$ & 14.9 & 5.8 & .4 & 899 \\
\hline WI Bz p1f & $\mathrm{mp} 2$ & 382611 & 0752106 & 2 & 4 & 3/30/99 & 1500 & $\mathrm{n} / \mathrm{a}$ & 16.5 & 5.8 & .2 & 417 \\
\hline WI Bz p1g & mp 3 & 382611 & 0752106 & 2.25 & 8.5 & 3/30/99 & 1400 & $\mathrm{n} / \mathrm{a}$ & 17.1 & 6.3 & .3 & 127 \\
\hline WI Bz p1h & mp 4 & 382611 & 0752106 & 2 & 11 & 3/30/99 & 1200 & $\mathrm{n} / \mathrm{a}$ & 17.7 & 5.9 & .2 & 160 \\
\hline WI Bz p1i & mp 5 & 382611 & 0752106 & 2.5 & 14 & 3/31/99 & 1000 & $\mathrm{n} / \mathrm{a}$ & 18.1 & 6.5 & .5 & 163 \\
\hline WI Bz p1j & mp 6 & 382611 & 0752106 & 4.5 & 18 & $3 / 31 / 99$ & 1100 & $\mathrm{n} / \mathrm{a}$ & 19.7 & 6.6 & .5 & 161 \\
\hline WI Bz p1k & $\mathrm{mp} 7$ & 382611 & 0752106 & 4.5 & 22 & 3/31/99 & 1200 & $\mathrm{n} / \mathrm{a}$ & 19.9 & 6.3 & .5 & 174 \\
\hline
\end{tabular}


Appendix A. Site information and field measurements of stream and ground water collected in the Chesapeake Bay Watershed, June 1998 through May $2000-$ Continued

${ }^{\circ}$, degrees;', minutes;", seconds; BLS, below land surface; ft, feet; LEW, left edge of water; ${ }^{\circ} \mathrm{C}$, degrees Celsius; DO, dissolved oxygen; mg/L, milligrams per liter; $\mu \mathrm{S} / \mathrm{cm}$, microsiemens per centimeter at $25^{\circ} \mathrm{C} ; \mathrm{mp}$, minipiezometer; $\mathrm{n} / \mathrm{a}$, not applicable; --, missing data]

\begin{tabular}{|c|c|c|c|c|c|c|c|c|c|c|c|c|}
\hline Site name & Local ID & $\begin{array}{c}\text { Latitude } \\
\left({ }^{\circ},,^{\prime},\right)\end{array}$ & $\begin{array}{c}\text { Longitude } \\
\left({ }^{\circ},,^{\prime},\right)\end{array}$ & $\begin{array}{c}\text { Depth of } \\
\text { bottom of } \\
\text { screen BLS } \\
\quad \text { (ft) }\end{array}$ & $\begin{array}{l}\text { Distance } \\
\text { from } L E W \\
\quad(f t)\end{array}$ & Date & Time & $\begin{array}{l}\text { Water level } \\
\text { elevation } \\
\text { (feet) }\end{array}$ & $\begin{array}{c}\text { Tempera- } \\
\text { ture } \\
\left({ }^{\circ} \mathrm{C}\right) \\
(\mathbf{0 0 0 1 0})\end{array}$ & $\begin{array}{c}\text { pH } \\
(00400)\end{array}$ & $\begin{array}{c}\text { DO } \\
(\mathbf{m g} / \mathrm{L}) \\
(\mathbf{0 0 3 0 0})\end{array}$ & $\begin{array}{c}\text { Specific } \\
\text { conductance } \\
(\mu \mathrm{S} / \mathrm{cm}) \\
(\mathbf{0 0 0 9 5})\end{array}$ \\
\hline \multicolumn{13}{|c|}{ Additional wells in Upper Pocomoke River Basin } \\
\hline WI Bh 8 & & 382609 & 0752105 & 11 & $\mathrm{n} / \mathrm{a}$ & 9/23/98 & 1600 & 28.4 & 17.9 & 5.8 & -- & 269 \\
\hline WI Bh 8 & & & & & & 3/31/99 & 1300 & 30.4 & 16.2 & 6.0 & 0.1 & 267 \\
\hline WI Bh 9 & & 382609 & 0752105 & 38 & $\mathrm{n} / \mathrm{a}$ & 9/23/98 & 1400 & 30.4 & 14.4 & 6.0 & 1.1 & 159 \\
\hline WI Bh 9 & & & & & & $3 / 31 / 99$ & 1400 & 32.8 & 14.9 & 6.4 & .1 & 158 \\
\hline WI Ch 56 & & 382452 & 0750290 & 15 & $\mathrm{n} / \mathrm{a}$ & $9 / 24 / 98$ & 1000 & 29.7 & 15.6 & 5.6 & 1.0 & 161 \\
\hline WI Ch 57 & & 382452 & 0750290 & 47 & $\mathrm{n} / \mathrm{a}$ & $9 / 24 / 98$ & 0900 & 30.1 & 14.0 & 5.7 & .9 & 210 \\
\hline \multicolumn{13}{|c|}{ Springs in Muddy Creek watershed (Owner's name is Local ID) } \\
\hline \multirow[t]{3}{*}{ 39SS-001 } & Goode & 383216 & 0785728 & $\mathrm{n} / \mathrm{a}$ & $\mathrm{n} / \mathrm{a}$ & $11 / 09 / 98$ & 1000 & $\mathrm{n} / \mathrm{a}$ & 11.7 & 7.3 & 4.2 & 341 \\
\hline & & & & & & 4/14/99 & 1030 & $\mathrm{n} / \mathrm{a}$ & 11.1 & 7.0 & 6.4 & 290 \\
\hline & & & & & & 4/17/00 & 1500 & $\mathrm{n} / \mathrm{a}$ & 11.5 & 7.2 & 6.5 & 260 \\
\hline \multirow[t]{2}{*}{ 39SS-002 } & Thompson & 383234 & 0785532 & $\mathrm{n} / \mathrm{a}$ & $\mathrm{n} / \mathrm{a}$ & $11 / 09 / 98$ & 1330 & $\mathrm{n} / \mathrm{a}$ & 12.9 & 7.3 & 6.9 & 394 \\
\hline & & & & & & 4/14/99 & 1300 & $\mathrm{n} / \mathrm{a}$ & 11.2 & 7.2 & 7.8 & 455 \\
\hline \multirow[t]{2}{*}{$39 \mathrm{SS}-003$} & Dove & 383136 & 0785634 & $\mathrm{n} / \mathrm{a}$ & $\mathrm{n} / \mathrm{a}$ & $11 / 09 / 98$ & 1400 & $\mathrm{n} / \mathrm{a}$ & 12.7 & 7.2 & 6.6 & 379 \\
\hline & & & & & & 4/14/99 & 1400 & $\mathrm{n} / \mathrm{a}$ & 11.5 & 7.5 & 7.0 & 388 \\
\hline 39SS-005 & Heatwole & 383149 & 0785704 & $\mathrm{n} / \mathrm{a}$ & & 4/14/99 & 1130 & $\mathrm{n} / \mathrm{a}$ & 11.8 & 6.9 & 4.5 & 413 \\
\hline \multirow[t]{2}{*}{ 39RS-001 } & Heatwole & 382948 & 0785753 & $\mathrm{n} / \mathrm{a}$ & $\mathrm{n} / \mathrm{a}$ & $11 / 10 / 98$ & 0830 & $\mathrm{n} / \mathrm{a}$ & 12.2 & 7.0 & 7.2 & 408 \\
\hline & & & & & & 4/14/99 & 1500 & $\mathrm{n} / \mathrm{a}$ & 11.5 & 7.0 & 6.8 & 415 \\
\hline \multicolumn{13}{|c|}{ Muddy Creek near Mt. Clinton, Va. } \\
\hline \multirow[t]{2}{*}{ stream } & 01621050 & 382912 & 0785738 & $\mathrm{n} / \mathrm{a}$ & $\mathrm{n} / \mathrm{a}$ & $5 / 26 / 99$ & 1130 & $\mathrm{n} / \mathrm{a}$ & 19.5 & 8.3 & 10.3 & 424 \\
\hline & & & & & & $4 / 17 / 00$ & 1600 & $\mathrm{n} / \mathrm{a}$ & 16.2 & 7.9 & 9.0 & 399 \\
\hline
\end{tabular}


Appendix A. Site information and field measurements of stream and ground water collected in the Chesapeake Bay Watershed, June 1998 through May $2000-$ Continued

[ ${ }^{\circ}$, degrees; ', minutes;", seconds; BLS, below land surface; ft, feet; LEW, left edge of water; ${ }^{\circ} \mathrm{C}$, degrees Celsius; DO, dissolved oxygen; mg/L, milligrams per liter; $\mu \mathrm{S} / \mathrm{cm}$, microsiemens per centimeter at $25^{\circ} \mathrm{C} ; \mathrm{mp}$, minipiezometer; $\mathrm{n} / \mathrm{a}$, not applicable; --, missing data]

\begin{tabular}{|c|c|c|c|c|c|c|c|c|c|c|c|c|}
\hline Site name & Local ID & $\begin{array}{c}\text { Latitude } \\
\left({ }^{\circ},,^{\prime},\right)\end{array}$ & $\begin{array}{c}\text { Longitude } \\
\left({ }^{\circ},,^{\prime},\right)\end{array}$ & $\begin{array}{c}\text { Depth of } \\
\text { bottom of } \\
\text { screen BLS } \\
\quad \text { (ft) }\end{array}$ & $\begin{array}{c}\text { Distance } \\
\text { from LEW } \\
(\mathbf{f t})\end{array}$ & Date & Time & $\begin{array}{c}\text { Water level } \\
\text { elevation } \\
\text { (feet) }\end{array}$ & $\begin{array}{c}\text { Tempera- } \\
\text { ture } \\
\left({ }^{\circ} \mathbf{C}\right) \\
(\mathbf{0 0 0 1 0})\end{array}$ & $\begin{array}{c}\text { pH } \\
(00400)\end{array}$ & $\begin{array}{c}\text { DO } \\
(\mathrm{mg} / \mathrm{L}) \\
(00300)\end{array}$ & $\begin{array}{c}\text { Specific } \\
\text { conductance } \\
(\mu \mathrm{S} / \mathrm{cm}) \\
(\mathbf{0 0 0 9 5})\end{array}$ \\
\hline \multicolumn{13}{|c|}{ Monitoring wells in Muddy Creek Watershed } \\
\hline \multirow[t]{2}{*}{$39 \mathrm{~S} 2$} & MC-4 & 383152 & 0785709 & 12 & & $4 / 13 / 99$ & 1200 & $1,511.2$ & 11.5 & 7.1 & 1.6 & 372 \\
\hline & & & & & & $4 / 18 / 00$ & 1100 & $1,512.2$ & 9.2 & 6.9 & 1.5 & 454 \\
\hline \multirow[t]{2}{*}{ 39S4 } & MC-8 & 383155 & 0785712 & 21 & & $4 / 13 / 99$ & 0900 & $1,516.8$ & 11.7 & 7.4 & 1.9 & 382 \\
\hline & & & & & & $4 / 18 / 00$ & 0900 & $1,517.8$ & 9.8 & 5.5 & 2.7 & 393 \\
\hline \multirow[t]{2}{*}{3959} & MC-17 & 383152 & 0785709 & 30 & & 4/13/99 & 1300 & $1,512.7$ & 13.1 & 7.6 & 3.6 & 397 \\
\hline & & & & & & $4 / 18 / 00$ & 1200 & $1,513.3$ & 10.9 & 6.8 & 2.1 & 411 \\
\hline \multirow[t]{2}{*}{$39 \mathrm{~S} 14$} & MC-28 & 383211 & 0785740 & 59 & & $4 / 12 / 99$ & 1300 & $1,600.8$ & 12.9 & 7.3 & 3.2 & 371 \\
\hline & & & & & & $4 / 17 / 00$ & 1000 & $1,599.9$ & 12.6 & 6.9 & 1.5 & 430 \\
\hline \multirow[t]{2}{*}{$39 \mathrm{~S} 15$} & MC-29 & 383211 & 0785740 & 95 & & $4 / 12 / 99$ & 1500 & $1,601.2$ & 11.9 & 7.3 & 4.6 & 327 \\
\hline & & & & & & $4 / 17 / 00$ & 1200 & $1,599.9$ & 12.2 & 7.2 & 4.3 & 328 \\
\hline \multirow[t]{2}{*}{$39 S 16$} & MC-30 & 383211 & 0785732 & 27 & & $4 / 12 / 99$ & 1100 & $1,570.4$ & 11.1 & 7.0 & 5.5 & 373 \\
\hline & & & & & & $4 / 17 / 00$ & 1400 & $1,574.5$ & 10.5 & 6.7 & 5.1 & 397 \\
\hline \multirow[t]{2}{*}{39 S19 } & MC-34 & 383155 & 0785712 & 49 & & 4/13/99 & 1100 & $1,516.9$ & 11.8 & 7.2 & 4.1 & 350 \\
\hline & & & & & & $4 / 18 / 00$ & 0800 & $1,518.1$ & 10.9 & 6.3 & 5.1 & 358 \\
\hline \multicolumn{13}{|c|}{ Domestic wells in Muddy Creek watershed (Owner's name is Local ID) } \\
\hline \multirow[t]{2}{*}{ 39S34 } & Harmon (1) & 383204 & 0785704 & 225 & & $4 / 13 / 99$ & 1500 & -- & 12.2 & 7.3 & 1.9 & 453 \\
\hline & & & & & & $4 / 14 / 99$ & 0900 & -- & 13.3 & 7.2 & 1.8 & 484 \\
\hline 39S35 & Harmon (2) & 383226 & 0785715 & 35 & & $4 / 13 / 99$ & 1600 & -- & 11.4 & 6.9 & 5.6 & 296 \\
\hline $39 S 39$ & Fairview Church & 383032 & 0785630 & 280 & & $4 / 15 / 99$ & 1500 & -- & 12.4 & 7.2 & 6.8 & 400 \\
\hline $39 S 40$ & Dove & 383137 & 0785648 & 375 & & $4 / 15 / 99$ & 1000 & -- & 13.1 & 7.3 & 2.0 & 442 \\
\hline $39 S 41$ & Weintraub (1) & 383055 & 0785702 & 30 & & $4 / 15 / 99$ & 1200 & -- & 12.7 & 6.8 & 2.4 & 786 \\
\hline $39 S 42$ & Weintraub (2) & 383055 & 0785702 & 125 & & $4 / 15 / 99$ & 1300 & -- & 12.4 & 7.3 & 3.1 & 741 \\
\hline $39 S 43$ & Martin & 383119 & 0785648 & 300 & & $4 / 16 / 99$ & 0900 & -- & 13.5 & 7.3 & .1 & 478 \\
\hline $39 S 44$ & Smith & 382941 & 0785701 & 62 & & $4 / 16 / 99$ & 1100 & -- & 13.2 & 7.1 & 5.8 & 742 \\
\hline
\end{tabular}


Appendix A. Site information and field measurements of stream and ground water collected in the Chesapeake Bay Watershed, June 1998 through May 2000Continued

${ }^{\circ}$, degrees; ', minutes; ", seconds; BLS, below land surface; ft, feet; LEW, left edge of water; ${ }^{\circ} \mathrm{C}$, degrees Celsius; DO, dissolved oxygen; mg/L, milligrams per liter; $\mu \mathrm{S} / \mathrm{cm}$, microsiemens per centimeter at $25^{\circ} \mathrm{C}$; mp, minipiezometer; n/a, not applicable; --, missing data]

\begin{tabular}{|c|c|c|c|c|c|c|c|c|c|c|c|c|}
\hline Site name & Local ID & $\begin{array}{c}\text { Latitude } \\
\left({ }^{\circ},,^{\prime},\right)\end{array}$ & $\begin{array}{c}\text { Longitude } \\
\left({ }^{\circ},,^{\prime},\right)\end{array}$ & $\begin{array}{c}\text { Depth of } \\
\text { bottom of } \\
\text { screen BLS } \\
\quad \text { (ft) }\end{array}$ & $\begin{array}{c}\text { Distance } \\
\text { from LEW } \\
\text { (ft) }\end{array}$ & Date & Time & $\begin{array}{c}\text { Water level } \\
\text { elevation } \\
\text { (feet) }\end{array}$ & $\begin{array}{c}\text { Tempera- } \\
\text { ture } \\
\left({ }^{\circ} \mathbf{C}\right) \\
(\mathbf{0 0 0 1 0})\end{array}$ & $\begin{array}{c}\text { pH } \\
(00400)\end{array}$ & $\begin{array}{c}\text { DO } \\
(\mathrm{mg} / \mathrm{L}) \\
(\mathbf{0 0 3 0 0})\end{array}$ & $\begin{array}{c}\text { Specific } \\
\text { conductance } \\
(\mu \mathrm{S} / \mathrm{cm}) \\
(\mathbf{0 0 0 9 5})\end{array}$ \\
\hline \multicolumn{13}{|c|}{ Polecat Creek, Virginia } \\
\hline $50 \mathrm{M} 2$ & & 385814 & 0773214 & 39.94 & & $4 / 19 / 99$ & 1000 & 237.0 & 16.2 & 5.6 & 5.0 & 58 \\
\hline $50 \mathrm{M} 3$ & & 385814 & 0773214 & 25.14 & & $4 / 19 / 99$ & 1100 & 239.5 & 15.9 & 4.7 & 8.6 & 39 \\
\hline $50 \mathrm{M} 4$ & & 385812 & 0773218 & 15.49 & & $4 / 19 / 99$ & 1800 & 227.2 & 12.7 & 4.8 & 6.9 & 50 \\
\hline 50M5 & & 385809 & 0773220 & 8.62 & & $4 / 20 / 99$ & 1500 & 206.4 & 12.9 & 4.8 & .5 & 35 \\
\hline $50 \mathrm{M} 6$ & & 385809 & 0773220 & 4.84 & & $4 / 21 / 99$ & 0800 & 207.2 & 10.3 & 4.0 & .3 & 33 \\
\hline $50 \mathrm{M} 7$ & & 385806 & 0773225 & 46.28 & & $4 / 21 / 99$ & 1500 & 213.8 & 14.5 & 6.3 & 1.6 & 83 \\
\hline $50 \mathrm{M} 16$ & & 385814 & 0773214 & 16.2 & & $4 / 19 / 99$ & 1200 & 242.2 & 17.7 & 4.9 & 8.7 & 56 \\
\hline $50 \mathrm{M} 17$ & & 385814 & 0773214 & 1.5 & & $4 / 19 / 99$ & 1500 & 242.3 & 14.6 & 4.7 & 8.9 & 55 \\
\hline $50 \mathrm{M} 18$ & & 385812 & 0773218 & 14.7 & & 4/20/99 & 0800 & 227.2 & 15.0 & 4.7 & 6.2 & 39 \\
\hline $50 \mathrm{M} 19$ & & 385812 & 0773218 & 11.5 & & 4/19/99 & 1700 & 227.6 & 15.4 & 4.9 & 6.7 & 50 \\
\hline $50 \mathrm{M} 21$ & & 385810 & 0773219 & 1.1 & & 4/20/99 & 1100 & 213.8 & 12.2 & 4.7 & 2.9 & 34 \\
\hline $50 \mathrm{M} 22$ & & 385810 & 0773219 & 7.6 & & 4/20/99 & 1300 & 214.3 & 19.0 & 4.7 & 4.0 & 31 \\
\hline $50 \mathrm{M} 23$ & & 385809 & 0773220 & 7.7 & & $4 / 21 / 99$ & 0900 & 206.7 & 10.5 & -- & .7 & 29 \\
\hline $50 \mathrm{M} 24$ & & 385808 & 0773218 & 4.3 & & $4 / 21 / 99$ & 1000 & 207.7 & 11.1 & 4.3 & .4 & 31 \\
\hline $50 \mathrm{M} 25$ & & 385808 & 0773220 & 3.6 & & $4 / 21 / 99$ & 1200 & 209.5 & 11.3 & 5.0 & 4.8 & 66 \\
\hline $50 \mathrm{M} 26$ & & 385807 & 0773221 & 9.1 & & $4 / 21 / 99$ & 1400 & 211.9 & 10.9 & 4.6 & 5.2 & 79 \\
\hline $50 \mathrm{M} 28$ & & 385808 & 0773218 & 3.9 & & $4 / 21 / 99$ & 0930 & 206.7 & -- & -- & -- & -- \\
\hline $50 \mathrm{M} 27$ & & 375808 & 0773220 & 24.6 & & $3 / 29 / 00$ & 1415 & 217.1 & 14.1 & -- & 6.4 & 92 \\
\hline $50 \mathrm{M} 29$ & & 385808 & 0773219 & 7.4 & & $4 / 10 / 00$ & 1300 & 207.8 & 14.0 & 5.3 & .7 & 84 \\
\hline $50 \mathrm{M} 30$ & & 385808 & 0773219 & 3.4 & & $4 / 10 / 00$ & 1100 & 209.0 & 13.0 & 5.4 & .6 & 120 \\
\hline \multicolumn{13}{|c|}{ Unnamed tributary to Little Mahantango Creek near Hepler, Pa. } \\
\hline \multirow[t]{3}{*}{ Stream } & 01555370 & 404233 & 0763532 & $\mathrm{n} / \mathrm{a}$ & & $6 / 15 / 98$ & 1700 & $\mathrm{n} / \mathrm{a}$ & 16.5 & 7.2 & 7.4 & 73 \\
\hline & & & & & & $5 / 19 / 99$ & 1400 & $\mathrm{n} / \mathrm{a}$ & -- & -- & -- & -- \\
\hline & & & & & & $5 / 9 / 00$ & 1130 & $\mathrm{n} / \mathrm{a}$ & 21.0 & 7.2 & 9.4 & 116 \\
\hline \multicolumn{13}{|c|}{ Mahantango WE-38 Watershed, East Transect } \\
\hline NU 538 & E1-10 & 404235 & 0763530 & 10 & & $5 / 10 / 99$ & 1145 & -- & 10.7 & 6.7 & .3 & 232 \\
\hline NU 539 & E1-20 & 404235 & 0763530 & 20 & & $5 / 10 / 99$ & 1245 & 735.1 & 11.7 & 7.8 & .3 & 236 \\
\hline
\end{tabular}


Appendix A. Site information and field measurements of stream and ground water collected in the Chesapeake Bay Watershed, June 1998 through May $2000-$ Continued

[ ${ }^{\circ}$, degrees; ', minutes;", seconds; BLS, below land surface; ft, feet; LEW, left edge of water; ${ }^{\circ} \mathrm{C}$, degrees Celsius; DO, dissolved oxygen; mg/L, milligrams per liter; $\mu \mathrm{S} / \mathrm{cm}$, microsiemens per centimeter at $25^{\circ} \mathrm{C} ; \mathrm{mp}$, minipiezometer; $\mathrm{n} / \mathrm{a}$, not applicable; --, missing data]

\begin{tabular}{|c|c|c|c|c|c|c|c|c|c|c|c|c|}
\hline Site name & Local ID & $\begin{array}{c}\text { Latitude } \\
\left({ }^{\circ},{ }^{\prime}, "\right)\end{array}$ & $\begin{array}{c}\text { Longitude } \\
\quad\left({ }^{\circ},{ }^{\prime},{ }^{\prime}\right)\end{array}$ & $\begin{array}{c}\text { Depth of } \\
\text { bottom of } \\
\text { screen BLS } \\
\quad \text { (ft) }\end{array}$ & $\begin{array}{l}\text { Distance } \\
\text { from } L E W \\
\quad(f t)\end{array}$ & Date & Time & $\begin{array}{c}\text { Water level } \\
\text { elevation } \\
\text { (feet) }\end{array}$ & $\begin{array}{c}\text { Tempera- } \\
\text { ture } \\
\left({ }^{\circ} \mathrm{C}\right) \\
(\mathbf{0 0 0 1 0})\end{array}$ & $\begin{array}{c}\text { pH } \\
(00400)\end{array}$ & $\begin{array}{c}\text { DO } \\
(\mathrm{mg} / \mathrm{L}) \\
(\mathbf{0 0 3 0 0})\end{array}$ & $\begin{array}{c}\text { Specific } \\
\text { conductanc } \\
(\mu \mathrm{S} / \mathrm{cm}) \\
(\mathbf{0 0 0 9 5})\end{array}$ \\
\hline \multicolumn{13}{|c|}{ Mahantango WE-38 Watershed, East Transect-Continued } \\
\hline \multirow{2}{*}{ NU 540} & E2-10 & 404234 & 0763531 & 10 & & $5 / 10 / 99$ & 1345 & 729.6 & 11.8 & 8.3 & .1 & 216 \\
\hline & & & & & & $5 / 9 / 00$ & 1600 & 730.1 & 11.4 & 8.2 & .2 & 211 \\
\hline NU 541 & E2-35 & 404234 & 0763531 & 35 & & $5 / 10 / 99$ & 1500 & -- & 11.8 & 8.9 & .1 & 221 \\
\hline \multirow[t]{3}{*}{ NU 534} & E3-10 & 404233 & 0763532 & 10 & & $6 / 16 / 98$ & 1550 & 727.2 & 11.8 & 7.6 & .8 & 205 \\
\hline & & & & & & $5 / 11 / 99$ & 0900 & 727.0 & 9.8 & 8.6 & .0 & 206 \\
\hline & & & & & & $5 / 9 / 00$ & 1500 & 727.8 & 11.5 & 8.1 & .1 & 200 \\
\hline \multirow[t]{2}{*}{ NU 535} & E3-20 & 404233 & 0763532 & 20 & & $6 / 15 / 98$ & 1720 & 726.7 & 14.5 & 8.0 & .7 & 205 \\
\hline & & & & & & $5 / 11 / 99$ & 1100 & -- & 13.8 & 8.3 & .0 & 209 \\
\hline \multirow[t]{2}{*}{ NU 536} & E3-30 & 404233 & 0763532 & 30 & & $6 / 17 / 98$ & 1120 & 726.4 & 14.8 & 6.8 & .2 & 199 \\
\hline & & & & & & $5 / 11 / 99$ & 1200 & -- & 11.5 & 8.5 & .1 & 201 \\
\hline \multirow[t]{2}{*}{ NU 537} & E3-45 & 404233 & 0763532 & 45 & & $6 / 18 / 98$ & 0930 & 724.0 & 14.1 & 5.7 & 6.1 & 159 \\
\hline & & & & & & $5 / 10 / 99$ & 1600 & -- & 11.7 & 8.1 & 2.0 & 190 \\
\hline \multirow[t]{3}{*}{ NU 529} & E4-10 & 404233 & 0763532 & 10 & & $6 / 16 / 98$ & 1420 & 725.2 & 14.1 & 6.1 & 8.1 & 150 \\
\hline & & & & & & $5 / 11 / 99$ & 1300 & -- & 11.3 & 6.7 & 7.1 & 149 \\
\hline & & & & & & $5 / 9 / 00$ & 0930 & 726.4 & 12.4 & 6.1 & 6.7 & 151 \\
\hline \multirow[t]{3}{*}{ NU 530} & E4-20 & 404233 & 0763532 & 20 & & $6 / 17 / 98$ & 1020 & 724.2 & 14.1 & 5.0 & 7.4 & 153 \\
\hline & & & & & & $5 / 11 / 99$ & 1400 & -- & 11.5 & 6.8 & 6.5 & 150 \\
\hline & & & & & & $5 / 9 / 00$ & 1000 & 726.5 & 11.9 & 6.1 & 7.5 & 151 \\
\hline \multirow[t]{2}{*}{ NU 531} & E4-30 & 404233 & 0763532 & 30 & & $6 / 16 / 98$ & 1630 & 722.7 & 14.3 & 6.4 & 6.4 & 149 \\
\hline & & & & & & $5 / 11 / 99$ & 1445 & -- & 12.7 & 6.9 & 5.0 & 153 \\
\hline \multirow[t]{3}{*}{ NU 532} & E4-45 & 404233 & 0763532 & 45 & & $6 / 17 / 98$ & 1430 & 722.3 & 16.9 & 6.0 & 4.2 & 159 \\
\hline & & & & & & $5 / 11 / 99$ & 1530 & -- & 14.3 & 7.0 & 3.5 & 158 \\
\hline & & & & & & $5 / 9 / 00$ & 1100 & 725.3 & 12.9 & 6.8 & 3.9 & 158 \\
\hline \multirow[t]{3}{*}{ NU 533} & E4-60 & 404233 & 0763532 & 60 & & $6 / 18 / 98$ & 1015 & 720.3 & 19.3 & 6.1 & 4.3 & 149 \\
\hline & & & & & & $5 / 11 / 99$ & 1600 & -- & 13.8 & 7.2 & 3.2 & 150 \\
\hline & & & & & & $5 / 9 / 00$ & 1300 & 722.6 & 11.9 & 6.3 & 6.3 & 151 \\
\hline
\end{tabular}


Appendix A. Site information and field measurements of stream and ground water collected in the Chesapeake Bay Watershed, June 1998 through May $2000-$ Continued

[ ${ }^{\circ}$, degrees; ', minutes;", seconds; BLS, below land surface; ft, feet; LEW, left edge of water; ${ }^{\circ} \mathrm{C}$, degrees Celsius; DO, dissolved oxygen; mg/L, milligrams per liter; $\mu \mathrm{S} / \mathrm{cm}$, microsiemens per centimeter at $25^{\circ} \mathrm{C} ; \mathrm{mp}$, minipiezometer; $\mathrm{n} / \mathrm{a}$, not applicable; --, missing data]

\begin{tabular}{|c|c|c|c|c|c|c|c|c|c|c|c|c|}
\hline Site name & Local ID & $\begin{array}{c}\text { Latitude } \\
\left({ }^{\circ},{ }^{\prime},{ }^{\prime}\right)\end{array}$ & $\begin{array}{c}\text { Longitude } \\
\left({ }^{\circ},,^{\prime},\right)\end{array}$ & $\begin{array}{c}\text { Depth of } \\
\text { bottom of } \\
\text { screen BLS } \\
\quad \text { (ft) }\end{array}$ & $\begin{array}{c}\text { Distance } \\
\text { from LEW } \\
(\mathbf{f t})\end{array}$ & Date & Time & $\begin{array}{c}\text { Water level } \\
\text { elevation } \\
\text { (feet) }\end{array}$ & $\begin{array}{c}\text { Tempera- } \\
\text { ture } \\
\left({ }^{\circ} \mathbf{C}\right) \\
(\mathbf{0 0 0 1 0})\end{array}$ & $\begin{array}{c}\text { pH } \\
(00400)\end{array}$ & $\begin{array}{c}\text { DO } \\
(\mathrm{mg} / \mathrm{L}) \\
(00300)\end{array}$ & $\begin{array}{c}\text { Specific } \\
\text { conductance } \\
(\mu \mathrm{S} / \mathrm{cm}) \\
(\mathbf{0 0 0 9 5})\end{array}$ \\
\hline \multicolumn{13}{|c|}{ Mahantango WE-38 Watershed, East Transect-Continued } \\
\hline \multirow[t]{3}{*}{ NU 526} & E5-10 & 404233 & 0763532 & 10 & & $6 / 16 / 98$ & 1130 & 724.5 & 16.7 & 5.8 & 5.2 & 157 \\
\hline & & & & & & $5 / 12 / 99$ & 1100 & -- & 12.7 & 6.1 & 6.4 & 155 \\
\hline & & & & & & $5 / 9 / 00$ & 1300 & 725.2 & 12.9 & 5.8 & 6.2 & 162 \\
\hline NU 527 & E5-45 & 404233 & 0763532 & 45 & & $6 / 17 / 98$ & 1300 & 725.4 & 14.1 & 5.4 & 9.3 & 167 \\
\hline \multirow[t]{2}{*}{ NU 528} & E5-60 & 404233 & 0763532 & 60 & & $6 / 17 / 98$ & 1700 & 726.6 & 14.4 & 6.3 & 6.0 & 165 \\
\hline & & & & & & $5 / 12 / 99$ & 1000 & -- & 12.6 & 7.2 & 3.5 & 161 \\
\hline \multirow[t]{2}{*}{ NU 542} & E6-35 & 404232 & 0763533 & 35 & & $5 / 12 / 99$ & 1200 & 729.5 & 13.0 & 6.3 & 8.3 & 160 \\
\hline & & & & & & $5 / 9 / 00$ & 1400 & 727.2 & 11.9 & 5.9 & 9.4 & 169 \\
\hline NU 543 & E7-10 & 404232 & 0763533 & 10 & & $5 / 12 / 99$ & 1330 & 734.2 & 12.0 & 5.6 & 8.5 & 155 \\
\hline \multicolumn{13}{|c|}{ Mahantango WE-38 Watershed, West Transect } \\
\hline NU 544 & W1-20 & 404235 & 0763542 & 20 & & $5 / 14 / 99$ & 1030 & 759.1 & 13.1 & 6.8 & 3.6 & 90 \\
\hline \multirow[t]{2}{*}{ NU 545} & W2-20 & 404235 & 0763542 & 20 & & $5 / 14 / 99$ & 0930 & 747.3 & 10.7 & 6.8 & 1.3 & 100 \\
\hline & & & & & & $5 / 10 / 00$ & 0900 & 749.1 & 11.5 & 6.4 & 1.3 & 92 \\
\hline \multirow[t]{2}{*}{ NU 546} & W2-30 & 404235 & 0763542 & 30 & & $5 / 14 / 99$ & 0900 & 748.9 & 12.3 & 6.8 & 1.8 & 109 \\
\hline & & & & & & $5 / 10 / 00$ & 1100 & 749.1 & 13.2 & 6.5 & .3 & 111 \\
\hline \multirow[t]{2}{*}{ NU 547} & W2-40 & 404235 & 0763542 & 40 & & $5 / 14 / 99$ & 0800 & 749.9 & 11.9 & 6.7 & 1.1 & 97 \\
\hline & & & & & & $5 / 10 / 00$ & 1200 & 750.5 & 14.4 & 7.0 & .5 & 181 \\
\hline NU 548 & W3-10 & 404234 & 0763542 & 10 & & $5 / 12 / 99$ & 1500 & 748.7 & 14.5 & 6.0 & 3.5 & 151 \\
\hline NU 549 & W3-20 & 404234 & 0763542 & 20 & & $5 / 12 / 99$ & 1600 & 748.3 & 12.0 & 6.4 & 3.7 & 107 \\
\hline NU 550 & W3-30 & 404234 & 0763542 & 30 & & $5 / 12 / 99$ & 1630 & 748.2 & 12.8 & 6.1 & 3.0 & 117 \\
\hline NU 551 & W3-45 & 404234 & 0763542 & 45 & & $5 / 13 / 99$ & 1500 & 748.1 & 12.5 & 7.3 & 3.0 & 117 \\
\hline NU 552 & W3-65 & 404234 & 0763542 & 65 & & $5 / 13 / 99$ & 1600 & 747.8 & 12.1 & 7.2 & 3.3 & 124 \\
\hline \multirow[t]{2}{*}{ NU 533} & W4-30 & 404234 & 0763542 & 30 & & $5 / 13 / 99$ & 1200 & 748.7 & 10.9 & 6.7 & 5.0 & 136 \\
\hline & & & & & & $5 / 10 / 00$ & 1300 & 748.7 & 11.4 & 6.4 & 5.1 & 133 \\
\hline
\end{tabular}


Appendix A. Site information and field measurements of stream and ground water collected in the Chesapeake Bay Watershed, June 1998 through May $2000-$ Continued

[ ${ }^{\circ}$, degrees; ', minutes;", seconds; BLS, below land surface; ft, feet; LEW, left edge of water; ${ }^{\circ} \mathrm{C}$, degrees Celsius; DO, dissolved oxygen; mg/L, milligrams per liter; $\mu \mathrm{S} / \mathrm{cm}$, microsiemens per centimeter at $25^{\circ} \mathrm{C}$; mp, minipiezometer; $\mathrm{n} / \mathrm{a}$, not applicable; --, missing data]

\begin{tabular}{|c|c|c|c|c|c|c|c|c|c|c|c|c|}
\hline Site name & Local ID & $\begin{array}{c}\text { Latitude } \\
\left({ }^{\circ},,^{\prime},\right)\end{array}$ & $\begin{array}{c}\text { Longitude } \\
\left({ }^{\circ},,^{\prime},\right)\end{array}$ & $\begin{array}{c}\text { Depth of } \\
\text { bottom of } \\
\text { screen BLS } \\
\text { (ft) }\end{array}$ & $\begin{array}{c}\text { Distance } \\
\text { from } L E W \\
(\mathbf{f t})\end{array}$ & Date & Time & $\begin{array}{c}\text { Water level } \\
\text { elevation } \\
\text { (feet) }\end{array}$ & $\begin{array}{c}\text { Tempera- } \\
\text { ture } \\
\left({ }^{\circ} \mathbf{C}\right) \\
(00010)\end{array}$ & $\begin{array}{c}\text { pH } \\
(00400)\end{array}$ & $\begin{array}{c}\text { DO } \\
(\mathrm{mg} / \mathrm{L}) \\
(\mathbf{0 0 3 0 0})\end{array}$ & $\begin{array}{c}\begin{array}{c}\text { Specific } \\
\text { conductance } \\
(\mu \mathrm{S} / \mathrm{cm}) \\
(\mathbf{0 0 0 9 5})\end{array}\end{array}$ \\
\hline \multicolumn{13}{|c|}{ Mahantango WE-38 Watershed, West Transect-Continued } \\
\hline \multirow[t]{2}{*}{ NU 554} & W4-40 & 404234 & 0763542 & 40 & & $5 / 13 / 99$ & 1300 & 749.7 & 11.1 & 7.2 & 1.5 & 170 \\
\hline & & & & & & $5 / 10 / 00$ & 1330 & 749.5 & 12.2 & 6.6 & 3.1 & 168 \\
\hline \multirow[t]{2}{*}{ NU 555} & W5-10 & 404233 & 0763541 & 10 & & $5 / 13 / 99$ & 1100 & 754.9 & 8.9 & 6.7 & 9.4 & 160 \\
\hline & & & & & & $5 / 10 / 00$ & 1500 & 753.3 & 9.9 & 5.8 & 8.2 & 152 \\
\hline NU 556 & W5-45 & 404233 & 0763541 & 45 & & $5 / 13 / 99$ & 1000 & 754.6 & 9.6 & 6.2 & 5.5 & 162 \\
\hline NU 562 & Forested site & 404340 & 0763534 & 150 & & $5 / 17 / 00$ & 1330 & 951.9 & 10.6 & 4.9 & 7.3 & 13 \\
\hline NU 563 & Hog manure site & 404319 & 0763612 & 153 & & $5 / 17 / 00$ & 1500 & 850.5 & 12.3 & 6.6 & 6.8 & 82 \\
\hline \multicolumn{13}{|c|}{ Masser's Recharge site (fertilizer applied) } \\
\hline NU 558-S & NW shallow & 404258 & 0763734 & 42.3 & & $5 / 8 / 00$ & 1400 & 848.1 & 11.7 & 5.3 & 8.1 & 249 \\
\hline NU 558-D & NW deep & 404258 & 0763734 & 82.6 & & $5 / 8 / 00$ & 1500 & 832.6 & 11.4 & 6.1 & 6.4 & 306 \\
\hline NU 559-S & NE shallow & 404258 & 0763733 & 45.3 & & $5 / 8 / 00$ & 1300 & 853.7 & 12.6 & 6.2 & 8.1 & 299 \\
\hline NU 559-D & NE deep & 404258 & 0763733 & 86 & & $5 / 8 / 00$ & 1130 & -- & 13.2 & 6.1 & 6.4 & 331 \\
\hline \multicolumn{13}{|c|}{ Springs sampled as part of Chesapeake Bay Ground Water initiative during 1997} \\
\hline \multicolumn{13}{|l|}{ Maryland } \\
\hline $4 \mathrm{H}$ camp spr. & MD-HA-Bc-30 & 393759 & 0763400 & $\mathrm{n} / \mathrm{a}$ & & 08/05/97 & 1017 & $\mathrm{n} / \mathrm{a}$ & 12.0 & 8.6 & 5.2 & 35 \\
\hline Black Rock Spr. & MD-WA CJ23 & 394009 & 0771422 & $\mathrm{n} / \mathrm{a}$ & & 08/08/97 & 1615 & $\mathrm{n} / \mathrm{a}$ & 12.1 & 6.3 & 7.2 & 304 \\
\hline Blue Hole Spr. & MD-AL-CE-1 & 393431 & 0784349 & $\mathrm{n} / \mathrm{a}$ & & 08/11/97 & 1230 & $\mathrm{n} / \mathrm{a}$ & 11.6 & 9.3 & 7.4 & 317 \\
\hline Harver Spr. & MD-WA-Ak-3 & 394039 & 0773418 & $\mathrm{n} / \mathrm{a}$ & & 08/08/97 & 1000 & $\mathrm{n} / \mathrm{a}$ & 10.6 & 6.7 & 7.2 & 30 \\
\hline Hillbilly Spr. & MD-FR ED 82 & 392316 & 0772828 & $\mathrm{n} / \mathrm{a}$ & & 08/07/97 & 1530 & $\mathrm{n} / \mathrm{a}$ & 12.3 & 6.9 & 7.1 & 332 \\
\hline Jefferson Davis spr & MD-AL CF46 & 393356 & 0783922 & $\mathrm{n} / \mathrm{a}$ & & 08/11/97 & 1500 & $\mathrm{n} / \mathrm{a}$ & 13.1 & 7.1 & 7.1 & 168 \\
\hline Keedysville spr. & MD-WA-Di-6 & 392916 & 0774133 & $\mathrm{n} / \mathrm{a}$ & & 08/08/97 & 1305 & $\mathrm{n} / \mathrm{a}$ & 12.1 & 5.9 & 7.1 & 405 \\
\hline Lilypons Spr. & MD-FR-FD-55 & 391643 & 0772752 & $\mathrm{n} / \mathrm{a}$ & & 08/07/97 & 1013 & $\mathrm{n} / \mathrm{a}$ & 12.2 & 6.9 & 6.9 & 548 \\
\hline Manchester Spr. & MD CL Bf 183 & 393943 & 0765330 & $\mathrm{n} / \mathrm{a}$ & & 08/06/97 & 1034 & $\mathrm{n} / \mathrm{a}$ & 12.5 & 3.4 & 5.7 & 343 \\
\hline Oregon Ridge spr. & MD-BA-DC-440 & 392951 & 0764115 & $\mathrm{n} / \mathrm{a}$ & & $08 / 05 / 97$ & 1320 & $\mathrm{n} / \mathrm{a}$ & 12.1 & 2.9 & 7.3 & 329 \\
\hline Phillips Spring & MD-FR-PHILS & 393211 & 0772621 & $\mathrm{n} / \mathrm{a}$ & & 08/06/97 & 1740 & $\mathrm{n} / \mathrm{a}$ & 12.6 & 5.7 & 6.4 & 198 \\
\hline Retirement Center & MD-BA-DE1 & 392635 & 0763047 & $\mathrm{n} / \mathrm{a}$ & & 08/05/97 & 1547 & $\mathrm{n} / \mathrm{a}$ & 12.7 & 6.3 & 7.3 & 405 \\
\hline
\end{tabular}


Appendix A. Site information and field measurements of stream and ground water collected in the Chesapeake Bay Watershed, June 1998 through May $2000-$ Continued

[ ${ }^{\circ}$, degrees; ', minutes;", seconds; BLS, below land surface; ft, feet; LEW, left edge of water; ${ }^{\circ} \mathrm{C}$, degrees Celsius; DO, dissolved oxygen; mg/L, milligrams per liter; $\mu \mathrm{S} / \mathrm{cm}$, microsiemens per centimeter at $25^{\circ} \mathrm{C} ; \mathrm{mp}$, minipiezometer; $\mathrm{n} / \mathrm{a}$, not applicable; --, missing data]

\begin{tabular}{|c|c|c|c|c|c|c|c|c|c|c|c|c|}
\hline Site name & Local ID & $\begin{array}{c}\text { Latitude } \\
\left({ }^{\circ},{ }^{\prime}, "\right)\end{array}$ & $\begin{array}{c}\text { Longitude } \\
\left({ }^{\circ},{ }^{\prime}, "\right)\end{array}$ & $\begin{array}{c}\text { Depth of } \\
\text { bottom of } \\
\text { screen BLS } \\
\text { (ft) }\end{array}$ & $\begin{array}{l}\text { Distance } \\
\text { from } L E W \\
\quad(f t)\end{array}$ & Date & Time & $\begin{array}{c}\text { Water level } \\
\text { elevation } \\
\text { (feet) }\end{array}$ & $\begin{array}{c}\text { Tempera- } \\
\text { ture } \\
\left({ }^{\circ} \mathrm{C}\right) \\
(\mathbf{0 0 0 1 0})\end{array}$ & $\begin{array}{c}\text { pH } \\
(00400)\end{array}$ & $\begin{array}{c}\text { DO } \\
(\mathrm{mg} / \mathrm{L}) \\
(\mathbf{0 0 3 0 0})\end{array}$ & $\begin{array}{c}\text { Specific } \\
\text { conductance } \\
(\mu \mathrm{S} / \mathrm{cm}) \\
(\mathbf{0 0 0 9 5})\end{array}$ \\
\hline \multicolumn{13}{|c|}{ Springs sampled as part of Chesapeake Bay Ground Water initiative during $1997-$ Continued } \\
\hline \multicolumn{13}{|c|}{ Maryland-Continued } \\
\hline South of Gum Spring & MD-FR-Fb-12 & 391847 & 0773705 & $\mathrm{n} / \mathrm{a}$ & & 08/07/97 & 1308 & $\mathrm{n} / \mathrm{a}$ & 13.1 & 9.3 & 6.4 & 365 \\
\hline Benner Spr. & PA-Ce-18 & 405108 & 0774917 & $\mathrm{n} / \mathrm{a}$ & & $08 / 21 / 97$ & 1200 & $\mathrm{n} / \mathrm{a}$ & 11.7 & 8.9 & 7.2 & 389 \\
\hline Big Spr. & $\mathrm{PA}-\mathrm{Cu}-22$ & 400742 & 0772428 & $\mathrm{n} / \mathrm{a}$ & & 08/19/97 & 1525 & $\mathrm{n} / \mathrm{a}$ & 11.3 & 8.5 & 7.4 & 459 \\
\hline Clouser Spr. & PA-Pe-10 & 402309 & 0770421 & $\mathrm{n} / \mathrm{a}$ & & 08/20/97 & 1040 & $\mathrm{n} / \mathrm{a}$ & 13.4 & 6.5 & 4.9 & 309 \\
\hline Donegal Spr. & PA-Ln-14 & 400605 & 0763356 & $\mathrm{n} / \mathrm{a}$ & & 08/18/97 & 1522 & $\mathrm{n} / \mathrm{a}$ & 11.8 & 4.7 & 7.2 & 726 \\
\hline Dykeman Spr. & PA-Cu-24 & 400232 & 0773055 & $\mathrm{n} / \mathrm{a}$ & & 08/19/97 & 0955 & $\mathrm{n} / \mathrm{a}$ & 10.9 & 7.5 & 7.5 & 335 \\
\hline Hanover Spr. & PA-Yo-19 & 395055 & 0765747 & $\mathrm{n} / \mathrm{a}$ & & 08/18/97 & 1222 & $\mathrm{n} / \mathrm{a}$ & 11.1 & 8.9 & 6.0 & 40 \\
\hline McAllisterville Spr. & PA-Ju-01 & 403956 & 0771749 & $\mathrm{n} / \mathrm{a}$ & & 08/23/97 & 1000 & $\mathrm{n} / \mathrm{a}$ & 11.2 & 8.3 & 4.9 & 26 \\
\hline Mount Rock Spr. & PA-Cu-17 & 400941 & 0771859 & $\mathrm{n} / \mathrm{a}$ & & 08/19/97 & 1340 & $\mathrm{n} / \mathrm{a}$ & 11.4 & 9.0 & 7.3 & 584 \\
\hline Pennrythe Spr. & PA-Lb-18 & 401946 & 0762945 & $\mathrm{n} / \mathrm{a}$ & & $08 / 22 / 97$ & 1440 & $\mathrm{n} / \mathrm{a}$ & 12.0 & 5.7 & 7.1 & 645 \\
\hline PSU Ag Spr. & PA-Ce-33 & 404228 & 0775658 & $\mathrm{n} / \mathrm{a}$ & & $08 / 21 / 97$ & 1435 & $\mathrm{n} / \mathrm{a}$ & 12.5 & 7.2 & 6.9 & 458 \\
\hline Trout Spr. & $\mathrm{PA}-\mathrm{Cu}-30$ & 400945 & 0770047 & $\mathrm{n} / \mathrm{a}$ & & 08/18/97 & 0930 & $\mathrm{n} / \mathrm{a}$ & 11.6 & 7.8 & 7.9 & 505 \\
\hline $\begin{array}{l}\text { Tylerville Spr. } \\
\text { Virginia }\end{array}$ & PA-Cn-09 & 405856 & 0772801 & $\mathrm{n} / \mathrm{a}$ & & 08/20/97 & 1520 & $\mathrm{n} / \mathrm{a}$ & 13.7 & 7.3 & 7.6 & 351 \\
\hline Arthur Weiss Spr. & VA 10 & 390839 & 0775458 & $\mathrm{n} / \mathrm{a}$ & & 08/05/97 & 1230 & $\mathrm{n} / \mathrm{a}$ & 19.8 & 5.0 & 7.1 & 596 \\
\hline Bear Lithia Spr. & VA 09 & 382608 & 0783708 & $\mathrm{n} / \mathrm{a}$ & & 08/06/97 & 0927 & $\mathrm{n} / \mathrm{a}$ & 12.0 & 7.5 & 7.8 & 178 \\
\hline Camp 2 Spr. & VA 11 & 383441 & 0772508 & $\mathrm{n} / \mathrm{a}$ & & $08 / 12 / 97$ & 1140 & $\mathrm{n} / \mathrm{a}$ & 13.0 & 7.8 & 5.4 & 34 \\
\hline CNHP28 & VA 14 & 371355 & 0763102 & $\mathrm{n} / \mathrm{a}$ & & 08/04/97 & 1225 & $\mathrm{n} / \mathrm{a}$ & 18.1 & 7.4 & 6.9 & 539 \\
\hline Coyner Spr. & VA 01 & 380310 & 0785554 & $\mathrm{n} / \mathrm{a}$ & & 08/13/97 & 0930 & $\mathrm{n} / \mathrm{a}$ & 12.6 & 7.7 & 8.0 & 186 \\
\hline Deerfield Spr. & VA 07 & 381131 & 0792419 & $\mathrm{n} / \mathrm{a}$ & & 08/08/97 & 1245 & $\mathrm{n} / \mathrm{a}$ & 18.2 & 6.6 & 7.2 & 166 \\
\hline Elkton & VA 08 & 382415 & 0783612 & $\mathrm{n} / \mathrm{a}$ & & 08/05/97 & 1710 & $\mathrm{n} / \mathrm{a}$ & 21.5 & 7.2 & 7.7 & 213 \\
\hline Gardner & & 381316 & 0790654 & $\mathrm{n} / \mathrm{a}$ & & 08/06/97 & 1515 & $\mathrm{n} / \mathrm{a}$ & 13.6 & 7.0 & 7.3 & 443 \\
\hline George Washington & VA 13 & 371211 & 0763153 & $\mathrm{n} / \mathrm{a}$ & & $08 / 11 / 97$ & 1045 & $\mathrm{n} / \mathrm{a}$ & 16.7 & 2.6 & 7.2 & 412 \\
\hline Green Spr. & VA 12 & 380056 & 0780952 & $\mathrm{n} / \mathrm{a}$ & & 08/13/97 & 1425 & $\mathrm{n} / \mathrm{a}$ & 13.7 & 7.9 & 7.5 & 1,230 \\
\hline Gypsy Hilll Golf Course & VA 05 & 380925 & 0790516 & $\mathrm{n} / \mathrm{a}$ & & 08/06/97 & 1240 & $\mathrm{n} / \mathrm{a}$ & 14.2 & 6.7 & 7.1 & 549 \\
\hline Loth Spr. & VA 02 & 380336 & 0785334 & $\mathrm{n} / \mathrm{a}$ & & 08/13/97 & 1145 & $\mathrm{n} / \mathrm{a}$ & 13.1 & 6.3 & 8.0 & 135 \\
\hline Masanetta & VA 04 & 382355 & 0784959 & $\mathrm{n} / \mathrm{a}$ & & 08/07/97 & 1520 & $\mathrm{n} / \mathrm{a}$ & 15.0 & 6.2 & 7.2 & 547 \\
\hline Timberville Spr. & VA 03 & 384000 & 0784809 & $\mathrm{n} / \mathrm{a}$ & & 08/08/97 & 0900 & $\mathrm{n} / \mathrm{a}$ & 14.3 & 6.3 & 7.0 & 589 \\
\hline $\begin{array}{l}\text { Warm Spr. } \\
\text { West Virginia }\end{array}$ & VA 06 & 380313 & 0794652 & $\mathrm{n} / \mathrm{a}$ & & 08/08/97 & 1543 & $\mathrm{n} / \mathrm{a}$ & 35.3 & 7.0 & 7.2 & 759 \\
\hline Berkeley Spr. & WV-BS-1 & 393737 & 0781344 & $\mathrm{n} / \mathrm{a}$ & & $08 / 11 / 97$ & 1710 & $\mathrm{n} / \mathrm{a}$ & 23 & 4.2 & 7 & 315 \\
\hline
\end{tabular}


Appendix B. Nutrient and ${ }^{15} \mathrm{~N}$ concentrations in stream and ground water collected in the Chesapeake Bay Watershed, June 1998 through May 2000

[mg/L, milligrams per liter; mp, minipiezometer; <, less than; $\mathrm{n} / \mathrm{a}$, not applicable; --, data not available; e, estimated value;

RSIL, Reston Stable Isotope Laboratory; analyses from U.S. Geological Survey National Water Quality Laboratory unless otherwise noted]

\begin{tabular}{|c|c|c|c|c|c|c|c|c|c|c|c|c|c|c|c|c|c|}
\hline $\begin{array}{c}\text { Site } \\
\text { name }\end{array}$ & $\begin{array}{l}\text { Local } \\
\text { ID }\end{array}$ & Date & Time & $\begin{array}{c}\text { Nitrogen, } \\
\text { ammonia, } \\
\text { dissolved } \\
(\mathbf{m g} / \mathrm{L} \text { as } \mathbf{N}) \\
(\mathbf{0 0 6 0 8})\end{array}$ & $\begin{array}{c}\text { Dissolved } \\
\text { ammonia } \\
\delta^{15} \mathrm{~N} \\
(\text { per } \\
\text { mil) }\end{array}$ & $\begin{array}{c}\text { Nitrogen, } \\
\text { nitrite, } \\
\text { dissolved } \\
(\mathrm{mg} / \mathrm{L} \\
\text { as N) } \\
(00613)\end{array}$ & $\begin{array}{c}\text { Nitrogen, } \\
\text { ammonia } \\
+ \text { organic, } \\
\text { dissolved } \\
(\mathrm{mg} / \mathrm{L} \\
\text { as N) } \\
(00623)\end{array}$ & $\begin{array}{c}\text { Nitrogen, } \\
\text { ammonia } \\
+ \text { organic, } \\
\text { total } \\
(\mathrm{mg} / \mathrm{L} \\
\text { as N) } \\
(00625)\end{array}$ & $\begin{array}{c}\text { Nitrate } \\
\text { plus } \\
\text { nitrite, } \\
\text { dissolved } \\
(\mathbf{m g} / \mathbf{L} \\
\text { as N) } \\
(00631)\end{array}$ & $\begin{array}{c}\text { Nitrate, } \\
\text { dissolved } \\
(\mathbf{m g} / \mathbf{L} \\
\text { as N) } \\
\text { (RSIL) }\end{array}$ & $\begin{array}{c}\begin{array}{c}\text { Nitrate } \\
\text { plus }\end{array} \\
\text { nitrite, } \\
\text { dissolved } \\
(\mathbf{m g} / \mathbf{L} \\
\text { as N) } \\
(\text { RSIL) } \\
(\mathbf{0 0 6 3 1})\end{array}$ & $\begin{array}{c}\text { Dis- } \\
\text { solved } \\
\text { nitrate } \\
\text { plus } \\
\text { nitrite } \\
\delta^{15} \mathbf{N} \\
\text { (per mil) }\end{array}$ & $\begin{array}{c}\text { Phos- } \\
\text { phorus, } \\
\text { total } \\
(\mathbf{m g} / \mathbf{L} \\
\text { as P) } \\
(\mathbf{0 0 6 6 5})\end{array}$ & $\begin{array}{c}\text { Phos- } \\
\text { phorus, } \\
\text { dissolved } \\
(\mathbf{m g} / \mathrm{L}) \\
(\mathbf{0 0 6 6 6})\end{array}$ & $\begin{array}{c}\text { Phos- } \\
\text { phorus, } \\
\text { ortho, } \\
\text { dissolved } \\
(\mathrm{mg} / \mathrm{L} \\
\text { as P) } \\
(00671)\end{array}$ & 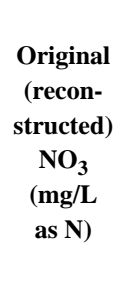 & $\begin{array}{c}\text { Excess } \mathbf{N}_{2} \\
(\mathrm{mg} / \mathbf{L} \\
\text { as N) }\end{array}$ \\
\hline \multicolumn{18}{|c|}{ Pocomoke River at Careytown, Md. } \\
\hline Stream & 01484980 & $8 / 24 / 98$ & 0900 & 0.114 & -- & $<0.010$ & 0.372 & -- & 0.220 & 0.316 & -- & -- & -- & 0.026 & 0.036 & -- & -- \\
\hline WI Bh p1a & mp 1 & $8 / 24 / 98$ & 0915 & .326 & -- & $<.010$ & 1.23 & -- & $<.050$ & $<.020$ & -- & -- & -- & .074 & .093 & 0.00 & 0.00 \\
\hline WI Bh p1b & mp 2 & $8 / 24 / 98$ & 1100 & .197 & -- & $<.010$ & .989 & -- & $<.050$ & $<.020$ & -- & -- & -- & .043 & .046 & .00 & .00 \\
\hline WI Bh p1c & mp 3 & $8 / 24 / 98$ & 1400 & .209 & -- & $<.010$ & 1.08 & -- & $<.050$ & $<.020$ & -- & -- & -- & .049 & .041 & .00 & .00 \\
\hline WI Bh pld & $\mathrm{mp} 4$ & $8 / 24 / 98$ & 1515 & .221 & -- & $<.010$ & 1.04 & -- & $<.050$ & .038 & -- & -- & -- & .023 & .047 & .00 & .00 \\
\hline WI Bh ple & mp 5 & $8 / 24 / 98$ & 1600 & .350 & -- & $<.010$ & 1.09 & -- & $<.050$ & $<.020$ & -- & -- & -- & .091 & .076 & .00 & .00 \\
\hline WI Bh p1f & mp 6 & $8 / 25 / 98$ & 0900 & .546 & -- & $<.010$ & .959 & -- & $<.050$ & $<.020$ & -- & -- & -- & .076 & .108 & .00 & .00 \\
\hline WI Bh p1g & mp 7 & $8 / 25 / 98$ & 1015 & 1.56 & -- & $<.010$ & 1.69 & -- & $<.050$ & $<.020$ & -- & -- & -- & .225 & .297 & .00 & .00 \\
\hline WI Bh p1h & mp 8 & $8 / 25 / 98$ & 1130 & 1.93 & -- & $<.010$ & 2.15 & -- & $<.050$ & .043 & -- & -- & -- & .322 & .380 & .00 & .00 \\
\hline WI Bh p1i & mp 9 & $8 / 25 / 98$ & 1230 & 2.06 & -- & $<.010$ & 2.19 & -- & $<.050$ & $<.020$ & -- & -- & -- & .312 & .397 & .00 & .00 \\
\hline WI Bh p1j & $\mathrm{mp} 10$ & $8 / 25 / 98$ & 1330 & 2.00 & -- & $<.010$ & 2.22 & -- & $<.050$ & $<.020$ & -- & -- & -- & .348 & .402 & .00 & .00 \\
\hline \multicolumn{18}{|c|}{ Pine Ridge Branch near Careytown, Md. } \\
\hline Stream & 01484995 & 9/23/98 & 0900 & .184 & -- & .064 & 1.22 & -- & 4.38 & 4.11 & 4.50 & 20.2 & -- & .039 & $<.010$ & -- & -- \\
\hline WO Be p1a & mp 1 & 9/23/98 & 1030 & $<.020$ & -- & $<.010$ & .601 & -- & 25.4 & 23.5 & 13.6 & 12.3 & -- & .037 & $<.010$ & 25.4 & .00 \\
\hline WO Be p1b & $\mathrm{mp} 2$ & 9/23/98 & 0830 & $<.020$ & -- & .037 & -- & -- & 18.7 & 17.4 & 17.6 & 12.7 & -- & .114 & .066 & 2.90 & 2.20 \\
\hline WO Be p1c & mp 3 & 9/23/98 & 1130 & $<.020$ & -- & .033 & .450 & -- & 3.95 & 3.02 & 4.07 & 22.4 & -- & .463 & .404 & 3.92 & .00 \\
\hline \multicolumn{18}{|c|}{ North Fork Green Run near Whitesville, Del. } \\
\hline \multirow[t]{4}{*}{ Stream } & 01484981 & $9 / 21 / 98$ & 1030 & .610 & -- & .017 & .900 & -- & .130 & .093 & -- & -- & -- & .024 & $<.010$ & -- & -- \\
\hline & & $3 / 25 / 99$ & 1600 & .055 & -- & $<.010$ & .466 & -- & 5.23 & 5.04 & 5.21 & 13.0 & -- & e .032 & .029 & 5.22 & -- \\
\hline & & 9/29/99 & 1230 & .050 & -- & .012 & .329 & 0.440 & 2.30 & 2.22 & 2.59 & 14.7 & 0.075 & .015 & .017 & 2.29 & -- \\
\hline & & $3 / 14 / 00$ & 1000 & .038 & -- & .011 & .372 & .418 & 3.49 & 3.29 & 3.57 & 14.0 & .063 & .009 & .010 & 3.49 & -- \\
\hline WI Bx p1a & $\mathrm{mp} 1$ & 9/21/98 & 0930 & .491 & -- & $<.010$ & .878 & -- & .054 & $<.050$ & -- & -- & -- & .047 & .033 & 1.54 & 1.50 \\
\hline WI Bx p1b & mp 2 & 9/21/98 & 1130 & .455 & -- & $<.010$ & .811 & -- & .059 & $<.050$ & -- & -- & -- & .137 & .098 & 1.05 & 1.00 \\
\hline WI Bx p1c & mp 3 & 9/21/98 & 1300 & .989 & -- & $<.010$ & 1.50 & -- & .065 & $<.050$ & -- & -- & -- & 1.50 & 1.60 & .56 & .50 \\
\hline WI Bx p1d & mp 4 & 9/21/98 & 1500 & .624 & -- & $<.010$ & 1.04 & -- & .065 & $<.050$ & -- & -- & -- & .297 & .319 & 1.06 & 1.00 \\
\hline WI Bx p1e & mp 5 & 9/21/98 & 1600 & 1.01 & -- & $<.010$ & 1.54 & -- & .066 & $<.050$ & -- & -- & -- & .938 & .941 & .06 & .00 \\
\hline WI Bx p1f & mp 6 & 9/22/98 & 0900 & .579 & -- & $<.010$ & .998 & -- & .097 & $<.050$ & -- & -- & -- & 1.01 & .997 & .09 & .00 \\
\hline WI Bx p1g & mp 7 & 9/22/98 & 1100 & .645 & -- & $<.010$ & .95 & -- & .060 & $<.050$ & -- & -- & -- & 1.46 & 1.58 & .05 & .00 \\
\hline WI Bx p1h & $\mathrm{mp} 8$ & 9/22/98 & 1200 & .733 & -- & $<.010$ & 1.09 & -- & .061 & $<.050$ & -- & -- & -- & 1.45 & 1.61 & .05 & .00 \\
\hline
\end{tabular}


Appendix B. Nutrient and ${ }^{15} \mathrm{~N}$ concentrations in stream and ground water collected in the Chesapeake Bay Watershed, June 1998 through May 2000—Continued [mg/L, milligrams per liter; mp, minipiezometer; <, less than; n/a, not applicable; --, data not available; e, estimated value;

RSIL, Reston Stable Isotope Laboratory; analyses from U.S. Geological Survey National Water Quality Laboratory unless otherwise noted]

\begin{tabular}{|c|c|c|c|c|c|c|c|c|c|c|c|c|c|c|c|c|c|}
\hline $\begin{array}{c}\text { Site } \\
\text { name }\end{array}$ & $\begin{array}{l}\text { Local } \\
\text { ID }\end{array}$ & Date & Time & $\begin{array}{c}\text { Nitrogen, } \\
\text { ammonia, } \\
\text { dissolved } \\
(\mathbf{m g} / \mathrm{L} \text { as } \mathrm{N}) \\
(\mathbf{0 0 6 0 8})\end{array}$ & $\begin{array}{c}\text { Dissolved } \\
\text { ammonia } \\
\delta^{15} \mathrm{~N} \\
(\text { per } \\
\text { mil) }\end{array}$ & $\begin{array}{c}\text { Nitrogen, } \\
\text { nitrite, } \\
\text { dissolved } \\
(\mathrm{mg} / \mathrm{L} \\
\text { as N) } \\
(00613)\end{array}$ & $\begin{array}{c}\text { Nitrogen, } \\
\text { ammonia } \\
\text { + organic, } \\
\text { dissolved } \\
(\mathrm{mg} / \mathrm{L} \\
\text { as } \mathrm{N}) \\
(00623)\end{array}$ & $\begin{array}{c}\text { Nitrogen, } \\
\text { ammonia } \\
\text { + organic, } \\
\text { total } \\
(\mathrm{mg} / \mathrm{L} \\
\text { as } \mathrm{N}) \\
(00625)\end{array}$ & $\begin{array}{c}\text { Nitrate } \\
\text { plus } \\
\text { nitrite, } \\
\text { dissolved } \\
\text { (mg/L } \\
\text { as N) } \\
(00631)\end{array}$ & $\begin{array}{c}\text { Nitrate, } \\
\text { dissolved } \\
\text { (mg/L } \\
\text { as N) } \\
\text { (RSIL) }\end{array}$ & $\begin{array}{c}\begin{array}{c}\text { Nitrate } \\
\text { plus }\end{array} \\
\text { nitrite, } \\
\text { dissolved } \\
(\mathbf{m g} / \mathrm{L} \\
\text { as N) } \\
\text { (RSIL) } \\
(00631)\end{array}$ & $\begin{array}{c}\text { Dis- } \\
\text { solved } \\
\text { nitrate } \\
\text { plus } \\
\text { nitrite } \\
\delta^{15} \mathrm{~N} \\
\text { (per mil) }\end{array}$ & $\begin{array}{c}\text { Phos- } \\
\text { phorus, } \\
\text { total } \\
(\mathbf{m g} / \mathbf{L} \\
\text { as P) } \\
(\mathbf{0 0 6 6 5 )})\end{array}$ & $\begin{array}{c}\text { Phos- } \\
\text { phorus, } \\
\text { dissolved } \\
\text { (mg/L) } \\
\text { (00666) }\end{array}$ & $\begin{array}{c}\text { Phos- } \\
\text { phorus, } \\
\text { ortho, } \\
\text { dissolved } \\
\text { (mg/L } \\
\text { as P) } \\
(00671)\end{array}$ & $\begin{array}{c}\begin{array}{c}\text { Original } \\
\text { (recon- }\end{array} \\
\text { structed) } \\
\mathrm{NO}_{3} \\
(\mathrm{mg} / \mathrm{L} \\
\text { as N) }\end{array}$ & $\begin{array}{c}\text { Excess } \mathbf{N}_{2} \\
(\mathrm{mg} / \mathbf{L} \\
\text { as N) }\end{array}$ \\
\hline \multicolumn{18}{|c|}{ North Fork Green Run near Whitesville, Del.-Continued } \\
\hline WI Bx pli & mp 9 & $9 / 22 / 98$ & 1300 & 0.722 & -- & $<0.010$ & 1.02 & -- & 0.109 & $<0.050$ & -- & -- & -- & 1.02 & 1.04 & 0.10 & 0.00 \\
\hline WI Bx p1j & $\mathrm{mp} 10$ & $9 / 22 / 98$ & 1430 & 1.04 & -- & $<.010$ & 1.49 & -- & .056 & $<.050$ & -- & -- & -- & 1.15 & 1.26 & .05 & .00 \\
\hline \multirow[t]{3}{*}{ WI Bx p2a } & NF Well \#1 & $3 / 25 / 99$ & 0900 & 2.04 & -- & $<.010$ & 2.52 & -- & .225 & .285 & -- & -- & -- & .078 & .085 & .22 & .00 \\
\hline & & 9/22/99 & 1500 & .929 & -- & $<.010$ & 1.42 & 1.92 & $<.050$ & $<.050$ & -- & -- & 0.160 & .129 & .133 & .34 & .30 \\
\hline & & $3 / 14 / 00$ & 0900 & 1.08 & -- & $<.010$ & 1.57 & 1.82 & $<.050$ & $<.050$ & -- & -- & .896 & .075 & .065 & .64 & .60 \\
\hline \multirow[t]{2}{*}{ WI Bx p2b } & NF Well \#2 & $3 / 25 / 99$ & 1100 & .71 & -- & $<.010$ & .877 & -- & .127 & .319 & -- & -- & -- & $<.050$ & $<.010$ & .12 & -- \\
\hline & & 9/29/99 & 1100 & .425 & -- & $<.010$ & .466 & 3.90 & $<.050$ & -- & -- & -- & .422 & .020 & .032 & .04 & -- \\
\hline \multirow[t]{3}{*}{ WI Bx p2c } & NF Well \#3 & $3 / 25 / 99$ & 1200 & 1.63 & 8.95 & $<.010$ & 1.84 & -- & $<.050$ & $<.050$ & -- & -- & -- & 1.13 & 1.24 & .64 & .60 \\
\hline & & 9/29/99 & 1300 & .908 & -- & $<.010$ & 1.05 & 1.10 & $<.050$ & $<.050$ & -- & -- & .456 & .308 & .430 & .04 & .00 \\
\hline & & $3 / 14 / 00$ & 1100 & .667 & -- & $<.010$ & .751 & .71 & $<.050$ & $<.050$ & -- & -- & .376 & .398 & .425 & 1.14 & 1.10 \\
\hline \multirow[t]{3}{*}{ WI Bx p2d } & NF Well \#4 & $3 / 25 / 99$ & 1330 & .138 & -- & $<.010$ & .219 & -- & $<.050$ & $<.050$ & -- & -- & -- & e .032 & .027 & .84 & .80 \\
\hline & & 9/29/99 & 1500 & .120 & -- & $<.010$ & .176 & .309 & $<.050$ & $<.050$ & -- & -- & .055 & .038 & .040 & .44 & .40 \\
\hline & & $3 / 14 / 00$ & 1200 & .094 & -- & $<.010$ & .162 & .210 & $<.050$ & $<.050$ & -- & -- & .032 & .027 & .017 & .84 & .80 \\
\hline WI Bx p2e & $\mathrm{mp} 1$ & $3 / 29 / 99$ & 1400 & 1.53 & 6.72 & $<0.010$ & 1.79 & -- & .051 & $<.050$ & -- & -- & -- & .932 & 1.06 & 1.74 & 1.70 \\
\hline WI Bx p2f & $\mathrm{mp} 2$ & $3 / 29 / 99$ & 1200 & 1.19 & 6.93 & $<.010$ & 1.50 & -- & $<.050$ & $<.050$ & -- & -- & -- & .473 & .475 & 1.64 & 1.60 \\
\hline WI Bx p2g & $\mathrm{mp} 3$ & $3 / 25 / 99$ & 1500 & 1.49 & -- & $<.010$ & 1.67 & -- & $<.050$ & $<.050$ & -- & -- & -- & 1.55 & .610 & 1.04 & 1.00 \\
\hline WI Bx p2h & $\mathrm{mp} 4$ & $3 / 26 / 99$ & 1000 & 2.47 & -- & $<.010$ & 2.61 & -- & $<.050$ & $<.050$ & -- & -- & -- & .928 & .975 & 3.74 & 3.70 \\
\hline WI Bx p2i & mp 5 & $3 / 26 / 99$ & 0900 & 2.27 & 9.98 & $<.010$ & 2.68 & -- & $<.050$ & $<.050$ & -- & -- & -- & .245 & .264 & 5.14 & 5.10 \\
\hline \multicolumn{18}{|c|}{ Unnamed ditch to North Fork Green Run near Whitesville, Del. (Wayne Tull's Farm) } \\
\hline \multirow[t]{3}{*}{ Stream } & 0148498080 & $3 / 23 / 99$ & 1030 & .022 & -- & $<.010$ & .836 & -- & 14.2 & 12.9 & 12.4 & 10.5 & -- & e .033 & $<.010$ & -- & -- \\
\hline & & 9/24/99 & 1000 & $<.020$ & -- & $<.010$ & 2.23 & 3.34 & $<.050$ & $<.050$ & -- & -- & .887 & 1.26 & 1.21 & -- & -- \\
\hline & & $3 / 13 / 00$ & 1200 & .103 & -- & .029 & 1.37 & 1.31 & 9.49 & 9.22 & 7.05 & -- & .026 & .023 & $<.010$ & -- & -- \\
\hline \multirow[t]{3}{*}{ WI By p1a } & WT Well \#1 & $3 / 23 / 99$ & 1230 & .146 & -- & .020 & .709 & -- & 15.6 & 16.7 & 14.0 & 10.8 & -- & $<.050$ & $<.010$ & 15.6 & .00 \\
\hline & & 9/23/99 & 1000 & $<.020$ & -- & $<.010$ & .514 & .498 & .942 & .976 & 1.12 & -- & .006 & $<.004$ & $<.010$ & .93 & .00 \\
\hline & & $3 / 13 / 00$ & 1400 & $<.020$ & -- & $<.010$ & .553 & .807 & 7.81 & 7.85 & 8.42 & -- & .009 & .006 & .010 & 7.80 & .- \\
\hline
\end{tabular}


Appendix B. Nutrient and ${ }^{15} \mathrm{~N}$ concentrations in stream and ground water collected in the Chesapeake Bay Watershed, June 1998 through May 2000—Continued [mg/L, milligrams per liter; mp, minipiezometer; <, less than; n/a, not applicable; --, data not available; e, estimated value;

RSIL, Reston Stable Isotope Laboratory; analyses from U.S. Geological Survey National Water Quality Laboratory unless otherwise noted]

\begin{tabular}{|c|c|c|c|c|c|c|c|c|c|c|c|c|c|c|c|c|c|}
\hline $\begin{array}{c}\text { Site } \\
\text { name }\end{array}$ & $\begin{array}{c}\text { Local } \\
\text { ID }\end{array}$ & Date & Time & $\begin{array}{c}\text { Nitrogen, } \\
\text { ammonia, } \\
\text { dissolved } \\
(\mathbf{m g} / \mathrm{L} \text { as } \mathrm{N}) \\
(\mathbf{0 0 6 0 8})\end{array}$ & $\begin{array}{c}\text { Dissolved } \\
\text { ammonia } \\
\delta^{15} \mathrm{~N} \\
(\text { per } \\
\text { mil) }\end{array}$ & $\begin{array}{c}\text { Nitrogen, } \\
\text { nitrite, } \\
\text { dissolved } \\
(\mathbf{m g} / \mathbf{L} \\
\text { as N) } \\
(00613)\end{array}$ & $\begin{array}{c}\text { Nitrogen, } \\
\text { ammonia } \\
\text { + organic, } \\
\text { dissolved } \\
(\mathrm{mg} / \mathrm{L} \\
\text { as N) } \\
(00623)\end{array}$ & $\begin{array}{c}\text { Nitrogen, } \\
\text { ammonia } \\
\text { + organic, } \\
\text { total } \\
(\mathrm{mg} / \mathrm{L} \\
\text { as N) } \\
(00625)\end{array}$ & $\begin{array}{c}\text { Nitrate } \\
\text { plus } \\
\text { nitrite, } \\
\text { dissolved } \\
\text { (mg/L } \\
\text { as N) } \\
(00631)\end{array}$ & $\begin{array}{c}\text { Nitrate, } \\
\text { dissolved } \\
(\mathbf{m g} / \mathbf{L} \\
\text { as N) } \\
\text { (RSIL) }\end{array}$ & $\begin{array}{c}\text { Nitrate } \\
\text { plus } \\
\text { nitrite, } \\
\text { dissolved } \\
\text { (mg/L } \\
\text { as N) } \\
(\text { RSIL) } \\
(\mathbf{0 0 6 3 1})\end{array}$ & $\begin{array}{c}\text { Dis- } \\
\text { solved } \\
\text { nitrate } \\
\text { plus } \\
\text { nitrite } \\
\delta^{15} \mathbf{N} \\
\text { (per mil) }\end{array}$ & $\begin{array}{c}\text { Phos- } \\
\text { phorus, } \\
\text { total } \\
(\mathbf{m g} / \mathbf{L} \\
\text { as P) } \\
(\mathbf{0 0 6 6 5 )})\end{array}$ & $\begin{array}{c}\text { Phos- } \\
\text { phorus, } \\
\text { dissolved } \\
(\mathbf{m g} / \mathrm{L}) \\
(00666)\end{array}$ & $\begin{array}{c}\text { Phos- } \\
\text { phorus, } \\
\text { ortho, } \\
\text { dissolved } \\
\text { (mg/L } \\
\text { as P) } \\
(00671)\end{array}$ & $\begin{array}{c}\begin{array}{c}\text { Original } \\
\text { (recon- } \\
\text { structed) }\end{array} \\
\mathrm{NO}_{3} \\
(\mathrm{mg} / \mathrm{L} \\
\text { as N) }\end{array}$ & $\begin{array}{c}\text { Excess } \mathbf{N}_{2} \\
(\mathrm{mg} / \mathrm{L} \\
\text { as N) }\end{array}$ \\
\hline \multicolumn{18}{|c|}{ Unnamed ditch to North Fork Green Run near Whitesville, Del. (Wayne Tull's Farm)-Continued } \\
\hline \multirow[t]{3}{*}{ WI By p1b } & WT Well \#2 & $3 / 23 / 99$ & 1400 & 0.065 & -- & $<0.010$ & 0.970 & -- & 68.4 & 61.7 & 39.7 & 9.2 & & $<0.050$ & $<0.010$ & 68.4 & 0.00 \\
\hline & & 9/23/99 & 1300 & $<.020$ & -- & $<.010$ & 1.00 & 0.763 & 7.79 & 5.94 & 8.15 & -- & 0.005 & $<.004$ & $<.010$ & 7.78 & .00 \\
\hline & & $3 / 13 / 00$ & 1600 & $<.02$ & -- & $<.010$ & 1.06 & .953 & 57.5 & 63.0 & 6.03 & -- & .008 & .006 & .010 & 57.5 & \\
\hline \multirow[t]{2}{*}{ WI By p1c } & WT Well \#3 & $3 / 23 / 99$ & 1000 & .130 & -- & $<.010$ & .361 & -- & $<.050$ & $<.050$ & -- & -- & & $<.050$ & $<.010$ & 7.04 & 7.00 \\
\hline & & 9/23/99 & 1600 & .109 & -- & $<.010$ & .377 & .430 & $<.050$ & $<.050$ & -- & -- & $<.004$ & $<.004$ & $<.010$ & 5.04 & 5.00 \\
\hline \multirow[t]{3}{*}{ WI By p1d } & WT Well \#4 & $3 / 23 / 99$ & 1200 & .120 & -- & $<.010$ & .334 & -- & .072 & $<.050$ & -- & -- & & $<.05$ & $<.010$ & 8.06 & 8.00 \\
\hline & & 9/24/99 & 0900 & .112 & -- & $<.010$ & .408 & .427 & $<.050$ & $<.050$ & -- & -- & .006 & $<.004$ & $<.010$ & 7.04 & 7.00 \\
\hline & & $3 / 13 / 00$ & 1300 & .081 & -- & $<.010$ & .374 & .362 & $<.050$ & $<.050$ & -- & -- & .008 & .006 & .010 & 9.34 & 9.30 \\
\hline WI By ple & $\mathrm{mp} 1$ & $3 / 24 / 99$ & 1300 & .194 & -- & $<.010$ & .500 & -- & .306 & .325 & -- & -- & -- & $<.010$ & .194 & 5.30 & 5.00 \\
\hline WI By p1f & $\mathrm{mp} 2$ & $3 / 24 / 99$ & 1030 & .073 & -- & $<.010$ & .315 & -- & .341 & .359 & -- & -- & -- & $<.010$ & .073 & .33 & .00 \\
\hline WI By p1g & mp 3 & $3 / 24 / 99$ & 1430 & .028 & -- & $<.010$ & .333 & -- & 1.39 & 1.43 & 1.82 & 18.2 & -- & $<.010$ & .028 & 1.38 & .00 \\
\hline \multicolumn{18}{|c|}{ Green Run near Careytown, Md. (Green Run at Bethel Road) } \\
\hline \multirow[t]{2}{*}{ Stream } & 01484985 & $9 / 30 / 99$ & 1200 & .144 & -- & .014 & .641 & .880 & 1.12 & 1.16 & 1.68 & -- & .129 & .023 & .026 & -- & -- \\
\hline & & $3 / 14 / 00$ & 1400 & .028 & -- & $<.010$ & .427 & .478 & 2.19 & 2.15 & 2.51 & -- & .047 & .012 & .010 & -- & -- \\
\hline \multirow[t]{2}{*}{ WI Bz p1a } & GR Well \#1 & $3 / 30 / 99$ & 0830 & .040 & -- & $<.010$ & .539 & -- & 10.3 & 10.3 & 7.67 & 6.5 & -- & $<.050$ & $<.010$ & 10.28 & -- \\
\hline & & 9/21/99 & 1200 & $<.020$ & -- & $<.010$ & .620 & .825 & 8.60 & 10.2 & 8.32 & -- & .016 & .008 & $<.010$ & 8.69 & .10 \\
\hline WI Bz p1b & GR Well \#2 & $3 / 30 / 99$ & 0900 & .502 & -- & $<.010$ & .568 & -- & $<.050$ & $<.050$ & -- & -- & -- & $<.050$ & $<.010$ & .44 & .40 \\
\hline WI Bz p1c & GR Well \#3 & $3 / 30 / 99$ & 1000 & .822 & 5.59 & $<.010$ & 1.03 & -- & .052 & $<.050$ & -- & -- & -- & .163 & .181 & .54 & .50 \\
\hline \multirow[t]{3}{*}{ WI Bz pld } & GR Well \#4 & $3 / 29 / 99$ & 1500 & .981 & 4.37 & $<.010$ & 1.16 & -- & .938 & .847 & 1.68 & 5.5 & -- & e .040 & $<.010$ & 6.58 & 5.65 \\
\hline & & 9/22/99 & 1300 & 1.08 & -- & .016 & 1.15 & 1.30 & $<.050$ & $<.050$ & -- & -- & .087 & .009 & .049 & 4.43 & 4.40 \\
\hline & & $3 / 14 / 00$ & 1500 & .964 & -- & $<.010$ & 1.20 & 1.06 & .243 & .230 & -- & -- & .043 & .024 & .017 & 5.83 & 5.60 \\
\hline
\end{tabular}


Appendix B. Nutrient and ${ }^{15} \mathrm{~N}$ concentrations in stream and ground water collected in the Chesapeake Bay Watershed, June 1998 through May 2000—Continued [mg/L, milligrams per liter; $\mathrm{mp}$, minipiezometer; <, less than; $\mathrm{n} / \mathrm{a}$, not applicable; --, data not available; e, estimated value;

RSIL, Reston Stable Isotope Laboratory; analyses from U.S. Geological Survey National Water Quality Laboratory unless otherwise noted]

\begin{tabular}{|c|c|c|c|c|c|c|c|c|c|c|c|c|c|c|c|c|c|}
\hline $\begin{array}{c}\text { Site } \\
\text { name }\end{array}$ & $\begin{array}{c}\text { Local } \\
\text { ID }\end{array}$ & Date & Time & $\begin{array}{c}\text { Nitrogen, } \\
\text { ammonia, } \\
\text { dissolved } \\
(\mathrm{mg} / \mathrm{L} \text { as } \mathbf{N}) \\
(\mathbf{0 0 6 0 8})\end{array}$ & $\begin{array}{c}\text { Dissolved } \\
\text { ammonia } \\
\delta^{15} \mathbf{N} \\
(\text { per } \\
\text { mil) }\end{array}$ & $\begin{array}{c}\text { Nitrogen, } \\
\text { nitrite, } \\
\text { dissolved } \\
(\mathrm{mg} / \mathrm{L} \\
\text { as N) } \\
(00613)\end{array}$ & $\begin{array}{c}\text { Nitrogen, } \\
\text { ammonia } \\
+ \text { organic, } \\
\text { dissolved } \\
(\mathrm{mg} / \mathrm{L} \\
\text { as N) } \\
(00623)\end{array}$ & $\begin{array}{c}\text { Nitrogen, } \\
\text { ammonia } \\
+ \text { organic, } \\
\text { total } \\
(\mathrm{mg} / \mathrm{L} \\
\text { as } \mathrm{N}) \\
(00625)\end{array}$ & $\begin{array}{c}\text { Nitrate } \\
\text { plus } \\
\text { nitrite, } \\
\text { dissolved } \\
\text { (mg/L } \\
\text { as N) } \\
(00631)\end{array}$ & $\begin{array}{c}\text { Nitrate, } \\
\text { dissolved } \\
\text { (mg/L } \\
\text { as N) } \\
\text { (RSIL) }\end{array}$ & 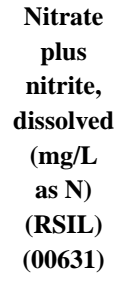 & $\begin{array}{c}\text { Dis- } \\
\text { solved } \\
\text { nitrate } \\
\text { plus } \\
\text { nitrite } \\
\delta^{15} \mathbf{N} \\
\text { (per mil) }\end{array}$ & $\begin{array}{c}\text { Phos- } \\
\text { phorus, } \\
\text { total } \\
(\mathrm{mg} / \mathrm{L} \\
\text { as } \mathrm{P}) \\
(\mathbf{0 0 6 6 5 )}\end{array}$ & $\begin{array}{c}\text { Phos- } \\
\text { phorus, } \\
\text { dissolved } \\
(\mathbf{m g} / \mathrm{L}) \\
(\mathbf{0 0 6 6 6})\end{array}$ & $\begin{array}{c}\begin{array}{c}\text { Phos- } \\
\text { phorus, } \\
\text { ortho, } \\
\text { dissolved } \\
(\mathrm{mg} / \mathrm{L} \\
\text { as P) } \\
(00671)\end{array}\end{array}$ & $\begin{array}{c}\begin{array}{c}\text { Original } \\
\text { (recon- } \\
\text { structed) }\end{array} \\
\mathrm{NO}_{3} \\
(\mathrm{mg} / \mathrm{L} \\
\text { as N) }\end{array}$ & $\begin{array}{c}\text { Excess } \mathbf{N}_{2} \\
(\mathbf{m g} / \mathbf{L} \\
\text { as N) }\end{array}$ \\
\hline \multicolumn{18}{|c|}{ Green Run near Careytown, Md. (Green Run at Bethel Road)—Continued } \\
\hline WI Bz p1e & $\mathrm{mp} 1$ & $3 / 31 / 99$ & 0800 & 1.33 & 4.41 & $<0.010$ & 1.51 & -- & 0.058 & $<0.050$ & -- & -- & -- & e 0.032 & $<0.010$ & 4.05 & 4.00 \\
\hline WI Bz p1f & $\mathrm{mp} 2$ & $3 / 30 / 99$ & 1500 & .918 & 4.13 & $<.010$ & 1.04 & -- & $<.050$ & $<.050$ & -- & -- & -- & .122 & .125 & 1.59 & 1.55 \\
\hline WI Bz p1g & $\mathrm{mp} 3$ & 3/30/99 & 1400 & .814 & -- & $<.010$ & .915 & -- & $<.050$ & $<.050$ & -- & -- & -- & .190 & .206 & .04 & .00 \\
\hline WI Bz p1h & $\mathrm{mp} 4$ & $3 / 30 / 99$ & 1200 & .855 & 5.50 & $<.010$ & 1.04 & -- & .054 & $<.050$ & -- & -- & -- & .174 & .190 & .04 & .00 \\
\hline WI Bz pli & mp 5 & 3/31/99 & 1000 & .849 & 5.37 & $<.010$ & 1.02 & -- & $<.050$ & $<.050$ & -- & -- & -- & .182 & .202 & .04 & .00 \\
\hline WI Bz p1j & mp 6 & $3 / 31 / 99$ & 1100 & .382 & 4.61 & $<.010$ & .53 & -- & .052 & $<.050$ & -- & -- & -- & .121 & .139 & .04 & .00 \\
\hline WI Bz p1k & $\mathrm{mp} 7$ & 3/31/99 & 1200 & .989 & 4.70 & $<.010$ & 1.25 & -- & $<.050$ & $<.050$ & -- & -- & -- & .147 & .167 & 1.04 & 1.00 \\
\hline \multicolumn{18}{|c|}{ Additional wells in Upper Pocomoke River Basin } \\
\hline WI Bh 8 & & 9/23/98 & 1600 & 3.85 & 4.50 & $<.010$ & 4.07 & -- & .060 & $<.050$ & -- & -- & -- & .210 & .048 & .05 & .00 \\
\hline WI Bh 8 & & $3 / 31 / 99$ & 1300 & 3.49 & -- & $<.010$ & 3.67 & -- & .056 & $<.050$ & -- & -- & -- & .224 & .168 & .05 & .00 \\
\hline WI Bh 9 & & 9/23/98 & 1400 & .18 & -- & .01 & .252 & -- & .078 & $<.050$ & -- & -- & -- & .229 & .220 & .06 & .00 \\
\hline WI Bh 9 & & $3 / 31 / 99$ & 1400 & .15 & -- & .01 & .235 & -- & .055 & $<.050$ & -- & -- & -- & .200 & .231 & .04 & .00 \\
\hline WI Ch 56 & & $9 / 24 / 98$ & 1000 & $<.020$ & -- & $<.010$ & .283 & -- & 4.07 & 3.80 & 4.31 & 6.20 & -- & .026 & $<.010$ & 4.96 & .90 \\
\hline WI Ch 57 & & $9 / 24 / 98$ & 0900 & $<.020$ & -- & $<.010$ & .406 & -- & 3.64 & 3.32 & 3.57 & 15.20 & -- & .017 & $<.010$ & 16.9 & 13.3 \\
\hline \multicolumn{18}{|c|}{ Springs in Muddy Creek watershed (Owner's name is Local ID) } \\
\hline \multirow[t]{3}{*}{ 39SS-001 } & Goode & $11 / 09 / 98$ & 1000 & .044 & -- & .01 & $<.100$ & -- & 2.27 & 2.41 & 2.34 & 9.63 & -- & .010 & .027 & 2.26 & .00 \\
\hline & & $4 / 14 / 99$ & 1030 & $<.020$ & -- & $<.010$ & $<.100$ & -- & 1.65 & 1.65 & 1.65 & 8.26 & -- & $<.050$ & .025 & 1.64 & .00 \\
\hline & & $4 / 17 / 00$ & 1500 & $<.020$ & -- & $<.010$ & .100 & e 0.083 & 1.24 & 1.28 & 1.13 & 7.89 & $<0.008$ & $<.014$ & $<.013$ & 1.33 & .10 \\
\hline \multirow[t]{2}{*}{ 39SS-002 } & Thompson & $11 / 09 / 98$ & 1330 & .045 & -- & $<.010$ & $<.100$ & -- & 4.00 & 3.89 & -- & -- & -- & $<.050$ & .017 & 3.99 & .00 \\
\hline & & 4/14/99 & 1300 & $<.020$ & -- & $<.010$ & $<.100$ & -- & 3.17 & 4.57 & 4.55 & 6.85 & -- & $<.050$ & $<.014$ & 3.16 & .00 \\
\hline \multirow[t]{2}{*}{ 39SS-003 } & Dove & $11 / 09 / 98$ & 1400 & .044 & -- & .01 & $<.100$ & -- & 3.37 & 3.35 & -- & -- & -- & $<.050$ & .018 & 3.36 & .00 \\
\hline & & $4 / 14 / 99$ & 1400 & $<.020$ & -- & $<.010$ & $<.100$ & -- & 3.55 & 3.42 & 3.25 & 6.68 & -- & $<.050$ & .016 & 3.54 & .00 \\
\hline $39 \mathrm{SS}-005$ & Heatwole & $4 / 14 / 99$ & 1130 & $<.020$ & -- & $<.010$ & .104 & -- & 5.97 & 5.53 & 5.46 & 11.2 & -- & $<.050$ & .032 & 6.06 & .10 \\
\hline \multirow[t]{2}{*}{ 39RS-001 } & Heatwole & $11 / 10 / 98$ & 0830 & .048 & -- & $<.010$ & $<.100$ & -- & 4.70 & 4.53 & -- & -- & -- & $<.050$ & .017 & 4.69 & .00 \\
\hline & & $4 / 14 / 99$ & 1500 & $<.020$ & -- & $<.010$ & .338 & -- & 4.11 & 4.47 & 4.52 & 6.52 & -- & e .033 & .020 & 4.10 & .00 \\
\hline
\end{tabular}


Appendix B. Nutrient and ${ }^{15} \mathrm{~N}$ concentrations in stream and ground water collected in the Chesapeake Bay Watershed, June 1998 through May 2000—Continued [mg/L, milligrams per liter; mp, minipiezometer; <, less than; $\mathrm{n} / \mathrm{a}$, not applicable; --, data not available; e, estimated value;

RSIL, Reston Stable Isotope Laboratory; analyses from U.S. Geological Survey National Water Quality Laboratory unless otherwise noted]

\begin{tabular}{|c|c|c|c|c|c|c|c|c|c|c|c|c|c|c|c|c|c|}
\hline $\begin{array}{c}\text { Site } \\
\text { name }\end{array}$ & $\begin{array}{l}\text { Local } \\
\text { ID }\end{array}$ & Date & Time & $\begin{array}{c}\text { Nitrogen, } \\
\text { ammonia, } \\
\text { dissolved } \\
(\mathbf{m g} / \mathbf{L} \text { as } \mathbf{N}) \\
(\mathbf{0 0 6 0 8})\end{array}$ & $\begin{array}{c}\text { Dissolved } \\
\text { ammonia } \\
\delta^{15} \mathbf{N} \\
(\text { per } \\
\text { mil) }\end{array}$ & $\begin{array}{c}\text { Nitrogen, } \\
\text { nitrite, } \\
\text { dissolved } \\
(\mathrm{mg} / \mathrm{L} \\
\text { as N) } \\
(\mathbf{0 0 6 1 3})\end{array}$ & $\begin{array}{c}\text { Nitrogen, } \\
\text { ammonia } \\
\text { + organic, } \\
\text { dissolved } \\
(\mathrm{mg} / \mathrm{L} \\
\text { as N) } \\
(00623)\end{array}$ & $\begin{array}{c}\text { Nitrogen, } \\
\text { ammonia } \\
+ \text { organic, } \\
\text { total } \\
(\mathrm{mg} / \mathrm{L} \\
\text { as } \mathrm{N}) \\
(00625)\end{array}$ & $\begin{array}{c}\text { Nitrate } \\
\text { plus } \\
\text { nitrite, } \\
\text { dissolved } \\
\text { (mg/L } \\
\text { as N) } \\
(\mathbf{0 0 6 3 1})\end{array}$ & $\begin{array}{c}\text { Nitrate, } \\
\text { dissolved } \\
(\mathrm{mg} / \mathrm{L} \\
\text { as N) } \\
(\mathrm{RSIL})\end{array}$ & $\begin{array}{c}\begin{array}{c}\text { Nitrate } \\
\text { plus }\end{array} \\
\text { nitrite, } \\
\text { dissolved } \\
\text { (mg/L } \\
\text { as N) } \\
\text { (RSIL) } \\
\text { (00631) }\end{array}$ & $\begin{array}{c}\text { Dis- } \\
\text { solved } \\
\text { nitrate } \\
\text { plus } \\
\text { nitrite } \\
\delta^{15} \mathrm{~N} \\
\text { (per mil) }\end{array}$ & $\begin{array}{c}\text { Phos- } \\
\text { phorus, } \\
\text { total } \\
(\mathbf{m g} / \mathbf{L} \\
\text { as P) } \\
(\mathbf{0 0 6 6 5 )})\end{array}$ & $\begin{array}{c}\text { Phos- } \\
\text { phorus, } \\
\text { dissolved } \\
(\mathbf{m g} / \mathrm{L}) \\
(00666)\end{array}$ & $\begin{array}{c}\text { Phos- } \\
\text { phorus, } \\
\text { ortho, } \\
\text { dissolved } \\
\text { (mg/L } \\
\text { as P) } \\
(00671)\end{array}$ & 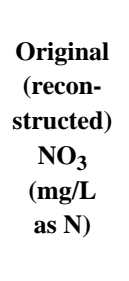 & $\begin{array}{c}\text { Excess } \mathbf{N}_{2} \\
(\mathrm{mg} / \mathbf{L} \\
\text { as N) }\end{array}$ \\
\hline \multicolumn{18}{|c|}{ Muddy Creek near Mt. Clinton, Va. } \\
\hline \multirow[t]{2}{*}{ stream } & 01621050 & $5 / 26 / 99$ & 1130 & 0.067 & -- & 0.062 & 0.418 & -- & 2.16 & 2.15 & -- & -- & -- & 0.059 & 0.038 & -- & -- \\
\hline & & $4 / 17 / 00$ & 1600 & .065 & -- & .063 & .536 & 0.669 & 2.69 & 2.80 & 3.00 & 11.16 & 0.155 & .067 & .042 & -- & -- \\
\hline \multicolumn{18}{|c|}{ Monitoring wells in Muddy Creek watershed } \\
\hline \multirow[t]{2}{*}{$39 S 2$} & MC-4 & $4 / 13 / 99$ & 1200 & $<.020$ & -- & $<.010$ & 0.111 & -- & 1.42 & 1.40 & 1.47 & 12.91 & -- & $<.050$ & .016 & 2.51 & 1.10 \\
\hline & & $4 / 18 / 00$ & 1100 & $<.020$ & -- & $<.010$ & .115 & .208 & 2.48 & 2.46 & 2.52 & 15.12 & e .007 & .01 & $<.010$ & 3.77 & 1.30 \\
\hline \multirow[t]{2}{*}{$39 \mathrm{~S} 4$} & MC-8 & 4/13/99 & 0900 & $<.020$ & -- & .015 & e.097 & -- & 4.41 & 4.13 & 3.98 & 19.86 & -- & e .033 & .047 & 6.20 & 1.80 \\
\hline & & $4 / 18 / 00$ & 0900 & $<.020$ & -- & .012 & .384 & .909 & 5.07 & 4.88 & 4.96 & 18.64 & $<.008$ & .096 & .066 & 6.25 & 1.20 \\
\hline \multirow[t]{2}{*}{3959} & MC-17 & 4/13/99 & 1300 & $<.020$ & -- & .011 & e. 083 & -- & .348 & .359 & .392 & 11.56 & -- & $<.050$ & .015 & 1.94 & 1.60 \\
\hline & & $4 / 18 / 00$ & 1200 & $<.020$ & -- & .018 & $<.010$ & .118 & .809 & .866 & .760 & 13.60 & .153 & $<.096$ & $<.010$ & 2.89 & 2.10 \\
\hline \multirow[t]{2}{*}{ 39S14 } & MC-28 & $4 / 12 / 99$ & 1300 & $<.020$ & -- & $<.010$ & .150 & -- & 6.83 & 7.16 & 11.9 & 13.20 & -- & $<.050$ & .024 & 6.82 & .00 \\
\hline & & $4 / 17 / 00$ & 1000 & $<.020$ & -- & $<.010$ & .104 & .162 & 7.80 & 7.39 & 7.63 & 17.40 & .150 & .028 & .020 & 8.19 & .40 \\
\hline \multirow[t]{2}{*}{$39 \mathrm{~S} 15$} & MC-29 & $4 / 12 / 99$ & 1500 & $<.020$ & -- & $<.010$ & .146 & -- & 5.86 & 6.03 & 5.98 & 10.77 & -- & $<.050$ & .031 & 5.85 & .00 \\
\hline & & $4 / 17 / 00$ & 1200 & $<.020$ & -- & $<.010$ & $<.010$ & $<.010$ & 4.71 & 4.61 & 4.65 & 10.54 & .013 & .022 & .018 & 5.80 & 1.10 \\
\hline \multirow[t]{2}{*}{$39 \mathrm{~S} 16$} & MC-30 & $4 / 12 / 99$ & 1100 & $<.020$ & -- & $<.010$ & .162 & -- & 4.37 & 4.25 & 4.15 & 17.68 & -- & $<.050$ & .014 & 4.36 & .00 \\
\hline & & $4 / 17 / 00$ & 1400 & $<.020$ & -- & $<.010$ & $<.010$ & .153 & 5.61 & 5.41 & 5.62 & 13.08 & .029 & e .005 & $<.010$ & 5.90 & .30 \\
\hline \multirow[t]{2}{*}{$39 S 19$} & MC-34 & $4 / 13 / 99$ & 1100 & $<.020$ & -- & $<.010$ & .123 & -- & 4.22 & 4.47 & 4.49 & 10.96 & -- & e 0.031 & .039 & 4.21 & .00 \\
\hline & & $4 / 18 / 00$ & 0800 & $<.020$ & -- & $<.010$ & .599 & .861 & 6.07 & 5.85 & 6.50 & 12.71 & $<.008$ & .215 & .179 & 6.06 & .00 \\
\hline \multicolumn{18}{|c|}{ Dometic wells in Muddy Creek watershed (Owner's name is Local ID) } \\
\hline \multirow[t]{2}{*}{$39 S 34$} & Harmon (1) & $4 / 13 / 99$ & 1500 & $<.020$ & -- & $<.010$ & e .071 & -- & 4.08 & 3.92 & 3.57 & 14.48 & -- & $<.050$ & .019 & 4.07 & .00 \\
\hline & & $4 / 14 / 99$ & 0900 & $<.020$ & -- & $<.010$ & e. 051 & -- & 4.47 & 4.35 & 4.27 & 14.47 & -- & $<.050$ & .019 & 4.46 & .00 \\
\hline $39 S 35$ & Harmon (2) & $4 / 13 / 99$ & 1600 & $<.020$ & -- & $<.010$ & e .070 & -- & 2.83 & 2.83 & 2.75 & 9.36 & -- & $<.050$ & .024 & 2.82 & .00 \\
\hline $39 S 39$ & Fairview Church & $4 / 15 / 99$ & 1500 & $<.020$ & -- & $<.010$ & $<.100$ & -- & 4.14 & 4.20 & 4.07 & 7.50 & -- & $<.050$ & $<.014$ & 4.13 & .00 \\
\hline $39 \mathrm{~S} 40$ & Dove & $4 / 15 / 99$ & 1000 & $<.020$ & -- & $<.010$ & $<.100$ & -- & .547 & .535 & .550 & 7.15 & -- & $<.050$ & $<.013$ & .54 & .00 \\
\hline
\end{tabular}


Appendix B. Nutrient and ${ }^{15} \mathrm{~N}$ concentrations in stream and ground water collected in the Chesapeake Bay Watershed, June 1998 through May 2000—Continued [mg/L, milligrams per liter; mp, minipiezometer; <, less than; n/a, not applicable; --, data not available; e, estimated value;

RSIL, Reston Stable Isotope Laboratory; analyses from U.S. Geological Survey National Water Quality Laboratory unless otherwise noted]

\begin{tabular}{|c|c|c|c|c|c|c|c|c|c|c|c|c|c|c|c|c|c|}
\hline $\begin{array}{c}\text { Site } \\
\text { name }\end{array}$ & $\begin{array}{c}\text { Local } \\
\text { ID }\end{array}$ & Date & Time & $\begin{array}{c}\text { Nitrogen, } \\
\text { ammonia, } \\
\text { dissolved } \\
(\mathbf{m g} / \mathbf{L} \text { as } \mathbf{N}) \\
(\mathbf{0 0 6 0 8})\end{array}$ & $\begin{array}{c}\text { Dissolved } \\
\text { ammonia } \\
\delta^{15} \mathrm{~N} \\
\text { (per } \\
\text { mil) }\end{array}$ & $\begin{array}{c}\text { Nitrogen, } \\
\text { nitrite, } \\
\text { dissolved } \\
(\mathrm{mg} / \mathrm{L} \\
\text { as N) } \\
(00613)\end{array}$ & $\begin{array}{c}\text { Nitrogen, } \\
\text { ammonia } \\
+ \text { organic, } \\
\text { dissolved } \\
(\mathrm{mg} / \mathrm{L} \\
\text { as N) } \\
(00623)\end{array}$ & $\begin{array}{c}\text { Nitrogen, } \\
\text { ammonia } \\
+ \text { organic, } \\
\text { total } \\
(\mathrm{mg} / \mathrm{L} \\
\text { as } \mathrm{N}) \\
(00625)\end{array}$ & $\begin{array}{c}\text { Nitrate } \\
\text { plus } \\
\text { nitrite, } \\
\text { dissolved } \\
\text { (mg/L } \\
\text { as N) } \\
(00631)\end{array}$ & $\begin{array}{c}\text { Nitrate, } \\
\text { dissolved } \\
(\mathrm{mg} / \mathrm{L} \\
\text { as N) } \\
\text { (RSIL) }\end{array}$ & $\begin{array}{c}\begin{array}{c}\text { Nitrate } \\
\text { plus }\end{array} \\
\text { nitrite, } \\
\text { dissolved } \\
\text { (mg/L } \\
\text { as N) } \\
\text { (RSIL) } \\
\text { (00631) }\end{array}$ & $\begin{array}{c}\text { Dis- } \\
\text { solved } \\
\text { nitrate } \\
\text { plus } \\
\text { nitrite } \\
\delta^{\mathbf{1 5} N} \\
\text { (per mil) }\end{array}$ & $\begin{array}{c}\text { Phos- } \\
\text { phorus, } \\
\text { total } \\
(\mathbf{m g} / \mathbf{L} \\
\text { as P) } \\
(\mathbf{0 0 6 6 5})\end{array}$ & $\begin{array}{c}\text { Phos- } \\
\text { phorus, } \\
\text { dissolved } \\
(\mathbf{m g} / \mathrm{L}) \\
(\mathbf{0 0 6 6 6})\end{array}$ & $\begin{array}{c}\text { Phos- } \\
\text { phorus, } \\
\text { ortho, } \\
\text { dissolved } \\
\text { (mg/L } \\
\text { as P) } \\
(00671)\end{array}$ & $\begin{array}{c}\begin{array}{c}\text { Original } \\
\text { (recon- } \\
\text { structed) }\end{array} \\
\mathrm{NO}_{3} \\
(\mathrm{mg} / \mathrm{L} \\
\text { as N) }\end{array}$ & $\begin{array}{c}\text { Excess } \mathbf{N}_{2} \\
(\mathrm{mg} / \mathbf{L} \\
\text { as } \mathbf{N})\end{array}$ \\
\hline \multicolumn{18}{|c|}{ Dometic wells in Muddy Creek watershed (Owner's name is Local ID)—Continued } \\
\hline 39S41 & Weintraub (1) & $4 / 15 / 99$ & 1200 & 0.097 & -- & $<0.010$ & 0.246 & -- & 15.7 & 16.1 & 15.9 & 11.98 & -- & $<0.050$ & 0.017 & 17.9 & 2.20 \\
\hline $39 \mathrm{~S} 42$ & Weintraub (2) & $4 / 15 / 99$ & 1300 & $<.020$ & -- & $<.010$ & e .054 & -- & 4.68 & 3.23 & 3.22 & 15.06 & -- & $<.050$ & .010 & 9.57 & 4.90 \\
\hline $39 \mathrm{~S} 43$ & Martin & $4 / 16 / 99$ & 0900 & $<.020$ & -- & $<.010$ & $<.100$ & -- & $<.050$ & $<.050$ & -- & -- & -- & $<.050$ & $<.011$ & .34 & .30 \\
\hline 39S44 & Smith & $4 / 16 / 99$ & 1100 & $<.020$ & -- & $<.010$ & e .069 & -- & 22.3 & 23.5 & 22.9 & 10.31 & -- & $<.050$ & $<.011$ & 23.1 & .85 \\
\hline \multicolumn{18}{|c|}{ Polecat Creek Watershed } \\
\hline $50 \mathrm{M} 2$ & & $4 / 19 / 99$ & 1000 & $<0.020$ & -- & $<.010$ & $<.100$ & -- & .252 & .269 & & & -- & $<.050$ & .018 & .24 & .00 \\
\hline $50 \mathrm{M} 3$ & & $4 / 19 / 99$ & 1100 & $<.020$ & -- & $<.010$ & $<.100$ & -- & 2.60 & 2.62 & 2.49 & 3.20 & -- & $<.050$ & $<.010$ & 2.59 & .00 \\
\hline $50 \mathrm{M} 4$ & & $4 / 19 / 99$ & 1800 & $<.020$ & -- & $<.010$ & $<.100$ & -- & 3.51 & 3.28 & 3.01 & 2.21 & -- & $<.050$ & .015 & 3.50 & .00 \\
\hline 50M5 & & $4 / 20 / 99$ & 1500 & .04 & -- & $<.010$ & e .068 & -- & .100 & $<.050$ & -- & -- & -- & $<.050$ & .010 & .09 & .00 \\
\hline $50 \mathrm{M} 6$ & & $4 / 21 / 99$ & 0800 & $<.020$ & -- & $<.010$ & $<.100$ & -- & .097 & $<.050$ & -- & -- & -- & $<.050$ & .011 & .09 & .00 \\
\hline $50 \mathrm{M} 7$ & & $4 / 21 / 99$ & 1500 & $<.020$ & -- & $<.010$ & $<.100$ & -- & .230 & .269 & -- & -- & -- & e .041 & .047 & .22 & .00 \\
\hline 50M16 & & 4/19/99 & 1200 & $<.020$ & -- & $<.010$ & $<.100$ & -- & 3.82 & 3.70 & 3.64 & 2.19 & -- & $<.050$ & $<.010$ & 3.81 & .00 \\
\hline 50M17 & & 4/19/99 & 1500 & $<.020$ & -- & $<.010$ & $<.100$ & -- & 3.74 & 3.68 & 2.33 & 2.36 & -- & $<.050$ & $<.011$ & 3.73 & .00 \\
\hline 50M18 & & $4 / 20 / 99$ & 0800 & $<.020$ & -- & $<.010$ & e .053 & -- & 2.41 & 2.39 & 2.13 & 2.43 & -- & $<.050$ & $<.012$ & 2.40 & .00 \\
\hline 50M19 & & $4 / 19 / 99$ & 1700 & .02 & -- & $<.010$ & $<.100$ & -- & 3.29 & 3.16 & 2.90 & 2.14 & -- & $<.050$ & $<.011$ & 3.28 & .00 \\
\hline $50 \mathrm{M} 21$ & & $4 / 20 / 99$ & 1100 & $<.020$ & -- & $<.010$ & $<.100$ & -- & .109 & $<.050$ & -- & -- & -- & $<.050$ & $<.013$ & .10 & .00 \\
\hline $50 \mathrm{M} 22$ & & $4 / 20 / 99$ & 1300 & $<.020$ & -- & $<.010$ & $<.100$ & -- & . 106 & $<.050$ & -- & -- & -- & $<.050$ & $<.010$ & .10 & .00 \\
\hline $50 \mathrm{M} 23$ & & $4 / 21 / 99$ & 0900 & .063 & -- & $<.010$ & . 136 & -- & .094 & $<.050$ & -- & -- & -- & $<.050$ & $<.012$ & . 08 & -- \\
\hline $50 \mathrm{M} 24$ & & $4 / 21 / 99$ & 1000 & $<.020$ & -- & $<.010$ & $<.100$ & -- & .101 & $<.050$ & -- & -- & -- & $<.050$ & $<.011$ & .09 & .00 \\
\hline $50 \mathrm{M} 25$ & & $4 / 21 / 99$ & 1200 & $<.020$ & -- & $<.010$ & $<.100$ & -- & 2.46 & 2.76 & 2.87 & 3.32 & -- & $<.050$ & $<.012$ & 2.45 & .00 \\
\hline $50 \mathrm{M} 26$ & & $4 / 21 / 99$ & 1400 & $<.020$ & -- & $<.010$ & $<.100$ & -- & 4.12 & 4.07 & 4.40 & 2.88 & -- & e. .031 & $<.012$ & 4.11 & .00 \\
\hline $50 \mathrm{M} 28$ & & $4 / 21 / 99$ & 0930 & .028 & -- & $<.010$ & .203 & -- & .101 & -- & & & & $<.050$ & .016 & .09 & -- \\
\hline $50 \mathrm{M} 27$ & & $3 / 29 / 00$ & 1415 & .060 & -- & $<.010$ & .380 & -- & 7.42 & -- & -- & -- & -- & .070 & .165 & 7.42 & \\
\hline $50 \mathrm{M} 29$ & & $4 / 10 / 00$ & 1300 & $<.020$ & -- & .013 & $<.100$ & e 0.060 & 1.02 & 1.18 & 1.05 & 4.27 & e 0.007 & . 006 & .010 & 1.01 & .00 \\
\hline 50M30 & & $4 / 10 / 00$ & 1100 & $<.020$ & -- & $<.010$ & .160 & .460 & $<.050$ & .102 & -- & -- & .057 & .006 & .010 & .04 & .00 \\
\hline \multicolumn{18}{|c|}{ Unnamed tributary to Little Mahantango Creek near Hepler, Pa. } \\
\hline \multirow[t]{3}{*}{ Stream } & 01555370 & $6 / 15 / 98$ & 1700 & .040 & -- & .012 & .246 & -- & 6.10 & 6.12 & 6.45 & 7.44 & -- & $<.010$ & $<.012$ & -- & -- \\
\hline & & $5 / 19 / 99$ & 1400 & .030 & -- & $<.010$ & .174 & -- & 3.59 & 3.46 & 3.58 & 6.90 & -- & $<.050$ & $<.012$ & -- & -- \\
\hline & & $5 / 9 / 00$ & 1130 & .048 & -- & .012 & .478 & .563 & 4.73 & 4.76 & 5.34 & 6.07 & .038 & .017 & $<.010$ & -- & -- \\
\hline
\end{tabular}


Appendix B. Nutrient and ${ }^{15} \mathrm{~N}$ concentrations in stream and ground water collected in the Chesapeake Bay Watershed, June 1998 through May 2000—Continued [mg/L, milligrams per liter; mp, minipiezometer; <, less than; $\mathrm{n} / \mathrm{a}$, not applicable; --, data not available; e, estimated value;

RSIL, Reston Stable Isotope Laboratory; analyses from U.S. Geological Survey National Water Quality Laboratory unless otherwise noted]

\begin{tabular}{|c|c|c|c|c|c|c|c|c|c|c|c|c|c|c|c|c|c|}
\hline $\begin{array}{c}\text { Site } \\
\text { name }\end{array}$ & $\begin{array}{c}\text { Local } \\
\text { ID }\end{array}$ & Date & Time & $\begin{array}{c}\text { Nitrogen, } \\
\text { ammonia, } \\
\text { dissolved } \\
(\mathbf{m g} / \mathrm{L} \text { as N) } \\
(\mathbf{0 0 6 0 8 )})\end{array}$ & $\begin{array}{c}\text { Dissolved } \\
\text { ammonia } \\
\delta^{15} \mathrm{~N} \\
(\text { per } \\
\text { mil) }\end{array}$ & $\begin{array}{c}\text { Nitrogen, } \\
\text { nitrite, } \\
\text { dissolved } \\
(\mathbf{m g} / \mathbf{L} \\
\text { as N) } \\
(00613)\end{array}$ & $\begin{array}{c}\text { Nitrogen, } \\
\text { ammonia } \\
+ \text { organic, } \\
\text { dissolved } \\
(\mathrm{mg} / \mathrm{L} \\
\text { as N) } \\
(00623)\end{array}$ & $\begin{array}{c}\text { Nitrogen, } \\
\text { ammonia } \\
+ \text { organic, } \\
\text { total } \\
(\mathrm{mg} / \mathrm{L} \\
\text { as } \mathrm{N}) \\
(00625)\end{array}$ & $\begin{array}{c}\text { Nitrate } \\
\text { plus } \\
\text { nitrite, } \\
\text { dissolved } \\
\text { (mg/L } \\
\text { as N) } \\
(00631)\end{array}$ & $\begin{array}{c}\text { Nitrate, } \\
\text { dissolved } \\
(\mathbf{m g} / \mathbf{L} \\
\text { as N) } \\
\text { (RSIL) }\end{array}$ & $\begin{array}{c}\text { Nitrate } \\
\text { plus } \\
\text { nitrite, } \\
\text { dissolved } \\
\text { (mg/L } \\
\text { as N) } \\
(\mathbf{R S I L}) \\
(\mathbf{0 0 6 3 1})\end{array}$ & $\begin{array}{c}\begin{array}{c}\text { Dis- } \\
\text { solved }\end{array} \\
\text { nitrate } \\
\text { plus } \\
\text { nitrite } \\
\delta^{15} \mathrm{~N} \\
\text { (per mil) }\end{array}$ & $\begin{array}{c}\text { Phos- } \\
\text { phorus, } \\
\text { total } \\
(\mathbf{m g} / \mathbf{L} \\
\text { as P) } \\
(\mathbf{0 0 6 6 5 )})\end{array}$ & $\begin{array}{c}\text { Phos- } \\
\text { phorus, } \\
\text { dissolved } \\
(\mathbf{m g} / \mathrm{L}) \\
(\mathbf{0 0 6 6 6})\end{array}$ & $\begin{array}{c}\text { Phos- } \\
\text { phorus, } \\
\text { ortho, } \\
\text { dissolved } \\
(\mathrm{mg} / \mathrm{L} \\
\text { as P) } \\
(00671)\end{array}$ & 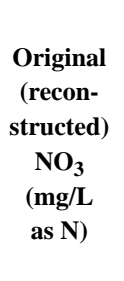 & $\begin{array}{c}\text { Excess } \mathbf{N}_{2} \\
(\mathrm{mg} / \mathrm{L} \\
\text { as N) }\end{array}$ \\
\hline \multicolumn{18}{|c|}{ Mahantango WE-38 Watershed, East Transect } \\
\hline & E1-10 & $5 / 10 / 99$ & 1145 & 0.033 & -- & $<0.010$ & e 0.086 & -- & 7.10 & 6.55 & 6.61 & 10.77 & -- & $<0.050$ & 0.915 & 1.99 & 3.90 \\
\hline & E1-20 & $5 / 10 / 99$ & 1245 & .050 & -- & $<.010$ & e. 091 & -- & $<.050$ & $<.050$ & -- & -- & -- & $<.050$ & .022 & 5.24 & 5.20 \\
\hline \multirow[t]{2}{*}{ NU 540} & $\mathrm{E} 2-10$ & $5 / 10 / 99$ & 1345 & .095 & -- & $<.010$ & .132 & -- & $<.050$ & $<.050$ & -- & -- & -- & .084 & .091 & 3.04 & 3.00 \\
\hline & & $5 / 9 / 00$ & 1600 & .052 & -- & $<.010$ & .146 & 1.75 & $<.050$ & $<.050$ & -- & -- & 1.13 & .104 & .088 & 3.94 & 3.90 \\
\hline \multirow{4}{*}{ NU 534} & E2-35 & $5 / 10 / 99$ & 1500 & .097 & -- & $<.010$ & .110 & -- & $<.050$ & $<.050$ & -- & -- & -- & .050 & .071 & 1.64 & 1.60 \\
\hline & E3-10 & $6 / 16 / 98$ & 1550 & .020 & -- & $<.010$ & $<.100$ & -- & .170 & .204 & -- & -- & -- & .070 & .086 & 1.46 & 1.30 \\
\hline & & $5 / 11 / 99$ & 0900 & .041 & -- & $<.010$ & e .093 & -- & $<.050$ & $<.050$ & -- & -- & -- & .093 & .091 & 1.74 & 1.70 \\
\hline & & $5 / 9 / 00$ & 1500 & .034 & -- & $<.010$ & $<.100$ & .245 & $<.050$ & $<.050$ & -- & -- & .026 & .105 & .084 & 2.14 & 2.10 \\
\hline \multirow[t]{2}{*}{ NU 535} & E3-20 & $6 / 15 / 98$ & 1720 & $<.020$ & -- & $<.010$ & .101 & -- & $<.050$ & $<.050$ & -- & -- & -- & .033 & $<.010$ & 2.94 & 2.90 \\
\hline & & $5 / 11 / 99$ & 1100 & .053 & -- & $<.010$ & e .085 & -- & $<.050$ & $<.050$ & -- & -- & -- & $<.050$ & .026 & 1.24 & 1.20 \\
\hline \multirow[t]{2}{*}{ NU 536} & E3-30 & $6 / 17 / 98$ & 1120 & .037 & -- & $<.010$ & $<.100$ & -- & .068 & $<.050$ & -- & -- & -- & .024 & .029 & 1.56 & 1.50 \\
\hline & & $5 / 11 / 99$ & 1200 & .038 & -- & $<.010$ & .111 & -- & $<.050$ & $<.050$ & -- & -- & -- & .058 & .06 & 2.04 & 2.00 \\
\hline \multirow[t]{2}{*}{ NU 537} & E3-45 & $6 / 18 / 98$ & 0930 & $<.020$ & -- & .01 & $<.100$ & -- & 2.85 & $<.050$ & 2.67 & 3.51 & -- & $<.010$ & $<.010$ & 4.24 & 1.40 \\
\hline & & $5 / 10 / 99$ & 1600 & .045 & -- & $<.010$ & $<.100$ & -- & .660 & .599 & .322 & 2.21 & -- & $<.050$ & .022 & 1.35 & .70 \\
\hline \multirow[t]{3}{*}{ NU 529} & E4-10 & $6 / 16 / 98$ & 1420 & .026 & -- & $<.010$ & $<.100$ & -- & 9.83 & 9.55 & 8.93 & 2.60 & -- & $<.010$ & $<.010$ & 9.82 & .00 \\
\hline & & $5 / 11 / 99$ & 1300 & $<.020$ & -- & $<.010$ & e .084 & -- & 10.0 & 9.19 & 9.34 & 2.61 & -- & $<.050$ & .027 & 10.3 & .30 \\
\hline & & $5 / 9 / 00$ & 0930 & .049 & -- & .01 & .139 & .346 & 9.87 & 10.1 & 10.3 & 2.64 & .024 & .012 & $<.010$ & 10.5 & .60 \\
\hline \multirow[t]{3}{*}{ NU 530} & E4-20 & $6 / 17 / 98$ & 1020 & .023 & -- & $<.010$ & $<.100$ & -- & 9.36 & 9.40 & 8.57 & 2.53 & -- & $<.010$ & $<.010$ & 9.35 & .00 \\
\hline & & $5 / 11 / 99$ & 1400 & .034 & -- & $<.010$ & e .087 & -- & 9.85 & 9.22 & 9.23 & 2.69 & -- & $<.050$ & .019 & 9.94 & .10 \\
\hline & & $5 / 9 / 00$ & 1000 & $<.020$ & -- & $<.010$ & $<.100$ & .206 & 9.80 & 9.75 & 9.93 & 2.71 & .092 & .009 & $<.010$ & 10.4 & .60 \\
\hline
\end{tabular}


Appendix B. Nutrient and ${ }^{15} \mathrm{~N}$ concentrations in stream and ground water collected in the Chesapeake Bay Watershed, June 1998 through May 2000—Continued [mg/L, milligrams per liter; mp, minipiezometer; <, less than; $\mathrm{n} / \mathrm{a}$, not applicable; --, data not available; e, estimated value;

RSIL, Reston Stable Isotope Laboratory; analyses from U.S. Geological Survey National Water Quality Laboratory unless otherwise noted]

\begin{tabular}{|c|c|c|c|c|c|c|c|c|c|c|c|c|c|c|c|c|c|}
\hline $\begin{array}{c}\text { Site } \\
\text { name }\end{array}$ & $\begin{array}{c}\text { Local } \\
\text { ID }\end{array}$ & Date & Time & $\begin{array}{c}\text { Nitrogen, } \\
\text { ammonia, } \\
\text { dissolved } \\
(\mathbf{m g} / \mathbf{L} \text { as } \mathbf{N}) \\
(\mathbf{0 0 6 0 8})\end{array}$ & $\begin{array}{c}\text { Dissolved } \\
\text { ammonia } \\
\delta^{15} \mathrm{~N} \\
(\mathrm{per} \\
\text { mil) }\end{array}$ & $\begin{array}{c}\text { Nitrogen, } \\
\text { nitrite, } \\
\text { dissolved } \\
(\mathrm{mg} / \mathrm{L} \\
\text { as N) } \\
(\mathbf{0 0 6 1 3})\end{array}$ & $\begin{array}{c}\text { Nitrogen, } \\
\text { ammonia } \\
\text { + organic, } \\
\text { dissolved } \\
(\mathrm{mg} / \mathrm{L} \\
\text { as N) } \\
(00623)\end{array}$ & $\begin{array}{c}\text { Nitrogen, } \\
\text { ammonia } \\
\text { + organic, } \\
\text { total } \\
(\mathrm{mg} / \mathrm{L} \\
\text { as N) } \\
(00625)\end{array}$ & $\begin{array}{c}\text { Nitrate } \\
\text { plus } \\
\text { nitrite, } \\
\text { dissolved } \\
\text { (mg/L } \\
\text { as N) } \\
(00631)\end{array}$ & $\begin{array}{c}\text { Nitrate, } \\
\text { dissolved } \\
\text { (mg/L } \\
\text { as N) } \\
\text { (RSIL) }\end{array}$ & 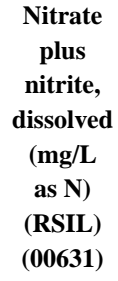 & $\begin{array}{c}\text { Dis- } \\
\text { solved } \\
\text { nitrate } \\
\text { plus } \\
\text { nitrite } \\
\delta^{15} \mathrm{~N} \\
\text { (per mil) }\end{array}$ & $\begin{array}{c}\text { Phos- } \\
\text { phorus, } \\
\text { total } \\
(\mathbf{m g} / \mathrm{L} \\
\text { as P) } \\
(\mathbf{0 0 6 6 5 )})\end{array}$ & $\begin{array}{c}\text { Phos- } \\
\text { phorus, } \\
\text { dissolved } \\
(\mathbf{m g} / \mathrm{L}) \\
(00666)\end{array}$ & $\begin{array}{c}\text { Phos- } \\
\text { phorus, } \\
\text { ortho, } \\
\text { dissolved } \\
(\mathrm{mg} / \mathrm{L} \\
\text { as P) } \\
(00671)\end{array}$ & $\begin{array}{c}\begin{array}{c}\text { Original } \\
\text { (recon- } \\
\text { structed) }\end{array} \\
\mathrm{NO}_{3} \\
(\mathrm{mg} / \mathrm{L} \\
\text { as N) }\end{array}$ & $\begin{array}{c}\text { Excess } \mathbf{N}_{2} \\
(\mathrm{mg} / \mathrm{L} \\
\text { as N) }\end{array}$ \\
\hline \multicolumn{18}{|c|}{ Mahantango WE-38 Watershed, East Transect-Continued } \\
\hline \multirow[t]{2}{*}{ NU 531} & $\mathrm{E} 4-30$ & $6 / 16 / 98$ & 1630 & 0.038 & -- & $<0.010$ & $<0.100$ & -- & 7.51 & 7.88 & 7.00 & 3.50 & -- & $<0.010$ & $<0.010$ & 7.60 & 0.10 \\
\hline & $\mathrm{E} 4-30$ & $5 / 11 / 99$ & 1445 & $<.020$ & -- & $<.010$ & $<.100$ & -- & 8.87 & 8.54 & 8.30 & 2.83 & -- & $<.050$ & $<.010$ & 8.96 & .10 \\
\hline \multirow[t]{3}{*}{ NU 532} & E4-45 & $6 / 17 / 98$ & 1430 & $<.020$ & -- & .013 & $<.100$ & -- & 7.03 & 6.91 & 6.95 & 3.49 & -- & $<.010$ & $<.010$ & 8.12 & 1.10 \\
\hline & & $5 / 11 / 99$ & 1530 & .140 & -- & $<.010$ & .161 & -- & 7.87 & 7.39 & 7.35 & 3.02 & -- & $<.050$ & .018 & 8.36 & .50 \\
\hline & & $5 / 9 / 00$ & 1100 & .179 & -- & $<.010$ & .199 & 0.607 & 7.43 & 7.42 & 7.23 & 3.11 & 0.172 & e .003 & $<.010$ & 8.22 & .80 \\
\hline \multirow[t]{3}{*}{ NU 533} & E4-60 & $6 / 18 / 98$ & 1015 & $<.020$ & -- & $<.010$ & $<.100$ & -- & 7.41 & 7.24 & 7.23 & 2.95 & -- & $<.010$ & $<.010$ & 7.40 & .00 \\
\hline & & $5 / 11 / 99$ & 1600 & .042 & -- & $<.010$ & $<.100$ & -- & 7.86 & 6.55 & 6.64 & 2.90 & -- & $<.05$ & .031 & 7.95 & .10 \\
\hline & & $5 / 9 / 00$ & 1300 & .071 & -- & $<.010$ & .101 & .188 & 7.03 & 6.92 & 7.40 & 3.42 & .032 & .016 & .011 & 7.32 & .30 \\
\hline \multirow[t]{3}{*}{ NU 526} & E5-10 & $6 / 16 / 98$ & 1130 & $<.020$ & -- & $<.010$ & .163 & -- & 9.71 & 8.98 & 9.59 & 3.04 & -- & $<.010$ & $<.010$ & 9.70 & .00 \\
\hline & & $5 / 12 / 99$ & 1100 & .026 & -- & $<.010$ & e .050 & -- & 10.3 & 9.53 & 9.31 & 2.60 & -- & $<.050$ & .011 & 10.32 & .00 \\
\hline & & $5 / 9 / 00$ & 1300 & $<.020$ & -- & $<.010$ & $<.100$ & .865 & 11.2 & 11.5 & 11.3 & 3.45 & .205 & e .003 & $<.010$ & 11.5 & .30 \\
\hline NU 527 & E5-45 & $6 / 17 / 98$ & 1300 & $<.020$ & -- & $<.010$ & $<.100$ & -- & 11.8 & 10.6 & 10.2 & 2.38 & -- & $<.010$ & $<.010$ & 11.8 & .00 \\
\hline \multirow[t]{2}{*}{ NU 528} & E5-60 & $6 / 17 / 98$ & 1700 & .026 & -- & .029 & $<.100$ & -- & 7.26 & 7.39 & 7.11 & 2.62 & -- & $<.010$ & $<.010$ & 7.23 & .00 \\
\hline & & $5 / 12 / 99$ & 1000 & .034 & -- & $<.010$ & .103 & -- & 8.07 & 7.23 & 6.83 & 2.59 & -- & $<.050$ & .033 & 8.06 & .00 \\
\hline \multirow[t]{3}{*}{ NU 542} & E6-35 & $5 / 12 / 99$ & 1200 & .035 & -- & $<.010$ & .150 & -- & 10.6 & 10.6 & 10.5 & 2.45 & -- & $<.050$ & .049 & 10.6 & .00 \\
\hline & & $5 / 9 / 00$ & 1400 & $<.020$ & -- & $<.010$ & e .092 & .448 & 12.3 & 12.6 & 12.90 & 2.59 & .194 & .010 & $<.010$ & 12.2 & .00 \\
\hline & E7-10 & $5 / 12 / 99$ & 1330 & .047 & -- & $<.010$ & e .059 & -- & 11.6 & 10.5 & 10.4 & 2.36 & -- & $<.05$ & .019 & 11.6 & .00 \\
\hline \multicolumn{18}{|c|}{ Mahantango WE-38 Watershed, West Transect } \\
\hline & W1-20 & $5 / 14 / 99$ & 1030 & .036 & -- & $<.010$ & e .090 & -- & 1.60 & 1.67 & 1.57 & 2.53 & -- & e .036 & .041 & 1.89 & .30 \\
\hline \multirow[t]{2}{*}{ NU 545} & W2-20 & $5 / 14 / 99$ & 0930 & .054 & -- & $<.010$ & e .058 & -- & .783 & .825 & .826 & 5.34 & -- & .087 & .063 & 1.47 & .70 \\
\hline & & $5 / 10 / 00$ & 0900 & .050 & -- & $<.010$ & e .081 & .191 & .798 & .893 & .590 & 4.22 & .211 & .081 & .076 & 1.29 & .50 \\
\hline \multirow[t]{2}{*}{ NU 546} & W2-30 & $5 / 14 / 99$ & 0900 & .121 & -- & .016 & .151 & -- & .687 & .680 & .714 & 3.82 & -- & .067 & .064 & .67 & .00 \\
\hline & & $5 / 10 / 00$ & 1100 & .111 & -- & $<.010$ & .247 & .470 & .481 & .508 & .500 & 10.54 & .262 & .148 & .115 & 1.37 & .90 \\
\hline
\end{tabular}


Appendix B. Nutrient and ${ }^{15} \mathrm{~N}$ concentrations in stream and ground water collected in the Chesapeake Bay Watershed, June 1998 through May 2000—Continued [mg/L, milligrams per liter; mp, minipiezometer; <, less than; n/a, not applicable; --, data not available; e, estimated value;

RSIL, Reston Stable Isotope Laboratory; analyses from U.S. Geological Survey National Water Quality Laboratory unless otherwise noted]

\begin{tabular}{|c|c|c|c|c|c|c|c|c|c|c|c|c|c|c|c|c|c|}
\hline $\begin{array}{c}\text { Site } \\
\text { name }\end{array}$ & $\begin{array}{l}\text { Local } \\
\text { ID }\end{array}$ & Date & Time & $\begin{array}{c}\text { Nitrogen, } \\
\text { ammonia, } \\
\text { dissolved } \\
(\mathrm{mg} / \mathrm{L} \text { as } \mathrm{N}) \\
(\mathbf{0 0 6 0 8})\end{array}$ & $\begin{array}{c}\text { Dissolved } \\
\text { ammonia } \\
\delta^{15} \mathrm{~N} \\
\text { (per } \\
\text { mil) }\end{array}$ & $\begin{array}{c}\text { Nitrogen, } \\
\text { nitrite, } \\
\text { dissolved } \\
(\mathrm{mg} / \mathrm{L} \\
\text { as N) } \\
(00613)\end{array}$ & $\begin{array}{c}\text { Nitrogen, } \\
\text { ammonia } \\
\text { + organic, } \\
\text { dissolved } \\
(\mathrm{mg} / \mathrm{L} \\
\text { as N) } \\
(00623)\end{array}$ & $\begin{array}{c}\text { Nitrogen, } \\
\text { ammonia } \\
+ \text { organic, } \\
\text { total } \\
(\mathrm{mg} / \mathrm{L} \\
\text { as } \mathrm{N}) \\
(00625)\end{array}$ & $\begin{array}{c}\text { Nitrate } \\
\text { plus } \\
\text { nitrite, } \\
\text { dissolved } \\
(\mathrm{mg} / \mathrm{L} \\
\text { as N) } \\
(00631)\end{array}$ & $\begin{array}{c}\text { Nitrate, } \\
\text { dissolved } \\
(\mathrm{mg} / \mathrm{L} \\
\text { as N) } \\
\text { (RSIL) }\end{array}$ & $\begin{array}{c}\begin{array}{c}\text { Nitrate } \\
\text { plus }\end{array} \\
\text { nitrite, } \\
\text { dissolved } \\
\text { (mg/L } \\
\text { as N) } \\
\text { (RSIL) } \\
\text { (00631) }\end{array}$ & $\begin{array}{c}\text { Dis- } \\
\text { solved } \\
\text { nitrate } \\
\text { plus } \\
\text { nitrite } \\
\delta^{15} \mathbf{N} \\
\text { (per mil) }\end{array}$ & $\begin{array}{c}\text { Phos- } \\
\text { phorus, } \\
\text { total } \\
(\mathbf{m g} / \mathrm{L} \\
\text { as P) } \\
(\mathbf{0 0 6 6 5})\end{array}$ & $\begin{array}{c}\text { Phos- } \\
\text { phorus, } \\
\text { dissolved } \\
(\mathbf{m g} / \mathrm{L}) \\
(\mathbf{0 0 6 6 6 )})\end{array}$ & $\begin{array}{c}\text { Phos- } \\
\text { phorus, } \\
\text { ortho, } \\
\text { dissolved } \\
(\mathrm{mg} / \mathrm{L} \\
\text { as P) } \\
(\mathbf{0 0 6 7 1})\end{array}$ & $\begin{array}{c}\begin{array}{c}\text { Original } \\
\text { (recon- }\end{array} \\
\text { structed) } \\
\mathrm{NO}_{3} \\
(\mathbf{m g} / \mathrm{L} \\
\text { as N) }\end{array}$ & $\begin{array}{c}\text { Excess } \mathbf{N}_{2} \\
(\mathbf{m g} / \mathbf{L} \\
\text { as N) }\end{array}$ \\
\hline \multicolumn{18}{|c|}{ Mahantango WE-38 Watershed, West Transect-Continued } \\
\hline \multirow[t]{7}{*}{ NU 547} & W2-40 & $5 / 14 / 99$ & 0800 & 0.326 & -- & $<0.010$ & 0.348 & -- & .846 & .825 & .868 & 3.79 & -- & 0.074 & 0.069 & 1.74 & 0.90 \\
\hline & & $5 / 10 / 00$ & 1200 & 3.69 & -- & .015 & 4.2 & 5.45 & .479 & 4.32 & 5.28 & 4.04 & 0.833 & .439 & .334 & .96 & .50 \\
\hline & W3-10 & $5 / 12 / 99$ & 1500 & .038 & -- & $<.010$ & .104 & -- & 10.6 & 9.85 & 9.09 & 4.33 & -- & $<.050$ & .017 & 10.7 & .10 \\
\hline & W3-20 & $5 / 12 / 99$ & 1600 & .036 & -- & $<.010$ & e .061 & -- & 8.01 & 7.12 & 6.87 & 3.33 & -- & e .033 & .040 & 8.30 & .30 \\
\hline & W3-30 & $5 / 12 / 99$ & 1630 & .042 & -- & $<.010$ & e .087 & -- & 6.54 & 5.83 & 5.66 & 4.04 & -- & $<.050$ & .027 & 6.73 & .20 \\
\hline & W3-45 & $5 / 13 / 99$ & 1500 & .042 & -- & $<.010$ & .144 & -- & 2.65 & 2.70 & 2.62 & 4.94 & -- & $<.050$ & .031 & 2.64 & .00 \\
\hline & W3-65 & $5 / 13 / 99$ & 1600 & .205 & -- & $<.010$ & .395 & -- & 3.10 & 3.30 & 3.32 & 3.51 & -- & $<.050$ & .056 & 3.09 & .00 \\
\hline \multirow[t]{2}{*}{ NU 533} & W4-30 & $5 / 13 / 99$ & 1200 & .051 & -- & $<.010$ & $<.1$ & -- & 9.53 & 8.58 & 8.26 & 4.79 & -- & e .031 & .030 & 9.52 & .00 \\
\hline & & $5 / 10 / 00$ & 1300 & $<.020$ & -- & $<.010$ & $<.1$ & .301 & 8.43 & 8.42 & 8.70 & 4.76 & .264 & .021 & .013 & 9.82 & 1.40 \\
\hline \multirow[t]{2}{*}{ NU 554} & W4-40 & $5 / 13 / 99$ & 1300 & .061 & -- & $<.010$ & .181 & -- & 5.14 & 6.58 & 7.03 & 7.01 & -- & $<.050$ & .035 & 6.43 & 1.30 \\
\hline & & $5 / 10 / 00$ & 1330 & .022 & -- & $<.010$ & .141 & .421 & 7.93 & 8.01 & 8.15 & 5.98 & .142 & .034 & .019 & 9.22 & 1.30 \\
\hline \multirow[t]{3}{*}{ NU 555} & W5-10 & $5 / 13 / 99$ & 1100 & .039 & -- & $<.010$ & .132 & -- & 12.3 & 11.9 & 11.6 & 2.88 & -- & $<.050$ & .014 & 12.8 & .50 \\
\hline & & $5 / 10 / 00$ & 1500 & $<.020$ & -- & $<.010$ & e .073 & .368 & 11.5 & 12.0 & 12.1 & 2.87 & .063 & .006 & $<.010$ & 12.0 & .50 \\
\hline & W5-45 & $5 / 13 / 99$ & 1000 & .040 & -- & $<.010$ & .148 & -- & 8.92 & 8.90 & 8.53 & 4.41 & -- & $<.050$ & .024 & 9.31 & .40 \\
\hline $\begin{array}{l}\text { NU } 562 \\
\quad \text { (forested) }\end{array}$ & & $5 / 17 / 00$ & 1330 & $<.020$ & -- & $<.010$ & $<.100$ & e .060 & .243 & .351 & .240 & .77 & $<.008$ & $<.006$ & $<.010$ & .23 & .00 \\
\hline $\begin{array}{l}\text { NU } 563 \\
\text { (hog manure } \\
\text { applied) }\end{array}$ & & $5 / 17 / 00$ & 1500 & $<.020$ & -- & $<.010$ & $<.100$ & .198 & 5.24 & 5.29 & 5.42 & 4.32 & .129 & .122 & .115 & 6.03 & .80 \\
\hline \multicolumn{18}{|c|}{$\begin{array}{l}\text { applied) } \\
\text { Masser's (recharge site - fertilizer applied) }\end{array}$} \\
\hline $\begin{array}{l}\text { NU } 558 \\
\quad \text { (shallow) } \\
\text { Well NW }\end{array}$ & & $5 / 8 / 00$ & 1400 & $<.020$ & -- & $<.010$ & .122 & .144 & 21.1 & $<.050$ & 21.3 & 6.97 & .107 & e .003 & .010 & 21.1 & .00 \\
\hline $\begin{array}{l}\text { NU } 558 \text { (deep) } \\
\text { Well NW }\end{array}$ & & $5 / 8 / 00$ & 1500 & .022 & -- & $<.010$ & .100 & .277 & 19.0 & $<.050$ & 20.8 & 6.62 & .105 & $<.006$ & $<.010$ & 23.5 & 4.50 \\
\hline
\end{tabular}


Appendix B. Nutrient and ${ }^{15} \mathrm{~N}$ concentrations in stream and ground water collected in the Chesapeake Bay Watershed, June 1998 through May 2000—Continued [mg/L, milligrams per liter; mp, minipiezometer; <, less than; $\mathrm{n} / \mathrm{a}$, not applicable; --, data not available; e, estimated value;

RSIL, Reston Stable Isotope Laboratory; analyses from U.S. Geological Survey National Water Quality Laboratory unless otherwise noted]

\begin{tabular}{|c|c|c|c|c|c|c|c|c|c|c|c|c|c|c|c|c|c|}
\hline $\begin{array}{l}\text { Site } \\
\text { name }\end{array}$ & $\begin{array}{l}\text { Local } \\
\text { ID }\end{array}$ & Date & Time & $\begin{array}{c}\text { Nitrogen, } \\
\text { ammonia, } \\
\text { dissolved } \\
(\mathrm{mg} / \mathrm{L} \text { as } \mathbf{N}) \\
(\mathbf{0 0 6 0 8})\end{array}$ & $\begin{array}{c}\text { Dissolved } \\
\text { ammonia } \\
\delta^{\mathbf{1 5}} \mathrm{N} \\
\text { (per } \\
\text { mil) }\end{array}$ & $\begin{array}{c}\text { Nitrogen, } \\
\text { nitrite, } \\
\text { dissolved } \\
(\mathbf{m g} / \mathrm{L} \\
\text { as N) } \\
(00613)\end{array}$ & $\begin{array}{c}\text { Nitrogen, } \\
\text { ammonia } \\
\text { + organic, } \\
\text { dissolved } \\
(\mathrm{mg} / \mathrm{L} \\
\text { as N) } \\
(00623)\end{array}$ & $\begin{array}{c}\text { Nitrogen, } \\
\text { ammonia } \\
\text { + organic, } \\
\text { total } \\
(\mathrm{mg} / \mathrm{L} \\
\text { as } \mathrm{N}) \\
(00625)\end{array}$ & $\begin{array}{c}\text { Nitrate } \\
\text { plus } \\
\text { nitrite, } \\
\text { dissolved } \\
\text { (mg/L } \\
\text { as N) } \\
(\mathbf{0 0 6 3 1})\end{array}$ & $\begin{array}{c}\text { Nitrate, } \\
\text { dissolved } \\
\text { (mg/L } \\
\text { as N) } \\
\text { (RSIL) }\end{array}$ & $\begin{array}{c}\begin{array}{c}\text { Nitrate } \\
\text { plus }\end{array} \\
\text { nitrite, } \\
\text { dissolved } \\
\text { (mg/L } \\
\text { as N) } \\
\text { (RSIL) } \\
(\mathbf{0 0 6 3 1})\end{array}$ & $\begin{array}{c}\text { Dis- } \\
\text { solved } \\
\text { nitrate } \\
\text { plus } \\
\text { nitrite } \\
\delta^{15} \mathrm{~N} \\
\text { (per mil) }\end{array}$ & $\begin{array}{c}\text { Phos- } \\
\text { phorus, } \\
\text { total } \\
(\mathbf{m g} / \mathrm{L} \\
\text { as } \mathrm{P}) \\
(\mathbf{0 0 6 6 5 )}\end{array}$ & $\begin{array}{c}\text { Phos- } \\
\text { phorus, } \\
\text { dissolved } \\
(\mathbf{m g} / \mathrm{L}) \\
(\mathbf{0 0 6 6 6})\end{array}$ & $\begin{array}{c}\text { Phos- } \\
\text { phorus, } \\
\text { ortho, } \\
\text { dissolved } \\
(\mathrm{mg} / \mathrm{L} \\
\text { as P) } \\
(00671)\end{array}$ & $\begin{array}{c}\begin{array}{c}\text { Original } \\
\text { (recon- } \\
\text { structed) }\end{array} \\
\mathrm{NO}_{3} \\
(\mathrm{mg} / \mathrm{L} \\
\text { as N) }\end{array}$ & $\begin{array}{c}\text { Excess } \mathbf{N}_{2} \\
(\mathrm{mg} / \mathrm{L} \\
\text { as } \mathbf{N})\end{array}$ \\
\hline \multicolumn{18}{|c|}{ Masser's (recharge site - fertilizer applied)—Continued } \\
\hline $\begin{array}{l}\text { NU } 559 \\
\text { (shallow) } \\
\text { Well NE }\end{array}$ & & $5 / 8 / 00$ & 1300 & .026 & -- & $<.010$ & .126 & .226 & 21.0 & $<.050$ & 22.7 & 7.01 & .050 & $<.006$ & $<.010$ & 2.98 & .00 \\
\hline $\begin{array}{l}\text { NU } 559 \text { (deep) } \\
\text { Well NE }\end{array}$ & & $5 / 8 / 00$ & 1130 & 0.020 & -- & $<.010$ & 0.157 & 0.153 & 21.4 & $<0.050$ & 23.2 & 7.70 & .024 & $<.006$ & $<0.010$ & 21.4 & 0.00 \\
\hline \multicolumn{18}{|c|}{ Springs sampled as part of Chesapeake Bay Ground Water initiative during 1997} \\
\hline $4 \mathrm{H}$ camp spr. & MD-HA-Bc-30 & 08/05/97 & 1017 & -- & -- & -- & -- & -- & -- & -- & 1.2 & 6.7 & -- & -- & -- & -- & -- \\
\hline Black Rock Spr. & MD-WA CJ23 & 08/08/97 & 1615 & -- & -- & -- & -- & -- & -- & -- & 2.0 & 6.0 & -- & -- & -- & -- & -- \\
\hline Blue Hole Spr. & MD-AL-CE-1 & 08/11/97 & 1230 & -- & -- & -- & -- & -- & -- & -- & .7 & 5.1 & -- & -- & -- & -- & -- \\
\hline Harver Spr. & MD-WA-Ak-3 & 08/08/97 & 1000 & & & & & & & & 3.0 & 5.5 & & & & & \\
\hline Hillbilly Spr. & MD-FR ED 82 & 08/07/97 & 1530 & -- & -- & -- & -- & -- & -- & -- & 5.9 & 4.6 & -- & -- & -- & -- & -- \\
\hline $\begin{array}{l}\text { Jefferson Davis } \\
\text { spr }\end{array}$ & MD-AL CF46 & 08/11/97 & 1500 & -- & -- & -- & -- & -- & -- & -- & -- & -- & -- & -- & -- & -- & -- \\
\hline Keedysville spr. & MD-WA-Di-6 & 08/08/97 & 1305 & & & & & & & & 3.6 & 5.7 & & & & & \\
\hline Lilypons Spr. & MD-FR-FD-55 & 08/07/97 & 1013 & -- & -- & -- & -- & -- & -- & -- & 11.7 & 7.0 & -- & -- & -- & -- & -- \\
\hline Manchester Spr. & MD CL Bf 183 & 08/06/97 & 1034 & -- & -- & -- & -- & -- & -- & -- & 7.1 & 9.0 & -- & -- & -- & -- & -- \\
\hline $\begin{array}{l}\text { Oregon Ridge } \\
\text { spr. }\end{array}$ & MD-BA-DC-440 & 08/05/97 & 1320 & -- & -- & -- & -- & -- & -- & -- & 2.5 & 5.3 & -- & -- & -- & -- & -- \\
\hline Phillips Spring & MD-FR-PHILS & 08/06/97 & 1740 & -- & -- & -- & -- & -- & -- & -- & 3.1 & 6.2 & -- & -- & -- & -- & -- \\
\hline $\begin{array}{l}\text { Retirement Cen- } \\
\text { ter }\end{array}$ & MD-BA-DE1 & 08/05/97 & 1547 & -- & -- & -- & -- & -- & -- & -- & 5.0 & 5.2 & -- & -- & -- & -- & -- \\
\hline $\begin{array}{l}\text { South of Gum } \\
\text { Spring } \\
\text { Pennsylvania }\end{array}$ & MD-FR-Fb-12 & 08/07/97 & 1308 & -- & -- & -- & -- & -- & -- & -- & 6.0 & 9.9 & -- & -- & -- & -- & -- \\
\hline Alexander Spr. & PA-Cu-16 & 08/19/97 & 1210 & -- & -- & -- & -- & -- & -- & -- & 6.0 & 4.0 & -- & -- & -- & -- & -- \\
\hline $\begin{array}{l}\text { Bellfonte } \\
\text { Fishery Spr. }\end{array}$ & PA-Ce-12 & $08 / 21 / 97$ & 850 & -- & -- & -- & -- & -- & -- & -- & 3.2 & 6.6 & -- & -- & -- & -- & -- \\
\hline Benner Spr. & PA-Ce-18 & $08 / 21 / 97$ & 1200 & & & & & & & & 2.5 & 5.0 & & & & & \\
\hline Big Spr. & PA-Cu-22 & 08/19/97 & 1525 & -- & -- & -- & -- & -- & -- & -- & 4.8 & 4.5 & -- & -- & -- & -- & -- \\
\hline Clouser Spr. & PA-Pe-10 & 08/20/97 & 1040 & -- & -- & -- & -- & -- & -- & -- & 6.2 & 7.4 & -- & -- & -- & -- & -- \\
\hline Donegal Spr. & PA-Ln-14 & 08/18/97 & 1522 & -- & -- & -- & -- & -- & -- & -- & 21.3 & 1.1 & -- & -- & -- & -- & -- \\
\hline
\end{tabular}


Appendix B. Nutrient and ${ }^{15} \mathrm{~N}$ concentrations in stream and ground water collected in the Chesapeake Bay Watershed, June 1998 through May 2000—Continued [mg/L, milligrams per liter; mp, minipiezometer; <, less than; $\mathrm{n} / \mathrm{a}$, not applicable; --, data not available; e, estimated value;

RSIL, Reston Stable Isotope Laboratory; analyses from U.S. Geological Survey National Water Quality Laboratory unless otherwise noted]

\begin{tabular}{|c|c|c|c|c|c|c|c|c|c|c|c|c|c|c|c|c|c|}
\hline $\begin{array}{c}\text { Site } \\
\text { name }\end{array}$ & $\begin{array}{l}\text { Local } \\
\text { ID }\end{array}$ & Date & Time & $\begin{array}{c}\text { Nitrogen, } \\
\text { ammonia, } \\
\text { dissolved } \\
(\mathbf{m g} / \mathbf{L} \text { as } \mathbf{N}) \\
(\mathbf{0 0 6 0 8})\end{array}$ & $\begin{array}{c}\text { Dissolved } \\
\text { ammonia } \\
\delta^{15} \mathbf{N} \\
(\text { per } \\
\text { mil) }\end{array}$ & $\begin{array}{c}\text { Nitrogen, } \\
\text { nitrite, } \\
\text { dissolved } \\
(\mathrm{mg} / \mathrm{L} \\
\text { as N) } \\
(00613)\end{array}$ & $\begin{array}{c}\text { Nitrogen, } \\
\text { ammonia } \\
+ \text { organic, } \\
\text { dissolved } \\
(\mathrm{mg} / \mathrm{L} \\
\text { as } \mathrm{N}) \\
(00623)\end{array}$ & $\begin{array}{c}\text { Nitrogen, } \\
\text { ammonia } \\
+ \text { organic, } \\
\text { total } \\
(\mathrm{mg} / \mathrm{L} \\
\text { as N) } \\
(00625)\end{array}$ & $\begin{array}{c}\text { Nitrate } \\
\text { plus } \\
\text { nitrite, } \\
\text { dissolved } \\
\text { (mg/L } \\
\text { as N) } \\
(00631)\end{array}$ & $\begin{array}{c}\text { Nitrate, } \\
\text { dissolved } \\
(\mathrm{mg} / \mathrm{L} \\
\text { as N) } \\
\text { (RSIL) }\end{array}$ & $\begin{array}{c}\begin{array}{c}\text { Nitrate } \\
\text { plus }\end{array} \\
\text { nitrite, } \\
\text { dissolved } \\
(\mathbf{m g} / \mathbf{L} \\
\text { as N) } \\
(\text { RSIL) } \\
(00631)\end{array}$ & $\begin{array}{c}\text { Dis- } \\
\text { solved } \\
\text { nitrate } \\
\text { plus } \\
\text { nitrite } \\
\delta^{15} \mathrm{~N} \\
\text { (per mil) }\end{array}$ & $\begin{array}{c}\text { Phos- } \\
\text { phorus, } \\
\text { total } \\
(\mathbf{m g} / \mathrm{L} \\
\text { as P) } \\
(\mathbf{0 0 6 6 5 )})\end{array}$ & $\begin{array}{c}\text { Phos- } \\
\text { phorus, } \\
\text { dissolved } \\
(\mathbf{m g} / \mathrm{L}) \\
(\mathbf{0 0 6 6 6})\end{array}$ & $\begin{array}{c}\text { Phos- } \\
\text { phorus, } \\
\text { ortho, } \\
\text { dissolved } \\
(\mathrm{mg} / \mathrm{L} \\
\text { as P) } \\
(00671)\end{array}$ & $\begin{array}{c}\begin{array}{c}\text { Original } \\
\text { (recon- }\end{array} \\
\text { structed) } \\
\mathrm{NO}_{3} \\
(\mathrm{mg} / \mathrm{L} \\
\text { as N) }\end{array}$ & $\begin{array}{c}\text { Excess } \mathbf{N}_{2} \\
(\mathbf{m g} / \mathbf{L} \\
\text { as N) }\end{array}$ \\
\hline \multicolumn{18}{|c|}{ Pennsylvania-Continued } \\
\hline Dykeman Spr. & $\mathrm{PA}-\mathrm{Cu}-24$ & 08/19/97 & 955 & -- & -- & -- & -- & -- & -- & -- & 4.6 & 4.1 & -- & -- & -- & -- & -- \\
\hline Hanover Spr. & PA-Yo-19 & $08 / 18 / 97$ & 1222 & -- & -- & -- & -- & -- & -- & -- & -- & -- & -- & -- & -- & -- & -- \\
\hline $\begin{array}{l}\text { McAllisterville } \\
\text { Spr. }\end{array}$ & PA-Ju-01 & $08 / 23 / 97$ & 1000 & -- & -- & -- & -- & -- & -- & -- & -- & -- & -- & -- & -- & -- & -- \\
\hline $\begin{array}{l}\text { Mount Rock } \\
\text { Spr. }\end{array}$ & PA-Cu-17 & 08/19/97 & 1340 & -- & -- & -- & -- & -- & -- & -- & 6.0 & 4.2 & -- & -- & -- & -- & -- \\
\hline Pennrythe Spr. & PA-Lb-18 & $08 / 22 / 97$ & 1440 & -- & -- & -- & -- & -- & -- & -- & -- & -- & -- & -- & -- & -- & -- \\
\hline PSU Ag Spr. & PA-Ce-33 & $08 / 21 / 97$ & 1435 & -- & -- & -- & -- & -- & -- & -- & 4.8 & 4.5 & -- & -- & -- & -- & -- \\
\hline Trout Spr. & PA-Cu-30 & 08/18/97 & 930 & -- & -- & -- & -- & -- & -- & -- & 9.0 & 5.5 & -- & -- & -- & -- & -- \\
\hline $\begin{array}{l}\text { Tylerville Spr. } \\
\text { Virginia }\end{array}$ & PA-Cn-09 & 08/20/97 & 1520 & & & & & & & & 2.7 & 6.5 & & & & & \\
\hline $\begin{array}{l}\text { Arthur Weiss } \\
\text { Spr. }\end{array}$ & VA 10 & 08/05/97 & 1230 & -- & -- & -- & -- & -- & -- & -- & 4.5 & 8.5 & -- & -- & -- & -- & -- \\
\hline Bear Lithia Spr. & VA 09 & 08/06/97 & 927 & -- & -- & -- & -- & -- & -- & -- & .4 & 7.2 & -- & -- & -- & -- & -- \\
\hline Camp 2 Spr. & VA 11 & 08/12/97 & 1140 & -- & -- & -- & -- & -- & -- & -- & -- & -- & -- & -- & -- & -- & -- \\
\hline CNHP28 & VA 14 & 08/04/97 & 1225 & -- & -- & -- & -- & -- & -- & -- & -- & -- & -- & -- & -- & -- & -- \\
\hline Coyner Spr. & VA 01 & 08/13/97 & 930 & -- & -- & -- & -- & -- & -- & -- & .6 & 5.9 & -- & -- & -- & -- & -- \\
\hline Deerfield Spr. & VA 07 & 08/08/97 & 1245 & -- & -- & -- & -- & -- & -- & -- & .4 & 4.6 & -- & -- & -- & -- & -- \\
\hline Elkton & VA 08 & 08/05/97 & 1710 & -- & -- & -- & -- & -- & -- & -- & -- & -- & -- & -- & -- & -- & -- \\
\hline Gardner & & 08/06/97 & 1515 & & & & & & & & .8 & 6.0 & & & & & \\
\hline $\begin{array}{l}\text { George } \\
\text { Washington }\end{array}$ & VA 13 & 08/11/97 & 1045 & -- & -- & -- & -- & -- & -- & -- & -- & -- & -- & -- & -- & -- & -- \\
\hline Green Spr. & VA 12 & 08/13/97 & 1425 & -- & -- & -- & -- & -- & -- & -- & -- & -- & -- & -- & -- & -- & -- \\
\hline $\begin{array}{l}\text { Gypsy Hilll } \\
\text { Golf Course }\end{array}$ & VA 05 & 08/06/97 & 1240 & -- & -- & -- & -- & -- & -- & -- & 1.8 & 7.1 & -- & -- & -- & -- & -- \\
\hline Loth Spr. & VA 02 & 08/13/97 & 1145 & -- & -- & -- & -- & -- & -- & -- & .5 & 6.0 & -- & -- & -- & -- & -- \\
\hline Masanetta & VA 04 & 08/07/97 & 1520 & -- & -- & -- & -- & -- & -- & -- & 1.8 & 5.9 & -- & -- & -- & -- & -- \\
\hline Timberville Spr. & VA 03 & 08/08/97 & 900 & -- & -- & -- & -- & -- & -- & -- & 3.9 & 6.3 & -- & -- & -- & -- & -- \\
\hline Warm Spr. & VA 06 & 08/08/97 & 1543 & -- & -- & -- & -- & -- & -- & -- & & -- & -- & -- & -- & -- & -- \\
\hline West Virginia & & & & -- & -- & -- & -- & -- & -- & -- & & & -- & -- & -- & -- & -- \\
\hline Berkeley Spr. & WV-BS-1 & $08 / 11 / 97$ & 1710 & -- & -- & -- & -- & -- & -- & -- & .1 & 4.5 & -- & -- & -- & -- & -- \\
\hline
\end{tabular}


Appendix C. Apparent ages and ancillary data used for modeled recharge dates for ground water collected in the Chesapeake Bay Watershed, June 1998 through May 2000

[ft, feet; ${ }^{\circ} \mathrm{C}$, degrees Celsius; mg/L, milligrams per liter; mp, minipiezometer; $\mathrm{n} / \mathrm{a}$, not applicable; --, data not available; cc/L, cubic centimeter per liter; CFC, chlorofluorocarbon; $\mathrm{SF}_{6}$, sulfur hexafluoride; P, piston; $\mathrm{M}$, mixture; n.p., not possible; n.d., not determined]

\begin{tabular}{|c|c|c|c|c|c|c|c|c|c|c|c|c|c|}
\hline $\begin{array}{c}\text { Site } \\
\text { name }\end{array}$ & Local ID & Date & Time & $\begin{array}{c}\text { Elevation } \\
(\mathbf{f t})\end{array}$ & $\begin{array}{c}\text { Nitrogen } \\
\text { gas } \\
(\mathrm{mg} / \mathrm{L})\end{array}$ & $\begin{array}{c}\text { Argon } \\
\text { gas } \\
(\mathrm{mg} / \mathrm{L})\end{array}$ & $\begin{array}{c}\text { Methane } \\
(\mathrm{mg} / \mathrm{L})\end{array}$ & $\begin{array}{c}\text { Recharge } \\
\text { temperature } \\
\left({ }^{\circ} \mathrm{C}\right)\end{array}$ & $\begin{array}{l}\text { Excess } \\
\text { air } \\
(\mathrm{cc} / \mathrm{L})\end{array}$ & $\begin{array}{c}\text { Recom- } \\
\text { mended } \\
\text { recharge date }\end{array}$ & $\begin{array}{c}\text { Type of } \\
\text { model used } \\
\text { (P or M) }\end{array}$ & $\begin{array}{c}\text { Recom- } \\
\text { mended age } \\
\text { based on }\end{array}$ & $\begin{array}{l}\text { Perc } \\
\text { your }\end{array}$ \\
\hline
\end{tabular}

\section{Pocomoke River at Careytown, Md.}

\begin{tabular}{|c|c|c|c|}
\hline WI Bh p1a & $\mathrm{mp} 1$ & $8 / 24 / 98$ & 0915 \\
\hline WI Bh p1b & $\mathrm{mp} 2$ & $8 / 24 / 98$ & 1100 \\
\hline WI Bh p1c & $\mathrm{mp} 3$ & $8 / 24 / 98$ & 1400 \\
\hline WI Bh p1d & $\mathrm{mp} 4$ & $8 / 24 / 98$ & 1515 \\
\hline WI Bh p1e & mp 5 & $8 / 24 / 98$ & 1600 \\
\hline WI Bh p1f & mp 6 & $8 / 25 / 98$ & 0900 \\
\hline WI Bh p1g & $\mathrm{mp} 7$ & $8 / 25 / 98$ & 1015 \\
\hline WI Bh p1h & $\mathrm{mp} 8$ & $8 / 25 / 98$ & 1130 \\
\hline WI Bh p1i & mp 9 & $8 / 25 / 98$ & 1230 \\
\hline WI Bh p1j & $\mathrm{mp} 10$ & $8 / 25 / 98$ & 1330 \\
\hline
\end{tabular}

$\begin{array}{lr}25 & 9.66 \\ 25 & 17.49 \\ 25 & 17.77 \\ 25 & 20.99 \\ 25 & 19.25 \\ 25 & 16.95 \\ 25 & 16.46 \\ 25 & 17.24 \\ 25 & 17.64 \\ 25 & 16.48\end{array}$

$\begin{array}{rr}0.50 & 2.07 \\ .64 & .00 \\ .65 & .28 \\ .73 & .77 \\ .70 & 2.26 \\ .65 & 5.14 \\ .64 & 5.94 \\ .67 & 5.99 \\ .66 & 6.52 \\ .64 & 5.84\end{array}$

$0.0 \quad 0.0$

\section{Pine Ridge Branch near Careytown, Md.}

\begin{tabular}{|c|c|c|c|c|c|}
\hline WO Be p1a & $\mathrm{mp} 1$ & 9/23/98 & 1030 & 25 & 18.16 \\
\hline WO Be p1b & $\mathrm{mp} 2$ & 9/23/98 & 0830 & 25 & 19.64 \\
\hline WO Be p1c & $\mathrm{mp} 3$ & 9/23/98 & 1130 & 25 & 20.24 \\
\hline
\end{tabular}

$\begin{array}{ll}.67 & .00 \\ .65 & .00 \\ .49 & .00\end{array}$

$\begin{array}{rr}0.0 & 0.0 \\ 13.7 & .6 \\ 13.8 & 1.0 \\ 10.9 & 3.1 \\ 11.0 & 1.4 \\ 11.9 & 1-.5 \\ 11.7 & { }^{1}-1.1 \\ 10.3 & 1-.9 \\ 11.7 & .1 \\ 12.0 & 1-1.0\end{array}$

n.p.
n.p.
n.p.
n.p.
n.p.
n.p.
n.p.
n.p.
n.p.
n.p.

$\begin{array}{ccc} & & \\ \mathrm{n} / \mathrm{a} & \mathrm{n} / \mathrm{a} & \mathrm{n} / \mathrm{a} \\ \mathrm{n} / \mathrm{a} & \mathrm{n} / \mathrm{a} & \mathrm{n} / \mathrm{a} \\ \mathrm{n} / \mathrm{a} & \mathrm{n} / \mathrm{a} & \mathrm{n} / \mathrm{a} \\ \mathrm{n} / \mathrm{a} & \mathrm{n} / \mathrm{a} & \mathrm{n} / \mathrm{a} \\ \mathrm{n} / \mathrm{a} & \mathrm{n} / \mathrm{a} & \mathrm{n} / \mathrm{a} \\ \mathrm{n} / \mathrm{a} & \mathrm{n} / \mathrm{a} & \mathrm{n} / \mathrm{a} \\ \mathrm{n} / \mathrm{a} & \mathrm{n} / \mathrm{a} & \mathrm{n} / \mathrm{a} \\ \mathrm{n} / \mathrm{a} & \mathrm{n} / \mathrm{a} & \mathrm{n} / \mathrm{a} \\ \mathrm{n} / \mathrm{a} & \mathrm{n} / \mathrm{a} & \mathrm{n} / \mathrm{a} \\ \mathrm{n} / \mathrm{a} & \mathrm{n} / \mathrm{a} & \mathrm{n} / \mathrm{a} \\ & & \\ \mathrm{n} / \mathrm{a} & \mathrm{n} / \mathrm{a} & \mathrm{n} / \mathrm{a} \\ \mathrm{M} & \mathrm{n} / \mathrm{a} & \mathrm{n} / \mathrm{a} \\ -- & \mathrm{n} / \mathrm{a} & \mathrm{n} / \mathrm{a}\end{array}$

North Fork Green Run near Whitesville, Del.

\begin{tabular}{|c|c|c|c|c|c|}
\hline WI Bx p1a & mp 1 & $9 / 21 / 98$ & 0930 & 50 & 17.02 \\
\hline WI Bx p1b & mp 2 & $9 / 21 / 98$ & 1130 & 50 & 15.41 \\
\hline WI Bx p1c & mp 3 & $9 / 21 / 98$ & 1300 & 50 & 17.82 \\
\hline WI Bx p1d & $\mathrm{mp} 4$ & $9 / 21 / 98$ & 1500 & 50 & 17.41 \\
\hline WI Bx p1e & mp 5 & $9 / 21 / 98$ & 1600 & 50 & 17.78 \\
\hline WI Bx p1f & mp 6 & $9 / 22 / 98$ & 0900 & 50 & 17.06 \\
\hline WI Bx p1g & $\mathrm{mp} 7$ & $9 / 22 / 98$ & 1100 & 50 & 16.34 \\
\hline WI Bx plh & mp 8 & $9 / 22 / 98$ & 1200 & 50 & 15.98 \\
\hline WI Bx p1i & mp 9 & $9 / 22 / 98$ & 1300 & 50 & 15.81 \\
\hline WI Bx p1j & $\mathrm{mp} 10$ & $9 / 22 / 98$ & 1430 & 50 & 15.16 \\
\hline \multirow[t]{3}{*}{ WI Bx p2a } & NF Well \#1 & 3/25/99 & 0900 & 50 & 18.33 \\
\hline & & 9/22/99 & 1500 & 50 & 16.62 \\
\hline & & $3 / 14 / 00$ & 0900 & 50 & 18.91 \\
\hline \multirow[t]{3}{*}{ WI Bx p2c } & NF Well \#3 & $3 / 25 / 99$ & 1200 & 50 & 19.69 \\
\hline & & 9/29/99 & 1300 & 50 & 14.75 \\
\hline & & $3 / 14 / 00$ & 1100 & 50 & 20.70 \\
\hline
\end{tabular}

$\begin{array}{lrrr}.56 & 3.67 & 21.1 & .9 \\ .53 & 1.09 & 22.7 & .1 \\ .59 & 2.09 & 20.9 & 2.7 \\ .57 & 3.03 & 21.0 & 1.8 \\ .59 & 2.19 & 21.1 & 3.2 \\ .59 & 1.10 & 20.3 & 2.3 \\ .57 & 1.09 & 21.1 & 1.7 \\ .56 & 2.69 & 21.1 & 1.4 \\ .56 & 4.14 & 21.5 & 1.3 \\ .55 & 6.00 & 21.1 & .5 \\ .65 & 2.01 & 14.7 & 1.9 \\ .58 & .64 & 19.0 & 1.1 \\ .65 & 1.59 & 14.5 & 1.8 \\ .69 & 6.09 & 11.0 & 1.3 \\ .54 & 6.03 & 21.3 & .2 \\ .70 & 3.99 & 11.1 & 1.9\end{array}$

n.p.
n.p.
n.p.
n.p.
n.p.
n.p.
n.p.
n.p.
n.p.
n.p.
1992.0
--
--
n.p.
n.p.
n.p.

$\begin{array}{rrr}\mathrm{n} / \mathrm{a} & \mathrm{n} / \mathrm{a} & \mathrm{n} / \mathrm{a} \\ \mathrm{n} / \mathrm{a} & \mathrm{n} / \mathrm{a} & \mathrm{n} / \mathrm{a} \\ \mathrm{n} / \mathrm{a} & \mathrm{n} / \mathrm{a} & \mathrm{n} / \mathrm{a} \\ \mathrm{n} / \mathrm{a} & \mathrm{n} / \mathrm{a} & \mathrm{n} / \mathrm{a} \\ \mathrm{n} / \mathrm{a} & \mathrm{n} / \mathrm{a} & \mathrm{n} / \mathrm{a} \\ \mathrm{n} / \mathrm{a} & \mathrm{n} / \mathrm{a} & \mathrm{n} / \mathrm{a} \\ \mathrm{n} / \mathrm{a} & \mathrm{n} / \mathrm{a} & \mathrm{n} / \mathrm{a} \\ \mathrm{n} / \mathrm{a} & \mathrm{n} / \mathrm{a} & \mathrm{n} / \mathrm{a} \\ \mathrm{n} / \mathrm{a} & \mathrm{n} / \mathrm{a} & \mathrm{n} / \mathrm{a} \\ \mathrm{n} / \mathrm{a} & \mathrm{n} / \mathrm{a} & \mathrm{n} / \mathrm{a} \\ \mathrm{P} & \mathrm{SF} & 100 \\ -- & -- & -- \\ -- & -- & -- \\ \mathrm{n} / \mathrm{a} & \mathrm{n} / \mathrm{a} & \mathrm{n} / \mathrm{a} \\ \mathrm{n} / \mathrm{a} & \mathrm{n} / \mathrm{a} & \mathrm{n} / \mathrm{a} \\ \mathrm{n} / \mathrm{a} & \mathrm{n} / \mathrm{a} & \mathrm{n} / \mathrm{a}\end{array}$


Appendix C. Apparent ages and ancillary data used for modeled recharge dates for ground water collected in the Chesapeake Bay Watershed, June 1998 through May 2000-Continued

[ft, feet; ${ }^{\circ} \mathrm{C}$, degrees Celsius; mg/L, milligrams per liter; mp, minipiezometer; n/a, not applicable; --, data not available; cc/L, cubic centimeter per liter;

CFC, chlorofluorocarbon; $\mathrm{SF}_{6}$, sulfur hexafluoride; P, piston; $\mathrm{M}$, mixture; n.p., not possible; n.d., not determined]

\begin{tabular}{|c|c|c|c|c|c|c|c|c|c|c|c|c|c|}
\hline $\begin{array}{c}\text { Site } \\
\text { name }\end{array}$ & Local ID & Date & Time & $\begin{array}{c}\text { Elevation } \\
\text { (ft) }\end{array}$ & $\begin{array}{c}\text { Nitrogen } \\
\text { gas } \\
(\mathrm{mg} / \mathrm{L})\end{array}$ & $\begin{array}{c}\text { Argon } \\
\text { gas } \\
(\mathbf{m g} / \mathbf{L})\end{array}$ & $\begin{array}{c}\text { Methane } \\
(\mathrm{mg} / \mathrm{L})\end{array}$ & $\begin{array}{c}\text { Recharge } \\
\text { temperature } \\
\left({ }^{\circ} \mathrm{C}\right)\end{array}$ & $\begin{array}{c}\text { Excess } \\
\text { air } \\
(\mathrm{cc} / \mathrm{L})\end{array}$ & $\begin{array}{c}\text { Recom- } \\
\text { mended } \\
\text { recharge date }\end{array}$ & $\begin{array}{c}\text { Type of } \\
\text { model used } \\
\text { (P or M) }\end{array}$ & $\begin{array}{c}\text { Recom- } \\
\text { mended age } \\
\text { based on }\end{array}$ & $\begin{array}{l}\text { Percentage of } \\
\text { young water }\end{array}$ \\
\hline \multicolumn{14}{|c|}{ North Fork Green Run near Whitesville, Del.-Continued } \\
\hline \multirow[t]{3}{*}{ WI Bx p2d } & NF Well \#4 & $3 / 25 / 99$ & 1330 & 50 & 22.63 & 0.78 & 1.37 & 7.2 & 2.5 & 1983.5 & $\mathrm{P}$ & $\mathrm{SF}_{6}$ & 100 \\
\hline & & $9 / 29 / 99$ & 1500 & 50 & 17.56 & .64 & .93 & 14.0 & .4 & 1983.3 & $\mathrm{P}$ & $\mathrm{SF}_{6}$ & 100 \\
\hline & & $3 / 14 / 00$ & 1200 & 50 & 19.96 & .71 & .41 & 9.6 & .8 & 1984.8 & $P$ & $\mathrm{SF}_{6}$ & 100 \\
\hline WI Bx p2e & $\mathrm{mp} 1$ & $3 / 29 / 99$ & 1400 & 50 & 19.99 & .69 & 5.68 & 10.0 & .1 & n.p. & $\mathrm{n} / \mathrm{a}$ & $\mathrm{n} / \mathrm{a}$ & $\mathrm{n} / \mathrm{a}$ \\
\hline WI Bx p2f & $\mathrm{mp} 2$ & $3 / 29 / 99$ & 1200 & 50 & 19.60 & .67 & 5.57 & 11.1 & .3 & n.p. & $\mathrm{n} / \mathrm{a}$ & $\mathrm{n} / \mathrm{a}$ & $\mathrm{n} / \mathrm{a}$ \\
\hline WI Bx p2g & mp 3 & $3 / 25 / 99$ & 1500 & 50 & 20.93 & .71 & 5.14 & 10.4 & 1.9 & n.p. & $\mathrm{n} / \mathrm{a}$ & $\mathrm{n} / \mathrm{a}$ & $\mathrm{n} / \mathrm{a}$ \\
\hline WI Bx p2h & $\mathrm{mp} 4$ & $3 / 26 / 99$ & 1000 & 50 & 22.75 & .69 & 3.32 & 11.0 & 1.3 & 1999.0 & $P$ & $\mathrm{SF}_{6}$ & 100 \\
\hline WI Bx p2i & mp 5 & $3 / 26 / 99$ & 0900 & 50 & 24.24 & .70 & .60 & 9.9 & 1.0 & 1990.5 & $P$ & $\mathrm{SF}_{6}$ & 100 \\
\hline \multicolumn{14}{|c|}{ Unnamed ditch to North Fork Green Run near Whitesville, Del. (Wayne Tull's Farm) } \\
\hline \multirow[t]{2}{*}{ WI By p1a } & WT Well \#1 & $3 / 23 / 99$ & 1230 & 50 & 19.90 & .75 & .00 & 6.6 & .3 & 1999.8 & $\mathrm{P}$ & $\mathrm{SF}_{6}$ & 100 \\
\hline & & $9 / 23 / 99$ & 1000 & 50 & 14.99 & .56 & .00 & 19.6 & ${ }^{1}-.1$ & n.p. & $\mathrm{n} / \mathrm{a}$ & $\mathrm{n} / \mathrm{a}$ & $\mathrm{n} / \mathrm{a}$ \\
\hline \multirow[t]{2}{*}{ WI By p1b } & WT Well \#2 & $3 / 23 / 99$ & 1400 & 50 & 20.98 & .78 & .00 & 5.9 & 1.1 & 1997.0 & $P$ & $\mathrm{SF}_{6}$ & 100 \\
\hline & & 9/23/99 & 1300 & 50 & 15.14 & .56 & .00 & 19.7 & .1 & n.p. & $\mathrm{n} / \mathrm{a}$ & $\mathrm{n} / \mathrm{a}$ & $\mathrm{n} / \mathrm{a}$ \\
\hline \multirow[t]{2}{*}{ WI By p1c } & WT Well \#3 & $3 / 23 / 99$ & 1000 & 50 & 24.09 & .63 & .02 & 14.3 & .5 & 1984.5 & $\mathrm{P}$ & $\mathrm{SF}_{6}$ & 100 \\
\hline & & 9/23/99 & 1600 & 50 & 19.98 & .53 & .02 & 24.3 & 1.1 & 1985.5 & $P$ & $\mathrm{SF}_{6}$ & 100 \\
\hline \multirow[t]{3}{*}{ WI By p1d } & WT Well \#4 & $3 / 23 / 99$ & 1200 & 50 & 25.05 & .63 & .03 & 13.8 & .3 & 1983.5 & $P$ & $\mathrm{SF}_{6}$ & 100 \\
\hline & & $9 / 24 / 99$ & 0900 & 50 & 24.36 & .63 & .02 & 15.0 & 1.0 & 1985.8 & $P$ & $\mathrm{SF}_{6}$ & 100 \\
\hline & & $3 / 13 / 00$ & 1300 & 50 & 24.49 & .56 & .02 & 19.5 & .1 & n.p. & $\mathrm{n} / \mathrm{a}$ & $\mathrm{n} / \mathrm{a}$ & $\mathrm{n} / \mathrm{a}$ \\
\hline WI By ple & $\mathrm{mp} 1$ & $3 / 24 / 99$ & 1300 & 50 & 22.07 & .63 & .01 & 14.1 & .4 & 1997.5 & $P$ & $\mathrm{SF}_{6}$ & 100 \\
\hline WI By p1f & mp 2 & $3 / 24 / 99$ & 1030 & 50 & 9.62 & .36 & .00 & n.d. & n.d. & 1981.0 & $P$ & $\mathrm{SF}_{6}$ & 100 \\
\hline WI By p1g & $\mathrm{mp} 3$ & $3 / 24 / 99$ & 1430 & 50 & 19.70 & .69 & .00 & 13.0 & 2.8 & 1991.0 & $P$ & $\mathrm{SF}_{6}$ & 100 \\
\hline \multicolumn{14}{|c|}{ Green Run near Careytown, Md. (Green Run at Bethel Road) } \\
\hline \multirow[t]{2}{*}{ WI Bz p1a } & GR Well \#1 & $9 / 21 / 99$ & 1200 & 50 & 16.79 & .59 & .00 & 18.5 & 1.4 & 1994.8 & $P$ & $\mathrm{SF}_{6}$ & 100 \\
\hline & & & & & & & & & & & & & 100 \\
\hline WI Bz p1b & GR Well \#2 & $3 / 30 / 99$ & 0900 & 50 & 22.19 & .76 & 2.21 & 8.7 & 3.2 & 1978.5 & $\mathrm{P}$ & $\mathrm{SF}_{6}$ & 100 \\
\hline
\end{tabular}


Appendix C. Apparent ages and ancillary data used for modeled recharge dates for ground water collected in the Chesapeake Bay Watershed, June 1998 through May 2000-Continued

[ft, feet; ${ }^{\circ} \mathrm{C}$, degrees Celsius; mg/L, milligrams per liter; mp, minipiezometer; n/a, not applicable; --, data not available; cc/L, cubic centimeter per liter;

CFC, chlorofluorocarbon; $\mathrm{SF}_{6}$, sulfur hexafluoride; P, piston; $\mathrm{M}$, mixture; n.p., not possible; n.d., not determined]

\begin{tabular}{|c|c|c|c|c|c|c|c|c|c|c|c|c|c|}
\hline $\begin{array}{c}\text { Site } \\
\text { name }\end{array}$ & Local ID & Date & Time & $\begin{array}{c}\text { Elevation } \\
\text { (ft) }\end{array}$ & $\begin{array}{l}\text { Nitrogen } \\
\text { gas } \\
(\mathrm{mg} / \mathrm{L})\end{array}$ & $\begin{array}{c}\text { Argon } \\
\text { gas } \\
(\mathrm{mg} / \mathrm{L})\end{array}$ & $\begin{array}{c}\text { Methane } \\
(\mathrm{mg} / \mathrm{L})\end{array}$ & $\begin{array}{l}\text { Recharge } \\
\text { temperature } \\
\left({ }^{\circ} \mathbf{C}\right)\end{array}$ & $\begin{array}{l}\text { Excess } \\
\text { air } \\
(\mathbf{c c} / \mathbf{L})\end{array}$ & $\begin{array}{c}\text { Recom- } \\
\text { mended } \\
\text { recharge date }\end{array}$ & $\begin{array}{c}\text { Type of } \\
\text { model used } \\
(\mathrm{P} \text { or } \mathrm{M})\end{array}$ & $\begin{array}{c}\text { Recom- } \\
\text { mended age } \\
\text { based on }\end{array}$ & $\begin{array}{l}\text { Percentage of } \\
\text { young water }\end{array}$ \\
\hline \multicolumn{14}{|c|}{ Green Run near Careytown, Md. (Green Run at Bethel Road)-Continued } \\
\hline WI Bz p1c & GR Well \#3 & $3 / 30 / 99$ & 1000 & 50 & 20.89 & 0.72 & 2.90 & 10.5 & 2.5 & 1984.0 & $P$ & $\mathrm{SF}_{6}$ & 100 \\
\hline \multirow[t]{3}{*}{ WI Bz p1d } & GR Well \#4 & $3 / 29 / 99$ & 1500 & 50 & 26.68 & .73 & .02 & 11.0 & 3.3 & 1984.5 & $P$ & $\mathrm{SF}_{6}$ & 100 \\
\hline & & 9/22/99 & 1300 & 50 & 20.27 & .59 & .04 & 16.8 & .0 & 1987.0 & $\mathrm{P}$ & $\mathrm{SF}_{6}$ & 100 \\
\hline & & $3 / 14 / 00$ & 1500 & 50 & 22.40 & .63 & .03 & 14.0 & .1 & n.p. & $\mathrm{n} / \mathrm{a}$ & $\mathrm{n} / \mathrm{a}$ & $\mathrm{n} / \mathrm{a}$ \\
\hline WI Bz p1e & $\mathrm{mp} 1$ & $3 / 31 / 99$ & 0800 & 50 & 23.15 & .69 & .10 & 11.0 & 1.4 & 1991.0 & $P$ & $\mathrm{SF}_{6}$ & 100 \\
\hline WI Bz p1f & $\mathrm{mp} 2$ & 3/30/99 & 1500 & 50 & 22.43 & .72 & 2.18 & 11.0 & 3.2 & 1985.0 & $P$ & $\mathrm{SF}_{6}$ & 100 \\
\hline WI Bz p1g & $\mathrm{mp} 3$ & 3/30/99 & 1400 & 50 & 21.38 & .74 & 2.26 & 10.5 & 3.5 & 1981.0 & $P$ & $\mathrm{SF}_{6}$ & 100 \\
\hline WI Bz p1h & $\mathrm{mp} 4$ & 3/30/99 & 1200 & 50 & 20.74 & .72 & 2.87 & 11.3 & 3.1 & 1982.5 & $P$ & $\mathrm{SF}_{6}$ & 100 \\
\hline WI Bz p1i & mp 5 & $3 / 31 / 99$ & 1000 & 50 & 21.35 & .73 & 3.27 & 11.0 & 3.6 & 1985.1 & $P$ & $\mathrm{SF}_{6}$ & 100 \\
\hline WI Bz p1j & mp 6 & $3 / 31 / 99$ & 1100 & 50 & 20.87 & .72 & 1.64 & 11.6 & 3.4 & 1977.0 & $P$ & $\mathrm{SF}_{6}$ & 100 \\
\hline WI Bz p1k & $\mathrm{mp} 7$ & $3 / 31 / 99$ & 1200 & 50 & 20.30 & .70 & 1.40 & 11.1 & 1.6 & -- & -- & -- & -- \\
\hline \multicolumn{14}{|c|}{ Additional wells in Upper Pocomoke River Basin } \\
\hline WI Bh 8 & & 9/23/98 & 1600 & 50 & 16.74 & .62 & 5.76 & 14.9 & .3 & 1962.1 & $P$ & $\mathrm{SF}_{6}$ & 100 \\
\hline WI Bh 8 & & $3 / 31 / 99$ & 1300 & 50 & 16.41 & .61 & 5.55 & 16.2 & .4 & 1957.2 & $P$ & $\mathrm{SF}_{6}$ & 100 \\
\hline WI Bh 9 & & 9/23/98 & 1400 & 50 & 22.33 & .77 & 2.01 & 8.5 & 3.6 & 1945.9 & $P$ & $\mathrm{SF}_{6}$ & 100 \\
\hline WI Bh 9 & & 3/31/99 & 1400 & 50 & 22.48 & .77 & 2.06 & 8.7 & 3.9 & 1940.6 & $P$ & $\mathrm{SF}_{6}$ & 100 \\
\hline WI Ch 56 & & 9/24/98 & 1000 & 50 & 18.48 & .66 & .00 & 11.7 & .0 & 1993.2 & $P$ & CFC-12 & 100 \\
\hline WI Ch 57 & & 9/24/98 & 0900 & 50 & 31.13 & .67 & .00 & 11.2 & .1 & 1987.7 & $P$ & CFC-12 & 100 \\
\hline \multicolumn{14}{|c|}{ Springs in Muddy Creek watershed (Owner's name is Local ID) } \\
\hline \multirow[t]{3}{*}{ 39SS-001 } & Goode & $11 / 09 / 98$ & 1000 & 1,500 & 20.26 & .72 & .00 & 7.6 & 2.2 & 1982.7 & $\mathrm{M}, \mathrm{P}$ & $\begin{array}{l}\text { CFC-113/ } \\
\text { CFC-12 }\end{array}$ & 96.5 \\
\hline & & $4 / 14 / 99$ & 1030 & 1,500 & 20.15 & .72 & .00 & 7.5 & 2.0 & 1988.0 & $P$ & $\begin{array}{l}\text { CFC-12, } \\
\text { CFC-113 }\end{array}$ & 100 \\
\hline & & $4 / 17 / 00$ & 1500 & 1,500 & 20.27 & .72 & .00 & 8.2 & 2.3 & 1988.0 & $P$ & $\begin{array}{l}\text { CFC-12, } \\
\text { CFC-113 }\end{array}$ & 100 \\
\hline \multirow[t]{2}{*}{ 39SS-002 } & Thompson & $11 / 09 / 98$ & 1330 & 1,560 & 17.39 & .64 & .00 & 11.1 & 0.6 & 1989.2 & $P$ & $\mathrm{CFC}-12$ & 100 \\
\hline & & 4/14/99 & 1300 & 1,560 & 17.57 & .64 & .00 & 11.5 & .9 & 1988.0 & $P$ & CFC-113 & 100 \\
\hline
\end{tabular}


Appendix C. Apparent ages and ancillary data used for modeled recharge dates for ground water collected in the Chesapeake Bay Watershed, June 1998 through May 2000-Continued

[ft, feet; ${ }^{\circ} \mathrm{C}$, degrees Celsius; mg/L, milligrams per liter; mp, minipiezometer; n/a, not applicable; --, data not available; cc/L, cubic centimeter per liter; CFC, chlorofluorocarbon; $\mathrm{SF}_{6}$, sulfur hexafluoride; P, piston; $\mathrm{M}$, mixture; n.p., not possible; n.d., not determined]

\begin{tabular}{|c|c|c|c|c|c|c|c|c|c|c|c|c|c|}
\hline $\begin{array}{c}\text { Site } \\
\text { name }\end{array}$ & Local ID & Date & Time & $\begin{array}{c}\text { Elevation } \\
\text { (ft) }\end{array}$ & $\begin{array}{c}\text { Nitrogen } \\
\text { gas } \\
(\mathrm{mg} / \mathrm{L})\end{array}$ & $\begin{array}{c}\text { Argon } \\
\text { gas } \\
(\mathrm{mg} / \mathrm{L})\end{array}$ & $\begin{array}{c}\text { Methane } \\
(\mathrm{mg} / \mathrm{L})\end{array}$ & $\begin{array}{c}\text { Recharge } \\
\text { temperature } \\
\left({ }^{\circ} \mathrm{C}\right)\end{array}$ & $\begin{array}{l}\text { Excess } \\
\text { air } \\
(\mathrm{cc} / \mathrm{L})\end{array}$ & $\begin{array}{c}\text { Recom- } \\
\text { mended } \\
\text { recharge date }\end{array}$ & $\begin{array}{c}\text { Type of } \\
\text { model used } \\
(\text { P or M) }\end{array}$ & $\begin{array}{c}\text { Recom- } \\
\text { mended age } \\
\text { based on }\end{array}$ & $\begin{array}{l}\text { Percentage of } \\
\text { young water }\end{array}$ \\
\hline \multicolumn{14}{|c|}{ Springs in Muddy Creek watershed (Owner's name is Local ID)-Continued } \\
\hline \multirow[t]{2}{*}{ 39SS-003 } & Dove & $11 / 09 / 98$ & 1400 & 1,500 & 18.81 & 0.68 & 0.00 & 10.0 & 1.6 & 1986.2 & M & $\begin{array}{l}\text { CFC-113/ } \\
\text { CFC-12 }\end{array}$ & 67.0 \\
\hline & & $4 / 14 / 99$ & 1400 & 1,500 & 18.72 & .67 & .00 & 11.0 & 1.9 & 1988.0 & M & $\begin{array}{l}\text { CFC-113/ } \\
\text { CFC-12 }\end{array}$ & 61.3 \\
\hline 39SS-005 & Heatwole & $4 / 14 / 99$ & 1130 & 1,500 & 19.16 & .69 & .00 & 9.0 & 1.5 & 1986.5 & $P$ & CFC-113 & 100 \\
\hline \multirow[t]{2}{*}{ 39RS-001 } & Heatwole & $11 / 10 / 98$ & 0830 & 1,500 & 19.55 & .72 & .00 & 7.4 & 1.2 & 1988.3 & M & $\begin{array}{l}\text { CFC-113/ } \\
\text { CFC-12 }\end{array}$ & 91.9 \\
\hline & & $4 / 14 / 99$ & 1500 & 1,500 & 17.04 & .64 & .00 & 11.4 & .3 & 1990.0 & $P$ & $\begin{array}{l}\text { CFC-12, } \\
\text { CFC-113 }\end{array}$ & 100 \\
\hline \multicolumn{14}{|c|}{ Observation wells in Muddy Creek watershed } \\
\hline \multirow[t]{2}{*}{$39 \mathrm{~S} 2$} & MC-4 & $4 / 13 / 99$ & 1200 & 1,500 & 20.34 & .70 & .00 & 8.1 & 1.3 & 1985.7 & $P$ & CFC-113 & 100 \\
\hline & & $4 / 18 / 00$ & 1100 & 1,500 & 20.01 & .68 & .01 & 9.1 & 1.2 & 1984.0 & $P$ & CFC-113 & 100 \\
\hline \multirow[t]{2}{*}{$39 \mathrm{~S} 4$} & MC-8 & 4/13/99 & 0900 & 1,500 & 20.66 & .69 & .00 & 9.1 & 1.3 & 1982.5 & $P$ & CFC-113 & 100 \\
\hline & & $4 / 18 / 00$ & 0900 & 1,500 & 20.21 & .69 & .00 & 8.6 & 1.3 & 1984.0 & $P$ & CFC-113 & 100 \\
\hline \multirow[t]{2}{*}{$39 \mathrm{~S} 9$} & MC-17 & $4 / 13 / 99$ & 1300 & 1,500 & 19.21 & .64 & .00 & 12.4 & 1.3 & 1984.7 & $P$ & CFC-113 & 100 \\
\hline & & $4 / 18 / 00$ & 1200 & 1,500 & 19.55 & .66 & .00 & 9.7 & .1 & 1978.0 & $P$ & CFC-113 & 100 \\
\hline \multirow[t]{2}{*}{ 39S14 } & MC-28 & $4 / 12 / 99$ & 1300 & 1,600 & 22.91 & .75 & .00 & 9.2 & 5.6 & 1984.7 & $P$ & $\begin{array}{l}\text { CFC-12, } \\
\text { CFC-113 }\end{array}$ & 100 \\
\hline & & $4 / 17 / 00$ & 1000 & 1,600 & 24.16 & .80 & .00 & 6.1 & 5.2 & 1982.0 & $P$ & $\begin{array}{l}\text { CFC-12, } \\
\text { CFC-113 }\end{array}$ & 100 \\
\hline \multirow[t]{2}{*}{$39 \mathrm{~S} 15$} & MC-29 & 4/12/99 & 1500 & 1,600 & 22.35 & .74 & .00 & 9.2 & 5.0 & 1981.1 & $P, M$ & $\begin{array}{l}\text { CFC-12, } \\
\text { CFC-113, } \\
\text { CFC-113/ } \\
\text { CFC-12 }\end{array}$ & 104.3 \\
\hline & & $4 / 17 / 00$ & 1200 & 1,600 & 22.67 & .76 & .00 & 6.2 & 3.0 & 1979.0 & M & $\begin{array}{l}\text { CFC-12, } \\
\text { CFC-113 }\end{array}$ & 93 \\
\hline
\end{tabular}


Appendix C. Apparent ages and ancillary data used for modeled recharge dates for ground water collected in the Chesapeake Bay Watershed, June 1998 through May 2000-Continued

[ft, feet; ${ }^{\circ} \mathrm{C}$, degrees Celsius; mg/L, milligrams per liter; mp, minipiezometer; n/a, not applicable; --, data not available; cc/L, cubic centimeter per liter;

CFC, chlorofluorocarbon; $\mathrm{SF}_{6}$, sulfur hexafluoride; P, piston; $\mathrm{M}$, mixture; n.p., not possible; n.d., not determined]

\begin{tabular}{|c|c|c|c|c|c|c|c|c|c|c|c|c|c|}
\hline $\begin{array}{c}\text { Site } \\
\text { name }\end{array}$ & Local ID & Date & Time & $\begin{array}{c}\text { Elevation } \\
\text { (ft) }\end{array}$ & $\begin{array}{l}\text { Nitrogen } \\
\text { gas } \\
(\mathrm{mg} / \mathrm{L})\end{array}$ & $\begin{array}{c}\text { Argon } \\
\text { gas } \\
(\mathrm{mg} / \mathrm{L})\end{array}$ & $\begin{array}{c}\text { Methane } \\
(\mathrm{mg} / \mathrm{L})\end{array}$ & $\begin{array}{l}\text { Recharge } \\
\text { temperature } \\
\left({ }^{\circ} \mathrm{C}\right)\end{array}$ & $\begin{array}{l}\text { Excess } \\
\text { air } \\
(\mathbf{c c} / \mathbf{L})\end{array}$ & $\begin{array}{c}\text { Recom- } \\
\text { mended } \\
\text { recharge date }\end{array}$ & $\begin{array}{c}\text { Type of } \\
\text { model used } \\
(\mathrm{P} \text { or } \mathrm{M})\end{array}$ & $\begin{array}{c}\text { Recom- } \\
\text { mended age } \\
\text { based on }\end{array}$ & $\begin{array}{l}\text { Percentage of } \\
\text { young water }\end{array}$ \\
\hline \multicolumn{14}{|c|}{ Observation wells in Muddy Creek watershed-Continued } \\
\hline \multirow[t]{2}{*}{$39 S 16$} & MC-30 & $4 / 12 / 99$ & 1100 & 1,580 & 20.08 & .72 & 0.00 & 7.7 & 2.1 & 1986.9 & $P$ & $\begin{array}{l}\text { CFC-12, } \\
\text { CFC-113 }\end{array}$ & 100 \\
\hline & & $4 / 17 / 00$ & 1400 & 1,580 & 23.69 & .79 & .00 & 6.7 & 5.0 & 1986.0 & $\mathrm{P}$ & $\begin{array}{l}\text { CFC-12, } \\
\text { CFC-113 }\end{array}$ & 100 \\
\hline \multirow[t]{2}{*}{39 S19 } & MC-34 & $4 / 13 / 99$ & 1100 & 1,500 & 19.69 & .70 & .00 & 9.3 & 2.2 & 1984.5 & $P$ & CFC-113 & 100 \\
\hline & & $4 / 18 / 00$ & 0800 & 1,500 & 19.12 & .69 & .00 & 8.8 & 1.5 & 1989.0 & $P$ & $\begin{array}{l}\text { CFC-12, } \\
\text { CFC-113 }\end{array}$ & 100 \\
\hline \multicolumn{14}{|c|}{ Domestic wells in Muddy Creek watershed (Owner's name is Local ID) } \\
\hline \multirow[t]{2}{*}{$39 S 34$} & Harmon (1) & $4 / 13 / 99$ & 1500 & 1,500 & 27.16 & .86 & .00 & 5.7 & 8.4 & 1981.3 & M & $\begin{array}{l}\text { CFC-113/ } \\
\text { CFC-12 }\end{array}$ & 49.8 \\
\hline & & $4 / 14 / 99$ & 0900 & 1,500 & 26.27 & .83 & .00 & 6.9 & 8.0 & 1980.5 & $M$ & $\begin{array}{l}\text { CFC-113/ } \\
\text { CFC-12 }\end{array}$ & 45.7 \\
\hline $39 \mathrm{~S} 35$ & Harmon (2) & 4/13/99 & 1600 & 1,500 & 20.22 & .73 & .00 & 7.3 & 2.0 & 1985.0 & P & CFC-113 & 100 \\
\hline 39 S39 & Fairview Church & $4 / 15 / 99$ & 1500 & 1,500 & 24.31 & .77 & .00 & 10.2 & 7.3 & 1979.0 & $\mathrm{M}, \mathrm{P}$ & $\begin{array}{l}\text { CFC-113/ } \\
\text { CFC-12 }\end{array}$ & 91.9 \\
\hline $39 \mathrm{~S} 40$ & Dove & $4 / 15 / 99$ & 1000 & 1,500 & 21.11 & .72 & .00 & 9.5 & 3.8 & 1983.5 & M & $\begin{array}{l}\text { CFC-113/ } \\
\text { CFC-12 }\end{array}$ & 12.5 \\
\hline $39 S 41$ & Weintraub (1) & $4 / 15 / 99$ & 1200 & 1,500 & 19.81 & .67 & .00 & 9.0 & .0 & 1986.5 & M & $\begin{array}{l}\text { CFC-113/ } \\
\text { CFC-12 }\end{array}$ & 75.3 \\
\hline $39 \mathrm{~S} 42$ & Weintraub (2) & $4 / 15 / 99$ & 1300 & 1,500 & 24.49 & .70 & .00 & 8.9 & 2.0 & 1986.0 & M & $\begin{array}{l}\text { CFC-113/ } \\
\text { CFC-12 }\end{array}$ & 48.2 \\
\hline $39 \mathrm{~S} 43$ & Martin & 4/16/99 & 0900 & 1,500 & 22.64 & .75 & .02 & 8.4 & 4.6 & 1954.4 & M & $\begin{array}{l}\text { CFC-11/ } \\
\text { CFC-12 }\end{array}$ & 21.1 \\
\hline $39 S 44$ & Smith & $4 / 16 / 99$ & 1100 & 1,500 & 21.16 & .71 & .00 & 9.0 & 2.8 & 1988.3 & $P$ & $\begin{array}{l}\text { CFC-12, } \\
\text { CFC-113 }\end{array}$ & 100 \\
\hline \multicolumn{14}{|c|}{ Polecat Creek Watershed } \\
\hline $50 \mathrm{M} 2$ & & $4 / 19 / 99$ & 1000 & 200 & 20.01 & .69 & .00 & 12.8 & 3.0 & 1968.8 & $\mathrm{P}, \mathrm{M}$ & $\begin{array}{l}\text { CFC-11, } \\
\text { CFC-12, } \\
\text { CFC-113 }\end{array}$ & 100 \\
\hline $50 \mathrm{M} 3$ & & 4/19/99 & 1100 & 200 & 20.19 & .69 & .00 & 13.7 & 3.5 & 1994.0 & $\mathrm{P}$ & $\mathrm{SF}_{6}$ & 100 \\
\hline
\end{tabular}


Appendix C. Apparent ages and ancillary data used for modeled recharge dates for ground water collected in the Chesapeake Bay Watershed, June 1998 through May 2000-Continued

[ft, feet; ${ }^{\circ} \mathrm{C}$, degrees Celsius; mg/L, milligrams per liter; mp, minipiezometer; $\mathrm{n} / \mathrm{a}$, not applicable; --, data not available; cc/L, cubic centimeter per liter; CFC, chlorofluorocarbon; $\mathrm{SF}_{6}$, sulfur hexafluoride; P, piston; $\mathrm{M}$, mixture; n.p., not possible; n.d., not determined]

\begin{tabular}{|c|c|c|c|c|c|c|c|c|c|c|c|c|c|}
\hline $\begin{array}{c}\text { Site } \\
\text { name }\end{array}$ & Local ID & Date & Time & $\begin{array}{c}\text { Elevation } \\
\quad(\mathrm{ft})\end{array}$ & $\begin{array}{c}\text { Nitrogen } \\
\text { gas } \\
(\mathrm{mg} / \mathrm{L})\end{array}$ & $\begin{array}{c}\text { Argon } \\
\text { gas } \\
(\mathrm{mg} / \mathrm{L})\end{array}$ & $\begin{array}{c}\text { Methane } \\
(\mathrm{mg} / \mathrm{L})\end{array}$ & $\begin{array}{c}\text { Recharge } \\
\text { temperature } \\
\left({ }^{\circ} \mathrm{C}\right)\end{array}$ & $\begin{array}{l}\text { Excess } \\
\text { air } \\
(\mathrm{cc} / \mathrm{L})\end{array}$ & $\begin{array}{c}\text { Recom- } \\
\text { mended } \\
\text { recharge date }\end{array}$ & $\begin{array}{c}\text { Type of } \\
\text { model used } \\
\text { (P or M) }\end{array}$ & $\begin{array}{c}\text { Recom- } \\
\text { mended age } \\
\text { based on }\end{array}$ & $\begin{array}{l}\text { Percentage of } \\
\text { young water }\end{array}$ \\
\hline \multicolumn{14}{|c|}{ Polecat Creek Watershed-Continued } \\
\hline $50 \mathrm{M} 4$ & & $4 / 19 / 99$ & 1800 & 200 & 20.02 & 0.70 & 0.00 & 12.2 & 2.8 & 1988.0 & $M, P$ & $\begin{array}{l}\text { CFC-113/ } \\
\text { CFC-12 }\end{array}$ & 99.1 \\
\hline $50 \mathrm{M} 5$ & & $4 / 20 / 99$ & 1500 & 200 & 23.41 & .79 & .00 & 8.1 & 4.7 & 1972.0 & $P$ & CFC-12 & 100 \\
\hline $50 \mathrm{M} 6$ & & $4 / 21 / 99$ & 0800 & 200 & 22.16 & .78 & .00 & 7.1 & 3.0 & 1993.5 & $P$ & CFC-12 & 100 \\
\hline $50 \mathrm{M} 7$ & & $4 / 21 / 99$ & 1500 & 200 & 20.44 & .71 & .00 & 11.5 & 3.0 & 1972.3 & $P$ & $\begin{array}{l}\text { CFC-12, } \\
\text { CFC-113 }\end{array}$ & 100 \\
\hline $50 \mathrm{M} 16$ & & $4 / 19 / 99$ & 1200 & 200 & 18.01 & .66 & .00 & 12.2 & .8 & 1995.5 & $P$ & $\mathrm{CFC}-12, \mathrm{SF}_{6}$ & 100 \\
\hline $50 \mathrm{M} 17$ & & $4 / 19 / 99$ & 1500 & 200 & 18.02 & .66 & .00 & 12.4 & .9 & 1996.2 & $P$ & $\mathrm{CFC}-12, \mathrm{SF}_{6}$ & 100 \\
\hline $50 \mathrm{M} 18$ & & $4 / 20 / 99$ & 0800 & 200 & 19.72 & .70 & .00 & 11.7 & 2.3 & 1988.3 & $M, P$ & $\begin{array}{l}\text { CFC-113/ } \\
\text { CFC-12 }\end{array}$ & 101.3 \\
\hline 50M19 & & $4 / 19 / 99$ & 1700 & 200 & 20.75 & .72 & .00 & 10.9 & 3.1 & 1990.3 & $P$ & $\begin{array}{l}\text { CFC-12, } \\
\text { CFC-113 }\end{array}$ & 100 \\
\hline $50 \mathrm{M} 21$ & & $4 / 20 / 99$ & 1100 & 200 & 21.57 & .78 & .00 & 6.6 & 2.1 & 1999.0 & M & $\begin{array}{l}\text { CFC-12, } \\
\mathrm{SF}_{6}\end{array}$ & 100 \\
\hline $50 \mathrm{M} 22$ & & $4 / 20 / 99$ & 1300 & 200 & 20.33 & .74 & .00 & 7.8 & 1.4 & 1999.0 & M & $\begin{array}{l}\text { CFC-12, } \\
\mathrm{SF}_{6}\end{array}$ & 100 \\
\hline $50 \mathrm{M} 23$ & & $4 / 21 / 99$ & 0900 & 200 & -- & -- & -- & -- & -- & -- & -- & -- & -- \\
\hline $50 \mathrm{M} 24$ & & $4 / 21 / 99$ & 1000 & 200 & 21.85 & .76 & .00 & 8.6 & 3.3 & 1987.5 & $M, P$ & $\begin{array}{l}\text { CFC-113/ } \\
\text { CFC-12 }\end{array}$ & 95.0 \\
\hline $50 \mathrm{M} 25$ & & $4 / 21 / 99$ & 1200 & 200 & 20.23 & .72 & .00 & 9.5 & 2.0 & 1994.5 & $P$ & $\mathrm{CFC}-12, \mathrm{SF}_{6}$ & 100 \\
\hline $50 \mathrm{M} 26$ & & $4 / 21 / 99$ & 1400 & 200 & 20.50 & .73 & .00 & 9.1 & 2.1 & 1993.5 & $P$ & $\begin{array}{l}\text { CFC-12, } \\
\mathrm{SF}_{6}\end{array}$ & 100 \\
\hline $50 \mathrm{M} 28$ & & $4 / 21 / 99$ & 0930 & 200 & -- & -- & -- & -- & -- & -- & -- & -- & -- \\
\hline $50 \mathrm{M} 27$ & & $3 / 29 / 00$ & 1415 & 200 & -- & -- & -- & -- & -- & -- & -- & -- & -- \\
\hline $50 \mathrm{M} 29$ & & $4 / 10 / 00$ & 1300 & 200 & 21.50 & .75 & .00 & 8.7 & 3.0 & 1985.0 & $M$ & $\begin{array}{l}\text { CFC-113/ } \\
\text { CFC-12 }\end{array}$ & 87.5 \\
\hline $50 \mathrm{M} 30$ & & $4 / 10 / 00$ & 1100 & 200 & 18.91 & .71 & .03 & 8.8 & .4 & 1984.0 & $M$ & $\begin{array}{l}\text { CFC-113/ } \\
\text { CFC-12 }\end{array}$ & 63.6 \\
\hline
\end{tabular}


Appendix C. Apparent ages and ancillary data used for modeled recharge dates for ground water collected in the Chesapeake Bay Watershed, June 1998 through May 2000-Continued

[ft, feet; ${ }^{\circ} \mathrm{C}$, degrees Celsius; mg/L, milligrams per liter; mp, minipiezometer; n/a, not applicable; --, data not available; cc/L, cubic centimeter per liter;

CFC, chlorofluorocarbon; $\mathrm{SF}_{6}$, sulfur hexafluoride; P, piston; $\mathrm{M}$, mixture; n.p., not possible; n.d., not determined]

\begin{tabular}{|c|c|c|c|c|c|c|c|c|c|c|c|c|c|}
\hline $\begin{array}{c}\text { Site } \\
\text { name }\end{array}$ & Local ID & Date & Time & $\begin{array}{c}\text { Elevation } \\
\quad(\mathrm{ft})\end{array}$ & $\begin{array}{l}\text { Nitrogen } \\
\text { gas } \\
(\mathrm{mg} / \mathrm{L})\end{array}$ & $\begin{array}{c}\text { Argon } \\
\text { gas } \\
(\mathrm{mg} / \mathrm{L})\end{array}$ & $\begin{array}{c}\text { Methane } \\
\text { (mg/L) }\end{array}$ & $\begin{array}{l}\text { Recharge } \\
\text { temperature } \\
\left({ }^{\circ} \mathrm{C}\right)\end{array}$ & $\begin{array}{l}\text { Excess } \\
\text { air } \\
(\mathbf{c c} / \mathrm{L})\end{array}$ & $\begin{array}{c}\text { Recom- } \\
\text { mended } \\
\text { recharge date }\end{array}$ & $\begin{array}{c}\text { Type of } \\
\text { model used } \\
(\mathrm{P} \text { or } \mathrm{M})\end{array}$ & $\begin{array}{c}\text { Recom- } \\
\text { mended age } \\
\text { based on }\end{array}$ & $\begin{array}{l}\text { Percentage of } \\
\text { young water }\end{array}$ \\
\hline \multicolumn{14}{|c|}{ Mahantango WE-38 Watershed, East Transect } \\
\hline NU 538 & E1-10 & $5 / 10 / 99$ & 1145 & 800 & 25.24 & 0.76 & 0.00 & 6.9 & 4.6 & 1979.6 & M & $\begin{array}{l}\text { CFC-113/ } \\
\text { CFC-12 }\end{array}$ & 89.9 \\
\hline NU 539 & E1-20 & $5 / 10 / 99$ & 1245 & 800 & 25.82 & .73 & .08 & 9.0 & 2.8 & 1957.0 & $P$ & $\begin{array}{l}\text { CFC-11, } \\
\text { CFC-12 }\end{array}$ & 100 \\
\hline \multirow[t]{2}{*}{ NU 540} & $\mathrm{E} 2-10$ & $5 / 10 / 99$ & 1345 & 800 & 23.55 & .73 & .41 & 8.9 & 2.5 & 1952.2 & $P$ & $\begin{array}{l}\text { CFC-11, } \\
\text { CFC-12 }\end{array}$ & 100 \\
\hline & & $5 / 9 / 00$ & 1600 & 800 & 25.23 & .76 & .48 & 7.0 & 4.1 & 1951.9 & $P$ & $\begin{array}{l}\text { CFC-11, } \\
\text { CFC-12 }\end{array}$ & 100 \\
\hline NU 541 & E2-35 & $5 / 10 / 99$ & 1500 & 800 & 22.73 & .75 & .80 & 7.5 & 4.1 & 1958.0 & $P$ & $\begin{array}{l}\text { CFC-11, } \\
\text { CFC-12 }\end{array}$ & 100 \\
\hline \multirow[t]{3}{*}{ NU 534} & E3-10 & 6/16/98 & 1550 & 800 & 20.49 & .70 & .14 & 9.5 & 3.5 & 1951.7 & $P$ & $\begin{array}{l}\text { CFC-11, } \\
\text { CFC-12 }\end{array}$ & 100 \\
\hline & & $5 / 11 / 99$ & 0900 & 800 & 23.31 & .77 & .16 & 6.5 & 5.2 & 1949.8 & $P$ & $\begin{array}{l}\text { CFC-11, } \\
\text { CFC-12 }\end{array}$ & 100 \\
\hline & & $5 / 9 / 00$ & 1500 & 800 & 23.45 & .76 & .19 & 7.0 & 4.6 & 1987.9 & $M$ & $\begin{array}{l}\text { CFC-11, } \\
\text { CFC-113, } \\
\text { CFC-12 }\end{array}$ & 6.6 \\
\hline \multirow[t]{2}{*}{ NU 535} & E3-20 & $6 / 15 / 98$ & 1720 & 800 & 21.24 & .71 & .20 & 7.3 & 4.6 & 1953.4 & $P$ & $\begin{array}{l}\text { CFC-11, } \\
\text { CFC-12 }\end{array}$ & 100 \\
\hline & & $5 / 11 / 99$ & 1100 & 800 & 22.09 & .74 & .16 & 8.3 & 3.3 & 1951.8 & $P$ & $\begin{array}{l}\text { CFC-11, } \\
\text { CFC-12 }\end{array}$ & 100 \\
\hline \multirow[t]{2}{*}{ NU 536} & E3-30 & $6 / 17 / 98$ & 1120 & 800 & 22.76 & .74 & .14 & 9.5 & 6.0 & 1952.6 & $P$ & $\begin{array}{l}\text { CFC-11, } \\
\text { CFC-12 }\end{array}$ & 100 \\
\hline & & $5 / 11 / 99$ & 1200 & 800 & 23.46 & .77 & .04 & 6.6 & 4.7 & 1956.6 & $P$ & $\begin{array}{l}\text { CFC-11, } \\
\text { CFC-12 }\end{array}$ & 100 \\
\hline NU 537 & E3-45 & $6 / 18 / 98$ & 0930 & 800 & 19.88 & .67 & .03 & 11.1 & 3.6 & 1962.7 & P & CFC-12 & 100 \\
\hline
\end{tabular}


Appendix C. Apparent ages and ancillary data used for modeled recharge dates for ground water collected in the Chesapeake Bay Watershed, June 1998 through May 2000-Continued

[ft, feet; ${ }^{\circ} \mathrm{C}$, degrees Celsius; mg/L, milligrams per liter; mp, minipiezometer; n/a, not applicable; --, data not available; cc/L, cubic centimeter per liter;

CFC, chlorofluorocarbon; $\mathrm{SF}_{6}$, sulfur hexafluoride; P, piston; $\mathrm{M}$, mixture; n.p., not possible; n.d., not determined]

\begin{tabular}{|c|c|c|c|c|c|c|c|c|c|c|c|c|c|}
\hline $\begin{array}{c}\text { Site } \\
\text { name }\end{array}$ & Local ID & Date & Time & $\begin{array}{c}\text { Elevation } \\
\text { (ft) }\end{array}$ & $\begin{array}{l}\text { Nitrogen } \\
\text { gas } \\
(\mathrm{mg} / \mathrm{L})\end{array}$ & $\begin{array}{c}\text { Argon } \\
\text { gas } \\
(\mathrm{mg} / \mathrm{L})\end{array}$ & $\begin{array}{c}\text { Methane } \\
(\mathrm{mg} / \mathrm{L})\end{array}$ & $\begin{array}{c}\text { Recharge } \\
\text { temperature } \\
\left({ }^{\circ} \mathbf{C}\right)\end{array}$ & $\begin{array}{c}\text { Excess } \\
\text { air } \\
(\mathrm{cc} / \mathrm{L})\end{array}$ & $\begin{array}{c}\text { Recom- } \\
\text { mended } \\
\text { recharge date }\end{array}$ & $\begin{array}{c}\text { Type of } \\
\text { model used } \\
(\text { P or M) }\end{array}$ & $\begin{array}{c}\text { Recom- } \\
\text { mended age } \\
\text { based on }\end{array}$ & $\begin{array}{l}\text { Percentage of } \\
\text { young water }\end{array}$ \\
\hline \multicolumn{14}{|c|}{ Mahantango WE-38 Watershed, East Transect-Continued } \\
\hline \multirow[t]{3}{*}{ NU 529} & $\mathrm{E} 4-10$ & $6 / 16 / 98$ & 1420 & 800 & 15.96 & .63 & 0.02 & 9.6 & ${ }^{1}-1.4$ & 1986.8 & M & $\begin{array}{l}\text { CFC-113/ } \\
\text { CFC-12 }\end{array}$ & 76.9 \\
\hline & & $5 / 11 / 99$ & 1300 & 800 & 20.72 & .73 & .00 & 8.8 & 2.9 & 1986.1 & M & $\begin{array}{l}\text { CFC-113/ } \\
\text { CFC-12 }\end{array}$ & 78.8 \\
\hline & & $5 / 9 / 00$ & 0930 & 800 & 20.37 & .69 & .00 & 12.2 & 1.3 & 1984.5 & $P, M$ & $\begin{array}{l}\text { CFC-12, } \\
\text { CFC-113 }\end{array}$ & 8.6 \\
\hline \multirow[t]{3}{*}{ NU 530} & $\mathrm{E} 4-20$ & $6 / 17 / 98$ & 1020 & 800 & 19.94 & .70 & .00 & 10.6 & 2.8 & 1984.8 & $M$ & $\begin{array}{l}\text { CFC-113/ } \\
\text { CFC-12 }\end{array}$ & 93.2 \\
\hline & & $5 / 11 / 99$ & 1400 & 800 & 21.08 & .74 & .00 & 8.0 & 2.8 & 1985.6 & $M$ & $\begin{array}{l}\text { CFC-113/ } \\
\text { CFC-12 }\end{array}$ & 77.2 \\
\hline & & $5 / 9 / 00$ & 1000 & 800 & 20.95 & .72 & .01 & 9.0 & 2.6 & 1981.7 & $P, M$ & $\begin{array}{l}\text { CFC-12, } \\
\text { CFC-113 }\end{array}$ & 82 \\
\hline \multirow[t]{2}{*}{ NU 531} & E4-30 & $6 / 16 / 98$ & 1630 & 800 & 19.49 & .68 & .00 & 11.5 & 2.6 & 1982.0 & $M$ & $\begin{array}{l}\text { CFC-113/ } \\
\text { CFC-12 }\end{array}$ & 78.4 \\
\hline & & $5 / 11 / 99$ & 1445 & 800 & 20.30 & .71 & .00 & 9.8 & 2.7 & 1983.6 & $M$ & $\begin{array}{l}\text { CFC-113/ } \\
\text { CFC-12 }\end{array}$ & 76.9 \\
\hline \multirow[t]{3}{*}{ NU 532} & E4-45 & $6 / 17 / 98$ & 1430 & 800 & 20.30 & .70 & .00 & 9.8 & 3.4 & 1977.0 & $M$ & $\begin{array}{l}\text { CFC-113/ } \\
\text { CFC-12 }\end{array}$ & 67.0 \\
\hline & & $5 / 11 / 99$ & 1530 & 800 & 20.98 & .73 & .00 & 8.8 & 3.3 & 1974.1 & $P$ & CFC- 12 & 100 \\
\hline & & $5 / 9 / 00$ & 1100 & 800 & 20.99 & .71 & .00 & 9.6 & 2.2 & 1982.7 & $M$ & $\begin{array}{l}\text { CFC-12, } \\
\text { CFC-113 }\end{array}$ & 56.9 \\
\hline \multirow[t]{3}{*}{ NU 533} & $\mathrm{E} 4-60$ & $6 / 18 / 98$ & 1015 & 800 & 19.18 & .67 & .00 & 12.9 & 2.6 & 1977.0 & $M$ & $\begin{array}{l}\text { CFC-113/ } \\
\text { CFC-12 }\end{array}$ & 54.6 \\
\hline & & $5 / 11 / 99$ & 1600 & 800 & 20.31 & .72 & .00 & 9.6 & 2.6 & 1982.6 & $M$ & $\begin{array}{l}\text { CFC-113/ } \\
\text { CFC-12 }\end{array}$ & 59.5 \\
\hline & & $5 / 9 / 00$ & 1300 & 800 & 20.05 & .69 & .00 & 11.6 & .6 & 1990.5 & $\mathrm{M}$ & $\begin{array}{l}\text { CFC-113/ } \\
\text { CFC-12 }\end{array}$ & 41 \\
\hline
\end{tabular}


Appendix C. Apparent ages and ancillary data used for modeled recharge dates for ground water collected in the Chesapeake Bay Watershed, June 1998 through May 2000-Continued

[ft, feet; ${ }^{\circ} \mathrm{C}$, degrees Celsius; mg/L, milligrams per liter; mp, minipiezometer; n/a, not applicable; --, data not available; cc/L, cubic centimeter per liter;

CFC, chlorofluorocarbon; $\mathrm{SF}_{6}$, sulfur hexafluoride; P, piston; $\mathrm{M}$, mixture; n.p., not possible; n.d., not determined]

\begin{tabular}{|c|c|c|c|c|c|c|c|c|c|c|c|c|c|}
\hline $\begin{array}{c}\text { Site } \\
\text { name }\end{array}$ & Local ID & Date & Time & $\begin{array}{c}\text { Elevation } \\
\text { (ft) }\end{array}$ & $\begin{array}{c}\text { Nitrogen } \\
\text { gas } \\
(\mathrm{mg} / \mathrm{L})\end{array}$ & $\begin{array}{c}\text { Argon } \\
\text { gas } \\
(\mathbf{m g} / \mathbf{L})\end{array}$ & $\begin{array}{c}\text { Methane } \\
(\mathrm{mg} / \mathrm{L})\end{array}$ & $\begin{array}{c}\text { Recharge } \\
\text { temperature } \\
\left({ }^{\circ} \mathbf{C}\right)\end{array}$ & $\begin{array}{l}\text { Excess } \\
\text { air } \\
(\mathrm{cc} / \mathrm{L})\end{array}$ & $\begin{array}{c}\text { Recom- } \\
\text { mended } \\
\text { recharge date }\end{array}$ & $\begin{array}{c}\text { Type of } \\
\text { model used } \\
(\text { P or M) }\end{array}$ & $\begin{array}{c}\text { Recom- } \\
\text { mended age } \\
\text { based on }\end{array}$ & $\begin{array}{l}\text { Percentage of } \\
\text { young water }\end{array}$ \\
\hline \multicolumn{14}{|c|}{ Mahantango WE-38 Watershed, East Transect-Continued } \\
\hline \multirow[t]{3}{*}{ NU 526} & E5-10 & $6 / 16 / 98$ & 1130 & 800 & 17.71 & 0.66 & 0.00 & 11.3 & 0.6 & 1990.1 & $P$ & $\begin{array}{l}\text { CFC-12, } \\
\text { CFC-113 }\end{array}$ & 100 \\
\hline & & $5 / 12 / 99$ & 1100 & 800 & 20.24 & .74 & .00 & 7.4 & 1.6 & 1986.1 & M & $\begin{array}{l}\text { CFC-113/ } \\
\text { CFC-12 }\end{array}$ & ${ }^{3} 105$ \\
\hline & & $5 / 9 / 00$ & 1300 & 800 & 20.89 & .73 & .00 & 8.7 & 2.1 & 1988.9 & $P$ & $\begin{array}{l}\text { CFC-113, } \\
\text { CFC-12 }\end{array}$ & 100 \\
\hline NU 527 & E5-45 & 6/17/98 & 1300 & 800 & 18.01 & .66 & .00 & 11.9 & 1.0 & 1989.7 & $P$ & $\begin{array}{l}\text { CFC-12, } \\
\text { CFC-113 }\end{array}$ & 100 \\
\hline \multirow[t]{2}{*}{ NU 528} & E5-60 & $6 / 17 / 98$ & 1700 & 800 & 18.52 & .66 & .00 & 12.0 & 1.7 & 1986.2 & $M$ & $\begin{array}{l}\text { CFC-113/ } \\
\text { CFC-12, } \\
\text { CFC-11, } \\
\text { CFC-113 }\end{array}$ & 91.7 \\
\hline & & $5 / 12 / 99$ & 1000 & 800 & 19.21 & .70 & .00 & 9.8 & 1.5 & 1986.6 & $M$ & $\begin{array}{l}\text { CFC-113/ } \\
\text { CFC-12 }\end{array}$ & 72.5 \\
\hline \multirow[t]{3}{*}{ NU 542} & E6-35 & $5 / 12 / 99$ & 1200 & 800 & 18.92 & .69 & .00 & 9.7 & 1.2 & 1994.1 & $\mathrm{P}$ & CFC-12 & 100 \\
\hline & & $5 / 9 / 00$ & 1400 & 800 & 18.39 & .68 & .00 & 10.5 & .5 & 1991.0 & $P$ & $\begin{array}{l}\text { CFC-113, } \\
\text { CFC-12 }\end{array}$ & 100 \\
\hline & E7-10 & $5 / 12 / 99$ & 1330 & 800 & 18.86 & .70 & .00 & 8.9 & .8 & 1994.1 & $P$ & CFC-12 & 100 \\
\hline \multicolumn{14}{|c|}{ Mahantango WE-38 Watershed, West Transect } \\
\hline & W1-20 & $5 / 14 / 99$ & 1030 & 800 & 20.48 & .71 & .00 & 9.8 & 3.0 & 1971.6 & M & $\begin{array}{l}\text { CFC-113/ } \\
\text { CFC-12 }\end{array}$ & 95.2 \\
\hline \multirow[t]{2}{*}{ NU 545} & W2-20 & $5 / 14 / 99$ & 0930 & 800 & 21.67 & .74 & .00 & 8.3 & 3.9 & 1990.7 & M & $\begin{array}{l}\text { CFC-113/ } \\
\text { CFC-12 }\end{array}$ & 23.4 \\
\hline & & $5 / 10 / 00$ & 0900 & 800 & 21.99 & .73 & .00 & 9.8 & 2.1 & 1977.5 & M & $\begin{array}{l}\text { CFC-113/ } \\
\text { CFC-12 }\end{array}$ & 38 \\
\hline \multirow[t]{2}{*}{ NU 546} & $\mathrm{~W} 2-30$ & $5 / 14 / 99$ & 0900 & 800 & 19.12 & .67 & .00 & 12.6 & 2.4 & 1982.1 & M & $\begin{array}{l}\text { CFC-113/ } \\
\text { CFC-12 }\end{array}$ & 41.4 \\
\hline & & $5 / 10 / 00$ & 1100 & 800 & 20.59 & .69 & .00 & 11.2 & .6 & 1986.7 & $\mathrm{P}, \mathrm{M}$ & $\begin{array}{l}\text { CFC-12, } \\
\text { CFC-113 }\end{array}$ & 81.3 \\
\hline
\end{tabular}


Appendix C. Apparent ages and ancillary data used for modeled recharge dates for ground water collected in the Chesapeake Bay Watershed, June 1998 through May 2000-Continued

[ft, feet; ${ }^{\circ} \mathrm{C}$, degrees Celsius; mg/L, milligrams per liter; $\mathrm{mp}$, minipiezometer; $\mathrm{n} / \mathrm{a}$, not applicable; --, data not available; cc/L, cubic centimeter per liter;

CFC, chlorofluorocarbon; $\mathrm{SF}_{6}$, sulfur hexafluoride; P, piston; $\mathrm{M}$, mixture; n.p., not possible; n.d., not determined]

\begin{tabular}{|c|c|c|c|c|c|c|c|c|c|c|c|c|c|}
\hline $\begin{array}{c}\text { Site } \\
\text { name }\end{array}$ & Local ID & Date & Time & $\begin{array}{c}\text { Elevation } \\
\quad(\mathbf{f t})\end{array}$ & $\begin{array}{c}\text { Nitrogen } \\
\text { gas } \\
(\mathrm{mg} / \mathrm{L})\end{array}$ & $\begin{array}{l}\text { Argon } \\
\text { gas } \\
(\mathrm{mg} / \mathrm{L})\end{array}$ & $\begin{array}{c}\text { Methane } \\
(\mathrm{mg} / \mathrm{L})\end{array}$ & $\begin{array}{c}\text { Recharge } \\
\text { temperature } \\
\left({ }^{\circ} \mathrm{C}\right)\end{array}$ & $\begin{array}{l}\text { Excess } \\
\text { air } \\
(\mathrm{cc} / \mathrm{L})\end{array}$ & $\begin{array}{c}\text { Recom- } \\
\text { mended } \\
\text { recharge date }\end{array}$ & $\begin{array}{c}\text { Type of } \\
\text { model used } \\
\text { (P or M) }\end{array}$ & $\begin{array}{c}\text { Recom- } \\
\text { mended age } \\
\text { based on }\end{array}$ & $\begin{array}{l}\text { Percentage of } \\
\text { young water }\end{array}$ \\
\hline \multicolumn{14}{|c|}{ Mahantango WE-38 Watershed, West Transect-Continued } \\
\hline \multirow[t]{7}{*}{ NU 547} & W2-40 & $5 / 14 / 99$ & 0800 & 800 & 21.78 & 0.74 & 0.00 & 8.2 & 4.1 & 1982.6 & M & $\begin{array}{l}\text { CFC-113/ } \\
\text { CFC-12 }\end{array}$ & 16.5 \\
\hline & & $5 / 10 / 00$ & 1200 & 800 & 20.32 & .69 & 1.95 & 11.0 & 0.9 & 1979.7 & $\mathrm{P}$ & $\begin{array}{l}\text { CFC-12, } \\
\text { CFC-113 }\end{array}$ & 100 \\
\hline & W3-10 & $5 / 12 / 99$ & 1500 & 800 & 20.62 & .72 & .00 & 9.5 & 3.0 & 1987.0 & $P$ & $\begin{array}{l}\text { CFC-12, } \\
\text { CFC-113 }\end{array}$ & 100 \\
\hline & W3-20 & $5 / 12 / 99$ & 1600 & 800 & 20.74 & .73 & .00 & 9.0 & 2.9 & 1988.6 & $M$ & $\begin{array}{l}\text { CFC-113/ } \\
\text { CFC-12 }\end{array}$ & 45.4 \\
\hline & W3-30 & $5 / 12 / 99$ & 1630 & 800 & 19.67 & .67 & .00 & 13.0 & 3.4 & 1971.5 & $P$ & $\begin{array}{l}\text { CFC-113, } \\
\text { CFC-12 }\end{array}$ & 100 \\
\hline & W3-45 & $5 / 13 / 99$ & 1500 & 800 & 16.67 & .61 & .00 & 10.3 & .8 & 1975.4 & $P$ & CFC-12 & n.d. ${ }^{2}$ \\
\hline & W3-65 & $5 / 13 / 99$ & 1600 & 800 & 19.05 & .68 & .00 & 10.8 & 1.7 & 1993.1 & $M$ & $\begin{array}{l}\text { CFC-113/ } \\
\text { CFC-12 }\end{array}$ & 38.2 \\
\hline \multirow[t]{2}{*}{ NU 533} & W4-30 & $5 / 13 / 99$ & 1200 & 800 & 17.65 & .62 & .00 & 10.3 & 1.9 & 1977.1 & $M$ & $\begin{array}{l}\text { CFC-113/ } \\
\text { CFC-12 }\end{array}$ & 93.8 \\
\hline & & $5 / 10 / 00$ & 1300 & 800 & 22.15 & .73 & .00 & 9.4 & 2.6 & 1973.0 & $P$ & $\begin{array}{l}\text { CFC-12, } \\
\text { CFC-113 }\end{array}$ & 100 \\
\hline \multirow[t]{2}{*}{ NU 554} & W4-40 & $5 / 13 / 99$ & 1300 & 800 & 20.28 & .66 & .00 & 13.2 & 1.3 & 1985.1 & $M$ & $\begin{array}{l}\text { CFC-113/ } \\
\text { CFC-12 }\end{array}$ & 63.6 \\
\hline & & $5 / 10 / 00$ & 1330 & 800 & 21.18 & .71 & .00 & 10.4 & 1.9 & 1988.4 & $M$ & $\begin{array}{l}\text { CFC-113/ } \\
\text { CFC-12 }\end{array}$ & 67.8 \\
\hline \multirow[t]{3}{*}{ NU 555} & W5-10 & $5 / 13 / 99$ & 1100 & 800 & 21.70 & .75 & .00 & 7.6 & 3.5 & 1987.6 & $M$ & $\begin{array}{l}\text { CFC-113/ } \\
\text { CFC-12 }\end{array}$ & ${ }^{3} 124$ \\
\hline & & $5 / 10 / 00$ & 1500 & 800 & 20.88 & .72 & .00 & 9.4 & 1.7 & 1989.0 & $P$ & $\begin{array}{l}\text { CFC-11, } \\
\text { CFC-113 }\end{array}$ & 100 \\
\hline & W5-45 & $5 / 13 / 99$ & 1000 & 800 & 19.08 & .67 & .00 & 11.1 & 2.4 & 1999.4 & $P$ & $\begin{array}{l}\text { CFC-12, } \\
\text { CFC-11 }\end{array}$ & 100 \\
\hline
\end{tabular}


Appendix C. Apparent ages and ancillary data used for modeled recharge dates for ground water collected in the Chesapeake Bay Watershed, June 1998 through May 2000-Continued

[ft, feet; ${ }^{\circ} \mathrm{C}$, degrees Celsius; mg/L, milligrams per liter; mp, minipiezometer; n/a, not applicable; --, data not available; cc/L, cubic centimeter per liter;

CFC, chlorofluorocarbon; $\mathrm{SF}_{6}$, sulfur hexafluoride; P, piston; $\mathrm{M}$, mixture; n.p., not possible; n.d., not determined]

\begin{tabular}{|c|c|c|c|c|c|c|c|c|c|c|c|c|c|}
\hline $\begin{array}{c}\text { Site } \\
\text { name }\end{array}$ & Local ID & Date & Time & $\begin{array}{c}\text { Elevation } \\
\text { (ft) }\end{array}$ & $\begin{array}{l}\text { Nitrogen } \\
\text { gas } \\
(\mathrm{mg} / \mathrm{L})\end{array}$ & $\begin{array}{c}\text { Argon } \\
\text { gas } \\
(\mathrm{mg} / \mathrm{L})\end{array}$ & $\begin{array}{c}\text { Methane } \\
(\mathrm{mg} / \mathrm{L})\end{array}$ & $\begin{array}{c}\text { Recharge } \\
\text { temperature } \\
\left({ }^{\circ} \mathrm{C}\right)\end{array}$ & $\begin{array}{l}\text { Excess } \\
\text { air } \\
(\mathrm{cc} / \mathrm{L})\end{array}$ & $\begin{array}{c}\text { Recom- } \\
\text { mended } \\
\text { recharge date }\end{array}$ & $\begin{array}{c}\text { Type of } \\
\text { model used } \\
(\text { P or M) }\end{array}$ & $\begin{array}{c}\text { Recom- } \\
\text { mended age } \\
\text { based on }\end{array}$ & $\begin{array}{l}\text { Percentage of } \\
\text { young water }\end{array}$ \\
\hline \multicolumn{14}{|c|}{ Mahantango WE-38 Watershed, West Transect-Continued } \\
\hline NU 562 (forested) & & $5 / 17 / 00$ & 1330 & 980 & 19.21 & 0.71 & 0.00 & 8.6 & 1.1 & 1994.5 & $\mathrm{P}$ & $\begin{array}{l}\text { CFC-12, } \\
\text { CFC-113 }\end{array}$ & 100 \\
\hline $\begin{array}{l}\text { NU } 563 \text { (hog manure } \\
\text { applied) }\end{array}$ & & $5 / 17 / 00$ & 1500 & 884 & 20.42 & .71 & .00 & 9.2 & 1.2 & 1989.2 & M & $\begin{array}{l}\text { CFC-113/ } \\
\text { CFC-12 }\end{array}$ & 32.8 \\
\hline \multicolumn{14}{|c|}{ Masser's (recharge site - fertilizer applied) } \\
\hline $\begin{array}{l}\text { NU } 558 \text { (shallow) } \\
\text { Well NW }\end{array}$ & & $5 / 8 / 00$ & 1400 & 900 & 18.34 & .63 & .00 & 10.9 & .9 & 1989.0 & $P$ & CFC-11 & 100 \\
\hline $\begin{array}{l}\text { NU } 558 \text { (deep) } \\
\text { Well NW }\end{array}$ & & $5 / 8 / 00$ & 1500 & 900 & 20.71 & .59 & .00 & 10.9 & .6 & 1986.1 & $P$ & $\begin{array}{l}\text { CFC-11, } \\
\text { CFC-12 }\end{array}$ & 100 \\
\hline $\begin{array}{l}\text { NU } 559 \text { (shallow) } \\
\text { Well NE }\end{array}$ & & $5 / 8 / 00$ & 1300 & 900 & 17.60 & .66 & .00 & 10.8 & .3 & 1999.5 & $P$ & CFC-12 & 100 \\
\hline $\begin{array}{l}\text { NU } 559 \text { (deep) } \\
\text { Well NE }\end{array}$ & & $5 / 8 / 00$ & 1130 & 900 & 18.77 & .68 & .00 & 10.6 & .5 & 2000.4 & $P$ & CFC-12 & 100 \\
\hline
\end{tabular}

\section{Springs sampled as part of Chesapeake Bay Ground Water initiative during 1997}

\section{Maryland}

\begin{tabular}{|c|c|c|c|c|c|}
\hline 4 H camp spr. & Md.-HA-Bc-30 & 08/05/97 & 1017 & 380 & 18.57 \\
\hline Black Rock Spr. & Md.-WA CJ23 & 08/08/97 & 1615 & 540 & 18.09 \\
\hline Blue Hole Spr. & Md.-AL-CE-1 & 08/11/97 & 1230 & 560 & 17.49 \\
\hline Harver Spr. & Md.-WA-Ak-3 & 08/08/97 & 1000 & 660 & 20.31 \\
\hline Hillbilly Spr. & Md.-FR ED 82 & 08/07/97 & 1530 & 350 & 20.81 \\
\hline Jefferson Davis spr. & Md.-AL CF46 & 08/11/97 & 1500 & 660 & 17.68 \\
\hline Keedysville spr. & Md.-WA-Di-6 & 08/08/97 & 1305 & 380 & 18.80 \\
\hline Lilypons Spr. & Md.-FR-FD-55 & 08/07/97 & 1013 & 280 & 18.84 \\
\hline Manchester Spr. & Md. CL Bf 183 & 08/06/97 & 1034 & 890 & 18.85 \\
\hline Oregon Ridge spr. & Md.-BA-DC-440 & 08/05/97 & 1320 & 400 & 21.64 \\
\hline Phillips Spring & Md.-FR-PHILS & 08/06/97 & 1740 & 440 & 20.22 \\
\hline Retirement Center & Md.-BA-Del.1 & 08/05/97 & 1547 & 220 & 19.98 \\
\hline South of Gum Spring & Md.-FR-Fb-12 & 08/07/97 & 1308 & 300 & 16.80 \\
\hline
\end{tabular}

$\begin{array}{ll}.69 & .00 \\ .69 & .00 \\ .67 & .00 \\ .72 & .00 \\ .73 & .00 \\ .66 & .00 \\ .68 & .00 \\ .70 & .00 \\ .68 & .00 \\ .75 & .00 \\ .71 & .00 \\ .71 & .00 \\ .64 & .00\end{array}$

.00
.00
.00
.00
.00
.00
.00
.00
.00
.00
.00
.00
.00

$\begin{array}{rrc}10.1 & .7 & 1989 \\ 10.2 & .3 & 1997 \\ 10.4 & 1-.2 & 1986 \\ 10.0 & 2.5 & \text { n.p. } \\ 9.9 & 2.8 & 1991 \\ 11.4 & .4 & 1962 \\ & & \\ 12.1 & 1.6 & 1991 \\ 10.7 & 1.1 & 1990 \\ 11.4 & 1.7 & \text { n.p. } \\ 8.9 & 3.3 & 1988 \\ 10.4 & 2.5 & 1986 \\ & & \\ 10.5 & 2.1 & \text { n.p. } \\ 12.9 & 1-.2 & 1997\end{array}$

$\begin{array}{rcr}\mathrm{P} & \text { CFC-113 } & 100 \\ \mathrm{P} & \text { CFC-113 } & 100 \\ \mathrm{M} & \text { CFC-113 } & 58 \\ \mathrm{n} / \mathrm{a} & \mathrm{n} / \mathrm{a} & \mathrm{n} / \mathrm{a} \\ \mathrm{P} & \text { CFC-113 } & 100 \\ \mathrm{M} & \text { CFC-11, } & 10 \\ & \text { CFC-12 } & \\ \mathrm{P} & \text { CFC-113 } & 100 \\ \mathrm{P} & \text { CFC-113 } & 100 \\ \mathrm{n} / \mathrm{a} & \mathrm{n} / \mathrm{a} & \mathrm{n} / \mathrm{a} \\ \mathrm{P} & \text { CFC-113 } & 100 \\ \mathrm{M} & \text { CFC-11, } & 97 \\ & \text { CFC-113 } & \\ \mathrm{n} / \mathrm{a} & \mathrm{n} / \mathrm{a} & \mathrm{n} / \mathrm{a} \\ \mathrm{P} & \text { CFC-113 } & 100\end{array}$


Appendix C. Apparent ages and ancillary data used for modeled recharge dates for ground water collected in the Chesapeake Bay Watershed, June 1998 through May 2000-Continued

[ft, feet; ${ }^{\circ} \mathrm{C}$, degrees Celsius; mg/L, milligrams per liter; mp, minipiezometer; n/a, not applicable; --, data not available; cc/L, cubic centimeter per liter; CFC, chlorofluorocarbon; $\mathrm{SF}_{6}$, sulfur hexafluoride; P, piston; $\mathrm{M}$, mixture; n.p., not possible; n.d., not determined]

\begin{tabular}{|c|c|c|c|c|c|c|c|c|c|c|c|c|c|}
\hline $\begin{array}{c}\text { Site } \\
\text { name }\end{array}$ & Local ID & Date & Time & $\begin{array}{c}\text { Elevation } \\
\quad \text { (ft) }\end{array}$ & $\begin{array}{c}\text { Nitrogen } \\
\text { gas } \\
(\mathrm{mg} / \mathrm{L})\end{array}$ & $\begin{array}{c}\text { Argon } \\
\text { gas } \\
(\mathbf{m g} / \mathbf{L})\end{array}$ & $\begin{array}{c}\text { Methane } \\
(\mathrm{mg} / \mathrm{L})\end{array}$ & $\begin{array}{c}\text { Recharge } \\
\text { temperature } \\
\left({ }^{\circ} \mathbf{C}\right)\end{array}$ & $\begin{array}{l}\text { Excess } \\
\text { air } \\
(\mathrm{cc} / \mathrm{L})\end{array}$ & $\begin{array}{c}\text { Recom- } \\
\text { mended } \\
\text { recharge date }\end{array}$ & $\begin{array}{c}\text { Type of } \\
\text { model used } \\
(\text { P or M) }\end{array}$ & $\begin{array}{c}\text { Recom- } \\
\text { mended age } \\
\text { based on }\end{array}$ & $\begin{array}{l}\text { Percentage of } \\
\text { young water }\end{array}$ \\
\hline \multicolumn{14}{|l|}{ Pennsylvania } \\
\hline Alexander Spr. & PA-Cu-16 & 08/19/97 & 1210 & 512 & 20.86 & 0.72 & 0.00 & 10.9 & 3.1 & n.p. & $\mathrm{n} / \mathrm{a}$ & $\mathrm{n} / \mathrm{a}$ & $\mathrm{n} / \mathrm{a}$ \\
\hline Bellfonte Fishery Spr. & PA-Ce-12 & 08/21/97 & 850 & 824 & 17.97 & .64 & .00 & 13.4 & 1.7 & n.p. & $\mathrm{n} / \mathrm{a}$ & $\mathrm{n} / \mathrm{a}$ & $\mathrm{n} / \mathrm{a}$ \\
\hline Benner Spr. & PA-Ce-18 & 08/21/97 & 1200 & 920 & 20.67 & .71 & .00 & 11.1 & 3.5 & n.p. & $\mathrm{n} / \mathrm{a}$ & $\mathrm{n} / \mathrm{a}$ & $\mathrm{n} / \mathrm{a}$ \\
\hline Big Spr. & $\mathrm{PA}-\mathrm{Cu}-22$ & 08/19/97 & 1525 & 520 & 22.02 & .76 & .00 & 8.9 & 3.7 & n.p. & $\mathrm{n} / \mathrm{a}$ & $\mathrm{n} / \mathrm{a}$ & $\mathrm{n} / \mathrm{a}$ \\
\hline Clouser Spr. & PA-Pe-10 & 08/20/97 & 1040 & 500 & 22.02 & .76 & .00 & 12.9 & 0.1 & 1997 & $P$ & $\begin{array}{l}\text { CFC-11, } \\
\text { CFC-113 }\end{array}$ & 100 \\
\hline Donegal Spr. & PA-Ln-14 & 08/18/97 & 1522 & 354 & 25.95 & .80 & .00 & 11.2 & 2.3 & 1997 & $P$ & CFC-113 & 100 \\
\hline Dykeman Spr. & PA-Cu-24 & 08/19/97 & 955 & 680 & 20.81 & .73 & .00 & 9.4 & 2.8 & 1988 & $P$ & CFC-113 & 100 \\
\hline Hanover Spr. & PA-Yo-19 & 08/18/97 & 1222 & 852 & 21.06 & .71 & .00 & 10.9 & 3.7 & 1990 & $P$ & CFC-113 & 100 \\
\hline McAllisterville Spr. & PA-Ju-01 & 08/23/97 & 1000 & 1,120 & 17.53 & .66 & .00 & 10.4 & .2 & 1987 & $P$ & CFC-11 & 100 \\
\hline Mount Rock Spr. & PA-Cu-17 & 08/19/97 & 1340 & 530 & 21.59 & .76 & .00 & 9.6 & 3.6 & 1988 & $P$ & CFC-113 & 100 \\
\hline Pennrythe Spr. & PA-Lb-18 & 08/22/97 & 1440 & 450 & 19.13 & .68 & .00 & 11.6 & 1.8 & n.p. & $\mathrm{n} / \mathrm{a}$ & $\mathrm{n} / \mathrm{a}$ & $\mathrm{n} / \mathrm{a}$ \\
\hline PSU Ag Spr. & PA-Ce-33 & $08 / 21 / 97$ & 1435 & 1,242 & 17.65 & .65 & .00 & 11.4 & .8 & 1993 & $P$ & CFC-12 & 100 \\
\hline Trout Spr. & $\mathrm{PA}-\mathrm{Cu}-30$ & 08/18/97 & 930 & 440 & 17.65 & .65 & .00 & 11.6 & 1.3 & n.p. & $\mathrm{n} / \mathrm{a}$ & $\mathrm{n} / \mathrm{a}$ & $\mathrm{n} / \mathrm{a}$ \\
\hline Tylerville Spr. & PA-Cn-09 & 08/20/97 & 1520 & 1,049 & 16.97 & .62 & .00 & 13.0 & .5 & 1990 & $\mathrm{P}$ & $\begin{array}{l}\text { CFC-11, } \\
\text { CFC-113 }\end{array}$ & 100 \\
\hline \multicolumn{14}{|l|}{ Virginia } \\
\hline Arthur Weiss Spr. & VA 10 & 08/05/97 & 1230 & 460 & 18.82 & .66 & .00 & 14.3 & 2.4 & 1986 & M & CFC-113 & 87 \\
\hline Bear Lithia Spr. & VA 09 & 08/06/97 & 927 & 936 & 19.78 & .69 & .00 & 10.8 & 2.5 & 1974 & $P$ & $\begin{array}{l}\text { CFC-11, } \\
\text { CFC-12 }\end{array}$ & 70 \\
\hline Camp 2 Spr. & VA 11 & 08/12/97 & 1140 & 265 & 19.13 & .70 & .00 & 10.3 & 1.2 & 1987 & $P$ & $\begin{array}{l}\text { CFC-12, } \\
\text { CFC-113 }\end{array}$ & 100 \\
\hline CNHP28 & VA 14 & 08/04/97 & 1225 & 10 & 15.38 & .57 & .00 & 18.1 & ${ }^{1}-.1$ & 1989 & $P$ & $\begin{array}{l}\text { CFC-12, } \\
\text { CFC-113 }\end{array}$ & 100 \\
\hline Coyner Spr. & VA 01 & 08/13/97 & 930 & 1,310 & 21.04 & .73 & .00 & 9.5 & 3.5 & 1979 & $P$ & $\begin{array}{l}\text { CFC-11, } \\
\text { CFC-12 }\end{array}$ & 100 \\
\hline Deerfield Spr. & VA 07 & 08/08/97 & 1245 & 1,730 & 16.73 & .61 & .00 & 14.3 & 1.1 & 1986 & $P$ & $\begin{array}{l}\text { CFC-12, } \\
\text { CFC-113 }\end{array}$ & 100 \\
\hline Elkton & VA 08 & 08/05/97 & 1710 & 1,005 & 17.95 & .66 & .00 & 11.7 & 1.0 & 1964 & $P$ & $\begin{array}{l}\text { CFC-11, } \\
\text { CFC-12 }\end{array}$ & 100 \\
\hline Gardner & & 08/06/97 & 1515 & 1,361 & 21.17 & .70 & .00 & 12.8 & 4.8 & 1978 & M & $\begin{array}{l}\text { CFC-11, } \\
\text { CFC-12 }\end{array}$ & 62 \\
\hline George Washington & VA 13 & 08/11/97 & 1045 & 25 & 20.40 & .73 & .00 & 9.9 & 2.2 & 1985 & $P$ & $\begin{array}{l}\text { CFC-12, } \\
\text { CFC-113 }\end{array}$ & 100 \\
\hline
\end{tabular}


Appendix C. Apparent ages and ancillary data used for modeled recharge dates for ground water collected in the Chesapeake Bay Watershed, June 1998 through May 2000-Continued

[ft, feet; ${ }^{\circ} \mathrm{C}$, degrees Celsius; mg/L, milligrams per liter; mp, minipiezometer; $\mathrm{n} / \mathrm{a}$, not applicable; --, data not available; cc/L, cubic centimeter per liter; CFC, chlorofluorocarbon; $\mathrm{SF}_{6}$, sulfur hexafluoride; P, piston; $\mathrm{M}$, mixture; n.p., not possible; n.d., not determined]

\begin{tabular}{|c|c|c|c|c|c|c|c|c|c|c|c|c|c|}
\hline $\begin{array}{c}\text { Site } \\
\text { name }\end{array}$ & Local ID & Date & Time & $\begin{array}{c}\text { Elevation } \\
\text { (ft) }\end{array}$ & $\begin{array}{c}\text { Nitrogen } \\
\text { gas } \\
(\mathrm{mg} / \mathrm{L})\end{array}$ & $\begin{array}{c}\text { Argon } \\
\text { gas } \\
(\mathbf{m g} / \mathrm{L})\end{array}$ & $\begin{array}{l}\text { Methane } \\
\text { (mg/L) }\end{array}$ & $\begin{array}{c}\text { Recharge } \\
\text { temperature } \\
\left({ }^{\circ} \mathrm{C}\right)\end{array}$ & $\begin{array}{l}\text { Excess } \\
\text { air } \\
(\mathrm{cc} / \mathrm{L})\end{array}$ & $\begin{array}{c}\text { Recom- } \\
\text { mended } \\
\text { recharge date }\end{array}$ & $\begin{array}{c}\text { Type of } \\
\text { model used } \\
(P \text { or } M)\end{array}$ & $\begin{array}{c}\text { Recom- } \\
\text { mended age } \\
\text { based on }\end{array}$ & $\begin{array}{l}\text { Percentage of } \\
\text { young water }\end{array}$ \\
\hline \multicolumn{14}{|c|}{ Virginia-Continued } \\
\hline Green Spr. & VA 12 & 08/13/97 & 1425 & 345 & 20.50 & 0.73 & 0.00 & 10.2 & 2.6 & $<1940$ & $P$ & $\begin{array}{l}\text { CFC-11, } \\
\text { CFC-12 }\end{array}$ & 100 \\
\hline $\begin{array}{l}\text { Gypsy Hilll Golf } \\
\text { Course }\end{array}$ & VA 05 & 08/06/97 & 1240 & 1470 & 18.07 & .65 & .00 & 12.0 & 1.5 & n.p. & $\mathrm{n} / \mathrm{a}$ & $\mathrm{n} / \mathrm{a}$ & $\mathrm{n} / \mathrm{a}$ \\
\hline Loth Spr. & VA 02 & 08/13/97 & 1145 & 1285 & 18.92 & .68 & .00 & 11.0 & 1.9 & 1982 & $\mathrm{P}$ & CFC-11 & 100 \\
\hline Masanetta & VA 04 & 08/07/97 & 1520 & 1385 & 19.75 & .69 & .00 & 11.7 & 2.3 & 1977 & $P$ & CFC-11 & 100 \\
\hline Timberville Spr. & VA 03 & 08/08/97 & 900 & 1260 & 17.76 & .65 & .00 & 12.2 & 1.2 & 1988 & $P$ & $\begin{array}{l}\text { CFC-11, } \\
\text { CFC-113 }\end{array}$ & 100 \\
\hline Warm Spr. & VA 06 & 08/08/97 & 1543 & 2335 & 16.32 & .61 & .00 & 11.9 & 3 & 1950 & $P$ & CFC-12 & 100 \\
\hline \multicolumn{14}{|l|}{ West Virginia } \\
\hline Berkeley Spr. & WV-BS-1 & 08/11/97 & 1710 & 620 & 23.84 & .79 & .00 & 9.5 & 5.8 & 1948 & $P$ & CFC-12 & 100 \\
\hline
\end{tabular}

${ }^{1}$ Sample may be degassed.

${ }^{2}$ Contains excess CFC-113, fraction of young water undetermined.

${ }^{3}$ Young fraction near 100 percent. 
Appendix D. Average concentration of CFC-11,12, and 113, SF , tritium, and ${ }^{3} \mathrm{He}$ for ground water collected in the Chesapeake Bay Watershed, June 1998 through May 2000

[pg/kg, picograms per kilogram; mp, minipiezometer; --, data not available; fMol/L, femtomol per liter;

$\mathrm{CFC}$, chlorofluorocarbon; $\mathrm{SF}_{6}$, sulfur hexafluoride; $\mathrm{TU}$, tritium units]

\begin{tabular}{|c|c|c|c|c|c|c|c|c|}
\hline \multirow[b]{2}{*}{$\begin{array}{c}\text { Site } \\
\text { name }\end{array}$} & \multirow[b]{2}{*}{$\begin{array}{c}\text { Local } \\
\text { ID }\end{array}$} & \multirow[b]{2}{*}{ Date } & \multirow[b]{2}{*}{ Time } & \multicolumn{3}{|c|}{$\begin{array}{c}\text { Concentration in solution } \\
\qquad(\mathrm{pg} / \mathrm{kg})\end{array}$} & \multirow{2}{*}{$\begin{array}{c}\begin{array}{c}\text { Concentration } \\
\text { in water } \\
\text { (fMol/L) }\end{array} \\
\mathrm{SF}_{6}\end{array}$} & \multirow{2}{*}{$\begin{array}{c}\begin{array}{c}\text { Concentration } \\
\text { (TU) }\end{array} \\
\text { Tritium }\end{array}$} \\
\hline & & & & CFC-11 & CFC-12 & CFC-113 & & \\
\hline \multicolumn{9}{|c|}{ Pocomoke River at Careytown, Md. } \\
\hline WI Bh p1a & mp 1 & $8 / 24 / 98$ & 0915 & 2,628 & 63.0 & -- & -- & -- \\
\hline WI Bh p1b & $\mathrm{mp} 2$ & $8 / 24 / 98$ & 1100 & 524 & 209 & -- & -- & -- \\
\hline WI Bh p1c & $\mathrm{mp} 3$ & $8 / 24 / 98$ & 1400 & 1,709 & 217 & -- & -- & -- \\
\hline WI Bh p1d & $\mathrm{mp} 4$ & $8 / 24 / 98$ & 1515 & 310 & 198 & -- & -- & -- \\
\hline WI Bh p1e & mp 5 & $8 / 24 / 98$ & 1600 & 233 & 101 & -- & -- & -- \\
\hline WI Bh p1f & mp 6 & $8 / 25 / 98$ & 0900 & 265 & 45.3 & -- & -- & -- \\
\hline WI Bh p1g & $\mathrm{mp} 7$ & $8 / 25 / 98$ & 1015 & 115 & 14.4 & -- & -- & -- \\
\hline WI Bh p1h & $\mathrm{mp} 8$ & $8 / 25 / 98$ & 1130 & 327 & 3.7 & -- & -- & -- \\
\hline WI Bh pli & mp 9 & $8 / 25 / 98$ & 1230 & 121 & 2.4 & -- & -- & -- \\
\hline WI Bh p1j & $\mathrm{mp} 10$ & $8 / 25 / 98$ & 1330 & 106 & 3.1 & -- & -- & -- \\
\hline \multicolumn{9}{|c|}{ Pine Ridge Branch near Careytown, Md. } \\
\hline WO Be p1a & $\mathrm{mp} 1$ & 9/23/98 & 1030 & 9,492 & 32,284 & 108 & -- & -- \\
\hline WO Be p1b & $\mathrm{mp} 2$ & 9/23/98 & 0830 & 4,489 & 5,954 & 93.2 & -- & -- \\
\hline WO Be p1c & $\mathrm{mp} 3$ & 9/23/98 & 1130 & 7,049 & 16,849 & 23.0 & -- & -- \\
\hline \multicolumn{9}{|c|}{ North Fork Green Run near Whitesville, Del. } \\
\hline WI Bx p1a & $\mathrm{mp} 1$ & 9/21/98 & 0930 & 3.3 & 72.0 & .5 & -- & -- \\
\hline WI Bx p1b & $\mathrm{mp} 2$ & 9/21/98 & 1130 & 1.5 & 80.6 & .0 & -- & -- \\
\hline WI Bx p1c & $\mathrm{mp} 3$ & $9 / 21 / 98$ & 1300 & .0 & 110 & .7 & -- & -- \\
\hline WI Bx p1d & $\mathrm{mp} 4$ & 9/21/98 & 1500 & .5 & 54.2 & .0 & -- & -- \\
\hline WI Bx p1e & mp 5 & 9/21/98 & 1600 & .9 & 91.5 & 3.4 & -- & -- \\
\hline WI Bx p1f & mp 6 & $9 / 22 / 98$ & 0900 & 3.8 & 165 & 7.7 & -- & -- \\
\hline WI Bx p1g & $\mathrm{mp} 7$ & $9 / 22 / 98$ & 1100 & .3 & 147 & .5 & -- & -- \\
\hline WI Bx p1h & mp 8 & $9 / 22 / 98$ & 1200 & 1.2 & 114 & 3.7 & -- & -- \\
\hline WI Bx pli & mp 9 & 9/22/98 & 1300 & 1.5 & 89.8 & 44 & -- & -- \\
\hline WI Bx p1j & $\mathrm{mp} 10$ & 9/22/98 & 1430 & .2 & 41.2 & .0 & -- & -- \\
\hline \multirow[t]{3}{*}{ WI Bx p2a } & NF Well \#1 & $3 / 25 / 99$ & 0900 & 63.5 & 129 & 11.3 & 1.21 & 4.42 \\
\hline & & 9/22/99 & 1500 & & & & -- & 3.63 \\
\hline & & $3 / 14 / 00$ & 0900 & 4.0 & 18.2 & .0 & & 2.49 \\
\hline \multirow[t]{3}{*}{ WI Bx p2c } & NF Well \#3 & $3 / 25 / 99$ & 1200 & 1.2 & 1.9 & .0 & 7.10 & 1.42 \\
\hline & & 9/29/99 & 1300 & & & & 2.42 & 1.77 \\
\hline & & $3 / 14 / 00$ & 1100 & 1.3 & 6.3 & .0 & 4.44 & -.86 \\
\hline \multirow[t]{3}{*}{ WI Bx p2d } & NF Well \#4 & $3 / 25 / 99$ & 1330 & 91.9 & 88.0 & 19.9 & .71 & 1.03 \\
\hline & & 9/29/99 & 1500 & & & & .45 & .71 \\
\hline & & $3 / 14 / 00$ & 1200 & 10.3 & 16.5 & 4.0 & .66 & .44 \\
\hline
\end{tabular}


Appendix $D$. Average concentration of $C F C-11,12$, and $113, S F_{6}$, tritium, and ${ }^{3} \mathrm{He}$ for ground water collected in the Chesapeake Bay Watershed, June 1998 through May 2000—Continued

[pg/kg, picograms per kilogram; mp, minipiezometer; --, data not available; fMol/L, femtomol per liter; $\mathrm{CFC}$, chlorofluorocarbon; $\mathrm{SF}_{6}$, sulfur hexafluoride; $\mathrm{TU}$, tritium units]

\begin{tabular}{|c|c|c|c|c|c|c|c|c|}
\hline \multirow[b]{2}{*}{$\begin{array}{c}\text { Site } \\
\text { name }\end{array}$} & \multirow[b]{2}{*}{$\begin{array}{c}\text { Local } \\
\text { ID }\end{array}$} & \multirow[b]{2}{*}{ Date } & \multirow[b]{2}{*}{ Time } & \multicolumn{3}{|c|}{$\begin{array}{c}\text { Concentration in solution } \\
\qquad(\mathrm{pg} / \mathrm{kg})\end{array}$} & \multirow{2}{*}{$\begin{array}{c}\begin{array}{c}\text { Concentration } \\
\text { in water } \\
\text { (fMol/L) }\end{array} \\
\text { SF }_{6}\end{array}$} & \multirow{2}{*}{$\begin{array}{c}\begin{array}{c}\text { Concentration } \\
\text { (TU) }\end{array} \\
\text { Tritium }\end{array}$} \\
\hline & & & & CFC-11 & CFC-12 & CFC-113 & & \\
\hline \multicolumn{9}{|c|}{ North Fork Green Run near Whitesville, Del. } \\
\hline WI Bx p2e & $\mathrm{mp} 1$ & $3 / 29 / 99$ & 1400 & 0.7 & 2.2 & 0.9 & 3.68 & 3.40 \\
\hline WI Bx p2f & $\mathrm{mp} 2$ & $3 / 29 / 99$ & 1200 & .0 & 3.0 & .0 & 8.34 & -- \\
\hline WI Bx p2g & $\mathrm{mp} 3$ & $3 / 25 / 99$ & 1500 & .0 & 19.5 & .0 & 10.59 & 1.14 \\
\hline WI Bx p2h & $\mathrm{mp} 4$ & $3 / 26 / 99$ & 1000 & .0 & 2.1 & .0 & 2.06 & -- \\
\hline WI Bx p2i & mp 5 & $3 / 26 / 99$ & 0900 & 75.4 & 44.6 & 8.4 & 1.12 & 3.46 \\
\hline \multicolumn{9}{|c|}{ Unnamed ditch to North Fork Green Run near Whitesville, Del. (Wayne Tull's Farm) } \\
\hline \multirow[t]{3}{*}{ WI By p1a } & WT Well \#1 & $3 / 23 / 99$ & 1230 & 744 & 403 & 109 & 2.32 & .09 \\
\hline & & 9/23/99 & 1000 & & & & -- & 5.42 \\
\hline & & $3 / 13 / 00$ & 1400 & & & & -- & 5.47 \\
\hline \multirow[t]{3}{*}{ WI By plb } & WT Well \#2 & $3 / 23 / 99$ & 1400 & 668 & 419 & 97.0 & 2.16 & 5.75 \\
\hline & & 9/23/99 & 1300 & & & & -- & 5.81 \\
\hline & & $3 / 13 / 00$ & 1600 & & & & -- & 3.99 \\
\hline \multirow[t]{2}{*}{ WI By p1c } & WT Well \#3 & $3 / 23 / 99$ & 1000 & 7.5 & 229 & 7.0 & .52 & 6.76 \\
\hline & & 9/23/99 & 1600 & & & & .47 & 6.25 \\
\hline \multirow[t]{3}{*}{ WI By p1d } & WT Well \#4 & $3 / 23 / 99$ & 1200 & 4.6 & 211 & 8.0 & .46 & 5.28 \\
\hline & & $9 / 24 / 99$ & 0900 & & & & .61 & 5.74 \\
\hline & & $3 / 13 / 00$ & 1300 & 29.0 & 207 & 13.7 & -- & 5.75 \\
\hline WI By p1e & $\mathrm{mp} 1$ & $3 / 24 / 99$ & 1300 & 19.8 & 239 & 23.3 & 1.51 & -- \\
\hline WI By p1f & $\mathrm{mp} 2$ & $3 / 24 / 99$ & 1030 & 96.9 & 241 & 31.5 & .41 & -- \\
\hline WI By p1g & mp 3 & $3 / 24 / 99$ & 1430 & 34.8 & 227 & 20.9 & 1.25 & -- \\
\hline \multicolumn{9}{|c|}{ Green Run near Careytown, MD (Green Run at Bethel Road) } \\
\hline \multirow[t]{2}{*}{ WI Bz p1a } & GR Well \#1 & $3 / 30 / 99$ & 0830 & & & & -- & 0.0 \\
\hline & & $9 / 21 / 99$ & 1200 & & & & 1.23 & 5.80 \\
\hline WI Bz plb & GR Well \#2 & $3 / 30 / 99$ & 0900 & 5.0 & 2.9 & 0.0 & .40 & .34 \\
\hline WI Bz p1c & GR Well \#3 & $3 / 30 / 99$ & 1000 & 5.1 & 8.6 & .0 & .67 & .91 \\
\hline \multirow[t]{3}{*}{ WI Bz p1d } & GR Well \#4 & $3 / 29 / 99$ & 1500 & 153 & 234 & 23.1 & .76 & 7.12 \\
\hline & & $9 / 22 / 99$ & 1300 & & & & .58 & 8.29 \\
\hline & & $3 / 14 / 00$ & 1500 & 43.2 & 181 & 9.2 & -- & 6.76 \\
\hline WI Bz p1e & mp 1 & $3 / 31 / 99$ & 0800 & 210 & 213 & 29.8 & 1.18 & 6.32 \\
\hline WI Bz p1f & $\mathrm{mp} 2$ & $3 / 30 / 99$ & 1500 & 39.0 & 83.4 & 8.7 & .80 & 3.82 \\
\hline
\end{tabular}


Appendix D. Average concentration of CFC-11,12, and 113, $S F_{6}$, tritium, and ${ }^{3} \mathrm{He}$ for ground water collected in the Chesapeake Bay Watershed, June 1998 through May 2000-Continued

[pg/kg, picograms per kilogram; $\mathrm{mp}$, minipiezometer; --, data not available; fMol/L, femtomol per liter; $\mathrm{CFC}$, chlorofluorocarbon; $\mathrm{SF}_{6}$, sulfur hexafluoride; $\mathrm{TU}$, tritium units]

\begin{tabular}{|c|c|c|c|c|c|c|c|c|}
\hline \multirow[b]{2}{*}{$\begin{array}{c}\text { Site } \\
\text { name }\end{array}$} & \multirow[b]{2}{*}{$\begin{array}{c}\text { Local } \\
\text { ID }\end{array}$} & \multirow[b]{2}{*}{ Date } & \multirow[b]{2}{*}{ Time } & \multicolumn{3}{|c|}{$\begin{array}{c}\text { Concentration in solution } \\
(\mathbf{p g} / \mathrm{kg})\end{array}$} & \multirow{2}{*}{$\frac{\begin{array}{c}\text { Concentration } \\
\text { in water } \\
\text { (fMol/L) }\end{array}}{\mathrm{SF}_{6}}$} & \multirow{2}{*}{$\begin{array}{c}\begin{array}{c}\text { Concentration } \\
\text { (TU) }\end{array} \\
\text { Tritium }\end{array}$} \\
\hline & & & & CFC-11 & CFC-12 & CFC-113 & & \\
\hline \multicolumn{9}{|c|}{ Green Run near Careytown, MD (Green Run at Bethel Road)-Continued } \\
\hline WI Bz p1g & $\mathrm{mp} 3$ & 3/30/99 & 1400 & 228 & 78 & 3.8 & 0.55 & 0.89 \\
\hline WI Bz p1h & $\mathrm{mp} 4$ & $3 / 30 / 99$ & 1200 & 6.5 & 7.2 & .0 & .59 & 1.37 \\
\hline WI Bz pli & $\mathrm{mp} 5$ & $3 / 31 / 99$ & 1000 & 1.7 & 4.6 & .0 & .87 & 1.43 \\
\hline WI Bz plj & $\mathrm{mp} 6$ & $3 / 31 / 99$ & 1100 & .7 & 6.0 & .0 & .31 & 1.58 \\
\hline WI Bz p1k & $\mathrm{mp} 7$ & $3 / 31 / 99$ & 1200 & 4.0 & 8.2 & .0 & -- & 2.74 \\
\hline \multicolumn{9}{|c|}{ Additional wells in Upper Pocomoke River Basin } \\
\hline WI Bh 8 & & $9 / 23 / 98$ & 1600 & .7 & 13.2 & 1.1 & -- & -- \\
\hline WI Bh 8 & & $3 / 31 / 99$ & 1300 & 2.1 & 23.9 & .0 & .52 & -- \\
\hline WI Bh 9 & & 9/23/98 & 1400 & .2 & .0 & .0 & -- & -- \\
\hline WI Bh 9 & & $3 / 31 / 99$ & 1400 & 2.1 & 2.4 & .0 & .56 & -- \\
\hline WI Ch 56 & & 9/24/98 & 1000 & 535 & 321 & 79.3 & -- & -- \\
\hline WI Ch 57 & & $9 / 24 / 98$ & 0900 & 161 & 294 & 36.3 & -- & -- \\
\hline \multicolumn{9}{|c|}{ Springs in Muddy Creek watershed (Owner's name is Local ID) } \\
\hline \multirow[t]{3}{*}{ 39SS-001 } & Goode & $11 / 09 / 98$ & 1000 & 338 & 232 & 40.8 & -- & -- \\
\hline & & 4/14/99 & 1030 & 548 & 375 & 74.1 & 1.93 & -- \\
\hline & & 4/17/00 & 1500 & 681 & 348 & 83.3 & -- & 8.12 \\
\hline \multirow[t]{2}{*}{$39 S S-002$} & Thompson & $11 / 09 / 98$ & 1330 & 528 & 281 & .0 & -- & -- \\
\hline & & 4/14/99 & 1300 & 562 & 294 & 67.1 & 2.43 & -- \\
\hline \multirow[t]{2}{*}{ 39SS-003 } & Dove & $11 / 09 / 98$ & 1400 & 332 & 167 & 38.0 & -- & -- \\
\hline & & 4/14/99 & 1400 & 301 & 156 & 40.0 & 7.96 & -- \\
\hline 39SS-005 & Heatwole & 4/14/99 & 1130 & 7,810 & 360 & 64.8 & -- & 8.75 \\
\hline \multirow[t]{2}{*}{ 39RS-001 } & Heatwole & $11 / 10 / 98$ & 0830 & 563 & 287 & 79.2 & -- & -- \\
\hline & & 4/14/99 & 1500 & 545 & 284 & 83.2 & 1.55 & -- \\
\hline \multicolumn{9}{|c|}{ Observation wells in Muddy Creek watershed } \\
\hline \multirow[t]{2}{*}{$39 \mathrm{~S} 2$} & MC-4 & $4 / 13 / 99$ & 1200 & 8,773 & 385 & 63.3 & 2.93 & 9.58 \\
\hline & & $4 / 18 / 00$ & 1100 & 12,778 & 274 & 45.2 & -- & 8.07 \\
\hline \multirow[t]{2}{*}{$39 \mathrm{~S} 4$} & MC-8 & $4 / 13 / 99$ & 0900 & 9,098 & 690 & 38.7 & -- & -- \\
\hline & & $4 / 18 / 00$ & 0900 & 4,708 & 875 & 48.9 & -- & 6.14 \\
\hline
\end{tabular}


Appendix $D$. Average concentration of $C F C-11,12$, and $113, S F_{6}$, tritium, and ${ }^{3} \mathrm{He}$ for ground water collected in the Chesapeake Bay Watershed, June 1998 through May 2000—Continued

[pg/kg, picograms per kilogram; mp, minipiezometer; --, data not available; fMol/L, femtomol per liter; $\mathrm{CFC}$, chlorofluorocarbon; $\mathrm{SF}_{6}$, sulfur hexafluoride; $\mathrm{TU}$, tritium units]

\begin{tabular}{|c|c|c|c|c|c|c|c|c|}
\hline \multirow[b]{2}{*}{$\begin{array}{c}\text { Site } \\
\text { name }\end{array}$} & \multirow[b]{2}{*}{$\begin{array}{c}\text { Local } \\
\text { ID }\end{array}$} & \multirow[b]{2}{*}{ Date } & \multirow[b]{2}{*}{ Time } & \multicolumn{3}{|c|}{$\begin{array}{c}\text { Concentration in solution } \\
\qquad(\mathrm{pg} / \mathrm{kg})\end{array}$} & \multirow{2}{*}{$\begin{array}{c}\begin{array}{c}\text { Concentration } \\
\text { in water } \\
\text { (fMol/L) }\end{array} \\
\text { SF }_{6}\end{array}$} & \multirow{2}{*}{$\begin{array}{c}\begin{array}{c}\text { Concentration } \\
\text { (TU) }\end{array} \\
\text { Tritium }\end{array}$} \\
\hline & & & & CFC-11 & CFC-12 & CFC-113 & & \\
\hline \multicolumn{9}{|c|}{ Observation wells in Muddy Creek watershed-Continued } \\
\hline \multirow[t]{2}{*}{$39 S 9$} & MC-17 & 4/13/99 & 1300 & 6,232 & 3,327 & 43.3 & 1.04 & 9.29 \\
\hline & & $4 / 18 / 00$ & 1200 & 8,619 & 3,968 & 22.8 & -- & .24 \\
\hline \multirow[t]{2}{*}{$39 \mathrm{~S} 14$} & MC-28 & $4 / 12 / 99$ & 1300 & 10,922 & 255 & 43.6 & 2.13 & -- \\
\hline & & $4 / 17 / 00$ & 1000 & 9,765 & 265 & 44.8 & -- & .05 \\
\hline \multirow[t]{2}{*}{$39 \mathrm{~S} 15$} & MC-29 & 4/12/99 & 1500 & 6,010 & 224 & 32.7 & 1.88 & -- \\
\hline & & $4 / 17 / 00$ & 1200 & 278 & 183 & 23.6 & -- & .61 \\
\hline \multirow[t]{2}{*}{ 39S16 } & MC-30 & 4/12/99 & 1100 & 13,380 & 308 & 6.34 & 4.28 & -- \\
\hline & & $4 / 17 / 00$ & 1400 & 14,846 & 320 & 70.1 & -- & 5.21 \\
\hline \multirow[t]{2}{*}{$39 \mathrm{~S} 19$} & MC-34 & 4/13/99 & 1100 & 6,697 & 323 & 49.1 & 5.04 & -- \\
\hline & & $4 / 18 / 00$ & 0800 & 651 & 322 & 78.9 & -- & 4.24 \\
\hline \multicolumn{9}{|c|}{ Domestic wells in Muddy Creek watershed (Owner's name is Local ID) } \\
\hline \multirow[t]{2}{*}{$39 S 34$} & Harmon (1) & 4/13/99 & 1500 & 243 & 143 & 18.0 & -- & -- \\
\hline & & $4 / 14 / 99$ & 0900 & 116 & 108 & 16.8 & -- & -- \\
\hline 39S35 & Harmon (2) & $4 / 13 / 99$ & 1600 & 8,873 & 405 & 61.9 & -- & 9.39 \\
\hline $39 S 39$ & Fairview Church & 4/15/99 & 1500 & 278 & 166 & 20.8 & -- & -- \\
\hline $39 S 40$ & Dove & $4 / 15 / 99$ & 1000 & 85 & 28 & 5.3 & 59.6 & -- \\
\hline $39 S 41$ & Weintraub (1) & $4 / 15 / 99$ & 1200 & 347 & 202 & 47.7 & 2.37 & -- \\
\hline $39 S 42$ & Weintraub (2) & $4 / 15 / 99$ & 1300 & 201 & 119 & 28.8 & 2.87 & -- \\
\hline $39 S 43$ & Martin & 4/16/99 & 0900 & 1.9 & 2.2 & .0 & 1.15 & .38 \\
\hline 39S44 & Smith & $4 / 16 / 99$ & 1100 & 571 & 303 & 70.2 & 1.58 & -- \\
\hline \multicolumn{9}{|c|}{ Polecat Creek, Virginia } \\
\hline $50 \mathrm{M} 2$ & & 4/19/99 & 1000 & 124 & 64 & 5.0 & .16 & -- \\
\hline $50 \mathrm{M} 3$ & & 4/19/99 & 1100 & 605 & 302 & 82.3 & 1.67 & -- \\
\hline $50 \mathrm{M} 4$ & & 4/19/99 & 1800 & 546 & 253 & 65.0 & 1.41 & -- \\
\hline $50 \mathrm{M} 5$ & & $4 / 20 / 99$ & 1500 & 6.4 & 116 & 6.6 & 2.26 & -- \\
\hline $50 \mathrm{M} 6$ & & $4 / 21 / 99$ & 0800 & 494 & 395 & 93.6 & -- & .03 \\
\hline $50 \mathrm{M} 7$ & & $4 / 21 / 99$ & 1500 & 157 & 109 & 8.3 & .21 & -- \\
\hline $50 \mathrm{M} 16$ & & 4/19/99 & 1200 & 610 & 317 & 75.3 & 1.46 & -- \\
\hline 50M17 & & 4/19/99 & 1500 & 612 & 316 & 81.9 & 1.56 & -- \\
\hline $50 \mathrm{M} 18$ & & $4 / 20 / 99$ & 0800 & 564 & 274 & 67.9 & -- & -- \\
\hline $50 \mathrm{M} 19$ & & 4/19/99 & 1700 & 593 & 313 & 82.1 & 1.81 & -- \\
\hline $50 \mathrm{M} 21$ & & $4 / 20 / 99$ & 1100 & 648 & 382 & 87.0 & 1.95 & -- \\
\hline $50 \mathrm{M} 22$ & & 4/20/99 & 1300 & 670 & 381 & 83.9 & 1.95 & -- \\
\hline $50 \mathrm{M} 23$ & & 4/21/99 & 0900 & & & & -- & -- \\
\hline $50 \mathrm{M} 24$ & & 4/21/99 & 1000 & 246 & 296 & 73.0 & 2.23 & -- \\
\hline $50 \mathrm{M} 25$ & & 4/21/99 & 1200 & 619 & 336 & 90.5 & 1.61 & 7.68 \\
\hline
\end{tabular}


Appendix D. Average concentration of CFC-11,12, and 113, $S F_{6}$, tritium, and ${ }^{3} \mathrm{He}$ for ground water collected in the Chesapeake Bay Watershed, June 1998 through May 2000-Continued

[pg/kg, picograms per kilogram; mp, minipiezometer; --, data not available; fMol/L, femtomol per liter; $\mathrm{CFC}$, chlorofluorocarbon; $\mathrm{SF}_{6}$, sulfur hexafluoride; $\mathrm{TU}$, tritium units]

\begin{tabular}{|c|c|c|c|c|c|c|c|c|}
\hline \multirow[b]{2}{*}{$\begin{array}{c}\text { Site } \\
\text { name }\end{array}$} & \multirow[b]{2}{*}{$\begin{array}{c}\text { Local } \\
\text { ID }\end{array}$} & \multirow[b]{2}{*}{ Date } & \multirow[b]{2}{*}{ Time } & \multicolumn{3}{|c|}{$\begin{array}{l}\text { Concentration in solution } \\
\qquad(\mathrm{pg} / \mathrm{kg})\end{array}$} & \multirow{2}{*}{$\begin{array}{c}\begin{array}{c}\text { Concentration } \\
\text { in water } \\
\text { (fMol/L) }\end{array} \\
\mathrm{SF}_{6}\end{array}$} & \multirow{2}{*}{$\begin{array}{c}\begin{array}{c}\text { Concentration } \\
\text { (TU) }\end{array} \\
\text { Tritium }\end{array}$} \\
\hline & & & & CFC-11 & CFC-12 & CFC-113 & & \\
\hline \multicolumn{9}{|c|}{ Polecat Creek, Virginia-Continued } \\
\hline $50 \mathrm{M} 26$ & & $4 / 21 / 99$ & 1400 & 631 & 348 & 74.6 & 1.57 & 7.59 \\
\hline $50 \mathrm{M} 28$ & & $4 / 21 / 99$ & 0930 & & & & -- & -- \\
\hline $50 \mathrm{M} 27$ & & $3 / 29 / 00$ & 1415 & & & & -- & -- \\
\hline $50 \mathrm{M} 29$ & & $4 / 10 / 00$ & 1300 & 251 & 241 & 51.2 & -- & .1 \\
\hline $50 \mathrm{M} 30$ & & $4 / 10 / 00$ & 1100 & 80.9 & 167 & 33.5 & -- & 6.4 \\
\hline \multicolumn{9}{|c|}{ Mahantango WE-38 Watershed, East Transect } \\
\hline NU 538 & E1-10 & $5 / 10 / 99$ & 1145 & 251 & 196 & 27.6 & 1.65 & -- \\
\hline NU 539 & E1-20 & 5/10/99 & 1245 & 15.5 & 16.2 & .0 & .11 & -- \\
\hline \multirow[t]{3}{*}{ NU 540} & E2-10 & $5 / 10 / 99$ & 1345 & 10.7 & 5.9 & .0 & .06 & 2.88 \\
\hline & & $5 / 9 / 00$ & 1600 & 29.4 & 6.2 & .0 & & \\
\hline & E2-35 & 5/10/99 & 1500 & 15.8 & 21.7 & .0 & .05 & 2.90 \\
\hline \multirow[t]{3}{*}{ NU 534} & E3-10 & $6 / 16 / 98$ & 1550 & 3.0 & 7.9 & .0 & .22 & -- \\
\hline & & $5 / 11 / 99$ & 0900 & 7.9 & 3.5 & .0 & .05 & -- \\
\hline & & $5 / 9 / 00$ & 1500 & 32.3 & 18.5 & 4.5 & -- & -- \\
\hline \multirow[t]{2}{*}{ NU 535} & E3-20 & $6 / 15 / 98$ & 1720 & 7.9 & 12.1 & .9 & .20 & -- \\
\hline & & $5 / 11 / 99$ & 1100 & 4.8 & 9.5 & 1.4 & .19 & -- \\
\hline \multirow[t]{2}{*}{ NU 536} & E3-30 & $6 / 17 / 98$ & 1120 & 5.5 & 7.9 & 37.1 & .35 & -- \\
\hline & & $5 / 11 / 99$ & 1200 & 14.1 & 28.6 & 2.0 & .09 & -- \\
\hline \multirow[t]{2}{*}{ NU 537} & E3-45 & $6 / 18 / 98$ & 0930 & 18.1 & 30.4 & 2.0 & .57 & -- \\
\hline & & $5 / 10 / 99$ & 1600 & 102 & 62.2 & 22.1 & .21 & -- \\
\hline \multirow[t]{3}{*}{ NU 529} & E4-10 & $6 / 16 / 98$ & 1420 & 329 & 206 & 49.5 & 1.30 & -- \\
\hline & & $5 / 11 / 99$ & 1300 & 314 & 224 & 48.7 & 1.47 & 9.19 \\
\hline & & $5 / 9 / 00$ & 0930 & 354 & 210 & 48.2 & -- & 7.35 \\
\hline \multirow[t]{3}{*}{ NU 530} & E4-20 & $6 / 17 / 98$ & 1020 & 332 & 214 & 44.2 & 1.27 & -- \\
\hline & & $5 / 11 / 99$ & 1400 & 309 & 228 & 46.9 & 1.76 & 10.07 \\
\hline & & $5 / 9 / 00$ & 1000 & 285 & 217 & 42.4 & & \\
\hline \multirow[t]{2}{*}{ NU 531} & E4-30 & $6 / 16 / 98$ & 1630 & 206 & 152 & 24.8 & .96 & -- \\
\hline & $\mathrm{E} 4-30$ & $5 / 11 / 99$ & 1445 & 250 & 189 & 32.3 & 1.30 & 8.61 \\
\hline \multirow[t]{3}{*}{ NU 532} & E4-45 & $6 / 17 / 98$ & 1430 & 112 & 109 & 9.6 & 1.14 & -- \\
\hline & & $5 / 11 / 99$ & 1530 & 155 & 139 & 10.0 & 1.04 & 7.86 \\
\hline & & $5 / 9 / 00$ & 1100 & 152 & 129 & 22.1 & -- & -- \\
\hline
\end{tabular}


Appendix D. Average concentration of CFC-11,12, and 113, $S F_{6}$, tritium, and ${ }^{3} \mathrm{He}$ for ground water collected in the Chesapeake Bay Watershed, June 1998 through May 2000-Continued

[pg/kg, picograms per kilogram; mp, minipiezometer; --, data not available; fMol/L, femtomol per liter; $\mathrm{CFC}$, chlorofluorocarbon; $\mathrm{SF}_{6}$, sulfur hexafluoride; $\mathrm{TU}$, tritium units]

\begin{tabular}{|c|c|c|c|c|c|c|c|c|}
\hline \multirow[b]{2}{*}{$\begin{array}{c}\text { Site } \\
\text { name }\end{array}$} & \multirow[b]{2}{*}{$\begin{array}{l}\text { Local } \\
\text { ID }\end{array}$} & \multirow[b]{2}{*}{ Date } & \multirow[b]{2}{*}{ Time } & \multicolumn{3}{|c|}{$\begin{array}{l}\text { Concentration in solution } \\
\qquad(\mathrm{pg} / \mathrm{kg})\end{array}$} & \multirow{2}{*}{$\begin{array}{c}\begin{array}{c}\text { Concentration } \\
\text { in water } \\
\text { (fMol/L) }\end{array} \\
\text { SF }_{6}\end{array}$} & \multirow{2}{*}{$\begin{array}{c}\begin{array}{c}\text { Concentration } \\
\text { (TU) }\end{array} \\
\text { Tritium }\end{array}$} \\
\hline & & & & CFC-11 & CFC-12 & CFC-113 & & \\
\hline \multicolumn{9}{|c|}{ Mahantango WE-38 Watershed, East Transect } \\
\hline \multirow[t]{3}{*}{ NU 533} & E4-60 & $6 . / 18 / 98$ & 1015 & 74.0 & 75.2 & 6.4 & 0.82 & -- \\
\hline & & $5 / 11 / 99$ & 1600 & 142 & 119 & 22.4 & .97 & 7.67 \\
\hline & & $5 / 9 / 00$ & 1300 & 229 & 142 & 50.9 & -- & -- \\
\hline \multirow[t]{3}{*}{ NU 526} & E5-10 & $6 / 16 / 98$ & 1130 & 536 & 309 & 74.3 & 1.46 & -- \\
\hline & & $5 / 12 / 99$ & 1100 & 625 & 300 & 71.1 & 1.78 & -- \\
\hline & & $5 / 9 / 00$ & 1300 & 551 & 374 & 84.2 & -- & 8.58 \\
\hline NU 527 & E5-45 & 6/17/98 & 1300 & 573 & 292 & 73.2 & 1.39 & -- \\
\hline \multirow[t]{2}{*}{ NU 528} & E5-60 & 6/17/98 & 1700 & 477 & 223 & 53.4 & 1.10 & -- \\
\hline & & $5 / 12 / 99$ & 1000 & 353 & 195 & 44.8 & 1.14 & -- \\
\hline \multirow[t]{2}{*}{ NU 542} & E6-35 & $5 / 12 / 99$ & 1200 & 634 & 340 & 92.5 & 1.85 & 9.81 \\
\hline & & $5 / 9 / 00$ & 1400 & 646 & 320 & 81.7 & -- & -- \\
\hline NU 543 & E7-10 & $5 / 12 / 99$ & 1330 & 646 & 354 & 95.2 & 1.91 & -- \\
\hline \multicolumn{9}{|c|}{ Mahantango WE-38 Watershed, West Transect } \\
\hline NU 544 & W1-20 & $5 / 14 / 99$ & 1030 & 85.7 & 89.8 & 8.1 & .79 & -- \\
\hline \multirow[t]{2}{*}{ NU 545} & W2-20 & $5 / 14 / 99$ & 0930 & 90.0 & 76.1 & 22.6 & .55 & -- \\
\hline & & $5 / 10 / 00$ & 0900 & 75.0 & 71.0 & 8.2 & -- & 4.50 \\
\hline \multirow[t]{2}{*}{ NU 546} & W2-30 & $5 / 14 / 99$ & 0900 & 105 & 74.6 & 12.3 & .54 & -- \\
\hline & & $5 / 10 / 00$ & 1100 & 409 & 248 & 64.3 & -- & -- \\
\hline \multirow[t]{2}{*}{ NU 547} & W2-40 & $5 / 14 / 99$ & 0800 & 79.4 & 33.3 & 6.8 & .26 & -- \\
\hline & & $5 / 10 / 00$ & 1200 & 44.6 & 127 & 52.5 & -- & -- \\
\hline NU 548 & W3-10 & $5 / 12 / 99$ & 1500 & 504 & 284 & 65.6 & 1.79 & -- \\
\hline NU 549 & W3-20 & $5 / 12 / 99$ & 1600 & 160 & 136 & 37.6 & & \\
\hline NU 550 & W3-30 & $5 / 12 / 99$ & 1630 & 82.6 & 85.1 & 7.2 & .82 & -- \\
\hline NU 551 & W3-45 & $5 / 13 / 99$ & 1500 & 217 & 133 & 145 & -- & 5.37 \\
\hline NU 552 & W3-65 & 5/13/99 & 1600 & 180 & 118 & 36.3 & .78 & -- \\
\hline \multirow[t]{2}{*}{ NU 533} & W4-30 & 5/13/99 & 1200 & 92.0 & 118 & 12.2 & 1.30 & 8.62 \\
\hline & & $5 / 10 / 00$ & 1300 & 97.7 & 120 & 11.1 & -- & -- \\
\hline \multirow[t]{2}{*}{ NU 554} & W4-40 & $5 / 13 / 99$ & 1300 & 119 & 101 & 26.6 & -- & -- \\
\hline & & $5 / 10 / 00$ & 1330 & 306 & 193 & 48.8 & -- & -- \\
\hline
\end{tabular}


Appendix $D$. Average concentration of $C F C-11,12$, and $113, S F_{6}$, tritium, and ${ }^{3} \mathrm{He}$ for ground water collected in the Chesapeake Bay Watershed, June 1998 through May 2000—Continued

[pg/kg, picograms per kilogram; mp, minipiezometer; --, data not available; fMol/L, femtomol per liter; $\mathrm{CFC}$, chlorofluorocarbon; $\mathrm{SF}_{6}$, sulfur hexafluoride; $\mathrm{TU}$, tritium units]

\begin{tabular}{|c|c|c|c|c|c|c|c|c|}
\hline \multirow[b]{2}{*}{$\begin{array}{c}\text { Site } \\
\text { name }\end{array}$} & \multirow[b]{2}{*}{$\begin{array}{l}\text { Local } \\
\text { ID }\end{array}$} & \multirow[b]{2}{*}{ Date } & \multirow[b]{2}{*}{ Time } & \multicolumn{3}{|c|}{$\begin{array}{l}\text { Concentration in solution } \\
(\mathbf{p g} / \mathbf{k g})\end{array}$} & \multirow{2}{*}{$\frac{\begin{array}{c}\text { Concentration } \\
\text { in water } \\
\text { (fMol/L) }\end{array}}{\mathrm{SF}_{6}}$} & \multirow{2}{*}{$\begin{array}{c}\begin{array}{c}\text { Concentration } \\
\text { (TU) }\end{array} \\
\text { Tritium }\end{array}$} \\
\hline & & & & CFC-11 & CFC-12 & CFC-113 & & \\
\hline \multicolumn{9}{|c|}{ Mahantango WE-38 Watershed, West Transect-Continued } \\
\hline \multirow[t]{2}{*}{ NU 555} & W5-10 & $5 / 13 / 99$ & 1100 & 624 & 350 & 83.0 & 2.83 & 8.78 \\
\hline & & $5 / 10 / 00$ & 1500 & 620 & 519 & 119 & -- & 8.07 \\
\hline NU 556 & W5-45 & $5 / 13 / 99$ & 1000 & 653 & 380 & 105 & 2.07 & 8.85 \\
\hline $\begin{array}{l}\text { NU } 562 \\
\quad \text { (forested) }\end{array}$ & & $5 / 17 / 00$ & 1330 & 704 & 360 & 118 & -- & 8.69 \\
\hline $\begin{array}{l}\text { NU } 563 \\
\text { (hog manure } \\
\text { applied) }\end{array}$ & & $5 / 17 / 00$ & 1500 & 165 & 98.5 & 29.7 & -- & 6.14 \\
\hline \multicolumn{9}{|c|}{ Masser's (recharge site - fertilizer applied) } \\
\hline $\begin{array}{l}\text { NU } 558 \\
\quad \text { (shallow) } \\
\text { Well NW }\end{array}$ & & $5 / 8 / 00$ & 1400 & 695 & 349 & 97.6 & -- & -- \\
\hline $\begin{array}{l}\text { NU } 558 \text { (deep) } \\
\text { Well NW }\end{array}$ & & $5 / 8 / 00$ & 1500 & 581 & 274 & 1,335 & -- & -- \\
\hline $\begin{array}{l}\text { NU } 559 \\
\text { (shallow) } \\
\text { Well NE }\end{array}$ & & $5 / 8 / 00$ & 1300 & 728 & 346 & 109 & -- & -- \\
\hline $\begin{array}{l}\text { NU } 559 \text { (deep) } \\
\text { Well NE }\end{array}$ & & $5 / 8 / 00$ & 1130 & 676 & 352 & 701 & -- & 7.65 \\
\hline \multicolumn{9}{|c|}{ Springs sampled as part of Chesapeake Bay Ground Water initiative during 1997} \\
\hline \multicolumn{9}{|l|}{ Maryland } \\
\hline 4 H camp spr. & MD-HA-Bc-30 & $08 / 05 / 97$ & 1017 & & & & -- & -- \\
\hline Black Rock Spr. & MD-WA CJ23 & 08/08/97 & 1615 & & & & -- & -- \\
\hline Blue Hole Spr. & MD-AL-CE-1 & $08 / 11 / 97$ & 1230 & & & & -- & 6.32 \\
\hline Harver Spr. & MD-WA-Ak-3 & 08/08/97 & 1000 & & & & -- & -- \\
\hline Hillbilly Spr. & MD-FR ED 82 & 08/07/97 & 1530 & & & & -- & -- \\
\hline $\begin{array}{l}\text { Jefferson Davis } \\
\text { spr }\end{array}$ & MD-AL CF46 & 08/11/97 & 1500 & & & & -- & 2.33 \\
\hline Keedysville spr. & MD-WA-Di-6 & 08/08/97 & 1305 & & & & -- & -- \\
\hline Lilypons Spr. & MD-FR-FD-55 & 08/07/97 & 1013 & & & & -- & -- \\
\hline Manchester Spr. & MD CL Bf 183 & 08/06/97 & 1034 & & & & -- & -- \\
\hline $\begin{array}{l}\text { Oregon Ridge } \\
\text { spr. }\end{array}$ & MD-BA-DC-440 & 08/05/97 & 1320 & & & & -- & -- \\
\hline Phillips Spring & MD-FR-PHILS & 08/06/97 & 1740 & & & & -- & 11.5 \\
\hline $\begin{array}{l}\text { Retirement } \\
\text { Center }\end{array}$ & MD-BA-DE1 & 08/05/97 & 1547 & & & & -- & -- \\
\hline $\begin{array}{l}\text { South of Gum } \\
\text { Spring }\end{array}$ & MD-FR-Fb-12 & 08/07/97 & 1308 & & & & -- & -- \\
\hline
\end{tabular}


Appendix D. Average concentration of CFC-11,12, and 113, SF , tritium, and ${ }^{3} \mathrm{He}$ for ground water collected in the Chesapeake Bay Watershed, June 1998 through May 2000-Continued

[pg/kg, picograms per kilogram; mp, minipiezometer; --, data not available; fMol/L, femtomol per liter; $\mathrm{CFC}$, chlorofluorocarbon; $\mathrm{SF}_{6}$, sulfur hexafluoride; $\mathrm{TU}$, tritium units]

\begin{tabular}{|c|c|c|c|c|c|c|c|c|}
\hline \multirow[b]{2}{*}{$\begin{array}{c}\text { Site } \\
\text { name }\end{array}$} & \multirow[b]{2}{*}{$\begin{array}{l}\text { Local } \\
\text { ID }\end{array}$} & \multirow[b]{2}{*}{ Date } & \multirow[b]{2}{*}{ Time } & \multicolumn{3}{|c|}{$\begin{array}{l}\text { Concentration in solution } \\
\qquad(\mathrm{pg} / \mathrm{kg})\end{array}$} & \multirow{2}{*}{$\frac{\begin{array}{c}\text { Concentration } \\
\text { in water } \\
\text { (fMol/L) }\end{array}}{\mathrm{SF}_{6}}$} & \multirow{2}{*}{$\begin{array}{c}\begin{array}{c}\text { Concentration } \\
\text { (TU) }\end{array} \\
\text { Tritium }\end{array}$} \\
\hline & & & & CFC-11 & CFC-12 & CFC-113 & & \\
\hline \multicolumn{9}{|l|}{ Pennsylvania } \\
\hline Alexander Spr. & PA-Cu-16 & 08/19/97 & 1210 & & & & -- & -- \\
\hline $\begin{array}{l}\text { Bellfonte } \\
\text { Fishery Spr. }\end{array}$ & PA-Ce-12 & $08 / 21 / 97$ & 850 & & & & -- & -- \\
\hline Benner Spr. & PA-Ce-18 & $08 / 21 / 97$ & 1200 & & & & -- & -- \\
\hline Big Spr. & PA-Cu-22 & 08/19/97 & 1525 & & & & -- & -- \\
\hline Clouser Spr. & PA-Pe-10 & 08/20/97 & 1040 & & & & -- & 9.32 \\
\hline Donegal Spr. & PA-Ln-14 & 08/18/97 & 1522 & & & & -- & -- \\
\hline Dykeman Spr. & $\mathrm{PA}-\mathrm{Cu}-24$ & 08/19/97 & 955 & & & & -- & -- \\
\hline Hanover Spr. & PA-Yo-19 & 08/18/97 & 1222 & & & & -- & -- \\
\hline $\begin{array}{l}\text { McAllisterville } \\
\text { Spr. }\end{array}$ & PA-Ju-01 & $08 / 23 / 97$ & 1000 & & & & -- & -- \\
\hline Mount Rock Spr. & PA-Cu-17 & 08/19/97 & 1340 & & & & -- & -- \\
\hline Pennrythe Spr. & PA-Lb-18 & $08 / 22 / 97$ & 1440 & & & & -- & -- \\
\hline PSU Ag Spr. & PA-Ce-33 & $08 / 21 / 97$ & 1435 & & & & -- & -- \\
\hline Trout Spr. & $\mathrm{PA}-\mathrm{Cu}-30$ & 08/18/97 & 930 & & & & -- & -- \\
\hline Tylerville Spr. & PA-Cn-09 & 08/20/97 & 1520 & & & & -- & -- \\
\hline \multicolumn{9}{|l|}{ Virginia } \\
\hline $\begin{array}{l}\text { Arthur Weiss } \\
\text { Spr. }\end{array}$ & VA 10 & $08 / 05 / 97$ & 1230 & & & & -- & 8.24 \\
\hline Bear Lithia Spr. & VA 09 & $08 / 06 / 97$ & 927 & & & & -- & 4.66 \\
\hline Camp 2 Spr. & VA 11 & $08 / 12 / 97$ & 1140 & & & & -- & -- \\
\hline CNHP28 & VA 14 & $08 / 04 / 97$ & 1225 & & & & -- & -- \\
\hline Coyner Spr. & VA 01 & 08/13/97 & 930 & & & & -- & -- \\
\hline Deerfield Spr. & VA 07 & 08/08/97 & 1245 & & & & -- & -- \\
\hline Elkton & VA 08 & 08/05/97 & 1710 & & & & -- & .80 \\
\hline Gardner & & 08/06/97 & 1515 & & & & -- & 4.56 \\
\hline $\begin{array}{l}\text { George } \\
\text { Washington }\end{array}$ & VA 13 & 08/11/97 & 1045 & & & & -- & -- \\
\hline Green Spr. & VA 12 & 08/13/97 & 1425 & & & & -- & .21 \\
\hline $\begin{array}{l}\text { Gypsy Hilll Golf } \\
\text { Course }\end{array}$ & VA 05 & 08/06/97 & 1240 & & & & -- & -- \\
\hline Loth Spr. & VA 02 & 08/13/97 & 1145 & & & & -- & -- \\
\hline Masanetta & VA 04 & 08/07/97 & 1520 & & & & -- & 8.29 \\
\hline Timberville Spr. & VA 03 & 08/08/97 & 900 & & & & -- & -- \\
\hline Warm Spr. & VA 06 & 08/08/97 & 1543 & & & & -- & -- \\
\hline \multicolumn{9}{|l|}{ West Virginia } \\
\hline Berkeley Spr. & WV-BS-1 & $08 / 11 / 97$ & 1710 & & & & -- & -- \\
\hline
\end{tabular}


Appendix E. Tritium/helium data and apparent ages of water from wells and springs in the Chesapeake Bay Watershed, September 1996 through May 2000 [ft, feet; ${ }^{\circ} \mathrm{C}$, degrees Celsius; TU, tritium units; cc, cubic centimeters; STP/g, Standard Temperature and Pressure per gram; nd, no data; R, rejected; shaded boxes are estimated]

\begin{tabular}{|c|c|c|c|c|c|c|c|c|c|c|c|c|c|c|}
\hline $\begin{array}{c}\text { Site } \\
\text { name }\end{array}$ & $\begin{array}{c}\text { Sample } \\
\text { date }\end{array}$ & $\begin{array}{c}\text { Recharge } \\
\text { temp. } \\
{ }^{\circ} \mathrm{C}\end{array}$ & $\begin{array}{c}\text { Elevation } \\
(\mathbf{f t})\end{array}$ & $\begin{array}{c}\text { Tritium } \\
\text { TU }\end{array}$ & $\begin{array}{l}\text { Tritium } \\
\text { error } \\
1 \text { sigma } \\
\text { TU }\end{array}$ & $\begin{array}{c}\delta^{3} \mathrm{He} \\
\text { Meas. \% }\end{array}$ & $\begin{array}{c}{ }^{4} \text { He measured } \\
\text { cc STP/g } \\
\left(\times 10^{-8}\right)\end{array}$ & $\begin{array}{c}{ }^{3} \mathbf{H} /{ }^{3} \mathrm{He} \\
\text { Age No } \\
\text { Terr. He } \\
\text { Corr., } \\
\text { Years }\end{array}$ & $\begin{array}{c}{ }^{3} \mathrm{H} /{ }^{3} \mathrm{He} \\
\text { Age Error. } \\
\text { No Terr. } \\
\text { He Corr. } \\
\text { Years }\end{array}$ & $\begin{array}{c}\text { Excess He } \\
\text { as \% } \\
\text { solubility } \\
\Delta^{4} \mathrm{He}\end{array}$ & $\begin{array}{l}\text { Ne measured } \\
\text { cc STP/g } \\
\left(\times 10^{-7}\right)\end{array}$ & $\begin{array}{c}\text { Excess } \\
\text { He as \% } \\
\text { solubility } \\
\Delta \mathrm{Ne}\end{array}$ & $\begin{array}{c}{ }^{3} \mathrm{H} /{ }^{3} \mathrm{He} \\
\text { Age with } \\
\text { Terr. He } \\
\text { Corr., } \\
\text { Years }\end{array}$ & $\begin{array}{c}{ }^{3} \mathbf{H} /{ }^{3} \mathbf{H e} \\
\text { Age Error } \\
\text { with Terr. } \\
\text { He Corr., } \\
\text { Years }\end{array}$ \\
\hline \multicolumn{15}{|c|}{ North Fork Green Run near Whitesville, Del. } \\
\hline WI Bx p2a & $3 / 25 / 99$ & 14.7 & 50 & 4.42 & 0.11 & -0.79 & 5.194 & $\mathrm{R}^{1}$ & $\mathrm{R}^{1}$ & 14.17 & 2.285 & 18.41 & $\mathrm{R}^{1}$ & $\mathrm{R}^{1}$ \\
\hline WI Bx p2a & $9 / 22 / 99$ & 19.0 & 50 & 3.63 & .20 & -.59 & 4.820 & 1.2 & 0.5 & 7.53 & 2.049 & 10.03 & & \\
\hline WI Bx p2a & $3 / 14 / 00$ & 14.5 & 50 & 2.49 & .20 & .40 & 5.089 & $\mathrm{R}^{1}$ & $\mathrm{R}^{1}$ & 11.78 & 2.285 & 18.24 & $\mathrm{R}^{1}$ & $\mathrm{R}^{1}$ \\
\hline WI Bx p2c & $3 / 25 / 99$ & 11.0 & 50 & 1.42 & .20 & 2.39 & 5.114 & 10.4 & 1.4 & 10.77 & 2.240 & 12.28 & & \\
\hline WI Bx p2c & 9/29/99 & 21.3 & 50 & 1.77 & .20 & 1.56 & 4.190 & $\mathrm{R}^{1}$ & $\mathrm{R}^{1}$ & -5.86 & 1.876 & 2.55 & $\mathrm{R}^{1}$ & $\mathrm{R}^{1}$ \\
\hline WI Bx p2c & $3 / 14 / 00$ & 11.1 & 50 & -.86 & .20 & -13.68 & 2.583 & $\mathrm{R}^{1}$ & $\mathrm{R}^{1}$ & -44.03 & 1.490 & -25.24 & $\mathrm{R}^{1}$ & $\mathrm{R}^{1}$ \\
\hline WI Bx p2d & $3 / 25 / 99$ & 7.2 & 50 & 1.03 & .20 & 7.94 & 5.482 & $\mathrm{R}^{1}$ & $\mathrm{R}^{1}$ & 16.69 & 2.506 & 21.05 & $\mathrm{R}^{1}$ & $\mathrm{R}^{1}$ \\
\hline WI Bx p2d & 9/29/99 & 14.0 & 50 & .71 & .20 & 8.38 & 4.580 & $\mathrm{R}^{1}$ & $\mathrm{R}^{1}$ & .41 & 2.034 & 4.78 & $\mathrm{R}^{1}$ & $\mathrm{R}^{1}$ \\
\hline WI Bx p2d & $3 / 14 / 00$ & 9.6 & 50 & .44 & .20 & 10.18 & 4.626 & $\mathrm{R}^{1}$ & $\mathrm{R}^{1}$ & -.41 & 2.154 & 6.57 & $\mathrm{R}^{1}$ & $\mathrm{R}^{1}$ \\
\hline WI Bx p2e & 3/29/99 & 10.0 & 50 & 3.40 & .20 & 5.00 & 4.303 & $\mathrm{R}^{1}$ & $\mathrm{R}^{1}$ & -7.20 & 1.993 & -1.03 & $\mathrm{R}^{1}$ & $\mathrm{R}^{1}$ \\
\hline WI Bx p2g & $3 / 25 / 99$ & 10.4 & 50 & 1.14 & .38 & 3.71 & 5.358 & 15.3 & 3.5 & 15.76 & 2.319 & 15.62 & & \\
\hline WI Bx p2i & $3 / 26 / 99$ & 9.9 & 50 & 3.46 & .20 & .26 & 4.875 & 2.5 & .5 & 5.09 & 2.154 & 6.88 & & \\
\hline \multicolumn{15}{|c|}{ Unnamed ditch to North Fork Green Run near Whitesville, Del. (Wayne Tull's Farm) } \\
\hline WI By p1a & 9/23/99 & 19.6 & 50 & 5.42 & .20 & -2.26 & 4.540 & & & 1.48 & 1.867 & .73 & -0.1 & 0.6 \\
\hline WI By p1a & $3 / 13 / 00$ & 19.6 & 50 & 5.47 & .20 & -1.76 & 5.116 & $\mathrm{R}^{1}$ & $\mathrm{R}^{1}$ & 14.35 & 2.202 & 18.79 & $\mathrm{R}^{1}$ & $\mathrm{R}^{1}$ \\
\hline WI By p1b & $3 / 23 / 99$ & 5.9 & 50 & 5.75 & .20 & -4.36 & 3.012 & $\mathrm{R}^{1}$ & $\mathrm{R}^{1}$ & -36.31 & 1.597 & -23.90 & $\mathrm{R}^{1}$ & $\mathrm{R}^{1}$ \\
\hline WI By p1b & 9/23/99 & 19.7 & 50 & 5.81 & .20 & -1.50 & 4.800 & & & 7.32 & 1.933 & 4.38 & 1.5 & .6 \\
\hline WI By plb & $3 / 13 / 00$ & 19.7 & 50 & 3.99 & .20 & -1.99 & 5.339 & $\mathrm{R}^{1}$ & $\mathrm{R}^{1}$ & 19.37 & 2.336 & 26.12 & $\mathrm{R}^{1}$ & $\mathrm{R}^{1}$ \\
\hline WI By p1c & $3 / 23 / 99$ & 14.3 & 50 & 6.76 & .20 & 5.92 & 3.773 & $\mathrm{R}^{2}$ & $\mathrm{R}^{2}$ & -17.19 & 1.716 & -11.39 & $\mathrm{R}^{2}$ & $\mathrm{R}^{2}$ \\
\hline WI By p1c & 9/23/99 & 24.3 & 50 & 6.25 & .20 & 7.85 & 2.630 & $\mathrm{R}^{2}$ & $\mathrm{R}^{2}$ & -40.40 & 1.233 & -31.10 & $\mathrm{R}^{2}$ & $\mathrm{R}^{2}$ \\
\hline WI By p1d & $3 / 23 / 99$ & 13.8 & 50 & 5.28 & .20 & 8.31 & 3.592 & $\mathrm{R}^{2}$ & $\mathrm{R}^{2}$ & -21.31 & 1.650 & -15.13 & $\mathrm{R}^{2}$ & $\mathrm{R}^{2}$ \\
\hline WI By p1d & $9 / 24 / 99$ & 15.0 & 50 & 5.74 & .20 & 4.98 & 3.100 & $\mathrm{R}^{2}$ & $\mathrm{R}^{2}$ & -31.78 & 1.362 & -29.23 & $\mathrm{R}^{2}$ & $\mathrm{R}^{2}$ \\
\hline WI By p1d & $3 / 13 / 00$ & 19.5 & 50 & 5.75 & .20 & 7.83 & 3.684 & $\mathrm{R}^{2}$ & $\mathrm{R}^{2}$ & -17.68 & 1.596 & -13.93 & $\mathrm{R}^{2}$ & $\mathrm{R}^{2}$ \\
\hline \multicolumn{15}{|c|}{ Green Run near Careytown, Md. (Green Run at Bethel Road) } \\
\hline WI Bz pla & $9 / 21 / 99$ & 18.5 & 50 & 5.80 & .20 & -1.68 & 5.060 & -.2 & .3 & 12.70 & 2.096 & 12.11 & & \\
\hline WI Bz plb & 3/30/99 & 8.7 & 50 & .34 & .20 & 3.71 & 6.128 & 32.2 & 8.9 & 31.38 & 2.551 & 25.10 & & \\
\hline WI Bz p1c & $3 / 30 / 99$ & 10.5 & 50 & .91 & .20 & -.13 & 5.306 & $\mathrm{R}^{1}$ & $\mathrm{R}^{1}$ & 14.68 & 2.435 & 21.48 & $\mathrm{R}^{1}$ & $\mathrm{R}^{1}$ \\
\hline WI Bz p1d & $3 / 29 / 99$ & 11.0 & 50 & 7.12 & .20 & 12.76 & 4.457 & 7.3 & .3 & -3.46 & 1.948 & -2.36 & & \\
\hline WI Bz pld & 9/22/99 & 16.8 & 50 & 8.29 & .20 & 19.95 & 3.870 & $\mathrm{R}^{2}$ & $\mathrm{R}^{2}$ & -14.29 & 1.629 & -14.06 & $\mathrm{R}^{2}$ & $\mathrm{R}^{2}$ \\
\hline WI Bz p1d & $3 / 14 / 00$ & 14.0 & 50 & 6.76 & .20 & 13.75 & 4.220 & $\mathrm{R}^{2}$ & $\mathrm{R}^{2}$ & -7.48 & 1.824 & -6.04 & $\mathrm{R}^{2}$ & $\mathrm{R}^{2}$ \\
\hline
\end{tabular}


Appendix E. Tritium/helium data and apparent ages of water from wells and springs in the Chesapeake Bay Watershed, September 1996 through May $2000-$ Continued

[ft, feet; ${ }^{\circ} \mathrm{C}$, degrees Celsius; TU, tritium units; cc, cubic centimeters; STP/g, Standard Temperature and Pressure per gram; nd, no data; R, rejected; shaded boxes are estimated]

\begin{tabular}{|c|c|c|c|c|c|c|c|c|c|c|c|c|c|c|}
\hline $\begin{array}{c}\text { Site } \\
\text { name }\end{array}$ & $\begin{array}{c}\text { Sample } \\
\text { date }\end{array}$ & $\begin{array}{c}\text { Recharge } \\
\text { temp. } \\
{ }^{\circ} \mathrm{C}\end{array}$ & $\begin{array}{c}\text { Elevation } \\
(\mathbf{f t})\end{array}$ & $\begin{array}{c}\text { Tritium } \\
\text { TU }\end{array}$ & $\begin{array}{c}\text { Tritium } \\
\text { error } \\
1 \text { sigma } \\
\text { TU }\end{array}$ & $\begin{array}{c}\delta^{3} \mathbf{H e} \\
\text { Meas. \% }\end{array}$ & $\begin{array}{c}{ }^{4} \text { He measured } \\
\text { cc STP/g } \\
\left(\times 10^{-8}\right)\end{array}$ & $\begin{array}{c}{ }^{3} \mathrm{H} /{ }^{3} \mathrm{He} \\
\text { Age No } \\
\text { Terr. He } \\
\text { Corr., } \\
\text { Years }\end{array}$ & $\begin{array}{c}{ }^{3} \mathrm{H} /{ }^{3} \mathrm{He} \\
\text { Age Error. } \\
\text { No Terr. } \\
\text { He Corr., } \\
\text { Years }\end{array}$ & $\begin{array}{c}\text { Excess He } \\
\text { as \% } \\
\text { solubility } \\
\Delta^{\mathbf{4}} \mathrm{He}\end{array}$ & $\begin{array}{l}\text { Ne measured } \\
\text { cc STP/g } \\
\left(\times 10^{-7}\right)\end{array}$ & $\begin{array}{c}\text { Excess } \\
\text { He as \% } \\
\text { solubility } \\
\Delta \mathrm{Ne}\end{array}$ & $\begin{array}{c}{ }^{3} \mathrm{H} /{ }^{3} \mathrm{He} \\
\text { Age with } \\
\text { Terr. He } \\
\text { Corr., } \\
\text { Years }\end{array}$ & $\begin{array}{c}{ }^{3} \mathrm{H} /{ }^{3} \mathrm{He} \\
\text { Age Error } \\
\text { with Terr. } \\
\text { He Corr., } \\
\text { Years }\end{array}$ \\
\hline \multicolumn{15}{|c|}{ Springs in Muddy Creek Watershed } \\
\hline 39SS-001 & $4 / 17 / 00$ & 8.2 & 1,500 & 8.12 & 0.20 & 1.16 & 5.400 & 1.6 & 0.2 & 21.82 & 2.341 & 20.46 & & \\
\hline 39SS-005 & $4 / 14 / 99$ & 9.0 & 1,500 & 8.75 & .20 & 7.64 & 5.128 & 4.7 & .2 & 16.12 & 2.195 & 13.86 & & \\
\hline \multicolumn{15}{|c|}{ Monitoring wells in Muddy Creek Watershed } \\
\hline $39 \mathrm{~S} 2$ & $4 / 13 / 99$ & 8.1 & 1,500 & 9.58 & .20 & 1.65 & 4.860 & 1.6 & .2 & 9.59 & 2.158 & 10.91 & & \\
\hline $39 \mathrm{~S} 2$ & $4 / 18 / 00$ & 9.1 & 1,500 & 8.07 & .20 & 1.43 & 5.080 & 1.8 & .2 & 15.08 & 2.193 & 13.86 & & \\
\hline $39 S 4$ & $4 / 18 / 00$ & 8.6 & 1,500 & 6.14 & .20 & 10.15 & 5.010 & 7.6 & .3 & 13.24 & 2.166 & 11.90 & & \\
\hline $39 \mathrm{~S} 9$ & $4 / 13 / 99$ & 12.4 & 1,500 & 9.29 & .20 & 15.52 & 4.925 & 7.3 & .2 & 13.17 & 2.093 & 12.10 & & \\
\hline 3959 & $4 / 18 / 00$ & 9.7 & 1,500 & 8.86 & .20 & 5.05 & 4.950 & & & 12.44 & 2.082 & 8.73 & 3.9 & 0.4 \\
\hline $39 \mathrm{~S} 14$ & $4 / 17 / 00$ & 6.1 & 1,600 & .05 & .20 & 10.48 & 7.110 & $\mathrm{R}^{3}$ & $\mathrm{R}^{3}$ & 59.33 & 2.899 & 46.52 & $\mathrm{R}^{3}$ & $\mathrm{R}^{3}$ \\
\hline $39 \mathrm{~S} 15$ & $4 / 17 / 00$ & 6.2 & 1,600 & 6.23 & .20 & 14.19 & 5.690 & 10.45 & .35 & 27.57 & 2.474 & 25.18 & & \\
\hline $39 \mathrm{~S} 16$ & $4 / 17 / 00$ & 6.7 & 1,580 & 5.21 & .20 & 2.95 & 6.620 & $\mathrm{R}^{1}$ & $\mathrm{R}^{1}$ & 48.69 & 2.871 & 45.92 & $\mathrm{R}^{1}$ & $\mathrm{R}^{1}$ \\
\hline 39 S19 & $4 / 18 / 00$ & 8.8 & 1,500 & 4.24 & .20 & 8.55 & 5.060 & 9.2 & .5 & 14.46 & 2.178 & 12.72 & & \\
\hline \multicolumn{15}{|c|}{ Domestic wells in Muddy Creek Watershed } \\
\hline $39 \mathrm{~S} 35$ & 4/13/99 & 7.3 & 1,500 & 9.39 & .20 & 2.49 & 5.369 & 2.1 & .2 & 20.62 & 2.308 & 17.72 & & \\
\hline $39 \mathrm{~S} 43$ & $4 / 16 / 99$ & 8.4 & 1,500 & .38 & .20 & -14.64 & 8.352 & & & 88.60 & 2.770 & 42.83 & 33.2 & 8.4 \\
\hline \multicolumn{15}{|l|}{ Polecat Creek, Va. } \\
\hline $50 \mathrm{M} 6$ & $4 / 21 / 99$ & 7.1 & 200 & .03 & .20 & -1.71 & 5.690 & $\mathrm{R}^{3}$ & $\mathrm{R}^{3}$ & 21.75 & 2.511 & 21.86 & $\mathrm{R}^{3}$ & $\mathrm{R}^{3}$ \\
\hline $50 \mathrm{M} 25$ & $4 / 21 / 99$ & 9.5 & 200 & 7.68 & .20 & 1.75 & 5.510 & 2.2 & .3 & 19.23 & 2.373 & 17.93 & & \\
\hline $50 \mathrm{M} 26$ & $4 / 21 / 99$ & 9.1 & 200 & 7.59 & .20 & 2.16 & 5.580 & 2.5 & .3 & 20.52 & 2.387 & 18.17 & & \\
\hline $50 \mathrm{M} 30$ & $4 / 10 / 00$ & 8.8 & 200 & 6.40 & .20 & -.32 & 6.450 & & & 39.14 & 2.640 & 30.33 & 1.5 & .7 \\
\hline \multicolumn{15}{|c|}{ East Mahantango Creek Watershed, Pa. } \\
\hline NU 540 & $5 / 10 / 99$ & 8.9 & 800 & 2.88 & .21 & -94.09 & 150.2 & $\mathrm{R}^{4}$ & $\mathrm{R}^{4}$ & $3,213.15$ & 1.400 & -29.29 & $\mathrm{R}^{4}$ & $\mathrm{R}^{4}$ \\
\hline NU 541 & $5 / 10 / 99$ & 7.5 & 800 & 2.90 & .19 & -67.83 & 139.2 & $\mathrm{R}^{5}$ & $\mathrm{R}^{5}$ & $2,950.97$ & 2.657 & 32.31 & $\mathrm{R}^{5}$ & $\mathrm{R}^{5}$ \\
\hline NU 529 & $5 / 11 / 99$ & 8.8 & 800 & 9.19 & .19 & -31.61 & 9.820 & & & 116.52 & 2.382 & 20.18 & 8.8 & .4 \\
\hline NU 529 & $5 / 9 / 00$ & 12.2 & 800 & 7.35 & .18 & -50.73 & 13.78 & & & 208.35 & 2.416 & 25.89 & 8.9 & .7 \\
\hline NU 530 & $5 / 11 / 99$ & 8.0 & 800 & 10.07 & .30 & -18.13 & 8.430 & & & 85.17 & 2.565 & 28.38 & 6.3 & .4 \\
\hline NU 531 & $5 / 11 / 99$ & 9.8 & 800 & 8.61 & .17 & -39.53 & 12.37 & & & 173.99 & 2.422 & 23.39 & 12.9 & .4 \\
\hline NU 532 & $5 / 11 / 99$ & 8.8 & 800 & 7.86 & .20 & -33.30 & 12.41 & & & 173.63 & 2.403 & 21.24 & 18.3 & .5 \\
\hline
\end{tabular}


Appendix E. Tritium/helium data and apparent ages of water from wells and springs in the Chesapeake Bay Watershed, September 1996 through May $2000-$ Continued

[ft, feet; ${ }^{\circ} \mathrm{C}$, degrees Celsius; TU, tritium units; cc, cubic centimeters; STP/g, Standard Temperature and Pressure per gram; nd, no data; R, rejected; shaded boxes are estimated]

\begin{tabular}{|c|c|c|c|c|c|c|c|c|c|c|c|c|c|c|}
\hline $\begin{array}{c}\text { Site } \\
\text { name }\end{array}$ & $\begin{array}{c}\text { Sample } \\
\text { date }\end{array}$ & $\begin{array}{c}\text { Recharge } \\
\text { temp. } \\
{ }^{\circ} \mathrm{C}\end{array}$ & $\begin{array}{c}\text { Elevation } \\
\quad(\mathbf{f t})\end{array}$ & $\begin{array}{c}\text { Tritium } \\
\text { TU }\end{array}$ & $\begin{array}{c}\text { Tritium } \\
\text { error } \\
1 \text { sigma } \\
\text { TU }\end{array}$ & $\begin{array}{c}\delta^{3} \mathrm{He} \\
\text { Meas. \% }\end{array}$ & $\begin{array}{c}{ }^{4} \text { He measured } \\
\text { cc STP/g } \\
\left(\times 10^{-8}\right)\end{array}$ & $\begin{array}{c}{ }^{3} \mathrm{H} /{ }^{3} \mathrm{He} \\
\text { Age No } \\
\text { Terr. He } \\
\text { Corr., } \\
\text { Years }\end{array}$ & $\begin{array}{c}{ }^{3} \mathrm{H} /{ }^{3} \mathrm{He} \\
\text { Age Error. } \\
\text { No Terr. } \\
\text { He Corr., } \\
\text { Years }\end{array}$ & $\begin{array}{c}\text { Excess He } \\
\text { as \% } \\
\text { solubility } \\
\Delta^{\mathbf{4}} \mathrm{He}\end{array}$ & $\begin{array}{l}\text { Ne measured } \\
\text { cc STP/g } \\
\left(\times 10^{-7}\right)\end{array}$ & $\begin{array}{c}\text { Excess } \\
\text { He as \% } \\
\text { solubility } \\
\Delta \mathrm{Ne}\end{array}$ & $\begin{array}{c}{ }^{3} \mathrm{H} /{ }^{3} \mathrm{He} \\
\text { Age with } \\
\text { Terr. He } \\
\text { Corr., } \\
\text { Years }\end{array}$ & $\begin{array}{c}{ }^{3} \mathrm{H} /{ }^{3} \mathrm{He} \\
\text { Age Error } \\
\text { with Terr. } \\
\text { He Corr., } \\
\text { Years }\end{array}$ \\
\hline \multicolumn{15}{|c|}{ East Mahantango Creek Watershed, Pa.-Continued } \\
\hline NU 533 & $5 / 11 / 99$ & 9.6 & 800 & 7.67 & 0.17 & -17.08 & 10.77 & & & 138.33 & 2.397 & 21.89 & 21.4 & 0.4 \\
\hline NU 526 & $5 / 9 / 00$ & 8.7 & 800 & 8.58 & .26 & 2.89 & 5.790 & 2.7 & .3 & 27.60 & 2.428 & 22.38 & & \\
\hline NU 542 & $5 / 12 / 99$ & 9.7 & 800 & 9.81 & .20 & 2.45 & 5.090 & 1.9 & .2 & 12.71 & 2.185 & 11.26 & & \\
\hline NU 545 & $5 / 10 / 00$ & 9.8 & 800 & 4.50 & .17 & 32.00 & 7.130 & & & 57.92 & 2.701 & 37.61 & 27.0 & .6 \\
\hline NU 551 & $5 / 13 / 99$ & 10.3 & 800 & 5.37 & .15 & 34.79 & 5.780 & 20.6 & .4 & 28.31 & 2.404 & 23.07 & & \\
\hline NU 553 & $5 / 10 / 00$ & 9.4 & 800 & 8.62 & .19 & 34.28 & 6.120 & & & 35.31 & 2.506 & 27.18 & 16.0 & .4 \\
\hline NU 555 & $5 / 13 / 99$ & 7.6 & 800 & 8.78 & .19 & 31.46 & 2.730 & $\mathrm{R}^{2}$ & $\mathrm{R}^{2}$ & -40.15 & 1.373 & -31.56 & $\mathrm{R}^{2}$ & $\mathrm{R}^{2}$ \\
\hline NU 555 & $5 / 10 / 00$ & 9.4 & 800 & 8.07 & .24 & -.77 & 5.770 & .4 & .3 & 27.57 & 2.477 & 25.71 & & \\
\hline NU 556 & $5 / 13 / 99$ & 11.1 & 800 & 8.85 & .19 & -1.27 & 4.850 & .2 & .2 & 8.03 & 2.104 & 8.53 & & \\
\hline NU 562 & $5 / 17 / 00$ & 8.6 & 980 & 8.69 & .20 & -.12 & 4.950 & .8 & .2 & 9.76 & 2.146 & 8.77 & & \\
\hline NU 563 & $5 / 17 / 00$ & 9.2 & 884 & 6.14 & .58 & 49.73 & 6.340 & & & 40.48 & 2.448 & 24.38 & 26.3 & 1.3 \\
\hline NU 559-D & $5 / 8 / 00$ & 10.6 & 900 & 7.65 & .18 & .34 & 5.830 & & & 30.06 & 2.304 & 18.72 & 4.5 & .5 \\
\hline \multicolumn{15}{|c|}{ Springs sampled as part of Chesapeake Bay Ground Water Initiative } \\
\hline ML 3 Phillips Spring & $8 / 6 / 97$ & 10.5 & 440 & 11.50 & .22 & nd & nd & $\mathrm{R}^{6}$ & $\mathrm{R}^{6}$ & nd & nd & nd & $\mathrm{R}^{6}$ & $\mathrm{R}^{6}$ \\
\hline PC 1 Donegal Spr. & $11 / 20 / 96$ & 11.4 & 354 & 11.51 & .18 & -0.12 & 5.627 & & & 23.46 & 2.314 & 17.75 & 1.1 & 0.4 \\
\hline PC 1 Donegal Spr. & $9 / 11 / 96$ & 11.1 & 354 & 10.87 & .19 & 1.20 & 5.904 & & & 29.36 & 2.391 & 21.34 & 2.4 & .4 \\
\hline PC 2 Ft. Detrick Field Hole & $9 / 24 / 96$ & 11.0 & 340 & 5.53 & .06 & nd & nd & $\mathrm{R}^{6}$ & $\mathrm{R}^{6}$ & nd & nd & nd & $\mathrm{R}^{6}$ & $\mathrm{R}^{6}$ \\
\hline PC 3 Ft. Detrick Spring House & $9 / 24 / 96$ & 11.5 & 340 & 11.72 & .28 & nd & nd & $\mathrm{R}^{6}$ & $\mathrm{R}^{6}$ & nd & nd & nd & $\mathrm{R}^{6}$ & $\mathrm{R}^{6}$ \\
\hline PC 6 Retirement Center & $9 / 23 / 96$ & 10.6 & 220 & 10.88 & .13 & nd & nd & $\mathrm{R}^{6}$ & $\mathrm{R}^{6}$ & nd & nd & nd & $\mathrm{R}^{6}$ & $\mathrm{R}^{6}$ \\
\hline PCX 3 Green Spr. & $11 / 12 / 96$ & 10.8 & 345 & .14 & .04 & nd & nd & $\mathrm{R}^{6}$ & $\mathrm{R}^{6}$ & nd & 2.926 & 48.01 & $\mathrm{R}^{6}$ & $\mathrm{R}^{6}$ \\
\hline PCX 3 Green Spr. & $8 / 13 / 97$ & 10.0 & 345 & .21 & .05 & nd & nd & $\mathrm{R}^{6}$ & $\mathrm{R}^{6}$ & nd & 3.288 & 65.07 & $\mathrm{R}^{6}$ & $\mathrm{R}^{6}$ \\
\hline PCX 6 Manchester Spr. & $9 / 27 / 96$ & 11.7 & 890 & 14.95 & .19 & 14.39 & 6.064 & & & 35.87 & 2.254 & 17.28 & 8.3 & .2 \\
\hline PCX 7 South Gum Spr. & $9 / 26 / 96$ & 13.8 & 300 & 11.41 & .13 & -1.82 & 4.728 & -0.1 & 0.2 & 4.54 & 2.015 & 4.59 & & \\
\hline VRC 1 Alexander Spr. & 9/10/96 & 10.5 & 512 & 13.73 & .18 & 17.71 & 7.311 & & & 60.72 & 2.567 & 30.28 & 12.2 & .3 \\
\hline VRC 2 Arthur Weiss Spr. & $11 / 12 / 96$ & 12.0 & 600 & 10.98 & .15 & 4.60 & 6.031 & & & 33.85 & 2.450 & 26.48 & 3.3 & .4 \\
\hline VRC 2 Arthur Weiss Spr. & 9/19/96 & 12.5 & 460 & 10.60 & .14 & nd & nd & $\mathrm{R}^{6}$ & $\mathrm{R}^{6}$ & nd & nd & nd & $\mathrm{R}^{6}$ & $\mathrm{R}^{6}$ \\
\hline VRC 2 Arthur Weiss Spr. & $8 / 5 / 97$ & 14.2 & 460 & 8.24 & .20 & 11.58 & 6.121 & & & 36.33 & 2.364 & 23.87 & 10.0 & .4 \\
\hline VRC 3 Bear Lithia Spr. & $8 / 6 / 97$ & 10.8 & 936 & 4.66 & .20 & 18.09 & 6.358 & & & 42.14 & 2.552 & 31.90 & 17.1 & .7 \\
\hline VRC 5 Benner Spr. & $9 / 13 / 96$ & 10.5 & 920 & 13.42 & .16 & 13.17 & 6.825 & & & 52.30 & 2.739 & 41.11 & 6.3 & .3 \\
\hline
\end{tabular}


Appendix E. Tritium/helium data and apparent ages of water from wells and springs in the Chesapeake Bay Watershed, September 1996 through May $2000-$ Continued

[ft, feet; ${ }^{\circ} \mathrm{C}$, degrees Celsius; TU, tritium units; cc, cubic centimeters; STP/g, Standard Temperature and Pressure per gram; nd, no data; R, rejected; shaded boxes are estimated]

\begin{tabular}{|c|c|c|c|c|c|c|c|c|c|c|c|c|c|c|}
\hline $\begin{array}{c}\text { Site } \\
\text { name }\end{array}$ & $\begin{array}{c}\text { Sample } \\
\text { date }\end{array}$ & $\begin{array}{c}\text { Recharge } \\
\text { temp. } \\
{ }^{\circ} \mathrm{C}\end{array}$ & $\begin{array}{c}\text { Elevation } \\
\text { (ft) }\end{array}$ & $\begin{array}{c}\text { Tritium } \\
\text { TU }\end{array}$ & $\begin{array}{c}\text { Tritium } \\
\text { error } \\
1 \text { sigma } \\
\text { TU }\end{array}$ & $\begin{array}{c}\delta^{3} \mathrm{He} \\
\text { Meas. \% }\end{array}$ & $\begin{array}{c}{ }^{4} \text { He measured } \\
\text { cc STP/g } \\
\left(\times 10^{-8}\right)\end{array}$ & $\begin{array}{c}{ }^{3} \mathbf{H} /{ }^{3} \mathrm{He} \\
\text { Age No } \\
\text { Terr. He } \\
\text { Corr., } \\
\text { Years }\end{array}$ & $\begin{array}{c}{ }^{3} \mathrm{H} /{ }^{3} \mathrm{He} \\
\text { Age Error. } \\
\text { No Terr. } \\
\text { He Corr., } \\
\text { Years }\end{array}$ & $\begin{array}{c}\text { Excess He } \\
\text { as \% } \\
\text { solubility } \\
\Delta^{\mathbf{4}} \mathrm{He}\end{array}$ & $\begin{array}{l}\text { Ne measured } \\
\text { cc STP/g } \\
\left(\times 10^{-7}\right)\end{array}$ & $\begin{array}{c}\text { Excess } \\
\text { He as \% } \\
\text { solubility } \\
\Delta \mathrm{Ne}\end{array}$ & $\begin{array}{c}{ }^{3} \mathbf{H} /{ }^{3} \mathrm{He} \\
\text { Age with } \\
\text { Terr. He } \\
\text { Corr., } \\
\text { Years }\end{array}$ & $\begin{array}{c}{ }^{3} \mathrm{H} /{ }^{3} \mathrm{He} \\
\text { Age Error } \\
\text { with Terr. } \\
\text { He Corr., } \\
\text { Years }\end{array}$ \\
\hline \multicolumn{15}{|c|}{ Springs sampled as part of Chesapeake Bay Ground Water Initiative-Continued } \\
\hline VRC 6 Big Spr. & $9 / 10 / 96$ & 9.4 & 520 & 12.97 & 0.14 & nd & nd & $\mathrm{R}^{6}$ & $\mathrm{R}^{6}$ & nd & nd & nd & $\mathrm{R}^{6}$ & $\mathrm{R}^{6}$ \\
\hline VRC 7 Black Rock Spr. & $11 / 18 / 96$ & 8.3 & 540 & 10.82 & .15 & 2.16 & 5.809 & 1.8 & 0.2 & 26.57 & 2.444 & 21.54 & & \\
\hline VRC 8 Coyner Spr. & $11 / 12 / 96$ & 9.5 & 1,310 & 4.38 & .09 & nd & nd & $\mathrm{R}^{6}$ & $\mathrm{R}^{6}$ & nd & 7.172 & 271.22 & $\mathrm{R}^{6}$ & $\mathrm{R}^{6}$ \\
\hline VRC 11 Elkton Spr. & $8 / 5 / 97$ & 11.7 & 1,005 & .80 & .06 & -4.56 & 6.526 & & & 46.83 & 2.477 & 29.47 & 17.1 & 2.5 \\
\hline VRC 12 Gypsy Hill Golf Course & $9 / 13 / 96$ & 10.4 & 1,470 & 2.75 & .04 & nd & nd & $\mathrm{R}^{6}$ & $\mathrm{R}^{6}$ & nd & nd & nd & $\mathrm{R}^{6}$ & $\mathrm{R}^{6}$ \\
\hline VRC 16 Massanetta Spr. & $8 / 7 / 97$ & 10.4 & 1,385 & 8.29 & .13 & -97.80 & 1.043 & $\mathrm{R}^{5}$ & $\mathrm{R}^{5}$ & $2,267.41$ & 7.295 & 281.90 & $\mathrm{R}^{5}$ & $\mathrm{R}^{5}$ \\
\hline VRC 17 Mount Rock Spr. & $9 / 10 / 96$ & 10.9 & 530 & 14.10 & .28 & 29.67 & 6.386 & 10.3 & .2 & 40.73 & 2.640 & 34.59 & & \\
\hline VRC 18 Pennrythe Spr. & $9 / 9 / 96$ & 11.0 & 450 & 12.91 & .17 & .77 & 6.051 & & & 33.00 & 2.317 & 17.88 & 4.2 & .3 \\
\hline VRC 21 Trout Spr. & 9/9/96 & 10.2 & 440 & 12.29 & .20 & 14.36 & 5.194 & & & 13.74 & 2.173 & 9.65 & 6.1 & .3 \\
\hline VRC 21 Trout Spr. & $11 / 21 / 96$ & 11.0 & 440 & 12.80 & .15 & 13.84 & 5.179 & & & 13.81 & 2.169 & 10.29 & 5.6 & .3 \\
\hline VRC 23 Gardner Spr. & $8 / 6 / 97$ & 12.8 & 1,361 & 4.56 & .09 & 3.51 & 9.568 & & & 119.08 & 3.621 & 93.65 & 9.4 & 1.0 \\
\hline VRS 2 Blue Hole Spr. & $9 / 26 / 96$ & 12.9 & 560 & 9.36 & .24 & -30.70 & 7.102 & & & 57.97 & 2.089 & 8.58 & 0.0 & .5 \\
\hline VRS 2 Blue Hole Spr. & $8 / 11 / 97$ & 11.2 & 560 & 6.32 & .19 & -40.86 & 8.398 & & & 85.49 & 2.054 & 5.12 & 2.6 & .7 \\
\hline VRS 3 Clouser Spr. & $9 / 11 / 96$ & 12.2 & 500 & 9.60 & .21 & -1.24 & 4.993 & .2 & .2 & 10.51 & 2.120 & 9.25 & & \\
\hline VRS 3 Clouser Spr. & $8 / 20 / 97$ & 12.9 & 500 & 9.32 & .20 & -1.50 & 4.690 & .1 & .2 & 4.08 & 2.012 & 4.36 & & \\
\hline VRS 4 Jefferson Davis Spr. & $8 / 11 / 97$ & 11.4 & 660 & 2.33 & .15 & -36.12 & 8.288 & & & 83.91 & 2.147 & 10.48 & 7.9 & 1.4 \\
\hline
\end{tabular}

${ }^{1}$ Reason for rejection: Excess air from Helium < Excess air from Neon.

2 Reason for rejection: Degassed.

${ }^{3}$ Reason for rejection: Too old; low Tritium.

${ }^{4}$ Reason for rejection: Degassed, Terrigenic Helium very high.

${ }^{5}$ Reason for rejection: Terrigenic Helium very high.

${ }^{6}$ Reason for rejection: Missing Data. 